\section{Pacific Northwest} National Laboratory

Operated by Battelle for the

U.S. Department of Energy

\section{Natural Gas Storage in Basalt Aquifers of the Columbia Basin, Pacific Northwest USA: A Guide to Site Characterization}

\author{
prepared for \\ United States Department of Energy \\ National Energy Technology Laboratory \\ 626 Cochrans Mill Road \\ Pittsburgh, Pennsylvania 15236
}

August 2002 


\section{DISCLAIMER}

This report was prepared as an account of work sponsored by an agency of the United States Government. Neither the United States Government nor any agency thereof, nor any of their employees, makes any warranty, express or implied, or assumes any legal liability or responsibility for the accuracy, completeness, or usefulness of any information, apparatus, product, or process disclosed, or represents that its use would not infringe privately owned rights. Reference herein to any specific commercial product, process, or service by trade name, trademark, manufacturer, or otherwise does not necessarily constitute or imply its endorsement, recommendation, or favoring by the United States Government or any agency thereof. The views and opinions of authors expressed herein do not necessarily state or reflect those of the United States Government or any agency thereof.

Available to the public from the National Technical Information Service, U.S. Department of Commerce, 5285 Port Royal Road, Springfield, VA 22161; phone orders accepted at (703) 487-4650.

This document was printed on recycled paper. 


\title{
Natural Gas Storage in Basalt Aquifers of the Columbia Basin, Pacific Northwest USA: A Guide to Site Characterization
}

\author{
S. P. Reidel \\ V. G. Johnson \\ F. A. Spane
}

August 2002

Prepared for

the U.S. Department of Energy

under Contract DE-AC06-76RL01830

Pacific Northwest National Laboratory

Richland, Washington 99352 


\section{Executive Summary}

Increasing domestic and commercial demand for natural gas in the Pacific Northwest requires development of adequate storage facilities. Geologic storage is one economically attractive option provided adequate storage capacity and containment requirements can be met in favorable locations. Extensive areas of thick layers of basalt within central Washington State represent a large geologic province that is relatively unexplored for subsurface gas storage. Existing gas transmission pipelines cross this area, and certain basalt structures have been demonstrated to be capable of containing natural gas. The challenge is to identify specific locations that are suitable both for natural gas storage and near existing pipelines.

This report provides a preliminary screening assessment and a compilation of information and methods needed to select and characterize suitable locations for subsurface gas storage. The report is intended to serve as a guide for exploring the feasibility of natural gas storage reservoirs within the deep basalts of the Columbia Basin. Major findings and recommendations are summarized below.

General Findings. The deeper basalt aquifers in selected areas of the Columbia Basin are suitable for subsurface storage of natural gas provided certain conditions are met. Based on available information, the central portion of the basin appears to be the most favorable area of the region for potential natural gas storage. Characteristics favoring this area include the following:

- Thickness. There is sufficient thickness of basalt for natural gas storage and high hydrostatic pressures for gas containment. The total thickness of the basalt $(>5 \mathrm{~km})$ is greatest in this area. Individual basalt flows also reach their greatest thickness, which provides additional caprock sealing thickness for effective subsurface storage

- Closure. There are numerous anticlines (Yakima Fold Belt) that can provide geologic closure for gas storage. This increases the likelihood of locating a suitable structure for closure or containment of injected gas.

- Tectonic stability. Earthquake activity is minimal. Typical earthquake activity is low and concentrated in swarms within synclinal areas.

- Groundwater quality and water rights. Groundwater quality in potential deep basalt storage horizons is unsuitable for irrigation or domestic use (e.g., high fluoride content). The hydrochemical character of the deeper basalt interflow zones thus precludes their use for domestic purposes and creates minimal issues over water rights.

- Low groundwater flow rates. Isotopic and hydrochemical data suggest the deep groundwater is very old, with estimated flow rates of less than 1 to $2 \mathrm{~m} / \mathrm{yr}$. Dissolved gas in the groundwater would migrate advectively at very slow rates away from natural gas stored in this hydrogeologic regime. 
- Large database. A large subsurface characterization database exists for the geology and hydrology, including individual basalt interflow zones within central Columbia Basin. Studies over the years by the U.S. Department of Energy (DOE) have provided regional geology and deep basalt and aquifer characterization data. These data allow preliminary site screening for areas with the greatest likelihood of vertical hydrologic isolation (caprock/containment).

- Regional groundwater flow separation. Several observed regional stratigraphic horizons that separate groundwaters between the major hydrostratigraphic units have been identified in the central Columbia Basin. The presence of distinct groundwater flow systems provides additional sealing potential for the vertical migration of natural gas stored within underlying basalt interflow zones.

- Existing infrastructure. Natural gas pipelines run southeast to northwest through the center of the Yakima Fold Belt and along the southern boundary. In addition, a natural gas transmission line runs north to south across the eastern part of the Columbia Basin.

- Existing natural gas field. The occurrence of a commercial gas field along the western margin of the Pasco Basin (Rattlesnake Ridge) that was exploited until the 1940s provides evidence that basalt interflow zones can serve as natural gas storage reservoirs.

- Favorable land acquisition. Much of the land within the central Columbia Basin is already removed from the private sector (e.g., Hanford Site). Thus, developing a natural gas storage project on federal land would be consistent with the current energy strategy and would avoid condemnation suits often needed to acquire land from privately held interests.

A map summarizing the features described above is shown in Figure ES.1. This map shows areas of high and low potential and areas of uncertainty. Based on existing information, the most favorable Columbia Basin locations are in the vicinity of central Columbia Basin (innermost elliptical zone of Figure ES.1). The inner zone is also located at the intersection of two major pipeline systems from Canada and Wyoming. Proximity to pipelines, folded basalt, and water quality are all favorable for subsurface natural gas storage in deep basalt aquifers within this designated zone. The indicated favorable zone could be expanded if deep aquifer information were available (i.e., the area with uncertain groundwater chemistry shown in Figure ES.1).

Site Selection and Characterization. Several technical considerations and issues are identified that must be addressed to evaluate the suitability of a candidate basalt structure, once a specific location within the target area (Figure ES.1) is selected. The primary questions that must be addressed include the following:

- Are there zones within the basalt flows in the candidate structure that have sufficient size (lateral extent, thickness, continuity) to store natural gas?

- Do the storage zone(s) have favorable properties (i.e., sufficient porosity and permeability) for efficient natural gas storage and retrievability?

- Is there sufficient closure at depth to keep the gas from migrating away from the site? 


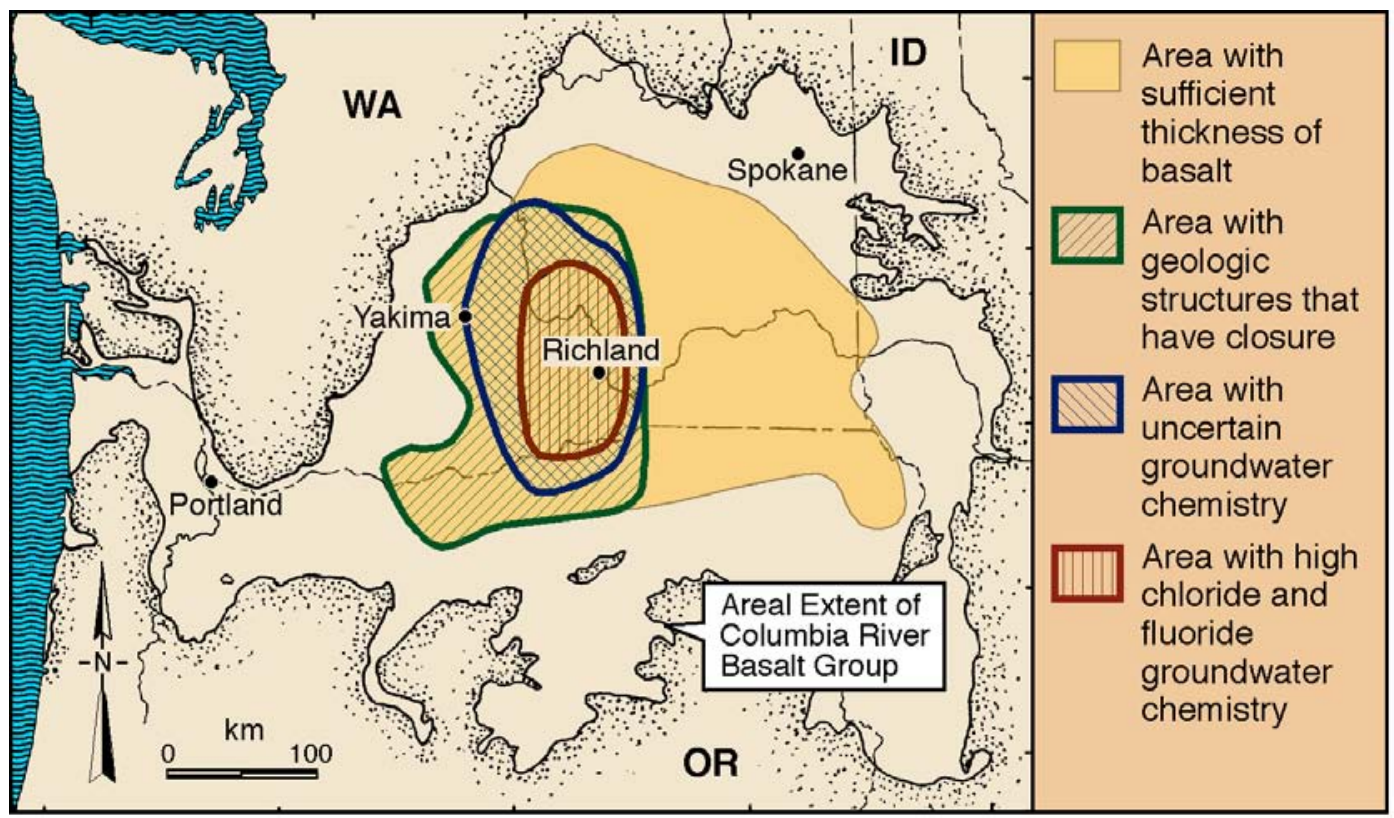

Figure ES.1. Map Showing Areas Comprising Favorable, Unfavorable, and Uncertain Areas for Natural Gas Storage in Columbia River Basalt Group Lava Flows

- Are there good caprocks that will prevent the stored natural gas from leaking from the storage horizon?

- Is the groundwater quality favorable (non-potable and the absence of $\mathrm{H}_{2} \mathrm{~S}$ )?

Collectively, the Columbia River Basalt Group (CRBG) covers an extensive area with individual lava flows covering many tens of thousands of square kilometers. The great volume and extent of CRBG lava flows sets them apart from typical small-size lava flows and provides attractive targets for gas storage reservoirs. Although only the interflow zones are usable for natural gas storage, the great volume and extent of CRBG flows put them on equal footing with the sedimentary formations within the United States that are currently being used for gas storage. Scoping calculations indicate that a single interflow zone (at a depth of 1,000 m) in an anticlinal basalt structure 1 to $2 \mathrm{~km}$ wide 5 to $10 \mathrm{~km}$ long can provide more than adequate storage space for a typical 0.4 billion cubic meter facility. Larger storage volumes can be achieved by using multiple interflow zones at an individual storage site location.

Detailed descriptions of drilling and hydrologic testing methods, geophysical tools, basalt flow identification methods, and lithologic and hydrochemical sampling procedures needed to evaluate the suitability of candidate site are provided in the main body of the report and in the extensive set of appendices. A key is also provided to facilitate cross-referencing the specific characterization needs and methods for successfully developing a subsurface gas storage facility within deep basalt aquifers of the Columbia Basin. These evaluation methods have application as well in other lava flow or volcanic provinces. 
Finally, the report should serve as a valuable source document for subsurface hydrogeologic investigations in the layered basalts of Washington and Oregon. In this regard, it should be useful to the natural gas transmission industry as an invaluable aid in:

- planning for potential subsurface gas storage facilities and related decision-making

- drilling and testing during the site investigation phase

- documenting appropriate supporting information for drilling and operating permit applications

- preparation of environmental impact assessments at proposed gas storage sites.

Regulatory agencies charged with implementing state groundwater environmental protection statutes should also find this compilation of hydrogeologic data and testing methods indispensable in evaluating applications for drilling permits, wastewater disposal permits, and facility operating permits.

Other Applications. Reduction of atmospheric releases of carbon dioxide is a critical national and international issue. Various schemes to sequester this greenhouse gas have been proposed, including geologic disposal. However, basalt has received little attention as a potential sequestration medium. Injection into deep basalt aquifers involves many of the same considerations as required for natural gas storage. Chemical reactions unique to basalt may enhance retention of the carbon dioxide as carbonate solid phases. In addition, a structural trap to restrict lateral movement of the injected gas is not required, making larger areas available for sequestration. Thus, this option is an attractive alternative to other modes of off-gas treatment for fossil-fired power plants located in the Columbia Basin. Much of the background information provided in this document is equally applicable to both gas storage and carbon dioxide disposal. Co-investigation of these two applications would be cost-efficient and could facilitate a more timely solution to some major problems facing the energy industry. 


\section{Contents}

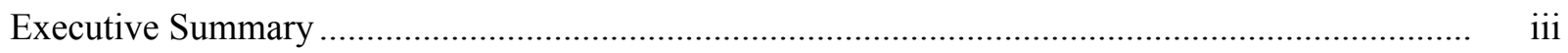

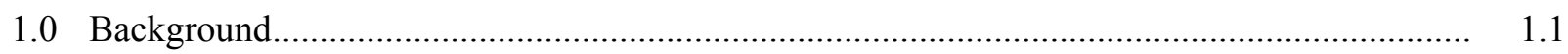

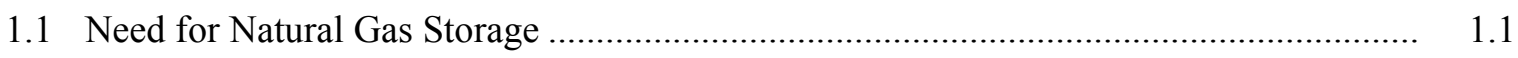

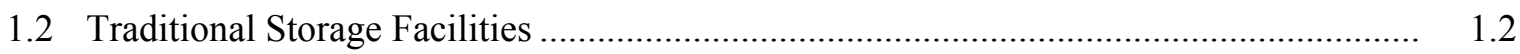

1.3 Natural Gas Occurrences in the Columbia Basin .................................................... 1.2

1.4 Purpose, Scope, and Organization of Report ...................................................... 1.4

2.0 Stratigraphy, Structural Framework, and Geophysical Studies ......................................... 2.1

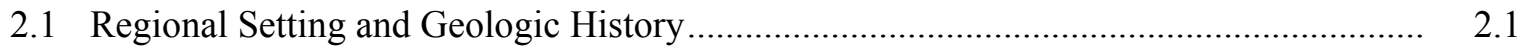

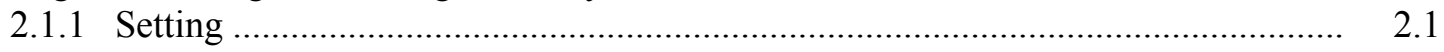

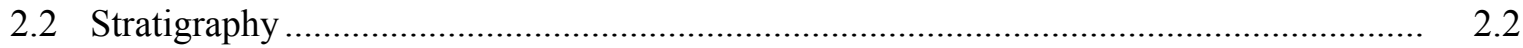

2.2.1 Stratigraphy Older than the Columbia River Basalt Group................................. 2.6

2.2.2 Stratigraphy Younger than the Columbia River Basalt Group............................. 2.6

2.2.3 Stratigraphy of the Columbia River Basalt Group ........................................... 2.7

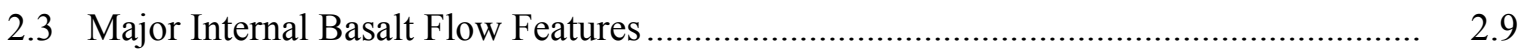

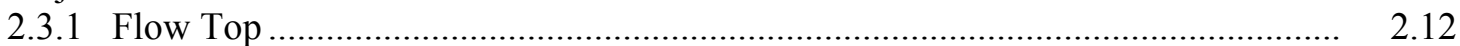

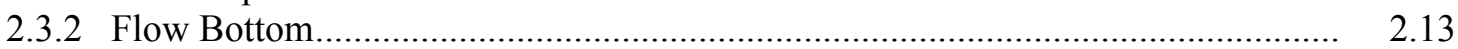

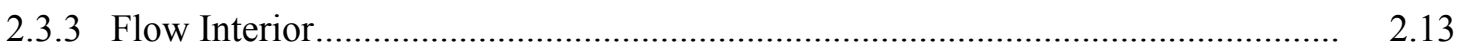

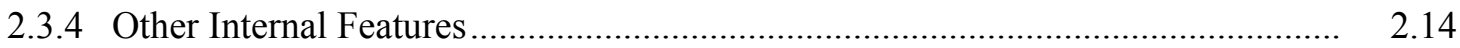

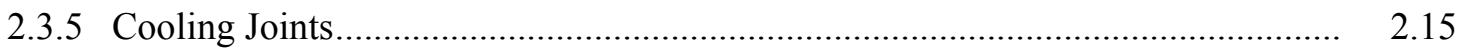

2.3.6 Intraflow Structure Variation .................................................................... 2.15

2.4 Regional Geologic Structures............................................................................. 2.16

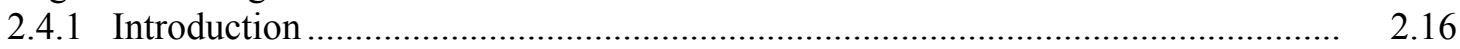

2.4.2 The Olympic-Wallowa Lineament ............................................................... 2.17

2.4.3 Hog Ranch-Naneum Ridge Anticline.......................................................... 2.17

2.4.4 White River-Naches River Fault Zone ............................................................ 2.18

2.4.5 Leavenworth Fault Zone .................................................................................. 2.18

2.4.6 Other Structures Marginal to the Columbia Basin ............................................ 2.18

2.4.7 Northwest-Trending Wrench Faults ......................................................... 2.18

2.4.8 The Yakima Folds and the Yakima Fold Belt ................................................. 2.18

2.4.9 Tectonic Brecciation and Shearing......................................................... 2.24

2.4.10 Tectonic Joint Sets ............................................................................... 2.25

2.4.11 Relationship Between Folding and Faulting .............................................. 2.26

2.4.12 Earthquake History and State of Stress in the Columbia Basin ........................... 2.28

2.4.13 The Yakima Folds: A Summary .................................................................. 2.31 
2.5 Geologic History of the Columbia Basin ............................................................... 2.31

2.5.1 The Pre-Miocene Columbia Basin ..................................................................... 2.31

2.5.2 The Middle Miocene Columbia Basin ........................................................... 2.34

2.5.3 The Late Miocene Columbia Basin ................................................................. 2.36

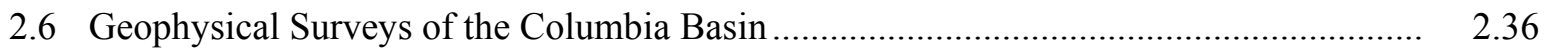

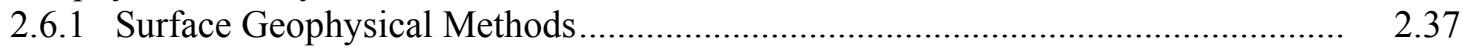

2.6.2 Borehole Geophysical Surveys ................................................................. 2.48

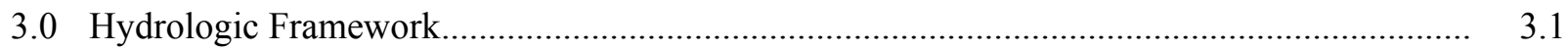

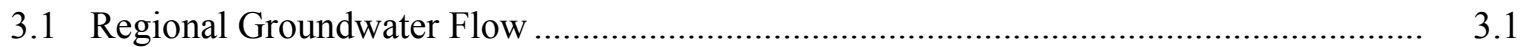

3.1.1 Features Conducive to Confinement ................................................................. 3.5

3.1.2 Features Conducive to Vertical Communication .............................................. 3.7

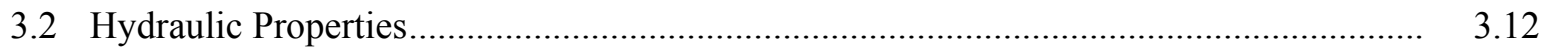

4.0 Hydrochemical Characteristics and Applications ....................................................... 4.1

4.1 Chemical Evolution of Basalt Groundwater ….......................................................... 4.1

4.2 Hydrochemical Indicators of Vertical Hydraulic Isolation .............................................

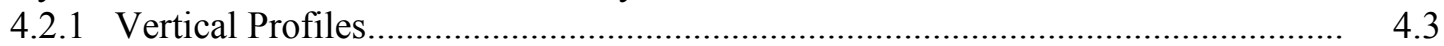

4.2.2 Chemical Ratio Plots .................................................................................. 4.5

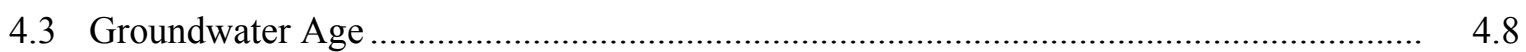

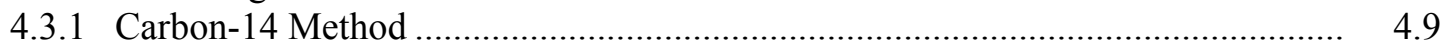

4.3.2 Helium Accumulation Method ............................................................................. 4.11

4.3.3 Chlorine-36 Method ............................................................................... 4.12

4.3.4 Example Age and Groundwater Flow Estimates.......................................... 4.12

4.4 Methane Concentrations and Isotopic Carbon and Hydrogen...................................... 4..20

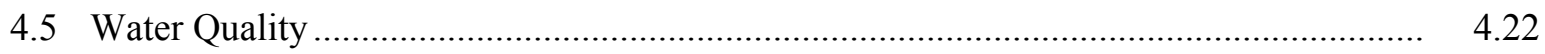

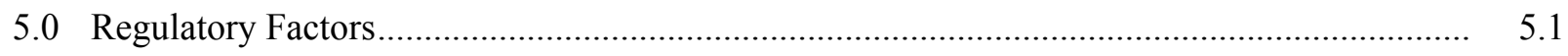

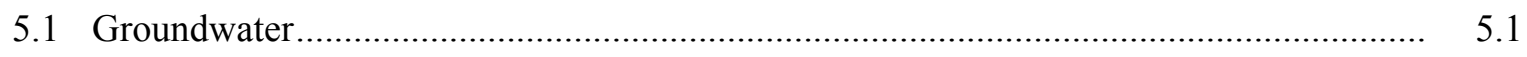

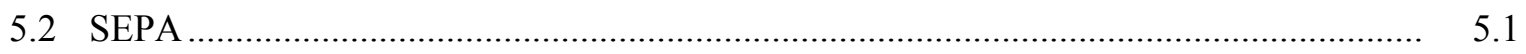

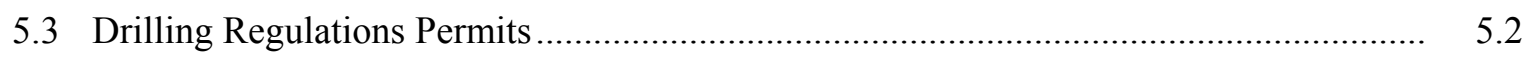

$5.3 .1 \quad$ Water Quality and Use ................................................................................ 5.3

5.3.2 Disposal of Produced Water ...................................................................... 5.3

5.3.3 Distinguishing Stored Gas from Naturally Occurring Gas................................. 5.4

6.0 Natural Gas Reservoir Considerations.................................................................. 6.1

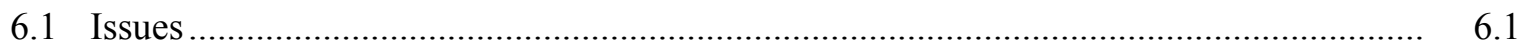

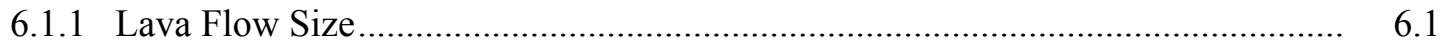

viii 
6.1.2 Rock Properties of Potential Storage Zones ..................................................... 6.2

6.1.3 Lateral Continuity of Reservoir Zones .............................................................. 6.2

6.1.4 Storage Zone Permeability and Effective Porosity ….......................................... 6.4

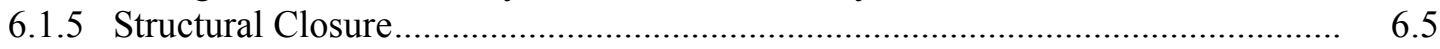

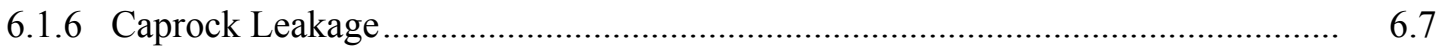

6.1.7 Gas Threshold Pressure .............................................................................. 6.9

6.1.8 Calculating Potential Gas Storage Volume in Basalt Interflow Zones ................. 6.9

6.2 Summary of Site Selection and Characterization Needs ............................................. 6.12

6.3 Recommendations for Well Drilling, Hydrochemical Sampling and Hydrologic Testing

7.0 Summary/Conclusions

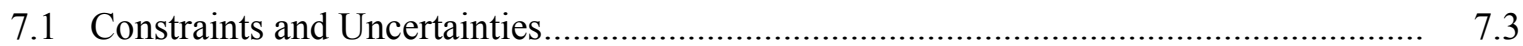

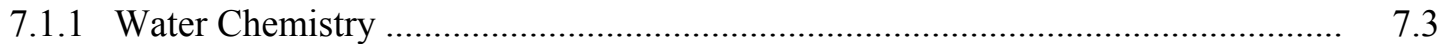

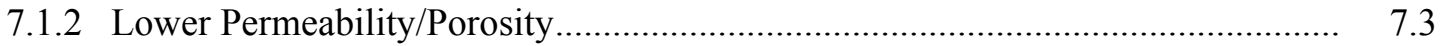

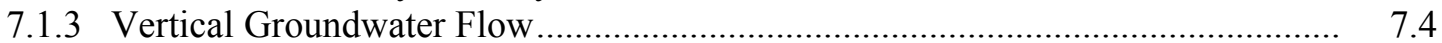

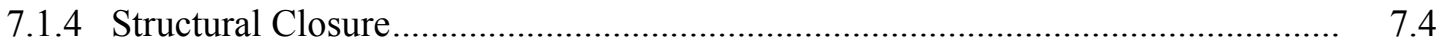

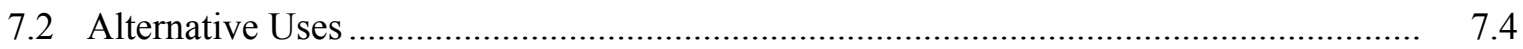

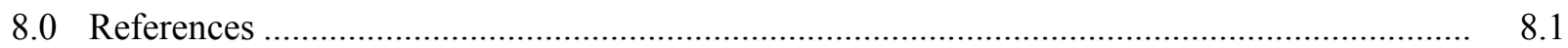

Appendix A - Examples of Columbia River Basalt Group Flow Features ................................... A.1

Appendix B - An Example of the Current State-of-the-Art Geophysical Logging Technology ....... B.1

Appendix C - Examples of Folds and Faults in Columbia River Basalt Group

Flows from the Columbia Basin......................................................................... C. C.1

Appendix D - Examples of Surface Geophysical Surveys ............................................... D. 1

Appendix E - Hydrologic Characterization Tests ................................................................... E.1

Appendix F - Isotopic and Hydrochemical Data ............................................................. F.1

Appendix G - Identification of Columbia River Basalt Group Lava Flows................................ G. 1

Appendix H - Catalog of Surface Mapping ....................................................................... H.1 


\section{Figures}

ES.1 Map Showing Areas Comprising Favorable, Unfavorable, and Uncertain Areas for Natural Gas Storage in Columbia River Basalt Group Lava Flows.................................... . v

1.1 Natural Gas Supply Lines Serving Eastern Washington and Eastern Oregon......................... 1.1

1.2 Rattlesnake Hills Gas Field in Southcentral Washington................................................... 1.3

2.1 Setting and Extent of the Columbia River Basalt Group in the Pacific Northwest

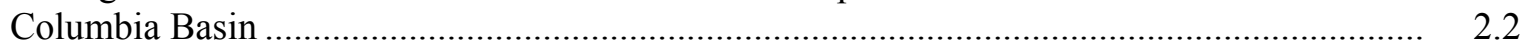

2.2 Principal Structural Features of the Columbia River Flood-Basalt Province .......................... 2.3

2.3 Nomenclature for the Columbia River Basalt Group ................................................. 2.8

2.4 Volume of Columbia River Basalt Group Eruptions Over Time ....................................... 2.9

2.5 Geologic Map of the Columbia River Basalt Group ................................................... 2.10

2.6 Thickness Map of the Columbia River Basalt Group.................................................... 2.11

2.7 Cross-Section Through the Columbia Basin Showing the Thickness Variation of the Grande Ronde Basalt

2.8 Major Basalt Flow Features of a Columbia River Basalt Group Lava Flow .......................... 2.12

2.9 Histogram and Cumulative Distribution Function for Cooling Joint Spacing for High-Angle Joints from an Exposure of the Rocky Coulee Flow of the Member of Sentinel Bluffs

2.10 Yakima Folds in the Pasco Basin Area.

2.11 Cross Section through the Yakima Fold Belt

2.12 Locations of Deep Hydrocarbon Exploration Boreholes Drilled that Penetrated Rocks Below the Columbia River Basalt Group

2.13 Historic Seismicity of the Columbia Basin and Surrounding Areas

2.14 Seismicity of the Columbia Basin and Surrounding Areas as Measured by Seismographs......

2.15 Geologic Cross Section through the Columbia Basin

2.16 Stratigraphy of Boreholes that Penetrate the Columbia River Basalt Group.

2.17 Growth Rate of the Saddle Mountains Anticline Based on Thinning of Basalt Flows Over Ridges 
2.19 Typical Geophysical Log from Cored Borehole RRL2 Showing Responses from Member of Sentinel Bluffs Basalt Flows, Grande Ronde Basalt.....

3.1 Groundwater-Potentiometric Map and Inferred, Regional Groundwater Flow Within the Grande Ronde Basalt

3.2 Groundwater-Potentiometric Map and Inferred, Regional Groundwater Flow Within the Wanapum Basalt

3.3 Groundwater-Potentiometric Map and Inferred, Regional Groundwater Flow Within the Saddle Mountains Basalt

3.4 Conceptualization of Vertical Flow to the West and East of the Cold Creek Fault ......

3.5 Areal Plot of Chloride Within the Upper Wanapum Basalt .....

3.6 Areal Plot of Dissolved Methane Concentration Within Grande Ronde Groundwaters

3.7 Idealized Depiction of a Hypothetical Basalt Flow Sequence with Various Flow Features that Could Provide Enhanced Communication

3.8 Hydraulic Conductivity with Depth

3.9 Hydraulic Conductivity for Selected Flow Interior Sections from Test Boreholes

3.10 Influence of Flow Attitude on Permeability Control for an Interflow Zone.

4.1 Conceptual Model of Chemical Evolution and Transport of Basalt Groundwater in the Columbia Basin ....

4.2 Hydrochemical Facies Map of the Grande Ronde Basalt, Columbia Basin

4.3 Comparison of Major Chemical Composition of the Grande Ronde Basalt in the Pasco Basin versus the Columbia Basin....

4.4 Vertical Distribution of Methane Concentration, Sulfate Concentration, $\delta^{13} \mathrm{C}-\mathrm{TIC}$, and Chloride Concentration from Boreholes RRL-2, DB-15, and DC-15 in the Cold Creek Syncline in the Central Columbia Basin.

4.5 Comparison of Vertical Chloride Concentration Profiles for Wells DC-16 and DC-14 Located in Adjacent Synclines

4.6 $\mathrm{Cl} / \mathrm{F}$ and $\mathrm{Cl} / \mathrm{B}$ Ratios versus Chloride Concentration for Multiple Stratigraphic Units in Well DB-15

4.7 $\mathrm{Cl} / \mathrm{F}$ and $\mathrm{Cl} / \mathrm{B}$ Ratios versus Chloride Concentration for Multiple Stratigraphic Units in Well DC-14 
4.8 $\mathrm{Cl} / \mathrm{F}$ and $\mathrm{Cl} / \mathrm{B}$ Ratios versus Chloride Concentration for Multiple Stratigraphic Units in Well DC-16A

$4.9{ }^{14} \mathrm{C}$-Based Groundwater Ages for the Mabton Interbed, Pasco Basin

4.10 Well Locations and Geologic Map of the Upper Cold Creek Valley, Pasco Basin

4.11 Helium Concentration versus ${ }^{14} \mathrm{C}$ Age, Upper Cold Creek Valley, Priest Rapids Member Flow Top Aquifers

4.12 Helium versus Chloride Concentrations in Selected Wanapum Basalt and Grande Ronde Basalt Aquifers.

4.13 Areal Distribution of Chloride Concentration in Groundwater from the Priest Rapids and Roza Members of the Wanapum Basalt

4.14 Carbon and Hydrogen Isotopic Compositions of Methane in Pasco Basin Basalt Groundwater....

4.15 Natural Gas Source Characteristics

6.1 Internal Features of a Columbia River Basalt Group Lava Flow

6.2 Example of Loss of Structural Closure from Faulting Involving Only a Single Lava Flow .....

6.5 Map of the Pasco Basin Showing Examples of Anticlines Suitable for Potential Gas Storage

6.6 Badger Mountain

6.7 Red Mountain.

6.8 Schematic of Flooded Reverse Circulation Airlift Drilling Method

6.9 Testing Using Airlift Techniques and Submersible Pump

7.1 Map Showing Areas Comprising Favorable, Unfavorable, and Uncertain Areas for Natural Gas Storage in Columbia River Basalt Group Lava Flows 


\section{Tables}

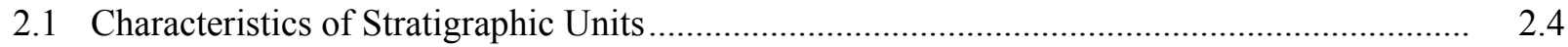

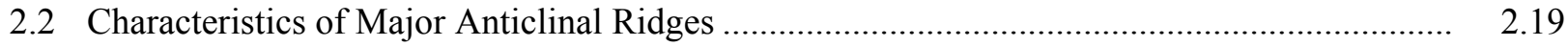

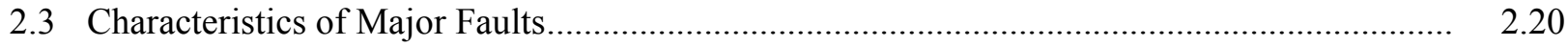

4.1 Helium and ${ }^{14} \mathrm{C}$ in Wanapum Basalt Aquifers, Upper Cold Creek Valley ............................. 4.15

4.2 Noble Gases in Groundwater from the Columbia River Basalt Group Aquifer and Comparison Compositions ......................................................................................... 4.16

$4.3{ }^{3} \mathrm{He}$ in Grande Ronde Groundwater Samples from Well DC-23 ....................................... 4.20

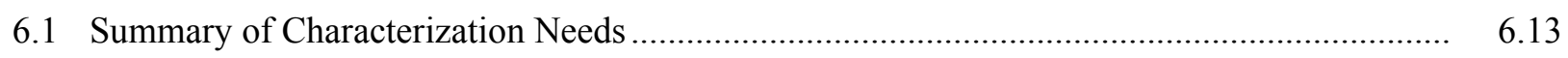




\subsection{Background}

\subsection{Need for Natural Gas Storage}

Natural gas is rapidly becoming an important source for energy generation in the Pacific Northwest. One of the biggest obstacles facing the increased use of natural gas east of the Cascade Range is the limitation imposed by supply lines. Currently, only two major supply lines provide service to eastern Washington and eastern Oregon, and they are approaching capacity. Branch line locations with respect to major physiographic regions are shown in Figure 1.1. The Pacific Gas Transmission Company has a gas transmission line supplying Canadian natural gas that crosses the international boundary in Idaho and primarily serves clients in California. The Williams Pipeline Company serves the Pacific Northwest from Wyoming, with its main supply line crossing the Blue Mountains and joining western Washington gas transmission lines near the Washington/Oregon border. To meet future needs for the region for both domestic consumption and proposed commercial power generation plants, especially for peak times, geologic storage of natural gas is becoming a necessity.

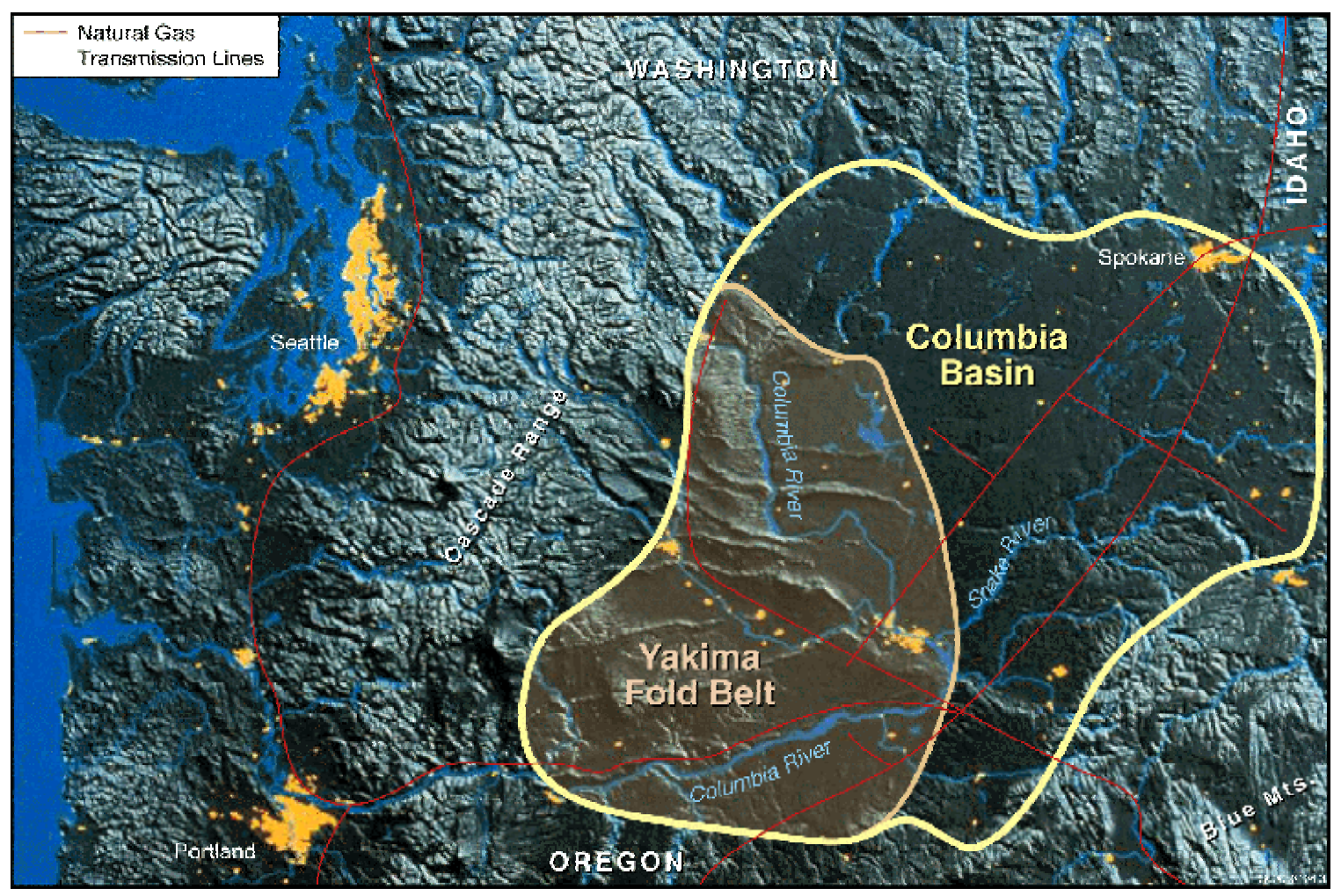

Figure 1.1. Natural Gas Supply Lines Serving Eastern Washington and Eastern Oregon 


\subsection{Traditional Storage Facilities}

In developing traditional storage facilities, natural gas storage operators look for reservoirs that will accept, hold, and release gas most efficiently. Targeted formations for natural gas storage contain high porosity and permeability and are well sealed and not overly complex or compartmentalized. Natural gas storage facilities are usually developed in one of three subsurface settings: depleted natural gas fields, salt domes, or aquifers. The Pacific Northwest has two existing subsurface, natural gas storage facilities. The Mist field in the Coast Range of northwest Oregon is an example of a depleted natural gas reservoir facility. The original Mist field produced natural gas from Eocene sediments. When the natural gas was depleted, the field was developed into a natural gas storage facility that is currently in operation. The second Pacific Northwest storage facility, the Jackson Prairie Storage field, is an example of an aquifer storage type. It is located along the Interstate- 5 corridor in the Challis Basin near Winlock, Washington (southwest Washington). It was never a source for natural gas, although some natural gas occurs in the sediments. Because of the favorable geologic structure conditions afforded by an anticline developed in Eocene marine sediments (like the Mist field), it was developed into a natural gas storage reservoir. East of the Cascades, similar sediments occur but they are at greater depths, making development of a similar gas storage facility more costly. However, natural gas occurrences in the Columbia River Basalt Group (CRBG) of eastern Washington and Oregon suggest that basalt flows might provide natural gas storage reservoirs.

\subsection{Natural Gas Occurrences in the Columbia Basin}

The Columbia Basin, which spans over $164,000 \mathrm{~km}^{2}$ of eastern Washington, northern Oregon, and western Idaho (Figure 1.1), is one of the last frontier provinces for petroleum exploration in the continental United States. The basin contains up to $4 \mathrm{~km}$ of layered Miocene lava flows of the Columbia River Basalt Group overlying more than $10 \mathrm{~km}$ of mid-Tertiary, non-marine arkosic sands (Campbell and Reidel 1994). In the western part of the basin, these basalt flows have been folded into a series of anticlines and synclines, some of which extend over $100 \mathrm{~km}$ in length and are 1 to $2 \mathrm{~km}$ wide.

The Rattlesnake Gas field, a low-pressure, anticlinal trap in the basalts, produced limited quantities of natural gas in the early 1900s (Figure 1.2). The presence of this gas field, and numerous natural gas occurrences in groundwater wells within the region, suggested that natural gas is present within and beneath the Columbia River basalt. To examine the potential of natural gas production for formations below the basalts, Chevron and Shell drilled a wildcat borehole in 1968 near the Rattlesnake gas field. They terminated drilling at a depth of 3,250 $\mathrm{m}$ below the ground surface, while still in the basalt.

In the late 1970s and 1980s, Shell Western Exploration and Production Company and ARCO actively investigated the region by drilling eight exploratory boreholes within the basin, and collected many miles of surface seismic data. Two wells, 1-23 Yakima Minerals and 1-9 BN, produced significant quantities of natural gas during testing (Campbell and Reidel 1994). One well, the 1-9 BN, also produced a small amount of condensate, but flared natural gas from the basalt flows during drilling. The six other wells had small natural gas shows, but no significant sustained gas flow. 


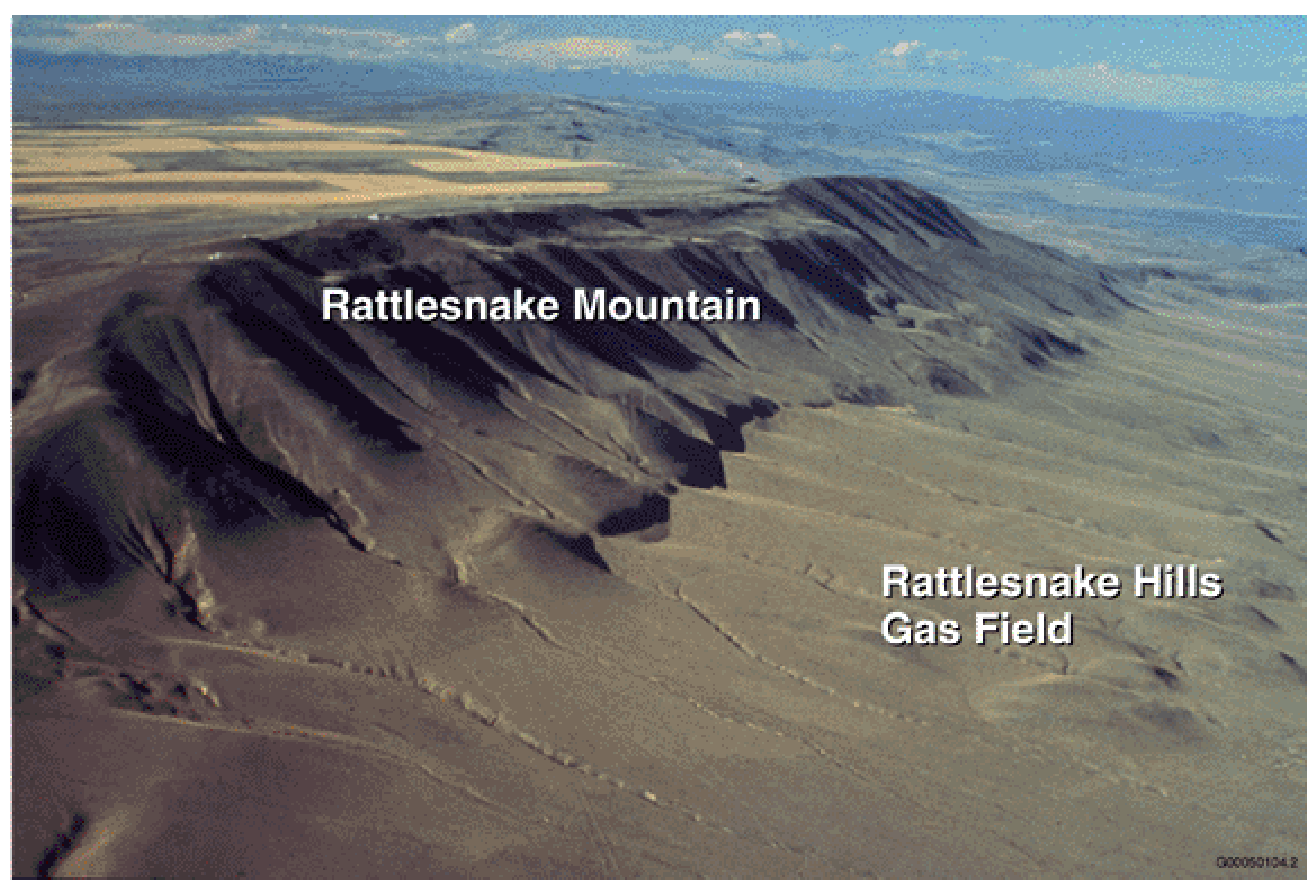

Figure 1.2. Rattlesnake Hills Gas Field in Southcentral Washington

The source bed(s) for the natural gas occurring at the Rattlesnake Hills gas field appears to be coals in Eocene to Oligocene fluvial sedimentary rocks that underlie the basalt (Johnson et al. 1993; Campbell and Reidel 1994). These source beds are similar to the formations occurring at the Mist field of northwest Oregon. Dense flow interior sections of the Columbia River basalt, together with clayey and tuffaceous sedimentary interbed layers occurring between basalt flows, form effective caprock seals for the deep, natural gas reservoirs. The high-angle faults in structurally deformed areas are believed to provide localized vertical pathways of enhanced permeability for the movement of natural gas occurring below the Columbia River basalt, to overlying zones of accumulation within permeable/porous basalt interflow zones. Similar localized vertical movement of hydrochemically distinct groundwaters within the basalts along similar structural features in the region has been noted by DOE (1988), Early et al. (1988), and Johnson et al. (1993).

Originally, anticlines within the basalt were thought to form structural traps for natural gas. It was soon realized, however, that these anticlines might be detached from sedimentary rocks underlying the base of the basalt. Although source rocks and caprocks were known to exist, the underlying sedimentary reservoir rock and trapping mechanism (as expressed structurally within the overlying basalts) became the target areas of the earlier exploration activities. The extent of natural gas trapped within basalt interflow zones was thought to be minor compared to that encountered below the basalt. Recently, the renewed interest in the Columbia Basin has focused on the natural gas occurring in basalt interflow zones as exploration targets, which supports the feasibility of managed, natural gas storage within basalts. 


\subsection{Purpose, Scope, and Organization of Report}

The presence of natural gas and natural gas fields within the basalts indicates a high potential for development of natural gas storage facilities within selected horizons of the Columbia River Basalt Group. Several companies have recently initiated exploration programs to assess this potential. However, a number of factors have slowed the progress of these exploration/feasibility programs. These factors include: the unconventional aspects of gas storage within basalt, the high cost of exploration (drilling) activities in basalt, and recent (2001-2002) economic uncertainties within the natural gas market of the United States.

To assess the potential of developing natural gas storage in basalt aquifers of the Columbia Basin, the U.S. Department of Energy (DOE) National Energy Technology Laboratory asked Pacific Northwest National Laboratory (PNNL) to compile existing information pertaining to permeable, groundwaterproducing zones within the CRBG (e.g., hydraulic/storage properties). These zones would be the focus of natural gas storage. This compilation, together with the authors' combined $>75$ years of experience in basalt studies, provides the basis of a report that can be used as a guide to explore the feasibility of establishing natural gas storage reservoirs within the CRBG in the Columbia Basin. The report is designed to provide companies interested in natural gas storage within basalts a detailed framework for the design and conduct of exploration characterization activities.

The report is organized into eight sections. Sections 2.0, 3.0, and 4.0 provide background information on the basalt, structures in the basalt and the aquifer systems. Section 5.0 discusses the regulatory requirements for the development of a natural gas storage facility in basalt. Section 6.0 describes methods necessary to adequately characterize the basalt, geologic structures, and the aquifer system. Section 7 provides a summary and conclusions. References are provided in Section 8.0. Appendixes A through $\mathrm{G}$ provide examples, datasets, and details of methodologies discussed in the text. Those readers interested in a quick overview of the geotechnical issues associated with gas storage in basalt aquifers are advised to skip to Sections 6.0 and 7.0 and then return to the main body of the report as time and interest dictate. 


\subsection{Stratigraphy, Structural Framework, and Geophysical Studies}

An understanding of subsurface physical conditions in the Columbia Basin is fundamental to geologic storage of natural gas in this area. This section provides a detailed account of our current understanding of structural, stratigraphic, tectonic, and geomorphic conditions for one of the world's largest lava flow fields. The detailed descriptions and linkage to the scientific literature provided in this section are necessary to support drilling and testing permits, facility permits, environmental impact assessments, and licensing applications as well as for site selection and characterization. Thus, this section serves as the primary source document for geologic and related information.

\subsection{Regional Setting and Geologic History}

\subsubsection{Setting}

The Columbia Basin is an intermontane basin between the Cascade Range and the Rocky Mountains (Figure 2.1) filled with Cenozoic volcanic rocks and sediments. This basin forms the northern part of the Columbia Basin physiographic province (Fenneman 1931) and the Columbia River flood-basalt province (Reidel and Hooper 1989). In the central and western parts of the Columbia Basin, CRBG overlies Tertiary continental sedimentary rocks that, in turn, overlie the crystalline basement. These rocks are overlain by late Tertiary and Quaternary fluvial and glaciofluvial deposits (Campbell 1989; Reidel et al. 1989a; Smith et al. 1989; DOE 1988). In the eastern part of the Columbia Basin, a thin $(<100 \mathrm{~m})$ sedimentary unit separates the basalt and underling crystalline basement and a thin $(<10 \mathrm{~m})$ veneer of eolian sediments overlies the basalt (Reidel et al. 1989a).

Beginning in the late 1950s and continuing through the 1980s, deep boreholes were drilled for both hydrocarbon exploration in the CRBG Columbia Basin and various projects at DOE's Hanford Site. These boreholes provided detailed data on the CRBG rocks and the underlying pre-basalt sediments (Reidel et al. 1994, 1998). The thickness of the basalt and the pre-basalt sediments was found to vary as a result of different tectonic environments. The western edge of the late Precambrian/early Paleozoic continental margin and Precambrian North American craton is shown in Figure 2.2. The stratigraphy on the craton consists of Columbia River Basalt Group rocks overlying crystalline basement; the crystalline basement is continental crustal rock typical of that which underlies much of western North America. The stratigraphy west of the craton consists of 4 to $5 \mathrm{~km}$ of CRBG rocks overlying more than $6 \mathrm{~km}$ of Eocene and Oligocene sediments. This in turn overlies accreted terranes of Mesozoic age.

The Columbia Basin includes two structural subdivisions or subprovinces: the Yakima Fold Belt and the Palouse Slope (Figure 2.1). The Yakima Fold Belt includes the western and central parts of the Columbia Basin and consists of a series of anticlinal ridges and synclinal valleys with northwest to southeast structural trends. The Palouse Slope is the eastern part of the basin and is the least deformed subprovince with only a few faults and low amplitude, long wavelength folds on an otherwise gently westward dipping paleoslope (Swanson et al. 1980). The Yakima Fold Belt overlies rock west of the craton, and the Palouse Slope overlies the craton. 


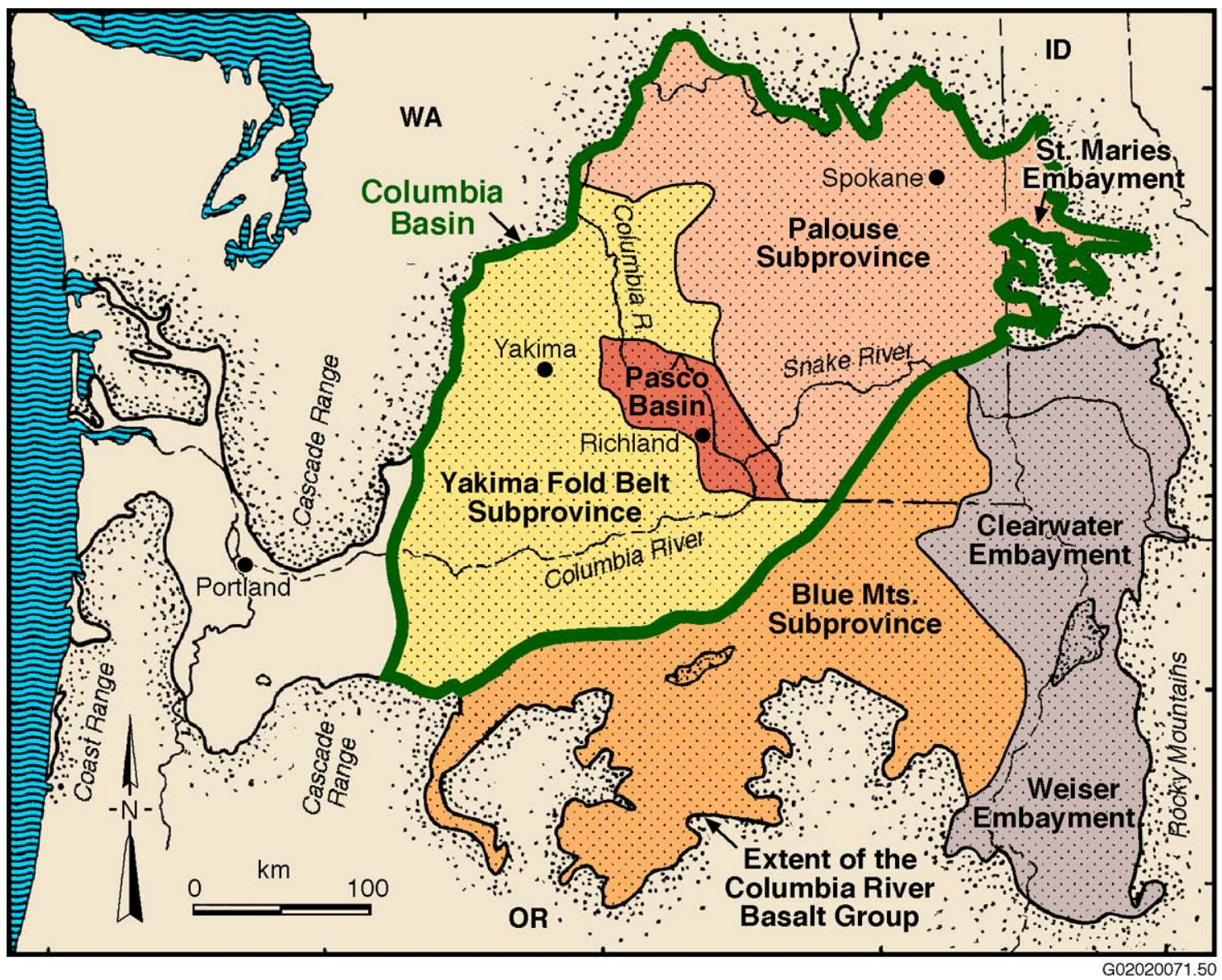

Figure 2.1. Setting and Extent of the Columbia River Basalt Group in the Pacific Northwest Columbia Basin

The Blue Mountains subprovince (Figure 2.1) of the Columbia River flood-basalt province forms the southeastern boundary of the Columbia Basin. The Blue Mountains is a northeast-trending anticlinorium that extends $250 \mathrm{~km}$ from the Oregon Cascades along the southeastern edge of the Columbia Basin. It overlies the accreted terrane rock assemblages and Eocene and Oligocene volcaniclastic rocks.

\subsection{Stratigraphy}

The generalized stratigraphy of the Columbia Basin is summarized in Table 2.1. The main rocks exposed in the basin are the Columbia River Basalt Group, intercalated sedimentary rocks of the Ellensburg Formation, and younger sedimentary rocks that include the Ringold Formation, Snipes Mountain conglomerate, the Thorp gravels, Pleistocene cataclysmic flood deposits of the Hanford formation, and other localized strata. 


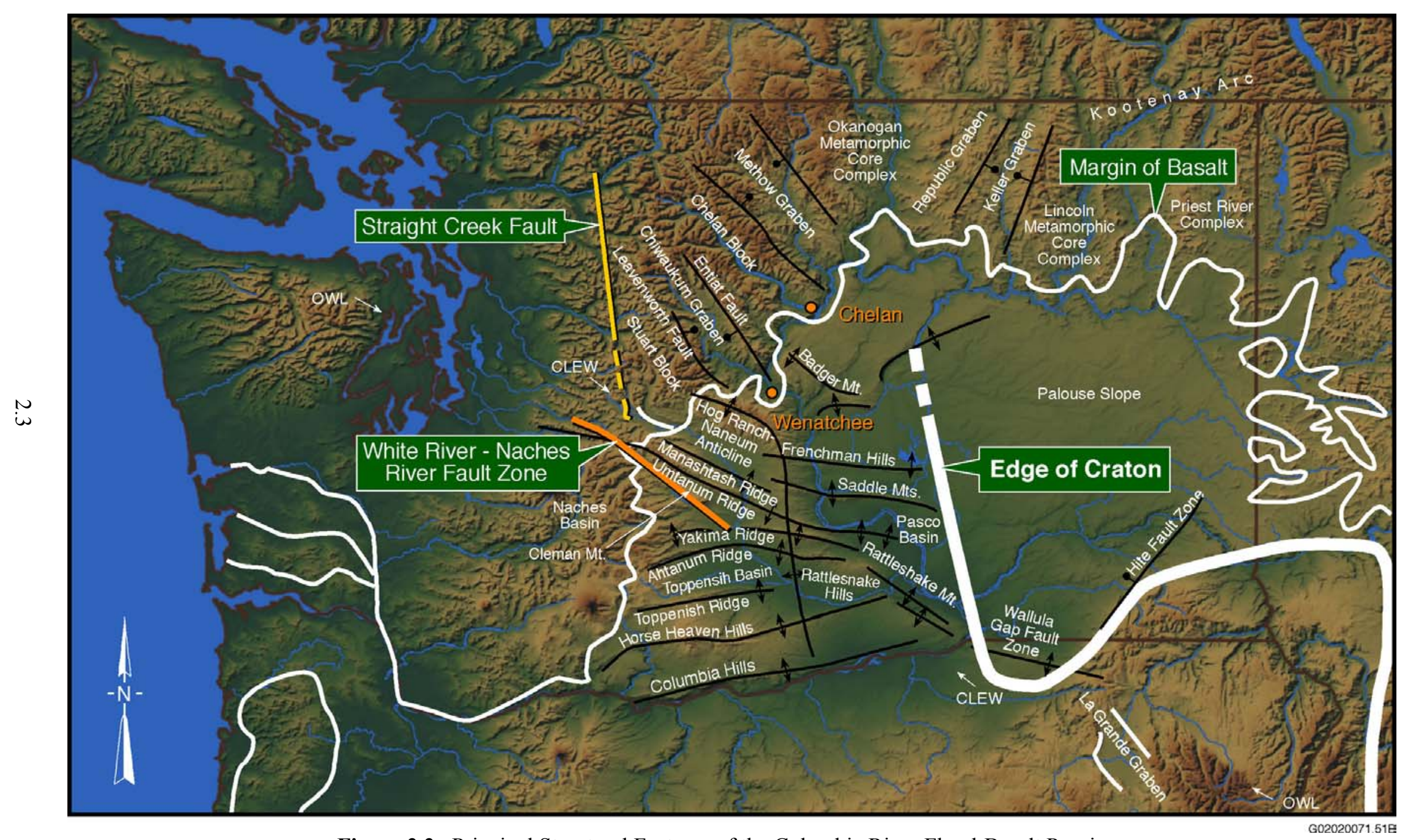

Figure 2.2. Principal Structural Features of the Columbia River Flood-Basalt Province 
Table 2.1. Characteristics of Stratigraphic Units

\begin{tabular}{|c|c|c|c|c|c|c|}
\hline Unit & Age & Thickness & Distribution & Lithology & Stratigraphic Trends & Tectonic Implications \\
\hline $\begin{array}{l}\text { Columbia River } \\
\text { Basalt Group } \\
\text { (Reidel and } \\
\text { Hooper 1989) }\end{array}$ & $\begin{array}{l}17 \mathrm{Ma} \\
\text { to } \\
6 \mathrm{Ma}\end{array}$ & \begin{tabular}{|l|} 
As much as \\
$4.0 \mathrm{~km}$ in central \\
Columbia Basin
\end{tabular} & $\begin{array}{l}\text { Extent defines the } \\
\text { Columbia Basin }\end{array}$ & $\begin{array}{l}\text { Tholeiitic flood- } \\
\text { basalt flows }\end{array}$ & $\begin{array}{l}\text { Older, more voluminous units } \\
\text { cover entire area; younger, } \\
\text { thinner units occur in eastern } \\
\text { and central Columbia Basin }\end{array}$ & $\begin{array}{l}\text { Records stability in the } \\
\text { eastern Columbia Basin, } \\
\text { subsidence in the central and } \\
\text { western basin, and Miocene } \\
\text { uplift of anticlinal ridges }\end{array}$ \\
\hline $\begin{array}{l}\text { Upper Ellensburg } \\
\text { Formation (Fecht } \\
\text { et al. 1987; Smith } \\
\text { 1988) }\end{array}$ & $\begin{array}{l}10 \mathrm{Ma} \\
\text { to } \\
4.7 \mathrm{Ma}\end{array}$ & $\begin{array}{l}\text { As much as } \\
350 \mathrm{~m} \text { in } \\
\text { Yakima Basin }\end{array}$ & $\begin{array}{l}\text { Nile, Selah, Yakima, } \\
\text { Kittitas, Satus, and } \\
\text { Toppenish Basins; } \\
\text { also in Goldendale } \\
\text { area }\end{array}$ & $\begin{array}{l}\text { Basalt sidestream } \\
\text { gravels, lahars, and } \\
\text { volcaniclastic sedi- } \\
\text { ments derived from } \\
\text { Cascade Range, } \\
\text { siliciclastics depos- } \\
\text { ited by Columbia } \\
\text { River }\end{array}$ & $\begin{array}{l}\text { Volcaniclastic sediments } \\
\text { common in west; siliciclastic } \\
\text { sediments in east; gravels } \\
\text { record channel system } \\
\text { positions }\end{array}$ & $\begin{array}{l}\text { Shifting channel deposits } \\
\text { reflect displacement of river } \\
\text { course caused by ridge uplift } \\
\text { and basin subsidence, espe- } \\
\text { cially in the Yakima River } \\
\text { and Columbia River } \\
\text { southwest of Pasco Basin }\end{array}$ \\
\hline $\begin{array}{l}\text { Snipes Mountain } \\
\text { Conglomerate } \\
\text { (Schminke 1964; } \\
\text { Fecht et al. 1987; } \\
\text { Smith 1988) }\end{array}$ & $\begin{array}{l}8.5 \text { to } \\
<8.5 \mathrm{Ma}\end{array}$ & 30 to $150 \mathrm{~m}$ & $\begin{array}{l}\text { Lower Yakima valley } \\
\text { and across western } \\
\text { Horse Heaven Hills; } \\
\text { also east Toppenish } \\
\text { Basin }\end{array}$ & $\begin{array}{l}\text { Quartzose gravel and } \\
\text { siliciclastic sands; } \\
\text { interbedded volcani- } \\
\text { clastic sediments } \\
\text { common in eastern } \\
\text { Toppenish Basin }\end{array}$ & $\begin{array}{l}\text { Linear channel tracts from } \\
\text { Sunnyside Gap up Moxie and } \\
\text { Yakima valleys and then } \\
\text { across Horse Heaven Hills to } \\
\text { Goldendale area }\end{array}$ & $\begin{array}{l}\text { Records Columbia River } \\
\text { course prior to diversion into } \\
\text { Pasco Basin }\end{array}$ \\
\hline
\end{tabular}


Table 2.1. (contd)

\begin{tabular}{|c|c|c|c|c|c|c|}
\hline Unit & Age & Thickness & Distribution & Lithology & Stratigraphic Trends & Tectonic Implications \\
\hline $\begin{array}{l}\text { Lake deposits } \\
\text { overlying Snipes } \\
\text { Mountain Cgl. } \\
\text { (Smith 1988) }\end{array}$ & $\begin{array}{l}<4.7 \pm \\
0.3 \mathrm{Ma}\end{array}$ & $>30 \mathrm{~m}$ & $\begin{array}{l}\text { Lower Yakima valley } \\
\text { near Sunnyside and } \\
\text { Granger and on } \\
\text { Ahtanum Ridge }\end{array}$ & $\begin{array}{l}\text { Laminated silts and } \\
\text { fine-grained } \\
\text { sandstone }\end{array}$ & $\begin{array}{l}\text { Equivalent to upper Ellens- } \\
\text { burg Formation; laterally } \\
\text { correlative with upper } \\
\text { Ringold lake deposits(?) }\end{array}$ & $\begin{array}{l}\text { Large lakes formed as a } \\
\text { result of regional gradient } \\
\text { changes }\end{array}$ \\
\hline $\begin{array}{l}\text { Thorp Gravel } \\
\text { (Waitt 1979; } \\
\text { Bentley and } \\
\text { Campbell 1983; } \\
\text { Campbell 1983; } \\
\text { Fecht et al. 1987; } \\
\text { Smith 1988) } \\
\end{array}$ & $\begin{array}{l}3.7 \pm \\
0.2 \mathrm{Ma} \\
\text { to } \\
<3.64 \\
\pm 0.74\end{array}$ & Up to $200 \mathrm{~m}$ & $\begin{array}{l}\text { Kittitas Basin, Selah } \\
\text { Basin, and south into } \\
\text { Yakima Basin as far as } \\
\text { Toppenish }\end{array}$ & $\begin{array}{l}\text { Basaltic sidestream } \\
\text { gravels and poly- } \\
\text { mictic mainstream } \\
\text { gravels deposited as } \\
\text { an alluvial wedge off } \\
\text { the Cascades }\end{array}$ & $\begin{array}{l}\text { Old terraces of the Yakima } \\
\text { River }\end{array}$ & $\begin{array}{l}\text { Records uplift and erosion of } \\
\text { Cascades and Yakima folds }\end{array}$ \\
\hline $\begin{array}{l}\text { Pliocene- } \\
\text { Pleistocene strata } \\
\text { (DOE 1988; } \\
\text { Baker et al. } \\
\text { 1991) }\end{array}$ & $\begin{array}{l}<3.5 \text { to } \\
\sim 1 \mathrm{Ma}\end{array}$ & $\mathrm{Up}$ to $10 \mathrm{~m}$ & $\begin{array}{l}\text { Regional distribution } \\
\text { in basins and on } \\
\text { uplifts }\end{array}$ & $\begin{array}{l}\text { Pedogenic } \\
\text { carbonates, basaltic } \\
\text { alluvium, eolian } \\
\text { deposits, and } \\
\text { multilithologic } \\
\text { quartzose gravels } \\
\end{array}$ & $\begin{array}{l}\text { Unconformably overlies } \\
\text { middle Pliocene and older } \\
(>3.5 \mathrm{Ma}) \text { strata; discon- } \\
\text { tinuous horizons in and } \\
\text { around basins and uplifted on } \\
\text { ridges }\end{array}$ & $\begin{array}{l}\text { Deposited after post-3.5-Ma } \\
\text { base level change that led to } \\
\text { regional incision of main } \\
\text { rivers; also records more } \\
\text { recent uplift of anticlinal } \\
\text { ridges }\end{array}$ \\
\hline $\begin{array}{l}\text { Hanford } \\
\text { formation (Fecht } \\
\text { et al. 1987; Baker } \\
\text { et al. 1991) }\end{array}$ & $\begin{array}{l}<1 \mathrm{Ma} \\
\text { to } \sim 12 \\
\mathrm{Ka}\end{array}$ & $\mathrm{Up}$ to $70 \mathrm{~m}$ & $\begin{array}{l}\text { Pasco Basin, } \\
\text { Toppenish Basin, } \\
\text { Yakima Basin, Walla } \\
\text { Walla Basin }\end{array}$ & $\begin{array}{l}\text { Pebble-to-boulder } \\
\text { gravel, sand, and } \\
\text { laminated silts } \\
\text { deposited by cata- } \\
\text { clysmic flood waters } \\
\text { released from glacial } \\
\text { Lake Missoula }\end{array}$ & $\begin{array}{l}\text { Common throughout region } \\
\text { below elevations of } \\
\text { approximately } 400 \mathrm{~m}\end{array}$ & $\begin{array}{l}\text { Strata locally offset by faults } \\
\text { recording Pleistocene } \\
\text { deformation }\end{array}$ \\
\hline $\begin{array}{l}\text { Quaternary } \\
\text { alluvium (Baker } \\
\text { et al. 1991) }\end{array}$ & $<2 \mathrm{Ma}$ & 0 to $75 \mathrm{~m}$ & Regional & $\begin{array}{l}\text { Locally derived } \\
\text { alluvial and colluvial } \\
\text { deposits }\end{array}$ & $\begin{array}{l}\text { Laterally discontinuous strata } \\
\text { common on basin margins and } \\
\text { on uplifted ridges }\end{array}$ & $\begin{array}{l}\text { Folded and faulted deposits } \\
\text { record neotectonic deforma- } \\
\text { tion in region }\end{array}$ \\
\hline
\end{tabular}




\subsubsection{Stratigraphy Older than the Columbia River Basalt Group}

Rocks older than the CRBG are only exposed along the margin of the Columbia Basin. Stratigraphy along the margin of the CRBG is complex and varies widely in both age and lithology (Campbell 1989). A series of sedimentary basins formed along the northwest margin in early Tertiary time (Tabor et al. 1984; Campbell 1989). Tectonic "blocks" or uplifts exposing pre-Tertiary rocks that have a northwest-trending structural grain now separate these basins (Figure 2.2).

Along the northeast and east margins of the Columbia Basin, the CRBG laps onto Paleozoic rocks and Precambrian metasedimentary rocks interspersed with crystalline rocks. These include Proterozoic metasediments of the Windermere and Belt Supergroups, miogeosynclinal lower Paleozoic shallow marine rocks, rocks associated with the Kootenay Arc, granitics of the Idaho Batholith, and other Jurassic and Cretaceous intrusions (Stoffel et al. 1991). The structural grain of these rocks is north to northeast.

To the south and southwest, lower to middle Tertiary volcanic rocks and related volcaniclastic rocks directly underlie the CRBG. The rocks include tuffs, lahars, and tuffaceous sedimentary rocks interbedded with rhyolite, andesite, and basalt flows and breccias; these are primarily assigned to the Clarno and John Day Formations. Older (Cretaceous-Permian) volcaniclastic sediments and metasediments of accreted intraarc- and volcanic arc-origin are exposed along the southeast margin of the CRBG (Walker and MacLeod 1991).

To the west, younger volcanic rocks erupted from the High Cascades cover the CRBG and obscure older rocks. Rare inliers of older accreted Paleozoic and Mesozoic rocks, such as the Rimrock inlier, are exposed below those rocks.

Only those sedimentary rocks associated with the northwest margin of the CRBG are thought to be present under the interior of the Columbia Basin. However, units exposed along the north, east, and south margins of the CRBG probably contributed to the sedimentary package because they were extensively eroded by westward flowing rivers (Fecht et al. 1987b) and their deposits accumulated in the subsiding western part of the basin.

\subsubsection{Stratigraphy Younger than the Columbia River Basalt Group}

Most post-CRBG sediments are confined to the synclinal valleys of the Yakima Fold Belt, which reflect the structural development of the Columbia Basin (Fecht et al. 1987). The upper Miocene to middle Pliocene record of the Columbia River system in the Columbia Basin is represented by the upper Ellensburg Formation, the Ringold Formation, and the Snipes Mountain Conglomerate (Table 2.1). The Thorp Gravel time (4.1 Ma), river terrace deposits, record the post-CRBG history of the upper Yakima River (Waitt 1979; Campbell 1983). Except for local deposits (for example, the "Pliocene-Pleistocene unit" and the "early Palouse soil" [DOE 1988]), there is a hiatus in the stratigraphic record between the end of the Ringold (3.4 Ma), Thorp Gravel (4.1 Ma), and the Pleistocene (1.6 Ma). Pleistocene to Recent sediments overlying the CRBG include flood gravels and slackwater sediments of the Hanford formation, terrace gravels of the Columbia, Snake, and Yakima rivers, and eolian deposits including the Palouse Formation (Keroher 1966) in eastern Washington. 


\subsubsection{Stratigraphy of the Columbia River Basalt Group}

The CRBG forms the bedrock framework for the Columbia Basin. The CRBG flows cover most of eastern Washington, northeast Oregon, and portions of western Idaho. Individual flows typically extend over many tens of thousands of square kilometers. Flows of the Saddle Mountains Basalt are exposed at the surface, with underlying flows of the Wanapum and Grande Ronde Basalts mainly in the subsurface. Intercalated with, and in some places overlying, the CRBG are epiclastic and volcaniclastic sedimentary rocks of the Ellensburg Formation (Waters 1961; Swanson et al. 1979b; Smith 1988). Most volcaniclastic material occurs in the western basin; in the central and eastern basin, epiclastic sediments of the ancestral Clearwater and Columbia rivers form the dominant lithologies (Fecht et al. 1982, 1987).

The CRBG consists of a thick sequence of about 300 continental tholeiitic flood-basalt flows that were erupted over an 11-million-year period from about 17 to $6 \mathrm{Ma}$ (Figure 2.3; Swanson et al. 1979c). These flood-basalt flows cover more than $200,000 \mathrm{~km}^{2}$ in Washington, Oregon, and western Idaho (Figure 2.1) and have a total estimated volume of more than $224,000 \mathrm{~km}^{3}$ (Camp and Ross 2000). The source for these flows was a series of north-northwest-trending linear fissure systems located in eastern Washington, eastern Oregon, and western Idaho (generally within the Palouse subprovince of Figure 2.1).

Although the eruption of CRBG flows spans an 11-million-year period, the majority of the CRBG ( $>96$ volume percent) was erupted over a period of about 2.5 million years, between 17 to $14.5 \mathrm{Ma}$ (Swanson et al. 1979c) (Figure 2.4). During this peak period of activity, many flows that were erupted were of extraordinary size, exceeding $2,500 \mathrm{~km}^{3}$ in volume, and traveled many hundreds of kilometers from their vent system.

\subsubsection{Stratigraphic Subdivisions of the Columbia River Basalt Group}

Detailed study and mapping of the Columbia River flood basalts have demonstrated that significant variations in lithological, geochemical, and paleomagnetic polarity properties exist between flows (and packets of flows), which has allowed for the establishment of stratigraphic units that can be reliably identified and correlated on a regional basis (e.g., see Swanson et al. 1979c; Beeson et al. 1985; Reidel et al. 1989b). Figure 2.3 presents the current stratigraphic nomenclature for the CRBG. Based on these abilities to recognize the flows, the CRBG has been divided into five formations (Swanson et al. 1979c): Imnaha, Grande Ronde, Picture Gorge, Wanapum, and Saddle Mountains Basalt.

Figure 2.5 is a geologic map showing the Columbia River Basalt Group units exposed at the surface, based upon distribution maps for each unit (Figure 2.3) shown in Appendix G and provides methodology for identifying basalt flows. Figure 2.6 shows the thickness of the entire CRBG, and Figure 2.7 shows a cross-section through the most voluminous formation, the Grande Ronde Basalt. The cross-section demonstrates that the greatest thickness of basalt occurs in the center of the Columbia Basin in the Pasco Basin. 


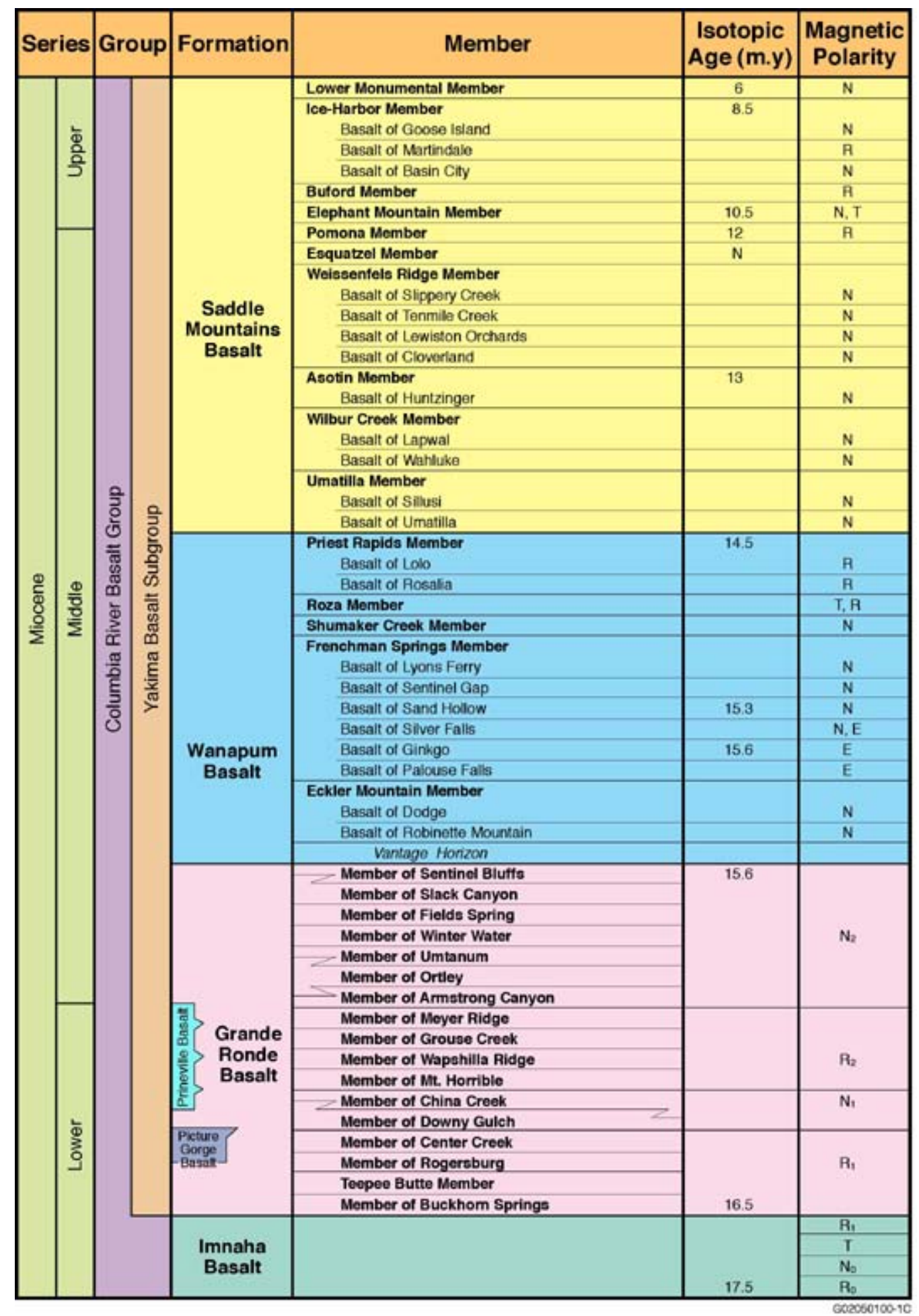

Figure 2.3. Nomenclature for the Columbia River Basalt Group. Sediment layers of the Ellensburg Formation interbedded with the basalt are not shown. 


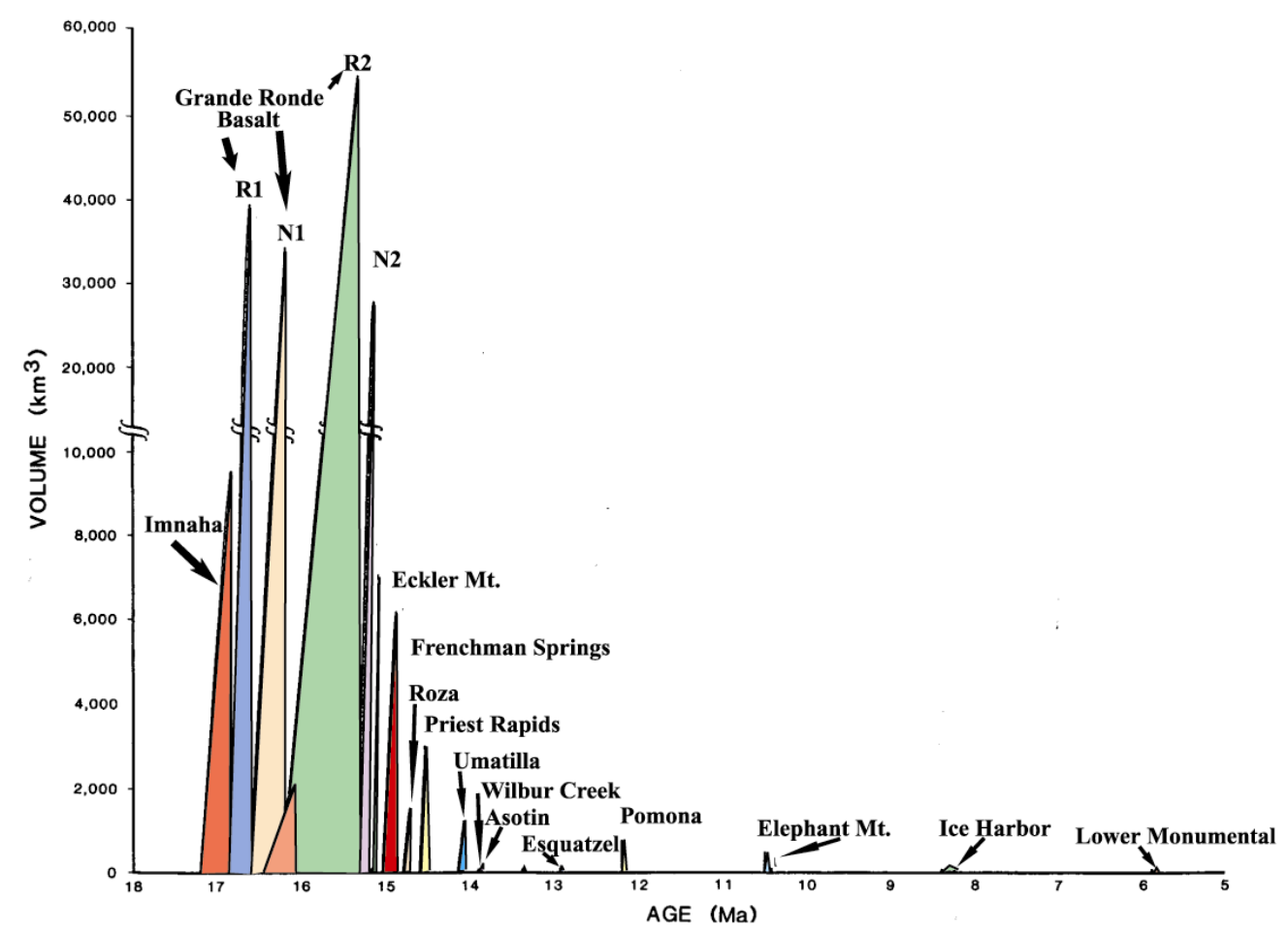

Figure 2.4. Volume of Columbia River Basalt Group Eruptions Over Time

\subsection{Major Internal Basalt Flow Features}

Intraflow structures are primary, internal features or stratified portions of basalt flows exhibiting grossly uniform macroscopic characteristics. These features originate during the emplacement and solidification of each flow and result from variations in cooling rates, degassing, thermal contraction, and interaction with surface water. They are distinct from features formed by tectonic processes. Appendix A contains a catalog of Columbia River Basalt flow features described below. The hydraulic properties for intraflow structures are described in Section 3.2.

Columbia River Basalt Group flows typically consist of a permeable flow top, a dense, relatively impermeable flow interior, and a flow bottom of variable thickness (Figure 2.8; DOE 1988). Figure 2.8 depicts the types of intraflow structures that are typically observed in a basalt flow; most flows do not show a complete set of these structures. Sedimentary layers (interbeds) and basalt intraflow zones (vesicular flow tops, brecciated flow tops, basal pillow complexes, and basal breccia zones) serve as the primary aquifers in the region, while dense flow interiors commonly act as aquitards. The contact zone between two individual basalt flows (i.e., between a flow top and overlying basalt flow bottom) is referred to as an interflow zone. 


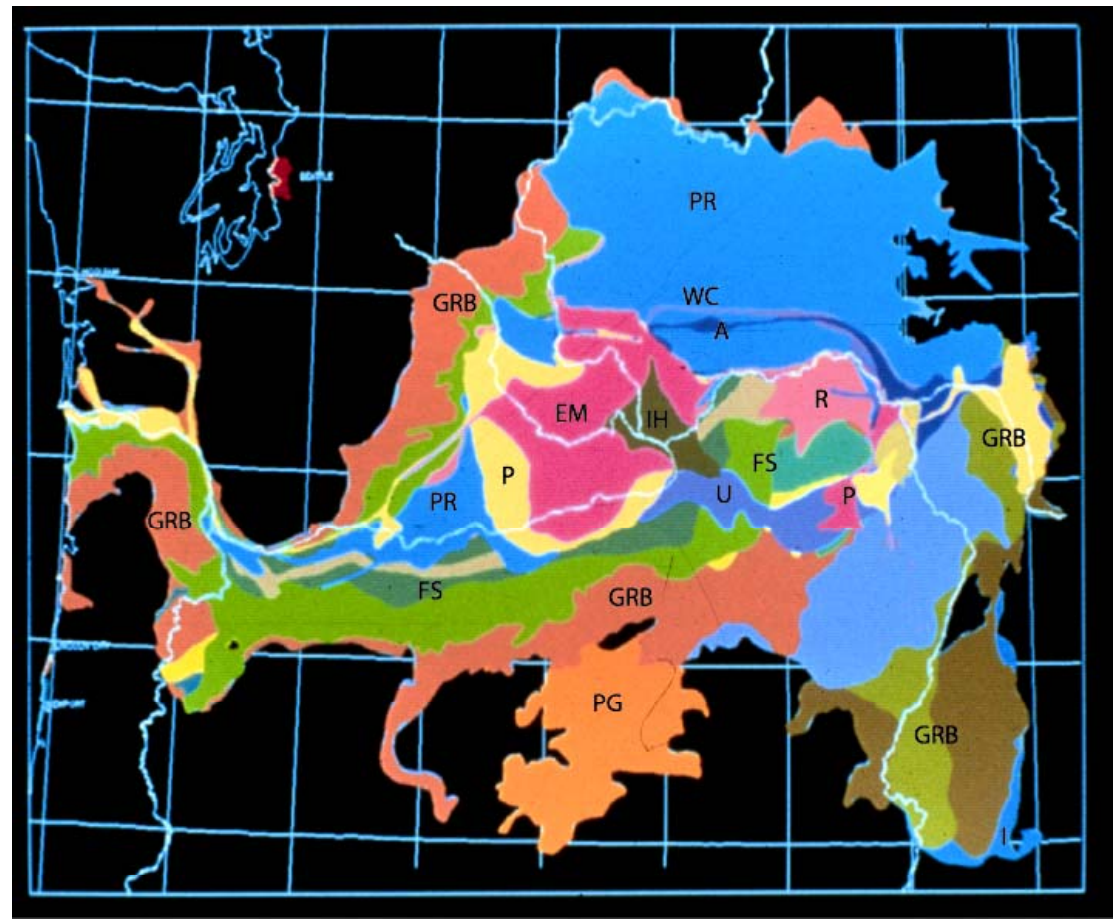

(a)

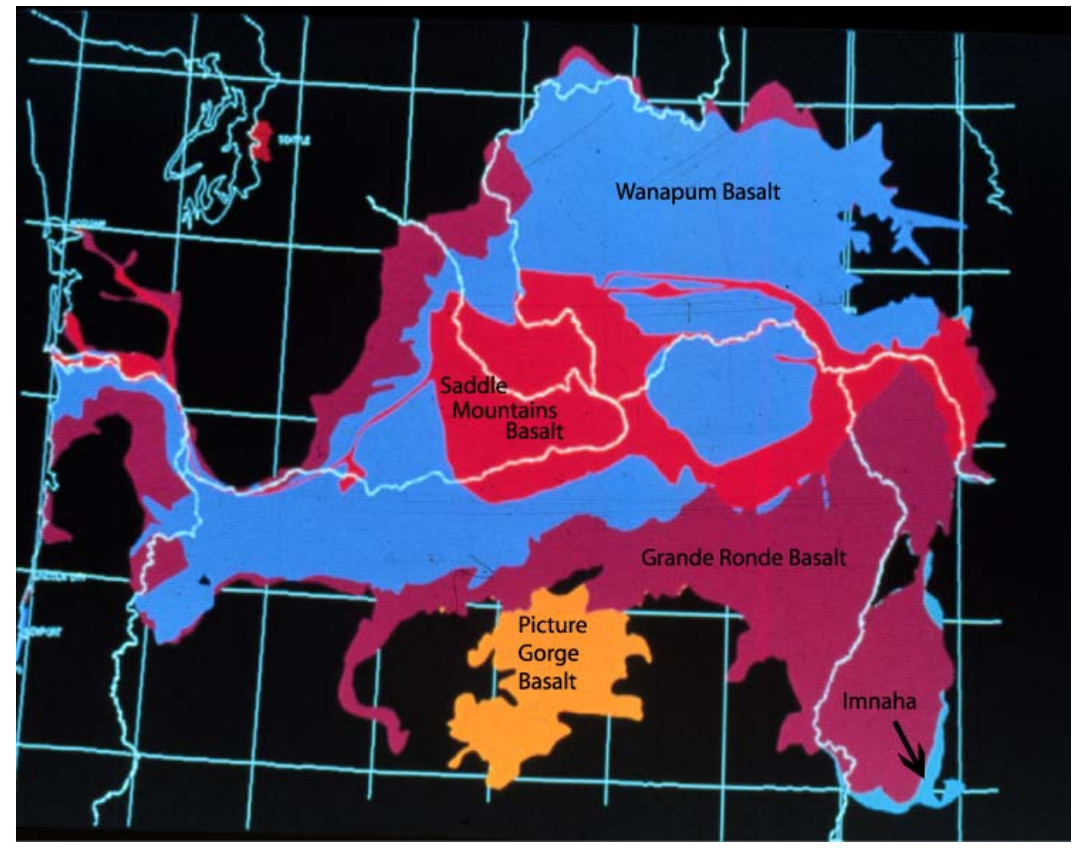

(b)

Figure 2.5. Geologic Map of the Columbia River Basalt Group. (a) Geologic map showing individual units. (Appendix $\mathrm{G}$ provides an explanation for each unit using youngest to oldest distribution maps.) (b) Distribution of Five Formations of the Columbia River Basalt Group. 


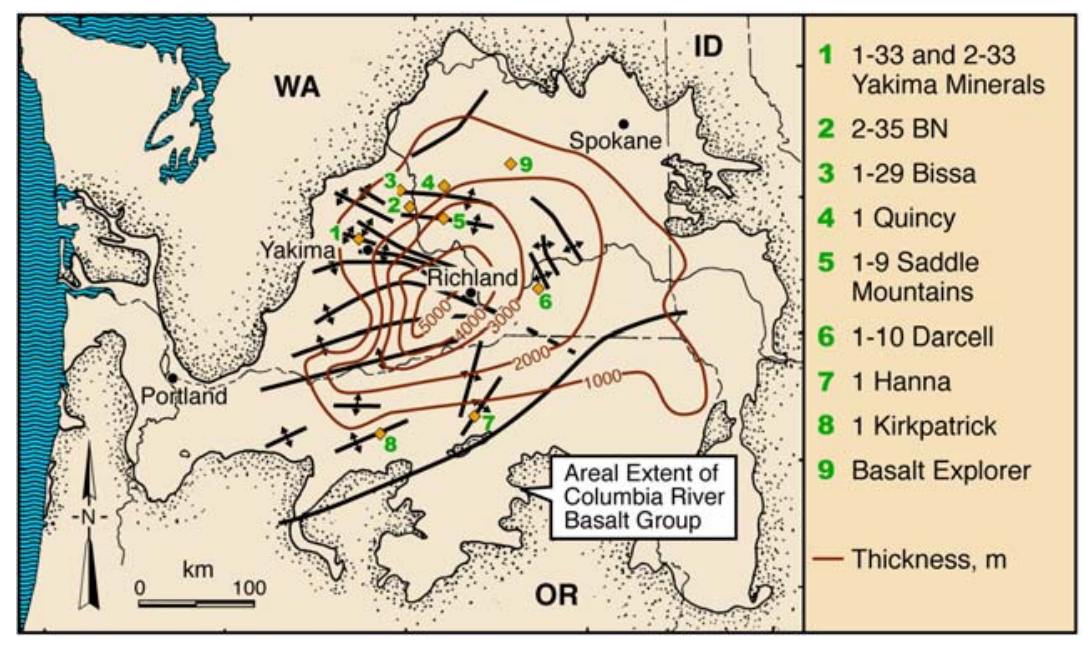

Figure 2.6. Thickness Map of the Columbia River Basalt Group

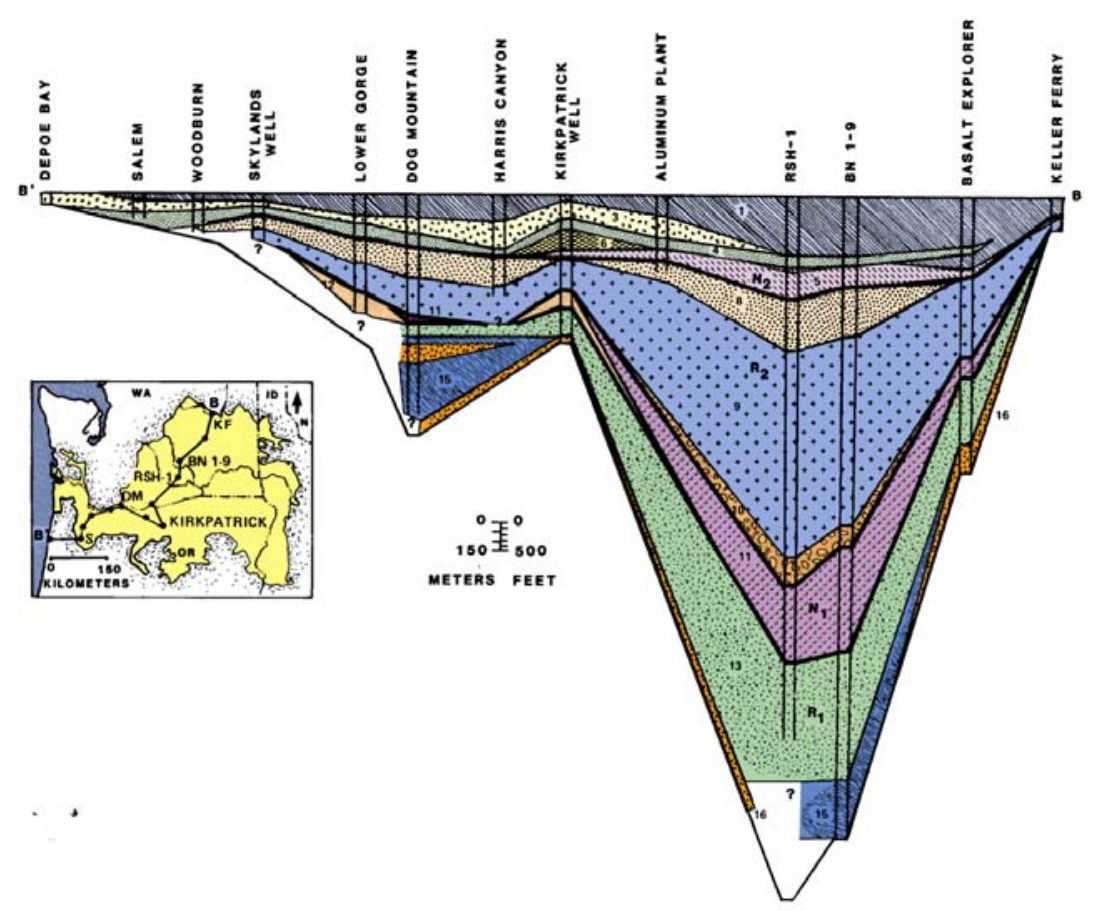

Figure 2.7. Cross-Section Through the Columbia Basin Showing the Thickness Variation of the Grande Ronde Basalt. Member of Sentinel Bluffs, Member of Slack Canyon, Member of Fields Spring, Member of Winter Water, Member of Umtanum, Member of Ortley, Member of Armstrong Canyon, Member of Meyer Ridge, Member of Grouse Creek, Member of Wapshilla Ridge, Member of Mt. Horrible, Member of China Creek, Member of Downy Gulch, Member of Center Creek, Member of Rogersburg, Member of Teepee Butte, Member of Buckhorn Springs 


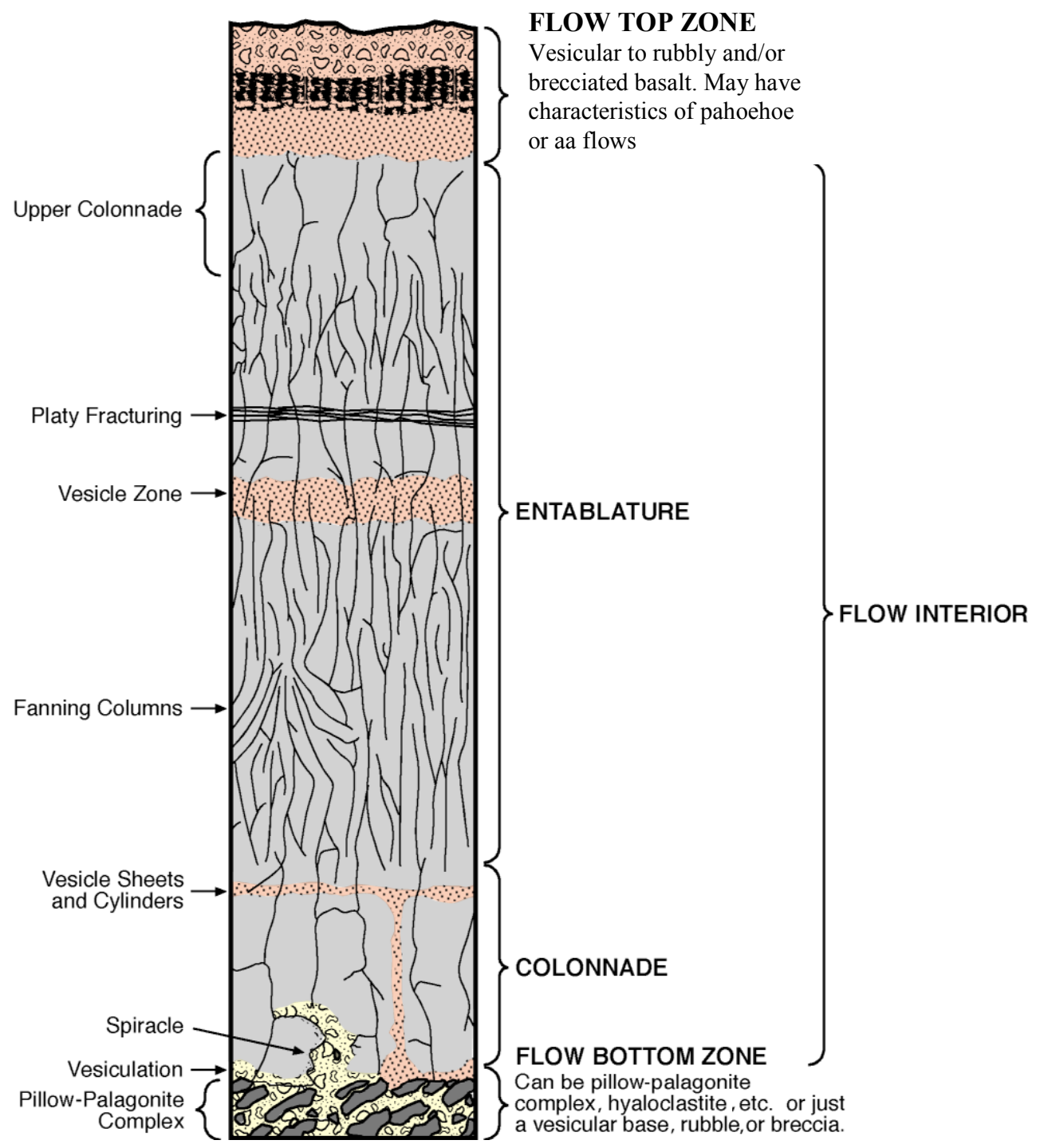

Figure 2.8. Major Basalt Flow Features of a Columbia River Basalt Group Lava Flow

\subsubsection{Flow Top}

The flow top is the chilled, glassy upper crust of the flow. It may consist of vesicular to scoriaceous basalt, displaying pahoehoe, or aa characteristics, or it may be rubbly to brecciated (Waters 1960; Diery 1967; Swanson and Wright 1981), as described on the next page. Typically, the flow top comprises approximately $10 \%$ of the thickness of a flow; however, it can be as thin as a few centimeters or occupy almost the entire flow thickness.

- Pahoehoe. Pahoehoe flow top is a type of lava flow that has a glassy, smooth, and billowy or undulating surface. Almost all CRBG flows are classified as pahoehoe. The surface is referred to as ropy. 
- Aa. An aa lava flow is one that has a rough, fragmented surface. It is blocky lava consisting of scoria. CRBG lavas are not considered to be aa lava flows. The closest similarity is the rubbly to brecciated flow top.

- Rubbly to brecciated flowtop. Flow top breccia occurs as a zone of angular to subrounded, broken volcanic rock fragments that may or may not be supported by a matrix and is located adjacent to the upper contact of the lava flow. An admixture of vesicular and nonvesicular clasts bound by the original glass often characterizes the breccia zone. The percentage of the breccia to rubbly surface is typically less that $30 \%$ but locally can be as much as $50 \%$ of the flow. This type of flow top usually forms from a cooled top that is broken up and carried along with the lava flow before it ceases movement.

\subsubsection{Flow Bottom}

The basal part of a Columbia River basalt lava flow is predominantly a glassy, chilled zone a few centimeters thick that may be vesicular. Where basalt flows encounter bodies of water or saturated sediments, the following features may occur:

- Pillow-palagonite complexes. Discontinuous pillow-shaped structures of basalt formed as basalt flows into water. The space between the pillows is usually composed of hydrated basaltic glass (palagonite) and hyaloclastite.

- Hyaloclastite complexes. These are deposits resembling tuff and form when basalt shatters as it flows into water.

- Foreset bedded breccias. These form as basalt flows into water and build out their own delta. Hyaloclastite and pillow-palagonite complexes usually compose the foreset beds.

- Peperites. Breccia-like mixture of basalt (or hyaloclastite or palagonite) and sediment. Forms as basalt burrows into sediments, especially wet sediments.

- Spiracles. A fumarolic vent-like feature that forms due to a gaseous explosion in fluid lava that flows over water-saturated soils or ground.

Typically, many thick flow bottoms observed within CRBG flows are associated with pillowpalagonite zones. Pillow-palagonite zones have been observed that are greater than $23 \mathrm{~m}$ thick and constitute more than $30 \%$ of the flow.

\subsubsection{Flow Interior}

Within the interior of a basalt flow, the predominant intraflow structures are zones characterized by patterns of cooling joints. These are commonly referred to as colonnade and entablature (Tomkeieff 1940). 
The colonnade consists of relatively well-formed polygonal columns of basalt, usually vertically oriented and typically $1 \mathrm{~m}$ in diameter or larger (some as large as $3 \mathrm{~m}$ have been observed). Colonnade, as defined by Tomkeieff (1940), occurs in the basal portion of flows. In CRBG flows, the colonnade can make up the entire flow thickness, or there may be one or more colonnades present that are tiered with entablatures.

Entablature is composed of irregular to regularly jointed, small columns frequently less than $0.5 \mathrm{~m}$ in diameter. Entablature columns are commonly fractured into hackly, fist-size fragments that can mask the columnar structure. Entablatures typically display a greater abundance of cooling joints than do colonnades. Entablature columns can be oriented vertically, exhibit regular patterns such as rosettes and fans, or appear completely disordered. Flows at a few localized occurrences in the Columbia Basin have been observed to consist wholly of entablature (Waters 1960).

\subsubsection{Other Internal Features}

Other intraflow features observed within the interior of Columbia River basalt lava flows include the following:

- Vesicle pipes and cylinders. Vesicle pipes and cylinders are cylindrical zones of gas bubbles that form as gas evolves from that lava and rises toward the top of the flow. The difference between pipes and cylinders is in size; cylinders are larger, but there is no size break. Vesicle cylinders, pipes, and sheets usually occur in relatively thin flows $(5-30 \mathrm{~m})$ composed mainly of colonnades and flow tops.

- Vesicle sheets. Vesicle sheets are horizontal to subhorizontal layers of vesicles. They typically are fed by vesicle cylinders and form below the solidification front. Vesicle zones within the interior of thicker flows can be thin (centimeters to meters thick) and can be laterally continuous, sometimes for kilometers.

- Vesicle zones. Vesicle zones are usually thicker than vesicle sheets but probably form in much the same way. Vesicle zones can be up to several meters thick and are typically located in the dense interior of a lava flow.

- Laminae or dispersed diktytaxitic vesiculation. Diktytaxitic vesiculation or interstitial microvesiculation with crystal linings can occur anywhere within a CRBG flow, but is most prominent in thin flows.

- Platy fracturing. Platy fracturing consists of zones of horizontal to subhorizontal, anastomosing joints across columns. Vertical to near-vertical curvilinear fractures are commonly observed in the field but are not easily recognized during drilling. This phenomenon is thought to have formed by stress release as weathering or other processes remove rock from above.

- Lava tubes. Lava tubes have not been observed in CRBG flows. This is because the flows were emplaced as sheets and were not tube fed as Hawaiian flows are. However, locally tube-like features have been observed but typically do not extend great distances. 
- Sag flowouts. Sag flowouts are described as localized zones of a complex tier of colonnades and entablatures with some isolated flow-top material occurring below the top of the flow. A sag flowout is thought to have formed as the result of lava draining from a partly solidified flow leaving room for vesiculation to occur at the top of the remaining liquid.

\subsubsection{Cooling Joints}

Cooling joints are ubiquitous features in CRBG flows and form during solidification of the flows. The cooling joints form the columns of the entablature and colonnade, subdivisions of columns and zones of irregular blocks. Cooling joints result from tensional stress in response to contraction of solidified portions of a flow as it cooled below the solidius (Spry 1962).

Cooling joints are distinct from secondary tectonic fractures such as faults, shear zones, and joint sets. These secondary features are distinguishable by their appearance and occurrence. Tectonic fractures typically occur as parallel to subparallel, closely spaced fractures. They often have breccias and clay minerals associated with them and can often be recognized by offsets or repeats in the stratigraphy (Appendix C). Such differences can be recognized in exposure but are difficult to detect in borehole data.

Frequency and spacing of joints measured in outcrops indicate that typical frequencies range from 1 to 37 joints per meter, with entablatures showing a greater number of joints per meter than colonnades.

The spacing of cooling joints (number of meters per fracture) appears to follow a log normal distribution for groups of cooling joints with similar attitudes. Figure 2.9 from Meints (1986) shows a histogram (Figure 2.9a) and a cumulative distribution function (Figure 2.9b) for cooling joint spacing for high-angle joints from an exposure of the Rocky Coulee flow of the member of Sentinel Bluffs (Figure 2.3). Meints (1986) found spacing of cooling joints to be highly variable both between flows and within flows, so they cannot be used to differentiate flows, intraflow structures, or even localities that are not close together.

Cooling joint widths average between 0.1 and $0.3 \mathrm{~mm}$. Histogram plots of cooling joint widths show that the distribution of widths is not symmetrical but is skewed with the smaller widths more common than larger widths.

Of the 1,454 cooling joints logged in drill core for the flows of the member of Sentinel Bluffs, $83 \%$ were completely filled with secondary minerals and at least $17 \%$ were partly filled (DOE 1988). The vast majority of unfilled or partly unfilled cooling joints were smaller in width than $0.3 \mathrm{~mm}$. Clay is the predominant infilling type, followed by silica and zeolite.

\subsubsection{Intraflow Structure Variation}

Intraflow structures can be continuous for great distances, but the thickness of intraflow structures is often highly variable. Lateral variations can occur gradually in some cases and very abruptly in others. The primary factor that appears to control changes is the environment where the feature formed. Studies in the central Columbia Basin (DOE 1988) showed that lateral changes in the member of Umtanum 


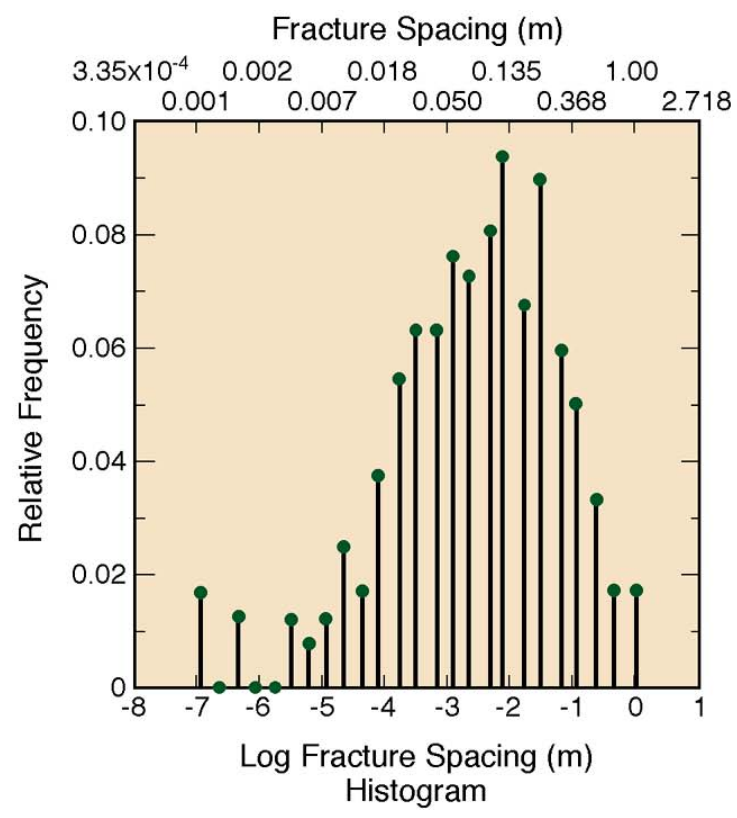

(a)

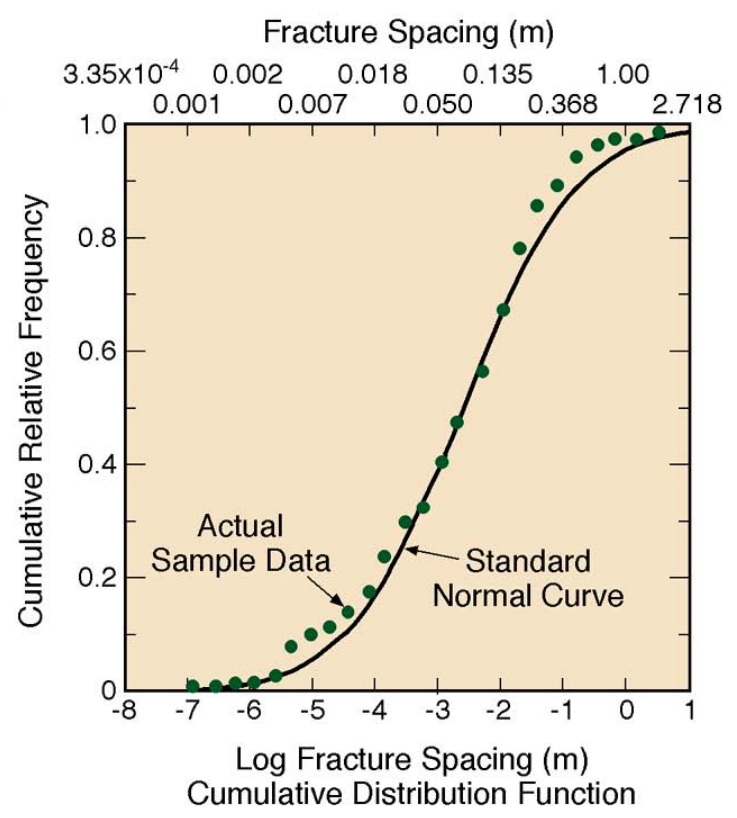

(b)

Figure 2.9. Histogram (a) and Cumulative Distribution Function (b) for Cooling Joint Spacing for High-Angle Joints from an Exposure of the Rocky Coulee Flow of the Member of Sentinel Bluffs (from Meints 1986)

(Figure 2.3 and Appendix G), which has a rubbly to brecciated flow top, extremely thick entablature, and very thin colonnade, occur over relatively short distances. However, studies on the McCoy Canyon flow of the member of Sentinel Bluffs (Figure 2.3 and Appendix G), which has a normal flow top with a thick entablature and thick colonnade, displays gradual changes with distance.

The composition of the paleo-ground surface, and whether it is wet or dry, is an important environmental consideration (Swanson and Wright 1981). A dry basalt flow top has the least impact and results in gradual changes in intraflow textures with distance. In contrast, wet sediment may be the cause of rapidly changing intraflow structure thickness. Wet sediments can reduce the temperature of the lava and increase its relative viscosity. The outward morphology of flows that advanced across wet sediments commonly resembles that of a compound flow, but the individual lobes are of much greater size (10 to $>30 \mathrm{~m}$ thick); the larger lobes (>15 m thick) often display a complex internal jointing pattern, which suggests lava was injected into the lobes (inflated) even after the flow came to rest.

\subsection{Regional Geologic Structures}

\subsubsection{Introduction}

Major geologic features that underlie the Columbia Basin are exposed along the west and north margin of the Columbia Basin. Major structures along the western margin have been mapped by Campbell (1988, 1989) and Tabor et al. (1984); those along the north margin have been compiled by Stoffel et al. (1991). All 
these features are older than the CRBG, but it is not clear how many of these extend under the CRBG or how far they extend under the basalt. Those structural features that we consider important to the Columbia Basin and are known to extend into or cross the Columbia Basin, interior, are summarized below.

\subsubsection{The Olympic-Wallowa Lineament}

The Olympic-Wallowa lineament (OWL) is a major topographic feature in Washington and Oregon that crosscuts the Columbia Basin (Raisz 1945). This feature parallels prebasalt structural trends along the northwest margin of the Columbia Basin, but it has not been linked to any individual structure (Campbell 1989; Reidel and Campbell 1989). Within the Yakima Fold Belt, the OWL includes a zone of Miocene and postMiocene deformation along Manastash Ridge and apparent bending of Umtanum Ridge, Yakima Ridge, and Rattlesnake Mountain (Figure 2.2).

The portion of the OWL that crosses the Columbia Basin is called the Cle Elum-Wallula (Figure 2.2) deformed zone (CLEW; Kienle et al. 1977). It is a 10-km-wide, moderately diffuse zone of anticlines that have a $50^{\circ} \mathrm{W}$ orientation. As defined by Davis (1981), the CLEW consists of three structural parts: 1) a broad zone of deflected or anomalous fold and fault trends extending south from Manashtash Ridge to Rattlesnake Mountain, 2) a narrow belt of topographically aligned domes and doubly plunging anticlines extending from Rattlesnake Mountain to Wallula Gap (RAW), and 3) the Wallula fault zone, extending from Wallula Gap to the Blue Mountains.

Northwest of the CRBG margin, numerous northwest- and north-trending faults and shear zones of the Straight Creek fault system (Figure 2.2) lie subparallel to the OWL (Tabor et al. 1984). The Snoqualmie batholith intrudes these faults but is not cut by them, indicating that any possible movement along the OWL at the western margin of the Columbia Basin must be older than the batholith, 17 to $19.7 \mathrm{Ma}$ (Frizzell et al. 1984).

The structural significance of the OWL has been called into question by two recent geophysical studies. Neither a seismic profiling survey by Jarchow (1991) nor a gravity survey by Saltus (1991) could find any obvious geophysical signature for the OWL below the CRBG.

\subsubsection{Hog Ranch-Naneum Ridge Anticline}

The Hog Ranch-Naneum Ridge anticline is a broad, south-trending anticline in the CRBG that crosses the Yakima Fold Belt at a high angle (Hog Ranch-Naneum anticline, Figure 2.2). The anticline begins at the north basalt margin on the continuation of the Stuart Block (Figure 2.2) southwest of Wenatchee, trends southeast for about $12 \mathrm{~km}$, and then turns south toward Prosser, Washington, where it separates the Toppenish Basin on the west from the Pasco Basin on the east. This south-plunging structure passes through five Yakima folds and the OWL. A gravity gradient and a series of gravity highs delineate part of the subsurface. The southern extension of the anticline appears to be a Bouguer gravity high near the Washington/Oregon border southeast of Prosser.

The Hog Ranch-Naneum Ridge anticline was active in late to middle Miocene as demonstrated by thinning of basalt flows across it (Reidel et al. 1989a), but the east-trending Yakima folds show no apparent 
offset by the cross structure (Campbell 1989; Tabor et al. 1982; Kienle et al. 1977; Reidel et al. 1989b), nor is the Hog Ranch-Naneum Ridge anticline offset where the OWL-CLEW crosses it. Growth of the Hog RanchNaneum Ridge anticline continued from the Miocene to Recent and is now marked by the highest structural points along the ridges that cross it.

\subsubsection{White River-Naches River Fault Zone}

The White River-Naches River Fault Zone (Figure 2.2), a major fault zone that extends $90 \mathrm{~km}$ from Naches to Enumclaw, Washington, separates two domains of dissimilar structure, stratigraphy, and topography (Campbell 1988, 1989). To the northeast, structures strike $\mathrm{N} 60^{\circ} \mathrm{W}$; to the southwest, structures in pre-Tertiary rocks trend $\mathrm{N} 5^{\circ} \mathrm{E}$ to $\mathrm{N} 20^{\circ} \mathrm{W}$. The White River-Naches River Fault Zone probably extends under the basalt at least as far as $20 \mathrm{~km}$ and may crosscut the Hog Ranch-Naneum Ridge anticline. The White River-Naches River Fault Zone is the major structure trending into the Columbia Basin that can be demonstrated to be a fundamental structural boundary in rock below the CRBG (Reidel et al. 1994).

\subsubsection{Leavenworth Fault Zone}

The Leavenworth Fault Zone is a series of northwest-trending high-angle faults and associated tight folds that mark the southwest side of the Chiwaukum Graben (Figure 2.2). Near the margin, the fault passes under the CRBG in alignment with the Hog Ranch-Naneum Ridge anticline. The Leavenworth Fault is assumed to continue under the basalt along the Hog Ranch-Naneum Ridge anticline and to have been a factor in the development (Campbell 1989).

\subsubsection{Other Structures Marginal to the Columbia Basin}

Other major structures, including the Entiat Fault, Methow, Republic, and Keller Grabens, and numerous faults associated with the Kootenay Arc (Figure 2.2) appear to die out, or the magnitude of the structure significantly reduced, before reaching the basalt margin. A series of northeast-trending folds near Badger Mountain anticline, Washington, are aligned with the Republic Graben and may be related to that structural trend.

\subsubsection{Northwest-Trending Wrench Faults}

A series of northwest-trending, dextral strike-slip wrench faults occurs in the CRBG west of the Pasco Basin (Newcomb 1969, 1970; Kienle et al. 1973; Bentley et al. 1980; Swanson et al. 1979b, 1981; Anderson 1987). They consist of a series of conjugate and en echelon faults with genetically related en echelon folds that have a mean strike of $\mathrm{N} 30-40^{\circ} \mathrm{W}$. Many of these faults can be traced for more than $100 \mathrm{~km}$, but do not extend beyond the CRBG. These wrench faults cross and offset several Yakima folds, but the total displacement appears to be less than several hundreds of meters.

\subsubsection{The Yakima Folds and the Yakima Fold Belt}

The Yakima Fold Belt subprovince covers about $14,000 \mathrm{~km}^{2}$ of the western Columbia Basin (Figure 2.1) and formed as basalt flows and intercalated sediments were folded and faulted under north-south directed compression. The reader is referred to Tables 2.2 and 2.3, and the plate in Reidel and Hooper (1989) showing a compilation of structural features for the Columbia Basin. 
Table 2.2. Characteristics of Major Anticlinal Ridges

\begin{tabular}{|c|c|c|c|c|c|c|c|c|}
\hline Anticline & $\begin{array}{c}\text { Length/ } \\
\text { Width }(\mathrm{km})\end{array}$ & $\begin{array}{l}\text { Maximum } \\
\text { amplitude } \\
\text { (m) }\end{array}$ & Trend $\left(^{\circ}\right)$ & $\begin{array}{l}\text { Number of } \\
\text { Segments }\end{array}$ & \begin{tabular}{|c} 
Segment \\
Length \\
(x=mean; $\sigma=1$ \\
standard \\
deviation)
\end{tabular} & $\begin{array}{c}\text { Vergence } \\
\text { (South = south } \\
\mathrm{N}=\text { north) }\end{array}$ & $\begin{array}{c}\text { Amount of } \\
\text { Shortening } \\
(\mathrm{NK}=\text { not } \\
\text { known; best } \\
\text { approx })\end{array}$ & Geometry \\
\hline Beezley Hills-Coulee & $160 / 5$ & 430 & 230 & 4 & $\begin{array}{l}x=40 \sigma=20 \\
R=30-70\end{array}$ & $\mathrm{~S}$ & $\mathrm{NK} ;<2 \mathrm{~km}$ & Asymmetrical, monoclinal \\
\hline \begin{tabular}{|l} 
Badger Hills-Moses \\
Stool
\end{tabular} & $50 / 5-15$ & 300 & 220 & 1 & - & $\mathrm{N}$ & $\mathrm{NK} ;<2 \mathrm{~km}$ & Asymmetrical, monoclinal \\
\hline Frenchman Hills & $100 / 5-10$ & 200 & $90-100$ & 7 & $\begin{array}{l}\mathrm{x}=14 \sigma=10 \\
\mathrm{R}=7 \text { to } 35\end{array}$ & $\mathrm{~N}$ & $\mathrm{NK} ;<2 \mathrm{~km}$ & Asymmetrical, gentle to open \\
\hline Saddle Mountains & $110 / 5-10$ & 550 & $90-115$ & 6 & $\begin{array}{l}\mathrm{X}=14 \sigma=10 \\
\mathrm{R}=5 \text { to } 20\end{array}$ & $\mathrm{~N}$ & $>3 \mathrm{~km}$ & $\begin{array}{l}\text { Asymmetrical, gentle to open, box } \\
\text { fold }\end{array}$ \\
\hline \begin{tabular}{|l} 
Manastash Ridge- \\
Thrall structure \\
\end{tabular} & $55 / 5-10$ & 370 & 120 & 4 & $\begin{array}{l}\mathrm{x}=12 \sigma=2.5 \\
\mathrm{R}=10 \text { to } 15\end{array}$ & $\mathrm{~N}$ & $\mathrm{NK} ;>3 \mathrm{~km}$ & Asymmetrical, gentle to open, \\
\hline Umtanum Ridge & $110 / 3-10$ & 520 & $90-130$ & 9 & $\begin{array}{l}\mathrm{x}=11 \sigma=4.2 \\
\mathrm{R}=5 \text { to } 17\end{array}$ & $\mathrm{~N}$ & $1-3 \mathrm{~km}$ & $\begin{array}{l}\text { Asymmetrical, tight to open, en } \\
\text { echelon segments on east end }\end{array}$ \\
\hline Cleman Mountain & $35 / 8$ & 950 & 130 & 2 & $\begin{array}{l}\mathrm{X}=18 \sigma=8 \\
\mathrm{R}=13 \text { to } 23\end{array}$ & $\mathrm{~S}$ & $\mathrm{NK} ;>1 \mathrm{~km}$ & Asymmetrical \\
\hline Yakima Ridge & $100 / 5-10$ & 550 & $135-225$ & 12 & $\begin{array}{l}\mathrm{x}=12 \sigma=8 \\
\mathrm{R}=5 \text { to } 30\end{array}$ & $\mathrm{~N}$ & $\mathrm{NK} ;>3 \mathrm{~km}$ & $\begin{array}{l}\text { Asymmetrical, gentle to open, en } \\
\text { echelon segments, box fold } \\
\text { segments }\end{array}$ \\
\hline \begin{tabular}{|l|}
$\begin{array}{l}\text { Rattlesnake Mtn. and } \\
\text { "rattles" }\end{array}$ \\
\end{tabular} & $85 / 5-20$ & 800 & 310 & 11 & $\begin{array}{l}\mathrm{X}=9 \sigma=6 \\
\mathrm{R}=5-25\end{array}$ & $\mathrm{~N}$ & $\mathrm{NK} ;>3 \mathrm{~km}$ & $\begin{array}{l}\text { Asymmetrical, tight to open, } \\
\text { faulted out hinge doubly plunging }\end{array}$ \\
\hline \begin{tabular}{|l} 
Rattlesnake-Ahtanum \\
Ridge
\end{tabular} & $100 / 5-8$ & 610 & $238-108$ & 11 & $\begin{array}{l}\mathrm{x}=9 \sigma=4 \\
\mathrm{R}=5 \text { to } 18\end{array}$ & $\mathrm{~N}$ & $\mathrm{NK} ;>1 \mathrm{~km}$ & Asymmetrical, gentle to open \\
\hline Toppenish Ridge & $85 / 4-8$ & 500 & $118-258$ & 5 & $\begin{array}{l}\mathrm{x}=17 \sigma=7 \\
\mathrm{R}=10 \text { to } 28\end{array}$ & $\mathrm{~N}$ & $\mathrm{NK} ;>1 \mathrm{~km}$ & Asymmetrical, tight to open \\
\hline Snipes Mountain & $13 / 1$ & 150 & 110 & 3 & $13 \mathrm{~km}$ & $\mathrm{~S}$ & $\mathrm{NK} ;<1 \mathrm{~km}$ & Asymmetrical, tight to open \\
\hline Horse Heaven Hills & $\begin{array}{l}185 / 5-30 \mathrm{E} \\
2-7 \mathrm{~W}\end{array}$ & $335-1100$ & $115-255$ & 21 & $\begin{array}{l}x=17 \sigma=5 \\
R=5 \text { to } 20\end{array}$ & $\mathrm{~N}$ & $\begin{array}{l}>2 \mathrm{~km} ;(0.67 \text { to } \\
1.25 \mathrm{~km}, 117 \% \\
\text { from folding }) \\
\end{array}$ & $\begin{array}{l}\text { Asymmetrical, tight to open, en } \\
\text { echelon subsidiary crest folds, box } \\
\text { folds }\end{array}$ \\
\hline Columbia Hills & $170 / 5-10$ & $250-365$ & 255 & 10 & $\begin{array}{l}x=15 \sigma=6 \\
R=6-23\end{array}$ & $\mathrm{~S}$ & $\mathrm{NK} ;>2 \mathrm{~km}$ & $\begin{array}{l}\text { Asymmetrical, tight to open doubly } \\
\text { plunging, en echelon subsidiary } \\
\text { crest folds, box folds }\end{array}$ \\
\hline
\end{tabular}


Table 2.3. Characteristics of Major Faults

\begin{tabular}{|c|c|c|c|c|c|c|}
\hline Fault Zone & \begin{tabular}{|c|} 
Length \\
$(\mathrm{km})$
\end{tabular} & Trend $\left(^{\circ}\right)$ & $\begin{array}{l}\text { Horizontal } \\
\text { Offset (NK= } \\
\text { unknown) }\end{array}$ & $\begin{array}{c}\text { Vertical Offset } \\
\text { (NK= unknown; } \\
\text { best approx.) }\end{array}$ & $\begin{array}{l}\text { Dip and Fault } \\
\text { Direction }\end{array}$ & $\begin{array}{l}\text { Age of Last } \\
\text { Movement }\end{array}$ \\
\hline CLEW & 290 & 310 & $0-4 \mathrm{~km}$ & $0-800 \mathrm{~m}$ & Reverse & Quaternary \\
\hline $\begin{array}{l}\text { RAW (includes } \\
\text { Wallula Fault zone) }\end{array}$ & 125 & 310 & $0-4 \mathrm{~km}$ & $0-800 \mathrm{~m}$ & Reverse & Quaternary \\
\hline Hite Fault system & 135 & $330-335$ & $\mathrm{NK}$ & $\mathrm{NK} ; 0-900 \mathrm{~m}$ & $\begin{array}{l}\text { Vertical, en } \\
\text { echelon, and } \\
\text { strike-slip }\end{array}$ & $\begin{array}{l}\text { Recent } 1936 \\
\text { Milton-Freewater } \\
\text { earthquake }\end{array}$ \\
\hline Frenchman Hills & $100+$ & $270-280$ & $>300 \mathrm{~m}$ & $\sim 200 \mathrm{~m}$ & $>45^{\circ} \mathrm{S}$ & $>500,000 \mathrm{yr}$ \\
\hline Saddle Mountains & 100 & $270-285$ & $>2.5 \mathrm{~km}$ & $600 \mathrm{~m}$ & $>60^{\circ} \mathrm{S}$ & $>3.4 \mathrm{Ma}$ \\
\hline $\begin{array}{l}\text { Manastash-Hansen } \\
\text { Creek }\end{array}$ & 70 & 300 & $<1 \mathrm{~km}$ & $\sim 300 \mathrm{~m}$ & Reverse-thrust & $>1-3.4 \mathrm{Ma}$ \\
\hline Umtanum & 110 & $270-310$ & $>300 \mathrm{~m}$ & $1500 \mathrm{~m}$ & $30-70^{\circ} \mathrm{S}$ & $13,000 \mathrm{yr}$ \\
\hline Cleman Mountain & $20 ?$ & 310 & NK & $\sim 900 \mathrm{~m}$ & $\begin{array}{l}\text { Reverse-thrust } \\
\text { N }\end{array}$ & Unknown \\
\hline Yakima Ridge & $120+$ & \begin{tabular}{|c|}
$225-\mathrm{S} 45$ \\
$\mathrm{E}$
\end{tabular} & NK & $\sim 500 \mathrm{~m}$ & $\begin{array}{l}\text { Reverse-thrust } \\
\text { S, locally N } \\
\end{array}$ & $<1 \mathrm{Ma}$ \\
\hline $\begin{array}{l}\text { Rattlesnake-Ahtanum } \\
\text { Ridge }\end{array}$ & 100 & $\begin{array}{c}\text { S58 W to } \\
315\end{array}$ & NK & $\sim 800 \mathrm{~m}$ & \begin{tabular}{|l} 
Reverse-thrust \\
$\mathrm{S}$
\end{tabular} & $>13,000 \mathrm{yr}$ \\
\hline Toppenish Ridge & $65-90$ & $\begin{array}{l}258 \text { to } \\
298 \mathrm{~W}\end{array}$ & NK & $\sim 500 \mathrm{~m}$ & $\begin{array}{l}\text { Reverse-thrust } \\
\text { S }\end{array}$ & $\begin{array}{l}\text { Recent; see } \\
\text { Campbell and } \\
\text { Bentley (1981) }\end{array}$ \\
\hline Horse Heaven Hills & $200+$ & $\begin{array}{l}245 \text { to } \\
295 \mathrm{~W}\end{array}$ & NK & $\sim 335-1100 \mathrm{~m}$ & Reverse-thrust $\mathrm{S}$ & Unknown \\
\hline Columbia Hills & 160 & 245 & $\mathrm{NK} ;>1 \mathrm{~km}$ & $\sim 365 \mathrm{~m}$ & $70^{\circ} \mathrm{N}$ & Unknown \\
\hline $\begin{array}{l}\text { Northwest-trending } \\
\text { faults }\end{array}$ & $40-120$ & 340 & $<100 \mathrm{~m}$ & $<100 \mathrm{~m}$ & $\begin{array}{l}\text { Strike-slip, } \\
\text { vertical (dip } \\
\text { reversal) }\end{array}$ & Holocene \\
\hline
\end{tabular}

Most of the present structural relief in the Columbia Basin has developed since about 10.5 Ma when the last massive outpouring of lava, the Elephant Mountain Member, buried much of the central Columbia Basin. The main deformation is concentrated in the Yakima Fold Belt; there is only minor deformation on the Palouse Slope. Almost all the present structural relief exposed at the surface is post-CRBG.

The Yakima Fold Belt consists of narrow anticlinal ridges separated by broad, synclinal valleys. The anticlines and synclines are typically segmented, and most have north vergence. However, some anticlines such as the Columbia Hills, Cleman Mountain, and a few segments of some other ridges, have a south vergence. Fold length ranges from $1 \mathrm{~km}$ to over $100 \mathrm{~km}$; fold wavelengths range from several kilometers to as much as $20 \mathrm{~km}$ (Table 2.3). The folds are segmented by crosscutting faults and folds (Reidel 1984; Reidel et al. 1989a). Structural relief is typically less than $600 \mathrm{~m}$ but varies along the length of the fold. The greatest structural relief along the Frenchman Hills, the Saddle Mountains, Umtanum Ridge, and Yakima Ridge occurs where they intersect the north-trending Hog Ranch-Naneum Ridge anticline (Figure 2.2). 
Anticlines in the southwest part of the Yakima Fold Belt, southwest of the CLEW, generally have N50 ${ }^{\circ} \mathrm{E}$ trends (Swanson et al. 1979c: Reidel et al. 1989a) (Figure 2.2). Anticlines in the central part have east trends except along the CLEW where a N50 ${ }^{\circ} \mathrm{W}$ trend predominates. The Rattlesnake Hills, Saddle Mountains, and Frenchman Hills have overall east trends, but Yakima Ridge and Umtanum Ridge change eastward from east to $\mathrm{N} 50^{\circ} \mathrm{W}$ in the CLEW. The Horse Heaven Hills, the $\mathrm{N} 50^{\circ} \mathrm{W}$ trending Rattlesnake Hills, and the Columbia Hills abruptly terminate against the CLEW.

Although rarely exposed, nearly all the steep forelimbs of the asymmetrical anticlines are faults. These frontal fault zones (Figures 2.10 and 2.11) typically consist of imbricated thrusts (Bentley 1977; Goff 1981; Bentley in Swanson et al. 1979b; Hagood 1986; Reidel 1984, 1987; Anderson 1987) that are emergent at ground surface. Near the ground surface, the thrust faults merge into the shallow dipping surface

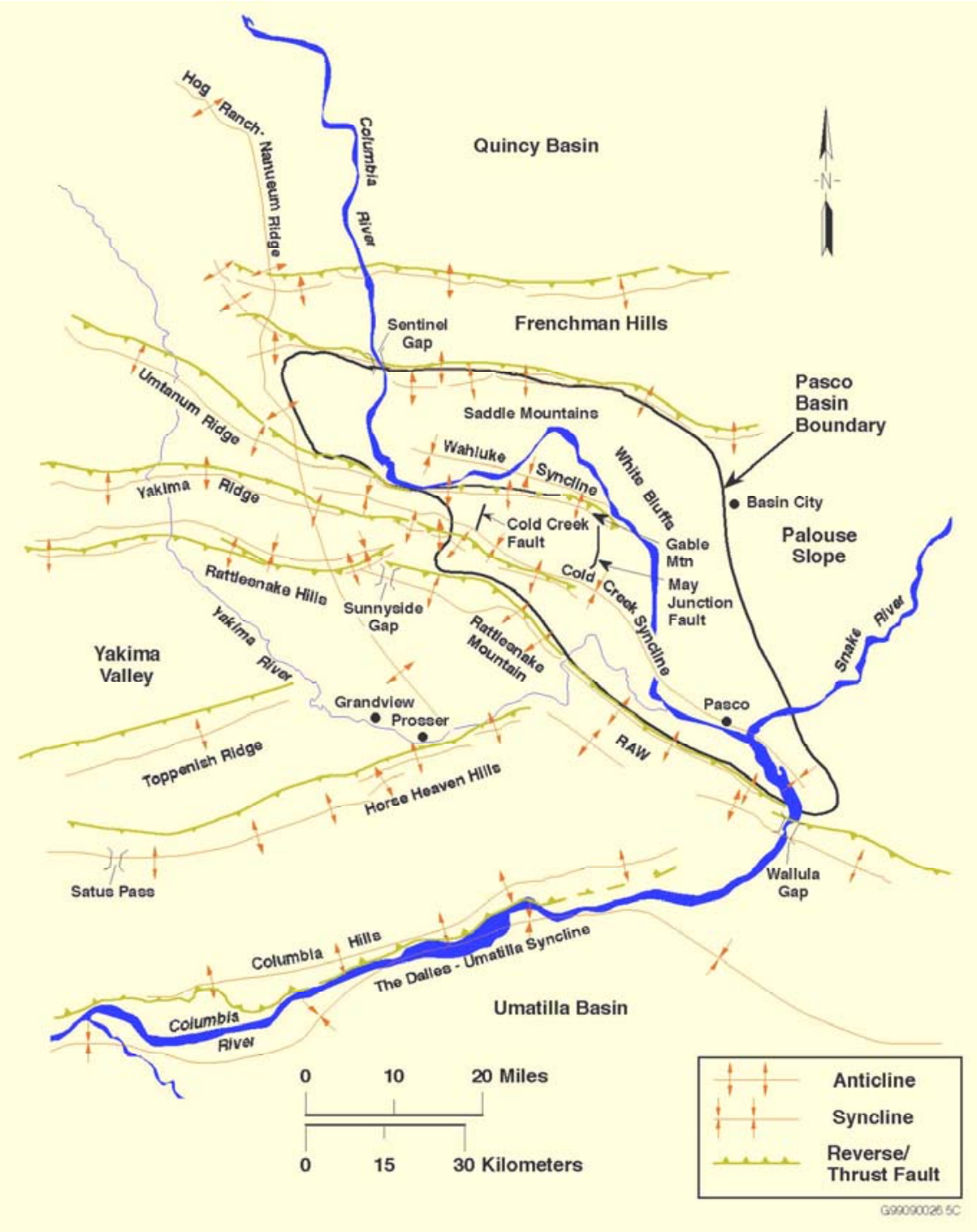

Figure 2.10. Yakima Folds in the Pasco Basin Area 


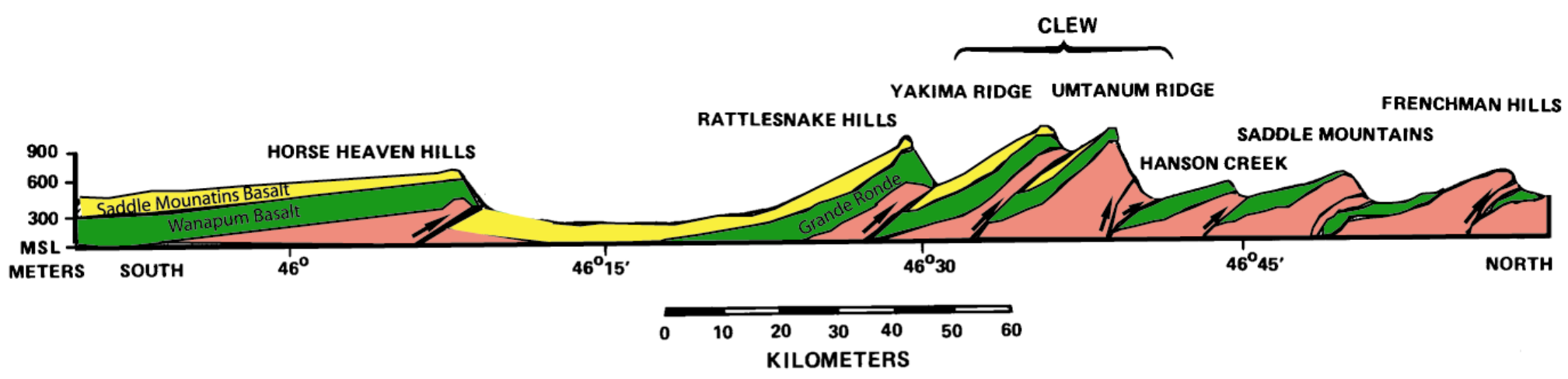

Figure 2.11. Cross Section through the Yakima Fold Belt 
of the basalt (Reidel 1984). Where erosion provides deeper exposures, these frontal faults are steep reverse faults [e.g., $45^{\circ} \mathrm{S}$ in the Frenchman Hills at the Columbia River water gap, (Grolier and Bingham 1971) and $50-70^{\circ}$ north in the Columbia Hills at Rock Creek, Washington (Swanson et al. 1979c)].

Hydrocarbon exploration boreholes provide direct evidence for the dips of these frontal faults. Reidel et al. (1989a) have shown that the Saddle Mountains fault must dip more than $60^{\circ}$ where the Shell-ARCO 1-9 BN borehole was drilled (Figure 2.12; see Appendix C, Figure C.19). Drilling of the Umtanum fault near Priest Rapids Dam (PSPL 1982) suggests that this fault dips southward under the ridge with a dip of at least $30^{\circ}$ to $40^{\circ}$ (PSPL 1982) but perhaps as high as $60^{\circ}$ (Price 1982; Price and Watkinson 1989).

Although it is difficult to assess, total shortening increases from east to west across the Yakima Fold Belt. At about $120^{\circ}$ longitude, it is estimated to be between $15 \mathrm{~km}$ and $25 \mathrm{~km}$ (Reidel et al. 1989a), or about $5 \%$ (Table 2.3). Typically, shortening on an individual anticline as a result of folding is approximately 1 to $1.5 \mathrm{~km}$. The amount of shortening on faults expressed at the surface is generally unknown. Estimates range from several hundreds of meters to as much as $3 \mathrm{~km}$ (Table 2.3).

Synclines in the Yakima Fold Belt are structurally low areas formed between the gently dipping limb of one anticline and the steeply dipping limb of another where that limb was thrust up onto the gently dipping limb of the neighboring anticline (Figure 2.11). Few synclines within the Yakima Fold Belt were formed by synclinal folding of the basalt.

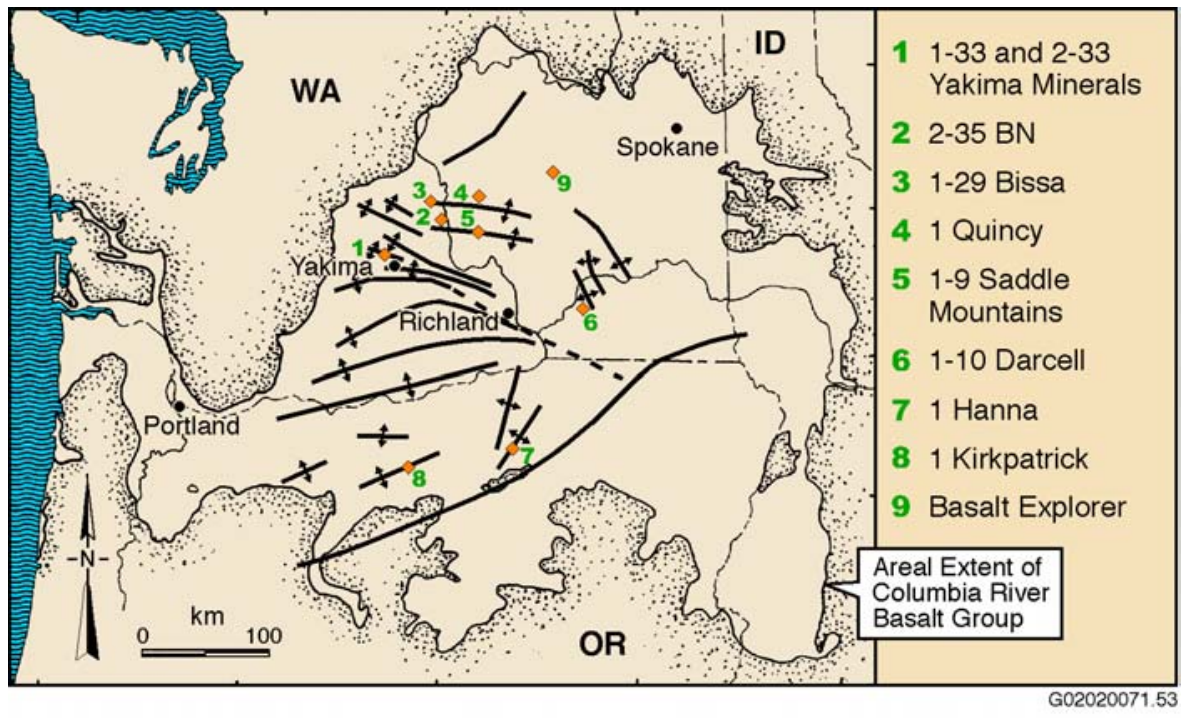

Figure 2.12. Locations of Deep Hydrocarbon Exploration Boreholes Drilled that Penetrated Rocks Below the Columbia River Basalt Group 


\subsubsection{Tectonic Brecciation and Shearing}

Tectonic breccia and shear zones are common in geologic structures in the CRBG (Price 1981; Gardner et al. 1981; Goff 1981; Reidel 1984; Barsotti 1986; see Appendix C). Three types of breccias are recognized: shatter breccias, anastomosing breccias, and shear zone and fault breccias (Price 1982).

- Shatter breccias are simply shattered basalt in which the original primary features of the basalt are still preserved (Appendix C, Figure C.14).

- Anastomosing breccias are composed of lenticular basalt fragments with a submicroscopic, pulverized basalt matrix, and are nontabular basalt breccias of no apparent measurable orientation (Appendix C, Figure C.15).

- Shear zones and fault breccias are tabular breccia zones that have three stages of development. The first stage is the development of a set of parallel, sigmoidal, extension fractures superimposed on primary structures (Appendix C, Figure C.16). The second stage involves rigid rotation of millimeter-scale basalt blocks, causing the initial granulation of basalt (Appendix C, Figure C.17). The third stage involves development of discrete slip surfaces either within, or bounding, a tabular breccia (Appendix C, Figure C.18).

Flow top breccias are distinguished from tectonic breccias by several characteristics (see Appendix A). Tectonic breccia typically contains more angular clasts of smaller size, usually a few centimeters or less, than flow top breccia. Clasts in flow top breccia often are bound by original glass and are an admixture of vesicular and nonvesicular basalt, whereas clasts in tectonic breccia have a homogeneous texture. When observed in drill core, tectonic breccia zones are typically bounded by fractures, resulting in a distinct demarcation between the zone and the surrounding intact rock, in contrast to the often degradational contacts of flow top breccia zones. The presence of subparallel fracturing within a tectonic breccia zone results in clasts being arranged parallel to subparallel to each other, which also contrasts with the random, chaotic nature of clasts in flow top breccias. Slickensides are present on some surfaces in tectonic breccias and absent in flow top breccias without tectonic fracturing. Tectonic breccias typically display a crushed basalt matrix, while flow top breccias may be partially to fully filled with secondary minerals or palagonite between fragments, or the fragments may be welded together.

Major high-angle, reverse to thrust faults along anticlinal ridges are associated with very thick breccia zones. In the Saddle Mountains, these zones are very distinct and in Sentinel Gap consist of a severalhundred-meter-thick zone of shatter breccias (Reidel 1984). Similar breccia zones have been found in Umtanum Ridge (Price 1982; Barsotti 1986) and at Wallula Gap (Gardner et al. 1981).

The greatest amount of brecciation and shearing occurs in the hinge zone of the anticlinal folds and decreases progressively down the flanks. Studies of several south-dipping limbs support these observations (e.g., see Price 1982; Barsotti 1986; Reidel et al. 1984). Detailed studies on Umtanum Ridge found that the degree of brecciation is related spatially to the dip of the layering (Price 1982). The greatest 
amount of tectonic jointing and faulting occurs in the hinge zone and in steeply dipping beds. On the flanks of the folds, faults with low dips (less than $45^{\circ}$ ) and limited extent often occur as conjugate shear zones (Price 1982).

On the well-exposed south limb of the Frenchman Hills, sparse, locally developed but widely disseminated, fault zones and shear zones can be observed (Price 1982). These features typically have small displacements, and the apparent maximum displacement of 1 to $2 \mathrm{~cm}$ decreases to no recognizable displacement at a lateral distance of $1 \mathrm{~m}$. Faulting is principally confined to the individual basalt layers.

Tectonic breccia zones in the Cold Creek syncline on the Hanford Site are infrequent in all the thousands of feet of core drilled into the Columbia River basalt. The breccia zones that do occur are generally intact and less than $10 \mathrm{~cm}$ in apparent thickness, although some may be thicker (Moak 1981).

Tectonic breccias that have been observed in boreholes in the Cold Creek syncline of the Hanford Site are similar in appearance to the widely disseminated fault and shear zones described from surface exposures. This suggests that their occurrence is not necessarily associated with areas of greatest deformation in a fold. An alternative interpretation is that they are associated with other, possibly larger, faults.

Core disking, the fracturing of core into thin saddle-shaped disks, is a drilling-induced phenomena observed in some cores from the Cold Creek syncline and is apparently related to de-stressing of zones with high ratios of horizontal to vertical stress (Paillet and Kim 1987). Numerical modeling of core disking indicates that it results from effects of shear and unloading as the bit penetrates rock under substantial horizontal stress. Paillet and Kim (1987) note an imperfect correlation between core-disking and borehole breakouts. Both tend to be confined to dense flow interiors. The imperfect correlation is attributed to differences in failure mechanisms. No correlation has been observed among borehole breakouts, core disking, and tectonic breccia zones. Paillet and Kim (1987) suggest that breakouts and core disking within the interiors of individual flows "may indicate that substantial stresses are being produced by concentration of regional stresses in relatively hard and thick basalt flows embedded within softer, more easily deformable sediments and altered flow top breccias."

\subsubsection{Tectonic Joint Sets}

Identifying regional joint sets is often done using remote sensing imagery, but this is complicated by the sedimentary cover that overlies much of the basalt bedrock. This type of study is also made more difficult by the presence of ubiquitous cooling joints, which are difficult to distinguish from tectonic joints both in outcrop and core samples.

Several compilations of photolineaments and topographic lineaments have been completed for various purposes. Sandness et al. (1982) compiled photolineaments and topographic lineaments for the entire Columbia Basin. They analyzed satellite imagery and aerial photography and categorized each lineament according to the feature that caused it. Their categories included features such as color or vegetation discontinuities, straight drainage features, known mapped faults, alignment of topographic 
features, and probable joints. The result of their work is a series of 1:250,000 quadrangle maps that contain a composite overlay of all lineaments, regardless of origin.

The most prominent joint sets that Sandness et al. (1982) noted were on the Walla Walla quadrangle, along the Palouse River. Here, Pleistocene cataclysmic flooding stripped away much of the sediment overlying the basalt. Other joint sets are found west of Connell, at Wallula Gap, along the Yakima River northwest of Prosser, near O'Sullivan Dam, and along Crab Creek along the north side of the Saddle Mountains.

A second compilation of lineaments was completed as part of the licensing investigations for the Washington Public Power Supply System's (now Energy Northwest's) nuclear plants (Glass and Slemmons 1977). Their objective was to identify features that might possibly aid in locating the epicenter of the 1872 "Chelan" earthquake. They used topographic maps as well as remote sensing imagery to identify possible surface faulting features.

\subsubsection{Relationship Between Folding and Faulting}

Most deformation in the Columbia Basin is a result of north-south compression. This section discusses the relationship among folds, faults, and tectonic joints and places them in the structural framework of the Yakima Fold Belt.

The deformation mechanisms by which folds, faults, and tectonic fractures develop are not yet fully understood. A structural analysis of part of Umtanum Ridge near Priest Rapids Dam by Price (1982) contends that deformation occurred by faulting, folding, and development of tectonic joints in the anticlinal crests during regional compression with substantially less deformation in the synclinal troughs. The gently dipping limbs of the anticlines contain widely disseminated, discrete shear zones and (or) faults. Steep strata on the north limbs of Yakima folds contain more extensive faults or breccia zones (Price 1982).

Price's (1982) study of the Umtanum Ridge anticline showed that folding included localized intralayer faulting, extensive shattering, and limited interlayer faulting. Most strain is cataclastic, but glassy flow tops appear to have been more ductile. Price determined that four tectonic joint sets are dominant. Two sets have vertical dips and strike perpendicular to and parallel to the fold axis, respectively. The other two sets are conjugate sets that strike perpendicular to the fold axis and dip to the east or west. These sets represent extension parallel to the fold axis and extension perpendicular to the fold axis during folding. Joints are most pronounced and abundant in the core of the fold; they decrease upward in the structure to where they are not recognized above the Vantage horizon. Because joints are systematically related to folds, joints within Umtanum Ridge are interpreted to be the same age as the folds (Price 1982).

The strain distributions and structural geometries agree well with a flexural-flow-buckle model. However, the internal cataclastic flow is not inherently penetrative, and limited flexural slip has occurred. Price's (1982) fold model suggests that most strain in the fold is simple shear and took place above the topographic surface of adjacent synclinal valleys. Large reverse faults associated with the anticlines are 
interpreted to be the faulting strain that is required by the folding, and they are interpreted to have propagated to the surface late in the folding process. Therefore, the observed folding strain and its distribution are interpreted to be the result of local stresses and resultant strains related to fold geometry, and are the direct results of regional plateau shortening.

Suppe $(1983,1985)$ proposed that large-scale folds that formed at shallow crustal levels at about the brittle-plastic transition are related to slip on adjacent faults, and this might be applicable to the Yakima folds. Suppe identifies three classes of fault-related folds:

- buckling, caused by compression above a bedding plane decollement

- fault-bend folding, caused by bending of a fault block over a nonplanar surface

- fault-propagation folding, caused by compression in front of a fault tip during fault propagation.

Fault-bend folding and fault-propagation folding models are among possible explanations for the origin of Yakima folds. The fault-propagation folding model is generally compatible with that proposed by Price (1982) and Reidel (1984), but with potentially significant differences. The presence or absence of a decollement is the major uncertainty in the Yakima folds.

Price's (1982) work suggests that relatively few tectonic fractures should be found in synclines. Those fractures present are inferred to strike either perpendicular to or parallel to the fold axis, to be nearly vertical, and to cross flow contacts at a high angle. Field studies in the Burbank Creek syncline north of Yakima and the syncline directly north of Umtanum Ridge show that synclines exhibit the least strain of any parts of a fold (Price 1982).

Tectonic breccias are present in many deep boreholes in synclinal folds on the Hanford Site, but breccia zones are infrequent in each borehole, typically intact, and generally less than $10 \mathrm{~cm}$ thick (Moak 1981). Tectonic breccias encountered in boreholes do not seem to be concentrated at any particular depth or interval.

Further insight into the mechanics of folding and faulting and the development of tectonic joints has been gained by analyzing paleomagnetic data from the Pasco Basin. Reidel et al. (1984) have found that paleomagnetic data from the Pomona flow in the Yakima Fold Belt show clockwise rotation of sample sites from the anticlinal ridges relative to the synclinal valleys. Two geographic patterns of rotation are present:

- a primary one in which greatest rotation occurs in the crest-hinge area of the anticlines and decreases toward the synclines

- a secondary pattern in which the amount of rotation is controlled by the geometric segments of the folds. 
Reidel et al. (1984) interpret the rotation mechanism to involve two axes: 1) a generally east-west horizontal axis corresponding to the fold axis of the anticlines, and 2) a vertical axis. Further study by Barsotti (1986) supports this interpretation, but also shows that the inclination angle of the paleomagnetic vector can be rotated by shear during folding. Rotation of the declination probably occurred along a closely spaced, northwest-trending, right-lateral shear system (conjugated set that strikes perpendicular to the fold axis) that developed in the anticlines as they grew under north-south compression. The confinement of rotation to the anticlines indicates that this shear system is principally limited to the anticlines.

\subsubsection{Earthquake History and State of Stress in the Columbia Basin}

Our knowledge on the current state of stress in the Columbia Basin comes from geodetic surveys, hydraulic fracturing tests, and earthquake monitoring. The recently initiated Pacific Northwest Geodetic Array (PANGA) global positioning system (GPS) network is just beginning to provide data along the western margin of the Columbia Basin. These methods indicate that the Columbia Basin is currently under north-south oriented stress. The pattern of geologic deformation is consistent with this and suggests that compression has occurred since at least the Miocene.

Hydraulic fracturing tests conducted at about $1 \mathrm{~km}$ depth in boreholes in the Cold Creek syncline at the Hanford Site indicate that the maximum horizontal stress ranges from 52.6 to $67.4 \mathrm{MPa}(7,630$ to 9,780 lbf/in ${ }^{2}$, and the minimum horizontal stress ranges from 30.3 to $35.7 \mathrm{MPa}\left(4,400\right.$ to $\left.5,180 \mathrm{lbf} / \mathrm{in}^{2}\right)$. The ratio of average horizontal stress $\left[\left(\sigma_{\mathrm{H}}+\sigma_{\mathrm{h}}\right) / 2\right]$ to the vertical stress $\left(\sigma_{\mathrm{v}}\right)$ ranges from 1.41 to 2.14 with a mean value of $1.77 \pm 0.20$. The mean orientation of induced fractures, and thus, the direction of the maximum horizontal stress is consistent with north-south compression (Paillet and Kim 1987).

The earthquake record from the Columbia Basin is also consistent with continuing north-south oriented compression. The historic record of earthquakes in the Pacific Northwest dates from about 1840 but seismograph networks did not start providing earthquake locations and magnitudes until about 1960. A comprehensive network of seismic stations providing accurate locating information for most earthquakes of magnitude $>2.5$ was installed in eastern Washington in 1969. Pacific Northwest National Laboratory operates this monitoring network for the DOE (PNNL 2001).

Although seismicity of the Columbia Basin, expressed as the rate of earthquakes per area and the historical magnitude of these events, is relatively low when compared with other regions of the Pacific Northwest, large earthquakes (Richter magnitude $>7$ ) are known to occur (Figure 2.13). A large earthquake having an estimated Richter magnitude of approximately 7 with an uncertain location occurred northwest of the Columbia Basin in 1872. The distribution of intensities suggests it occurred somewhere within a broad region north of Wenatchee, Washington.

The largest known earthquake in the Columbia Basin occurred in 1936 near Milton Freewater, Oregon, south of Walla Walla, Washington. This earthquake had a magnitude of approximately 6 and

a maximum MMI of VII, and was followed by a number of aftershocks whose epicenters suggest a northeast-trending fault plane, such as the Hite Fault (Figure 2.2). Other earthquakes with Richter 


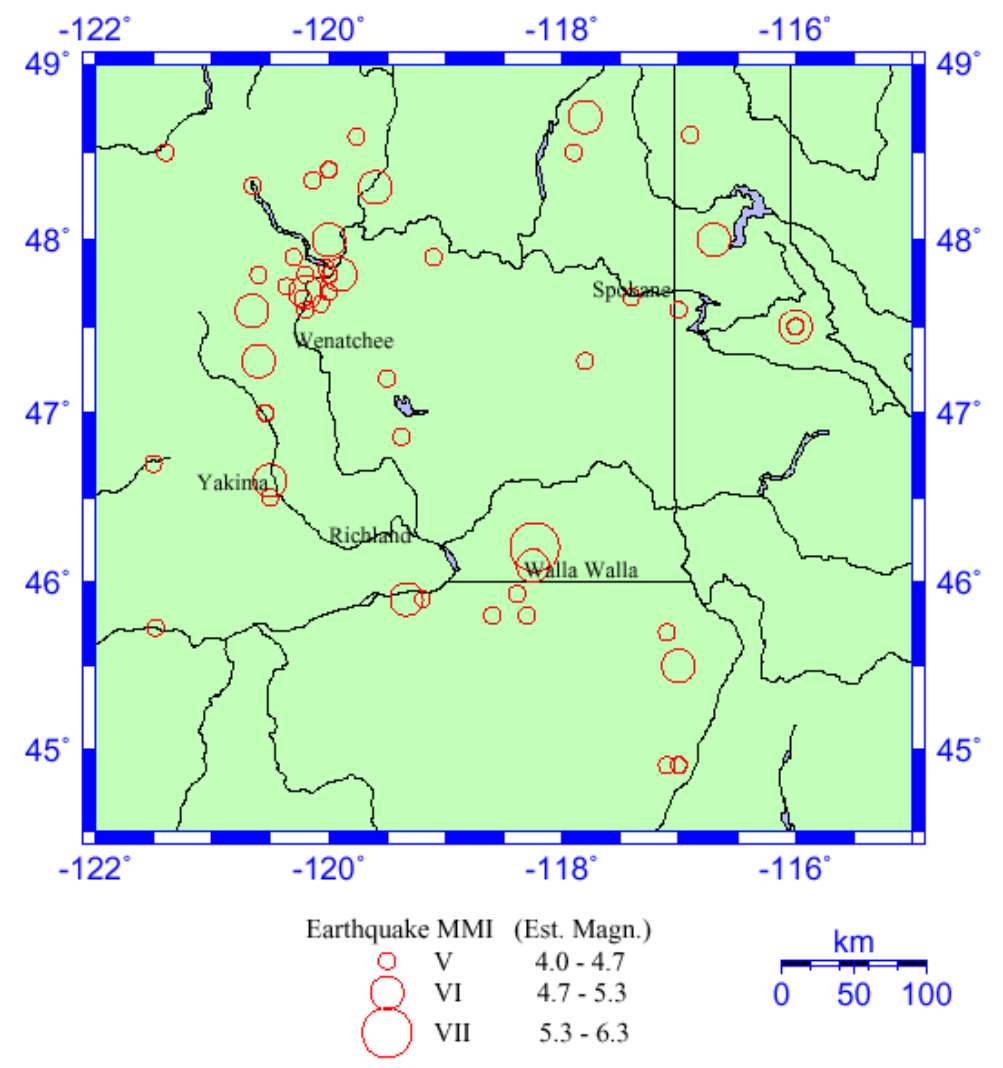

Figure 2.13. Historic Seismicity of the Columbia Basin and Surrounding Areas. Includes all earthquakes between 1850 and 1969, with a Modified Mercalli Intensity (MMI) of $\mathrm{V}$ or larger or a Richter magnitude of 4 or larger.

magnitudes $\geq 5$ and/or MMIs of VI occurred along the margin of the Columbia Basin. Three MMI VI earthquakes have occurred within the Columbia Basin, including one event in the Milton-Freewater, Oregon, region in 1921; one near Yakima, Washington, in 1892; and one near Umatilla, Oregon, in 1893. In the central portion of the Columbia Basin, two earthquakes having a magnitude 4.4 occurred in 1918 and 1973 near Othello, Washington (Figure 2.13).

The Eastern Washington Seismic Monitoring Network (PNNL 2001) shows that earthquakes in the Columbia Basin most often occur in spatial and temporal clusters and are termed "earthquake swarms" (Figure 2.14). The frequency of earthquakes in a swarm tends to gradually increase and decay with no one outstanding large event within the sequence. These earthquake swarms generally occur at shallow depths, with $75 \%$ of the events located at depths $<4 \mathrm{~km}$. Each earthquake swarm typically lasts several weeks to months, consists of several to 100 or more earthquakes, and the locations are clustered in an area 5 to $10 \mathrm{~km}$ in lateral dimension. Often, the longest dimension of the swarm area is elongated in an eastwest direction. Earthquakes also occur to depths of about $30 \mathrm{~km}$. These deeper earthquakes are less clustered and occur more often as single, isolated events. 


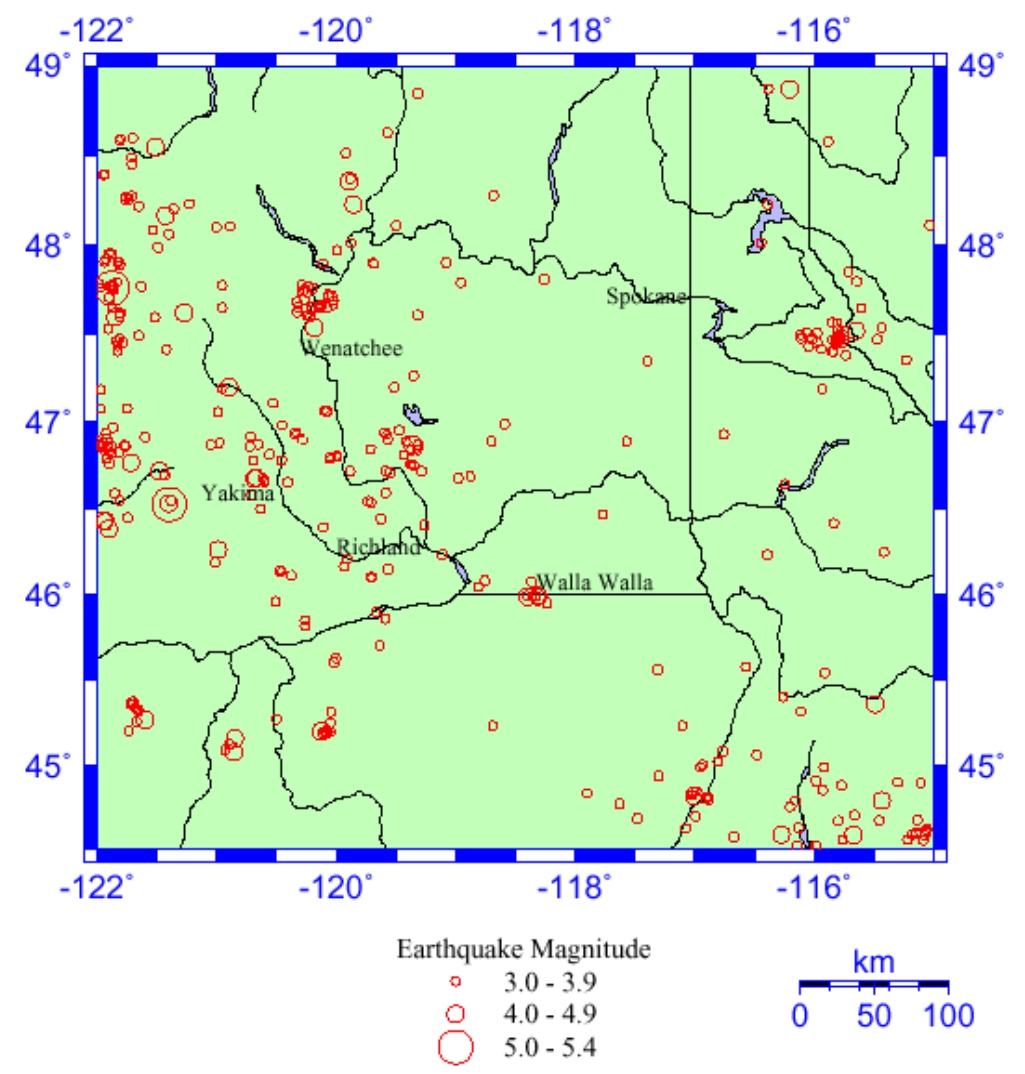

Figure 2.14. Seismicity of the Columbia Basin and Surrounding Areas as Measured by Seismographs. All earthquakes from 1969 to 2001 with Richter magnitude 3 or larger are shown.

The seismicity in the area north of Wenatchee is distinct from that of the Columbia Basin. The depth distribution is almost uniform in the top $8 \mathrm{~km}$, which contains roughly $90 \%$ of the seismicity (Figure 2.14). This region has exhibited seismicity throughout the historical period (Figure 2.13) and is suggestive of being related to the source area of the 1872 magnitude 7 earthquake.

Some of the larger earthquakes in eastern Washington during the instrumental period have occurred near Walla Walla, and near the epicenter of the 1936 Milton-Freewater earthquake. This is a second example of where the recent seismicity appears to correlate with that observed in the historical period. In contrast, in 2001, approximately 80 earthquakes with maximum magnitude of 4 have occurred beneath the city of Spokane in northeastern Washington. This area has been notably aseismic for the last 45 years and only a few events are historically located near there as far back as 1850 . These events also appear to have a swarm characteristic repeated in 4 to 5 clusters of events in time. Note that the cluster of earthquakes east of Spokane (Figure 2.14) is related to induced seismicity at deep silver mines. Although partially due to regional stresses, the mine openings change the local stress state, and most of these events are anomalous with implosional mechanisms. 
Earthquake focal mechanisms in the central Columbia Basin generally indicate reverse faulting on east-west planes, consistent with a north-south-directed maximum compressive stress and with the formation of the east-west-oriented anticlinal folds of the Yakima Fold Belt (Reidel et al. 1989a, 1994). However, earthquake focal mechanisms suggest faulting on a variety of fault plane orientations.

In summary, the seismicity of the Columbia Basin is low with earthquakes typically less than magnitude 3. Large earthquakes have long recurrence periods. Magnitude 7 earthquakes are estimated to recur every 10,000 years and magnitude 5 earthquakes every 5,000 years.

\subsubsection{The Yakima Folds: A Summary}

The Yakima folds are not unique geologic structures on the Earth or, for that matter, on the other terrestrial planets. Wrinkle ridges or volcanic plains anticlinal ridges on the terrestrial planets (Basaltic Volcanism Study Project 1981), which form as a result of basement involvement or detachment, are interpreted as geometric analogs of the Yakima folds (Watters 1989). The surface geometry of the Yakima folds resemble typical folds in a thrust belt. They form under generally north-south compression, based on geometry (Davis 1977), focal mechanisms (Rohay and Davis 1983), and in situ stress measurements (Kim et al. 1986), by brittle deformation, and at the surface of the Earth. Confining pressure is within the horizontal plane with minimal vertical confining pressure. When north-south compression was applied to the Columbia Basin, the result was shortening of the crust, accomplished principally by uplift and folding. Rock was forced over the uppermost lava flow at the surface (Reidel 1984) with the surface of this flow top becoming the fault plane. This surface is a low-angle thrust fault, because the flow is nearly horizontal. Less is known, however, about the fault orientation in the subsurface. Only two exposures of these faults can be seen in canyons adjacent to ridges in the plateau: $45^{\circ}$ for the Frenchman Hills along the Columbia River near Vantage (Grolier and Bingham 1971) and $70^{\circ}$ for the Columbia Hills in Rock Creek (Anderson, in Swanson et al. 1979a). Interpretations of the Saddle Mountains fault using borehole data also indicate a steeply dipping fault plane (Appendix C, Figure C.19).

Most synclinal valleys are not true synclines, in that they represent the gentle south-dipping limb of an anticline that has been overridden by the next anticline to the south. The upper Cold Creek syncline west of the Hanford Site is a tight, faulted, southern limb of Umtanum Ridge that is overridden by the north limb of Yakima Ridge. The Cold Creek syncline at the Hanford Site has a width of over $10 \mathrm{~km}$ and is a broad trough that has apparently undergone little deformation relative to anticlinal areas. It is an area that also has been undergoing subsidence since the beginning of CRBG volcanism.

\subsection{Geologic History of the Columbia Basin}

\subsubsection{The Pre-Miocene Columbia Basin}

The present Columbia Basin reflects the major structural elements that formed before flood-basalt volcanism. This section provides an interpretation of the structural setting of the Columbia Basin prior to the eruption of the CRBG. This interpretation is based on our field observations combined with data from the last two decades of geophysical surveys and from deep hydrocarbon exploration boreholes in the Columbia Basin. 
The Yakima Fold Belt and Palouse Slope (Figure 1.1) overlie the two major pre-CRBG structural features of the Columbia Basin (Reidel et al. 1989a). The Palouse Slope subprovince overlies a crystalline basement high with a thin $(<100 \mathrm{~m})$ sediment package between the basalt and basement (Figures 2.15 and 2.16). The Yakima Fold Belt overlies a large pre-basalt basin filled with as much as $7,000 \mathrm{~m}$ of continental sediments.

The crystalline basement underlying the Palouse Slope (Figures 2.2 and 2.16) has been penetrated by two boreholes (1-10 Darcell, and Basalt Explorer, Figure 2.12). This basement is essentially metasedimentary rock of late Precambrian to early Paleozoic age. It is composed of quartz, feldspar, and mica and resembles the Addy Quartzite and certain Precambrian Belt Supergroup rocks. Reidel et al. (1994) interpreted this basement to be part of the old continental craton that developed after the breakup of the supercontinent Rodinia and has remained relatively stable except for its west slope. The southern boundary lies along a major gravity anomaly that extends westward from Lewiston, Idaho, to Pomeroy, Washington (Mohl and Theissen 1985). Downhole data gathered from the 1-10 Darcell borehole (Figure 2.16) indicate that the craton also extends west and south from Pomeroy. We suggest that the trace of this cratonic margin is expressed at the surface by the Hite fault (Figure 2.2), the major fault that forms the western margin of the Blue Mountains between Pomeroy, Washington, and Pendleton, Oregon, and has been the locus of many historic earthquakes.

The Yakima Fold Belt is underlain by a thick sequence of sediments that was first recognized in deep hydrocarbon exploration boreholes (Campbell and Banning 1985). On the basis of seismic refraction survey data, Catchings and Mooney (1988) interpret this as a rift basin. Other studies using additional geophysical data sets (Rohay and Malone 1983; Rohay et al. 1985; Glover 1985; Zervas and Crosson 1986), however, question this interpretation. These studies did not find evidence for a rift basin in the deep crust or mantle.
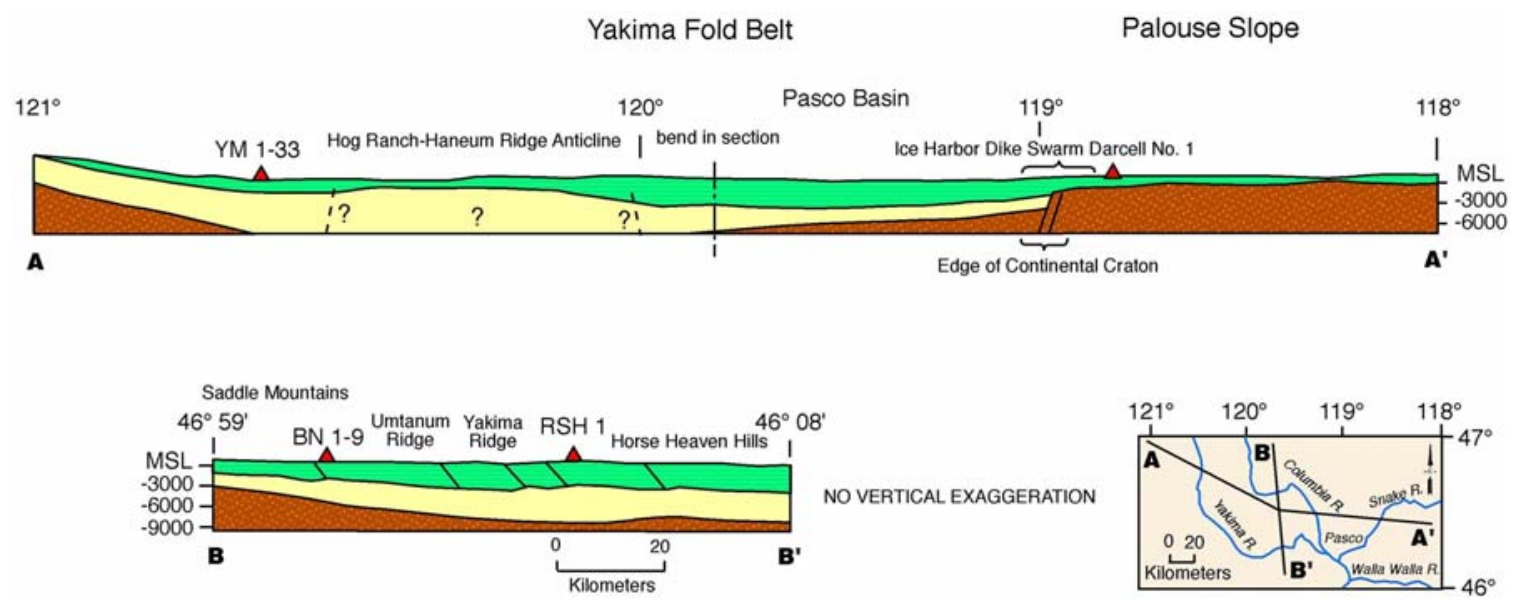

$\Delta$ Hydrocarbon exploration borehole

Columbia River Basalt Group

Tertiary sediments

Basement rock

Figure 2.15. Geologic Cross Section through the Columbia Basin 


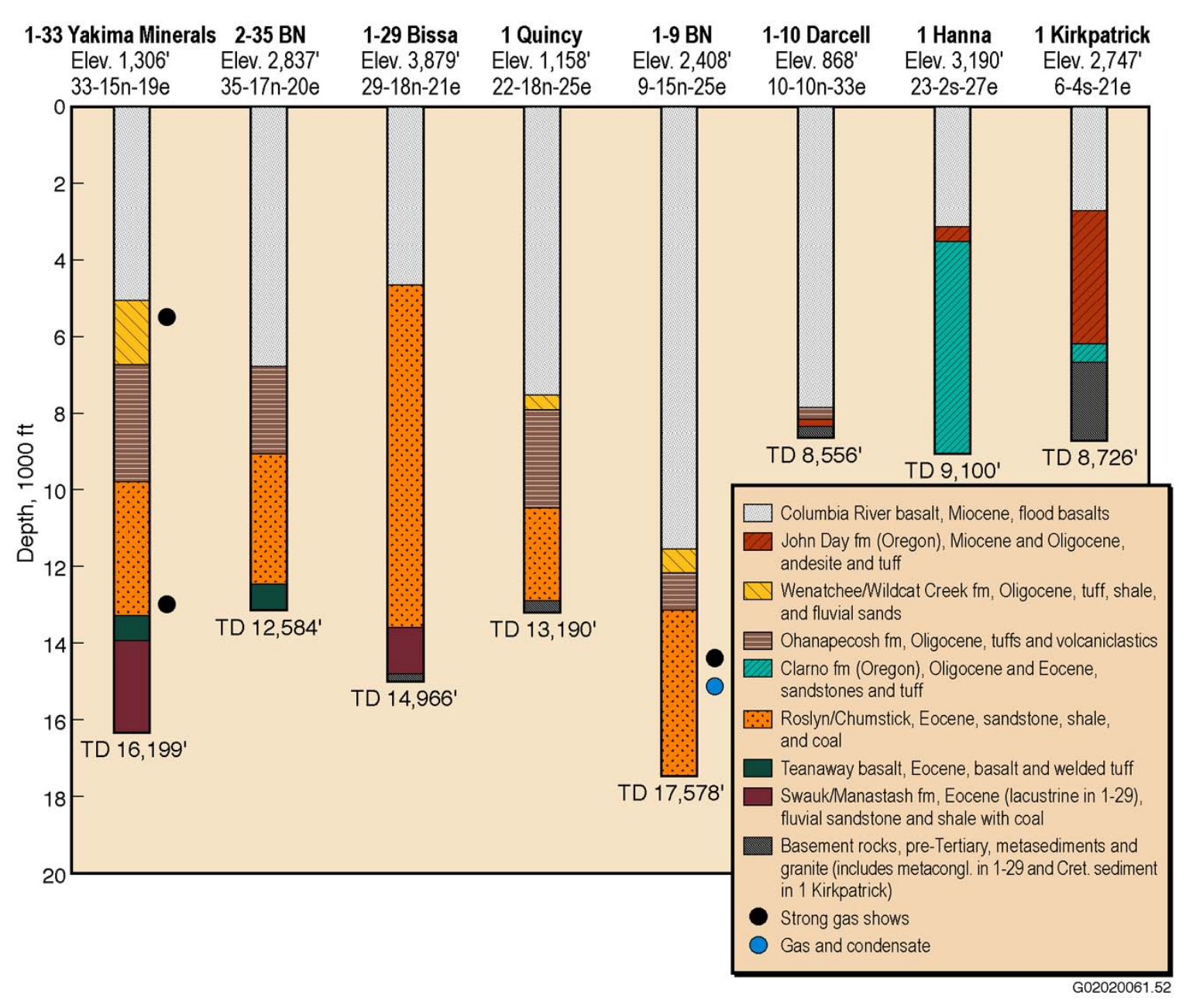

Figure 2.16. Stratigraphy of Boreholes that Penetrate the Columbia River Basalt Group. (For locations see Figure 2.6.)

The pre-CRBG basin above the crystalline basement is filled with early Cenozoic sediments consisting primarily of Eocene continental sediments and some Oligocene volcaniclastic and older rocks (Campbell and Banning 1985; Campbell 1989). Reidel et al. (1989a) interpreted the pre-CRBG basin and craton to be juxtaposed near the Ice Harbor dike swarm east of the Pasco Basin (Figure 2.15) and also interpreted a causative relationship between the dike swarm and this fundamental crustal boundary. Reidel et al. (1992) interpreted this boundary was the suture zone between the continental craton and accreted terrains to the west. Furthermore, they suggested that the suture is oriented approximately $\mathrm{N} 10^{\circ} \mathrm{W}$ and is marked at the surface by the Ice Harbor dikes and the boundary between the Saddle Gap and Eagle Lakes segments of the Saddle Mountains (Reidel 1984, 1988). The location of the suture also appears as a marked prominent aeromagnetic anomaly (Swanson et al. 1979a; also see Appendix D, Figure D.2) associated with the Ice Harbor dike swarm and extends as far south as the eastern side of Wallula Gap. This boundary appears to cross the CLEW, and intersect the Hite fault-craton boundary near Pendleton, Oregon. 
The Hog Ranch-Naneum Ridge anticline (Figure 2.2) parallels the suture and appears to divide the Yakima Fold Belt into two parts. Campbell and Banning (1985) have interpreted pre-CRBG rocks under the Hog Ranch-Naneum Ridge anticline to be part of a horst, but results from a recent seismic profile (Jarchow 1991) suggest that the Hog Ranch-Naneum Ridge anticline may not involve basement structure. We suggest that the Pasco Basin is underlain by a northwest-trending graben east of the Hog Ranch-Naneum Ridge anticline that may only be expressed in the basalt and prebasalt sediments (see Figure 2.15).

Tertiary sedimentary and volcaniclastic rocks west of the Hog Ranch-Naneum Ridge anticline extend beyond the margin of the CRBG and form part of the Cascade Range. There is no faulted western margin to the basin as suggested in the rift model of Catchings and Mooney (1988). The pre-CRBG sediments continue across the present Cascade Range and were arched upward during intrusion and uplift of the Cascade Range to form the present western edge of the Columbia Basin. This supports the previously mentioned geophysical studies and suggests that the Columbia Basin is not a rift basin but perhaps simply a back-arc basin.

The Blue Mountains uplift forms the southern boundary of the pre-CRBG basin, although the exact boundary is not well located. The boundary may lie near the present Blue Mountains ridge crest because of a thick sequence of sediment that occurs north of the crest below the basalt near the Washington-Oregon border (Fox and Reidel 1987). This boundary might coincide with Beeson et al. (1989) east-trending Transarc lowland that forms the low area extending along the Washington-Oregon border through the Columbia Gorge. The Transarc lowland and the pre-CRBG basin combine to produce an apparent northeast-trending trough through the Columbia Basin. The thickest sediment package lies along this trend; in addition, more CRBG flows are found along the trough than elsewhere in the basin. The lowland provided the main pathway for CRBG flows between the vent area and western Oregon and Washington (Reidel and Tolan 1992).

\subsubsection{The Middle Miocene Columbia Basin}

Borehole, geophysical, and stratigraphic data (Berkman et al. 1987; Catchings and Mooney 1988; Reidel et al. 1989a) indicate that the CRBG thins onto the Palouse Slope and thickens into the Yakima Fold Belt (Figures 2.15 and 2.16). The CRBG ranges from 500 to 1,500 $\mathrm{m}$ thick on the Palouse Slope but abruptly thickens to as much as 4,000 $\mathrm{m}$ in the Pasco Basin area (Reidel et al. 1982, 1989a). Regional thickness patterns for both the CRBG and underlying Tertiary sediments indicate that the pre-CRBG basin was subsiding relative to the Blue Mountains and Palouse Slope from the Paleocene-Eocene though the Miocene. By far the most significant tectonic activity was continued subsidence in the basin. The subaerial nature of the CRBG lava flows indicates that subsidence continued as long as basalt was being erupted, and that basalt accumulation kept pace with subsidence (Reidel et al. 1982, 1989a, 1989b). Subsidence rates from 17 to 15.6 Ma were approximately $1 \mathrm{~cm} / \mathrm{yr}$ initially and decreased to $3 \times 10^{-3} \mathrm{~cm} / \mathrm{yr}$ in the late Miocene (Reidel et al. 1989a).

During the eruption of the CRBG, the anticlinal ridges were topographic highs against which the basalt flows thinned during emplacement (Reidel 1984; Reidel et al. 1989a; Anderson 1987). Detailed analysis of borehole and field data (Reidel 1984; Reidel et al. 1989a) established a quantitative relationship between flow thickness and fold growth rates. During the initial eruption of the CRBG (17 to $15.6 \mathrm{Ma}$ ), the ridges grew at about $0.25 \mathrm{~mm} / \mathrm{yr}$ (Figure 2.17), and the rate decreased to about $0.04 \mathrm{~mm} / \mathrm{yr}$ during the waning phases (15.6 to $10.5 \mathrm{Ma}$ ) (Reidel 1984; Reidel et al. 1989a). A cartoon showing this process is shown in Figure 2.18. 


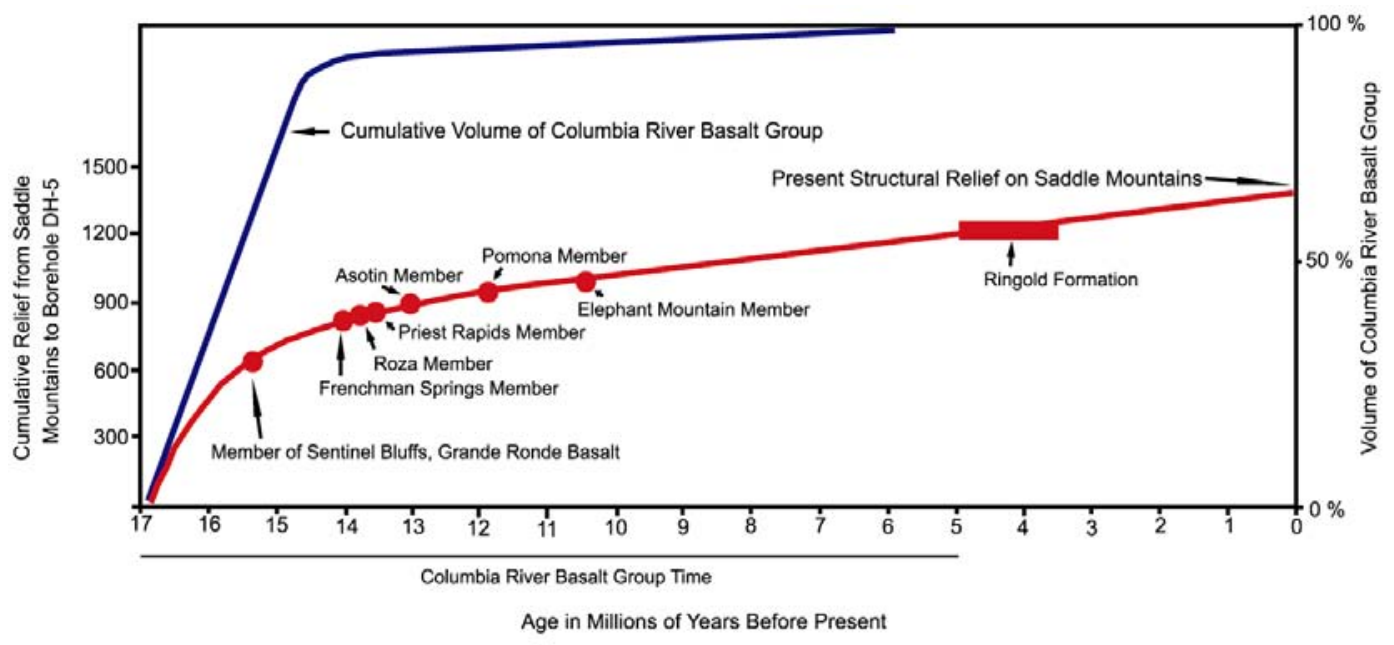

Figure 2.17. Growth Rate of the Saddle Mountains Anticline Based on Thinning of Basalt Flows Over Ridges

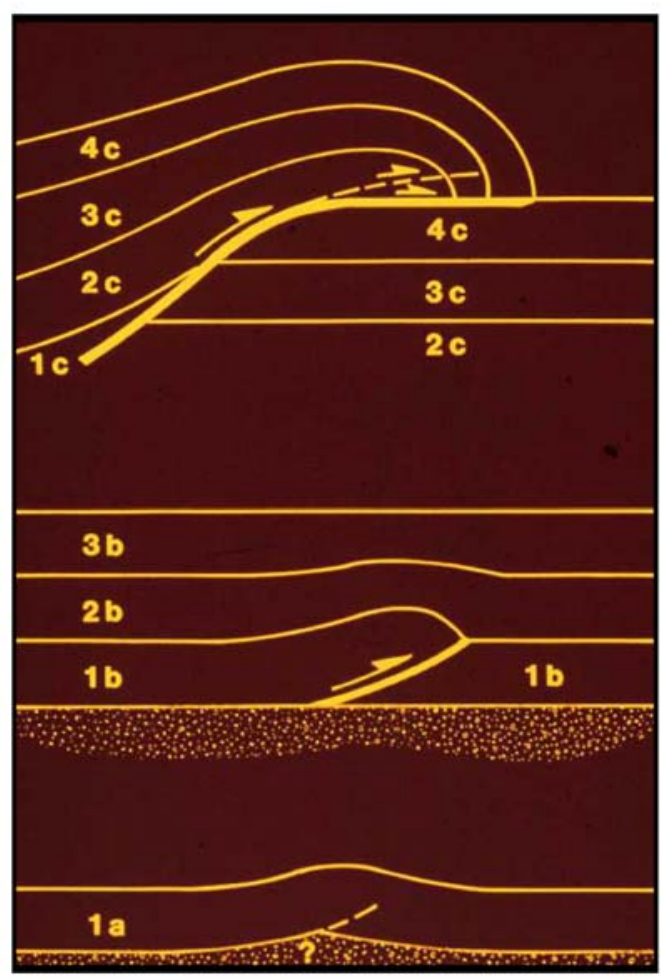

Figure 2.18. Growth of a Yakima Fold. (a) Initial growth of the fold due to buckling as basalt flows are folded. (b) Folding and faulting continue as each new flow is erupted but the deformation is buried by the younger flows. (c) After the last basalt flows are erupted, deformation reaches the surface and the fold-fault system develops. 
By the end of the massive eruptions of the CRBG (10.5 Ma), most of the Columbia Basin was a shallow, bowl-shaped, nearly featureless plain. The massive eruptions had buried most of the structural and topographic relief. In the western part of the Columbia Basin, only the anticlinal ridges that were not buried by younger flows stood above the plain. Across this plain flowed the ancestral Columbia River and its main tributaries, including the Salmon-Clearwater, Yakima, and Palouse rivers.

\subsubsection{The Late Miocene Columbia Basin}

The post-CRBG tectonic history of the Columbia Basin is recorded in the Yakima folds and post-CRBG sediments. Alluvial-lacustrine sediments (Table 2.1) deposited primarily by the Columbia River system show that the Yakima folds were growing and displacing river channels during the late Miocene and Pliocene (Fecht et al. 1987).

Progressive changes in the distribution of post-CRBG sedimentary facies are one of the best records of the post-CRBG history of the Columbia Basin. Sand and gravel deposits of the largest fluvial channels record the locations of major drainages. Lesser alluvial fans and sidestream alluvial systems were deposited adjacent to the main rivers. Ridge uplift and basin subsidence are recorded by progressive lateral shifts in these depositional environments over time (Fecht et al. 1987; Smith 1988).

During the waning phases of CRBG eruptions (12.5 to 8.5 Ma), the Columbia River flowed south across the Yakima Fold Belt. Prior to approximately $8 \mathrm{Ma}$, the post-CRBG pre-Ringold channel (upper Ellensburg Formation and Snipes Mountain Conglomerate) of the Columbia River flowed across the western Pasco Basin, entering at Sentinel Gap (Reidel 1984, 1987) and exiting near Sunnyside Gap (Figure 2.10); from there it flowed southwest toward Goldendale. About $8 \mathrm{Ma}$, the Columbia River began to shift eastward into the central Pasco Basin, occupying a water gap over the eastern end of Rattlesnake Mountain near Benton City, Washington (Fecht et al. 1987). By middle Ringold time (approximately $6 \mathrm{Ma}$ ), the Columbia River shifted position again, exiting the Pasco Basin at Wallula Gap as it does now (Fecht et al. 1987).

\subsection{Geophysical Surveys of the Columbia Basin}

This section summarizes the types and results of geophysical investigations conducted to characterize the subsurface in the Columbia Basin. The section is divided into surface geophysical methods and borehole-wireline methods. Geophysical methods, integrated with borehole and surface geology studies, provide the best means of determining the structural features and physical properties of a subsurface site in the Columbia River Basalt Group. Appendix D provides examples of selected surveys run by DOE that we consider useful for characterizing the subsurface for gas storage in the CRBG.

Geophysical methods involve measuring various physical parameters in the Earth. These are the Earth's natural fields (e.g., gravity, magnetic, and electrical) and discrete rock-mass properties (e.g., seismic velocity, density, bulk modulus, resistivity, and radioactivity). The natural fields are measured directly. Other rock parameters are derived by measuring the effects produced by the Earth when energy 
is induced into the Earth. Types of energy used typically include seismic, electric, and electromagnetic. Geophysical techniques detect discontinuities, layers, or regions in the Earth where the rock properties differ from those in surrounding rocks.

Individual geophysical methods provide information that typically does not have a unique interpretation. By integrating several types of geophysical data with geologic information, a model can be developed. In this way, a more reliable interpretation can be developed. With each new input of data, the values of some parameters are adjusted, and the model is modified until the model best satisfies the greatest number of parameters and measured fields.

\subsubsection{Surface Geophysical Methods}

\subsubsection{Gravity Studies}

Gravity data can be used to constrain structural models on both a regional and site-specific scale. This section is divided into three parts. The first part describes regional gravity surveys, the second Columbia Basin studies, and the third site-specific surveys.

Regional Gravity Setting. The Columbia Basin is a relative gravity high on the regional Bouguer anomaly maps (Appendix E; WPPSS 1981; Riddihough and Seemann 1982; Bonini et al. 1974; Finn et al. 1984; SEG 1982). A 40- to 80-mgal gravity gradient along the trend of the Blue Mountains is interpreted as the northwestern extent of the Basin and Range Province by Eaton et al. (1978) and Riddihough et al. (1986). To the east lies the gravity low of the Idaho Batholith, while to the north the gradient is relatively gentle as the basalts overlap the Omineca crystalline belt of northern Washington and southern British Columbia (Cady 1980). The western margin of the Columbia Basin is separated from the Cascade Range gravity low (described by Danes 1969) by a gradient that may represent the rapid decrease in basalt thickness (Konicek 1975).

Gravity Features of the Columbia Basin. The Washington Public Power Supply System (WPPSS 1977) described the residual gravity features of the Columbia Basin as having broad gravity highs over basalts, broad gravity lows over areas with thick sediment accumulation, and no obvious structural trends. In the western part of the Columbia Basin, Konicek (1975) and Robbins et al. (1975) noted that: Umtanum Ridge, Ahtanum Ridge, and the Rattlesnake Hills (Figure 2.2) are associated with positive anomalies. Konicek (1975) noted that the Cowiche Mountains along the western margin of the Basin also are expressed with a positive anomaly, but the anomaly is $5 \mathrm{~km}$ north of the topographic expression. Toppenish Ridge, by contrast, has a related gravity high that is south of its surface expression and is related to the Simco Volcanic field. Konicek also noted that a change in these anomalies occurred along the north-south regional gravity gradient discussed above. The Ellensburg, Wenas, Yakima, and Toppenish basins are expressed by gravity lows (Konicek 1975; Robbins et al. 1975).

Several structural models have been proposed using gravity data along profiles in the northern part of the Columbia Basin (Cady 1980; WPPSS 1981; Appendix 2.5L-1; Prieto et al. 1985). The north-south profile of Cady extends from east-central Oregon to east-central British Columbia and shows a 10-kmthick section of basalts that gently laps onto the Omineca crystalline belt. The east-west profiles of 
WPPSS (1981, Appendix 2.5L-1) and Prieto et al. (1985), which are located north of the Pasco Basin, show a thinner section of basalt. However, the profiles disagree as to the amount of thinning, because of differences in density contrasts used to model the data. These studies were done before the 1980s exploration activities that gave the exact thickness of the basalt.

Based on gravity analyses, Mohl and Thiessen (1985) extended the edge of the cratonic margin, as defined by strontium isotope data, underneath the basalt cover of the eastern Columbia Basin. Reidel et al. (1994) extended it along the north flank of the Blue Mountains near the Hite fault based on drill data (Figures 2.15 and 2.16) and surface exposures in the Blue Mountains.

The OWL of Raisz (1945) is not evident on Bouguer gravity maps (Konicek 1975; Riddihough et al. 1986). This does not preclude the possibility of the OWL from being a major tectonic structure, although it does lessen the possibility of significant vertical placement at depth. During the Washington Public Power Supply System's investigations (WPPSS 1981), the gravity effect of several simple models was calculated to constrain possible strike-slip offset along the Cle Elum to Wallowa segment of the OWL, where it crosses the north-south regional gravity gradient along the western margin of the Pasco Basin. They concluded that any fault at the base of the basalt that crosses the gradient with a strike between $\mathrm{N} 45^{\circ} \mathrm{W}$ and $\mathrm{S} 45^{\circ} \mathrm{W}$ would be restricted to a maximum horizontal displacement of 2 to $3 \mathrm{~km}$.

Along the central portion of the Cle Elum to Wallula, magnetotelluric data indicate as much as $1 \mathrm{~km}$ of relief at the base of the basalt near Rattlesnake Mountain. The Washington Public Power Supply System (WPPSS 1981) restricts the maximum vertical displacement to less than approximately $100 \mathrm{~m}$ using their gravity data; however, the gravity data coverage is probably not adequate to make such determinations.

Localized Studies. Gravity data have been used extensively during siting investigations for nuclear power plants in the Pasco Basin (Weston 1978a; WPPSS 1981; PSPL 1982). The Washington Public Power Supply System noted that the Saddle Mountains, which form the northern boundary of the Pasco Basin, display no obvious gravity expression (WPPSS 1981); however, the density of gravity data points in the area is low. This is in contrast to the Umtanum Ridge-Gable Mountain structure (PSPL 1982) and the Yakima Ridge structure (Cochran 1982), including their respective subsurface extensions that have clear expressions in the gravity data.

\subsubsection{Magnetic Studies}

Ground-level, site-specific, basin-wide, regional, and satellite-acquired magnetic data have been collected by various organizations across the Columbia Basin. For the discussion here, the data have been grouped into two sets: a regional set and the central Columbia Basin set.

Regional Magnetic Setting. Magnetic data for the region that includes the Columbia Basin include data from satellite, aerial, and land surveys. Continent-scale magnetic data from POGO and MAGSAT satellites and aeromagnetic data from Project MAGNET are discussed in Mayhew (1982a, 1982b, 1985), Mayhew and Galliher (1982), Won and Son (1982), and Sexton et al. (1982). Reasonable agreement exists between the MAGNET and MAGSAT data, although there is greater detail in the MAGNET data 
(Won and Son 1982). The amount of detail added to the regional trend varies, depending on the acquisition parameters, filtering wavelengths, and surface-fitting formulas that were used.

Trends in the POGO data are also apparent in the MAGSAT data, but a significant amount of detail is added. The MAGNET data generally are better correlated with known surface geology than are the MAGSAT data and offer the best representation of upper crustal geology.

In summary, the Columbia Basin does not exhibit any strong magnetic response in the abovementioned data sets, although regional trends are apparent.

Zietz et al. (1971) present the results of an aeromagnetic survey that was flown at 4,600 $\mathrm{m}$ over the Columbia Basin and surrounding regions. Their data show the same general characteristics as the MAGNET aeromagnetic data reported by Sexton et al. (1982), except that the data compiled by Zietz et al. exhibit higher amplitude anomalies. Higher frequency anomalies have been removed from the MAGNET data by low-pass filtering. Zeitz et al. (1971) note the subdued nature of anomalies over the Columbia Basin, in spite of the high magnetization of the basalts, and speculate that this is due to a canceling effect brought on by alternating normal and reversed polarity in the basalt layers (Zeitz et al. 1971). Zeitz et al. also speculate that the characteristics of the magnetic field over the Columbia Basin are influenced more by the sub-basalt rocks than by the basalts, and they base this interpretation on the relatively long wavelengths and low amplitudes of anomalies that are observed.

General magnetic characteristics of the area surrounding the Columbia Basin include a broad, magnetic low associated with most of Idaho (Sexton et al. 1982; Mayhew and Galliher 1982). The extension of this low into the Columbia Basin (see Zietz et al. 1971) suggests some similarities between the subsurface lithologies of Idaho and the Columbia Basin as far as $120^{\circ} \mathrm{W}$ longitude. This magnetic low is probably a reflection of the cratonic rocks in this area.

South of the Columbia Basin, a relative high is detected on the satellite and MAGNET surveys. This trend continues diagonally across southeastern Oregon to northern California. Mayhew (1985) shows a minor northwest excursion of this high that trends across southeastern Washington, reflecting the position of the Rattlesnake-Wallula alignment segment of the OWL proposed by Raisz (1945). Zietz et al. (1971) also show generally higher magnetic intensities in this area that extends from near Yakima, Washington, toward the Walla Walla, Washington, and Pendleton, Oregon, areas, and then northeastward to Clarkston, Washington. Zietz et al. (1971) refer to this feature as the Columbia arc and attribute the eastern high to the presence of pre-Tertiary basement lithologies (e.g., Clearwater Embayment of Swanson et al. 1981). The presence of these highs suggests that a different lithology exists south of the central Columbia Basin.

A magnetic low lies north of the Columbia Basin and corresponds to the North Cascades and Okanogan Highlands. Satellite data (Mayhew 1985) suggest that this low is connected with the similar low in Idaho. This interconnection is not as apparent in the MAGNET data set (Sexton et al. 1982).

The westward edge of the Columbia Basin exhibits the most striking differences between satellite and aeromagnetic data. Sexton et al. (1982) and Won and Son (1982) show a distinct magnetic low in the Cascade Range province. The apparent magnetization map from satellite data of Mayhew and Galliher 
(1982) shows only a gradual trend toward higher magnetization, reaching a maximum near the Pacific

Coast. The Zeitz et al. (1971) survey shows a general low in the Cascade Range with localized highs.

Central Columbia Basin Magnetic Studies. Total field aeromagnetic maps from various surveys over the central Columbia Basin all give comparable results, when differences in survey design are considered.

Zietz et al. (1971) noted a broad, accurate, magnetic low that passes through the central Columbia Basin. This low extends from Ellensburg, Washington, to the Blue Mountains, near Waitsburg, Washington, then to the northeast of Clarkston, Washington, where it connects with a magnetic low in Idaho. The magnetic low transects the topographic expression of the Blue Mountains, which precludes a purely topographic explanation for the feature. South of this low, the map shows a magnetic high centered near Richland, Washington. Subsequent magnetic surveys for the Washington Public Power Supply System and DOE show numerous anomalies superimposed on these larger features. Zietz et al. (1971) detected a prominent high in the northeastern Pasco Basin, at approximate latitude $46^{\circ} 45^{\prime} \mathrm{N}$, longitude $118^{\circ} 45^{\prime} \mathrm{W}$. Prieto et al. (1985) attribute this magnetic high to metamorphic basement material, which supports the Zietz et al. (1971) idea of basement influence in the magnetic field.

Weston Geophysical, using the Washington Public Power Supply System data set, interpreted aeromagnetic intensity maps and described several linears that cross the Pasco Basin. Werner deconvolution solutions of aeromagnetic profile data collected for DOE at Hanford provide limited help in interpreting the geologic significance of these features (Holmes and Mitchell 1981). The Nancy and the Juniper Springs aeromagnetic linears are discontinuous features on the Weston magnetic intensity contour map. They transect the northern Pasco Basin on a northeast trend. The tectonic significance of these linears is not known. Weston Geophysical interpreted the Juniper Springs linear as most probably related to a fault that is younger than Umtanum Ridge, Yakima Ridge, and the Rattlesnake Hills-Wallula Gap structures (WPPSS 1977; Weston 1978b). This interpretation is based on apparent offsets in magnetic anomalies associated with Umtanum Ridge, Yakima Ridge, and Rattlesnake Hills at their intersections with this linear.

Swanson et al. (1976), using data collected at an altitude of $150 \mathrm{~m}$ above ground level, noted a zone of northward-trending anomalies east of the Pasco Basin and associated the zone with the Ice Harbor dike system. They interpreted the southern termination of these anomalies, at the intersection of the OWL, as strike-slip faulting. A more recent map released by Flynn et al. (1998) shows that these anomalies do cross the OWL but do not support a strike-slip interpretation for this zone.

AERO (1980) flew an aeromagnetic survey at five different levels over the Pasco Basin and used the flight-line profiles to calculate Werner deconvolution solutions for DOE. Myers and Price (1981) discussed these solutions and qualitative interpretations of the results in the Cold Creek syncline area (north of Rattlesnake Mountain). Representative total-field magnetic contour and Werner deconvolution maps also are presented in Holmes and Mitchell (1981). Werner deconvolution (Werner 1953; Kilty 1983) is a mathematical analysis that detects magnetization contrasts. These contrasts can result from the 
influence of structural, stratigraphic, erosional, or topographic features. The number and scatter of Werner solutions in a given area are measures of the confidence in the existence and location of a geologic feature.

Several magnetic surveys of the land surface have been conducted in and around the Hanford Site (Ault 1981; Cochran 1981a, 1981b, 1982; Kunk 1981; Kunk and Ault 1986). The magnetic-field contour maps generated from these surveys depict the same general features as the aeromagnetic surveys discussed above, but in more detail; however, the features do not correlate with known geologic features. Improving the interpretation of magnetic data will require an improved understanding of 1) the effect of sediment overlying the basalt on the magnetic field, 2) the magnetic susceptibilities and natural remnant magnetism of the sediments and basalts, and 3) the structures in the basalt that are not recognized on existing maps.

There is considerable variability in susceptibility and natural remnant magnetism within the magnetostratigraphic units, which precludes detailed modeling and interpretation of the data sets. Van Alstine and Gillett $(1981,1982)$ discussed the magnetic variability of the basalts and concluded that comprehensive sampling programs are required to describe this variability adequately. Numerous magnetic polarity reversals in the basalt flows also complicate the interpretation of magnetic data.

\subsubsection{Magnetotelluric Studies}

Hydrocarbon exploration companies on the Columbia Basin have used magnetotelluric techniques extensively since approximately 1980 . While magnetotelluric surveys typically provide less resolution than seismic reflection data, their extensive use in the past was due, in part, to initially poor success with seismic reflection techniques in determining structure and stratigraphy beneath the basalts. Better success with seismic methods and poor resolution of magnetotelluric methods in areas where boreholes were drilled indicate that seismic methods are superior techniques.

Due to the acquisition parameters and state of technology at the time, most of the data collected before 1983 are not useful for detailed structural interpretations. The quality of data improved significantly over data of the late 1970s and early 1980s because of advances in magnetotelluric technology. Unfortunately, no data newer than 1983 is available for the Columbia Basin.

Five surveys (Czimer and Edwards 1978; Senturion 1979; Argonaut 1980; Geotronics 1982; Z-Axis 1985) have been conducted for DOE, and three proprietary regional data sets can be purchased (Geotronics 1982; Z-Axis 1983; Phoenix 1983). A regional magnetotelluric profile by the U.S. Geological Survey (USGS; Stanley 1982) also is available.

Geoelectric Stratigraphy. Crustal rocks have been grouped into five layers using magnetotelluric data for the central Columbia Basin. Layer 1 includes the sediments overlying the CRBG, the uppermost basalt flows, and the sediments between basalt flows of the Saddle Mountains Basalt. Layer 2 is the basalt section, mainly the Wanapum and Grande Ronde Basalts, and layer 3 is the Eocene and Oligocene sediment section underlying the basalts. Layer 4 presently has a rather wide range of resistivities, depending on the location of the measurements throughout the Columbia Basin. This variation is 
believed to be caused by the variety of rock types that are associated with it, mainly Mesozoic accreted terrains. The Pasco Basin data indicate a layer 4 resistivity of approximately $100 \mathrm{ohms}$ (Berkman et al. 1986). The lowermost, crustal layer, layer 5, is deep and not well defined in the magnetotelluric data.

Sub-Basalt Structures. Orange and Berkman (1985) quantitatively analyzed the DOE magnetotelluric data collected by Czimer and Edwards (1978), Senturion (1979), Argonaut (1980), and Geotronics (1984). They confirmed the findings of Geotronics (1981) that detailed structural interpretations, based on pre-1982 data, were not warranted because of poor data quality. Their analysis also indicated that the quality and density of data acquired in 1982 were not sufficient for the detailed interpretations presented by Geotronics (1984) and Mitchell and Bergstrom (1983). They recommended that the pre-1982 data be used only to define the gross geologic features of the sub-basalt rocks in the Pasco Basin.

Orange and Berkman (1985) interpreted the Geotronics data set for the central Columbia Basin as an accumulation of basalt ranging from 3 to $4.6 \mathrm{~km}$ in thickness. This accumulation is asymmetric in cross section and thins rapidly to the west of the Pasco Basin and more gently to the east on to the craton. Most of the thick section of basalt occurs within the boundaries of the Pasco Basin, although the thickest accumulation appears to occur slightly to the southwest of the boundary. They made no attempt to address the relationship between the observed surface structures and the base of the basalt. They concluded that additional, closely spaced, high-quality data are needed for detailed structural analysis.

Twenty-four relatively close-spaced magnetotelluric sites were occupied along two profiles across part of the Rattlesnake-Wallula alignment in 1985 (Z-Axis 1985). This study was the first attempt by DOE at a detailed investigation of a possible sub-basalt structure. The data are significantly better than previous data sets. Berkman et al. (1986) interpreted the data and concluded that there is approximately $1 \mathrm{~km}$ of relief at the base of the basalt beneath Rattlesnake Mountain. This is approximately the same amount of relief observed at the surface. They were not able to determine whether the base of the basalt was faulted, but indicated that with additional, carefully selected sites, the feature may be resolved with the magnetotelluric method.

\subsubsection{Seismic Refraction Surveys}

The DOE (1988) conducted large-scale refraction surveys to define geologic structures in and around the Hanford Site, to define a crustal model that better constrains earthquake locations, and to determine station corrections for the Hanford earthquake-monitoring network. Other investigators have conducted surveys to determine the regional variation of structures within the Columbia Basin and Pacific Northwest. Additional surveys have been conducted to support siting and licensing of nuclear power plants, engineering and foundation studies, and general exploration.

Seismic refraction results have given a general picture of the upper crustal variations in the Columbia Basin and Pasco Basin. The refraction data need to be subjected to additional interpretation, and these results need to be integrated with gravity, magnetic, magnetotelluric, borehole, and geologic data to determine a consistent structural model. 
Long-Range Refraction Surveys. Surveys conducted over and near the Columbia Basin have been reported by Dehlinger et al. (1965), White and Savage (1965), Johnson and Couch (1970), Hill (1972), and Crosson (1972). A summary of crustal thickness and upper mantle velocities in the western United States was given by Smith (1978). Velocity models used by PNNL and the University of Washington to locate earthquakes have a crustal thickness of $40 \mathrm{~km}$ beneath the Puget Sound region and crustal thickness of $25 \mathrm{~km}$ in northeastern Washington.

A seismic refraction experiment was conducted by the DOE and the University of Washington using blast data recorded by seismic networks. Rohay and Malone (1983), using a time-term analysis of these data, reported depths to the $6 \mathrm{~km} / \mathrm{s}$ layer, probably the crystalline basement. These data indicate that the basement is deepest beneath the Hanford Site and to the south. Odegard and Mitchell (1987) inverted a portion of these data recorded over the Pasco Basin using a single-ended refraction inversion program. This inversion was consistent with analyses by Rohay and Malone (1983), except that a low-velocity zone was included, and two basalt layers were used. The depth to basement for this inversion is nonunique, since the velocity of the low-velocity zone for the sediments (the $4.6-\mathrm{km} / \mathrm{s}$ layer) is assumed. The thickness of this $4.6 \mathrm{~km} / \mathrm{s}$ layer is partially determined by the assumed velocity of this zone.

In 1984, a long refraction survey was conducted by the DOE, USGS, and the University of Washington. Data were recorded along a $260-\mathrm{km}$ transect from eight points. The University of Washington and the DOE recorded cross-line data from these shots with temporary seismograph stations. They also recorded additional data using earthquake seismograph networks. Catchings and Moody (1988) published the results from the long-line experiment. These data agree with the previous work of Rohay and Malone (1983), showing the deep basement beneath the Hanford Site to be somewhat deeper. In the Catchings and Moody (1988) model, the basin does not extend as far to the south. The major discrepancy is between the Catchings and Moody model, which has a 40-km-thick crust with an $8.4 \mathrm{~km} / \mathrm{s}$ upper mantle velocity, and the Hill (1972) model, which has a $25-\mathrm{km}$-thick crust and a $7.9 \mathrm{~km} / \mathrm{s}$ upper mantle. This difference may be due (Glover 1985) to Hill's misinterpretation of data with an apparent velocity of $7.2 \mathrm{~km} / \mathrm{s}$ as being propagated through the upper mantle. It also may be due to the lack of a more detailed interpretation incorporating intracrustal structures.

Using the off-line data recorded by the University of Washington and DOE, Glover (1985) used iterative ray tracing in laterally varying structures to determine the thickness of basalt and the depth to basement. Results of these analyses show that the thickness of basalts, including the surface sediment layer and the depth to basement are in general agreement with results from magnetotelluric surveys and with Rohay and Malone (1983) described above. The data are, however, inconsistent with the rift model for the Pasco Basin proposed by Catchings and Moody (1988). This is because one would expect that the thick part of the basalt and sediments would have a much more elongated shape if the depression were caused by incipient rifting. Glover's results seem more consistent with simple basin development caused, perhaps, by the loss of material from the upper mantle.

Time-term analysis of refracting arrivals from earthquakes recorded by seismograph stations have been used by several investigators to determine upper mantle velocities and relative time-term delays for the crust in Washington. McCollom and Crosson (1975) determined the average upper mantle velocity of 
$7.8 \mathrm{~km} / \mathrm{s}$ in western Washington and to average $8.2 \mathrm{~km} / \mathrm{s}$ in eastern Washington. Rohay (1982) analyzed data from refraction profiles to estimate upper mantle velocities of 7.8 to $7.9 \mathrm{~km} / \mathrm{s}$ for the North Cascades.

Data from the DOE refraction survey recorded by the University of Washington and the PNNL earthquake seismograph networks also were analyzed by Rohay et al. (1985). They used time-term analysis primarily to determine depth to basement. These results are consistent with those of Glover (1985) and Catchings and Moody (1988) but do not include information on the thickness of the crust. In addition, this work gives a better picture of the regional variation in depth to basement. The results indicate that the depth to basement shallows to the southwest but may continue as a deeper feature to the northwest.

Zervas and Crosson (1986) analyzed refraction data from earthquakes recorded in Washington using time-term analysis to estimate upper mantle velocities and crustal thickness variation. They found an average mantle velocity of $8.2 \mathrm{~km} / \mathrm{s}$ and evidence for a $1^{\circ}$ dip of the crust mantle boundary from eastern Washington to the Cascade Range. They also found evidence for anisotropy in the upper mantle, with the fastest velocities in the northwest and southeast directions. These results do not support the unusually high velocities $(8.4 \mathrm{~km} / \mathrm{s}$ ) shown by Catchings and Moody (1988). The $8.4 \mathrm{~km} / \mathrm{s}$ velocity could be revised if the crustal model were thinner or had a higher average velocity.

Site-Specific Refraction Surveys at the Hanford Site. Seismic surveys on the Hanford Site have been conducted intermittently since 1959 (see Appendix D). These surveys consisted mainly of short $(<1 \mathrm{~km})$ seismic refraction profiles. They were conducted primarily for site investigations in support of engineering and foundation studies and are more applicable to evaluating basalt for natural gas storage. Other surveys were conducted to test the method and for general exploration.

Several seismic refraction surveys were conducted for the Washington Public Power Supply System Nuclear Project-2 (WNP-2; WPPSS 1981) and WNP-1 and WNP-4 (WPPSS 1986), and for the Puget Sound Power and Light Company Skagit/Hanford Nuclear (PSPL 1982). Over $50 \mathrm{~km}$ of seismic refraction lines were shot for WNP-2 (WPPSS 1981). Most of these data were either low resolution for depthto-bedrock determinations or relatively high resolution for shallow studies to determine overburden material velocities.

The best general-purpose data from the WNP-2 survey were obtained along a Hanford Road survey area, which was designed to investigate the possible extension of Yakima Ridge. The surface densities of shot and receiver locations were sufficient to give a somewhat detailed picture of not only the top of basalt, but also the sediments overlying the basalt. The results of this survey are shown in Appendix D. Because of the nature of the sediments and top-of-basalt velocity structures, the contractor-estimated depth errors of approximately $6 \mathrm{~m}$ seem to be somewhat optimistic. A more reasonable estimate might be $10 \%$ of the depth or velocity, or approximately 15 to $20 \mathrm{~m}$ for top of basalt.

Nineteen seismic refraction lines were run for siting WNP-1 and WNP-4 (WPPSS 1986). Four of these lines were low resolution with large shot spacings for depth to bedrock determinations. No sediment or basalt velocity values were given on these sections. No significant features were observed in the bedrock. The four low-resolution lines and the other 15 lines were used to determine the velocity 
structure of the sediments. A high-velocity refractor was observed in the Ringold Formation (sediments overlying the basalt), but no anomalous features were observed. This high-velocity refractor apparently corresponds to the upper-middle Ringold Formation found in the DOE survey discussed below.

Skagit/Hanford Seismic Refraction Surveys. The Skagit/Hanford Nuclear Project conducted over $115 \mathrm{~km}$ of seismic refraction surveys to determine the velocity structure of the sediments overlying the basalt, the depth to top of basalt, and the geologic character of structural features in the area. Except for a few lines in the area south of Gable Mountain, which is the eastern part of Umtanum Ridge, most lines were used to investigate the eastern part of Umtanum Ridge and its extensions (PSPL 1982). A survey, comprising 30 refraction lines, was conducted on a portion of Gable Mountain to investigate a northeasttrending fault and a possible pull-apart feature in the same location. The fault could not be traced effectively with the seismic lines, but they were subsequently used to plan a trenching survey.

Other lines in the Skagit/Hanford Nuclear Project survey were used to examine the May Junction linear, which was originally defined in DOE gravity and magnetic data (Myers et al. 1979). This linear is a north-south trending disturbance in gravity and magnetic features between Gable Mountain and the Southeast anticline, which forms the eastern extension of Umtanum Ridge.

U.S. DOE Seismic Refraction Surveys. Seismograph Service Corporation also conducted refraction surveys for DOE. Data were collected over eight lines with a total length of $32 \mathrm{~km}$ in the vicinity of the central Hanford Site. A low-powered energy source, the Betsy Seisgun (trademark of Mapco, Inc.), was used with 36 shots usually detonated at each shot point. The resulting data do not reveal penetration through as much as $100 \mathrm{~m}$ of sediments to the top of the basalt except in certain areas.

Weston (1982) made the initial interpretation of the data. The interpretation consisted of cross sections of the velocity structure and static correction tables for a $168 \mathrm{~m}$ datum above mean sea level. These static data were used in subsequent reflection processing (Berkman 1984).

Mitchell and Odegard (1984) and Odegard and Mitchell (1987) did a more detailed analysis of the refraction data along line 15 . They constructed a velocity-versus-depth section for this line and related it to lithology, using borehole data. The interpretation of the data also incorporated the vertical seismic profiling data. A comparison was made between the velocity model from the vertical seismic profiling data from borehole RRL-2 and an average of the seismic refraction profiles located around this borehole.

The velocity data have resulted in the middle Ringold sedimentary unit being subdivided into upper and lower units. These data also are consistent with the Skagit/Hanford Nuclear Project data (PSPL 1982).

\subsubsection{Seismic Reflection Surveys}

The DOE conducted seismic reflection surveys to delineate the stratigraphy of sediment and basalt layers within the Hanford Site and determine the presence and extent of anomalous features with potential structural significance (Appendix D, Figure D.4). 
Seismic reflection data were used to interpolate or extrapolate lithology and stratigraphy among borehole and outcrop data. This required careful integration of geology and borehole data with the seismic reflection data. Several seismic surveys have been conducted on the Hanford Site since 1963. Until 1979, these surveys consisted of testing the method. Testing of seismic reflection techniques was conducted by DOE in 1978 to determine the ability of the method to penetrate $1,000 \mathrm{~m}$ of basalt to the member of Umtanum of the Grande Ronde Basalt (Figure 2.3). A report of the test results is given in Seismograph Service Corporation (SSC 1978) and Heineck and Beggs (1978). The data showed good penetration with reasonably coherent energy down to approximately $0.5 \mathrm{~s}$. Below this, there appears to be energy at scattered locations penetrating to at least $1.0 \mathrm{~s}$. Also apparent are problems due to statics and off-line scattering. A section located just to the northeast of Gable Mountain shows the basalt layers ramping up as the line approaches the mountain (Appendix D, Figure D.6).

Because the results of the 1978 test were encouraging, 140 line kilometers of seismic reflection surveys were conducted by DOE in 1979 and 55 line kilometers in 1980. These lines were located to provide general coverage of the Hanford Site, but were concentrated in the Cold Creek syncline. Results of the surveys are reported in Seismograph Service Corporation (SSC 1979, 1980); Myers et al. (1979); and Holmes and Mitchell (1981). In addition to the record sections, Seismograph Service Corporation provided interpretations of the data to locate the top of basalt and anomalous features in the basalt.

The top-of-basalt maps produced by Seismograph Service Corporation were based on an assumption of a velocity-depth function from the stacking velocities. As discussed by Odegard and Mitchell (1987), this assumption was in error along line 5 and probably in much of the Hanford Site south of the eastern part of Umtanum Ridge. These errors result from a lack of velocity data from the sediments in the form of acoustic velocity logs or vertical seismic profile data. In addition, the interpretation appears to have been done without the constraint of top-of-basalt data from boreholes, although these data would be of limited use without velocity data.

Holmes and Mitchell (1981) evaluated the seismic reflection data from the 1979 and 1980 surveys in conjunction with other geophysical data. They concluded that some of the anomalous seismic features correlated with anomalies identified in magnetic and gravity data. During 1983, sections of lines 3, 5, and 8 were reprocessed for DOE. The results of this reprocessing were reported by Berkman (1984). The reprocessing was aimed at using better statics correction and stacking procedures based on velocity data from seismic reflection surveys. Careful attention also was paid to other parts of the processing sequence. This reprocessing resulted in somewhat better record sections.

The major result of the data reprocessing was the realization that there are severe statics problems in the western part of the Cold Creek syncline. It also was recognized that data acquisition should be conducted to give higher fold coverage at near offsets to better image the top of basalt. The statics problems and the need for higher fold data were not recognized initially, because the 1978 tests were conducted in an area that, on the surface, appeared to be similar, but in the subsurface was significantly different from the rest of the Hanford Site. Specifically, the thicknesses of the various sediment layers over the basalt are significantly different, thus affecting the seismic response. 
In 1985, additional seismic reflection was conducted to determine the best acquisition and processing parameters in the central Hanford Site (DOE 1988). This survey was conducted along a 3.2-km test line; this is just to the west of a segment of line 5 of the Seismograph Service Corporation survey. The survey included a series of tests to determine the best technique to acquire high-resolution seismic data.

The acquisition of these data was aimed at determining the depth (thickness of sediments overlying the basalt) to top of basalt. The acquisition used short geophone spreads, $1 \mathrm{~ms}$ sample rates, and relatively small energy sources. Three energy sources were tested, including a land air gun. Dynamite and primacord were tested to determine the optimum shot pattern, charge depth, and number of shots or shot size. After the initial tests, a shot point and group spacing of $7.6 \mathrm{~m}$ with a $15.44-\mathrm{m}$ group length was chosen for production work. The spread geometry was asymmetric with a maximum offset of $350 \mathrm{~m}$. The resultant data were processed by the contractor (Kunk 1986). It was determined that the best energy sources were the air gun and dynamite. The results from these two sources were quite similar, so detailed processing was conducted only on the air gun section, which is the easiest to acquire. Walker Geophysical, using standard seismic processing techniques, processed these data. The principal coherent arrival seen at a reflection time of just over $0.1 \mathrm{~s}$ can be correlated with the base of the caliche layer in the sediments. The apparent reflection is a result of the large velocity gradient at this point, which acts as an interface. Coherent reflectors can be seen at times down to slightly over $0.3 \mathrm{~s}$, although they do not correlate well across the section. The top of basalt is at a depth of $0.27 \mathrm{~s}$ near shot point 120 but also does not correlate well across the section.

This same line also was processed through Emerald Exploration Consultants, Inc. (Berkman et al. 1986). These data were processed using a similar processing sequence to that of Kunk (1986), except that an iterative, surface-consistent, statics and velocity-analysis procedure was used. In addition, a poststack, dip-correlation filter was used. This correction also shows reflectors at reflection times at least to $0.5 \mathrm{~s}$. This is approximately the depth of the middle of the member of Sentinel Bluffs $900 \mathrm{~m}$ depth (Figure 2.3) in this area. The top of basalt is not an obvious arrival in this section. The abundance of the coherent reflectors in this section could, to some extent, be an artifact of the dip-correlation filter, and the interpreter must be careful in interpreting these reflectors.

Kunk (1986) also processed this same section using a muting technique, which surgically removes areas of noise from the prestack data. The resultant common depth point gathers can be stacked in the normal way. Coherent noise trains due to channel waves produced in the sediments by the sediments overlying the basalt and top-of-basalt interfaces were removed from these data by muting data in a wedge near zero offset. The resultant reflectors used in the common depth point stack are primarily refracted. Thus, the resultant section is much like a high-resolution seismic refraction section. This section showed a coherent reflector near the expected top-of-basalt reflection time. Other reflectors are clearly seen in the sediments, although the caliche reflector is absent. No reflectors are seen below a reflection time of approximately $0.3 \mathrm{~s}$. 


\subsubsection{Borehole Geophysical Surveys}

Borehole geophysical surveys and logs are used to gather data on rock densities, velocities, porosities, and other parameters. The following discussion outlines several applications of these techniques and their potential for generating data useful to site characterization.

\subsubsection{Sonic Logs}

Sonic logging data from the Shell Oil Companys' 1-29 Bissa and 1-33 Yakima Mineral wells (Figure 2.12) were used to model the crustal structure of the Columbia Basin derived from large-scale seismic refraction surveys (Glover 1985). Sonic logging data have been used to generate seismic impedance profiles used in synthetic seismogram modeling (Berkman 1984). Seismic velocities in the basalt flows derived from sonic logging data have been used to aid contractor processing of seismic reflection data.

Synthetic seismogram modeling can be used in wavelet analysis performed as part of seismic stratigraphic interpretations. Compressional- and shear-wave velocities derived from full waveform sonic logging data assist seismic reflection investigations. Full waveform sonic logging data have been used in conjunction with borehole televiewer data to characterize intraflow structures, fracturing, and borehole breakouts in a limited number of wells (Paillet 1985).

Sonic logs are one of the most useful tools for determining the intraflow structures of basalt flows in a borehole. In particular, the sonic logs easily detect the vesicular flow tops, vesicular zones, and the pillowed bases of the lava flows (Figure 2.19). In addition, they can be used to detect fault zones and sedimentary interbeds.

\subsubsection{Density Logs}

The principal use of gamma-gamma density logging in geophysical investigations is to provide a constraint on the rock density values for gravity modeling. Gamma-gamma density logging also has provided corroboration of density values derived from borehole gravity surveys. Other applications of these logging data are for accurate determination of seismic impedance profiles used in synthetic seismogram modeling and quantitative logging analysis of intraflow structures and sedimentary interbeds.

\subsubsection{Vertical Seismic Profiling}

Vertical seismic profiling data have provided detailed velocity information about the sediments overlying the basalt and the velocities of the basalt layers penetrated by a borehole. This information is necessary to support seismic reflection processing. Drilling of sediments often necessitates cased boreholes and frequent cementing in many boreholes. This, coupled with the shallow sediments, has made it difficult or impossible to acquire good sonic logs in many horizons above the basalts. Therefore, velocity/vertical seismic profile surveys are most useful in the basalt. 


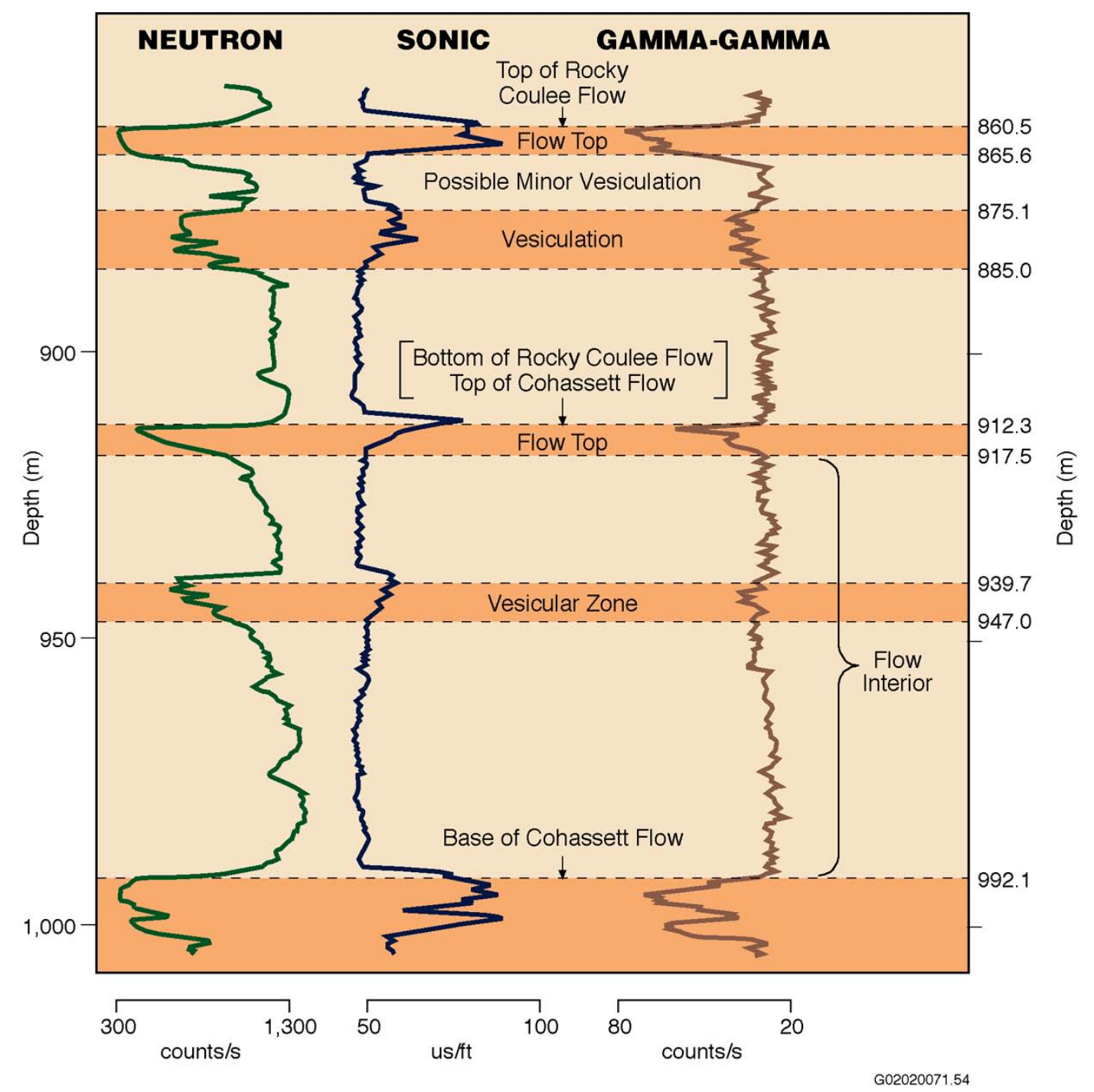

Figure 2.19. Typical Geophysical Log from Cored Borehole RRL2 (Pasco Basin) Showing Responses from Member of Sentinel Bluffs Basalt Flows, Grande Ronde Basalt (see Figure 2.3). Borehole location shown in Figure 3.6.

The Birdwell Division of Seismograph Service Corporation conducted check shot and sonic log surveys for DOE in deep boreholes $(1.6 \mathrm{~km})$ at Hanford (Birdwell 1979). Inversion of the check shot data is discussed by Odegard and Mitchell (1987). These surveys tested a maximum depth of 1,100 $\mathrm{m}$ in borehole DC-6. The surveys used a surface vibrator with a receiver placed at eight to eleven different depth levels in each borehole. The velocity data are good, although incomplete, but more levels of recording in more boreholes are needed to understand the velocity layering. A typical velocity section is shown in Appendix D, Figure D.3.

In 1981, Seismograph Service Corporation conducted vertical seismic profiling surveys in boreholes RRL-2, RRL-3, and RRL-4 at the Hanford Site (Odegard and Mitchell 1987). These surveys used the 
Betsy Seisgun as the energy source, and the receiver was placed at each 7.6-m level from the surface down to the top of basalt. These surveys revealed large velocity variations and low-velocity zones in the sediments overlying the basalt.

In 1984, Dresser Atlas conducted velocity/vertical seismic profiling surveys in boreholes RRL-5, RRL-7, RRL-8, RRL-10, and RRL-16 (Dresser 1985). Explosives and the Betsy Seisgun were used as energy sources. These surveys, like the surveys conducted in 1981, were used to determine the velocity structure in the sediments overlying the basalt, but sample levels were at 3-m intervals.

\subsubsection{Borehole Gravity}

Borehole gravity logs yield accurate, apparent bulk densities. Density information is necessary for gravity modeling and seismic reflection coefficient determinations. When layers are flat lying, and no structures are nearby, these apparent densities represent accurate, average bulk densities for the strata between reading levels. Determinations of accurate, apparent bulk densities are possible with borehole gravity data due to the deep penetration of the measured field (Jageler 1976). Furthermore, borehole gravity logs are not generally influenced by rugosity and are unaffected by drilling mud and casing.

Borehole gravity surveys have been run in DOE boreholes (Robbins et al. 1983) to obtain density information on the sediments overlying the basalt and to acquire density information within the deep basalt horizons (Robbins et al. 1979). This information has significantly aided the surface gravity modeling, allowing more quantitative models. The densities derived from borehole gravity indicate that the gravity high located with surface gravity near borehole RRL-9 (borehole location shown in Figure 3.6) can be attributed to a high-density layer near the surface (Kunk and Ault 1986).

\subsubsection{Other Geophysical Logs}

Stratigraphic correlation of geologic horizons and delineation of intraflow structures have been the primary uses of well-logging data during the regional studies conducted by DOE. Uncalibrated neutron porosity and passive gamma-ray logs have been the most commonly used wireline data for these purposes. Electric resistivity logs have not been particularly useful in the stratigraphic determinations, because of the poor quality of the data that have been acquired in the past. Poor electric log data quality and lack of well penetration into the sub-basalt sediments have resulted in limited use of these data as a constraint on magnetotelluric survey interpretation. Electric logging data from the Shell Oil Company 1-9 BN Saddle Mountain well have been used to estimate appropriate resistivity values for the sub-basalt sediments. 


\subsection{Hydrologic Framework}

An understanding of hydrologic conditions and relationships between principal hydrogeologic units within the CRBG is fundamental for considering natural gas storage and containment in deep basalt aquifers. The summary discussion presented in this chapter is taken largely from material presented in Gephart et al. (1979), Spane (1982), DOE (1988), Drost et al. (1990), and Whiteman et al. (1994).

As discussed in Section 2.0, basalt flows typically consist of a permeable flow top, and dense, relatively impermeable interior (Figure 2.8). Sedimentary interbeds and basalt contact zones (vesicular flow tops, brecciated flow tops, basal pillow complexes, and basal breccia zones) serve as the primary aquifers in the region, whereas dense flow interiors commonly act as aquitards. The collective contact boundary section between two individual basalt flows (i.e., a flow top and overlying basalt flow bottom) is referred to as an interflow zone. Lateral groundwater flow occurs primarily along the more pervious basalt interflow zones, which is reflective of the conditions and environment of emplacement during the basalt flow extrusion and solidification, and subsequent weathering and soil formation processes. Because of this dependence, a wide variation in groundwater production capacity may be exhibited for individual interflow zones in the CRBG.

The dense interior portions of basalt flows (i.e., entablature and colonnade) comprise approximately 80 to $90 \%$ of an individual flow's thickness, and greatly restrict the movement of groundwater. The preferential direction of groundwater flow within basalt interiors, however, is vertical. This is attributable to the preferential vertical fracture/joint attitude within flow interiors, and the permeability contrast exhibited between interflow/interior sections.

\subsection{Regional Groundwater Flow}

The CRBG flows cover most of eastern Washington, northeast Oregon, and portions of western Idaho. Individual flows typically extend over tens of thousands of square kilometers. As shown in Figure 2.5b, flows of the Saddle Mountains Basalt are restricted to the south-central section of the basin, and are underlain by flows of Wanapum Basalt and Grande Ronde Basalts within the subsurface. Basalt flows of the Wanapum and Grande Ronde crop out in the remainder of the surrounding Columbia Basin area not occupied by the Saddle Mountains Basalt. The Grande Ronde Basalt underlies the entire Columbia Basin area and comprises over $87 \%$ of the total basalt volume within the region (Reidel et al. 1989a) and nearly $90 \%$ of the entire basalt (Camp and Ross 2000).

Natural recharge to basalt units occurs where they are exposed to direct infiltration of precipitation and surface water runoff. Groundwater entering pervious basalt horizons generally flows from areas of higher elevation (i.e., areas of high estimated natural recharge) to areas of low topographic expression, ultimately discharging directly to major surface water drainages, e.g., the Columbia and Snake rivers, or to overlying hydrogeologic units that are in hydrologic communication with these major surface water systems. Figures 3.1, 3.2, and 3.3 show the groundwater-potentiometric maps and inferred, regional 


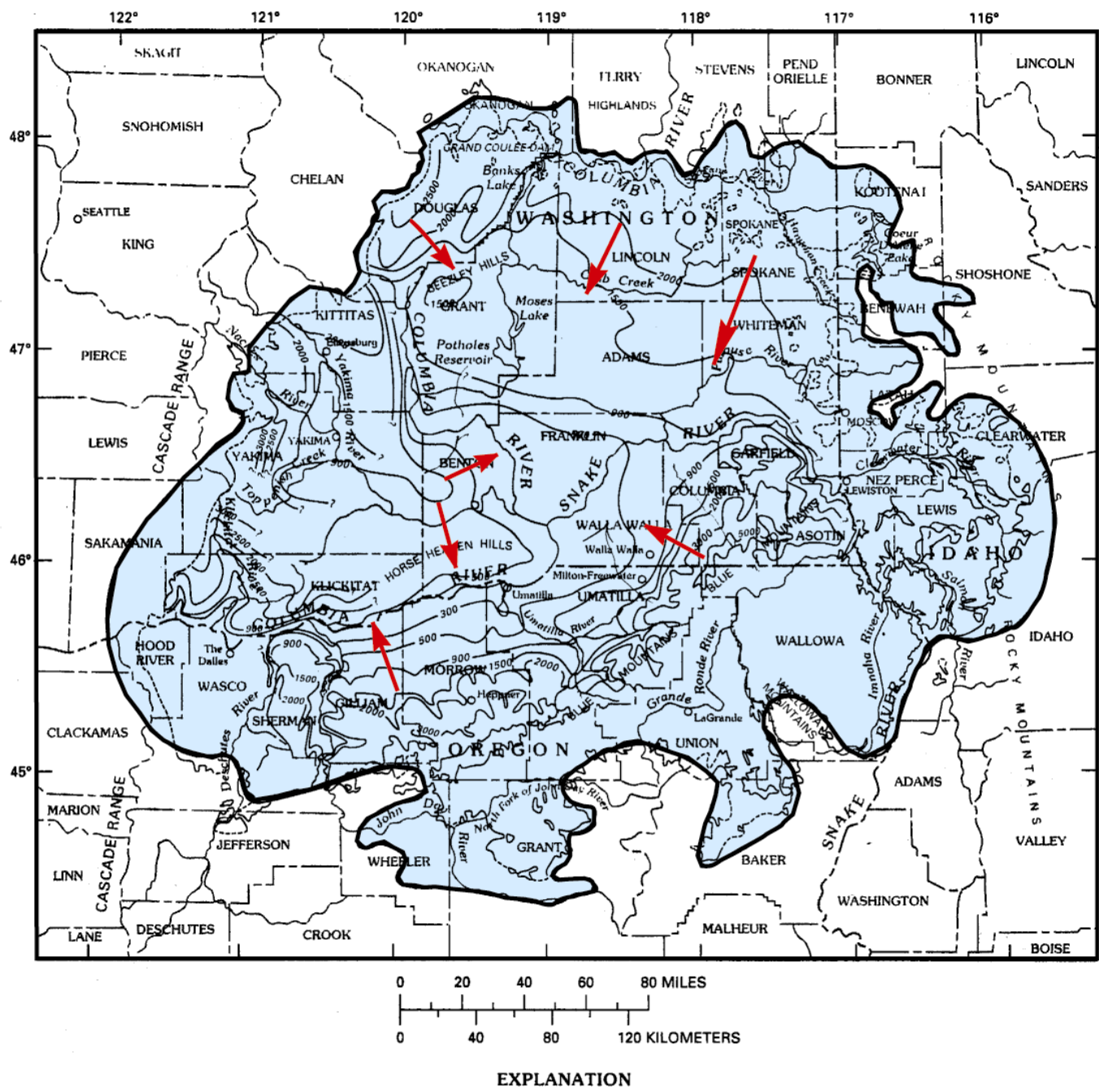

—

Approximate limit of Grande Ronde Basalt

Groundwater Flow Direction

Figure 3.1. Groundwater-Potentiometric Map and Inferred, Regional Groundwater Flow Within the Grande Ronde Basalt (modified from Whiteman et al. 1994)

groundwater flow within the Grande Ronde Basalt, Wanapum Basalt and Saddle Mountains Basalt, respectively. This general, regional flow pattern, however, can be modified locally by the presence of intervening structural features (e.g., folds and faults), which can cause significant disruption of lateral flow patterns and afford significant vertical communication between individual basalt groundwater-flow systems. Man-related activities associated with groundwater pumping and artificial recharge from agricultural irrigation and conveyance systems also significantly influence and distort the natural groundwater flow systems within members of the CRBG, as noted in various reports (e.g., Gephart et al. 1979; Cline 


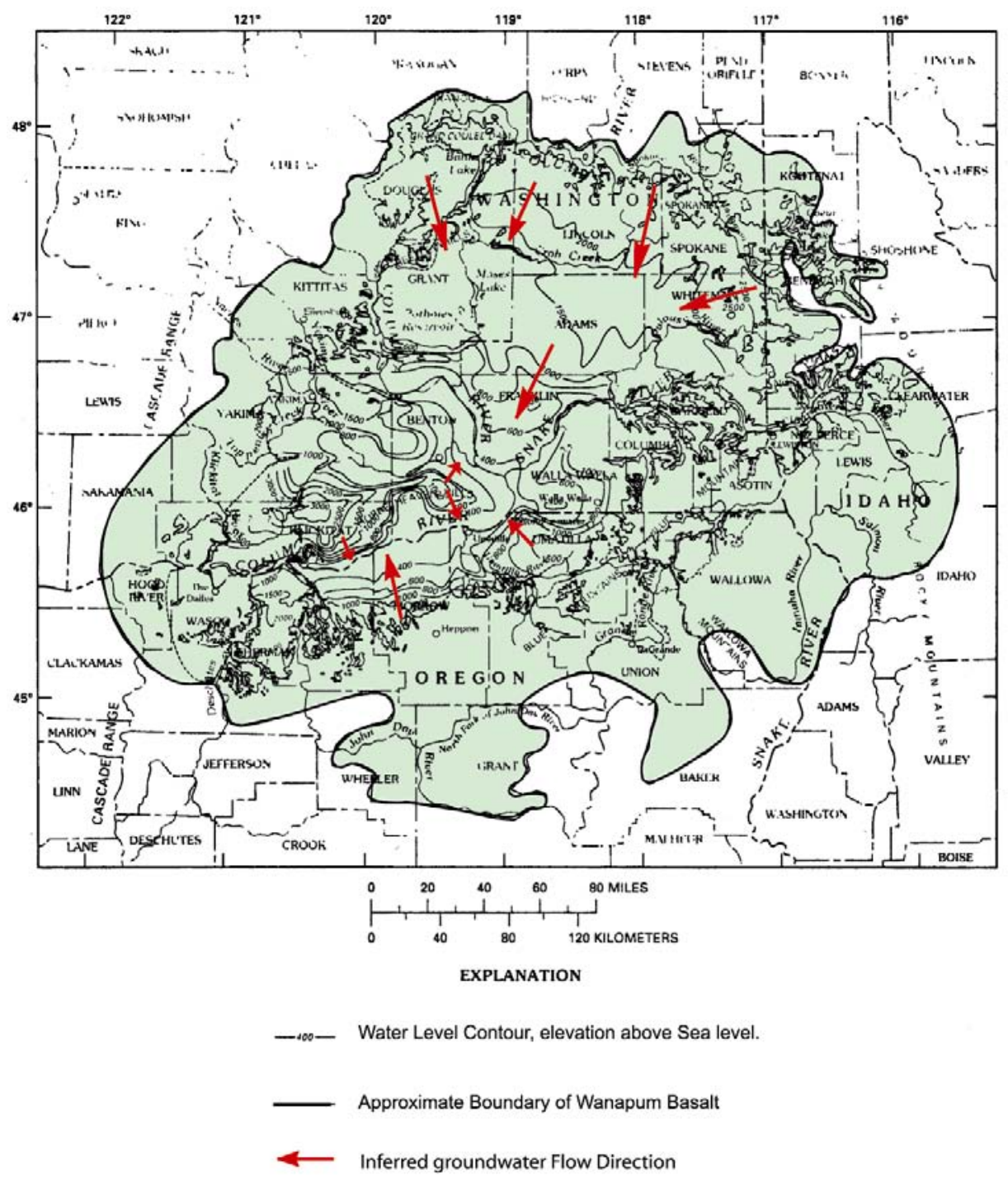

Figure 3.2. Groundwater-Potentiometric Map and Inferred, Regional Groundwater Flow Within the Wanapum Basalt (modified from Whiteman et al. 1994)

1984; Whiteman et al. 1994). Additionally, many wells within the region are uncased within the basalt section, which allows for direct vertical communication between basalt aquifers. In some localities, the vertical communication afforded by open wells may exceed the natural vertical groundwater flux between hydrogeologic units (Hearn et al. 1985; Steinkampf and Hearn 1996).

It is important to note that regionally abrupt hydraulic head changes may occur near two major CRBG formational contacts. In most cases, the abrupt change in hydraulic head across the formational contacts is attributed to a locally pervasive low permeability layer. For the Saddle Mountains/Wanapum Basalt contact, low permeability clay/tuff layers within the intervening Mabton interbed are commonly cited. For the deeper Wanapum/Grande Ronde contact, either low-permeability units within the intervening 


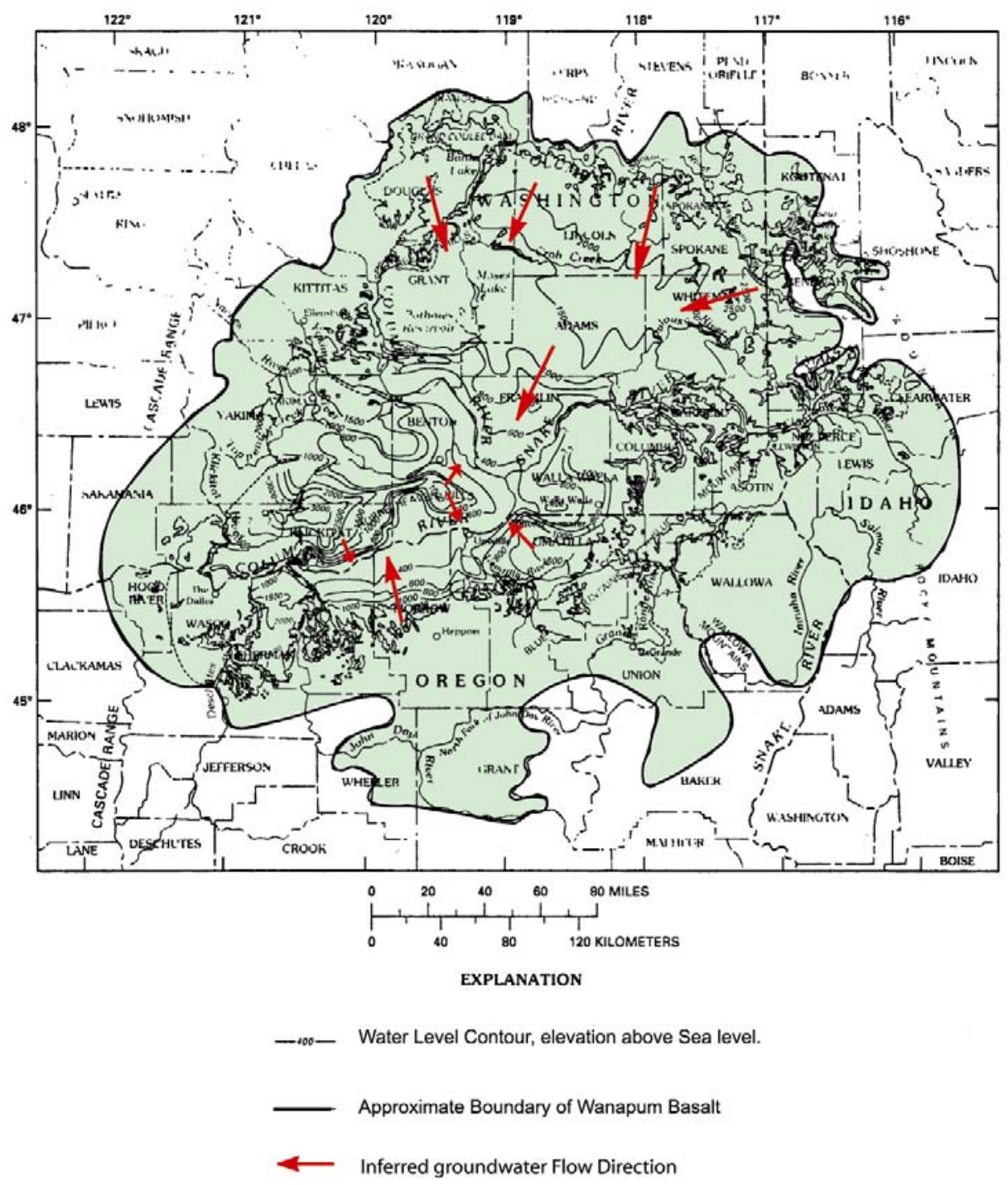

Figure 3.3. Groundwater-Potentiometric Map and Inferred, Regional Groundwater Flow Within the Saddle Mountains Basalt (modified from Whiteman et al. 1994)

Vantage Horizon (interbed), a deeply developed soil (saprolite) on the uppermost Grande Ronde Basalt flow, or a combination of interbed and soil horizon are reported (Gephart et al. 1979; DOE 1988). The presence of the Vantage interbed and upper Grande Ronde weathering zone (saprolite) represents a regional aquitard of low permeability, which tends to separate groundwater within the two Columbia River Basalt Group formations. The regionally observed stratigraphic horizons that separate groundwaters between the Grande Ronde Basalt and Wanapum Basalt (i.e., Vantage Horizon), and between the Wanapum Basalt and Saddle Mountains Basalt (i.e., Mabton interbed horizon) are present within the Pasco Basin. This is also demonstrated by the major hydrochemical (see Section 4.0) composition (content) differences that exist between Wanapum Basalt and Grande Ronde Basalt groundwaters. The presence of distinct groundwater flow systems is indicative of additional sealing potential for the vertical 
migration of natural gas stored within deep basalt interflow zones. Additional discussions concerning hydraulic confinement and communication between basalt groundwater zones are presented in Sections 3.1.1 and 3.1.2.

\subsubsection{Features Conducive to Confinement}

Features contributing to confinement of groundwater within individual interflow zones within the CRBG include:

- the occurrence of low-permeability, (silt/clay) sedimentary interbeds, and intensively developed soil horizons (saprolite layers)

- the presence of thick, dense basalt flow interior sections

- increased depth below land surface (i.e., increased thickness of basalt)

- secondary mineral formation.

Sedimentary interbeds commonly occur at the contact between two successive basalt flows and represent depositional phases between flow eruptions. Although sedimentary interbeds may be present locally within all the basalt formations of the CRBG, they occur most frequently within the uppermost formation, separating individual basalt flows of the Saddle Mountains Basalt where eruptions were separated by great time intervals. Although low-permeability, over-bank phases (lacustrine) predominate in the central region of the basin, sufficient higher permeability, main stream fluviatile facies occur within the sedimentary interbed sequence that may possess sufficient production capacity for domestic watersupply needs. Adding to the general low-permeability nature of the sedimentary interbeds are the presence of tuffaceous and diatomaceous units within the sedimentary deposits.

In most of the situations, a considerable time lag occurred between eruptions of successive basalt flows. This time span provided the opportunity for surface weathering to occur on exposed flow top horizons. Reidel et al. (1989b) estimated that the average time span between Grande Ronde Basalt flow eruptions averaged 20,000 years. Of importance hydrologically is the 250,000-year time span that occurred between the last Grande Ronde Basalt flow and first Wanapum Basalt flow. The intense saprolite horizon that developed on the Grande Ronde Basalt, together with a low-permeability sedimentary interbed (Vantage Horizon), form a regionally important confining horizon that hydrologically separates groundwater within the upper Grande Ronde Basalt from groundwater within the lower Wanapum Basalt. As discussed in Section 3.1, in areas not affected by structural deformation, the separation of groundwater flow systems is supported regionally by the occurrence of significant differences in hydrologic head profiles and hydrochemical and isotopic compositions across this hydrologic confining unit.

The presence of thick, dense flow interior (entablature) sections of a basalt flow (which may make up $\sim 85 \%$ of a typical flow thickness) can provide an effective confining unit between more permeable basalt interflow zones. Grande Ronde Basalt flows, which underlie nearly the entire Columbia Basin area (see Figure 2.4), are generally thicker and more extensive than their Saddle Mountains Basalt counterparts. This suggests that Grande Ronde Basalt interflows may, on average, exhibit more confinement than either 
Wanapum Basalt or Saddle Mountains Basalt flows. Basalt thickness also displays an areal dependence, with Columbia River Basalt flows generally being thicker (on average) within Pasco Basin. For example, Reidel and Fecht (1981) and Reidel et al. (1989) indicate the following average flow thickness for basalt flows, within and outside Pasco Basin: Saddle Mountains Basalt $=30$ to $50 \mathrm{~m}$ within (thins on topographic ridges to 0 and thickens in synclines), and 20 to $30 \mathrm{~m}$ outside; Grande Ronde basalt $\sim 100 \mathrm{~m}$ within, and $\sim 30$ m outside. The increase in flow thickness is attributed to ponding of basalts within the regional topographic low area of the Columbia Basin at the time of the basalt eruptions. The previous discussion suggests that basalt flow interior thickness and groundwater confinement may increase for individual interflow zones within the southcentral region of the Columbia Basin and with stratigraphic depth (i.e., from Saddle Mountains to Grande Ronde Basalt).

Newcomb (1971) noted that random fractures (entablature) and preferentially oriented joints (colonnade) within basalts that appear open near land surface (or outcrop exposures) become progressively more closed and tighter with depth, thereby increasing confinement. This depth dependence limits the production of groundwater to wells in some of the more permeable, rubbly interflow zones at greater depths (Newcomb 1971). Detailed hydraulic testing results of individual basalt interflow zones appear to support this general observation of decreasing groundwater productivity (i.e., permeability) with depth at individual borehole sites in Pasco Basin, and in particular, in comparing deeper Grande Ronde Basalt versus overlying Wanapum Basalt interflow zones (DOE 1988). As discussed in Spane (1982) and DOE (1988), the observed depth-permeability pattern is attributed to compaction (i.e., increasing effective stress) and secondary mineral formation. This particular general permeability-depth dependence is also exhibited for basalt flow interior/caprock intervals (Spane 1982), and is consistent with commonly cited decreases in permeability with depth relationships observed for sedimentary formations (e.g., Neuzil and Bredehoeft 1981; Somerton 1982). In addition, in areas such as Pasco Basin and surrounding Columbia Basin that exhibit high horizontal-to-vertical effective stress conditions at depth (stress ratio $=1.77 \pm$ 0.20; Section 2.0), fractures exhibiting more vertical, high-angle orientations may be more prone to closure.

Secondary mineral formation within basalt flow fractures is another factor that increases confinement within basalt flows. The hydrochemical evolution of groundwaters within the CRBG has been established by regional and vertical-depth studies previously described in Gephart et al. (1979), DOE (1988), Hearn et al. (1985), Whiteman et al. (1994), Steinkampf and Hearn (1996), and summarized in Section 4.0. Groundwater within deeper basalts (e.g., Grande Ronde Basalt) tends to be more hydrochemically evolved and, as a result, is at a state of saturation for a variety of mineral species. This level of saturation causes secondary mineral precipitation (e.g., smectite clays, calcite, quartz), particularly within basalt fractures that occur within flow interior sections. The percentage of fractures exhibiting complete secondary in-filling for core obtained within basalt flow interiors generally exceeds 80 to $85 \%$ for specific borehole locations (Section 2.0). 


\subsubsection{Features Conducive to Vertical Communication}

The ability of dense flow interiors (entablatures) to act as confining layers may be due to a number of factors. Features contributing to a lack of confinement or enhanced communication between groundwater within individual CRBG interflow zones include:

- effects of structural deformation

- presence of subsurface topographic highs

- shallow depth below land surface

- basalt flow irregularities.

The effects of structural deformation can impose a significant impact on the movement of groundwater within and between basalt interflow zones. Regional groundwater studies have identified the hydrologic barrier aspects of faults that occur at a number of locations within the Columbia Basin (e.g., Newcomb 1961, 1971). Hydrologic barriers imposed by fault zones to lateral groundwater flow within individual interflow zones can be significant and has been observed to exceed $150 \mathrm{~m}$ in hydraulic head difference across such structures in several cases (Newcomb 1961). The hydrologic barrier aspects caused by fault zones is attributed to lateral discontinuity of the interflow zone, due to vertical offset and the formation of lateral low-permeability materials along the immediate fault zone structure (i.e., fault gouge, secondary clays).

The brittle deformation of the basalt due to faulting and folding, however, can create preferential vertical flow pathways through basalt flow interiors (tectonic fractures), enabling vertical hydrologic communication between interflow zones in areas adjacent to fault zone structures. DOE (1988) and Johnson et al. (1993) have presented detailed hydrologic and hydrochemical data that demonstrate that faults can act both as barriers to lateral groundwater movement and as areas of enhanced vertical groundwater flow (i.e., on either side of the fault). Figures 3.4, 3.5, and 3.6 show various hydrologic and hydrochemical data plots that support a lateral hydrologic barrier and enhanced vertical communication in the vicinity of the Cold Creek fault that intersects the western part of the Hanford Site in Pasco Basin. The Cold Creek fault is a high-angle fault structure, striking in a roughly north-south direction. This was one of the previously recognized hydrologic barriers within basalts associated with faulting reported by Newcomb (1961) in his regional groundwater studies. Hydraulic head discontinuity or head difference across the fault ranges between 120 to $150 \mathrm{~m}$ for the various Wanapum and Grande Ronde basalt interflow zones at depth.

Figure 3.4 shows a conceptualization of vertical flow to the west and east of the Cold Creek fault, comparative vertical chloride vs. depth profiles for wells in these areas, and a hydraulic head difference of $\sim 150 \mathrm{~m}$ across the structure. Supporting the conceptualization of vertical flow west and east of the fault are vertical hydraulic head profiles that indicate a decreasing head with depth west and an increasing head profile east of the fault for Wanapum Basalt and Grande Ronde Basalt interflow zones (head profiles not shown; see DOE 1988). The chloride concentration versus depth profiles support a downward migration of dilute, hydrochemically immature groundwater downward to the Wanapum Basalt-Grande Ronde Basalt contact. East of the fault, a zone of mixing is indicated for Wanapum Basalt groundwaters that 


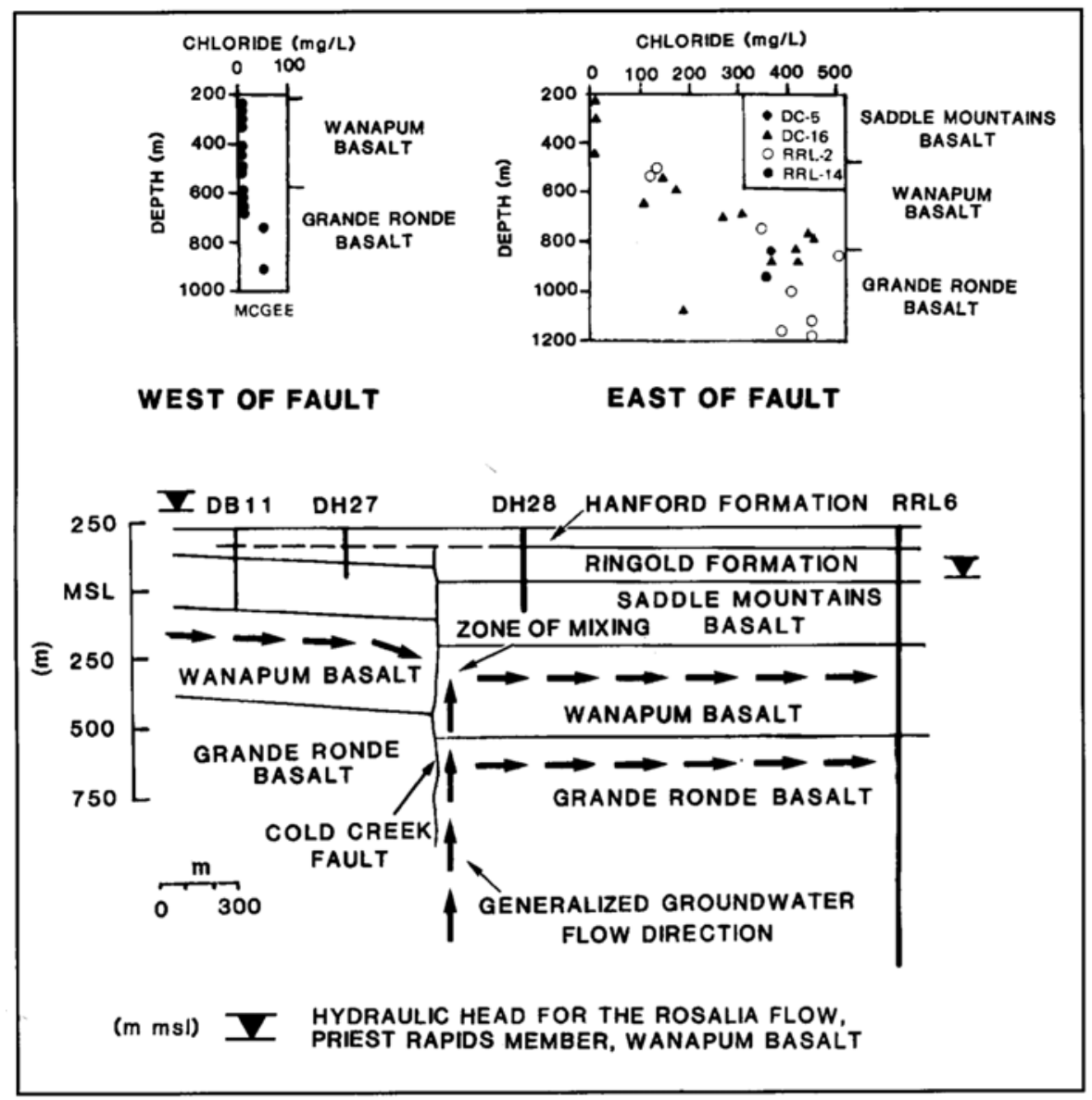

Figure 3.4. Conceptualization of Vertical Flow to the West and East of the Cold Creek Fault (Johnson et al. 1993)

represents mixing between dilute Saddle Mountains Basalt groundwaters and the more chloride rich, hydrochemically evolved Grande Ronde Basalt groundwaters. This mixing line between the Saddle Mountains Basalt and Grande Ronde Basalt groundwaters is consistent with the vertical hydraulic head relationship, which indicates an upward groundwater flow potential between the Grande Ronde Basalt and Wanapum Basalt interflow zones (DOE 1988).

Figure 3.5 shows an areal plot of chloride within the upper Wanapum Basalt interflows (Priest Rapids and Roza basalts), depicting the plume pattern emanating from the Cold Creek fault structure, which is consistent with the general east-southeast groundwater-flow pattern for these units. The chloride plume emanating from this structure argues strongly for a discrete line-source origin (i.e., a localized zone of enhanced vertical communication) for the chloride pattern exhibited, rather than pervasive areal leakage through the basalts. Similar, but slightly more concentrated, areal chloride patterns are exhibited for lower Wanapum interflow zones (e.g., Frenchman Springs basalt). 


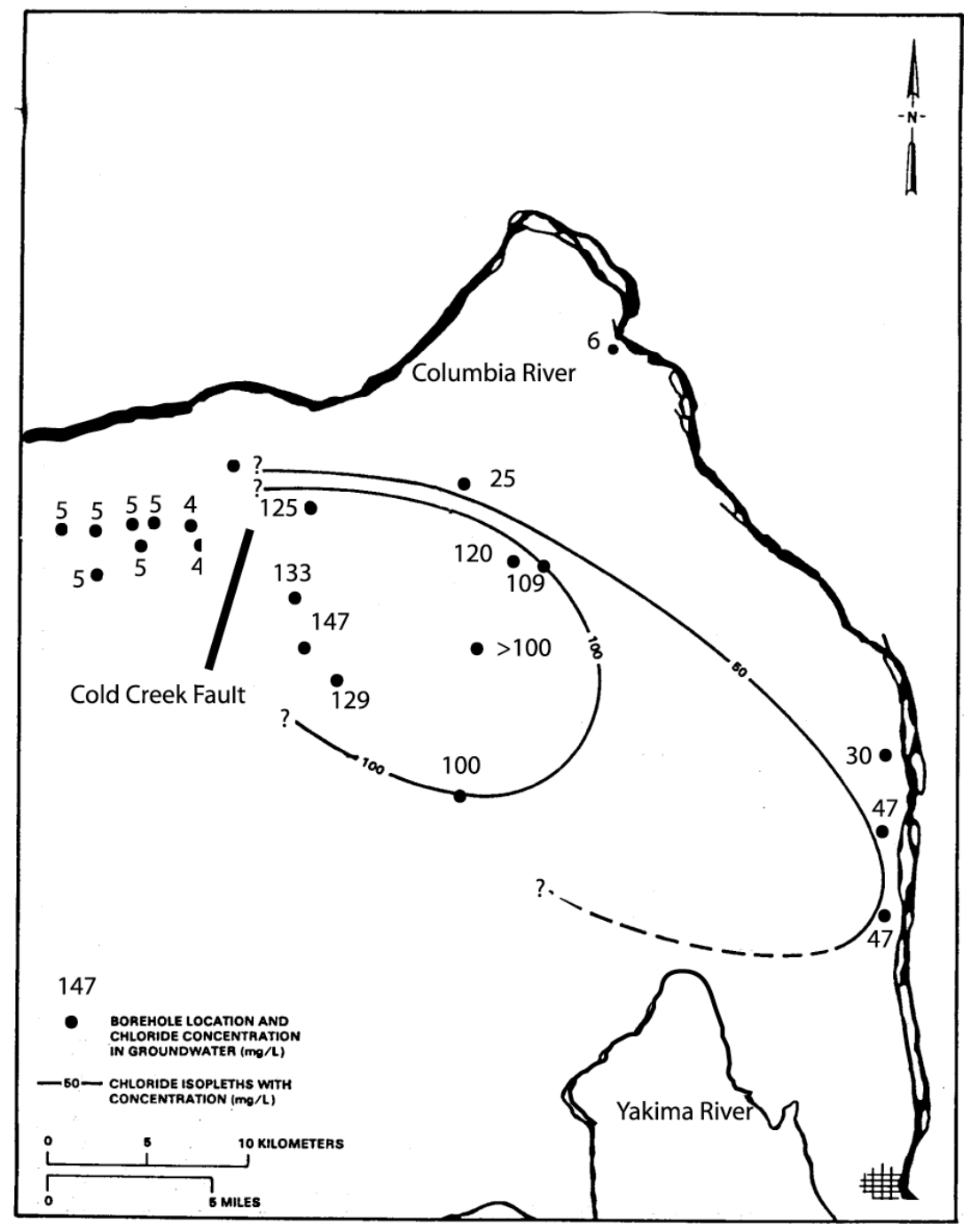

Figure 3.5. Areal Plot of Chloride Within the Upper Wanapum Basalt (adapted from DOE 1988)

Other hydrochemical parameters provide similar indications of upward vertical flow from the Grande Ronde Basalt into the overlying Wanapum Basalt interflow zones and a lateral east-southeast plume pattern consistent with the prevailing groundwater flow direction for these hydrogeologic units. The Cold Creek fault also provides vertical communication between groundwaters within the Grande Ronde Basalt and underlying formations. For example, Figure 3.6 shows an areal plot of dissolved methane concentrations within Grande Ronde basalt groundwaters, which supports the vertical upward movement of natural gas along the east side of the Cold Creek fault from sedimentary formations beneath the Columbia River basalt. Only in this region of the Cold Creek syncline does methane form the principal component of dissolved gas within Grande Ronde Basalt groundwaters. The plume pattern for dissolved methane (shown in Figure 3.6) provides strong evidence for a localized area of enhanced vertical communication associated with the east-side of the Cold Creek fault rather than pervasive leakage through basalt flow 


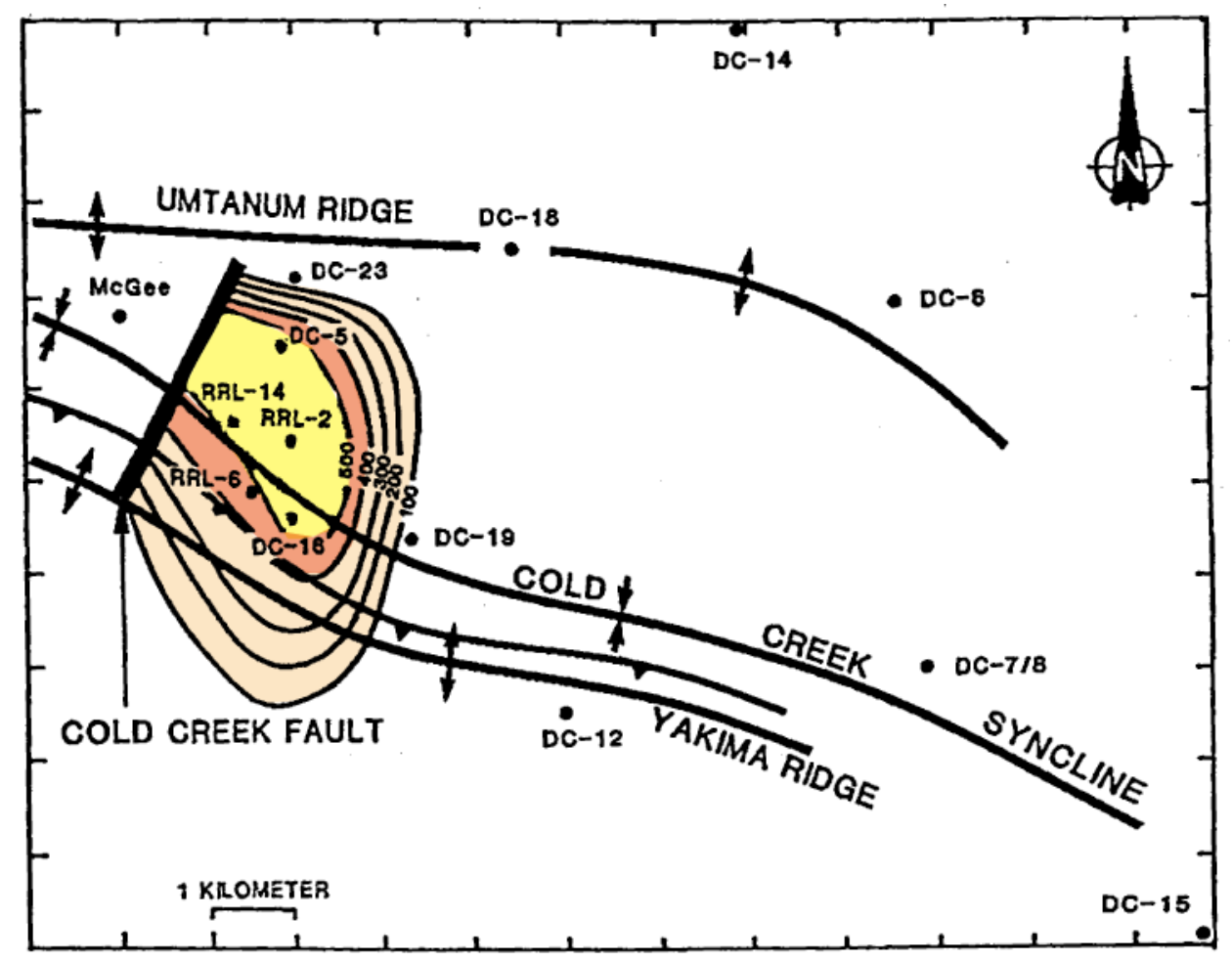

Figure 3.6. Areal Plot of Dissolved Methane Concentration (mg/L) Within Grande Ronde Basalt Groundwaters (Johnson et al. 1993)

interiors. As noted in Johnson et al. (1993) and Campbell and Reidel (1994), the source of natural gas within CRBG flows in this region is from sedimentary formations beneath the basalts. This is discussed in more detail in Section 4.0.

Basalt flow thickness and areal extent exhibit a strong association with the paleo-topography at the time of basalt flow eruption (Sections 2.0 and 3.1.1). Flows, on average, tend to be thicker in topographic lows and thin (to not present) along topographic highs. This is particularly relevant for individual flows of the Saddle Mountains Basalt, which collectively represent the least extensive formation (by volume) within the CRBG. Figure 2.5b shows the restricted areal occurrence of the Saddle Mountains Basalt within the south-central region of the Columbia Basin. Appendix G shows the areal extent of all Saddle Mountains Basalt flows. Reidel and Fecht (1981), DOE (1988), and Reidel et al. (1989a) present areal thickness information for individual Saddle Mountains Basalt flows within Pasco Basin, which are reflective of a topographic dependence (i.e., thinning on topographic ridges and thickening in synclines). This topographic dependence is also exhibited to a lesser degree within underlying Wanapum Basalt and Grande Ronde Basalt flows.

A number of factors contribute to a greater degree of groundwater confinement with increasing depth below land surface (see Section 3.1.1). For basalt flows occurring at or near land surface, the factors 
contributing to increased confinement are not operative. In addition, the uppermost or younger basalt flows that occur at land surface may have been subject to erosional events that were associated with repeated, cataclysmic Pleistocene flood events that occurred as a result of ice-dam failures across the Columbia River and the sudden emptying of prehistoric Lake Missoula, (i.e., the Missoula Floods, Bretz 1923; Baker and Nummedal 1979). The erosional effects of numerous catastrophic flood events within Pasco Basin have been cited by Gephart et al. (1979), DOE (1988), Spane and Raymond (1993), and Spane and Webber (1995) as contributing to localized areas of hydraulic communication (i.e., incised paleostream channels) between upper-basalt confined aquifers and the overlying unconfined aquifer system. Groundwater within basalt interflow zones occurring at shallow depths and previously subject to extreme erosional events, therefore, may exhibit low confinement and be in hydraulic communication with underlying and/or overlying aquifer systems.

Gephart et al. (1983) describe a number of internal and external basalt flow features, such as pillowbreccia/palogonite zones (e.g., at flow bottoms), flow margins, and spiracles, which if extensively developed, can provide localized areas of enhanced vertical communication between adjacent interflow zones. Figure 3.7 depicts a hypothetical basalt flow sequence with various flow features that could provide enhanced communication. Of these features, only tectonic fractures (discussed earlier in this

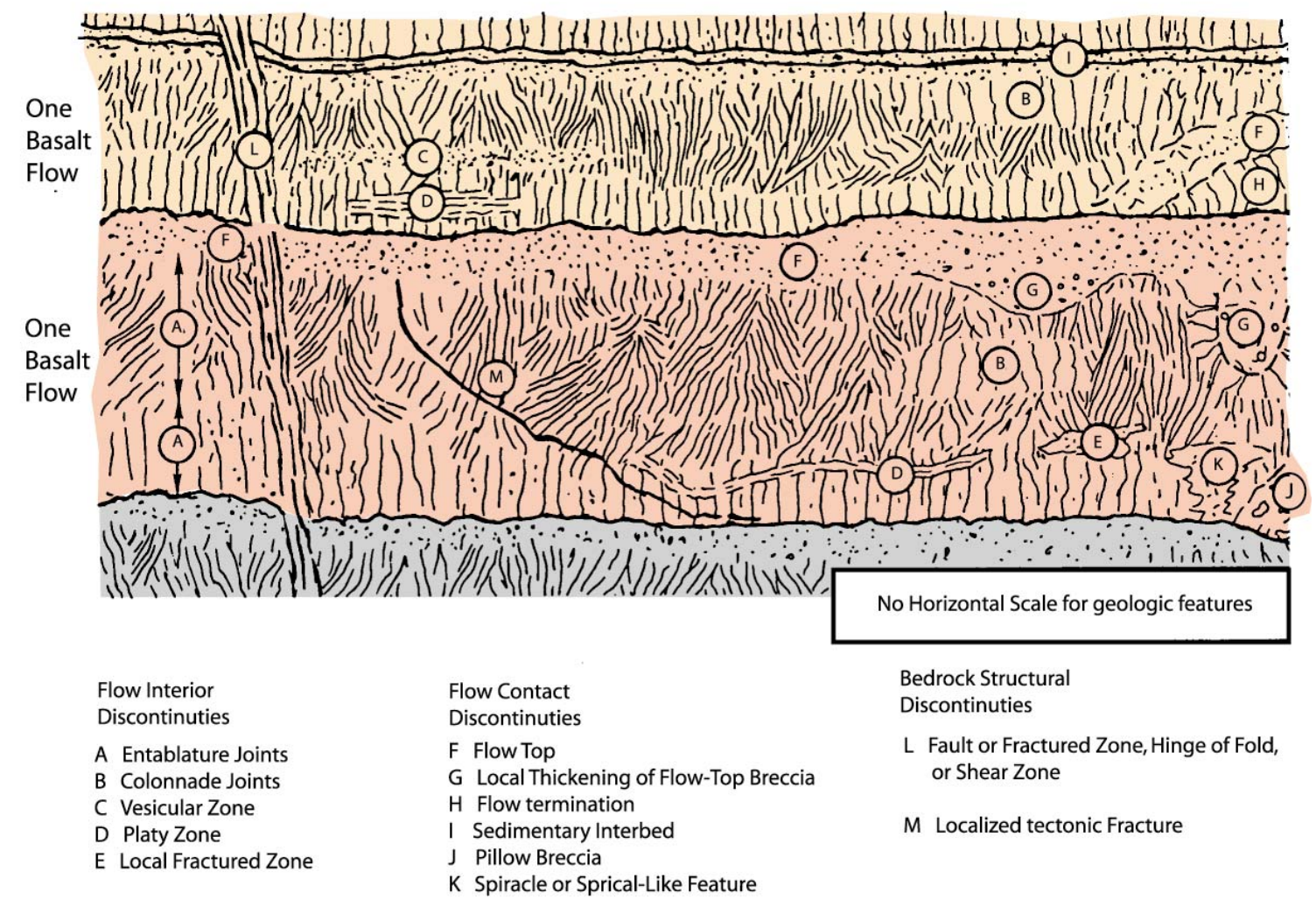

Figure 3.7. Idealized Depiction of a Hypothetical Basalt Flow Sequence with Various Flow Features that Could Provide Enhanced Groundwater Communication (adapted from DOE 1988) 
subsection) have the ability to provided hydraulic communication across multiple basalt flows or basalt formations. The ability of some of these basalt flow features to transmit groundwater may be restricted, if intensive clay alteration (a common secondary-mineral byproduct) is developed.

\subsection{Hydraulic Properties}

Interflow zones of the CRBG flows typically exhibit a wide range for hydraulic conductivity, ranging over 10 orders of magnitude from $10^{-2}$ to $10^{-12} \mathrm{~m} / \mathrm{sec}$ (DOE 1988). The collective results of hydraulic tests conducted on the Hanford Site indicate a general pattern of decreasing interflow hydraulic conductivity with depth with Grande Ronde Basalt interflow zones having a geometric mean value two orders of magnitude lower than overlying Saddle Mountains and Wanapum Basalt counterparts, i.e., $10^{-7}$ vs. $10^{-5} \mathrm{~m} / \mathrm{sec}$, as shown in Figure 3.8 (Spane 1982; DOE 1988). Detailed hydraulic testing results of
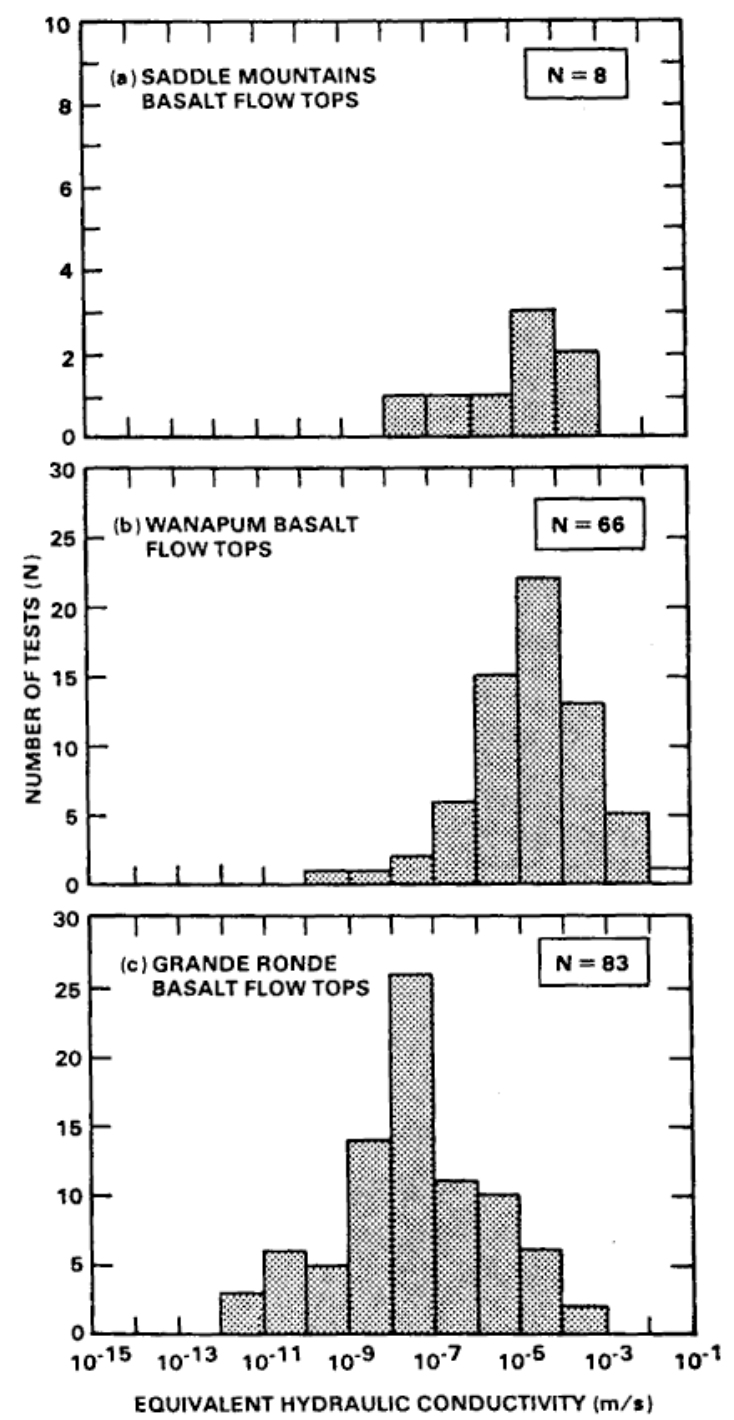

Figure 3.8. Hydraulic Conductivity with Depth (adapted from DOE 1988) 
individual basalt interflow zones at individual borehole sites in Pasco Basin also commonly exhibit a depth dependence, particularly in comparing Grande Ronde Basalt versus Wanapum Basalt interflow zones. As noted in Spane (1982) and DOE (1988), this observed depth-permeability pattern is attributed to compaction (i.e., increasing effective stress) and secondary mineral formation. It should be noted that this is a general observation of depth dependence and exceptions (i.e., a deep, high-permeability interflow zone) do occur.

The range and mean for hydraulic conductivity values for Saddle Mountains Basalt and Wanapum Basalt interflow zones within Pasco Basin compare reasonably well with cited values for these formations within the surrounding region. For example, Hansen et al. (1994) and Whiteman et al. (1994) reported median hydraulic conductivity values of $8.5 \times 10^{-6} \mathrm{~m} / \mathrm{s}$ and $1.8 \times 10^{-5} \mathrm{~m} / \mathrm{s}$ for the Saddle Mountains Basalt and Wanapum Basalt, respectively. These values were determined primarily from less precise specific capacity information (i.e., reported drawdown vs. pumping rate) that were reported for boreholes within the region, and that included an assumed interflow production zone thickness for all sites of $17 \mathrm{~m}$. Based on the limitations of the method, it is interesting that there is a reasonable level of correlation (i.e., between Pasco Basin hydrologic test results and regional estimates based on specific capacity relationships) for the Saddle Mountains Basalt and Wanapum Basalt. This is somewhat surprising given the criticism reported in the literature on the use of specific capacity to accurately predict actual hydraulic property conditions (e.g., Razak and Huntley 1991; Huntley et al. 1992; Meier et al. 1999). The reported regional, specific capacity-based median value for Grande Ronde Basalt interflow zones $\left(1.7 \times 10^{-5} \mathrm{~m} / \mathrm{s}\right)$, however, does not reflect the reduced values reported within Pasco Basin $\left(10^{-7} \mathrm{~m} / \mathrm{s}\right)$. This discrepancy may be explained by the simple fact that the regional values are primarily for open basalt wells completed at much shallower depths (i.e., $<600 \mathrm{~m}$ ), whereas Pasco Basin tests are for individual Grande Ronde Basalt interflow zones at depths of between $600 \mathrm{~m}$ and 1,500 $\mathrm{m}$. Such a wide difference in reported Grande Ronde Basalt hydraulic conductivity estimates might be expected, if the previously discussed depth dependent mechanism is the cause.

In contrast to interflow zones, basalt flow interiors (caprocks) exhibit considerably lower hydraulic conductivities than do interflow zones, with values ranging between $10^{-9}$ to $10^{-15} \mathrm{~m} / \mathrm{s}$, and a geometric mean between $10^{-12}$ to $10^{-13} \mathrm{~m} / \mathrm{s}$. A similar decreasing hydraulic conductivity versus depth relationship is also exhibited for flow interior (caprock) tests, suggesting a similar model for its cause. Figure 3.9 shows the pattern of decreasing flow interior hydraulic conductivity with depth for selected flow interior sections from a number of test borehole sites. No other test-derived hydraulic conductivity values are reported for flow interiors outside the Pasco Basin. A list of hydraulic properties determined for specific interflow zones, flow interiors, and sedimentary interbeds on the Hanford Site is presented in Appendix E.

A common conceptualization of the influence of flow attitude (dip) on permeability control for an interflow zone is shown in Figure 3.10. This is useful in understanding regional or large-scale groundwater flow concepts within basalt terrains. The relationships expressed in the figure are similar to those prevalent in any layered sedimentary sequence, where the major and minor directional "horizontal" hydraulic conductivities, $\mathrm{K}_{\mathrm{y}}$ and $\mathrm{K}_{\mathrm{x}}$, (i.e., parallel to the original bedding plane) are greater than the vertical hydraulic conductivity, $\mathrm{K}_{\mathrm{z}}$. Following deformation, a new, area-wide permeability field is developed, which is reflective of the newly established dip of the beds/basalt flows. For basalt terrains, the dip is a function of the paleo-topography at the time of basalt flow emplacement and any subsequent 


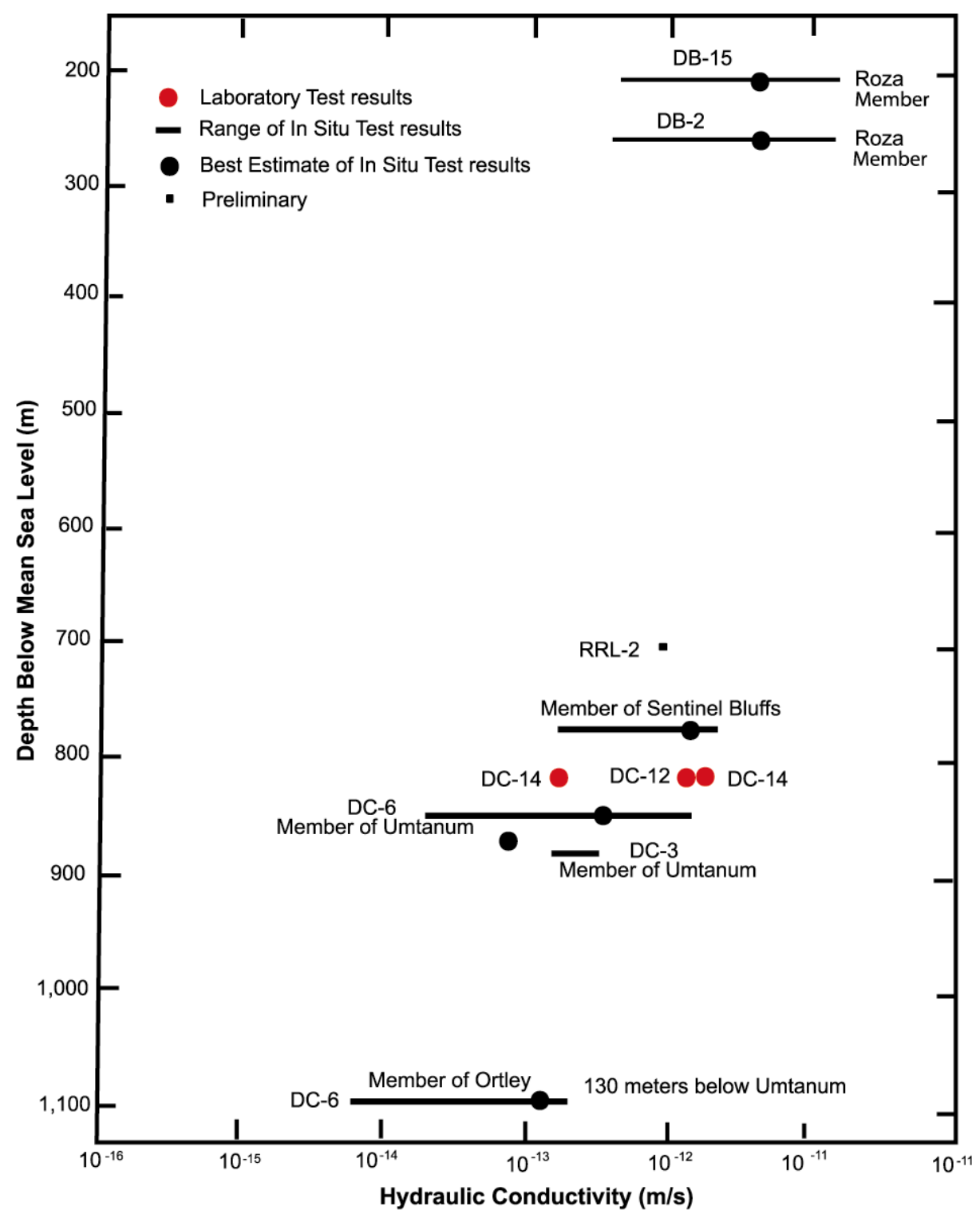

Figure 3.9. Hydraulic Conductivity for Selected Flow Interior Sections from Test Boreholes (modified from Spane 1982)

structural deformation that may have occurred. Groundwater flowing within such basalt interflow or sedimentary settings would be influenced by the preferential permeability direction established by the tilted layers. The influence of structural dip on groundwater flow is reflected in the regional potentiometric maps (and inferred groundwater flow directions) for the Grande Ronde and Wanapum Basalts (Figures 3.1 and 3.2). As shown, groundwater flows parallel to the regional dip of the basalt formations, from structurally high elevations along the margins of the Columbia Basin to regional discharge areas, primarily in the southcentral area of the basin. 


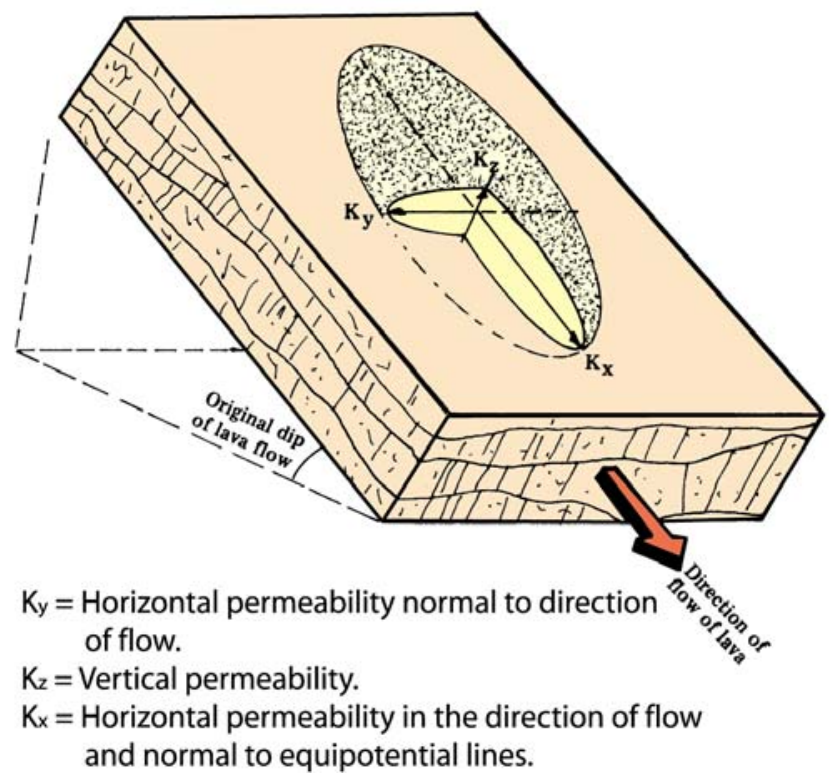

Figure 3.10. Influence of Flow Attitude (dip) on Permeability Control for an Interflow Zone (modified from Davis 1969) 


\subsection{Hydrochemical Characteristics and Applications}

Hydrochemical and isotopic data can be used to support evaluation or characterization of basalt aquifers for subsurface gas storage in two general areas:

- site suitability assessment (e.g., supporting evidence for vertical stratigraphic isolation, groundwater age, and flow rate)

- water quality factors (water use and discharge during characterization and/or operations, impacts on regional groundwater resources, distinguishing injected gas from natural gas)

Hydrochemical data are available from two principal sources: 1) data acquired by the Water Resources Division of the USGS from domestic and irrigation wells across the entire Columbia Basin region (Steinkampf 1996), and 2) discrete depth characterization data acquired by DOE for the Hanford Site (Early et al. 1986) in the central Pasco Basin. A subset of the latter data is included as Appendix F of this report.

Hydrochemical data from regional water supply wells cover a broader area but do not have the vertical resolution or extent of analytes available for the DOE data set for the Pasco Basin. However, use of both types of existing data should allow inferences about hydrochemical characteristics elsewhere in the region for site selection or characterization planning.

\subsection{Chemical Evolution of Basalt Groundwater}

A general understanding of the chemical changes that occur with both depth and distance in the Columbia Basin is needed to place the observed water quality and isotopic data in perspective. A brief summary of our current understanding of the chemical characteristics of basalt groundwater is discussed first, followed by specific isotopic and chemical characteristics relevant to gas storage considerations.

The chemical character of groundwater in CRBG aquifers in the Columbia Basin begins when carbon-dioxide-charged precipitation reacts with the basaltic rocks in the outcrop/recharge areas along ridges or regional outcrops (Figure 4.1). Infiltration of precipitation and initial reaction products results in dilute calcium-magnesium-bicarbonate-type water. Along the flow path, toward the center of the basin, silicate/silica hydrolysis and dissolution occurs, resulting in a gradual increase in $\mathrm{pH}$ from around 8 to over 10 while fluoride and chloride are leached from glass (mesostasis) in the basalt. Precipitation and ion-exchange reactions further modify the water by removing calcium and magnesium in exchange for sodium. The deep basalt groundwater is thought to discharge near the center of the basin along or near the Columbia River. As discussed in Section 3.0, an upward vertical hydraulic gradient in this area is implied. Vertical barriers to movement (fine sediment interbeds, basalt flow interiors with secondary mineral infillings) probably result in a slow, circuitous pathway to discharge areas. 


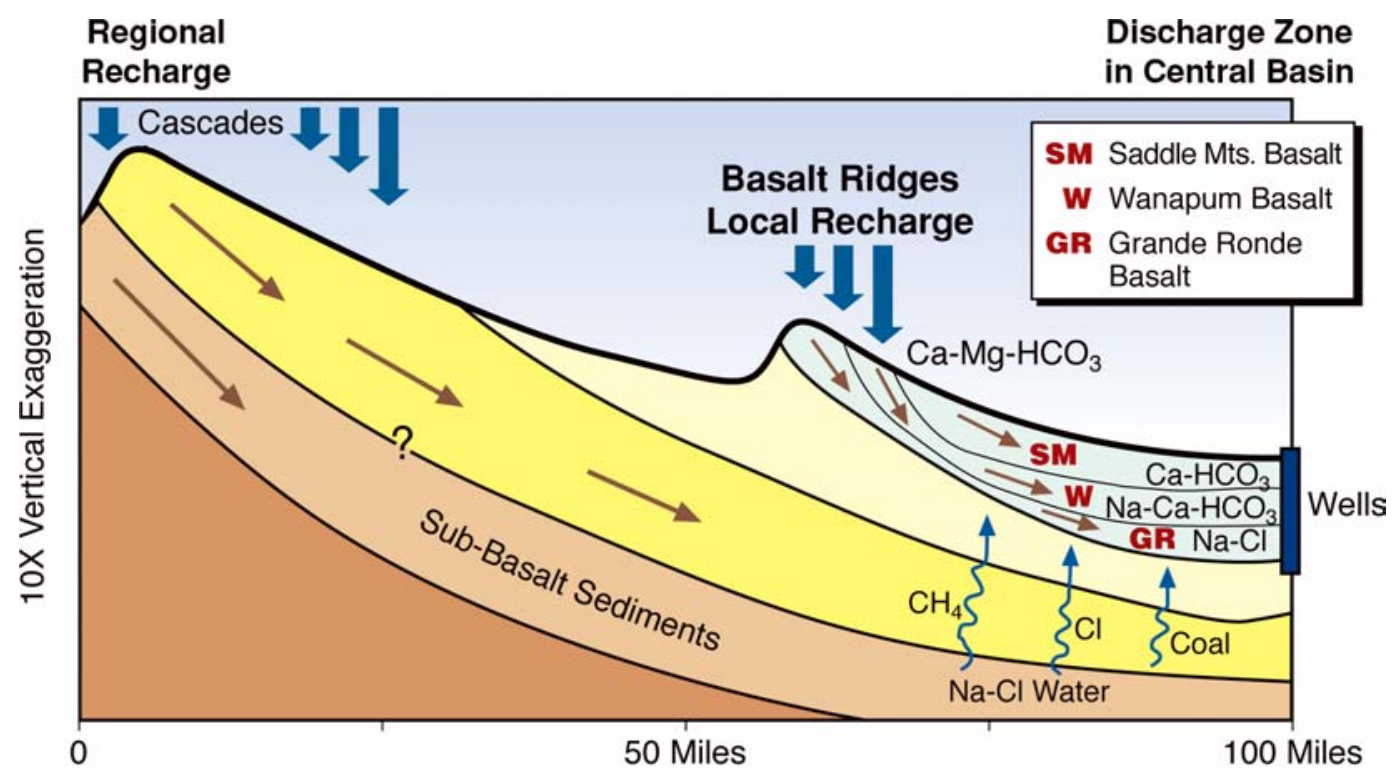

Figure 4.1. Conceptual Model of Chemical Evolution and Transport of Basalt Groundwater in the Columbia Basin

The chemistry of groundwater in contact with basalt changes over time. Long groundwater residence times during which secondary minerals (iron-rich smectite clays, zeolites, calcite, and silica) precipitate also result in removal of calcium, magnesium, potassium, iron, carbonate, and silica from basalt groundwaters. The result is sodium chloride dominated water in the deep basalts of the central basin. Since glass dissolution increases with temperature, and temperature increases with depth, the deep basalts in the central basin (see Figure 2.7) should have higher concentrations of dissolution products that either remain in solution such as sodium, chloride, and fluoride or form secondary minerals that precipitate from the formation fluid.

The most highly evolved (deeper and older) groundwater often contains fluoride concentrations that exceed the drinking water standard $(4 \mathrm{mg} / \mathrm{L})$ by 10 fold or more in the Grande Ronde Basalt units of the central Columbia Basin (Pasco Basin). Also, local anomalies involving elevated sulfate and dissolved methane are superimposed on the general evolutionary sequence noted above. For example, on the eastern side of the Pasco Basin, deep Grande Ronde Basalt aquifers are high in dissolved sulfate but devoid of dissolved methane. On the western side of the basin, high dissolved methane occurs with low dissolved sulfate (Johnson et al. 1993). Localized areas of methane, with a carbon-hydrogen isotopic signature that indicates a thermogenic source, occur near a fault in the northwestern part of the Pasco Basin (see Section 3.1.2). Available data suggest most of the lower concentrations are of biogenic origin while the highest methane concentrations have a thermogenic carbon-hydrogen isotopic signature (Johnson et al. 1993).

Reducing conditions prevail in the deep confined aquifers in the Pasco Basin, which are assumed to include sulfate-reducing bacteria that produce divalent sulfur precipitated as iron sulfide. The abundance of divalent iron in ferromagnesium mineral phases is another control on redox potential in basalt aquifers. The reactivity of natural gas injected into a sulfate-rich groundwater under $100 \mathrm{~atm}$ pressure (hypothetical 
storage site conditions) is unknown. What is known is that little, if any, methane occurs naturally in highsulfate groundwater in the Pasco Basin, which is consistent with microbial processes. For example, sulfate is the electron acceptor in one common mode of anaerobic microbial respiration. End products of this process include methane and hydrogen sulfide. In the absence of sulfate, bicarbonate is the electron acceptor, which results in formation of biogenic methane. The latter process is known as methanogenesis. Thus, sulfate reduction may occur early in a groundwater evolutionary sequence. After sulfate is depleted, methanogenesis dominates methane production.

Carbon-14 $\left({ }^{14} \mathrm{C}\right)$ and noble gas isotopes suggest the deep basalt groundwaters of the central basin are very old. For example, there is no detectable ${ }^{14} \mathrm{C}$ in basalt aquifers of the central basin except near areas of local recharge. The lack of ${ }^{14} \mathrm{C}$ suggests ages $>30,000 \mathrm{yr}$. Dissolved helium, which accumulates steadily with time in pore fluid due to uranium and thorium alpha decay in the basalt, suggests the deep Grande Ronde Basalt groundwaters in the central basin are $>100,000$ yr old (i.e., elapsed time since recharge; Johnson et al. 1993). Ages of this magnitude and distance to nearest sources of confined aquifer recharge suggest groundwater flow rates on the order of a meter per year or less. In contrast, Grande Ronde Basalt aquifers across the region appear to have groundwater flow rates in the 1-to 10-m/yr range (based on ${ }^{14} \mathrm{C}$ measurements; Steinkampf and Hearn 1996). The difference in apparent groundwater flow rates is consistent with the difference in hydraulic conductivities discussed in Section 3.2. This regional Grande Ronde Basalt groundwater also appears to be less evolved than the Grande Ronde Basalt groundwater in the Pasco Basin. A generalized hydrochemical facies map is shown in Figure 4.2 and a summary of average major cation and anion compositional characteristics of the two major types of groundwater found in the Grande Ronde Basalt is provided in Figure 4.3. The older and more highly evolved character of the Pasco Basin groundwater may be a result of the greater depth and higher temperatures in that groundwater.

In summary, the chemical and isotopic characteristics of basalt groundwater can be used as "tracers" to assess the likelihood of vertical isolation between important regional water supply aquifers (e.g., Wanapum Basalt aquifers) and the deeper Grande Ronde Basalt aquifers that generally are of poor quality (high fluoride and occasionally high iron) in the central basin. The latter water quality characteristic makes this zone attractive for gas storage, provided other structural and hydrologic characteristics are favorable. Semi-stagnant conditions (very slow groundwater movement) are also favorable for subsurface gas storage.

\subsection{Hydrochemical Indicators of Vertical Hydraulic Isolation}

Vertical concentration plots and chemical ratio plots provide important indications of the degree to which major hydrostratigraphic units are isolated from each other. This is an important consideration especially with a general upward vertical hydraulic gradient within the Grande Ronde Basalt in much of the Pasco Basin.

\subsubsection{Vertical Profiles}

Selected depth-concentration profiles for three characterization wells drilled in the Cold Creek syncline of the central Pasco Basin are shown in Figure 4.4. The vertical profiles of chloride, sulfate, methane, and ${ }^{13} \mathrm{C}$ (in total inorganic carbon or TIC) from Appendix F show abrupt concentration changes 


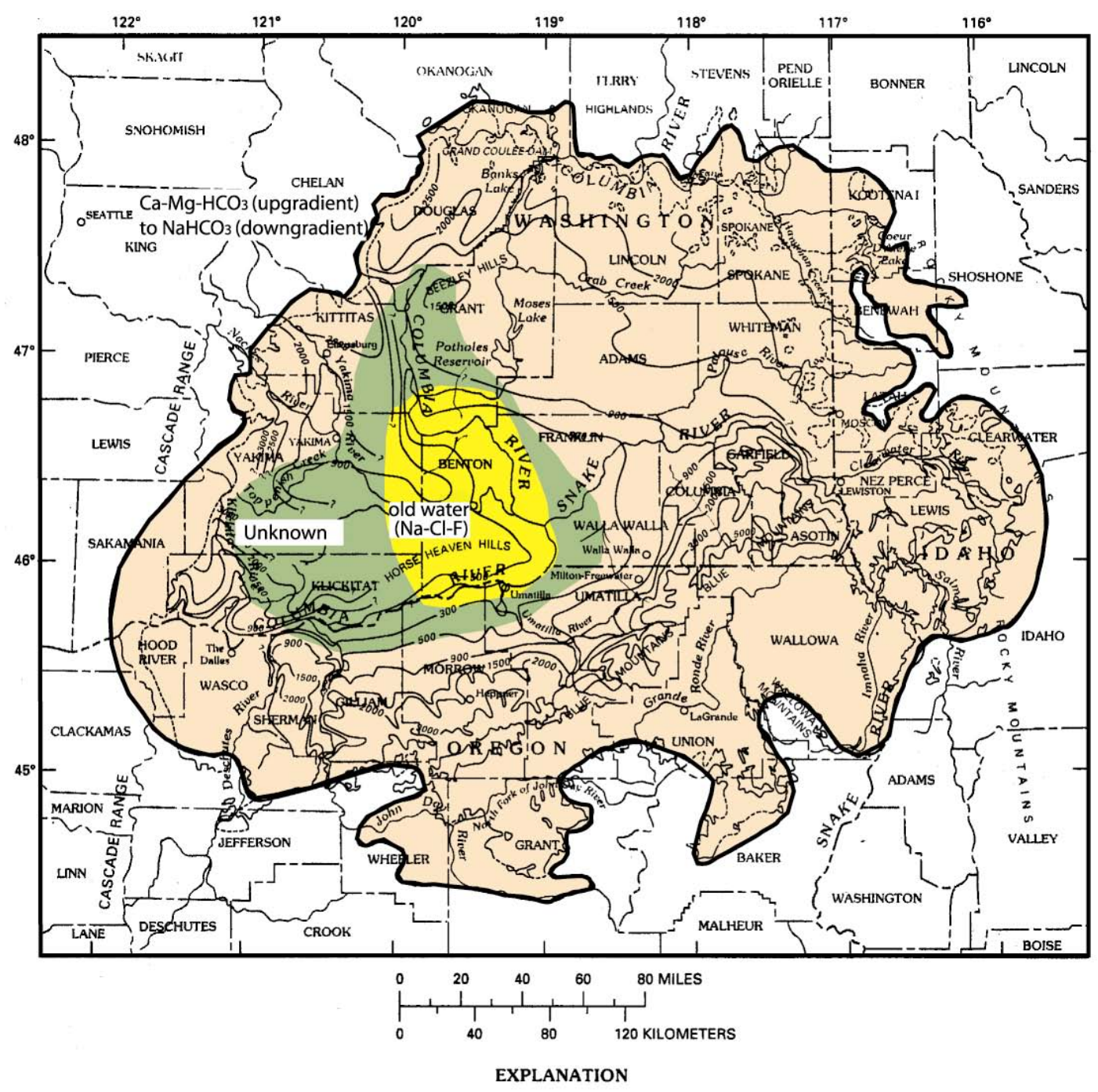

-400- Water Level Contour, approximate elevation

Approximate limit of Grande Ronde Basalt

Figure 4.2. Hydrochemical Facies Map of the Grande Ronde Basalt in the Columbia Basin. (The area shown in green is devoid of wells completed in the Grande Ronde.)

between the Wanapum and Grande Ronde units for wells DB-15 and DC-15. The vertical transition through the Wanapum for DC-16, located near the Cold Creek fault, is more gradual, suggesting there is some type of vertical mixing between the deeper Grande Ronde Basalt and the Wanapum Basalt. Vertical profiles in wells west of the Cold Creek fault show low and invariant chloride concentrations through the Wanapum Basalt. Johnson et al. (1993) explain the latter as resulting from deep, high chloride, methanerich groundwater rising upward along the Cold Creek fault, which bleeds into the Wanapum Basalt on the east side of the fault and then spreads eastward in the Cold Creek syncline (see Figures 3.4 and 3.5). 


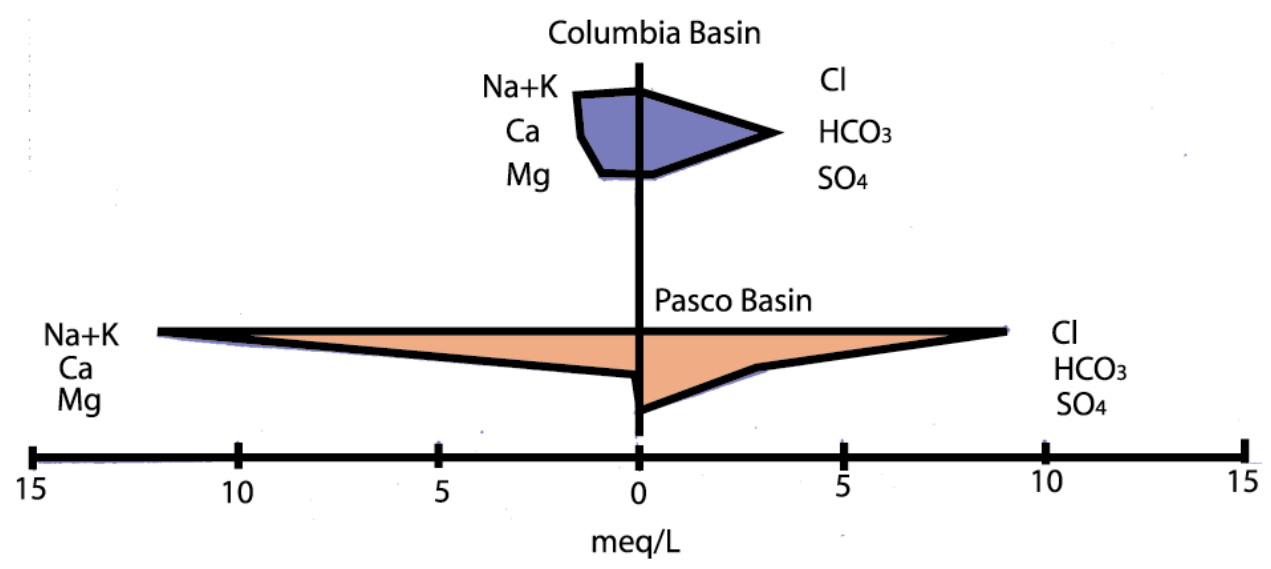

Figure 4.3. Comparison of Major Chemical Composition of the Grande Ronde Basalt in the Pasco Basin versus the Columbia Basin

In contrast to the profiles for well DC-16, which suggests vertical connectivity across the Grande Ronde and Wanapum, well DC-14 (located to the north in an adjacent syncline) exhibits a sharp break in chloride and other constituents at the interface between the Wanapum Basalt and Grande Ronde Basalt units (Figure 4.5). The primary difference between the two synclines is the cross cutting Cold Creek fault west of well DC-16. No similar feature exists for the adjacent syncline in which well DC-14 is located. These observations suggest that areas with cross-cutting faults should be avoided as candidate gas storage locations.

The deeper, high-chloride groundwaters tend to be depleted in the major divalent cations, especially magnesium. This is dramatically evident in nearly all the deep basalt groundwaters of the Pasco Basin listed in Appendix F. Magnesium is often less than $0.1 \mathrm{mg} / \mathrm{L}$ in the deep aquifers as compared to around $10 \mathrm{mg} / \mathrm{L}$ in the uppermost aquifers. Depletion of magnesium is attributed at least in part to formation of iron rich smectite clays filling fractures, which incorporate $\mathrm{Mg}^{2+}$ in the crystal structure of this three-layer clay mineral.

\subsubsection{Chemical Ratio Plots}

Chemical ratio plots are often used to identify hydrochemical populations in groundwater data. If there are distinct population groups for the major hydrostratigraphic units, vertical isolation is implied.

For example, plots of $\mathrm{Cl} / \mathrm{B}$ and $\mathrm{Cl} / \mathrm{F}$ versus chloride concentration for well $\mathrm{DB}-15$ suggest two populations of groundwater (Figure 4.6): one for the Saddle Mountains Basalt aquifer (grouped to the far left) and one group in the lower right for the Wanapum Basalt aquifer. A similar separation can be seen between the Wanapum Basalt and the Grande Ronde Basalt aquifers for well DC-14 located in the adjacent syncline (Figure 4.7). If groundwater moved vertically throughout the stratigraphic units, there would be just one population group or at least a gradual trend from deep, old water to shallow recently 
RRL-2/DC-16

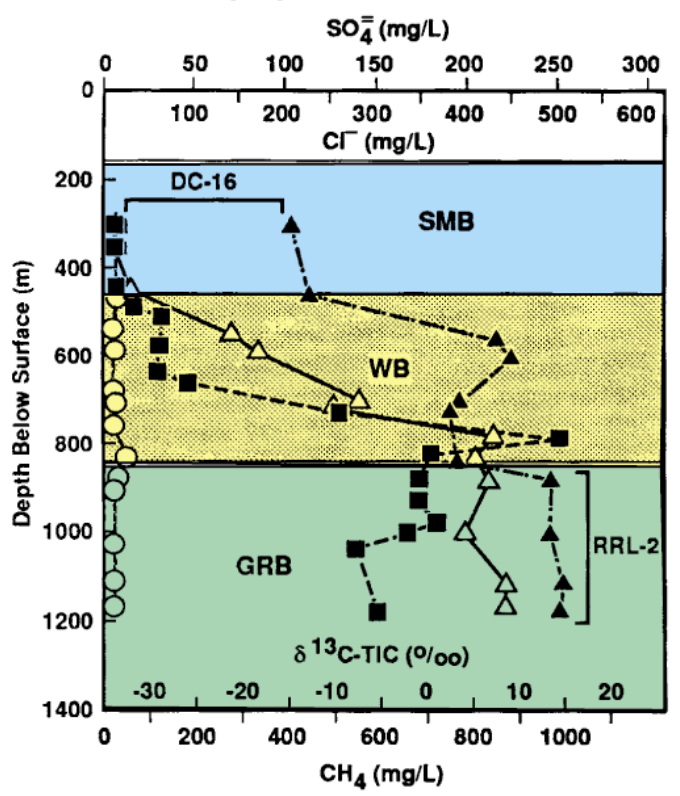

\section{Location Map}

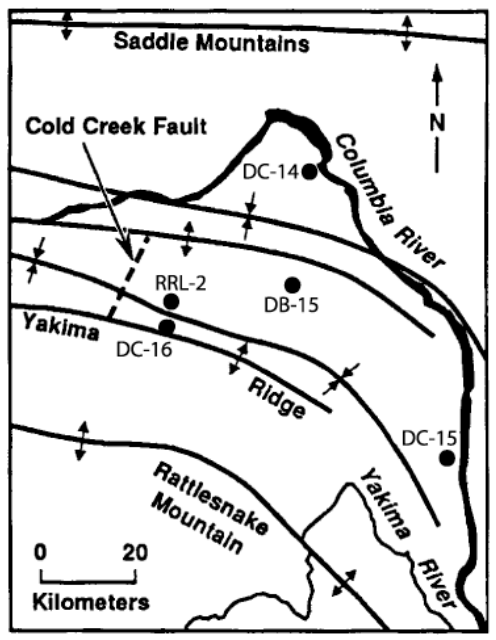

DB-15
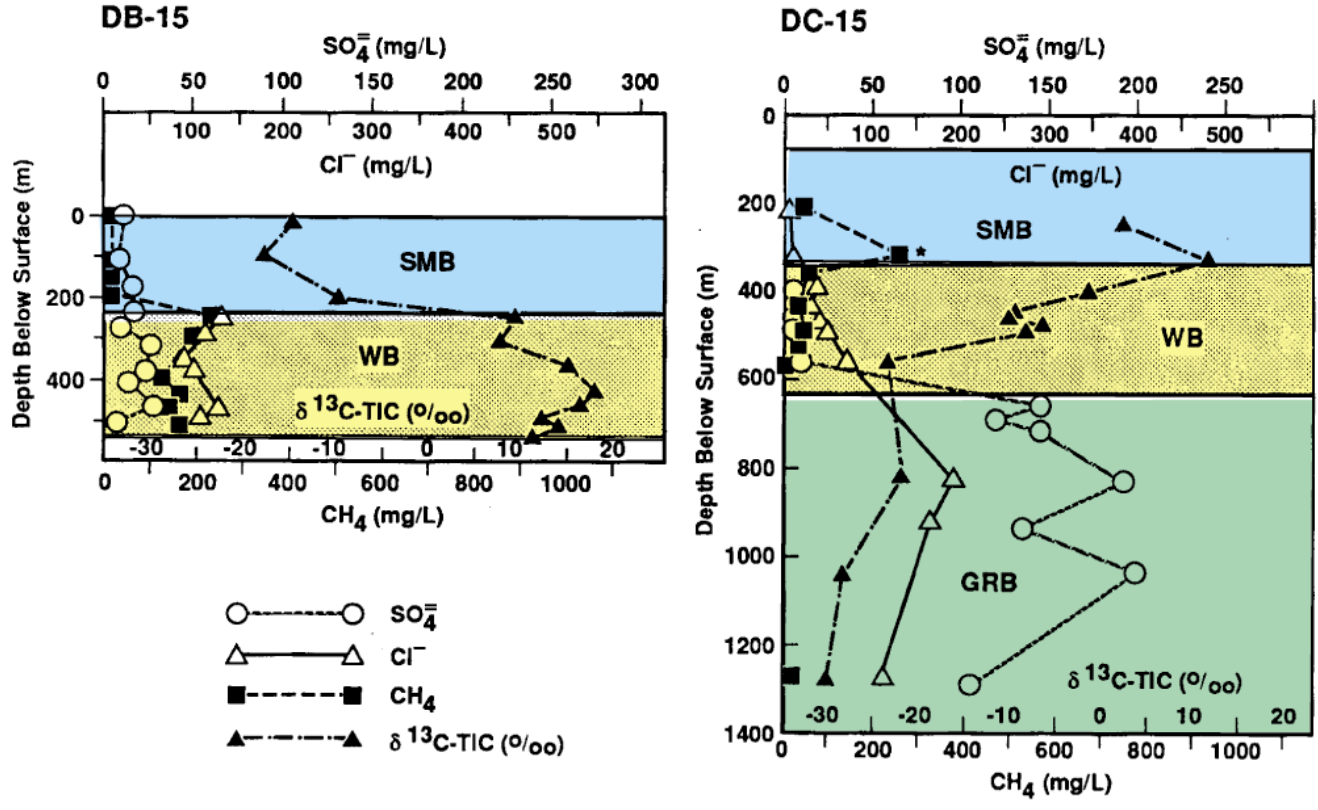

* Mabton Sedimentary Interbed

Figure 4.4. Vertical Distribution of Methane Concentration, Sulfate Concentration, $\delta^{13} \mathrm{C}$-TIC, and Chloride Concentration from Boreholes RRL-2, DB-15, and DC-15 in the Cold Creek Syncline in the Central Columbia Basin. [Note: Wanapum Basalt (WB) is shaded; SMB = Saddle Mountain Basalt; GRB = Grande Ronde Basalt.] 


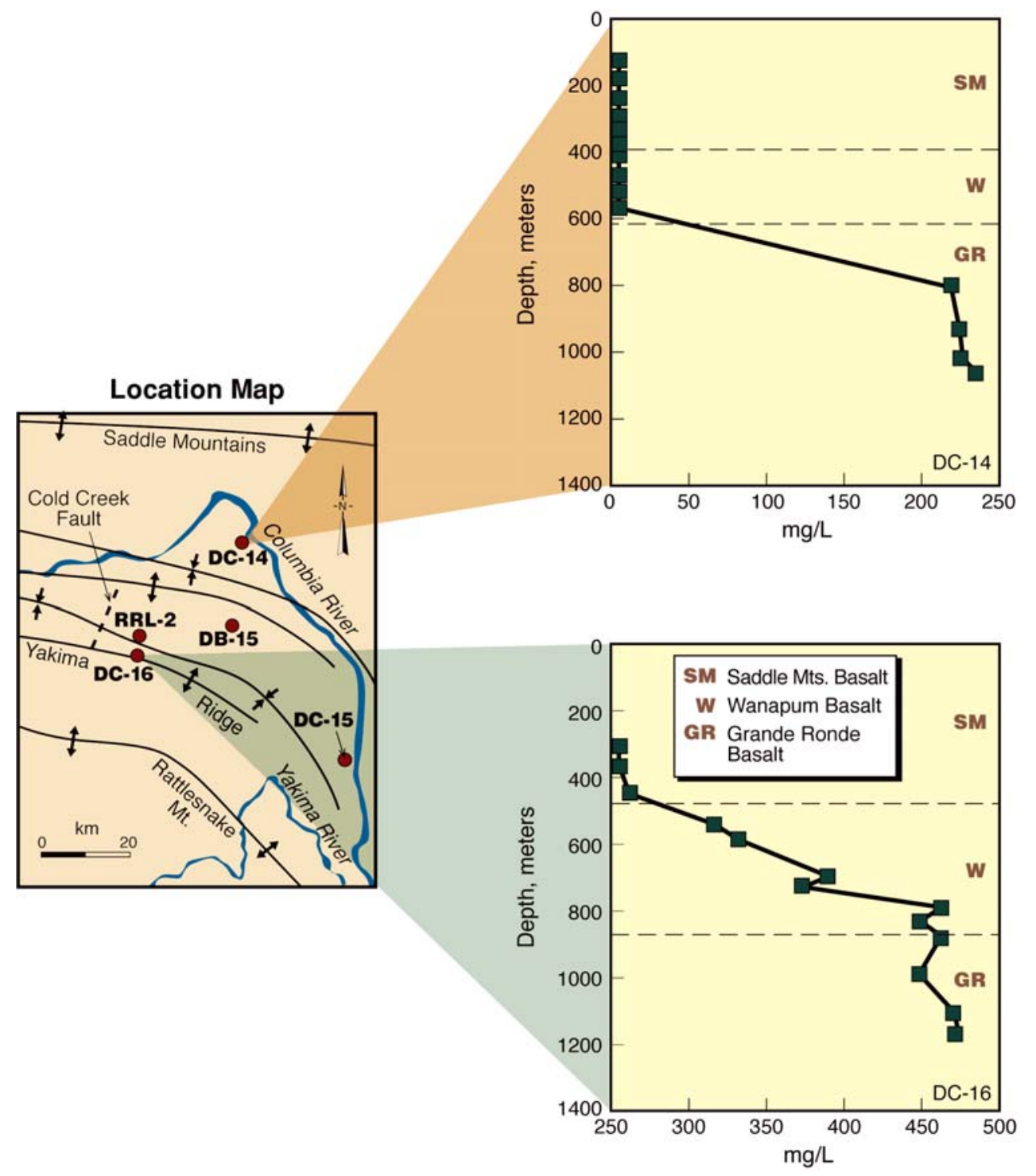

Figure 4.5. Comparison of Vertical Chloride Concentration Profiles for Wells DC-16 and DC-14 Located in Adjacent Synclines

infiltrated water. The presence of two distinct populations in the cases illustrated indicates isolation between the major hydrostratigraphic units. If mixing occurs between two or more water types, a range of ratios as a function of concentration may be observed. The latter case is illustrated in Figure 4.8 for well DC-16. As previously noted, a location similar to the location of well DC-16 (near the cross-cutting fault) would be unfavorable for gas storage at depth because of upward flow from the deeper aquifers into the overlying aquifers as discussed in Chapter 3. Integration of hydrogeologic, structural, and hydraulic information is needed for a complete evaluation. 


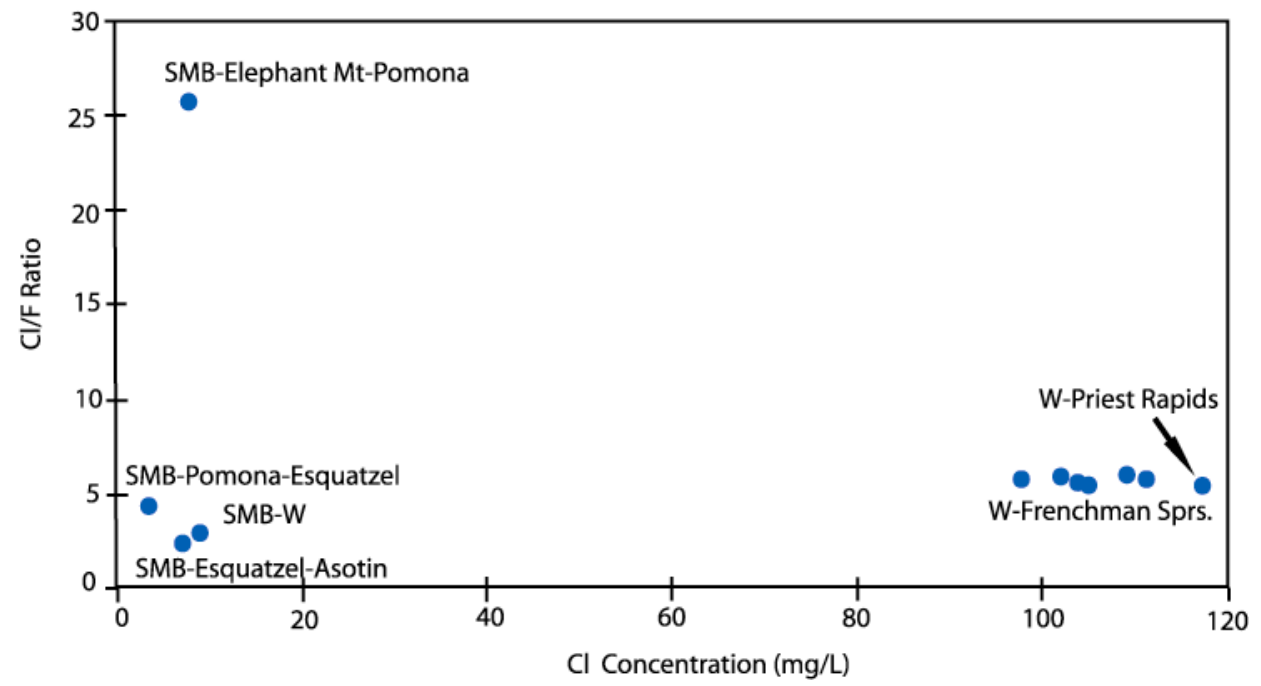

A

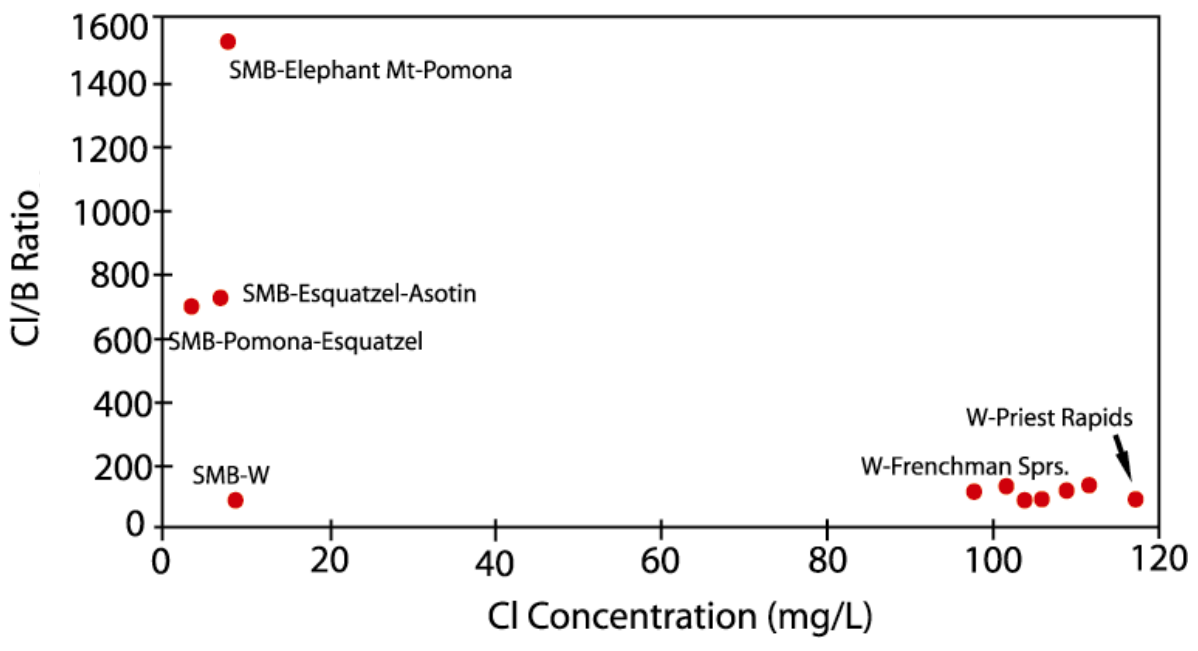

$\mathrm{B}$

Figure 4.6. $\mathrm{Cl} / \mathrm{F}$ (a) and $\mathrm{Cl} / \mathrm{B}$ (b) Ratios versus Chloride Concentration for Multiple Stratigraphic Units in Well DB-15. Letter prefixes: SMB = Saddle Mountains Basalt and $\mathrm{W}=$ Wanapum Basalt. Sampling interval follows.

\subsection{Groundwater Age}

Slow rates of groundwater movement in a candidate gas storage zone are desirable to keep dissolved gas from migrating beyond the boundary of the project. Carbon-14 and radiogenic helium in basalt aquifers can be used to assign approximate ages to the groundwater, and together with distance to recharge areas, average groundwater flow rate can be estimated. The ${ }^{14} \mathrm{C}$ method can estimate ages up to about 30,000 yr. The helium accumulation method can theoretically be used for ages $>10,000 \mathrm{yr}$ to millions of years. 


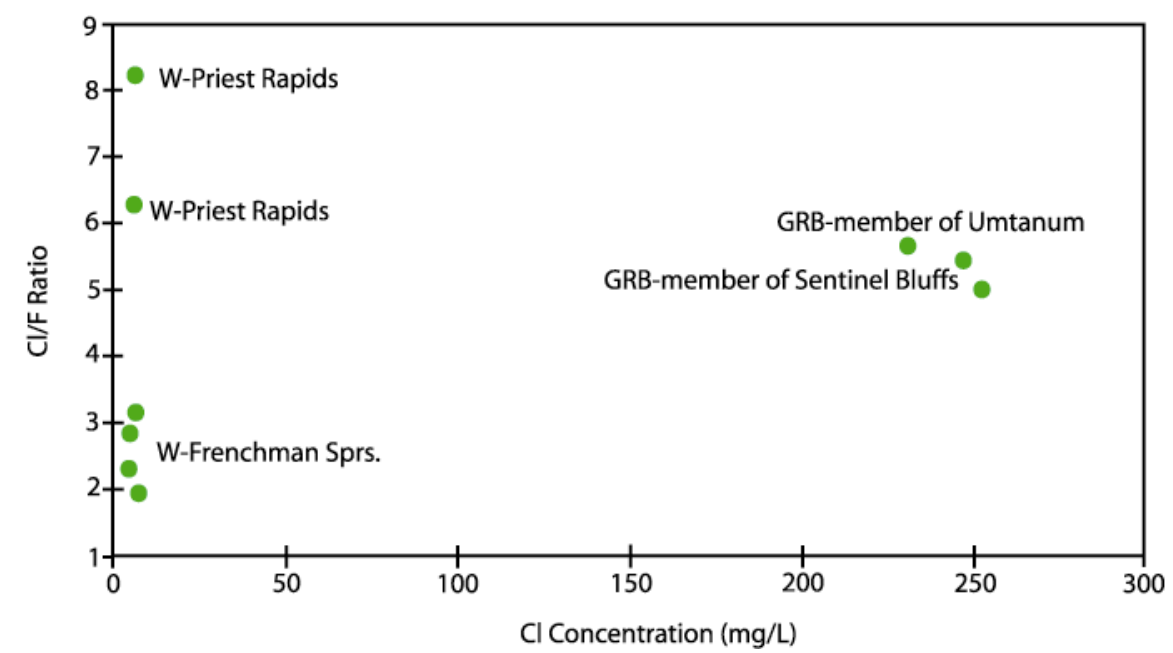

(a)

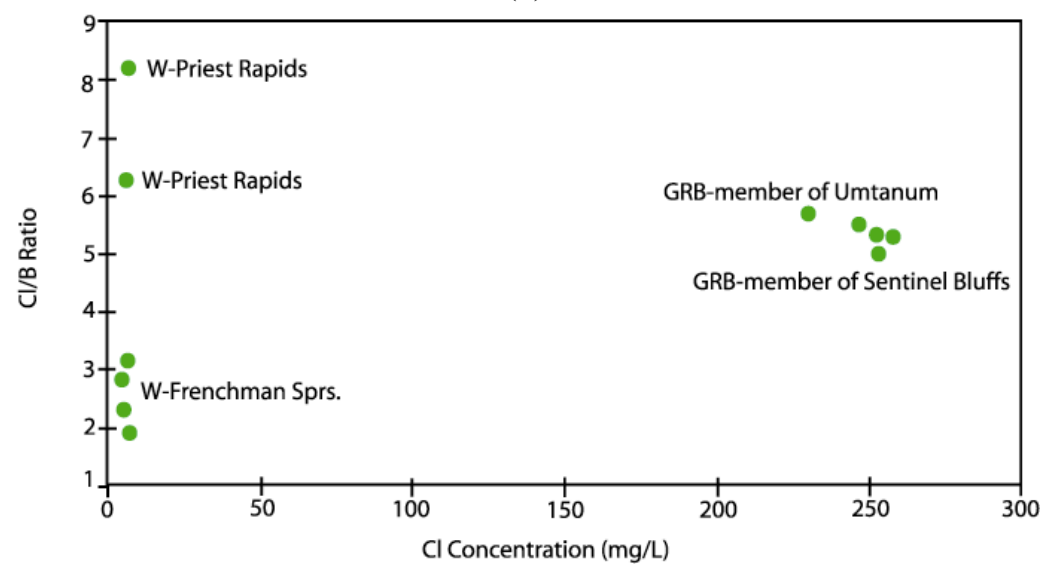

(b)

Figure 4.7. $\mathrm{Cl} / \mathrm{F}$ (a) and $\mathrm{Cl} / \mathrm{B}$ (b) Ratios versus Chloride Concentration for Multiple Stratigraphic Units in Well DC-14. Letter prefixes: W = Wanapum Basalt and GRB $=$ Grande Ronde Basalt. Sampling interval follows.

\subsubsection{Carbon-14 Method}

The ${ }^{14} \mathrm{C}$ method relies on the change in radioactive ${ }^{14} \mathrm{C}$ (half life 5,730 yr) relative to stable carbon in the carbon dioxide dissolved in atmospheric precipitation at the point of recharge. The radiogenic and stable carbon occurs in dissolved bicarbonate in the aquifer. As the groundwater moves through the aquifer, the radiogenic carbon decays, thus providing some indication of time since recharge. Age is calculated based on the following relationship:

$$
\mathrm{T}(\mathrm{yr})=-8270 \ln (\mathrm{A} / \mathrm{Ao})
$$

$\mathrm{A}={ }^{14} \mathrm{C}$ abundance of sample expressed as percent modern carbon (pmc)

Ao $=$ initial abundance, generally assigned a pmc of 75 


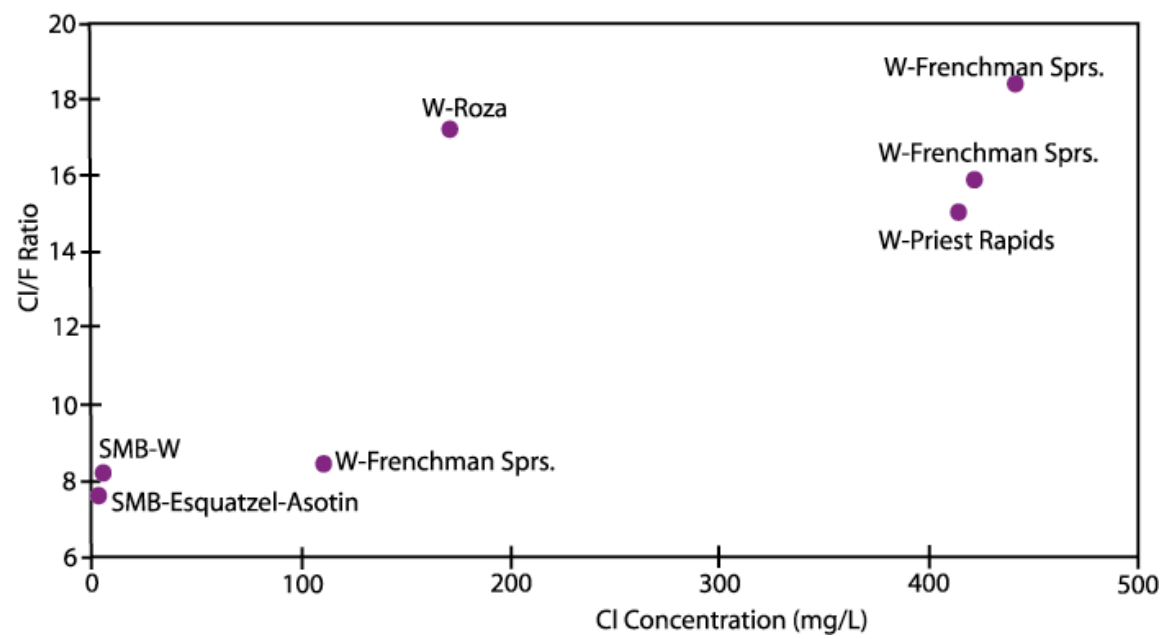

(a)

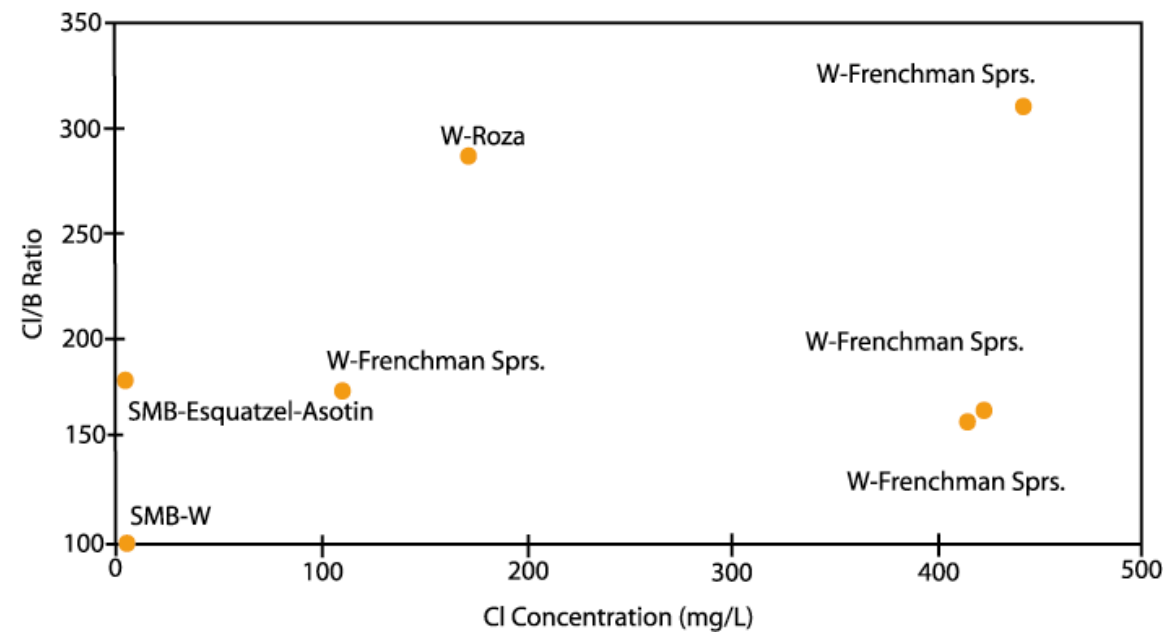

(b)

Figure 4.8. $\mathrm{Cl} / \mathrm{F}$ (a) and $\mathrm{Cl} / \mathrm{B}$ (b) Ratios versus Chloride Concentration for Multiple Stratigraphic Units in Well DC-16A. Letter prefixes: SMB = Saddle Mountains Basalt and $\mathrm{W}=$ Wanapum Basalt. (Sampling interval follows.)

The initial ${ }^{14} \mathrm{C}$ abundance, Ao, is less than $100 \mathrm{pmc}$ due to exchange of radiogenic carbon with dead carbon (stable carbon) in the recharge area and aquifer. Mazor et al. (1986) indicate a value of 75 pmc is commonly used. This was verified for the Pasco Basin using a linear regression of pmc and tritium for spring samples. For example, for a tritium content of $1 \mathrm{TU},{ }^{(a)}$ the pmc intercept was 78 , and for a tritium content of $0.5 \mathrm{TU}$ the intercept was 74 . Other refinements can be made for this method as described in Mazor et al. (1986) and Bard et al. (1990).

Perhaps the most important consideration in applying this method is to ensure exclusion of atmospheric carbon dioxide during sample handling and during drilling of the characterization well.

(a) $1 \mathrm{TU}=$ one atom of ${ }^{3} \mathrm{H}$ in $10^{18}$ atoms of ${ }^{1} \mathrm{H}$. 
Sample collection requires a closed system to exclude air. Drilling fluids, associated additives or recirculated cement cuttings must be avoided to eliminate introduction of either dead carbon or modern carbon to the water sample. Adequate purging of the test zone is also needed (Graham and Johnson 1991).

\subsubsection{Helium Accumulation Method}

Helium $\left({ }^{4} \mathrm{He}\right)$ is generated during alpha decay of uranium and thorium in the aquifer host rock. The helium so generated migrates from the rock into the pore fluid at a constant rate (steady state). Knowing the uranium and thorium content of the host rock and porosity, an age or residence time can be estimated for the pore fluid (Zaikowski and Kosanke 1987). If the pore fluid is completely stagnant, the amount of helium present will be consistent with the age of the host rock. If movement of groundwater has occurred, the amount of helium dissolved in pore fluid will be lower depending on residence time (flow rate). Residence time (age) can be calculated from the following relationship:

$$
\mathrm{T}(\text { years })=[\mathrm{C}] /[\mathrm{R}]=[\mathrm{He} * \mathrm{E}+07] /[(1-\mathrm{p}) / \mathrm{p}) * \rho *(1.2 \mathrm{U}+0.29 \mathrm{Th})]
$$

where $\mathrm{C}$ is the accumulated helium concentration ( $\mathrm{cc} \mathrm{He} / \mathrm{cc}$ ) in pore fluid, and $\mathrm{R}$ is the production rate of helium from the host rock available to the fluid in the pore space ( $\mathrm{cHe} / \mathrm{cc}$ of pore fluid/yr). Units are as follows:

$$
\begin{aligned}
\mathrm{He} & =\text { helium content of pore fluid, cc of He at STP per cc of fluid } \\
\mathrm{p} & =\text { effective porosity (unitless) } \\
\rho & =\text { host rock density, grams/cc } \\
\mathrm{U} & =\text { uranium content of host rock, g/g of rock } \\
\mathrm{Th} & =\text { thorium content of host rock, g/g of rock. }
\end{aligned}
$$

The bracket containing uranium and thorium is the helium production rate based on conversion of all alpha decays per unit time to cc of He at STP per unit time. Greater refinement of this basic equation can be found in Zaikowski and Kosanke (1987).

The advantage of the helium accumulation method is that it requires no major assumptions about initial conditions. However, like the ${ }^{14} \mathrm{C}$ method, air must be excluded during sample collection and during drilling. One problem, especially for basalt flow top aquifers, is estimating porosity. The highly variable nature of basalt flow tops makes it difficult to assign an average porosity for an entire aquifer. Geophysical logging methods can provide the uranium and thorium contents (natural gamma logs or KUT $\log$ ) and porosity. Unfortunately, the porosity based on neutron logging methods provides total porosity rather than effective porosity (interconnected pore space). Also, the high degree of variability in effective porosity of a basalt flow top over several square kilometers or more makes this method more of a qualitative indicator of age in basalt aquifers. Nevertheless, it is useful as an alternative method to determine an approximate age and flow rate. 
Samples of pore fluid for noble gas analysis must be collected at in situ hydrostatic pressures to ensure representative concentrations are obtained. Downhole pressurized fluid sampling devices are available for this purpose.

\subsubsection{Chlorine-36 Method}

The ${ }^{36} \mathrm{Cl}$ radiogenic method is similar to the ${ }^{14} \mathrm{C}$ method. The longer half life $(300,000 \mathrm{yr})$ of ${ }^{36} \mathrm{Cl}$ makes it theoretically useful for ages of up to 1 or 2 million years. The age equation is similar to the ${ }^{14} \mathrm{C}$ equation. Like ${ }^{14} \mathrm{C}$, this natural radionuclide is produced by cosmic particle interaction in the Earth's atmosphere, and the radiogenic chlorine becomes mixed with the stable (oceanic) chlorine. The measurement method (Tandom Accelerator Mass Spectrometry or TAMS) is more involved and higher in cost than either of the other two methods. An initial abundance is needed that is best obtained using local spring water that is pre-bomb in age (e.g., low or tritium free spring water, $<1 \mathrm{TU}$ ). However, if there is an added source of chlorine or chloride other than that which is derived from oceanic chloride in precipitation (recharge water), the method will yield erroneously long residence times or age. (For example, if mixing occurs with a deep source of upward migrating brine or seawater from subbasalt marine sediments.) Leaching of chloride from the basalt is another extraneous source of ${ }^{36} \mathrm{Cl}$ that invalidates the method for basaltic aquifers. For the above reasons, ${ }^{36} \mathrm{Cl}$ may not be a reliable age-dating tool for the older, more highly evolved chloride-rich basalt aquifers.

\subsubsection{Example Age and Groundwater Flow Estimates}

A limited amount of data were acquired for DOE that can be used to illustrate application of the ${ }^{14} \mathrm{C}$ and helium accumulation method and provide some indication of approximate groundwater ages and flow rates for the basalt groundwater system.

The first example is for the Mabton Sedimentary Interbed between the Saddle Mountains Basalt and Wanapum Basalt. Carbon-14 data are from the larger DOE data base (not included in Appendix F). The ages were calculated using the equation in Section 4.3.1 and assuming a pmc of 75 for the initial activity as a dead carbon correction. Iso-age contours were drawn based on the well array as shown in Figure 4.9. Using the distance in meters between age contours (delta years) along an assumed flow direction (X-X') a set of approximate groundwater flow rates was computed for each segment between contours labeled A through D in Figure 4.9. This interpretation of groundwater ${ }^{14} \mathrm{C}$ data suggests apparent flow rates of about $1 \mathrm{~m} / \mathrm{yr}$.

Another DOE study coupled both ${ }^{14} \mathrm{C}$ and helium to determine the rate of helium accumulation in pore fluid on an aquifer scale. A study site close to the recharge area was chosen where it was more likely to find detectable ${ }^{14} \mathrm{C}$ (i.e., ages less than $30,000 \mathrm{yr}$ ). For this purpose, wells in the upper Cold Creek Valley completed in the Priest Rapids Member, Roza Member, and Frenchman Springs Member of the Wanapum Basalt, were sampled for both helium and ${ }^{14} \mathrm{C}$. Well locations are shown together with outcrop areas (potential recharge locations) in Figure 4.10. Noble gas contents, ${ }^{14} \mathrm{C}$, and related hydrochemical information are shown in Table 4.1. 


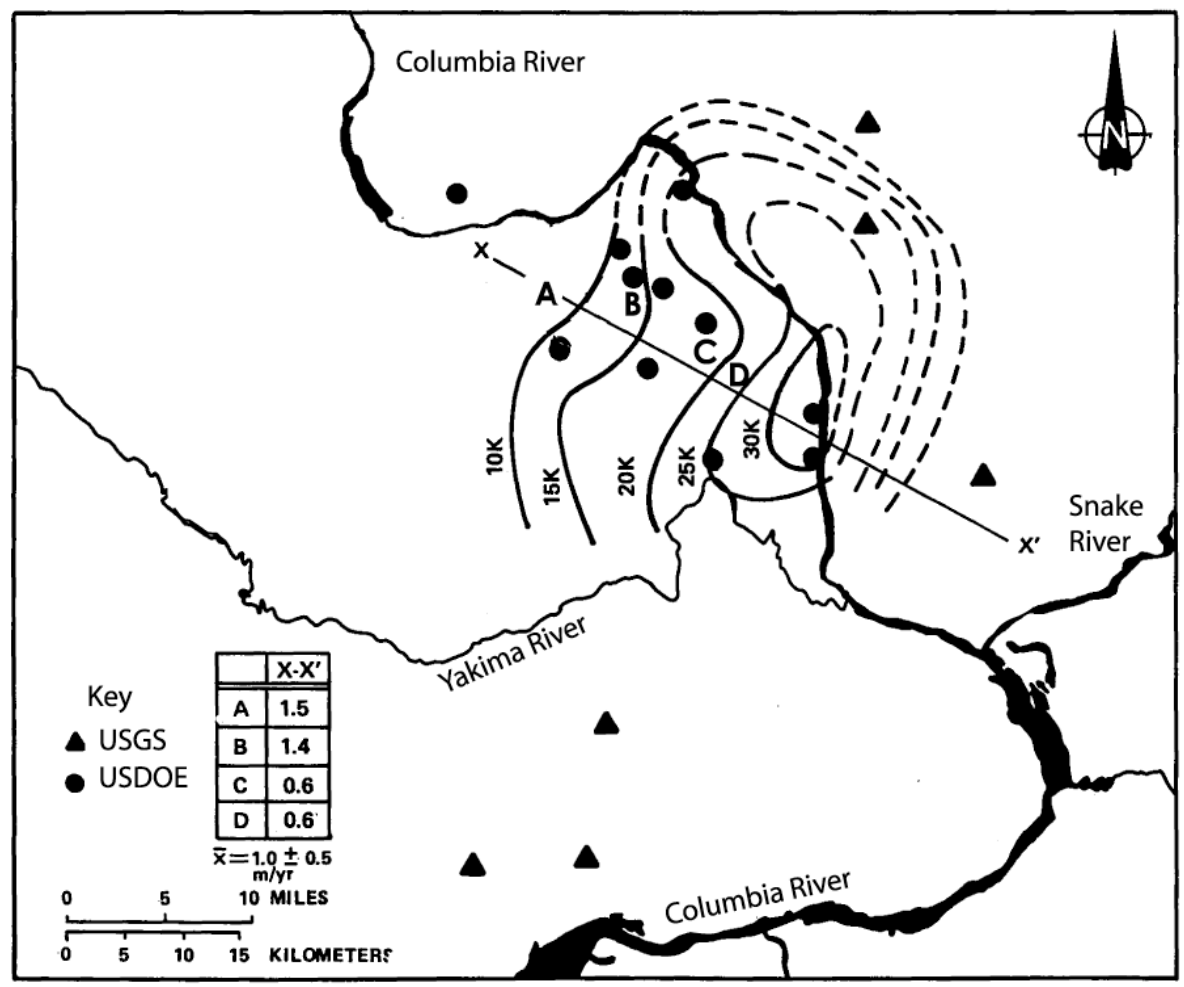

Figure 4.9. ${ }^{14} \mathrm{C}$-Based Groundwater Ages for the Mabton Interbed, Pasco Basin. (Ages are shown as isochrons, and calculated flow rates along $\mathrm{x}-\mathrm{x}$ ' are shown in the legend. The isochrons, or equal age contours, are in thousands of years.)

A plot of helium content versus ${ }^{14} \mathrm{C}$ age for these wells is shown in Figure 4.11. The helium content at zero apparent ${ }^{14} \mathrm{C}$ age represents atmospheric helium content in recharge water (assumed to be the same as contemporary levels). The linear relationship suggests an average helium accumulation rate $1.7 \times 10^{-11}$ $\mathrm{ccHe} / \mathrm{yr}$ per cc of pore fluid. If the average effective porosity for this aquifer is considered representative of CRB basalt aquifers, and the uranium and thorium contents are assumed to be similar, an estimate of approximate age can be made by dividing the pore fluid helium content by the above rate. For example, taking the average helium content of well DC-14, Table 4.2, the apparent age (assuming similar effective porosities) would be:

$$
\mathrm{T}(\mathrm{yr})=[\mathrm{C}] /[\mathrm{R}]=[3.1 \mathrm{E}-05 \mathrm{ccHe} / \mathrm{cc}] /[1.7 \mathrm{E}-11 \mathrm{ccHe} / \mathrm{yr} / \mathrm{cc}]=1.8 \text { million } \mathrm{yr}
$$

However, since the effective porosity of the Priest Rapids Member flow top aquifer is higher than Grande Ronde Basalt flow top aquifers, this age estimate could be too high. If one assumed the effective porosity is approximately 10 times lower for the Grande Ronde Basalt aquifer than the Priest Rapids Member aquifer, the estimated age would be lower by 10 fold or 180,000 yr. Assuming a travel distance from the nearest location where recharge of the deep Grande Ronde Basalt aquifers could occur (about $100 \mathrm{~km}$ ), an apparent flow rate would be:

$$
\mathrm{V}(\mathrm{m} / \mathrm{yr})=(100,000 \mathrm{~m}) /(180,000 \mathrm{yr})=0.6 \mathrm{~m} / \mathrm{yr} .
$$




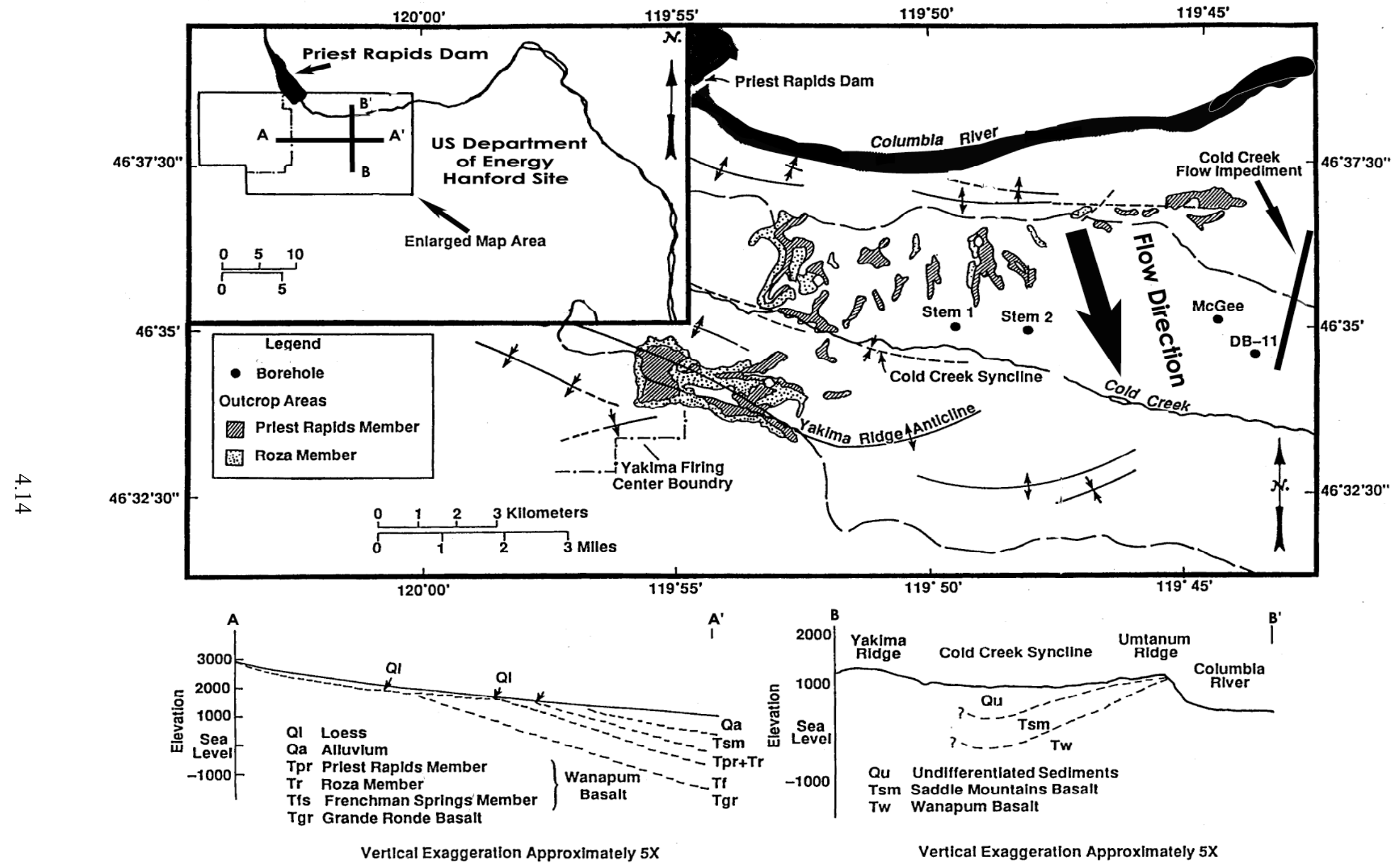

Figure 4.10. Well Locations and Geologic Map of the Upper Cold Creek Valley, Pasco Basin. (“Stem” is an abbreviation for St. Michelle.) 
Table 4.1. Helium and ${ }^{14} \mathrm{C}$ in Wanapum Basalt Aquifers, Upper Cold Creek Valley

\begin{tabular}{||l|c|c|c|c|c|c||}
\hline Borehole & $\begin{array}{c}\text { Packer } \\
\text { Depths (ft) }\end{array}$ & $\begin{array}{c}\text { He x 10-8 } \\
(\mathrm{cc} / \mathrm{cc})^{(\mathrm{a})}\end{array}$ & $\begin{array}{c}{ }^{14} \mathrm{C} \% \text { Modern } \\
\text { Carbon }(\mathrm{N})^{(\mathrm{b})}\end{array}$ & $\begin{array}{c}\text { Chloride } \\
(\mathrm{mg} / \mathrm{L})\end{array}$ & $\begin{array}{c}\delta^{13} \mathrm{C}, \mathrm{DIC} \\
(\mathrm{o} / \mathrm{oo})^{(\mathrm{c})}\end{array}$ & $\begin{array}{c}\text { Distance to Nearest } \\
\text { Recharge Outcrop }^{(\mathrm{km})}\end{array}$ \\
\hline \hline McGee & $691-978$ & $32.9 \pm 2.3$ & $8.4 \pm 2.5(4)$ & 4.3 & -11.2 & 3.2 \\
\hline STEM-1 & $469-970$ & $15.8 \pm 1.1$ & $21.4 \pm 1.9(1)$ & 4.9 & -14.0 & 1.8 \\
\hline STEM-2 & $565-1002$ & $16.6 \pm 1.5$ & $19.6 \pm 0.4(2)$ & 4.8 & -13.4 & 2.0 \\
\hline DB-11 & $1020-1210$ & $43.1 \pm 3.0$ & $3.0 \pm 1.1(5)$ & 3.2 & -10.0 & 4.5 \\
\hline
\end{tabular}

(a) Helium reported as cc He at STP per cc of pore fluid. Error terms are analytical uncertainty.

(b) Mean and standard deviation of replicate measurements. Number of replicates shown in parentheses. When there is only one measurement, the error term is analytical uncertainty (counting error + procedural error).

(c) Stable carbon in dissolved inorganic carbon fraction.

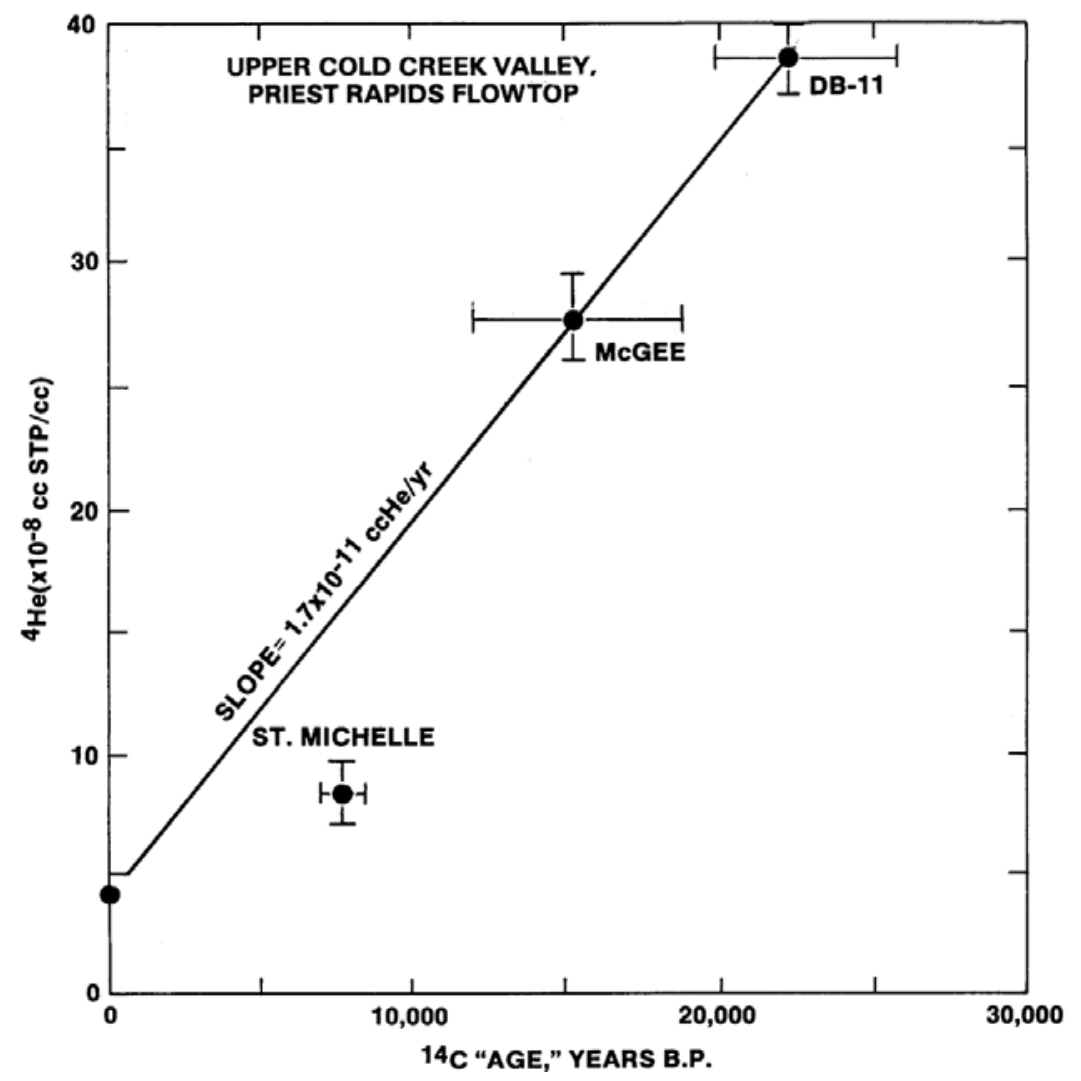

Figure 4.11. Helium Concentration versus ${ }^{14} \mathrm{C}$ Age, Upper Cold Creek Valley, Priest Rapids Member Flow Top Aquifers. (Well locations are shown in Figure 4.10.) 
Table 4.2. Noble Gases in Groundwater from the Columbia River Basalt Group Aquifer and Comparison Compositions

\begin{tabular}{|c|c|c|c|}
\hline $\begin{array}{l}\text { Well/Formation } \\
\text { Sample Type }\end{array}$ & $\begin{array}{l}{ }^{4} \mathrm{He} \times 10^{-5} \mathrm{~cm}^{3} \\
\text { STP } \mathrm{cm}^{3}\end{array}$ & $\begin{array}{l}{ }^{20} \mathrm{Ne} \times 10^{-8} \mathrm{~cm}^{3} \\
\text { STP } \mathrm{cm}^{3}\end{array}$ & $\begin{array}{c}{ }^{36} \operatorname{Ar} \times 10^{-8} \mathrm{~cm}^{3} \mathrm{STP} \\
\mathrm{cm}^{3}\end{array}$ \\
\hline \multicolumn{4}{|l|}{ Well DC-23 } \\
\hline Copper-tube barrel & $2.19 \pm 0.15$ & $25.6 \pm 1.8$ & $152 \pm 11$ \\
\hline gas fraction & $2.74 \pm 0.19$ & $24.5 \pm 1.7$ & $132 \pm 9$ \\
\hline water fraction & $\underline{0.11 \pm 0.01}$ & $6.7 \pm 0.5$ & $44 \pm 3$ \\
\hline $\begin{array}{l}\text { (total) } \\
\text { Umtanum }\end{array}$ & $2.85 \pm 0.20$ & $31.2 \pm 2.2$ & $\overline{176 \pm 12}$ \\
\hline Copper-tube & $6.91 \pm 0.48$ & $40.5 \pm 2.8$ & $161 \pm 11$ \\
\hline Copper-tube & $5.02 \pm 0.35$ & $26.6 \pm 1.9$ & $126 \pm 9$ \\
\hline surface flow & $4.05 \pm 0.28$ & $28.6 \pm 2.0$ & $125 \pm 9$ \\
\hline \multicolumn{4}{|l|}{ Sentinel Gap } \\
\hline $\begin{array}{l}\text { barrel } \\
\text { gas fraction }\end{array}$ & $1.91 \pm 0.13$ & $19.9 \pm 1.4$ & $102 \pm 7$ \\
\hline daster fraction & $\underline{0.11 \pm 0.01}$ & $14.4 \pm 1.0$ & $69 \pm 4$ \\
\hline (total) & $2.02 \pm 0.14$ & $\overline{34.4 \pm 2.4}$ & $\overline{162 \pm 11}$ \\
\hline $\begin{array}{l}\text { Ginkgo } \\
\text { surface }\end{array}$ & $1.42 \pm 0.10$ & $21.7 \pm 1.5$ & $137 \pm 10$ \\
\hline \multicolumn{4}{|l|}{ Well DC-14 } \\
\hline $\begin{array}{l}\text { Grande Ronde } \\
\text { surface A }\end{array}$ & & & \\
\hline $\begin{array}{l}\text { surface A } \\
\text { surface B }\end{array}$ & $\begin{array}{l}4.74 \pm 0.33 \\
3.39 \pm 0.24\end{array}$ & $\begin{array}{l}25.1 \pm 1.8 \\
15.1 \pm 1.1\end{array}$ & $\begin{array}{l}155 \pm 11 \\
83.8 \pm 5.9\end{array}$ \\
\hline surface $\mathrm{C}$ & $1.30 \pm 0.09$ & $5.31 \pm 0.37$ & $17.9 \pm 1.3$ \\
\hline \multicolumn{3}{|l|}{ Air Saturated } & 167 \\
\hline $\begin{array}{l}\text { Air Saturated } \\
\text { Water }\left(64^{\circ} \mathrm{C}\right) \text {, sea level }\end{array}$ & 0.003 & 12.0 & 53.2 \\
\hline $\begin{array}{l}\text { Miette } \\
\text { (hot spring) } \\
\text { (Mazor et al. 1983) }\end{array}$ & 0.045 & 5.71 & 27.2 \\
\hline \multicolumn{4}{|l|}{ Fairmont } \\
\hline $\begin{array}{l}\text { (water fractions) } \\
\text { (Mazor et al. 1983) }\end{array}$ & 0.42 & 4.79 & 38.1 \\
\hline \multicolumn{4}{|c|}{$\begin{array}{l}\text { The "copper tube" samples were obtained using a downhole pressurized fluid sampling device that main- } \\
\text { tained the sample at in situ pressures until analyzed. The "barrel" samples involved collection of the gas } \\
\text { and liquid fractions from a flow-through gas separator barrel. Flow meters on both the gas and water } \\
\text { phases were used to quantify the amounts in each fraction. The "surface" samples were collected by } \\
\text { attaching a stainless-steel flow-through cylinder to a sample T at the well head and allowing water to flow } \\
\text { through with as much back pressure as possible. The sample container valves were closed when there were } \\
\text { no visible signs of bubbles in a clear plastic tubing on the discharge side of the sample cylinder. Correction } \\
\text { of the samples for air contamination can be made if neon and argon isotopes are also measured (Mazor } \\
\text { et al. 1986). }\end{array}$} \\
\hline
\end{tabular}


Although more refinements can be made, this example suggests that groundwater flow rates in the deep basalt aquifers of the central Columbia Basin are very slow. It should be emphasized that this represents an average of conditions over a long distance and may include a vertical flow path segment as discussed in Section 4.3.4.1.

\subsubsection{Helium as an Indicator of Vertical Connectivity}

An additional or alternative use of the helium data shown in Table 4.2 is to assess the likelihood of upward vertical discharge for the deeper Grande Ronde Basalts.

As suggested in Figure 4.1, recharge water for the deep basalts enters along the margins of the Columbia Basin and migrates to the center of the basin where the Columbia River is assumed to be a discharge zone. Upward vertical movement must occur through the overlying basalts to reach a surface discharge point. If a basalt confined aquifer is a closed system (lateral movement only), the helium concentration will be strongly controlled by the average porosity of that flow top, all other factors being equal. Since the porosity can vary by as much as a factor of 10 or more between Wanapum Basalt and Grande Ronde Basalt aquifers, the helium content should vary widely between Wanapum Basalt and Grande Ronde Basalt aquifers because of porosity differences alone. However, the trend shown in Figure 4.12 suggests there is little relationship between porosity and helium content for the Wanapum and Grande Ronde stratigraphic units sampled. Instead, the plot suggests a simple dilution curve involving a common source with a constant $\mathrm{He} /$ chloride ratio. Dilution could occur if deeper Grande Ronde Basalt groundwater migrates vertically and permeates all the overlying stratigraphic units represented in Figure 4.12. This interpretation is consistent with the areal distribution of chloride, which has been interpreted to rise along the Cold Creek fault and spread laterally down the syncline to the east (Figure 4.13). The apparent flow rate based on helium accumulation in this case represents the average over the entire flow path (i.e., a long, lateral flow-path distance and a shorter vertical distance across multiple basalt layers where discharge occurs near the Columbia River). Most of the helium accumulation would occur along the lateral segment of the path (i.e., over a distance of 50 to 100 kilometers from the point of recharge) versus the vertical segment of only a few kilometers. Because of the uncertainty in porosity in this situation, the residence time estimated using the helium accumulation method is only an estimate.

Another issue concerning the relatively high helium contents of the deep basalt groundwater shown in Table 4.2 is the question of contamination by outgassing of the mantle. One hypothesis is that deep mantle helium may have permeated the crustal material and dominated the helium generated within the Grande Ronde Basalt aquifer system. To test this idea, pressurized fluid sample splits from the Umtanum member of the Grande Ronde (Table 4.2) were analyzed for ${ }^{3} \mathrm{He}$ (Berkeley Center for Isotope Geochemistry). Three sample splits were analyzed that yielded ${ }^{3} \mathrm{He} /{ }^{4} \mathrm{He}$ ratios that were 0.2 relative to the atmospheric ${ }^{3} \mathrm{He} /{ }^{4} \mathrm{He}$ ratio (Table 4.3). Mantle-derived helium is much higher than this. For example, Dodson et al. (1997) assign a value of 32 for the mantle. Thus, gases that may escape from deep magma chambers and emanate upward into crustal material should have ${ }^{3} \mathrm{He} /{ }^{4} \mathrm{He}$ signatures of 10 times higher than the atmospheric signature. The observed ${ }^{3} \mathrm{He} /{ }^{4} \mathrm{He}$ ratio in the high chloride Grande Ronde Basalt groundwaters of the Umtanum are about 100 -fold ( 0.2 versus 32 ) lower than a mantle source. Thus, the accumulated helium contents observed (Table 4.2 and Figure 4.12) are not from outgassing of the mantle. 

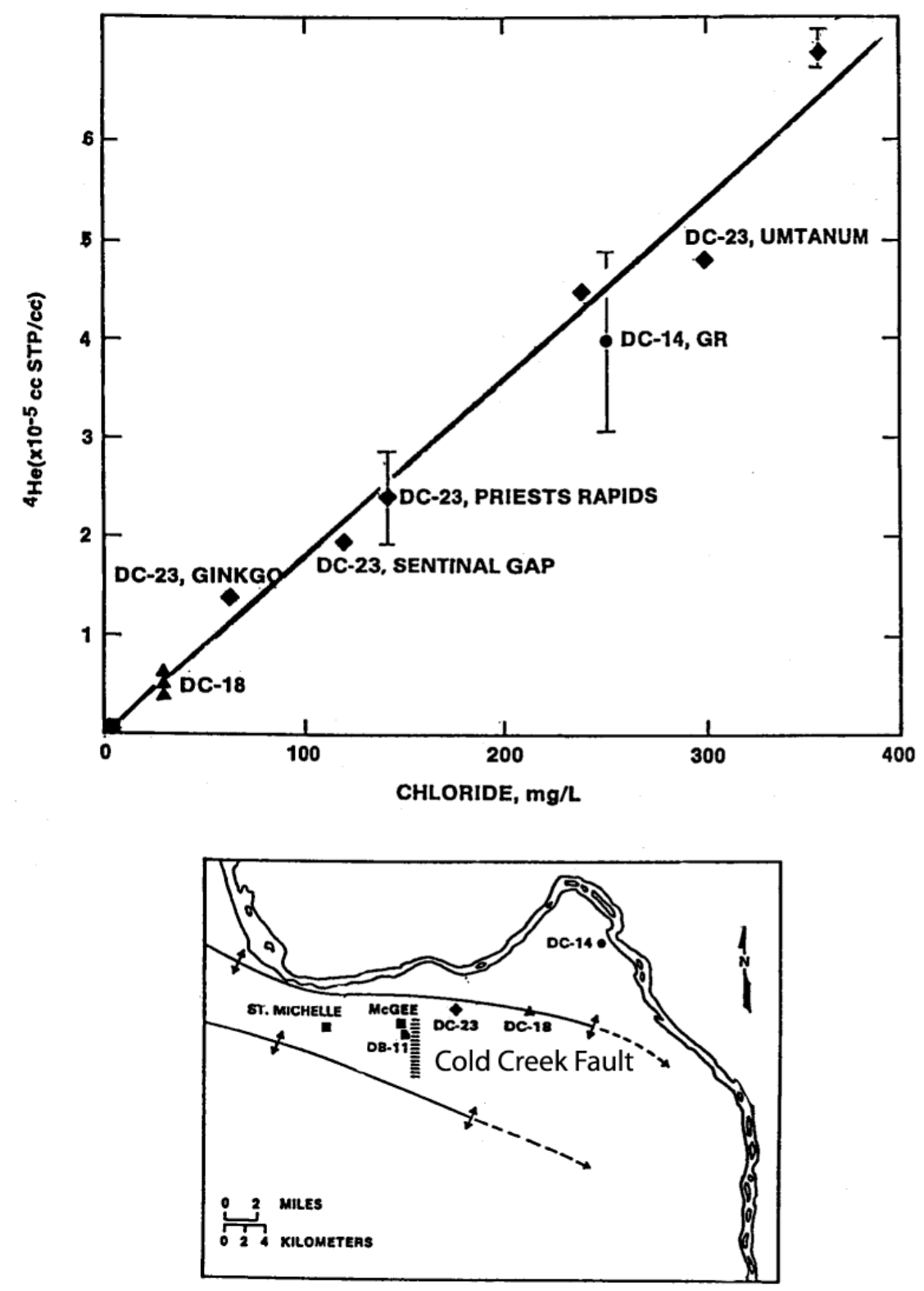

Figure 4.12. Helium versus Chloride Concentrations in Selected Wanapum Basalt and Grande Ronde Basalt Aquifers

Based on the helium versus ${ }^{14} \mathrm{C}$ age plot (Figure 4.11), helium appears to accumulate in a regular timedependent manner by diffusion of the radiogenic helium from the rock into the pore fluid.

The considerations discussed above suggest that high helium contents $\left(>10^{-5} \mathrm{cc} \mathrm{He} / \mathrm{cc}\right.$ of pore fluid) and a constant $\mathrm{He} / \mathrm{chloride}$ ratio across multiple stratigraphic units in a test well is indicative of old, deep water that has migrated vertically through interconnections between basalt aquifers. In contrast, increasing helium concentration with depth and variable $\mathrm{He} /$ chloride, $\mathrm{Cl} / \mathrm{B}$ and $\mathrm{Cl} / \mathrm{F}$ ratios versus depth or stratigraphic unit are favorable indicators for vertical isolation. 


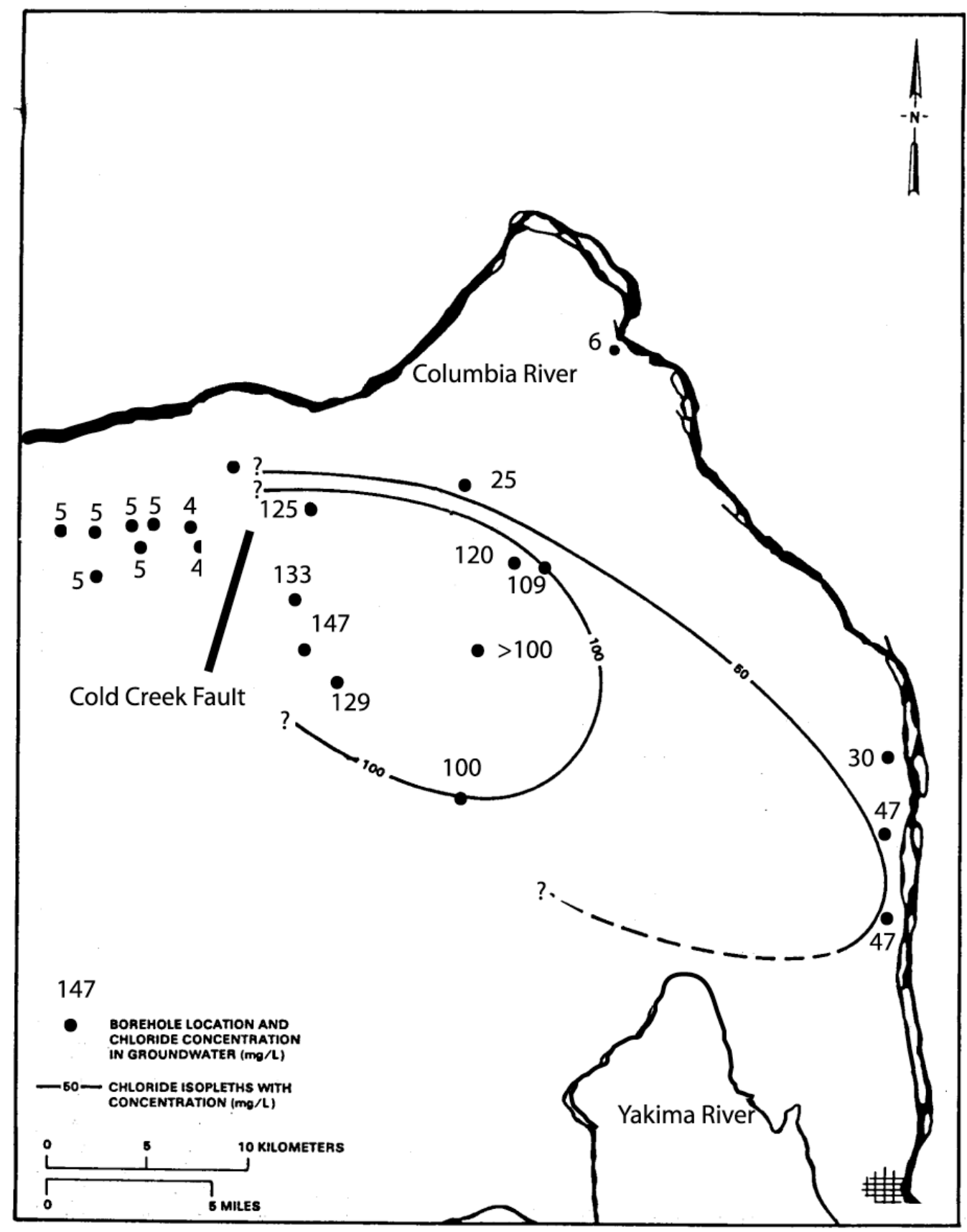

Figure 4.13. Areal Distribution of Chloride Concentration in Groundwater from the Priest Rapids and Roza Members of the Wanapum Basalt 
Table 4.3. ${ }^{3} \mathrm{He}$ in Grande Ronde Basalt Groundwater Samples from Well DC-23 (Member of Umtanum) $^{(1)}$

\begin{tabular}{|c|c|c|c|c|c|}
\hline Sample ID & $\mathrm{R} / \mathrm{Ra}$ & $\mathrm{F}\left({ }^{4} \mathrm{He}\right)$ & $\mathrm{F}\left({ }^{22} \mathrm{Ne}\right)$ & $\mathrm{F}\left({ }^{84} \mathrm{Kr}\right)$ & $\mathrm{F}\left({ }^{132} \mathrm{Xe}\right)$ \\
\hline MNS-218 & 0.163 & 210.51 & 0.458 & 1.625 & 3.04 \\
\hline \pm & 0.012 & 10.52 & 0.040 & 0.033 & 0.19 \\
\hline MNS-204 & 0.244 & 29.00 & 0.342 & 1.719 & 2.86 \\
\hline \pm & 0.010 & 1.45 & 0.040 & 0.035 & 0.18 \\
\hline MNS-214 & 0.242 & 40.97 & 0.387 & 1.556 & 2.18 \\
\hline \pm & 0.014 & 2.05 & 0.030 & 0.032 & 0.14 \\
\hline $10 \mathrm{C}$ ASW & 1.000 & 0.22 & 0.272 & 1.941 & 3.68 \\
\hline \multicolumn{6}{|c|}{$\begin{array}{l}\text { Notes: } \\
\text { (1) Analyses performed, as contracted, by Drs. John H. Reynolds and B. Mack } \\
\text { Kennedy, Dept. of Physics, Univ. of California, Berkeley, CA. } \\
\text { (2) } \mathrm{R} / \mathrm{Ra}:{ }^{3} \mathrm{He} /{ }^{4} \mathrm{He} \text { ratios normalized to the ratio in air }(\mathrm{Ra}=1.4 \mathrm{e}-6) \text {. } \\
\text { (3) } \mathrm{F}(\mathrm{i}) \text { values: Noble gas relative abundances normalized to air values e.g.: } \mathrm{F}\left({ }^{4} \mathrm{He}\right)= \\
\left({ }^{4} \mathrm{He} /{ }^{\beta 6} \mathrm{Ar}\right) \text { sample } /\left({ }^{4} \mathrm{He} \mathrm{e}^{36} \mathrm{Ar}\right) \text { air. } \\
\text { (4) The isotopic compositions of Ne and Ar were atmospheric within uncertainties. } \\
\text { (5) Date of Analyses: } 13-19 \text { November } 1987 \text {. }\end{array}$} \\
\hline
\end{tabular}

An estimate of flow rate based on the ${ }^{14} \mathrm{C}$ data for the upper Cold Creek area can also be made. From the ${ }^{14} \mathrm{C}$ age estimates, and using the estimated distance to nearest outcrop upgradient of each well where recharge could occur (Table 4.1), the apparent groundwater flow rates are about $0.15 \mathrm{~m} / \mathrm{yr}$. The agreement among the four well locations (range of 0.14 to $0.16 \mathrm{~m} / \mathrm{yr}$ ) is remarkable considering the calculated ages range from 12,700 to $29,000 \mathrm{yr}$ and distances to nearest outcrop range from 1,800 $\mathrm{m}$ to 4,500 m. The rather slow groundwater flow rates for this aquifer suggest the water is nearly stagnant. The permanent head loss for this aquifer of over $60 \mathrm{~m}$ due to agricultural withdrawal is consistent with the low apparent long-term average flow rates, indicating that the water is being mined from these basalt aquifers.

In summary, the example age and flow rate estimates presented above suggest that groundwater in deep, high-chloride basalt aquifers (Grande Ronde Basalt) of the west-central basin moves very slowly, perhaps on the order of a $\mathrm{m} / \mathrm{yr}$ or less. The poor water quality and long groundwater residence times make the Grande Ronde Basalt aquifers in the central Columbia Basin favorable locations for candidate gas storage sites. Conversely, those areas (eastern basin) where the Grande Ronde Basalt has suitable water quality for irrigation or domestic use would be less favorable locations for a gas storage project.

\subsection{Methane Concentrations and Isotopic Carbon and Hydrogen}

Dissolved methane of both biogenic and thermogenic origin occurs in the basalt aquifers of the Columbia Basin. Commercial quantities may be present. For gas storage site operation, it is important to be able to distinguish existing natural gas sources from injected gas to demonstrate containment of stored gas on the project site. That is, if dissolved methane is found in wells on adjacent lands it may become important to determine its origin.

A wide range of dissolved methane concentrations have been observed in the central Pasco Basin (Appendix F, and Figure 4.14). The highest concentrations have thermogenic carbon-hydrogen isotopic 
signatures (del ${ }^{13} \mathrm{C}$ to $-35 \mathrm{o} / \mathrm{oo}$ and $\mathrm{del}^{2} \mathrm{H}$ to $-135 \mathrm{o} / \mathrm{oo}$ ) and appear to be more limited in areal distribution, probably related to a fault (also see Section 3.0) that allows upward migration from a deep subbasalt coal bed source rock (Johnson et al. 1993). The more widely distributed, lower methane contents tend to have del ${ }^{13} \mathrm{C}$ to $-88 \mathrm{o} / \mathrm{oo}$ and $\mathrm{del}^{2} \mathrm{H}$ to $-265 \mathrm{o} / \mathrm{oo}$ (see columns 10 and 11 of Appendix F). The latter are attributed to a biogenic source generated within the basalt aquifers or sedimentary interbeds.

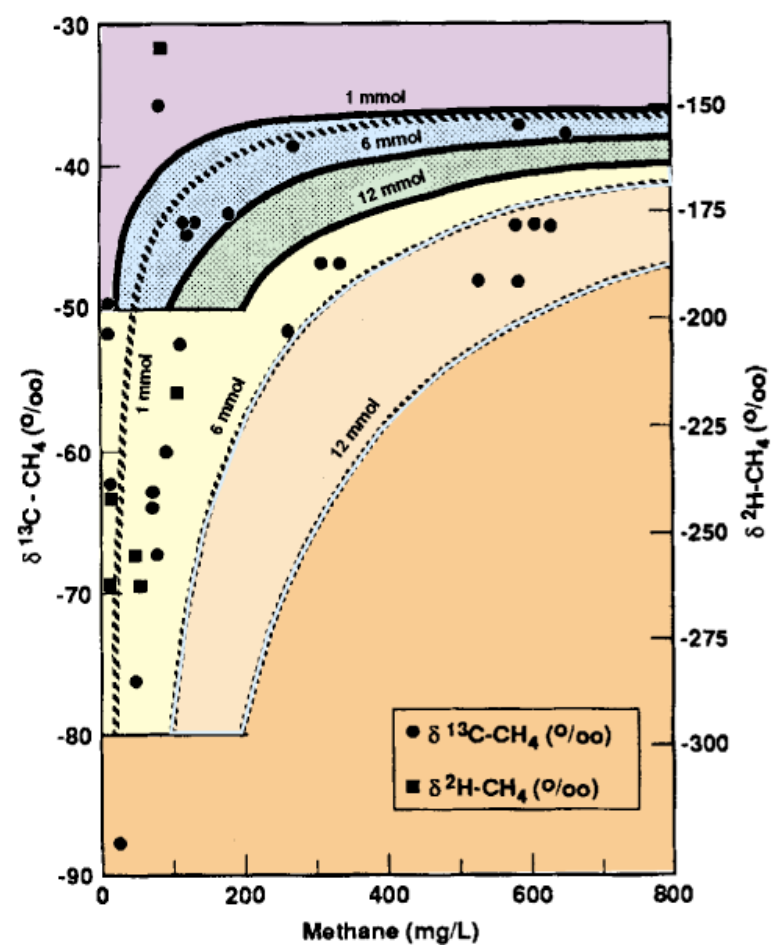

Figure 4.14. Carbon and Hydrogen Isotopic Compositions of Methane in Pasco Basin Basalt Groundwater (after Johnson et al. 1993). The data show a range in compositions from biogenic to thermogenic. The solid and dashed lines are theoretical curves for mixing between biogenic and thermogenic end members. The sets of curves labeled 1,6 , and $12 \mathrm{mmol}$ are three different biogenic pool sizes into which a thermogenic source is added.

The types of gas that might be stored in CRBG aquifers would likely come from the Alberta, Canada, or the Wyoming oil and gas fields. The Alberta gas is biogenic and would probably not be distinguishable from the ambient or natural biogenic methane in the Columbia Basin. Gas from Wyoming is associated with a mature oil source and may have a carbon/hydrogen isotopic composition similar to the thermogenic methane source in the Columbia Basin. One distinguishing feature in the latter case, however, is that ethane $\left(\mathrm{C}_{2}\right)$ occurs with the methane in the oil field gas source, whereas the thermogenic methane in the Columbia Basin is essentially pure methane $\left(\mathrm{C}_{2}<<1 \%\right)$. As indicated in Figure 4.15, gas with such a low ethane content and with del ${ }^{13} \mathrm{C}\left(\mathrm{CH}_{4}\right)$ in the -30 to $-40 \mathrm{o} / \mathrm{oo}$ range is classified as post mature or metamorphic. This is consistent with the burial depth $(4,000 \mathrm{~m})$, temperature $(\sim 150 \mathrm{C})$ and time ( $>15$ my) for the coal-bed source rock that underlies the basalt in part of the Columbia Basin (Johnson et al. 1993). As suggested by Figure 4.15, Wyoming gas/oil field sources of natural gas 


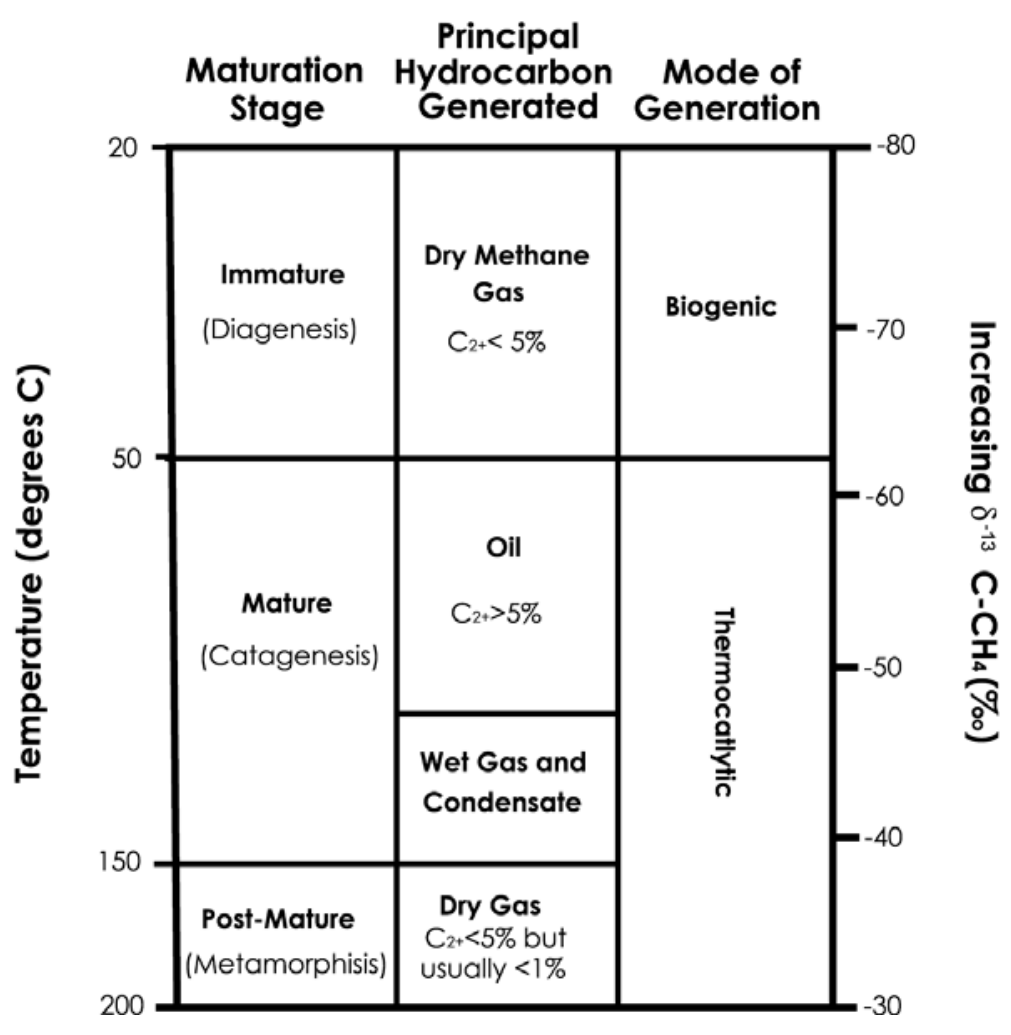

Figure 4.15. Natural Gas Source Characteristics. $C_{2}+$ refers to natural gas components with two or more carbon atoms per gas molecule $\left(\mathrm{C}_{2}=\right.$ ethane, $\mathrm{C}_{3}=$ propane, etc.). A "dry gas" is one dominated by methane $\left(\mathrm{C}_{1}\right)$. Columbia Basin natural gas covers the whole range of carbon isotope compositions from biogenic to postmature thermocatalytic but is almost entirely methane $\left(\mathrm{C}_{2}<<1 \%\right)$.

dissolved in groundwater near the storage site should be distinguishable from either local biogenic gas or the ultra dry Columbia Basin thermogenic gas by its $\mathrm{C}_{2}$ or ethane content and lighter (more negative) ${ }^{13} \mathrm{C}$ $\left(\mathrm{CH}_{4}\right)$.

A Canadian biogenic gas would be distinguishable from a local coal bed source type based on the carbon and hydrogen isotopic signature of the methane. However, it may also appear as a mixture as suggested by Figure 4.14 .

\subsection{Water Quality}

As discussed in Section 5.0, the water quality of basalt groundwater becomes an issue when produced water must be disposed of, and the naturally occurring constituents exceed water quality standards. This occurs most frequently for fluoride, which is often elevated above the $4 \mathrm{mg} / \mathrm{L}$ drinking water standard in the deeper aquifers of the central Columbia Basin. Well data provided in Appendix F indicate there is a wide range of fluoride concentrations in the Pasco Basin, with the highest observed concentration reaching over $50 \mathrm{mg} / \mathrm{L}$. Likewise, $\mathrm{pH}$ can often exceed the state standard of 8.5. The elevated $\mathrm{pH}$ (up to 
10) in basalt groundwaters is a result of hydrolysis of silica. Thus, consideration of how to handle water developed during hydrologic testing, and or large volumes of water withdrawn to increase gas storage space, must be made as part of the initial planning and characterization. Appropriate discharge permits will be required for disposal of all produced water.

Other constituents in deep basalt groundwater that can exceed state of Washington water quality standards include iron $(300 \mu \mathrm{g} / \mathrm{L})$ and manganese $(50 \mu \mathrm{g} / \mathrm{L})$. Data listed in Appendix F indicate iron concentrations that are frequently at or above the standard (up to $6300 \mu \mathrm{g} / \mathrm{L}$ ). Manganese also exceeds the state standard but less frequently. The existence of free or soluble iron and manganese is related to the anoxic, reducing conditions that prevail in the deep basalts. The reducing status is indicated by the prevalence of very low (negative) oxidation reduction potentials, as shown in Appendix F.

Discharge of large volumes of oxygen-depleted basalt groundwater to streams where ambient dissolved oxygen contents must be maintained for aquatic habitat purposes may be a concern in some cases. This and other water quality considerations would be included in the background information supporting a discharge permit for surface disposal of produced water. Based on the oxidation-reduction potential data shown in Appendix F, the complete absence of oxygen in produced water from the basalt aquifers can be expected more often than not.

Also, because the deeper basalt groundwaters of the central Columbia Basin are often unsuitable for domestic or commercial use, there is concern that wells might act as a conduit for aquifer intercommunication. Thus, care must be taken to seal all exploratory wells to prevent mixing of deeper non-usable water with the overlying aquifers that have suitable water quality for human use. These considerations are typically addressed in the drilling permit, as discussed in Section 5.0. 


\subsection{Regulatory Factors}

The majority of favorable land in the Columbia Basin for underground natural gas storage lies within the state of Washington. This section summarizes relevant Washington state regulations. Oregon has similar statutes and regulations, which can be obtained from the Oregon Department of Geology and Mineral Industries. Oregon regulates underground natural gas storage under Oregon Statute 520, Conversion of Oil and Gas Mineral Resources; oil and gas drilling is regulated under 632, Division 10, and seismic surveys fall under Division 15. The following sections provide guidance for regulatory issues; however, regulations change, and the appropriate agencies should be consulted for the most current regulations.

The Washington Division of Geology and Earth Resources regulates Underground Natural Gas Storage under chapter $80.40 \mathrm{RCW}$ (Underground Natural Storage Act) and drilling and related activities under the Oil and Gas Conservation Act and Department of Natural Resources rules (chapter 78.52 RCW and chapter 344-12 WAC). The Division also inspects all deep drilling operations, particularly those that affect groundwater and public safety.

\subsection{Groundwater}

The Washington Department of Ecology (Ecology) regulates groundwater resources. Impacts on groundwater aquifers fall under the jurisdiction of Ecology. A characterization well in the Columbia Basin will penetrate confined aquifers in the basalt and will require appropriate groundwater protection. Water quality standards intended to prevent degradation of groundwater resources of the state of Washington are set forth in Washington Administrative Code 173-200 ("Water Quality Standards for Ground Waters of the State of Washington").

\subsection{SEPA}

The Washington State Environmental Policy Act (SEPA), Chapter 43.21C RCW, requires all government agencies to consider the environmental impacts of a proposal before making a decision. An Environmental Impact Statement (EIS) must be prepared for all proposals with probable significant adverse impacts on the quality of the environment. The state of Washington provides a SEPA checklist for projects to complete. Agencies use that checklist to identify impacts from the proposed projects and determine whether an EIS is required. This checklist can be obtained from the Washington Department of Natural Resources, Division of Geology and Earth Resources, 111 Washington St. SE, P.O. Box 47000, Olympia, Washington.

The SEPA checklist is the first step in obtaining the necessary permits for a natural gas storage project. 


\subsection{Drilling Regulations Permits}

All oil and gas drilling, redrilling, or deepening operations require a drilling permit. A blanket permit for seismic shot holes is also required. Drilling characterization boreholes for underground natural gas storage falls under oil and gas drilling and requires a permit. The steps required are outlined below.

1. Permit Application. Obtain an oil and gas drilling permit from the Oil and Gas Supervisor, Washington Division of Geology and Earth Resources, Olympia Washington.

2. Permit Issuance. After the permit application has been submitted, the Oil and Gas Supervisor will notify other agencies with jurisdiction, and an inspection of the site will be made. Then Ecology will be notified, although it is probably best to contact the appropriate division office of Ecology before this stage because they will be involved with protecting groundwater resources via well design and other appropriate measures. If the land is state owned, or where local governments have jurisdiction, the lead agency for SEPA will be other than the Oil and Gas Supervisor. If the lead agency determines that there will be no significant impact on the environment, a SEPA determination of nonsignificant will be posted for 15 days (usually in a local newspaper), and if no significant impacts to the environment are noted during the posting, a drilling permit will be issued.

3. Permit Requirements. Follow the permit-related requirements applicable to natural gas storage characterization, as described below:

- The driller shall give adequate notice to the Oil and Gas Supervisor to allow witnessing of all tests, including drill stem, water shutoff and production tests, running of casing, plugging operations, and final site reclamations.

- A record and logs of the well on a WELL RECORD OR HISTORY FORM shall be presented to the Supervisor within 30 days of the completion or abandonment of the well (WAC Rule 344-12-070). A detailed description of the lithology shall be furnished within 30 days after completion or abandonment of any exploratory or characterization well.

- Well records and logs of all kinds not included above shall be furnished to the Supervisor within 6 months after completion. These will, upon request, be kept confidential for one year by the Supervisor (WAC Rule 344-12-070).

- The driller shall give notice to the Supervisor on a NOTICE OF INTENTION TO ABANDON AND PLUG WELL FORM prior to initiation of abandoning and plugging procedures (WAC Rule 344-12-125).

- Within 15 days after plugging the well, the driller shall file a REPORT ON RESULTS OF PLUGGING WELL FORM with the Supervisor giving the results of the plugging procedure. 
- Release of the bond requires approval by the Supervisor of the plugging of the wells and reclamation of the well site (WAC Rule 344-12-063).

\subsubsection{Water Quality and Use}

Deep basalt aquifers are used extensively in the Columbia Basin for both domestic and commercial agricultural purposes. The water quality varies considerably with depth and location within the basin. Those basalt aquifers that are unsuitable for either domestic or agricultural use are potential candidates for gas storage. However, as a permit condition, Ecology will require evidence that cross communication does not (or will not) occur between candidate gas storage horizons and the overlying aquifers that are important regional sources of water. Also, applications to the oil and gas conservation committee, as a prerequisite to an eminent domain determination, for a proposed storage project must demonstrate that the underground storage project will not injure, pollute, or contaminate any usable freshwater resources and that the proposed reservoir is not a productive source of fresh water in commercial quantities with reasonable and feasible pumping lift (see Underground Natural Gas Storage Act, Chapter 80.40). Findings to support the above application will most likely require site characterization and testing as well as reliance on available characterization data from deep domestic and irrigation wells or from previous oil and gas exploration boreholes.

As previously noted, the Grande Ronde Basalt aquifers in the central basin are typically high in fluoride. Iron is also elevated in some cases. Either of these constituents makes an aquifer unsuitable as a water resource and thus more favorable for gas storage.

Heavy use of basalt aquifers for irrigation in the basin has caused significant declines in hydraulic head in some areas. Such areas should be avoided, or at least be closely evaluated even if the deeper basalt aquifers underlying these areas are potentially suitable for gas storage. The permanent head loss could create structural instabilities in the overlying caprock that could, in turn, compromise the vertical containment of stored gas.

In other parts of the basin, intense irrigation using imported water has increased the hydraulic head in the upper basalt aquifers. The influence of this water-use practice on potential storage of natural gas in the deeper underlying basalts is unknown. However, a downward hydraulic gradient (hydrostatic pressure decreasing with depth) should be favorable to maintaining vertical containment of stored gas.

\subsubsection{Disposal of Produced Water}

Aquifer testing is an important part of characterization activities, and disposal of water from pump tests can be an issue if the water quality exceeds drinking water standards. Upper aquifers of the CRBG, Saddle Mountains and Wanapum Basalts, generally have water quality acceptable for disposal at the surface. Deeper aquifers of the Grande Ronde Basalt near the center of the Columbia Basin can have older water that may exceed drinking water standards for some analytes (e.g., fluoride, high pH, sulfide, and iron). Contingency plans should be in place for storage and disposal of groundwater that exceeds Ecology's limits for surface disposal. Contingency plans will typically require Ecology's approval. 
Large volumes of produced water may also occur during preparation of a deep aquifer gas storage zone. Discharge to adjacent rivers and streams would be subject to point source release water quality criteria. Conditions for a discharge permit would depend on the quantity and quality of the produced water and the flow rate of the receiving stream.

\subsubsection{Distinguishing Stored Gas from Naturally Occurring Gas}

Migration of stored gas beyond the designed storage site may be a concern of both local residential and commercial landowners as well as the regulatory sector. Since some natural gas does occur in the Columbia Basin, it is desirable to distinguish between the existing gas and the stored gas (see Section 4.4). The isotopic composition of the injected gas may serve as a marker that is unique to the source. For example, the carbon and hydrogen isotopic composition of biogenic methane is distinguishable from coal bed methane or natural gas associated with oil fields. Thus, determination of existing dissolved gas concentrations, amount of methane relative to higher hydrocarbons, and its isotopic composition are important during the characterization (and development) phase of site selection. 


\subsection{Natural Gas Reservoir Considerations}

There were 413 underground natural gas storage sites in the United States in 1999 with 2.13 billion cubic meters ( 76 billion cubic feet) per day of withdrawal capability and 111 billion cubic meters (3,933 billion cubic feet) of working gas capacity. Most of these existing storage sites are in porous sedimentary formations associated with depleted hydrocarbon reservoirs and/or salt dome structures. CRBG lava flows differ from the more uniformly porous media used in conventional natural gas storage facilities, primarily because only a portion of each lava flow (i.e., the top and bottom of the flow, the interflow zone, Figure 6.1) is capable of storing gas. A significant portion of the dense interior of an individual lava flow forms a barrier or a confining caprock to the vertical movement of gas. Thus, development of an economically feasible gas storage zone requires sufficient effective porosity in the interflow zone(s) to allow injection, storage, and withdrawal of gas at a rate that will meet system demands. This section discusses technical issues that must be taken into consideration in evaluating the suitability of candidate CRBG interflow zones for natural gas storage.

\subsection{Issues}

The primary technical issues that need to be addressed to determine if an interflow zone in the CRBG lavas can function as a natural gas storage zone are grouped into the following topics:

- Are there zones within the basalt flows that have sufficient size (lateral extent, thickness, continuity) to store natural gas?

- Do the storage zone(s) have favorable properties (i.e., sufficient porosity and permeability) for efficient natural gas storage and retrievability?

- Is there sufficient closure at depth to keep the gas from migrating away from the site?

- Are there good caprocks that will prevent the stored natural gas from leaking from the storage horizon?

- Is the water quality favorable (non-potable and the absence of $\mathrm{H}_{2} \mathrm{~S}$ )?

\subsubsection{Lava Flow Size}

Collectively, the CRBG covers an extensive area with individual lava flows covering many tens of thousands of square kilometers. Depending on the characteristics of flow at the time of eruption (i.e., volume, paleotopography, etc.), an individual CRBG flow can range from a few tens of feet to 300 feet thick. Generally, basalt flows of the Grande Ronde Basalt, particularly within the southcentral region of the Columbia Basin, are thicker than counterparts within the overlying Wanapum Basalt and Saddle Mountains Basalt. Appendix G shows the areal extent of individual CRBG flows. 
The great volume and extent of CRBG lava flows sets them apart from typical small-size lava flows and provide attractive targets for gas storage reservoirs. Even though only the interflow zone sections are usable for natural gas storage, the great volume and extent of CRBG flows put them on equal footing with the sedimentary formations within the United States that are currently being used for gas storage.

The most important tool for recognizing a CRBG lava flow in the subsurface, and thus its areal extent, is its chemical composition. The chemical signature of each lava flow allows mapping of its lateral extent. This is particularly true for lava flows of the Saddle Mountains Basalt and Wanapum Basalt that have unique chemical compositions that allow them to be easily recognized. In contrast, Grande Ronde Basalt flows, which were erupted rapidly in time, have more subtle compositional variations. Although the compositional variations for Grande Ronde Basalt flows are subtle, their chemical signatures are nevertheless distinguishable. Based on these chemical variations, Reidel et al. (1989b) have recognized 17 chemical compositional groups for the Grande Ronde Basalt. Appendix G provides a list of the chemical compositions of CRBG flows and a methodology for using chemical analyses from well cuttings or cores to recognize CRBG lava flows at depth. Because of the depth required for natural gas storage, the Grande Ronde Basalt would probably be the most likely target for site characterization.

\subsubsection{Rock Properties of Potential Storage Zones}

Columbia River Basalt Group lava flows typically consist of a permeable, rubbly flow top and bottom, and a dense, relatively impermeable flow interior section (Figure 6.1). The collective contact section between two successive basalt flows is referred to as an interflow zone, (vesicular flow tops, brecciated flow tops, basal pillow complexes and basal breccia zones), and form the primary aquifers within the Columbia Basin for agricultural, municipal, and domestic use. Sedimentary interbeds of the Ellensburg Formation that occur between successive flows occur most frequently within the Saddle Mountains Basalt and Wanapum Basalt and generally possess sufficient permeability to support domestic water supply needs. In the central region of the Columbia Basin, however, sedimentary interbeds commonly have fine-grained (tuffaceous sediments, clays) facies within their sections, which together with dense flow interior sections of basalt, act as local and regional confining/caprock layers.

Appendix A (Interflow structure) shows typical field exposures of the interflow and intraflow zones found in CRBG lava flows. The ability of selected interflow zones to produce groundwater throughout the region and the Rattlesnake Hills gas field demonstrate their potential for natural gas storage. The relatively low permeability afforded by basalt flow interiors also suggests that they can act as potential confining/caprock layers for the containment of natural gas that would be stored within underlying basalt interflow zones.

\subsubsection{Lateral Continuity of Reservoir Zones}

Two factors can affect the lateral continuity of CRBG internal lava flow features. They are: 1) initial variations imposed on the lava flows when they were erupted and emplaced, and 2) post-emplacement structural effects. 


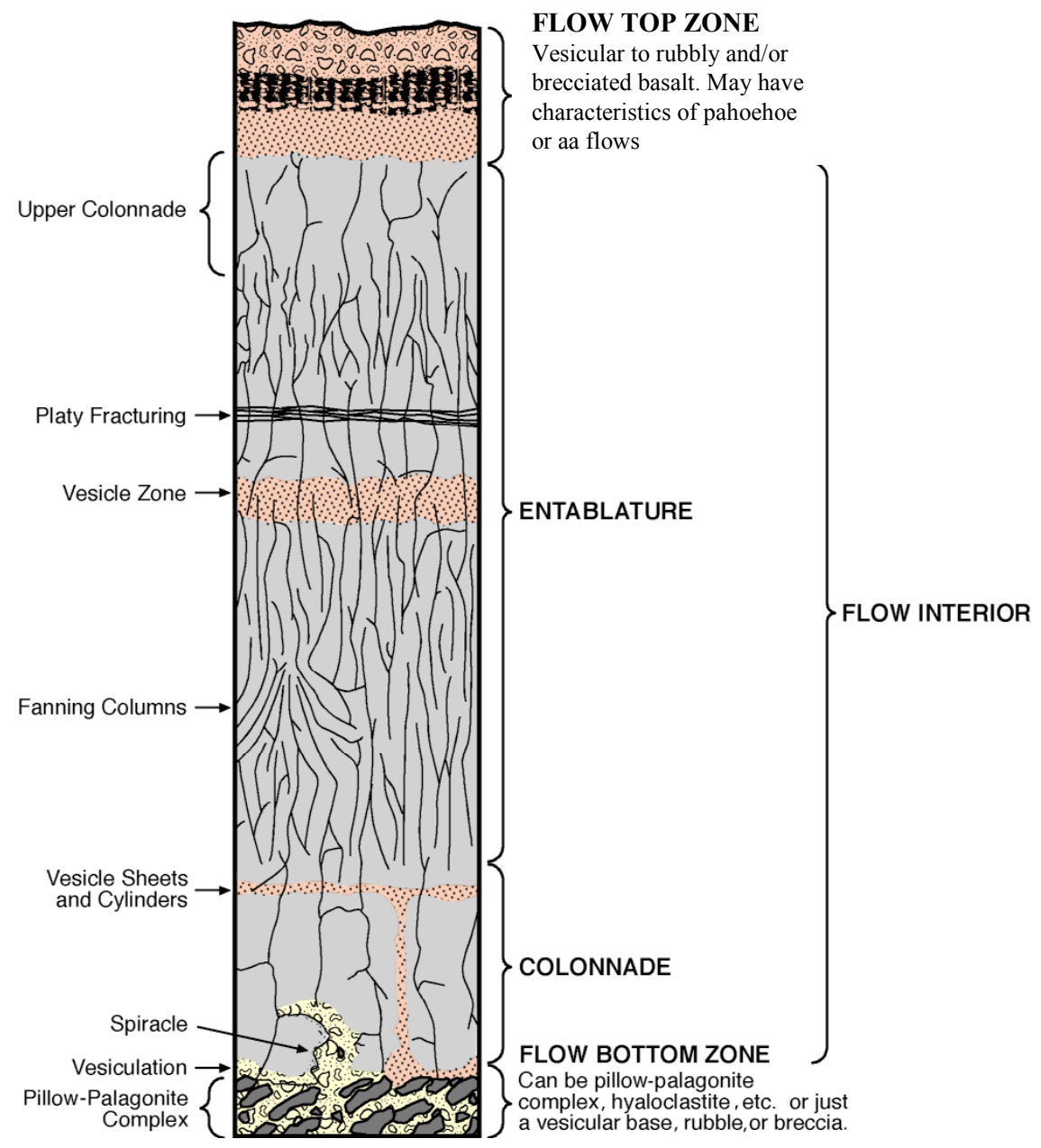

Figure 6.1. Internal Features of a Columbia River Basalt Group Lava Flow

Internal flow features form while the lava flow is being emplaced and/or after it has stopped and begins to solidify. The internal jointing that produces the colonnade and entablature sections of a basalt flow are a function of the solidification process and develops after the flow has stopped moving and begins solidifying. The joints usually follow the solidification thermal front, as it moves from the top and bottom through the flow. Rubbly zones associated with basalt flow tops and pillow-palagonite complexes commonly occur near the flow base and form during flow emplacement. Discontinuous internal vesicular sheets and pipes typically form after the flow has stopped moving and begins to solidify.

Flow tops form as the lava flow loses heat to the atmosphere by convection and begins to solidify. A number of factors contribute to the thickness and extent of a flow top development. Gas content is particularly important for the development of primary porosity in the formation of vesicles as the lava degasses. Although vesicles are an important contributor to primary porosity, the degree of vesicle interconnectivity is important in the development of permeability, as well as effective storage within the flow top zone. When the top of the lava surface solidifies while the flow is still moving, the flow top is susceptible to brecciation processes that provide enhanced areas of secondary porosity and permeability. 
Flow top breccias represent some of the most porous and permeable lava flow features. The continuity of these zones, however, is difficult to predict, and the locations where they can be expected is uncertain. Pillow-palagonite complexes (see Appendix A, Figure A.8) are also important contributors to the effecttive porosity of an interflow zone. Pillow zones form when lava enters surface-water features, e.g., river channels and lakes. A surface exposure of a well-developed pillow zone complex is visible at the base of the Ginkgo flow (Frenchman Springs Member, Wanapum Basalt) in the Vantage, Washington, area. It formed when this lava flowed into the ancestral Columbia River channel. Here, the pillow complex occupies an area of many tens of square kilometers.

Recognizing interflow zones and interflow structures in basalt flows can be facilitated by drilling continuous core, or, more economically, by using wireline logging technology (Appendix B). Flow top and internal vesicular zone delineation can be easily distinguished using either sonic tool or neutronneutron tool technology. This is because zones with higher porosity (e.g., vesicles) retard the sonic signal compared to the massive interior of the lava flow and produce an excellent response. Neutron-neutron tools respond to the water in the flow top and also produce an excellent zone definition. Both tools give a good measure of total porosity, which may not be indicative of actually interconnected storage volume, i.e., effective porosity. This can only be obtained by hydraulic characterization testing. Hydraulic testing can also be used to investigate the continuity of permeable/porous interflow zones and whether geologic boundaries (e.g., faults) are present that may disrupt their lateral extent. The use of hydraulic characterization tests for these applications is presented below and in more detail in Appendix E.

\subsubsection{Storage Zone Permeability and Effective Porosity}

As discussed in Section 3.0, interflow zones of the CRBG lava flows typically exhibit a wide range of hydraulic conductivity, ranging over 10 orders of magnitude from $10^{-2}$ to $10^{-12} \mathrm{~m} / \mathrm{sec}$. Detailed studies conducted on the Hanford Site indicated that interflow hydraulic conductivity generally decreases with depth, with Grande Ronde Basalt interflows (i.e., for depths $>800 \mathrm{~km}$ ) having a geometric mean value two-orders of magnitude lower than overlying Saddle Mountains Basalt and Wanapum Basalt counterparts, i.e., $10^{-7}$ vs. $10^{-5} \mathrm{~m} / \mathrm{sec}$ (Spane 1982; DOE 1988). This depth dependence for interflow hydraulic conductivity is believed to be associated with decreases in fracture permeability and porosity associated with increased secondary mineralization and greater effective stress conditions. These conditions are particularly relevant for the southcentral region of the Columbia Basin, where individual basalt flows tend to be thicker, and Grande Ronde Basalt flows occur at greater depths.

A variety of hydrologic tests can be used to determine the permeability (hydraulic conductivity) of candidate interflow zones. The hydrologic field tests recommended for hydraulic conductivity determination include dynamic flowmeter surveys, slug tests, and constant-rate pumping tests, in single- and multi-well field configurations. There are distinct advantages/disadvantages and area-of-investigation differences for each test method. The characteristics of each test/investigative method are discussed in greater detail in Appendix E.

Effective porosity refers to the interconnected void space within interflow zones that can collectively serve as the theoretical available volume for natural gas storage and retrieval. In contrast to hydraulic conductivity measurements, few field measurements of interflow zone effective porosity are available. 
Laboratory core analyses for Grande Ronde Basalt flow tops reported in Loo et al. (1984) range between 0.07 and $0.30(30 \%)$, but, due to scaling effects, are likely overestimated actual in-situ formation conditions.

Hydrologic tests that are best designed for direct determination of effective porosity include various single- and multi-well tracer tests. Theoretically, effective porosity can also be determined indirectly by storativity (S) analysis results derived from hydrologic tests (e.g., constant-rate pumping tests and slug tests), as well from well/aquifer barometric response analysis. Effective porosity estimates that are derived from these indirect methods, however, are subject to a wider range of uncertainty. The advantages, disadvantages, and characteristics of each test/investigative method for effective porosity determination are discussed in greater detail in Appendix E.

\subsubsection{Structural Closure}

Closure is an important issue that must be addressed for assessing site viability. Without structural closure, stored gas is susceptible to offsite migration, based on the prevailing groundwater flow dynamics and gas fluid potential distribution at reservoir depth. Because of the two-phase conditions that develop within an aquifer-type of natural gas storage reservoir, phase segregation exists within the reservoir, with natural gas forming a bubble at the top of the aquifer. The Yakima folds provide an attractive target for a natural gas storage facility, because the basalt has been folded into natural anticlines and domes. Although closure can be easily estimated at the surface from topographic maps, several factors can significantly influence structural closure at depth in the subsurface. These factors include variation in flow thickness across structural highs (anticlines) and faulting at depth. These influencing factors are discussed below.

\subsubsection{Flow Thickening and Thinning}

From field and borehole studies, it has been shown that the Yakima folds were growing during the eruption of the CRBG lava flows (Reidel et al. 1989a). This conclusion is based on studies showing thinner lava flows on the anticlinal ridge and thicker flows on the flanks and in synclines. This variation in flow thickness reflects the burial of the ridge during its growth by lava eruptions. The implication of this is that structural closure can be greater with depth compared to the surface closure measured from a topographic map. Closure can be evaluated at a site by drilling boreholes on the crest and flank of the structure and comparing the flow thickness or using seismic techniques (Appendix D).

It should be noted, however, that thinning of basalt flows in these anticlinal areas (and associated flow interior/caprock layers) is a factor that may be conducive for leakage and vertical communication between interflow zones. As discussed in Section 3.1.2, the relationships between flow thickness variations and paleotopography (i.e., the topography at the time of flow emplacement) appears to be most significant for individual flows of the Saddle Mountains Basalt, which collectively represent the least extensive formation (by volume) within the CRBG. Correspondingly, less thickness dependence is exhibited for the more voluminous flows of the Grande Ronde Basalt. 


\subsubsection{Faulting}

The Yakima Fold Belt formed within the CRBG as a direct result of compressional folding. Highangle reverse faults and thrust faults are commonly found within the fold-belt areas within the region. Normal faults are typically not present in the subsurface, but strike-slip faults can occur at near right angles to the reverse faults, often at segment boundaries along the length of the folds.

Reverse and thrust faults generally have the effect of reducing closure with depth (Figure 6.2). Closure occurs as a result of compression, as one block slides over another and repeats part of the subsurface stratigraphy. A repeat in the stratigraphic section produces an increase in the observed structural relief (e.g., at land surface) above the repeated section. Thus, in contrast to the influence of thinning discussed in Section 6.1.5.1, surface relief gives an overestimate of the structural relief (closure) at depth in the case depicted in Figure 6.2. If thrust faulting is constrained purely along flow contacts, or within sedimentary interbed, and does not intersect adjacent flows, no repeat in the stratigraphy will occur. In these situations, no loss in structural closure at depth would be produced, i.e., compared to land surface relationships.

Because individual basalt flows can be recognized by their chemical composition, sampling and analysis of borehole chip samples can detect repeats in subsurface stratigraphy. If only one flow is involved in the faulting, it will appear as a greatly thickened flow (Figure 6.2). However, if two or more flows are involved in faulting, the repeated stratigraphy will be easily detected (Appendix C, Figure C.20). This analytical tool provides the basis of assessing any potential reduction in closure occurring at depth, using information obtained with a single borehole.

Strike-slip faulting can impact reservoir continuity at depth, but its detection in the subsurface is more difficult. This is because a repeat in stratigraphy typically does not occur for strike-slip faulting. A change in the geometry of an anticline, expressed within surface outcrop patterns (segment boundaries), however, probably provides one of the best indications that a buried strike-slip fault exists. Surface geophysical techniques (e.g., seismic methods) provide the best method for detection of strike-slip faults within the subsurface.

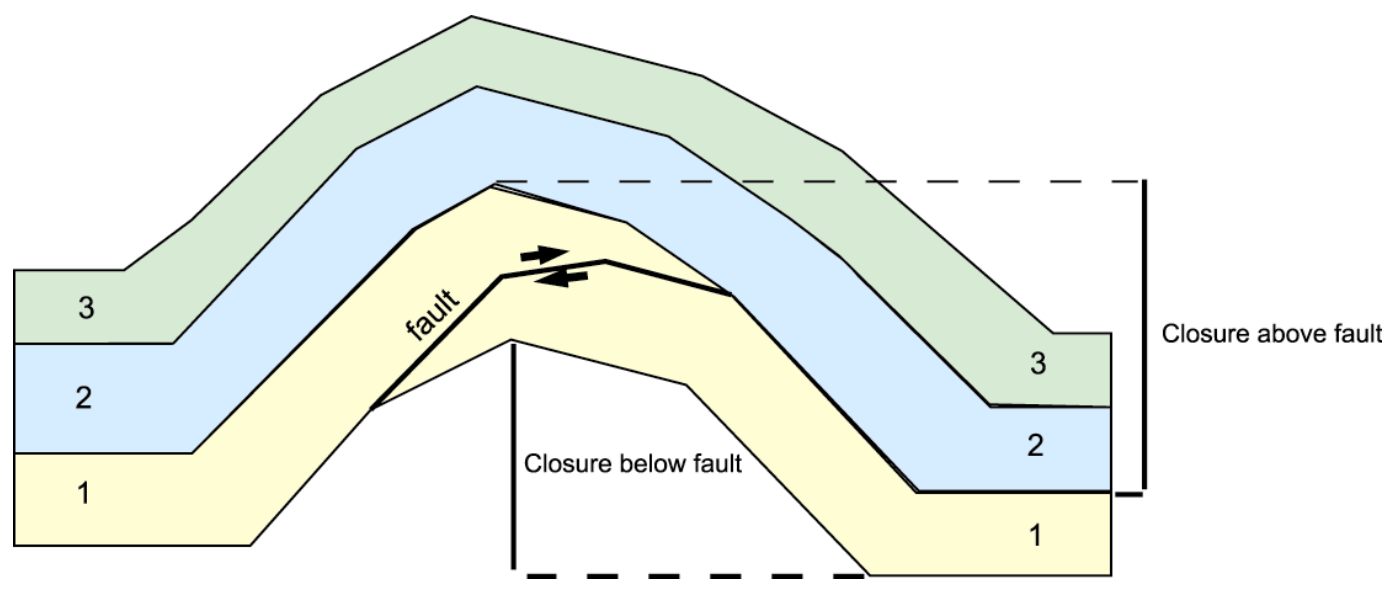

Figure 6.2. Example of Loss of Structural Closure from Faulting Involving a Single Lava Flow 
As discussed in Section 3.1.2, the brittle deformation of the basalt due to faulting and folding can create preferential vertical flow pathways through basalt flow interiors (tectonic fractures), enabling vertical hydrologic communication between interflow zones in areas adjacent to fault zone structures. This is the case in areas surrounding high-angle faults. The presence of faulting (and associated tectonic fracturing of confining caprock layers), therefore, should be considered a potential adverse factor for natural gas storage.

\subsubsection{Caprock Leakage}

The CRBG lava flows form a multilevel reservoir-caprock system. Confining caprock layers for natural gas storage within interflow zones are represented by flow interior sections (entablature zones) of massively thick flows. Basalt flow interiors exhibit considerably lower hydraulic conductivities than do interflow zones, with values ranging between $10^{-9}$ to $10^{-15} \mathrm{~m} / \mathrm{sec}$, and a geometric mean between $10^{-12}$ to $10^{-13} \mathrm{~m} / \mathrm{sec}$ (see Section 3). Detailed studies conducted on the Hanford Site also indicated (like interflow hydraulic conductivity) a general decrease in permeability with depth. The reason for this depth dependence for flow interior hydraulic conductivity is believed to be the same cited for interflow zones, and associated with decreases in fracture permeability and porosity due to increased secondary mineralization and greater effective stress conditions. The dense interior part of basalt flows provides a measure of interflow zone isolation, and can act as a cap rock for a gas storage horizon provided areas with crosscutting features (e.g., faults and stress fracturing) are avoided.

Low-permeability facies (clays, tuffaceous units) within sedimentary interbeds that occur intercalated between some basalt flows can also provide effective caprocks. Sedimentary interbeds are more prevalent within the Saddle Mountains Basalt, but also occur locally within the Wanapum Basalt and regionally between the Grande Ronde Basalt and Wanapum Basalt. The presence of sedimentary unit caprocks may be more prevalent within the southcentral region of the Columbia Basin, where low-permeability sedimentary units occur more frequently between individual basalt flows.

A variety of direct and indirect hydrologic tests can be used to determine the permeability (hydraulic conductivity) of candidate confining/caprock zones. Direct hydrologic field tests recommended for hydraulic conductivity determination include pulse tests and constant-pressure (head) injection tests (in single- and multi-well field configurations) and various direct and indirect techniques that use constantrate, interflow zone pumping tests (ratio method, leakage analysis methods). There are distinct advantages/disadvantages and area-of-investigation differences for each test method. The characteristics of each test/investigative method are discussed in greater detail in Appendix E.

In addition to hydrologic field tests, qualitative information concerning the sealing characteristics of caprocks can be obtained through observed differences in interflow zone hydrochemistry (see Section 4) and vertical head or fluid potential profiles. Distinct hydrochemical and isotopic compositional differences between groundwaters of the Grande Ronde Basalt, Wanapum Basalt, and Saddle Mountains Basalt have been used to imply aquifer isolation, and thus, the integrity of intervening caprock units (e.g., Gephart et al. 1979; Spane 1982; DOE 1988). Although hydrochemical information provides valuable information concerning the separation/communication between groundwater-flow systems (i.e., local, 
intermediate, and regional), the degree of isolation or leakage between individual interflow zones cannot be quantitatively determined using hydrochemical information.

Significant hydraulic head differences for aquifers (e.g., interflow zones) separated by a lowpermeability layer (e.g., flow interior) have been used as evidence for the sealing characteristics of confining/caprock rock horizons. An example of such an application is shown in Figure 6.3, which shows lateral hydraulic head (equipotential lines; higher head indicated numerically, i.e., $\mathrm{h}_{5}<\mathrm{h}_{9}$ ) within two aquifers (upper = medium permeability; lower $=$ high permeability), and the refraction of groundwater flow lines through a dipping low-permeability layer that separates the two aquifers. A vertical line drawn through the profile would indicate a significantly lower head for depths within the overlying aquifer, in comparison to heads encountered immediately below the low-permeability layer in the underlying, highpermeability aquifer. A variety of factors, however, can affect vertical hydraulic head differences and patterns with depth, and cannot be taken as definitive evidence for significant caprock confinement. Conversely, absence of significant hydraulic head differences between interflow zones at significant depths (e.g., $>500 \mathrm{~m}$ ) separated by tens of meters of flow interior thickness is not evidence of intercommunication, since regional groundwater flow systems having common areas of recharge and discharge would be expected to have similar lateral hydraulic head distributions across the majority of the flow field region.

In summary, vertical hydrochemical and hydraulic head data can provide inferential information pertaining to interflow communication. Caprock integrity/leakage, however, can only be definitively determined by direct hydrologic test characterization methods.

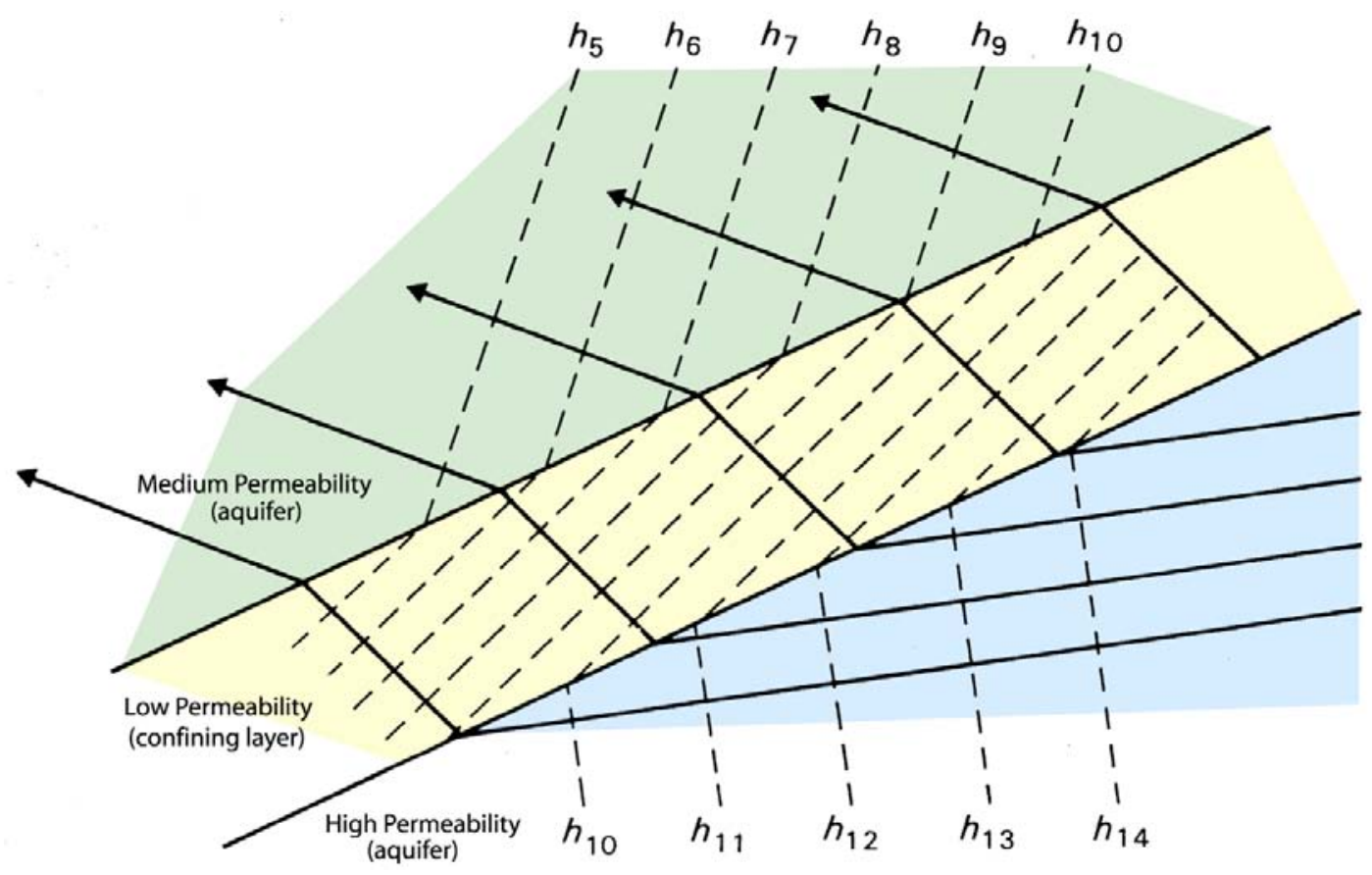

Figure 6.3. Lateral Hydraulic Head Within Two Aquifers 


\subsubsection{Gas Threshold Pressure}

The creation of a natural gas storage reservoir within an aquifer imposes a multiphase condition (i.e., gas and water) within the subsurface. For candidate interflow zones for gas storage and overlying lowpermeability caprocks, capillary forces may hold groundwater within the pore interstices, even in the presence of a pressure gradient. The pressure required to exceed the capillary forces within either an interflow zone or overlying caprock pores to displace the "held" water with injected gas is referred to as the gas entry or threshold pressure. Because of the greater permeability and porosity afforded by interflow zones, gas threshold pressure (GTP) would be expected to be considerably lower than for low permeability/porosity flow interior caprock layers. Determination of the GTP within caprocks is particularly important from a standpoint of leakage, since if gas injection pressures within the candidate reservoir zone (interflow zone) can be held below the GTP within the caprock, the effects of capillarity will impede the vertical leakage of stored reservoir gas. The standard field test for determining the caprock GTP is the gas threshold pressure test, which is described in Appendix E. For sedimentary formation caprocks, gas entry pressure information also can be derived from laboratory core tests; however, statistical analysis of large numbers of core test results must be performed to effectively evaluate this parameter. Because permeabilities of basalt flow interior caprock layers is inherently low and dependent on irregular fracture connectivity, the applicability of core analysis results for these units is highly questionable and better addressed using field tests.

It is also important to know the injection gas pressure at which the overlying caprock will fracture/ fail. Failure can occur when the candidate interflow zone is over-pressured during gas injection/storage operations. The injection over-pressure that induces hydrofracturing of the confining/caprock layer is a function of the existing hydrostatic pressure and in-situ stress conditions. Hydrostatic pressure can be estimated from the depth to the horizon of interest and areal water-level conditions. Information pertaining to the current state of stress within the Columbia Basin comes from geodetic surveys, hydraulic fracturing tests, and earthquake monitoring. Direct measurements on the state of stress in the basalt have been obtained by DOE from hydraulic fracturing tests on the Hanford Site. Hydraulic fracturing tests conducted at about $1 \mathrm{~km}$ depth in boreholes in the central Columbia Basin indicate that the maximum horizontal stress ranges from 52.6 to $67.4 \mathrm{MPa}\left(7,630\right.$ to $\left.9,780 \mathrm{lbf} / \mathrm{in}^{2}\right)$, and the minimum horizontal stress ranges from 30.3 to $35.7 \mathrm{MPa}\left(4,400\right.$ to $\left.5,180 \mathrm{lbf} / \mathrm{in}^{2}\right)$. The ratio of average horizontal stress $\left[\left(\sigma_{\mathrm{H}}+\sigma_{\mathrm{h}}\right) / 2\right]$ to the vertical stress $\left(\sigma_{v}\right)$ ranges from 1.41 to 2.14 with a mean value of $1.77 \pm 0.20$. This ratio is close to the higher end of known stress conditions at comparable depths at other locations and indicates that the propagation of fractures (in this region of the basin) would primarily parallel the principal horizontal stress direction (i.e., $\sim$ north-south direction), and any localized induced vertical fractures would be subject to horizontal roll-over to parallel the existing, principal stress field directions (DOE 1988).

\subsubsection{Calculating Potential Gas Storage Volume in Basalt Interflow Zones}

The economics of a viable natural gas storage project are variable and driven by the supplier needs pertaining to total/working storage volume requirements, recoverability, and deliverability/production rates. 
For example, the following hypothetical basalt conditions are considered for estimating potential natural gas reservoir storage (Figure 6.4). Using an average working volume requirement of 0.4 billion $\mathrm{m}^{3}$, the volume of basalt interflow needed can be estimated that would theoretically be capable of storing this volume of gas. A 10 -m-thick interflow zone, having an effective porosity of 0.15 will theoretically yield a pore space volume of $1.510^{6} \mathrm{~m}^{3}$ for every square kilometer. If the hydrostatic pressure of the target storage zone (depth $\cong 1000 \mathrm{~m}$ ) were $100 \mathrm{~atm}$ at 60 degrees $\mathrm{C}\left(333^{\circ} \mathrm{K}\right)$, then the volume of the gas at the surface would be $\sim 90$ times $\left(1.310^{8} \mathrm{~m}^{3}\right)$ the pore space volume at depth. The total subsurface area required to store the required 0.4 billion $\mathrm{m}^{3}$ would be approximately $3 \mathrm{~km}^{2}$. If it is assumed that the amount of gas that must be injected is approximately twice the volume indicated above to achieve the required working volume, then an effective storage area needed would be double or about $6 \mathrm{~km}^{2}$.

Typical anticlinal ridge systems in the Yakima Fold Belt are about 1 to $2 \mathrm{~km}$ wide. Although the anticline serves as the trap in the transverse direction, the length of a trap system is dictated by the occurrence of end closure points (i.e., where saddles or pinchouts occur). A likely length where end closure can be found will vary; however, $5 \mathrm{~km}$ may be taken as reasonable for purposes of estimating land requirements for a typical natural gas project. The total area of a hypothetical natural gas storage site would be $1.5 \times 5 \mathrm{~km}=7.5 \mathrm{~km}$. This area would provide a gas storage volume that is more than adequate
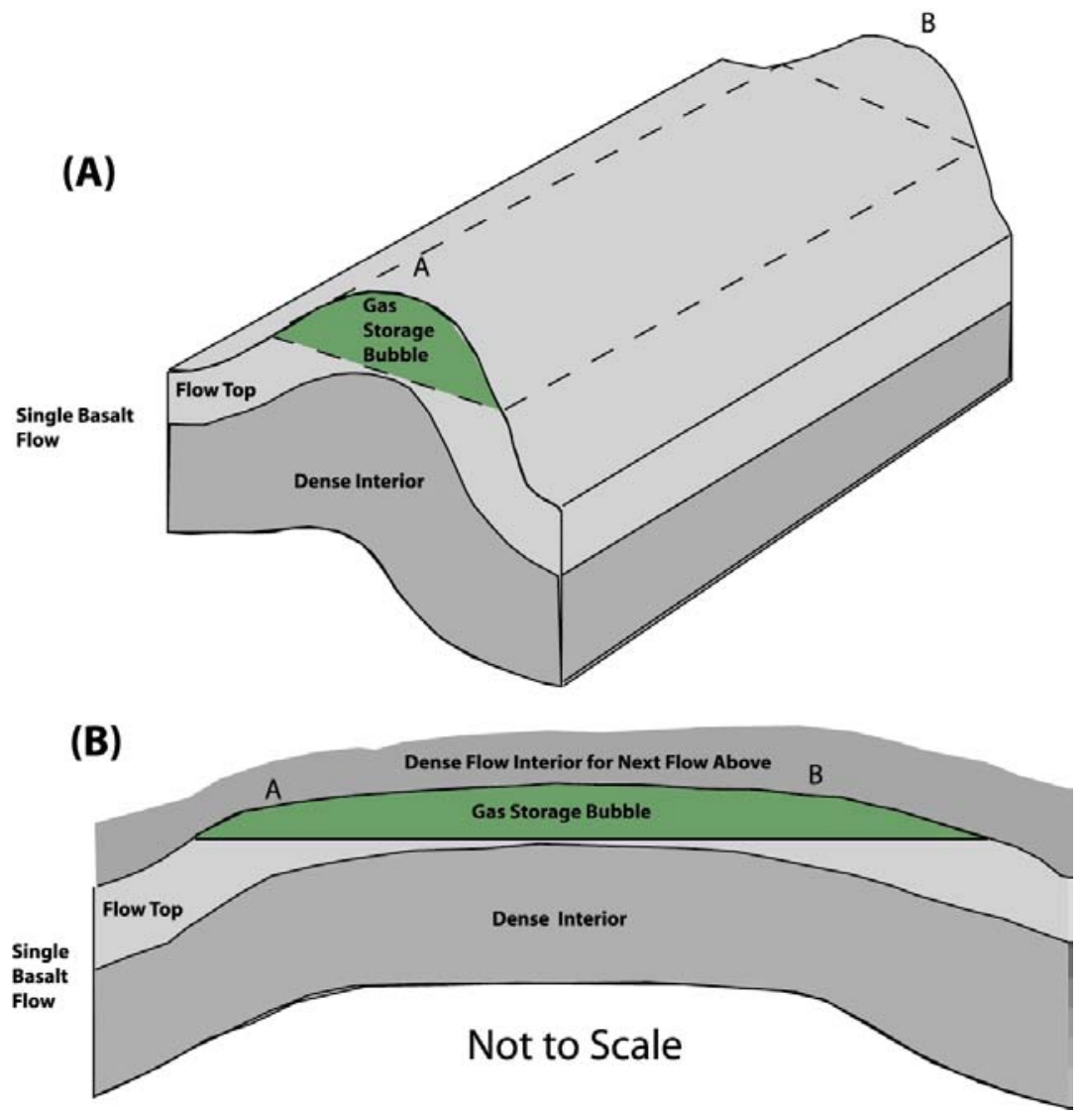

Figure 6.4. Example of Natural Gas Storage in a Columbia River Basalt Group Anticline 
for a 0.4 billion- $\mathrm{m}^{3}$ working gas storage facility. Using multiple flows for storage also greatly increases the calculated storage volume available at a site and would reduce the size of the ridge system needed.

More detailed and exacting reservoir calculations would be needed for an actual site screening analysis; however, the preliminary scoping calculations presented here demonstrate that suitable sections within a typical basalt fold structure meet theoretical storage capacity requirements. Thousands of square kilometers of basalt ridges are theoretically available within the Yakima Fold Belt (see Figures 6.5, 6.6, and 6.7 as examples of anticlinal structures with end closure). Some of the more attractive sites may be ones suitably located in close proximity to existing pipelines (Figure 1.1) and have favorable site characteristics (reasonable end closure points, non-potable water at the target depth, low seismicity, good caprock potential, etc.).

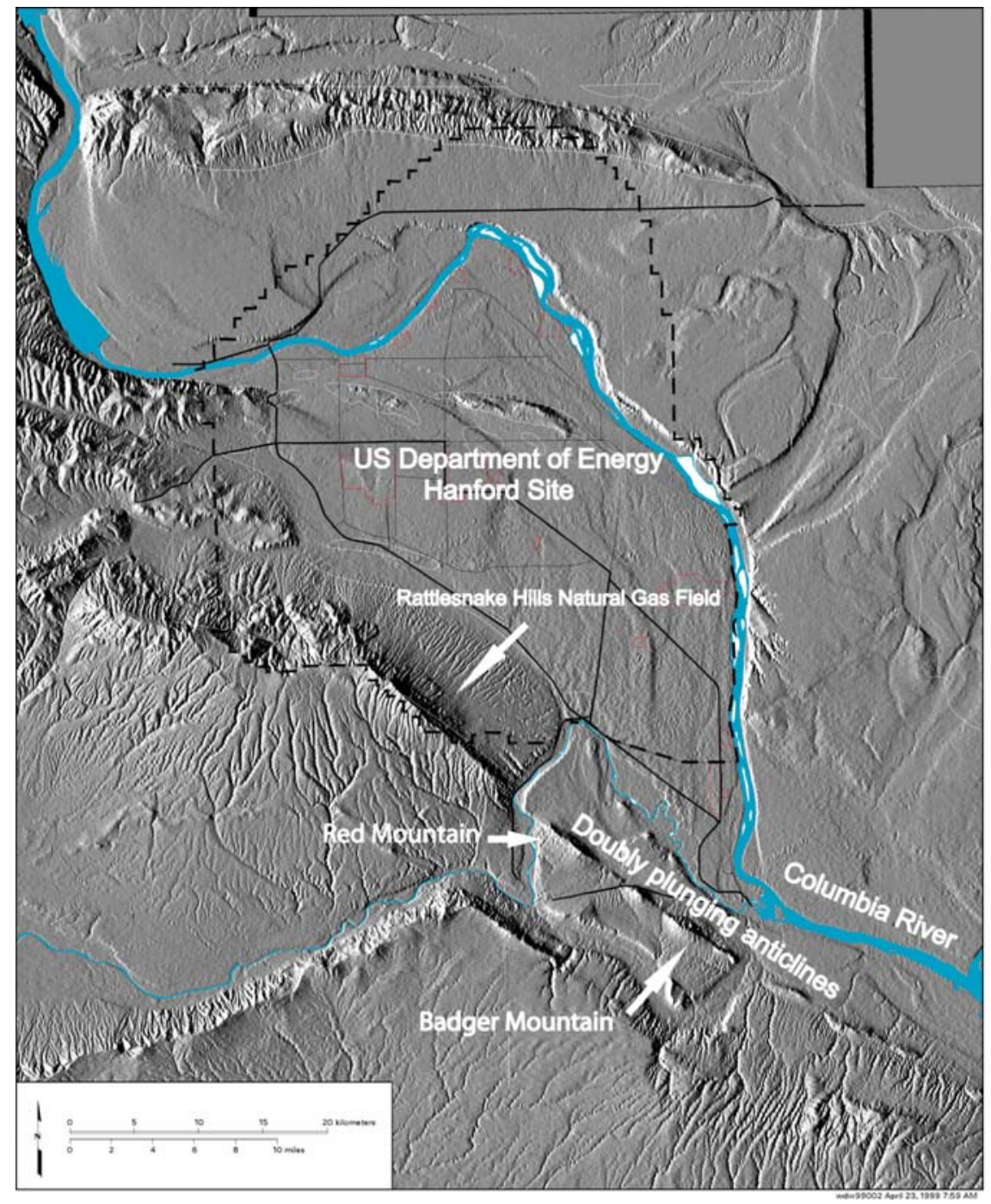

Figure 6.5. Map of the Pasco Basin Showing Examples of Anticlines Suitable for Potential Gas Storage (e.g., Red Mountain and Badger Mountain) 


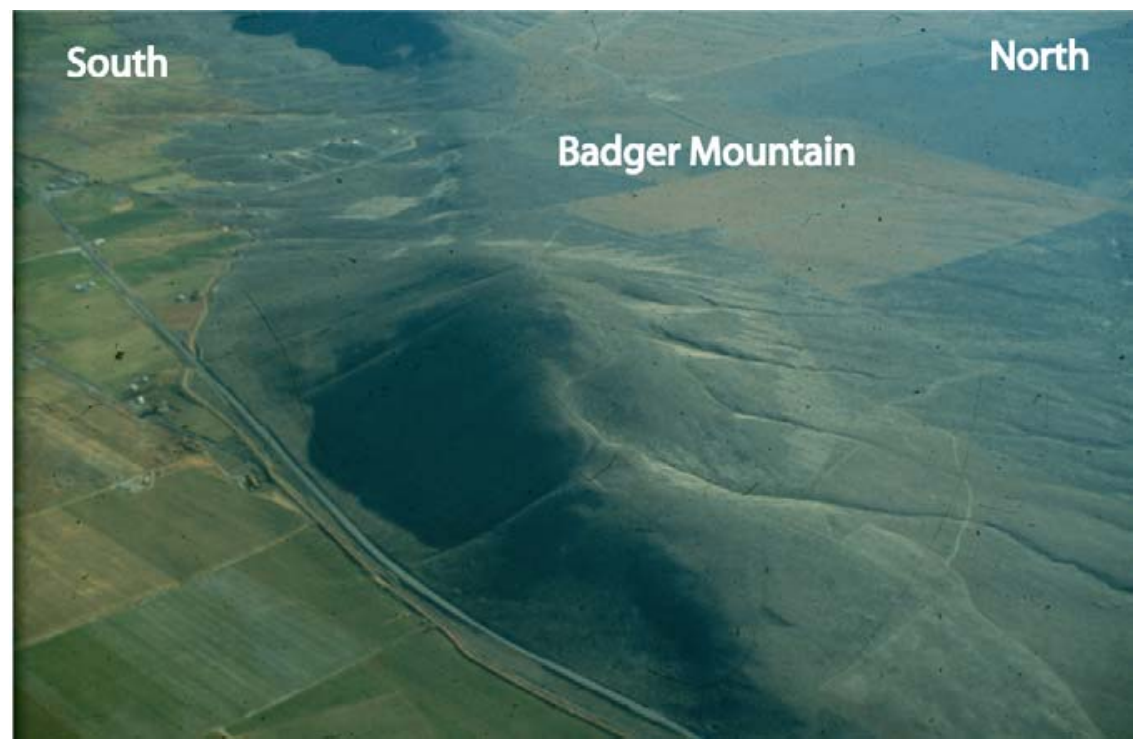

Figure 6.6. Badger Mountain (approximately 1.5 x $5 \mathrm{~km}$ )

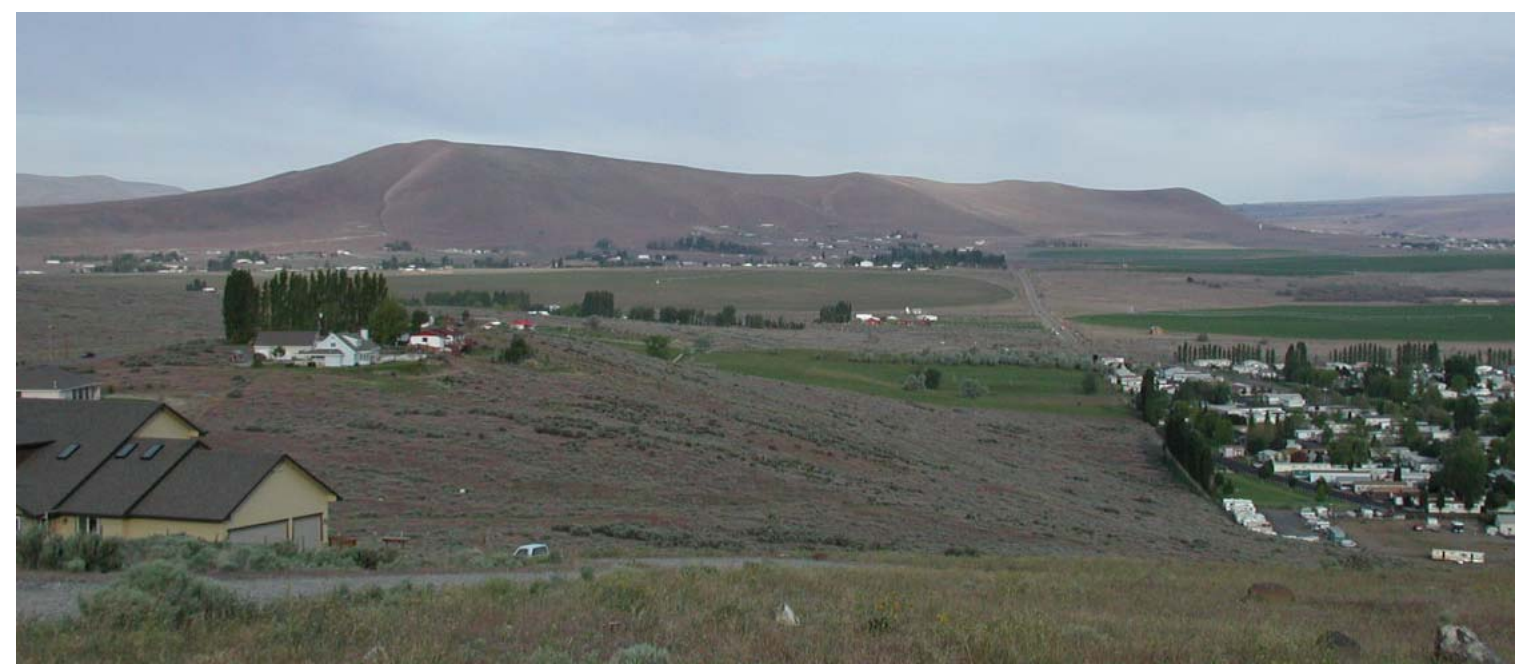

Figure 6.7. Red Mountain (approximately 1.5 x $5 \mathrm{~km}$ )

The background information provided in this report should facilitate and greatly reduce the amount of effort needed during the screening process to identify specific candidate site locations.

\subsection{Summary of Site Selection and Characterization Needs}

Information provided in this report can be used for pre-screening and selection of candidate locations for natural gas storage. However, additional, more detailed, site-specific characterization is needed once candidate sites are selected for further investigation. The DOE's experience in drilling and testing within the Pasco Basin for nuclear repository characterization, and participation in a preliminary reconnaissance 
investigation for development of a commercial natural gas storage reservoir in deep basalt is useful for planning future characterization programs for gas storage projects within the region. Based on this experience and the information provided in this report, issues, data needs, and recommended approaches for data acquisition are summarized in Table 6.1. A cross-reference also is provided in the table that directs the reader to appropriate sections in this report for additional details and information relevant to the issue identified. For the following summary of characterization needs, it is assumed that characterization boreholes will be drilled to the candidate depth $(\sim 1,000 \mathrm{~m})$ and that multiple zones will be tested.

\subsection{Recommendations for Well Drilling, Hydrochemical Sampling, and Hydrologic Testing}

Drilling deep boreholes in basalt can be a challenging and expensive undertaking. A large number of deep characterization boreholes have been drilled in the Pasco Basin as well as two exploratory boreholes for commercial natural gas storage projects in the Yakima Fold Belt region. Three basic drilling methods have been used:

Table 6.1. Summary of Characterization Needs

\begin{tabular}{|c|c|c|c|}
\hline Issue & Information Need & Approach & Cross-Reference \\
\hline $\begin{array}{l}\text { Stratigraphic } \\
\text { identification }\end{array}$ & $\begin{array}{l}\text { Correlation with regional } \\
\text { marker horizons }\end{array}$ & $\begin{array}{l}\text { Chip samples for chemical } \\
\text { identification; borehole } \\
\text { geophysics }\end{array}$ & $\begin{array}{l}\text { Sections 2.2.2, 2.6.2; } \\
\text { Appendix G }\end{array}$ \\
\hline Storage volume & $\begin{array}{l}\text { Porosity: aquifer thickness, } \\
\text { properties, and } \\
\text { discontinuities }\end{array}$ & Drill and hydrologic testing & $\begin{array}{l}\text { Sections 2.3, 2.49, 2.10; } \\
\text { Sections 3.1.1, 3.1.2; } \\
\text { Appendix E }\end{array}$ \\
\hline Closure & Structural relief at depth & $\begin{array}{l}\text { Seismic profiling; borehole } \\
\text { logging }\end{array}$ & $\begin{array}{l}\text { Sections 2.4.8, 2.4.9, 2.4.10, } \\
\text { 2.6.1.4, 2.6.1.5, 2.6.2; } \\
\text { Appendixes C and D }\end{array}$ \\
\hline Vertical isolation & $\begin{array}{l}\text { Hydraulic and } \\
\text { hydrochemical indicators }\end{array}$ & $\begin{array}{l}\text { Drill and test; pump tests, } \\
\text { single and dual well stress; } \\
\text { water sample analysis }\end{array}$ & $\begin{array}{l}\text { Sections 3.1.1, 3.1.2, 3.2; } \\
\text { Sections 4.2, 4.3.4.1; } \\
\text { Appendixes E and F }\end{array}$ \\
\hline Caprock leakage & $\begin{array}{l}\text { Vertical permeability; } \\
\text { leakage response }\end{array}$ & $\begin{array}{l}\text { Single- and multi-well } \\
\text { hydraulic tests }\end{array}$ & Section 3.1.2; Appendix E \\
\hline Lateral continuity & $\begin{array}{l}\text { Areal extent of reservoir and } \\
\text { caprock zones }\end{array}$ & $\begin{array}{l}\text { Borehole logging; multi- } \\
\text { well hydraulic tests }\end{array}$ & $\begin{array}{l}\text { Sections } 2.3,2.4 .9,2.4 .10 \text {, } \\
\text { 2.6.2; Section 3.1.1; } \\
\text { Appendixes B, E, and G }\end{array}$ \\
\hline $\begin{array}{l}\text { Gas threshold } \\
\text { pressure }\end{array}$ & $\begin{array}{l}\text { Gas entrance pressure within } \\
\text { reservoir/caprock }\end{array}$ & Gas injection tests & Section 6.1.7; Appendix E \\
\hline Non-potable water & Fluoride, Fe, Mn, chloride & Water samples & Sections 4.2, 4.5; Appendix F \\
\hline $\begin{array}{l}\text { Induced stress } \\
\text { fracturing }\end{array}$ & Change in porosity & \begin{tabular}{|l|} 
Pressure gas injection \\
testing Grande Ronde \\
Basalt flow tops; hydraulic \\
testing before and after \\
\end{tabular} & $\begin{array}{l}\text { Section 2.4.12; Section 6.1.7; } \\
\text { Appendix E }\end{array}$ \\
\hline Seismicity & Low seismic area & $\begin{array}{l}\text { Regional seismic network } \\
\text { records }\end{array}$ & Section 2.4 .12 \\
\hline
\end{tabular}


- reverse circulation drilling, using either water or drilling mud

- core drilling (to obtain continuous core, using water or drilling mud)

- flooded reverse circulation air-lift drilling, using either water or mud as the re-circulating fluid.

A schematic of the flooded reverse circulation, airlift method is shown in Figure 6.8. For this drilling method, a flooding fluid or added water source is used to maintain a positive pressure against the open borehole to minimize sloughing. This is a standard method typically used for drilling in solid rock. As applied to drilling through basalt and for testing interflow basalt aquifers, the drill bit can be removed, and the pipe string can be re-inserted. Together with a packer (Figure 6.9a), it can be used as an airlift pump for conducting hydrologic drawdown and recovery tests. As an alternative, a submersible pump can be inserted into the drill pipe (Figure 6.9b), which provides better control for constant-rate pumping tests. Use of a submersible pump adds additional costs to the testing program, but this incremental cost is minor compared to the overall cost of drilling a deep basalt characterization borehole. Because the objective is to gain the most characterization information from the borehole, the quality of the data derived from hydrologic testing should be factored into the selection of tests and test equipment used.

Water produced during hydrologic testing also serves to purge the well for obtaining representative formation water for hydrochemical and dissolved gas analyses. Several thousand gallons of water are typically removed during a hydrologic testing and sampling event. The flooded reverse circulation method appears to be very versatile and relatively efficient for drilling and testing multiple basalt layers.

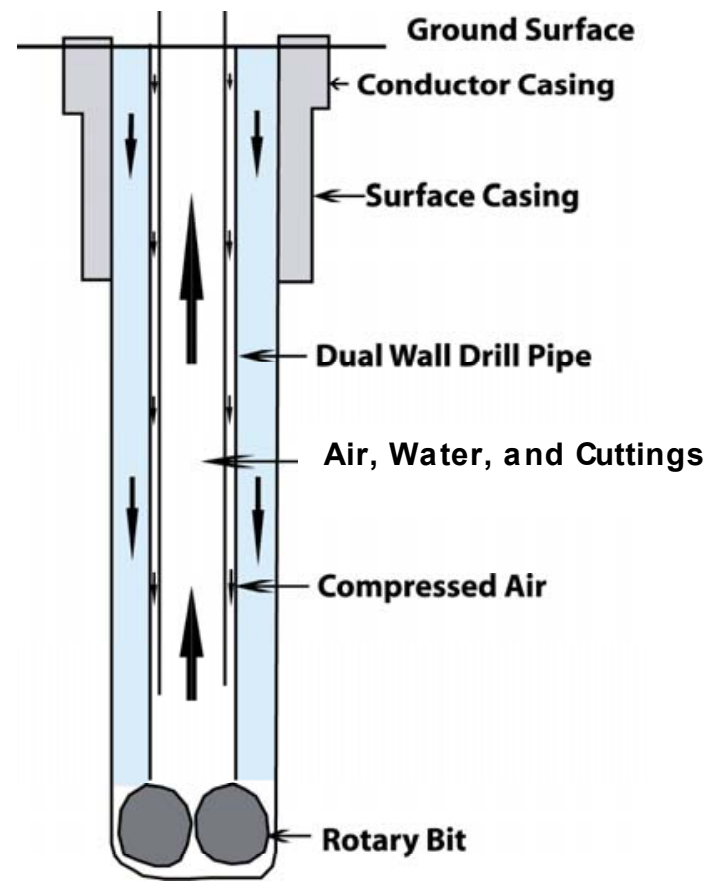

Figure 6.8. Schematic of Flooded Reverse Circulation Airlift Drilling Method 
In contrast to the flooded reverse circulation method, reverse circulation drilling does not use dual wall drill pipe and recirculates fluid (either water or drilling mud) during drilling. The drill pipe is considerably less expensive than the dual-wall pipe used in the flooded, reverse circulation, airlift drilling approach (Figure 6.8). Hydrologic testing can be conducted in a similar manner as shown in Figure 6.9b. All of the drilling methods require that the sedimentary interbeds (especially in the Saddle Mountains Basalt) be cased off and/or cemented to a varying extent to prevent cave-in on the drill string.

The core-drilling method is used primarily when solid rock is reached. It has the advantage of providing continuous core as well as a uniform diameter borehole for hydrologic testing. The coredrilling method is a much slower and time-consuming approach, but is the preferred drilling technique where intact core is needed. Hydrologic testing can be conducted as depicted in Figure 6.9b.

Whichever drilling method is used, judgment and experience in drilling deep basalt in the Columbia Basin is needed for attaining a successful characterization program. The DOE scientists at PNNL are good resources for providing advice for specialized drilling and test characterization of deep basalt layers. Some key points based on lessons learned in the past include, but are not limited to the following:

- For drilling and testing of deeper Wanapum Basalt zones, the overlying Saddle Mountains Basalt (if present) should be isolated using a cemented casing string to avoid potentially unstable (cave in) borehole conditions. For drilling and testing of deeper Grande Ronde Basalt zones, the overlying Wanapum Basalt should be isolated using a cemented casing string to avoid unstable borehole conditions and to prevent the potential for intermixing of formational groundwaters.

A

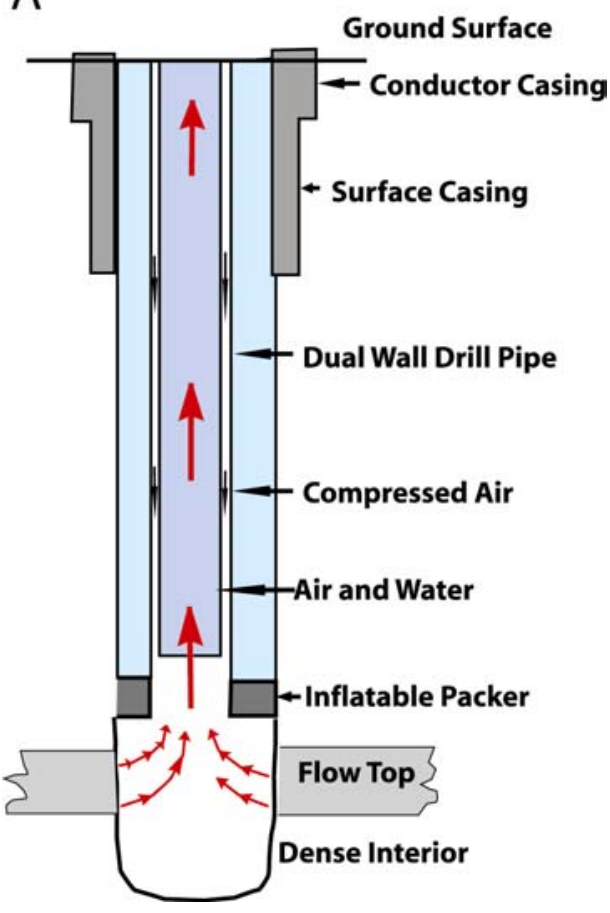

B

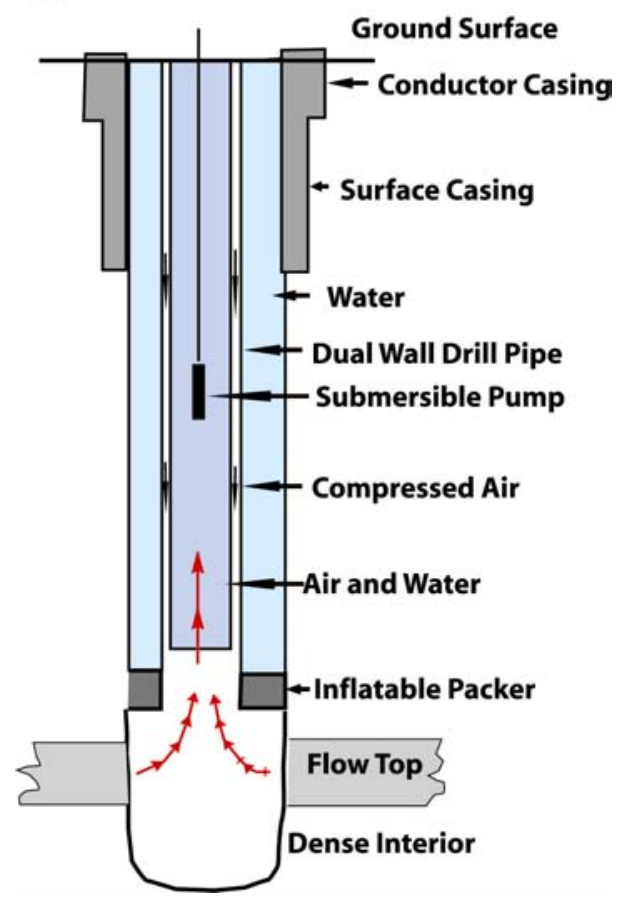

Figure 6.9. Testing Using Airlift Techniques (A) and Submersible Pump (B) 
- If possible, avoid recirculating drilling fluid after cemented zones are redrilled to advance the borehole to the next lower depth (cement raises the $\mathrm{pH}$ of the fluid and can compromise hydrochemical sample quality if purging is not able to remove all the cement-fluid from the test horizon).

- Chip samples collected for geologic description during the course of drilling should be unwashed initially because washing chip samples can remove indicators of a fault zone. Fine particles can also be indicative of sedimentary material and other lithologic changes.

- If the flooded reverse circulation airlift drilling method is used, collect downhole pressurized fluid samples for dissolved gases and other chemical analyses well below the air-injection ports on the drill string (usually located 50 to $100 \mathrm{ft}$ above the drill bit; see Figure 6.8).

- Continuous monitoring of fluid electrical conductivity (and periodic grab samples for major constituent analysis) during pumping tests provides hydrochemical time plots that can be used to track changes in chemistry that may be indicative of intercommunication between aquifers within the borehole (e.g., poor packer seals) or evidence of formational cross communication (e.g., via tectonic fracture network).

- Hydrologic field testing programs of interflow zones that are candidates for natural gas storage should focus on obtaining detailed vertical-depth distributed information pertaining to: hydraulic head, hydraulic/storage properties, and hydrochemical content. Acquisition of these characterization elements can be readily included in the test strategy adopted for borehole characterization (see Appendix E for a discussion on hydrologic test strategies). Detailed field-testing of confining/ caprock layers overlying candidate interflow zones should focus primarily on their local-scale sealing and leakage characteristics and gas threshold pressure properties. If favorable results are obtained following the completion of initial, reconnaissance-level characterization activities at individual borehole locations, additional nearby characterization boreholes can be constructed for multi-well characterization tests. Multi-well characterization tests will provide intermediate- to large-scale information on caprock leakage, interflow zone hydraulic/storage properties, layer continuity, and presence of hydrologic discontinuities/barriers (faults) or zones of enhanced vertical communication. A brief discussion of the various hydrologic tests that can be used to acquire detailed interflow and caprock characterization information is presented in Appendix E. 


\subsection{Summary/Conclusions}

Deeper CRBG interflow zones (i.e., within the Grande Ronde Basalt) in selected areas in the central Columbia Basin appear to be suitable for the subsurface storage of natural gas provided certain conditions are met. Based on available information, the central portion of the basin appears to be more favorable for potential gas storage than are areas near the basin margins. Characteristics favoring this general area include:

- Thickness. There is sufficient thickness of basalt for gas storage and high pressures. The total thickness of the basalt is greatest in the central Columbia Basin, exceeding $5 \mathrm{~km}$. Individual basalt flows also reach their greatest thickness, which provides additional caprock sealing thickness for natural gas storage.

- Closure. There are many anticlines (Yakima Fold Belt) that can provide closure for gas storage. This increases the likelihood of locating a suitable structure for closure or containment of injected gas.

- Tectonic stability. Earthquake activity is minimal. Typical earthquake activity is concentrated in swarms and in synclinal areas. Earthquakes rarely exceed magnitude 3. There is a long recurrence interval between large earthquakes (e.g., 10,000 yr for magnitude 7; 5,000 yr for magnitude 5).

- Groundwater quality and water rights. Groundwater quality in potential storage horizons is unsuitable for irrigation or domestic use (e.g., high fluoride content). The deeper Grande Ronde Basalt interflow zones, in particular, have water compositions that eliminate their use for domestic purposes, and therefore, there are minimal issues over waters rights.

- Low groundwater flow rates. Isotopic and hydrochemical data suggest the deep groundwater is very old with estimated flow rates of $<1$ to $2 \mathrm{~m} / \mathrm{yr}$. Dissolved gas in the groundwater would migrate advectively at very slow rates away from natural gas stored in this hydrogeologic regime without natural containment (i.e., structure closure).

- Large database. A large subsurface characterization database exists for the geology and hydrology, including individual basalt interflow zones within the central Columbia Basin. Studies over the years by DOE have provided regional geology and deep basalt and aquifer characterization data. These data allow preliminary site screening for areas with the greatest likelihood of vertical hydrologic isolation (caprock/containment). Other suitable areas outside the central Columbia Basin also exist; however, available hydrologic data are considerably less abundant, generally not flow specific (i.e., composite basalt flow information), and of shallower depth (i.e., $<800 \mathrm{~m}$ ).

- Regional groundwater flow separation. Several regionally observed stratigraphic horizons that separate groundwaters between the Grande Ronde Basalt and Wanapum Basalt (i.e., Vantage interbed horizon), and between the Wanapum Basalt and Saddle Mountains Basalt (i.e., Mabton interbed horizon) have been recognized as being operative within the central Columbia Basin. The presence 
of distinct groundwater flow systems provides evidence that natural seals exist for controlling vertical migration of natural gas stored within deep basalt interflow zones.

- Existing infrastructure. Gas pipelines currently run southeast to northwest through the center of the Yakima Fold Belt and along its southern boundary (along the Columbia Hills). In addition, a natural gas transmission line runs north to south across the Palouse subprovince. Several spur lines branch off these main trunk lines providing greater access to the central Columbia Basin.

- Existing natural gas field. The occurrence of a commercial gas field along the western margin of the Pasco Basin (on Rattlesnake Ridge) that was exploited until the 1940s, provides evidence that basalt interflow zones can serve as natural gas storage reservoirs. Other areas of natural gas occur in the Yakima Fold Belt indicating a broad area of the central Columbia Basin is capable of storing gas.

- Favorable land acquisition. Much land in the central Columbia Basin is already removed from the private sector. Development of a gas storage project on federal land would be consistent with the current energy strategy and would avoid condemnation suits often needed to acquire land from privately held interests.

A map summarizing the features described above is shown in Figure 7.1. This map shows areas of high and low potential for natural gas storage and areas of large uncertainty. Well data used for most of the area shown outside of the central Columbia Basin are based on irrigation or domestic water wells completed compositely in the Grande Ronde Basalt, for varying depths (median $300 \mathrm{~m}$ ). Depths for the same respective basalt units in the central Columbia Basin are $>600 \mathrm{~m}$. These uncertainties are elaborated below, as well as the data needs to reduce uncertainty.

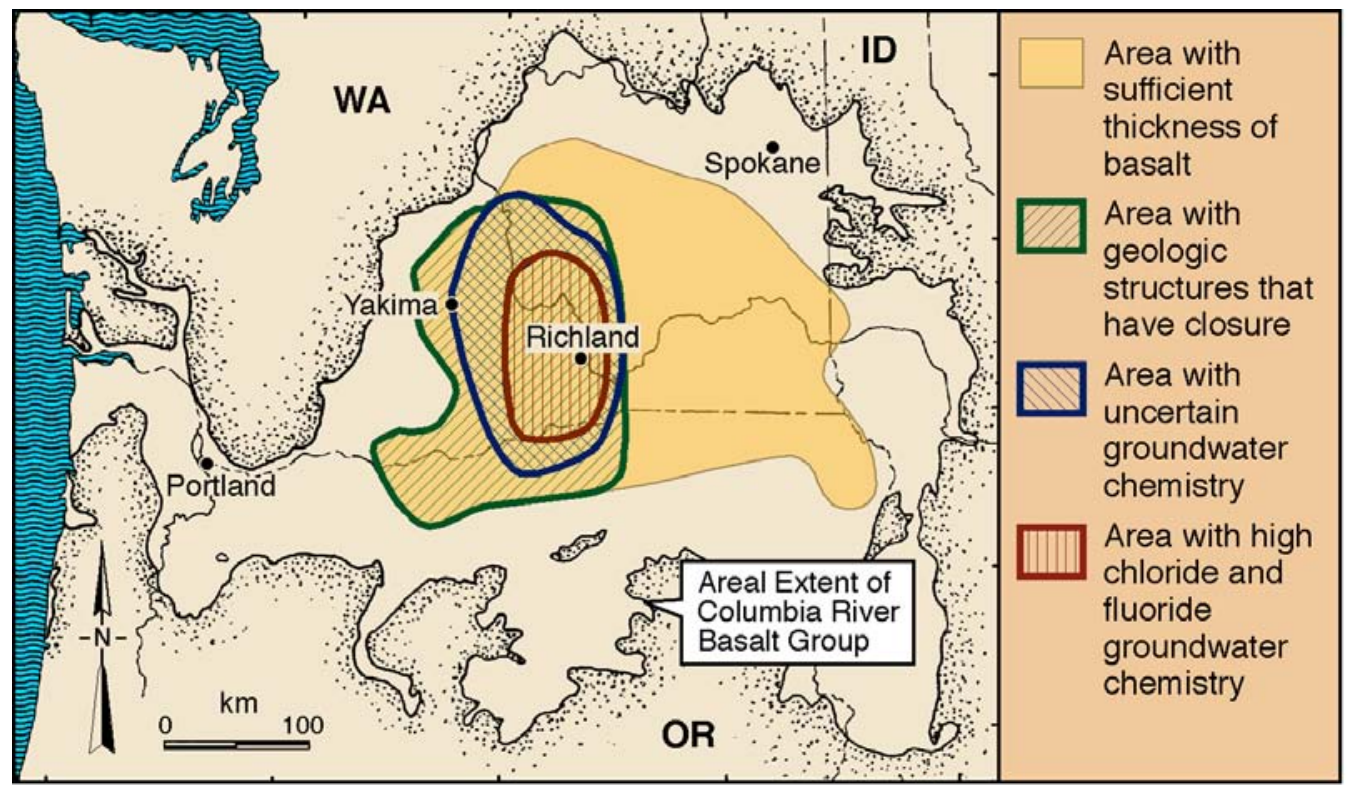

Figure 7.1. Map Showing Areas Comprising Favorable, Unfavorable, and Uncertain Areas for Natural Gas Storage in Columbia River Basalt Group Lava Flows 


\subsection{Constraints and Uncertainties}

\subsubsection{Water Chemistry}

The greater the depth, the higher the water temperature encountered in the basalt and, with the increased temperature comes increased basalt glass dissolution. The increased dissolved solids results in precipitation of solid phases as secondary minerals leaving sodium, chloride, and fluoride enriched in the fluid phase (Gephart et al. 1979; DOE 1988; Steinkampf and Hearn 1996).

The high chloride waters ( 300-400 mg/L) typically exhibit fluoride concentrations $>20 \mathrm{mg} / \mathrm{L}$, which greatly exceeds the drinking water standard of $4 \mathrm{mg} / \mathrm{L}$, rendering the water unsuitable for domestic use. If the occurrence of the high chloride Grande Ronde Basalt water is due to a depth-temperature effect (e.g., hydrolysis of volcanic glass) as it appears, then other areas in the Columbia Basin with high chloride-fluoride waters may exist that are favorable for gas storage (e.g., the anticlinal ridges to the north and northeast of the Pasco Basin). Unfortunately, there is very little, deep ( $>600 \mathrm{~m})$, groundwater data available for areas outside the Pasco Basin.

Additional hydrochemical data are needed to test the hypothesized, widespread occurrence of high chloride groundwaters at greater depths in the basin $(>600 \mathrm{~m})$. This requires collecting additional hydrochemical data that would be obtained from new (or revisiting existing), deep exploratory boreholes within the region.

\subsubsection{Lower Permeability/Porosity}

Detailed hydraulic testing results of individual basalt interflow zones commonly exhibited depth dependence at individual borehole sites in the Pasco Basin and in particular, the Grande Ronde Basalt versus Wanapum Basalt interflow zones (DOE 1988). Spane (1982) and DOE (1988) observed depthpermeability patterns that may be attributed to compaction (i.e., increasing effective stress) and secondary mineral precipitation. This permeability-depth dependence is also exhibited for basalt flow interior/ caprock intervals (Spane 1982). It should be noted that this is a general observation of depth-dependence and many exceptions (e.g., a deep, high-permeability interflow zone) occur. Secondary infraflow structures may counteract any decrease in permeability with depth.

The observed general decrease in permeability is believed to be associated with a reduction in porosity. This is probably the result of secondary mineral formation resulting from glass dissolution. As a general rule, a depth great enough to be in the high chloride zone is needed for restrictive water resource purposes, but not so deep that storage capacity may be adversely affected.

\subsubsection{Vertical Groundwater Flow}

Because of the location of the Columbia River within the regional groundwater flow system, general vertical (upward) groundwater flow discharge to the Columbia River would be expected. Although lateral and vertical hydraulic head distributions within the CRBG do not support the contention that the Columbia River forms a continuous discharge area for all groundwater within the basalt (e.g., see Spane 
1987; DOE 1988; Spane and Raymond 1993), for planning investigation programs it would be prudent to avoid areas in close proximity to major river drainages. In addition, areas in the vicinity of suspected high-angle normal faults or strike-slip faults (e.g., based on geologic mapping, surface geophysical surveys) also should be eliminated from consideration. Although faults generally form significant lateral groundwater barriers within the Columbia River basalts (e.g., Newcomb 1961; DOE 1988), they have been shown to provide localized enhanced zones for vertical hydraulic communication between basalt interflow zones (e.g., DOE 1988; Johnson et al. 1993). Detailed vertical hydrochemical profile data within these localized areas demonstrate the upward migration of chloride-, fluoride-, and heliumenriched waters from the underlying Grande Ronde Basalt that are indicative of enhanced vertical connectivity. Adjacent areas without cross-cutting, high-angle faults exhibit vertical isolation between the Grande Ronde Basalt and overlying basalt formations. The detailed dataset collected within the Pasco Basin may serve for the development of recognition criteria for avoiding unfavorable, cross-cutting, structural locations.

\subsubsection{Structural Closure}

In addition to effective porosity within candidate basalt interflow zones, the total storage capacity (useable volume) beneath an anticlinal ridge depends on the amount or degree of structural closure that exists within selected storage horizons at the projected reservoir depth. This may be difficult to assess based solely on surface relief relationships, i.e., the degree to which the surface relief is reflected at the anticipated gas storage depth $(\sim 1,000 \mathrm{~m})$ may be misleading. For example, there may be $500 \mathrm{~m}$ of vertical relief at the surface, but faulting at the storage target depth could significantly reduce closure. For viable natural gas storage within basalt interflows, at least $50 \mathrm{~m}$ of vertical relief is probably needed at the projected reservoir depth. Currently, the ratio of vertical relief at depth to relief at the surface is an uncertainty for many anticlines within the Columbia Basin.

\subsection{Alternative Uses}

Although this report concerns the storage of natural gas for commercial use, the data and methodology employed here have many applications beyond natural gas storage. There are a number of other national initiatives that could use the storage capacity within deep CRBG horizons. In addition to natural gas storage, reduction of greenhouse gases (oxides of nitrogen and carbon) by deep well injection of flue gases from gas-fired power plants may also be feasible in the Columbia Basin. In addition, other gases that could be used to generate energy (e.g., $\mathrm{H}_{2}$ ) could also use the methodology presented in this report. Many of the same considerations would apply for both flue gas disposal and natural gas storage. An important difference for this application, however, is that closure for the disposal site (critical for recovery natural gas stored) would not be an issue for flue gas disposal. Flue gas disposal, however, shares a similar program consideration pertaining to water resource and vertical isolation issues that are important for natural gas containment.

In addition to disposal in basalt formations, the sedimentary formations beneath the basalts may be a particularly attractive target horizon for flue gas disposal. Oil and gas exploration of this area during the 1980s used a conceptual model that considered the sub-basalt sediments as the storage/source reservoir, and the overlying basalt as the caprock. The same concept may be viable for disposal of flue gases and/or 
natural gas storage. Much of the area explored thus far (Shell and ARCO) is where the basalts are very thick (compositely). The great depth to underlying sedimentary formations would probably be impractical for natural gas storage projects; however, the area along the western perimeter of the basin, where the basalt thickness is $\leq 1,000 \mathrm{~m}$ would be in the practical reservoir depth range (Figure 7.1). Subsurface gas storage in these peripheral areas may be possible, provided favorable reservoir storage characteristics exist (i.e., closure, permeability/porosity, etc).

Laboratory studies of host rock-fluid reactivity under high pressure ( $>80 \mathrm{~atm})$ are needed to support flue gas disposal in either basalt or sub-basalt sediments. Possible reactions include basalt dissolution and release of iron II that in turn may precipitate as $\mathrm{FeCO}_{3}$ (siderite) or $\mathrm{CaCO}_{3}$. The kinetics of such reactions are important to assess the long-term viability of a disposal reservoir (e.g., eventual reduction in porosity due to precipitate formation). 


\subsection{References}

AERO. 1980. Final Report Multilevel Aeromagnetic Survey of the Hanford Site. BO35469, AERO Service for Rockwell Hanford Operations, Richland, Washington.

Anderson, J. L. 1987. Structural Geology and Ages of Deformation of a Portion of the Southwest Columbia Plateau, Washington and Oregon. Ph.D. Dissertation, University of Southern California, Los Angeles, California.

Argonaut. 1980. Tensor Magnetotelluric Surveys in the Area of Hanford, Washington, Fiscal Year 1979-80. Argonaut Enterprises, Richland, Washington.

Ault, T. D. 1981. "Geophysical Investigations of the Gable Mountain-Gable Butte Area." In Subsurface Geology of the Cold Creek Syncline, RHO-BWI-ST-14, eds. C. W. Myers and S. M. Price, pp. D1-D24. Rockwell Hanford Operations, Richland, Washington.

Baker, V. R., and D. Nummedal (eds.). 1979. The Channeled Scabland. "A Guide to the Geomorphology of the Columbia Basin, Washington," National Aeronautics and Space Administration, Washington, D.C.

Baker, V. R., B. N. Bjornstad, A. J. Busacca, K. R. Fecht, U. L. Moody, J. G. Rigby, D. F. Stradling, and A. M. Tallman. 1991. "Quaternary Geology of the Columbia Plateau." In Quaternary Nonglacial Geology; Conterminous U.S., ed. R. B. Morrison, Geological Society of America, Boulder, Colorado.

Bard, E., B. Hamelin, R. G. Fairbanks and A. Zindler. 1990. "Calibration of Carbon-14 Timescale Over the Past 30,000 Years Using Mass Spectrometric U-Th Ages from Barbados Corals." Nature 345:405-410.

Barsotti, A. T. 1986. Structural and Paleomagnetic Analysis of a Portion of Eastern Umtanum Ridge, South-Central Washington. Master of Science Thesis, Washington State University, Pullman, Washington.

Basaltic Volcanism Study Project. 1981. Basaltic Volcanism on the Terrestrial Planets, Pergamon Press, Inc., New York.

Beeson, M. H., T. L. Tolan, and J. L. Anderson. 1989. “The Columbia River Basalt Group in Western Oregon - Geologic Structures and Other Factors that Controlled Flow Emplacement Patterns," In Volcanism and Tectonism in the Columbia River Flood-Basalt Province, Special Paper 23, eds. S. P. Reidel and P. R. Hooper, pp. 223-240. Geological Society of America, Boulder, Colorado.

Beeson, M. H., K. R. Fecht, S. P. Reidel, and T. L. Tolan. 1985. "Regional Correlations Within the Frenchman Springs Member of the Columbia River Basalt Group: New Insights into the Middle Miocene Tectonics of Northwest Oregon." Oregon Geology 47(8):87-96. 
Bentley, R. D. 1977. "Stratigraphy of the Yakima Basalts and Structural Evolution of the Yakima Ridges in the Western Columbia Plateau." In Geology Excursions in the Pacific Northwest, eds. E. H. Brown and R. C. Ellis, pp. 339-389. Western Washington University, Bellingham, Washington.

Bentley, R. D., and N. P. Campbell. 1983. Geologic Map of the Yakima Quadrangle, Washington, Division of Geology and Earth Resources Geologic Map GM-29, 1 sheet, scale 1:62,500, Washington Department of Natural Resources, Olympia, Washington.

Bentley, R. D., J. L. Anderson, N. P. Campbell, and D. A. Swanson. 1980. Stratigraphy and Structure of the Yakima Reservation, with Emphasis on the Columbia River Basalt Group, Open-File Report 80-200, U.S. Geological Survey, Washington, D.C.

Berkman, E. 1984. Reprocessing and Interpretation-Seismic Reflection Data-Hanford Site, Pasco Basin, South Central Washington. SD-BWI-TI-177, Rockwell Hanford Operations, Richland, Washington.

Berkman, E., A. Orange, K. A. Bergstrom, and T. H. Mitchell. 1986. Interpretation of Magnetotelluric Data, Rattlesnake Mountain, Pasco Basin, Washington. SD-BWI-TI-354, Rockwell Hanford Operations, Richland, Washington.

Berkman, E. A., A. Orange, K. A. Bergstrom, and T. H. Mitchell. 1987. Interpretation of Magnetotelluric Data, Rattlesnake Mountain, Pasco Basin, Washington. SD-BWI-TI-354, Rockwell Hanford Operations, Richland, Washington.

Birdwell. 1979. Seismic Velocity Survey, Rockwell Hanford Operations ESG, DC-2, -3, -4, -6, and -7, Benton County, Washington, B040899. Birdwell Division of Seismograph Service Corporation for Rockwell Hanford Operations, Richland, Washington.

Bonini, W. E., D. W. Hughes, and Z. F. Danes. 1974. Complete Bouguer Gravity Anomaly Map of Washington. Washington State Department of Natural Resources, Division of Geology and Earth Resources, Olympia, Washington.

Bourdet, D., T. M. Whittle, A. A. Douglas, and Y. M. Pirard. 1983. "A New Set of Type Curves Simplifies Well Test Analysis.” World Oil, May:95-106.

Bourdet, D., A. Alagoa, J. A. Ayoub, and Y. M. Pirard. 1984. "New Method Enhances Well Test Interpretations." World Oil, September:37-44.

Bourdet, D., J. A. Ayoub, and Y. M. Pirard. 1989. Use of Pressure Derivative in Well-Test Interpretation. SPE Formation Evaluation, Society of Petroleum Engineers, Richardson, Texas. 
Bredehoeft, J. D., and S. S. Papadopulos. 1980. "A Method for Determining the Hydraulic Properties of Tight Formations." Water Resources Research 16(1):233-238.

Bretz, J. H. 1923. "The Channeled Scabland of the Columbia Plateau.” Journal of Geology 31:617-649.

Butler, J. J., Jr. 1990. "The Role of Pumping Tests in Site Characterization: Some Theoretical Considerations." Ground Water 28(3):394-402.

Butler J. J., Jr. 1998. The Design, Performance, and Analysis of Slug Tests. Lewis Publishers, CRC Press, Boca Raton, Florida.

Butler, J. J., Jr., G. C. Bohling, Z. H. Hyder, and C. D. McElwee. 1994. "The Use of Slug Tests to Describe Vertical Variations in Hydraulic Conductivity." Journal of Hydrology 156:137-162.

Cady, J. W. 1980. "Gravity Highs and Crustal Structure, Omineca Crystalline Belt, Northeastern Washington, and Southeastern British Columbia." Geology 8(7):328-332.

Camp, V. E., and M. E. Ross. 2000. "Mapping the Steens-Columbia River Basalt Connection: Iimplications for the Extent, Volume, and Magma Supply Rate of CRB Volcanism." In Abstracts with Programs - Geological Society of America 32:7.

Campbell, N. P. 1983. "Correlation of Late Cenozoic Gravel Deposits Along the Yakima River Drainage from Ellensburg to Richland, Washington.” Northwest Science 57(3):179-193.

Campbell, N. P. 1988. Structural Geology Along the Northwestern Columbia River Basalt Margin, Washington. Washington State Department of Natural Resources, Division of Geology and Earth Resources, Olympia, Washington.

Campbell, N. P. 1989. "Structural and Stratigraphic Interpretation of the Rocks Under the Yakima Fold Belt Based on Recent Surface Mapping and Well Data." In Volcanism and Tectonism in the Columbia River Flood-Basalt Province, eds. S. P. Reidel and P. R. Hooper, Special Paper 239, Geological Society of America, Boulder, Colorado.

Campbell, N. P., and D. L. Banning. 1985. Stratigraphy and Hydrocarbon Potential of the Northwestern Columbia Basin Based on Recent Drilling Activities. SD-BWI-TI-265, Rockwell Hanford Operations, Richland, Washington.

Campbell, N. P., and R. D. Bentley. 1981. "Late Quaternary Deformation of the Toppenish Ridge Uplift in South-Central Washington.” Geology 9(11):519-524.

Campbell, N. P., and S. P. Reidel. 1991. "Geologic Guide for State Routes 240 and 243 in South-Central Washington.” Washington Geology 19(3):3-17. 
Campbell, N. P., and S. P. Reidel. 1994. "Further Exploration for Gas Warranted in Columbia Basin." Oil and Gas Journal 92(18):127-130, 132.

Catchings, R. D., and W. D. Moody. 1988. "Crustal Structure of the Columbia Plateau - Evidence for Continental Rifting." Journal of Geophysical Research 19(B1):459-474.

Cline, D. R. 1984. "Ground-Water Levels and Pumpage in East-Central Washington, Including OdessaLind Area, 1967-1981.” Water-Supply Bulletin No. 55, Washington State Department of Ecology, Olympia, Washington.

Cochran, M. P. 1981a. "Geophysical Investigations in the West Gable Butte Area." In Subsurface Geology of the Cold Creek Syncline, eds. C. W. Myers and S. M. Price, RHO-BWI-ST-14, Rockwell Hanford Operations, Richland, Washington.

Cochran, M. P. 1981b. Ground Geophysical Investigations of a Segment of the Rattlesnake Hills Lineament. RHO-BWI-SA-155A, Rockwell Hanford Operations, Richland, Washington.

Cochran, M. P. 1982. Geophysical Investigation of Eastern Yakima Ridge, South-Central Washington. RHO-BW-SA-214 P, Rockwell Hanford Operations, Richland, Washington.

Cooper, H. H., Jr., and C. E. Jacob. 1946. "A Generalized Graphical Method for Evaluating Formation Constants and Summarizing Well-Field History." Transactions of the American Geophysical Union 27(4):526-534.

Cooper, H. H., J. D. Bredehoeft, and I. S. Papadopulos. 1967. "Response of a Finite-Diameter Well to an Instantaneous Charge of Water." Water Resources Research 3(1):263-269.

Crosson, R. S. 1972. "Small Earthquakes, Structure, and Tectonics of the Puget Sound Region." Seismological Society of America Bulletin 62(5):1133-1171.

Czimer, W. J., and R. C. Edwards. 1978. Magnetotelluric Survey on the Hanford Site and Adjacent Pasco Basin Area, Hanford, Washington. RHO-BWI-C-28, Rockwell Hanford Operations, Richland, Washington.

Danes, Z. F. 1969. “Gravity Results in Western Washington.” EOS, Transactions 50:548-550.

Davis, G. A. 1977. Tectonic Evolution of the Pacific Northwest Precambrian to Present, Preliminary Safety Analysis Report. Amendment 23, Subappendix 2R C, WPPSS Nuclear Project No. 2, Richland, Washington.

Davis, G. A. 1981. "Late Cenozoic Tectonics of the Pacific Northwest with Special Reference to the Columbia Plateau." In Final Safety Analysis Report, WNP-2, Appendix 2.5 N, Washington Public Power Supply System, Richland, Washington. 
Dehlinger, P., E. F. Chiburis, and M. M. Collver. 1965. "Local Travel Time Curves and their Geologic Implications for the Pacific Northwest States." Bulletin of the Seismological Society of America 50(3):587-607.

Diery, H. D. 1967. Stratigraphy and Structure of the Yakima Canyon Between Roza Gap and Kittitas Valley, Central Washington. University of Washington, Seattle, Washington.

Dresser Atlas (Dresser). 1985. Report of Borehole Seismic Analysis for Rockwell International RRL-5, -7, -8, -10, and -16, Benton County, Washington, B066327, B066329, B066331, B066333, and B066335. Dresser Atlas for Rockwell Hanford Operations, Richland, Washington.

Dodson, A., B. Mack Kennedy, and D. J. DePaolo. 1997. "Helium and Neon Isotopes in the Imnaha Basalt, Columbia River Basalt Group: Evidence for a Yellowstone Plume Source." Earth and Planetary Science Letters 150:443-451.

Drost, W., D. Klotz, A. Koch, H. Moser, F. Neumaier, and W. Rauert. 1968. "Point Dilution Methods of Investigating Groundwater Flow by Means of Radioisotopes." Water Resources Research 4(1):125-146.

Drost, B. W., K. J. Whiteman, and J. B. Gonthier. 1990. Geologic Framework of the Columbia Plateau Aquifer System, Washington, Oregon, and Idaho. U.S. Geological Survey, Water-Resources Investigations Report 87-4238, Washington, D.C.

Earlougher, R. C., Jr. 1977. Advances in Well Test Analysis. Monograph Vol. 5, Society Petroleum Engineers, Richardson, Texas.

Early, T. O., S. H. Hall, and V. G. Johnson. 1988. "Tritium, Carbon-14, and Iodine-129 as Indicators for Localized Vertical Recharge Along an Anticline in the Columbia River Basalts Using a Decay-Corrected Mixing Model." In Proceedings of the Ground Water Geochemistry Conference, National Water Well Association, Dublin, Ohio.

Early, T. O., G. D. Spice, and M. D. Mitchell. 1986. A Hydrochemical Data Base for the Hanford Site, Washington. SD-BWIP-DP-061, Rockwell Hanford Operations, Richland, Washington.

Eaton, G. P., R. R. Wahl, H. J. Prostka, D. R. Mabey, and D. R. Kleinkopf. 1978. "Regional Gravity and Tectonic Patterns, Their Relation to Late Cenozoic Epeirogeny and Lateral Spreading in the Western Cordillera." In Cenozoic Tectonics and Regional Geophysics of the Western Cordillera, Memoir 152, eds. R. B. Smith and G. P. Eaton, Geological Society of America, Boulder, Colorado.

Ehlig-Economides, C. 1988. "Use of the Pressure Derivative for Diagnosing Pressure-Transient Behavior." Journal of Petroleum Technology, October:1280-1282.

Fecht, K. R., and J. T. Lillie. 1982. A Catalog of Borehole Lithologic Logs from the 600 Area, Hanford Site. RHO-LD-158, Rockwell Hanford Operations, Richland, Washington. 
Fecht, K. R., S. P. Reidel, and A. M. Tallman. 1987. "Paleodrainage of the Columbia River System on the Columbia Plateau of Washington State-A Summary." In Selected Papers on the Geology of Washington, ed. J. E. Schuster, Division of Geology and Earth Resources, Bulletin 77, p 219-248, Washington State Department of Natural Resources, Olympia, Washington.

Fenneman, N. M. 1931. Physiography of the Western United States. McGraw-Hill Book Co., New York.

Finn, C., W. M. Phillips, and D. L. Williams. 1984. Gravity Maps of the State of Washington and Adjacent Areas, Scale 1:250,000. Open File Report 84-416, U.S. Geological Survey, Washington, D.C.

Fox, T. P., and S. P. Reidel. 1987. "Stratigraphy of the Standard Kirkpatrick No. 1, Gilliam County, Oregon: New Insight Into Tertiary Tectonism of the Blue Mountains.” Oregon Geology 49(2):15-22.

Frizzell, V. A., Jr., R. W. Tabor, D. B. Booth, K. M. Ort, and R. B. Waitt, Jr. 1984. Preliminary Geologic Map of the Snoqualmie Pass 1:100,000 Quadrangle, Washington. U.S. Geological Survey Open-File Report 84-693, 43 p., 1 plate, scale 1:100,000, USGS, Tacoma, Washington.

Gardner, J. N., M. G. Snow, and K. R. Fecht. 1981. Geology of the Wallula Gap Area, Washington. RHO-BWI-LD-9, Rockwell Hanford Operations, Richland, Washington.

Gelhar, L. 1982. Analysis of Two-Well Tracer Tests With a Pulse Input. RHO-BW-CR-131, Rockwell Hanford Operations, Richland, Washington.

Geotronics. 1981. Magnetotelluric Quality Control Study and Calibration Survey for Rockwell. SD-BWI-TI-178, Rockwell Hanford Operations, Richland, Washington.

Geotronics. 1982. Magnetotelluric Survey in the Northern Columbia River Plateau. Proprietary survey data acquired by Rockwell Hanford Operations from Geotronics for BWIP. BRMC \#B0/88876.

Geotronics. 1984. Magnetotelluric Survey in the Hanford Area. SD-BWI-TI-173, Rev. 0, Rockwell Hanford Operations, Richland, Washington.

Gephart, R. E., R. C. Arnet, R. G. Baca, L. S. Leonhart, and F. A. Spane, Jr. 1979. Hydrologic Studies Within the Columbia Plateau, Washington: An Integration of Current Knowledge. RHO-BWI-ST-5, Rockwell Hanford Operations, Richland, Washington.

Gephart, R. E., S. M. Price, R. L. Jackson, and C. W. Myers. 1983. "Geohydrologic Factors and Current Concepts Relevant to Characterization of a Potential Nuclear Waste Repository Site in Columbia River Basalt, Hanford Site, Washington." In Scientific Basis for Nuclear Waste Management VII, Proceedings of the Materials Research Society Symposium, Boston, Massachusetts; also RHO-BW-SA-326 P, Rockwell Hanford Operations, Richland, Washington. 
Glass, C. E., and D. B. Slemmons. 1977. "Imagery and Topographic Interpretation of Geologic Structures in Central Washington." In Preliminary Safety Analysis Report, WNP-1/4, Amendment 23, Subappendix 2RF, pp. 2R F-1 through F-19, Washington Public Power Supply System, Richland, Washington.

Glover, D. W. 1985. Crustal Structure of the Columbia Basin, Washington, from Borehole and Refraction Data. M.S. Thesis, University of Washington, Seattle, Washington.

Goff, F. E. 1981. Preliminary Geology of Eastern Umtanum Ridge, South-Central Washington. RHO-BWI-C-21, Rockwell Hanford Operations, Richland, Washington.

Graham, D. L., and V. G. Johnson. 1991. "Effects of Fluid Rotary Drilling on Hydrochemical Sampling Results from Deep Boreholes in Fractured Columbia River Basalt Groundwaters.” Journal of Hydrology 128:171-212.

Grolier, M. J., and J. W. Bingham. 1971. Geologic Map and Sections of Parts of Grant, Adams, and Franklin Counties, Washington. Miscellaneous Geologic Investigation Series, Map I-589, U.S. Geological Survey, Tacoma, Washington.

Güven, O., R. W. Falta, F. J. Molz, and J. G. Melville. 1985. “Analysis Interpretation of Single-Well Tracer Tests in Stratified Aquifers.” Water Resources Research 21(5):676-684.

Hagood, M. C. 1986. Structure and Evolution of the Horse Heaven Hills in South-Central Washington. RHO-BWI-SA-344 P, Rockwell Hanford Operations, Richland, Washington.

Halevy, E., H. Moser, O. Zellhofer, and A. Zuber. 1966. "Borehole Dilution Techniques - A Critical Review." In Isotopes in Hydrology, International Atomic Energy Agency, Vienna, Austria.

Hall, S. H. 1993. "Single Well Tracer Tests in Aquifer Characterization." Ground Water Monitoring \& Remediation 13(2):118-124.

Hall, S. H., S. P. Luttrell, and W. E. Cronin. 1991. "A Method for Estimating Effective Porosity and Ground-Water Velocity." Ground Water 29(2):171-174.

Hansen, A. J., Jr., J. J. Vacaro, and H. H. Bauer. 1994. "Ground-Water Flow Simulation of the Columbia Plateau Regional Aquifer System, Washington, Oregon, and Idaho.” U.S. Geological Survey, WaterResources Investigation Report, 91-4187.

Hantush, M. S. 1964. "Hydraulics of Wells." In ed. V. T. Chow, Advances in Hydroscience 1:282-433. 
Hartshorn, D. C., S. Reidel, A. C. Rohay and M. M. Valenta. 2001. Annual Hanford Seismic Report for Fiscal Year 2001. PNNL-11557-19, Pacific Northwest National Laboratory, Richland, Washington.

Hearn, P. P., W. C. Steinkampf, G. C. Borleson, and B. W. Drost. 1985. Geochemical Controls of Dissolved Sodium in Basalt Aquifers of the Columbia Plateau, Washington. U.S. Geological Survey, Water-Resources Investigations Report 84-4304, USGS, Tacoma, Washington.

Heineck, R. L., and H. G. Beggs. 1978. Evaluation of Seismic Reflection Surveying in the Hanford Site, Benton County, Washington. RHO-BWI-C-20, Rockwell Hanford Operations, Richland, Washington.

Hill, D. P. 1972. "Crustal and Upper Mantle Structure of the Columbia Plateau from Long Range Seismic-Refraction Measurements.” Geological Society of America Bulletin 83:1639-1648.

Holmes, G. E., and T. H. Mitchell. 1981. "Seismic Reflection and Multi-Level Aeromagnetic Surveys in Cold Creek Syncline Area." In Subsurface Geology of the Cold Creek Syncline, eds. C. W. Myers and S. M. Price, RHO-BWI-ST-14, Rockwell Hanford Operations, Richland, Washington.

Huntley, D., R. Nommensen, and D. Steffey. 1992. "The Use of Specific Capacity to Assess Transmissivity in Fractured-Rock Aquifers.” Ground Water 30(3):396-402.

Huyakorn, P. S., P. F. Andersen, F. J. Molz, O. Güven, and J. G. Melville. 1986. "Simulations of TwoWell Tracer Tests in Stratified Aquifers at the Chalk River and the Mobile Sites." Water Resources Research 22(7):1016-1030.

Jageler, A. H. 1976. "Improved Hydrocarbon Reservoir Evaluation Through Use of BoreholeGravimeter Data.” Journal of Petroleum Technology 28(6):709-718.

Jacob, C. E. 1940. "On the Flow of Water in an Elastic Artesian Aquifer." Transactions of the American Geophysical Union 14:446-460.

Jacob, C. E., and S. W. Lohman. 1952. "Non-Steady Flow to a Well of Constant Drawdown in an Extensive Aquifer." Transact American Geophysical Union 33(4):559-569.

Jarchow, C. M. 1991. Investigations of Magmatic Underplating Beneath the Northwestern Basin and Range Province, and Seismic Data Acquisition and Tectonic Problems of the Columbia Plateau,

Washington, and the Nature of the Mohorovic 'ic' Discontinuity Worldwide. Ph. D. Dissertation, Stanford University, Stanford, California.

Javandel, I., and P. A. Witherspoon. 1969. "A Method of Analyzing Transient Fluid Flow in Multilayered Aquifers." Water Resources Research 5:856-869. 
Johnson, S. H., and R. W. Couch. 1970. "Crustal Structure of the North Cascade Mountains of Washington and British Columbia from Seismic Refraction Measurements." Bulletin of the Seismological Society of America 60(4):1259-1269.

Johnson, V. G, D. L. Graham, and S. P. Reidel. 1993. "Methane in Columbia River Basalt Aquifers: Isotopic and Geohydrologic Evidence for a Deep Coal-Bed Gas Source in the Columbia Basin, Washington.” American Association of Petroleum Geologists Bulletin 77(7):1192-1207.

Kabala, Z. J. 1994. "Measuring Distributions of Hydraulic Conductivity and Specific Storativity by the Double Flowmeter Test. Water Resource Research 30(3):685-690.

Kearl, P. M., J. J. Dexter, and J. E. Price. 1988. Procedures, Analysis, and Comparison of Groundwater Velocity Measurement Methods for Unconfined Aquifers. UNC/GJ-TMC-3, UNC Geotech, Grand Junction, Colorado.

Keroher, G. C. 1966. "Lexicon of Geologic Names of the United States 1936-1960." U.S. Geological Survey Bulletin 1200:4341.

Kienle, C. F., R. C. Newcomb, and R. J. Deacon. 1973. Geologic Studies of Columbia River Basalt Structures and Age of Deformation The Dalles-Umatilla Region, Washington and Oregon. Letter Report to Portland General Electric Company from Shannon \& Wilson, Inc., Portland, Oregon.

Kienle, C. F., R. D. Bentley, and J. L. Anderson. 1977. "Geologic Reconnaissance of the Cle ElumWallula Lineament and Related Structures." In Preliminary Safety Analysis Report, Amendment 23, Vol. 2A, Subappendix 2R D, Shannon and Wilson, Inc. for Washington Public Power Supply System, Richland, Washington.

Kilty, K. T. 1983. "Werner Deconvolution of Profile Potential Field Data.” Geophysics 48(2):234-237.

Kim, K., S. A. Dischler, J. R. Aggson, and M. P. Hardy. 1986. The State of In Situ Stresses Determined by Hydraulic Fracturing at the Hanford Site. RHO-BW-ST-73 P, Rockwell Hanford Operations, Richland, Washington.

Konicek, D. L. 1975. "Geophysical Survey in South-Central Washington.” Northwest Science 49(2):106-117.

Kunk, J. R. 1981. "Geophysical Investigations in the Southwestern Cold Creek Syncline." In Subsurface Geology of the Cold Creek Syncline, RHO-BWI-ST-14, Appendix C, Rockwell Hanford Operations, Richland, Washington.

Kunk, J. R. 1986. Seismic Reflection Data. B062650, DAP No. 03-00035, Walker Geophysical Company for Rockwell Hanford Operations, Richland, Washington. 
Kunk, J. R., and T. D. Ault. 1986. Preliminary Analysis of Gravity and Magnetic Data in the Reference Repository Location. SD-BWI-TI, Rockwell Hanford Operations, Richland, Washington.

Leap D. I., and P. G. Kaplan. 1988. "A single-well tracing method for estimating regional advective velocity in a confined aquifer: Theory and preliminary laboratory verification." Water Resources Research 24(7):993-998.

Leonhart, L. S., R. L. Jackson, D. L. Graham, G. M. Thompson, and L. W. Gelhar. 1982. Groundwater Flow and Transport Characteristics of Flood Basalts as Determined from Tracer Experiments.

RHO-BWI-SA-220 P, Rockwell Hanford Operations, Richland, Washington.

Leonhart, L. S. R. L. Jackson, D. L. Graham, L. W. Gelhar, and G. M. Thompson. 1985. "Analysis and Interpretation of a Recirculating Tracer Experiment Performed in a Deep Basalt Flow Top." Bulletin of the Association of Engineering Geologists 23(3):259-274.

Lindberg, J. W. 1986. Width and Infilling of Fractures in Four Grande Ronde Basalt Flows Beneath the Reference Repository Location. SD-BWI-TI-282, Rockwell Hanford Operations, Richland, Washington.

Lindsey, K. A. 1991a. Revised Stratigraphy for the Ringold Formation, Hanford Site, South-Central Washington. WHC-SD-EN-EE-004 Rev. 0, Westinghouse Hanford Company, Richland, Washington.

Lindsey, K. A. 1991b. Geologic Setting of the 200 West Area: An Update. WHC-SD-EN-TI-008, Rev. 0, Westinghouse Hanford Company, Richland, Washington.

Long, P. E. 1978. Characterization and Recognition of Intraflow Structures, Grande Ronde Basalt. RHO-BWI-LD-10, Rockwell Hanford Operations, Richland, Washington.

Loo, W. W., R. C. Arnett, L. S. Leonhart, S. P. Luttrell, I. S. Wang, and W. R. McSpadden. 1984. Effective Porosities of Basalt: A Technical Basis for Values and Probability Distributions Used in Preliminary Performance Assessments. SD-BWI-TI-254, Rockwell Hanford Operations, Richland, Washington.

McCollom, R. L., and R. S. Crosson. 1975. "An Array Study of Mantle Velocity in Washington State." Bulletin of the Seismological Society of America 65(2):467-482.

Mayhew, M. A. 1982a. “An Equivalent Layer Magnetization Model for the United States Derived from Satellite Altitude Magnetic Anomalies.” Journal of Geophysical Research 87(B6):4837-4845.

Mayhew, M. A. 1982b. “Application of Satellite Magnetic Anomaly Data to Curie Isotherm Mapping." Journal of Geophysical Research 87(B6):4846-4854.

Mayhew, M. A. 1985. "Curie Isotherm Surfaces Inferred from High-Altitude Magnetic Anomaly Data." Journal of Geophysical Research 90(B3):2647-2654. 
Mayhew, M. A., and S. C. Galliher. 1982. "An Equivalent Layer Magnetization Model for the United States Derived from Magsat Data." Geophysical Research Letters 9(4):311-313.

Mazor, E. F., C. Jaff, J. Fluck and J. D. Dubois. 1986. "Tritium Corrected C-14 and Atmospheric Noble Gas Corrected He-4 Applied to Deduce Ages of Mixed Groundwaters: Examples from the Baden Region, Switzerland." Geochm. Cosmochimica. Acta 50:1611-1618.

Meier, P. M., J. Carrera, and X. Sanchez-Vila. 1999. "A Numerical Study on the Relationship Between Transmissivity and Specific Capacity in Heterogeneous Aquifers." Ground Water 37(4):611-617.

Meints, J. P. 1986. Statistical Characterization of Fractures in the Museum and Rocky Coulee Flows of the Grande Ronde Formation, Columbia River Basalts. M.S. Thesis, Washington State University, Pullman, Washington.

Mitchell, T. H., and K. A. Bergstrom. 1983. "Pre-Columbia River Basalt Group Stratigraphy and Structure in the Central Pasco Basin." In Preliminary Interpretation of the Tectonic Stability of the Reference Repository Location, Cold Creek Syncline, Hanford Site, eds. J. A. Caggiano and D.W. Duncan, RHO-BWI-ST-19 P, Rockwell Hanford Operations, Richland, Washington.

Mitchell, T. H., and M. E. Odegard. 1984. "Sedimentary Structure in the BWIP Reference Repository Location from Seismic Refraction and Vertical Seismic Profile Surveys.” EOS 65:1014.

Moak, D. J. 1981. "Borehole Geologic Studies." In Subsurface Geology of the Cold Creek Syncline, eds. C. W. Myers and S. M. Price, RHO-BWI-ST-14, Rockwell Hanford Operations, Richland, Washington.

Moak, D. J., and T. M. Wintczak. 1980. Near-Surface Test Facility Phase I Geologic Site Characterization Report. RHO-BWI-ST-8, Rockwell Hanford Operations, Richland, Washington.

Moench, A. F., and P. A. Hsieh. 1985. "Analysis of Slug Test Data in a Well with Finite Thickness Skin." In Proceedings of the $17^{\text {th }}$ International Conference of the Association of Hydrogeologists, Kenilworth, United Kingdom.

Mohl, G. B., and R. L. Thiessen. 1985. "A Study of Cratonic Margin in Eastern Washington as Defined by Gravity Measurements." EOS 66:26.

Molz, F. J., R. H. Morin, A. E. Hess, J. G. Melville, and O. Güven. 1989. “The Impeller Meter for Measuring Aquifer Permeability Variations: Evaluation and Comparison With Other Tests." Water Resources Research 25(7):1677-1683.

Molz, F. J., O. Güven, J. G. Melville, R. D. Crocker, and K. T. Matteson. 1986. "Performance, Analysis, and Simulation of a Two-Well Tracer Test at the Mobile Site." Water Resources Research 22(7):10311037. 
Molz, F. J., O. Güven, J. G. Melville, J. S. Nohrstedt, and J. K. Overholtzer. 1988. "Forced-Gradient Tracer Tests and Inferred Hydraulic Conductivity Distributions at the Mobile Site." Ground Water 26(5):570-579.

Myers, C. W., and S. M. Price (eds.). 1981. "Bedrock Structure of the Cold Creek Syncline Area." In Subsurface Geology of the Cold Creek Syncline. RHO-BWI-ST-14, Rockwell Hanford Operations, Richland, Washington.

Myers, C. W., S. M. Price, J. A. Caggiano, M. P. Cochran, W. H. Czimer, N. J. Davidson, R. C. Edwards, K. R. Fecht, G. E. Holmes, M. G. Jones, J. R. Kunk, R. D. Landon, R. K. Ledgerwood, J. T. Lillie, P. E. Long, T. H. Mitchell, E. H. Price, S. P. Reidel, and A. M. Tallman. 1979. Geologic Studies of the Columbia Plateau: A Status Report. RHO-BWI-ST-4, Rockwell Hanford Operations, Richland, Washington.

Neuman, S. P. 1975. "Analysis of Pumping Test Data from Anisotropic Unconfined Aquifers Considering Delayed Gravity Response." Water Resources Research 11(2):329-342.

Neuman, S. P., and P. A. Witherspoon. 1972. "Field Determination of the Hydraulic Properties of Leaky Multiple Aquifer Systems.” Water Resources Research, 8(5):1284-1298.

Neuzil, C. E., and J. D. Bredehoeft. 1981. "Measurement of In-Situ Hydraulic Conductivity in the Cretaceous Pierre Shale." In Proceedings of the Third Invitational Well-Testing Symposium "Well-Testing in Low Permeability Environments," pp. 96-102, Lawrence Berkeley Laboratory, Berkeley, California.

Neuzil, C. E. 1982. "On Conducting the Modified 'Slug Test' in Tight Formations." Water Resources Research 18(2):439-441.

Newcomb, R. C. 1961. Storage of Ground Water Behind Subsurface Dams in the Columbia River Basalt Washington, Oregon, and Idaho, U.S. Geological Survey Professional Paper 383-A, USGS, Tacoma, Washington.

Newcomb, R. C. 1969. Effect of Tectonic Structure on the Occurrence of Groundwater in the Basalt of the Columbia River Group of The Dalles Area Oregon and Washington. Professional Paper 383-C, U.S. Geological Survey, Washington, D.C.

Newcomb, R. C. 1970. Tectonic Structure of the Main Part of the Basalt of the Columbia River Group, Washington, Oregon, and Idaho. Miscellaneous Geological Investigations Map I-587, U.S. Geological Survey, Washington, D.C.

Newcomb, R. C. 1971. Geologic Map of the Proposed Paterson Ridge Pumped-Storage Reservoir, South-Central Washington. U.S. Geological Survey Miscellaneous Geologic Investigation I-653.

Novakowski, K. S. 1989. “Analysis of Pulse Interference Tests.” Water Resources Research 25(11):2377-2387. 
Odegard, M. E., and T. H. Mitchell. 1987. Seismic Velocity Structure in the BWIP Reference Repository Location from Seismic Refraction and Vertical Seismic Profiling Data. SD-BWI-TI-359, Westinghouse Hanford Company, Richland, Washington.

Orange, A., and E. Berkman. 1985. Interpretation of Magnetotelluric Data, Pasco Basin, South-Central Washington. SD-BWI-TI-233, Westinghouse Hanford Company, Richland, Washington.

Paillet, F. L. 1985. Acoustic-Televiewer and Acoustic-Waveform Logs Used to Characterize Deeply Buried Basalt Flows, Hanford Site, Benton County, Washington. Open-File Report 85-419, U.S. Geological Survey, Washington, D.C.

Pailett, F. L., and K. Kim. 1987. "Character and Distribution of Borehole Breakouts and Their Relationship to In Situ Stresses in Deep Columbia River Basalt.” Journal of Geophysical Research 92(87):6223-6234.

Phoenix Geophysics (Phoenix). 1983. Eastern Columbia River Plateau Magnetotelluric Survey. Proprietary Data, Phoenix Geophysics, Scarborough, Ontario, Canada.

Pickens, J. F., G. E. Grisak, J. D. Avis, D. W. Belanger, and M. Thury. 1987. "Analysis and Interpretation of Borehole Hydraulic Tests in Deep Boreholes. Principals, Model Development, and Applications." Water Resources Research 23(7):1341-1375.

PNNL. 2001. Annual Hanford Seismic Report for Fiscal Year 2001. PNNL-11557-19, Pacific Northwest National Laboratory, Richland, Washington.

Price, E. H. 1981. "Distribution of Strain Features Within Selected Yakima Fold Structures and Extrapolation of Their Nature into the Cold Creek Syncline Area." In Subsurface Geology of the Cold Creek Syncline, eds. C. W. Myers and S. M. Price, RHO-BWI-ST-14, Rockwell Hanford Operations, Richland, Washington.

Price, E. H. 1982. Structural Geometry, Strain Distribution, and Tectonic Evolution of Umtanum Ridge at Priest Rapids, and a Comparison with Other Selected Localities within the Yakima Fold Structures, South-Central Washington. RHO-BWI-SA-138, Rockwell Hanford Operations, Richland, Washington.

Price, E. H., and A. J. Watkinson. 1989. "Structural Geometry and Strain Distribution within Umtanum Ridge, South-Central, Washington, and its Tectonic Significance." In Volcanism and Tectonism on the Columbia Plateau, eds. S. P. Reidel and P. R. Hooper, Special Paper 239, pp. 265-282, Geological Society of America, Boulder, Colorado.

Prieto, C., C. Perkins, and E. Berkman. 1985. "Columbia River Basalt Plateau, An Integrated Approach to Interpretation of Basalt Covered Area." Geophysics 50(12):2709-2719. 
Puget Sound Power and Light (PSPL). 1982. Skagit/Hanford Nuclear Project, Preliminary Safety Analysis Report. Vol. 4, App. 20, Amendment 23, Puget Sound Power and Light Co., Bellevue, Washington.

Raisz, E. 1945. “The Olympic-Wallowa-Lineament.” American Journal of Science 243-A:479-485.

Rasmussen, T. C., and L. A. Crawford. 1997. "Identifying and Removing Barometric Pressure Effects in Confined and Unconfined Aquifers." Ground Water 35(3):502-511.

Razak, M., and D. Huntley. 1991. "Assessing Transmissivity From Specific Capacity in a Large and Heterogeneous Alluvial Aquifer." Ground Water 29(6):856-861.

Rehfeldt, K. R. 1989. “Application of the Borehole Flowmeter Method to Measure Spatially Variable Hydraulic Conductivity at the MADE Site." In Proceedings of the NWWA Conference: New Field Techniques for Quantifying the Physical and Chemical Properties of Heterogeneous Aquifers, NWWA, Dallas, Texas.

Reidel, S. P. 1984. "The Saddle Mountains: The Evolution of an Anticline in the Yakima Fold Belt." American Journal of Science 284:942-978.

Reidel, S. P. 1987. Geologic Map of Saddle Mountains, Central Washington. RHO-BW-SA-463 (5 plates), Westinghouse Hanford Company, Richland, Washington.

Reidel, S. P. 1988. Geologic Map of Saddle Mountains, Central Washington. Washington Department of Natural Resources, Division of Geology and Earth Resources, Geologic Map GM-38, WDNR, Olympia, Washington.

Reidel, S. P., and P. R. Hooper (eds.). 1989. Volcanism and Tectonism in the Columbia River Flood-Basalt Province. Geological Society of America Special Paper 239, Geological Society of America, Boulder, Colorado.

Reidel, S. P., and T. L. Tolan. 1992. "Eruption and Emplacement of Flood-Basalt Flows-An Example from the Teepee Butte Member, Columbia River Basalt Group." Geological Society of America Bulletin 104:1650-1671.

Reidel, S. P., D. G. Horton, and K. D. Reynolds. 1998. Immobilized Low-Activity Waste Site Borehole 299-E17-21. PNNL-11957, Pacific Northwest National Laboratory, Richland, Washington.

Reidel, S. P., and K. R. Fecht. 1981. "Wanapum and Saddle Mountains Basalts of the Cold Creek Syncline Area." In Subsurface Geology of the Cold Creek Syncline, eds. C. W. Myers and S. M. Price, RHO-BWI-ST-14, Rockwell Hanford Operations, Richland, Washington. 
Reidel, S. P., and N. P. Campbell. 1989. "Structure of the Yakima Fold Belt, Central Washington." Geologic Guidebook for Washington and Adjacent Areas, N. L. Joseph et al. (eds.), Washington Division of Geology and Earth Resources Information Circular 86, pp 275-303, Washington State Department of Natural Resources, Olympia, Washington.

Reidel, S. P., G. R. Scott, D. R. Bazard, R. W. Cross, and B. Dick. 1984. "Post-12 Million Year Clockwise Rotation in the Central Columbia Plateau, Washington." American Geophysical Union, Tectonics 3(2):251-273.

Reidel, S. P., K. A. Lindsey, K. R. Fecht, and N. P. Campbell. 1992. "Post-Columbia River Basalt Group Structure and Stratigraphy of the Central Columbia Basin.” Geological Society of America Abstracts with Program, Geological Society of America, Olympia, Washington.

Reidel, S. P., K. R. Fecht, K. A. Lindsey, and N. P. Campbell. 1994. Late Cenozoic Structure and Stratigraphy of South-Central Washington. Bulletin 80, Washington Division of Geology and Earth Resources, Washington State Department of Natural Resources, Olympia, Washington.

Reidel, S. P., K. R. Fecht, M. C. Hagood, and T. L. Tolan. 1989a. "The Geologic Evolution of the Central Columbia Plateau." In Volcanism and Tectonism in the Columbia River Flood-Basalt Province, eds. S. P. Reidel and P. R. Hooper, Special Paper 239, pp 247-264, Geological Society of America, Boulder, Colorado.

Reidel, S. P., T. L. Tolan, P. R. Hooper, M. H. Beeson, K. R. Fecht, R. D. Bentley, and J. L. Anderson. 1989a. "The Grande Ronde Basalt, Columbia River Basalt Group - Stratigraphic Descriptions and Correlations in Washington, Oregon, and Idaho." In Volcanism and Tectonism in the Columbia River Flood-Basalt Province, eds. S. P. Reidel and P. R. Hooper, Special Paper 239, pp 21-53, Geological Society of America, Boulder, Colorado.

Reidel, S. P., P. E. Long, C. W. Myers, and Jack Mase. 1982. "New Evidence for Greater than 3.2 Kilometers of Columbia River Basalt Beneath the Central Columbia Plateau." EOS (Transactions of American Geophysical Union) 63(8):173.

Riddihough, R. P., and D. A. Seeman. 1982. Juan De Fuca Plate Map: Gravity Anomalies Scale 1:2000000. Department of Energy, Mines, and Resources, Ottawa, Canada.

Riddihough, R. P., C. Finn, and R. Couch. 1986. "Klamath-Blue Mountain Lineament, Oregon." Geology 14:528-531.

Robbins, S. L., J. R. Kunk, and F. G. Clutson. 1983. Principal Facts and Density Estimates for Borehole Gravity Stations in Boreholes RRl-3, RRL-4, RRL-5, RRL-6b, RRL-7, RRL-8, and RRL-9, at the Hanford Site, Benton County, Washington. Open-File Report 83-386, U.S. Geological Survey, Richland, Washington. 
Robbins, S. L., R. J. Martinez, and D. L. Smith. 1979. Principal Facts for Borehole Gravity Stations in Wells DC-3, DC-5, DC-7 at the Hanford Site, Washington, and in Well RSH \#1 on Rattlesnake Hills, Washington. Open-File Report 79-849, U.S. Geological Survey, Washington, D.C.

Robbins, S. L., R. H. Burt, and D. O. Gregg. 1975. Gravity and Aeromagnetic Study of Part of the Yakima River Basin, Washington. Professional Paper 726-E, U.S. Geological Survey, Washington, D.C.

Rohay, A. C. 1982. Crust and Mantle Structure of the North Cascades Range. PhD. dissertation, University of Washington, Seattle, Washington.

Rohay, A. C., and J. D. Davis. 1983. "Contemporary Deformation in the Pasco Basin Area of the Central Columbia Plateau." In Preliminary Interpretation of the Tectonic Stability of the Reference Repository Location, Cold Creek Syncline, Hanford Site, eds. J. A. Caggiano and D. W. Duncan, RHO-BWI-ST-19 $\mathrm{P}$, Rockwell Hanford Operations, Richland, Washington.

Rohay, A. C., and S. D. Malone. 1983. Crustal Structure of the Columbia Plateau Region, Washington. RHO-BW-SA-289 P, Rockwell Hanford Operations, Richland, Washington.

Rohay, A. C., D. W. Glover, and S. D. Malone. 1985. Time-Term Analysis of Upper Crustal Structure in the Columbia Basin, Washington. RHO-BW-SA-435 P, Rockwell Hanford Operations, Richland, Washington.

Saltus, R. W. 1991. Gravity and Heat Flow Constraints on Cenozoic Tectonics of the Western United States Cordillera. Ph.D. Dissertation, Stanford University, Stanford, California.

Sandness, G. A., C. S. Kimball, K. E. Schmierer, and J. W. Lindberg. 1982. Report on Geologic Remote Sensing of the Columbia Plateau. RHO-BW-CR-133 P, PNL-3140, Pacific Northwest Laboratory and Rockwell Hanford Operations, Richland, Washington.

Schafer, P. S., T. Hower, and R. W. Owens. 1993. Managing Water-Drive Gas Reservoirs. Gas Research Institute, DesPlaines, Illinois.

Schmincke, H. 1964. Petrology, Paleocurrents, and Stratigraphy of the Ellensburg Formation. Johns Hopkins University, Baltimore, Massachusetts.

Senturion. 1979. Rockwell's Tensor Magnetotelluric Study of Pasco Basin Washington, B066282. Senturion Sciences for Rockwell Hanford Operations, Richland, Washington.

Seismograph Service Corporation (SSC). 1978. Final Report on a Seismic Reflection Field Testing Conducted in Benton County, Washington, Pasco Basin, Hanford Reservation, Basalt Waste Isolation Programs. Seismograph Service Corporation for Rockwell Hanford Operations, Richland, Washington. 
Seismograph Service Corporation (SSC). 1979. Final Report on a Seismic Reflection Survey Conducted in Benton and Grant Counties, Washington, Pasco Basin, Hanford Site, Basalt Waste Isolation Program. B067305, Seismograph Service Corporation for Rockwell Hanford Operations, Richland, Washington.

Seismograph Service Corporation (SSC). 1980. Final Report on a Seismic Reflection Survey Conducted in Benton County, Washington, FY-80 Program, Pasco Basin, Hanford Site, Basalt Waste Isolation Program. B067306, Seismograph Service Corporation for Rockwell Hanford Operations, Richland, Washington.

Sexton, J. L., W. J. Hinze, R.R.B. von Frese, and L. W. Braile. 1982. "Long-Wavelength Aeromagnetic Anomaly Map of Conterminous of the United States." Geology 10:364-369.

Smith, G. A. 1988. "Neogene Synvolcanic and Syntectonic Sedimentation in Central Washington." Geologic Society of America Bulletin 100:1479-1492.

Smith, G. A., B. N. Bjornstad, and K. R. Fecht. 1989. "Neogene Terrestrial Sedimentation on and Adjacent to the Columbia Plateau: Washington, Oregon, and Idaho."

Smith, R. B. 1978. "Seismicity, Crustal Structure, and Intraplate Tectonics of the Interior of the Western Cordillera." In Cenozoic Tectonic and Regional Geophysics of the Western Cordillera, eds. R. B. Smith and G. P. Eaton, Memoir 152, Geological Society of America, Boulder, Colorado.

Society of Exploration Geophysicists (SEG). 1982. Gravity Anomaly Map of the United States: Exclusive of Alaska and Hawaii Scale 1:2500000. Society of Exploration Geophysicists, Tulsa, Oklahoma.

Somerton, W. H. 1982. Porous Rock-Fluid Systems at Elevated Temperatures and Pressures. Special Paper 189, Geological Society of America, Boulder, Colorado.

Spane, F. A., Jr. 1982. "Hydrologic Studies Within the Pasco Basin.” In Proceedings of the 1982 National Waste Terminal Storage Program Information Meeting, pp. 23-28. U.S. Department of Energy, DOE/NWTS-30, Richland, Washington.

Spane, F. A., Jr. 1987. Potentiometric Map and Inferred Lateral Groundwater Flow Direction for the Mabton Interbed, Hanford Site, Washington State - January 1986. SD-BWI-TI-335, Basalt Waste Isolation Project, Rockwell Hanford Operations, Richland, Washington.

Spane, F. A., Jr. 1992. Applicability of Slug Interference Tests Under Hanford Site Test Conditions: Analytical Assessment and Field Test Evaluation. PNL-8070, Pacific Northwest Laboratory, Richland, Washington.

Spane, F. A., Jr. 1993. Selected Hydraulic Test Analysis Techniques for Constant-Rate Discharge Tests. PNL-8539, Pacific Northwest Laboratory, Richland, Washington. 
Spane, F. A., Jr. 1996. "Applicability of Slug Interference Tests for Hydraulic Characterization of Unconfined Aquifers: (1) Analytical Assessment.” Ground Water 34(1):66-74.

Spane, F. A., Jr., P. D. Thorne, and L. C. Swanson. 1996. "Applicability of Slug Interference Tests for Hydraulic Characterization of Unconfined Aquifer: (2) Field Test Examples." Ground Water 34(5):925-933.

Spane, F. A., Jr. 1999. Effects of Barometric Fluctuations on Well Water-Level Measurements and Aquifer Test Data. PNNL-13078, Pacific Northwest National Laboratory, Richland, Washington.

Spane, F. A. 2002. "Considering Barometric Pressure in Groundwater-Flow Investigations." Water Resources Research (in press).

Spane, F. A., Jr., and W. D. Webber. 1995. Hydrochemistry and Hydrogeologic Conditions Within the Hanford Site Upper Basalt Confined Aquifer System. PNL-10817, Pacific Northwest Laboratory, Richland, Washington.

Spane, F. A., Jr., and P. D. Thorne. 1985. "The Effects of Drilling Fluid Invasion on Hydraulic Characterization of Low-Permeability Basalt Horizons: A Field Evaluation.” Environmental Geology and Water Sciences 7(4):227-236.

Spane, F. A., Jr., P. D. Thorne, and W. H. Chapman-Riggsbee. 1983. Results and Evaluation of Experimental Vertical Hydraulic Conductivity Testing at Boreholes DC-4 and DC-5. SD-BWI-TI-136, Basalt Waste Isolation Project, Rockwell Hanford Operations, Richland, Washington.

Spane, F. A., Jr., and R. G. Raymond. 1993. Preliminary Potentiometric Map and Flow Dynamic Characteristics for the Upper-Basalt Confined Aquifer System. PNL-8869, Pacific Northwest Laboratory, Richland, Washington.

Spane, F. A., Jr., and S. K. Wurstner. 1993. "DERIV: A Program for Calculating Pressure Derivatives for Use in Hydraulic Test Analysis." Ground Water 31(5):814-822.

Spane, F. A., Jr., P. D. Thorne, and D. R. Newcomer. 2001a. Results of Detailed Hydrologic Characterization Tests - Fiscal Year 1999. PNNL-13378, Pacific Northwest National Laboratory, Richland, Washington.

Spane, F. A., Jr., P. D. Thorne, and D. R. Newcomer. 2001b. Results of Detailed Hydrologic Characterization Tests - Fiscal Year 2000. PNNL-13514, Pacific Northwest National Laboratory, Richland, Washington.

Spry, A. 1962. "The Origin of Columnar Jointing Particularly in Basalt Flows." Geological Society of Australia Journal 8:191-216.

Stanley, W. D. 1982. A Regional Magnetotelluric Survey of the Cascade Range Region, Northwestern United States. Open-File Report 82-126, U.S. Geological Survey, Washington, D.C. 
Steinkampf, W. C., and P. P. Hearn, Jr. 1996. Ground-Water Geochemistry of the Columbia Plateau Aquifer System, Washington, Oregon, and Idaho. U.S. Geological Survey, Open-File Report 95-467, USGS, Washington, D.C.

Stoffel, K. L, N. L. Joseph, S. Z. Waggoner, C. W. Gulick, M. A. Korosec, and B. B. Bunning. 1991. Geologic Map of Washington - Northeast Quadrant. Geologic Map GM-39. Washington Department of Natural Resources, Division of Geology and Earth Resources, Olympia, Washington.

Suppe, J. 1983. "Geometry and Kinematics of Fault-Bend Folding." American Journal of Science 283:648-721.

Suppe, J. 1985. Principles of Structural Geology. Prentice-Hall, Inc., Princeton, New Jersey.

Swanson, D. A., and T. L. Wright. 1981. "Guide to Geologic Field Trip Between Lewiston, Idaho and Kimberly, Oregon, Emphasizing the Columbia River Basalt Group.” D. A. Johnston and J. DonnellyNolen (eds.), Guides to Some Volcanic Terrains in Washington, Idaho, Oregon, and Northern California, U.S. Geological Survey Circular 838, pp. 1-28.

Swanson, D. A., and T. L. Wright. 1981. "Guide to Geologic Field Trip Between Lewiston, Idaho and Kimberly, Oregon, Emphasizing the Columbia River Basalt Group.” In Guides to Some Volcanic Terranes in Washington, Idaho, Oregon, and Northern California, eds. D. A. Johnston and J. DonnellyNolan, Circular 838, U.S. Geological Survey, Alexandria, Virginia.

Swanson, D. A., J. L. Anderson, V. E. Camp, P. R. Hooper, W. H. Taubeneck, and T. L. Wright. 1981. Reconnaissance Geologic Map of the Columbia River Basalt Group, Northern Oregon and Western Idaho. Open-File Report 81-0797, U.S. Geological Survey, Washington, D.C.

Swanson, D. A., T. L. Wright, and I. Zietz. 1976. Geologic Interpretation of an Aeromagnetic Map of West-Central Columbia Plateau, Washington and Oregon. Open-File Report 76-51, U.S. Geological Survey, Washington, D.C.

Swanson, D. A., T. L. Wright, and I. Zietz. 1979a. Aeromagnetic Map and Geologic Interpretation of the West-Central Columbia Plateau, Washington and Adjacent Oregon. U.S. Geological Survey Geophysical Investigations Map GP-917, 1 sheet, scale 1:250,000, USGS, Washington, D.C.

Swanson, D. A., J. L. Anderson, R. D. Bentley, V. E. Camp, J. N. Gardner, and T. L. Wright. 1979b. Reconnaissance Geologic Map of the Columbia River Basalt Group in Eastern Washington and Northern Idaho. Open-File Report 79-1363, U.S. Geological Survey, Washington, D.C.

Swanson, D. A., T. L. Wright, P. R. Hooper, and R. D. Bentley. 1979c. Revisions in Stratigraphic Nomenclature of the Columbia River Basalt Group. Bulletin 1457-G, U.S. Geological Survey, Washington, D.C. 
Swanson, D. A., T. L. Wright, V. E. Camp, J. N. Gardner, R. T. Helz, S. M. Price, S. P. Reidel, and M. E. Ross. 1980. Reconnaissance Geologic Map of the Columbia River Basalt Group, Pullman and Walla Walla Quadrangles, Southeast Washington and Adjacent Idaho. Miscellaneous Investigations Series Map I-1139, U.S. Geological Survey, Denver, Colorado.

Tabor, R. W., R. B., Waitt, Jr., V. A. Frizzell, Jr., D. A. Swanson, G. R. Byerly, and R. D. Bentley. 1982. Geologic Map of the Wenatchee 1:100,000 Quadrangle, Central Washington. Miscellaneous Investigations Series Map I-1311, U.S. Geological Survey, Washington, D.C.

Tabor, R. W., V. A. Frizzell, Jr., J. A. Vance, and C. W. Naeser. 1984. "Ages and Stratigraphy of Lower and Middle Tertiary Sedimentary and Volcanic Rocks of the Central Cascades, Washington-Application to the Tectonic History of the Straight Creek Fault." Geological Society of America Bulletin 95:26-44.

Theis, C. V. 1935. "The Relationship Between the Lowering of the Piezometric Surface and the Rate and Duration of Discharge of a Well Using Ground-Water Storage." American Geophysical Union, Transactions 2:519-524.

Thorne, P. D., and F. A. Spane, Jr. 1985. "A Comparison of Under-Pressure and Over-Pressure Pulse Tests Conducted in Low-Permeability Basalt Horizons at the Hanford Site, Washington State." Proceedings of the 17th International Congress, International Association of Hydrogeologists, Kenilworth, United Kingdom.

Tomkeieff, S. I. 1940. "The Basalt Lavas of the Giant's Causeway District of Northern Ireland." Bulletin of Volcanology 6:89-143.

U.S. Department of Energy (DOE). 1988. Site Characterization Plan Reference Repository Location, Hanford Site, Washington. DOE/RW-0164, Vol. 2, U.S. Department of Energy, Washington, D.C.

Van Alstine, D. R., and S. L. Gillett. 1981. Magnetostratigraphy of the Columbia River Basalt, Pasco Basin and Vicinity, Washington. RHO-BWI-C-110, Sierra Geophysics for Rockwell Hanford Operations, Richland, Washington.

Van Alstine, D. R., and S. L. Gillett. 1982. Variations in Magnetic Properties of Saddle Mountains Basalt and Vicinity, Washington B066339. Rockwell Hanford Operations, Richland, Washington.

Waitt, R. B. 1979. Late Cenozoic Deposits, Landforms, Stratigraphy, and Tectonism in Kittitas Valley, Washington. Professional Paper 1127, U.S. Geological Survey, Washington, D.C.

Walker, G. W., and N. S. MacLeod. 1991. Geologic Map of Oregon. U.S. Geological Survey, 2 Plates, USGS, Washington, D.C.

Waters, A. C. 1960. "Determining Direction of Flow in Basalts." American Journal of Science 258-A:350-366. 
Waters, A. C. 1961. "Stratigraphic and Lithologic Variations in the Columbia River Basalt." American Journal of Science 259:583-611.

Watters, T. R. 1989. "Periodically Spaced Anticlines of the Columbia Plateau." In Volcanism and Tectonism in the Columbia River Flood-Basalt Province, Special Paper 239, S. P. Reidel and P. R. Hooper eds., Geological Society of America, Boulder, Colorado.

Werner, S. 1953. "Interpretation of Magnetic Anomalies at Sheet-Like Bodies." Sveriges Geologiska Undersokning, Ser. C, Avhandlingar och uppsatser, No. 508, Arsbok 43 (1949) No. 6, Stockholm, Sweden.

Weston. 1978a. Ground Geophysical Studies, Columbia Plateau and Adjacent Cascade Mountains. Weston Geophysical Research for Washington Public Power Supply System, Richland, Washington.

Weston. 1978b. Qualitative Aeromagnetic Evaluation of Structures in the Columbia Plateau and Adjacent Cascade Mountain Area. Weston Geophysical Research for Washington Power Supply System, Richland, Washington.

Weston. 1982. Interpretation of Seismic Refraction Data, Hanford Site, B015828. Weston Geophysical Research for Rockwell Hanford Operations, Richland, Washington.

White, W.R.H., and J. C. Savage. 1965. “A Seismic Refraction and Gravity Study of the Earth's Crust in British Columbia." Bulletin of the Seismological Society of America 55:463-486.

Whiteman, K. J., J. J. Vaccaro, J. B. Gonthier, and H. H. Bauer. 1994. The Hydrogeologic Framework and Geochemistry of the Columbia Plateau Aquifer System, Washington, Oregon, and Idaho. U.S. Geological Survey, Professional Paper 1413-B, USGS, Washington, D.C.

Won, I. J. and K. H. Son. 1982. "A Preliminary Comparison of the Magsat Data and Aeromagnetic Data in the Continental U.S." Geophysical Research Letters 9(4):296-298.

Washington Public Power Supply System (WPPSS). 1977. Preliminary Safety Analysis Report, WNP-1/4. Washington Public Power Supply System, Richland, Washington.

Washington Public Power Supply System (WPPSS). 1981. Final Safety Analysis Report, WPPSS Nuclear Project No. 2. Amendment 18, WPPSS, Richland, Washington.

Washington Public Power Supply System (WPPSS). 1986. Nuclear Project Nos. 1 and 4, Final Safety Analysis Report. WPPSS, Richland, Washington.

Z-Axis. 1983. Non-Exclusive Magnetotelluric Survey, Northwest Columbia Plateau, Washington, Proprietary Data. Z-Axis Exploration. 
Z-Axis. 1985. Magnetotelluric Survey at the Hanford Nuclear Reservation, Rattlesnake Hills, Washington. BMRC \#'s B066283, B066284, B066285, Z-Axis Exploration, Richland, Washington.

Zaikowski, A., and B. Kosanke. 1987. "Noble Gas Composition of Deep Brines from Palo Duro Basin, Texas." Geochimica Cosmochimica Acta 51:73-84.

Zervas, C. E., and R. S. Crosson. 1986. "An Observation and Interpretation in Washington." Bulletin of the Seismological Society of America 76:521-546.

Zietz, I., C. B. Hearn, M. W. Higgins, G. D. Robinson, and D. A. Swanson. 1971. "Interpretation of an Aeromagnetic Strip Across the Northwestern United States." Geological Society of America Bulletin 82:3347-3372.

Zeigler, T. W. 1976. Determination of Rock Mass Permeability. Technical Report S-76-2. U.S. Army Engineers Waterways Experiment Station, Vicksburg, Mississippi. 


\section{Appendix A}

\section{Examples of Columbia River Basalt Group Flow Features}




\section{Appendix A}

\section{Examples of Columbia River Basalt Group Flow Features}

This appendix provides examples of typical features observed in CRBG lava flows.

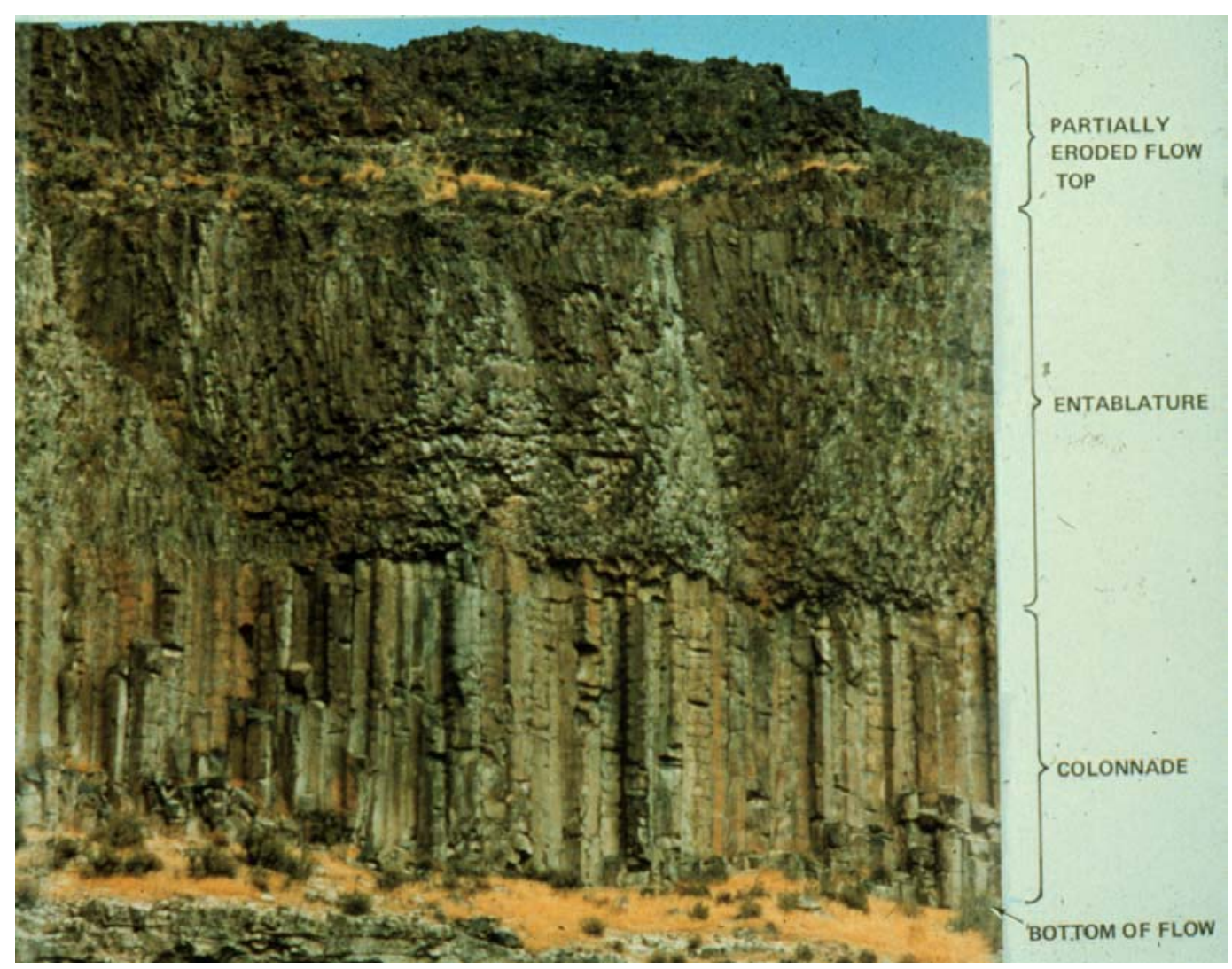

Figure A.1. Intraflow Structure Classification of a Columbia River Basalt Group Lava Flow 


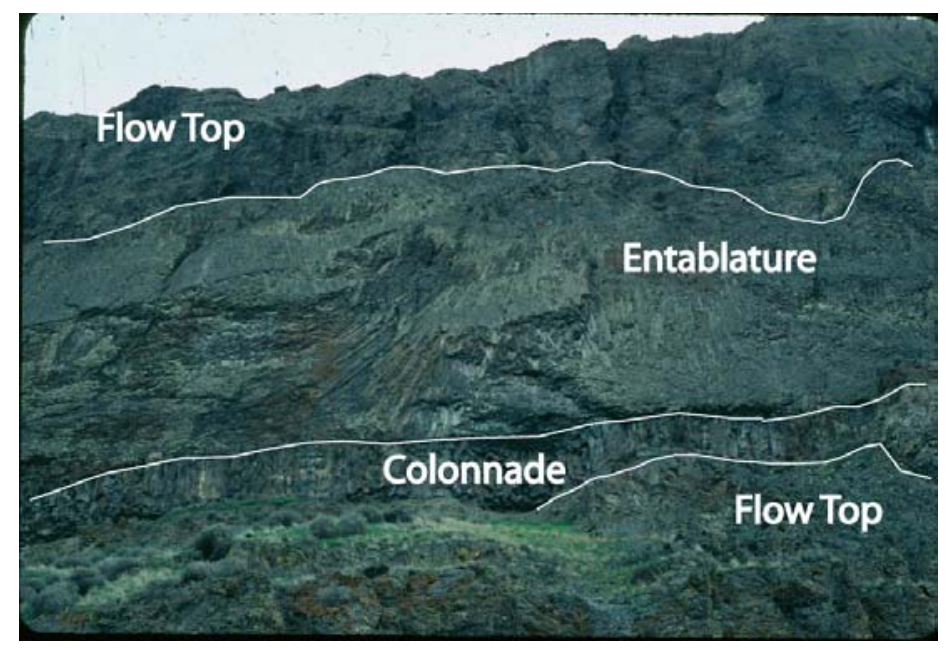

Figure A.2. Umtanum Flow, Umtanum Ridge. An example of a lava flow with a thick entablature and a thin colonnade with rubbly flow top.

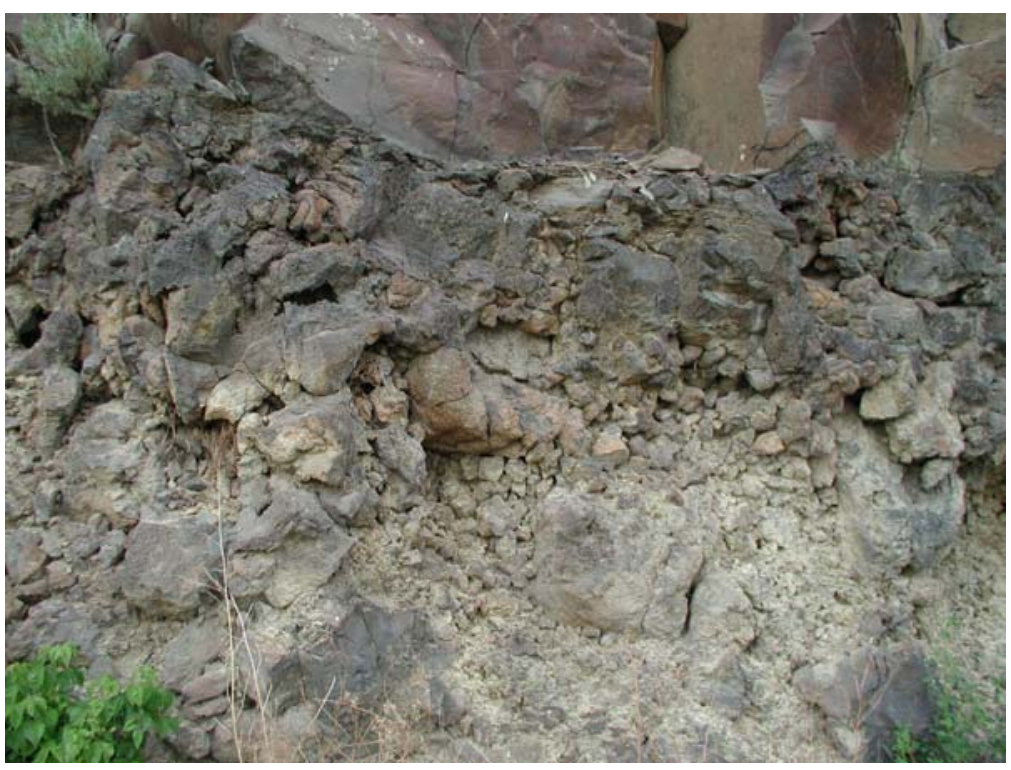

Figure A.3. Flow Top Rubble 


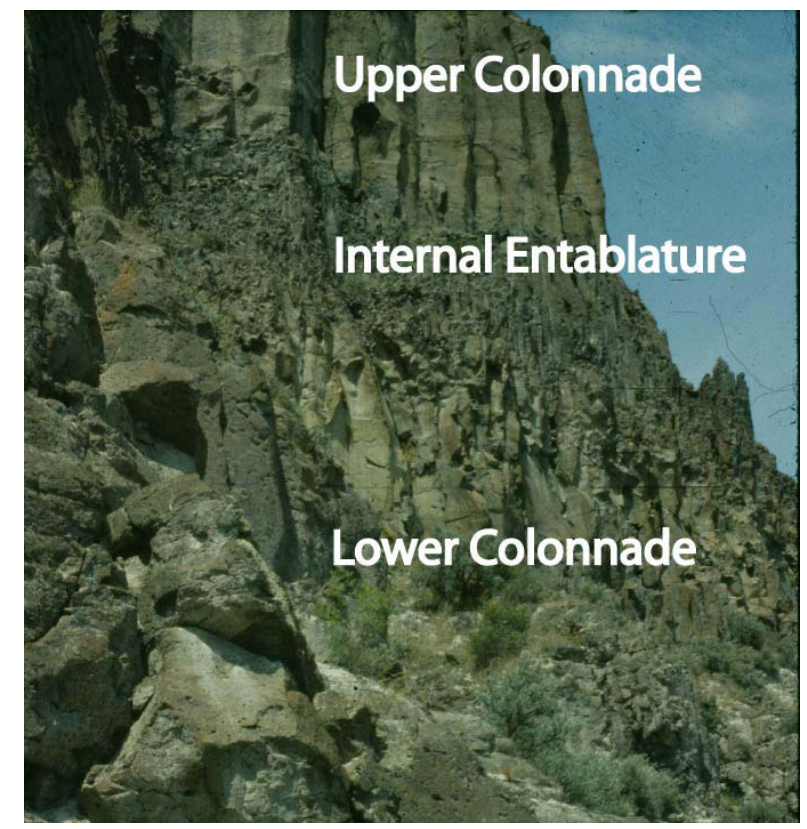

Figure A.4. Lava Flow with Internal Entablature Between Two Colonnades

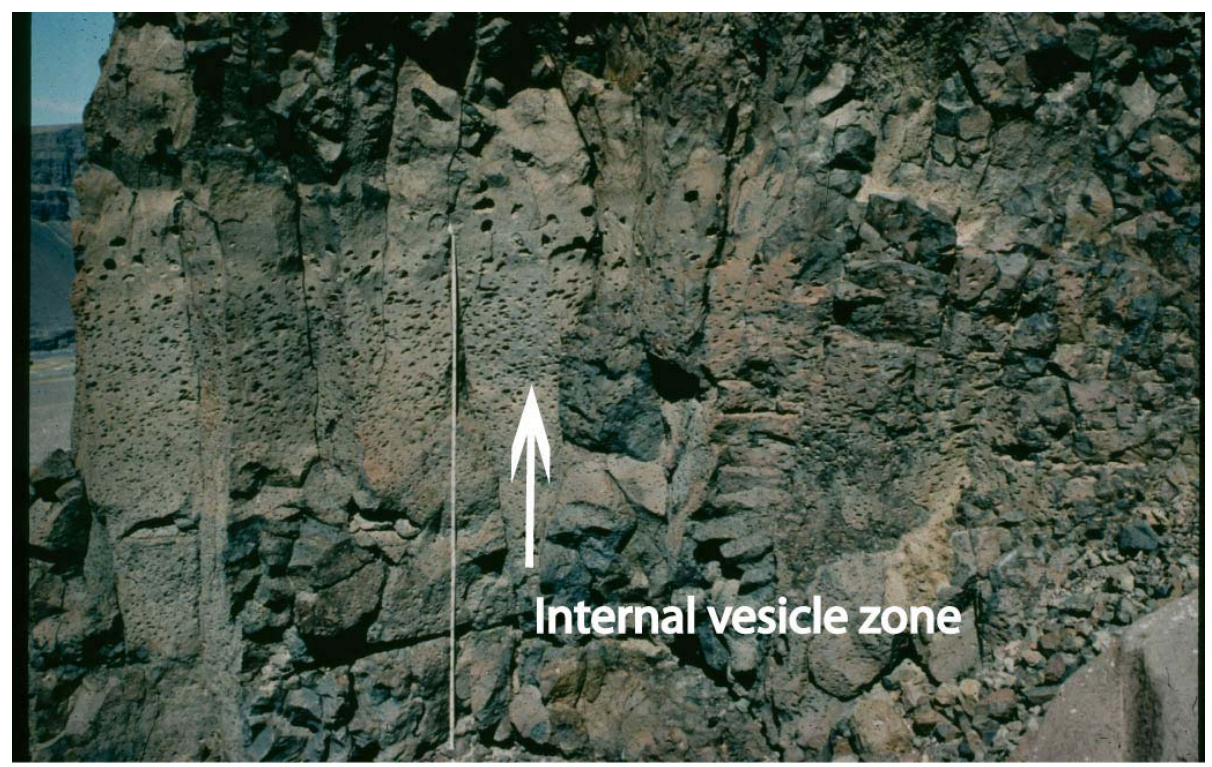

Figure A.5. Internal Vesicular Zone of the Cohassett Flow, Member of Sentinel Bluffs, Grande Ronde Basalt 


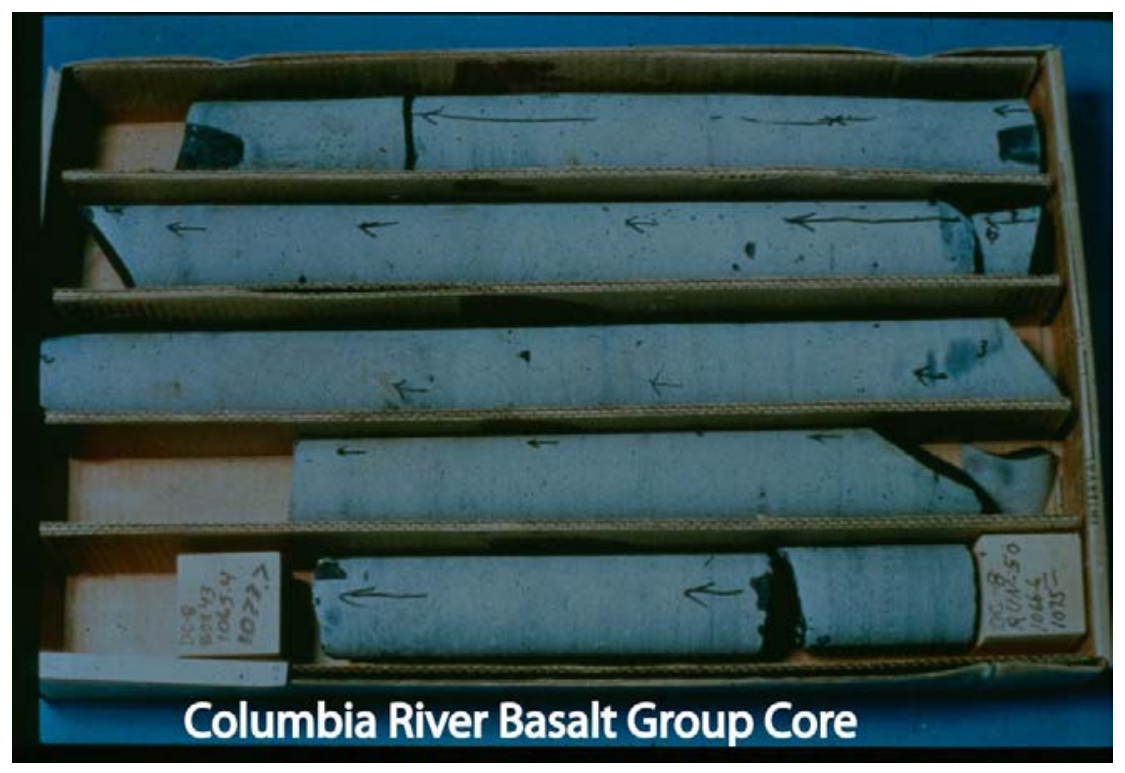

Figure A.6. Typical Core Box Containing Columbia River Basalt

Thin Section of Basalt

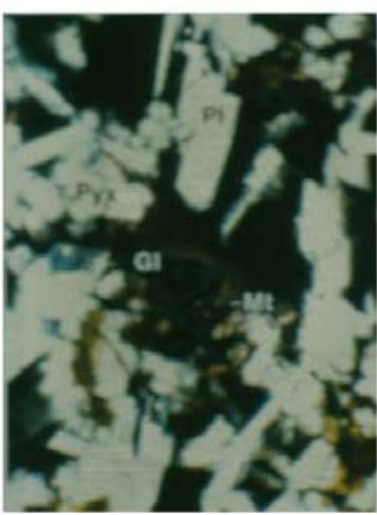

Entablature

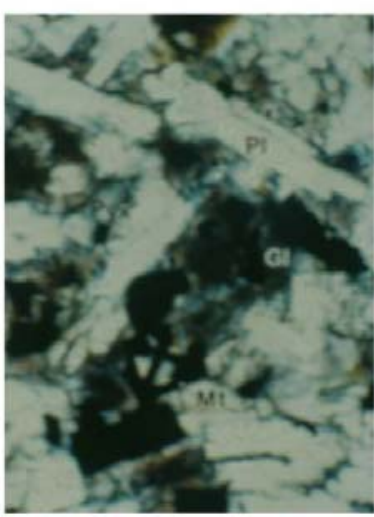

Colonnade

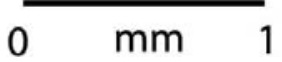

Figure A.7. Thin Section in Plain Polarized Light of Columbia River Basalt Showing Differences Between Colonnade and Entablature. Gl is glass, Mt is magnetite, $\mathrm{Pl}$ is plagioclase 


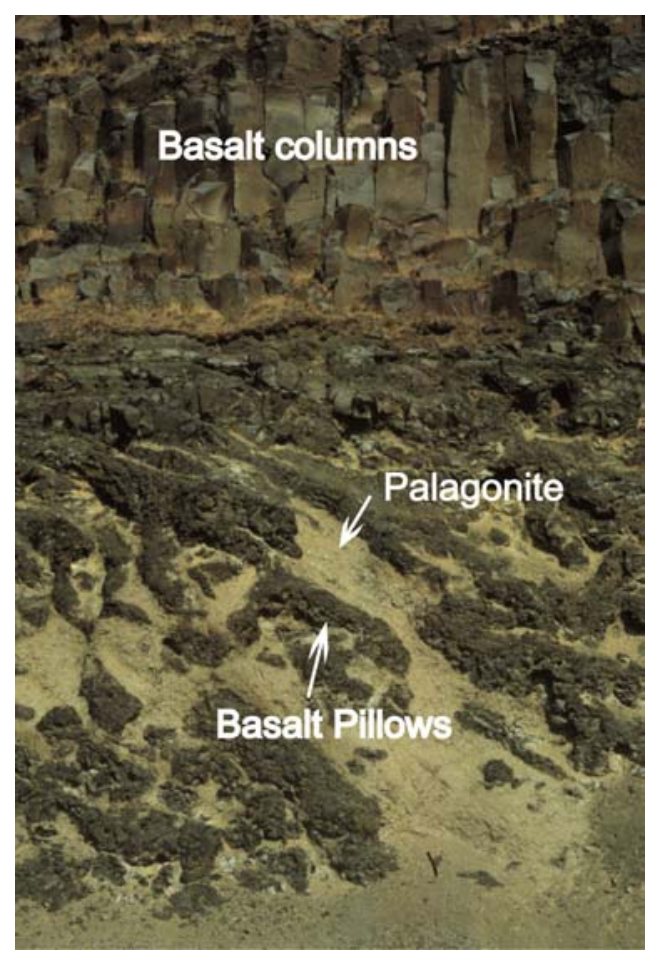

Figure A.8. Pillow-Palagonite Complex at the Base of a Columbia River Basalt Group Flow

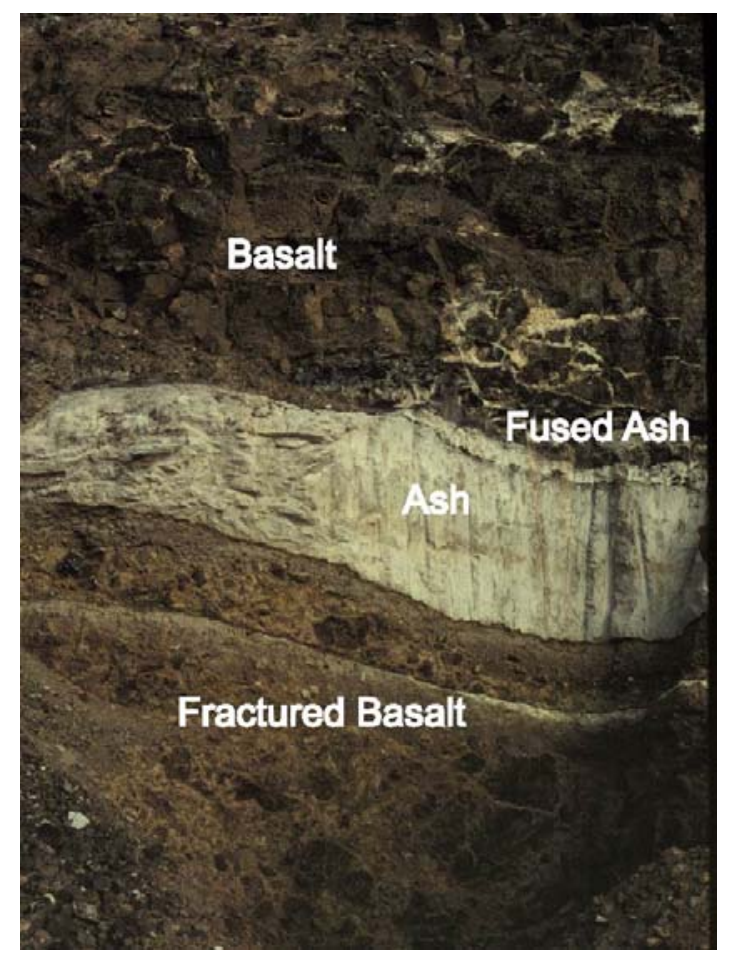

Figure A.9. Fused Ash at the Base of a Columbia River Basalt Group Flow 


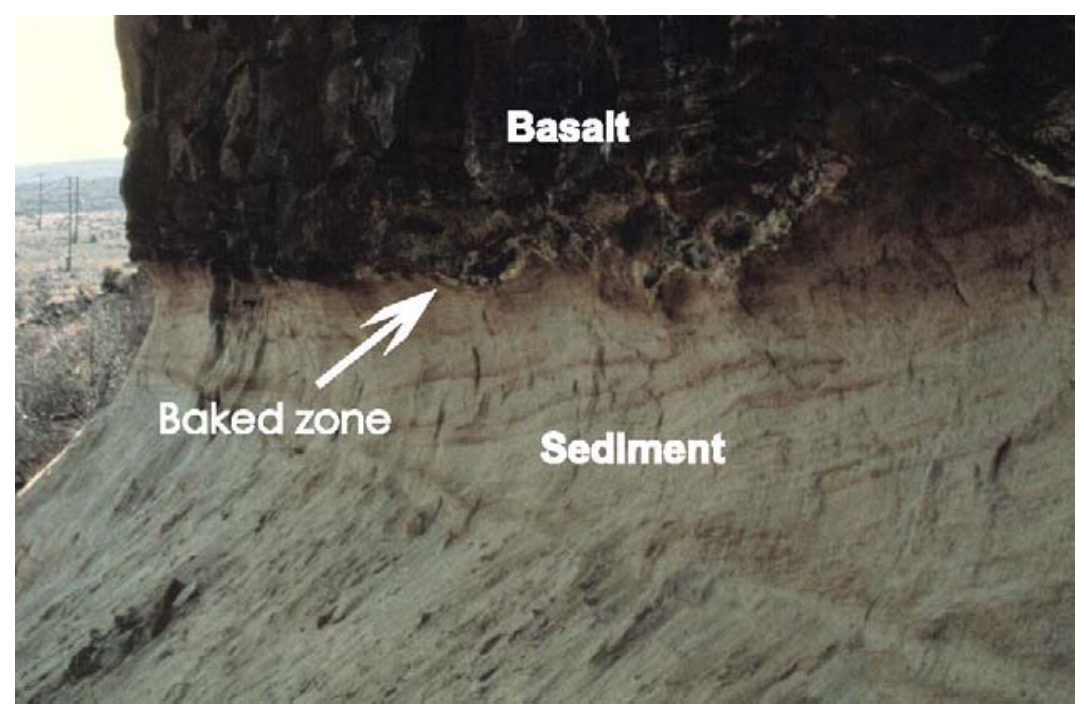

Figure A.10. Baked Sediment at the Base of a Columbia River Basalt Group Flow

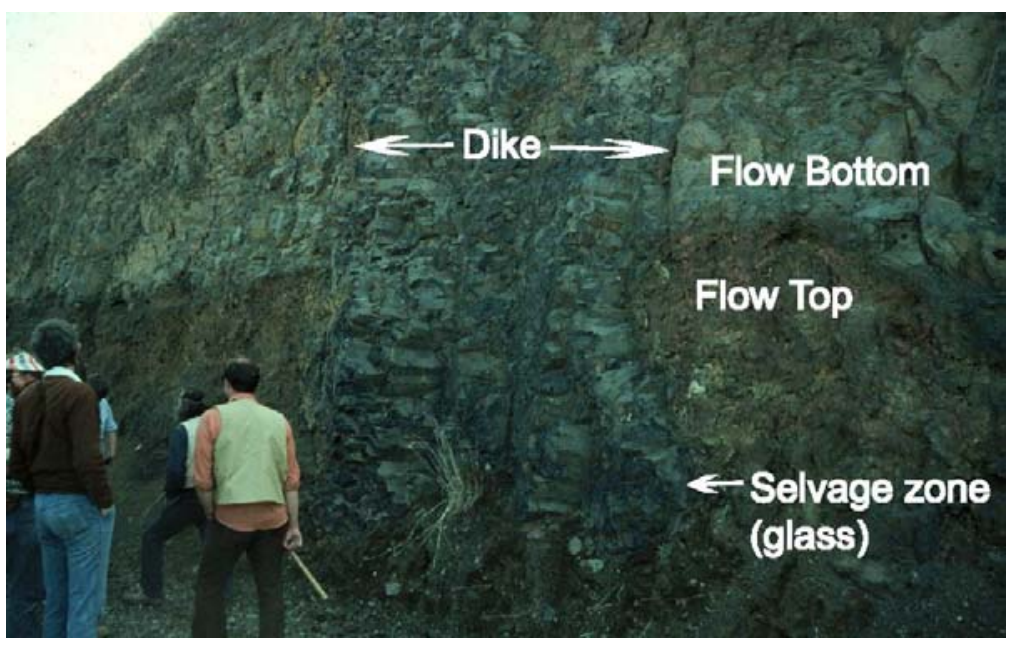

Figure A.11. Roza Member Dike 


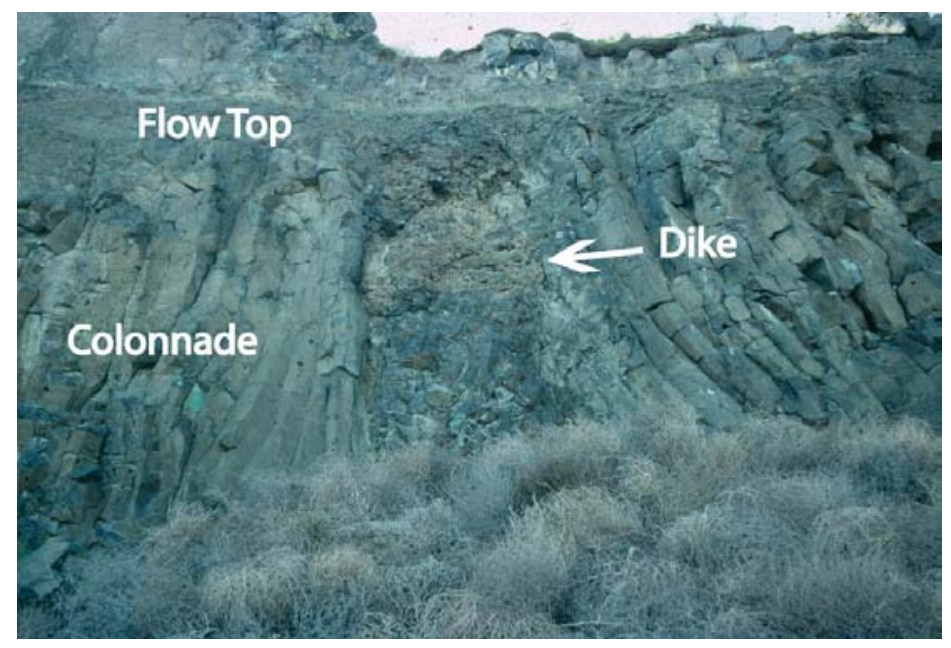

Figure A.12. Ice Harbor Member Dike Near Paleo-Land Surface

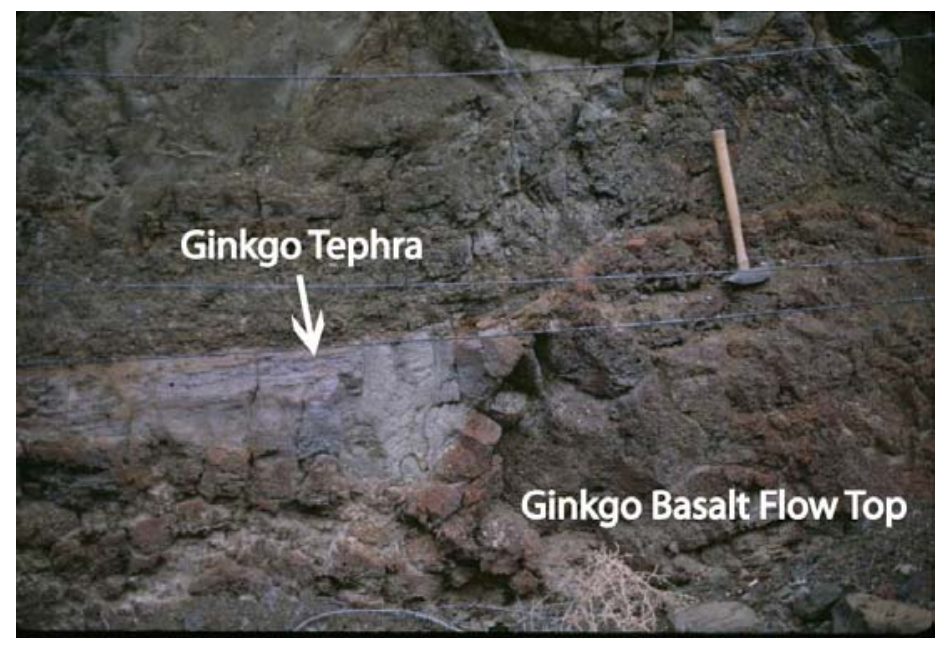

Figure A.13. Tephra at Top of Ginkgo Basalt Flow 


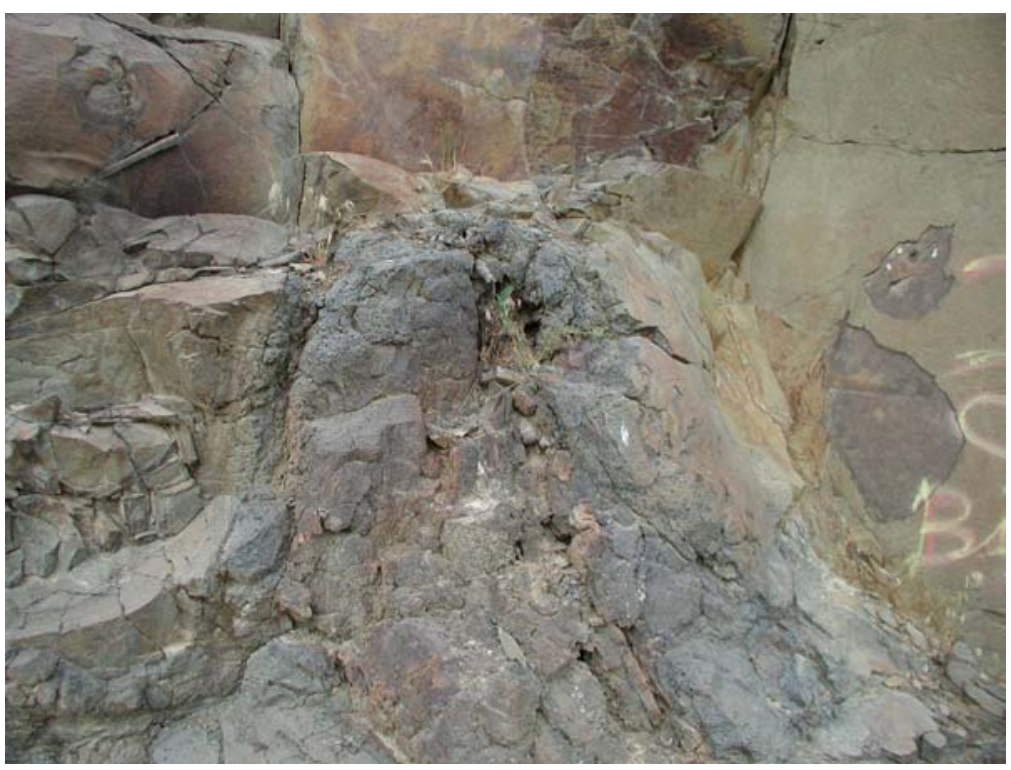

Figure A.14. Pressure Ridge (Tumulus) at Top of Flow (width $0.5 \mathrm{~m}$ )

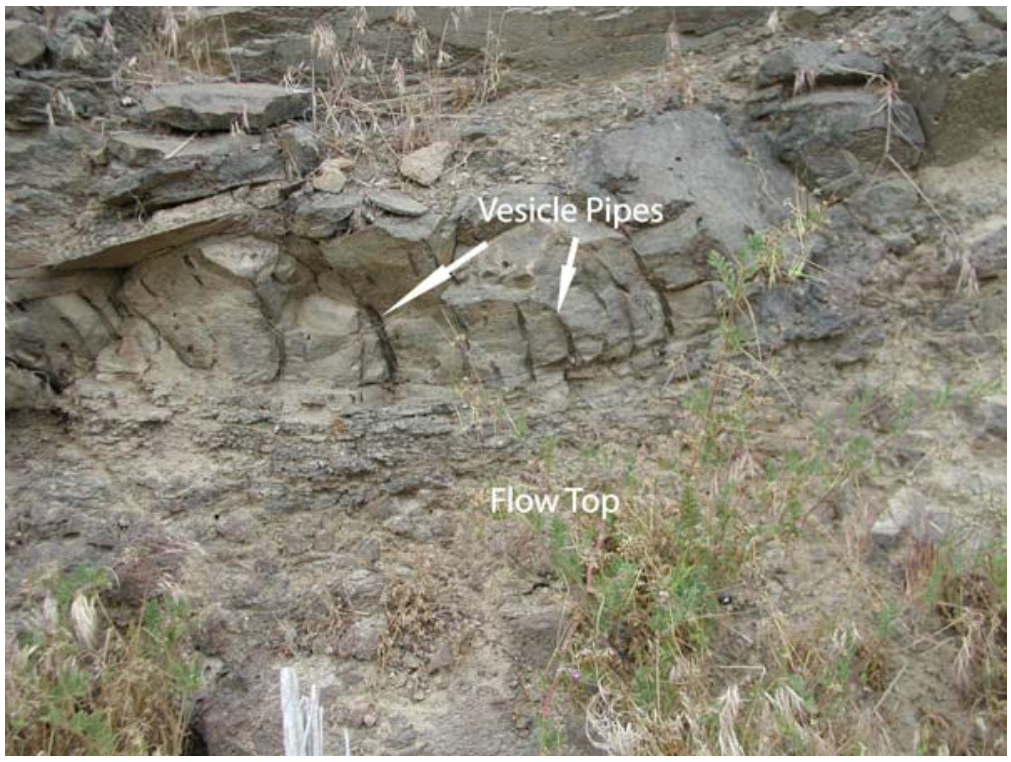

Figure A.15. Vesicle Pipes at Base of Basalt Flow. Vesicle pipes originate at base of flow and were truncated by movement of lava above solidified zone. Direction of flow movement is to the left. 


\section{Appendix B}

\section{An Example of the Current State-of-the-Art Geophysical Logging Technology}




\section{Appendix B}

\section{An Example of the Current State-of-the-Art Geophysical Logging Technology}

\section{Advanced Geophysical Logging Technologies for Aquifer Characterization \\ Richard E. Lewis and Edward A. Clayton \\ Schlumberger Intergrated Water Solutions \\ 6090 Greenwood Plaza Blvd., Englewood, CO, 80111,}

(303) 486-3236

The following is from Schlumberger Inc.

\section{Introduction}

Geophysical logging represents mature, yet constantly evolving, technologies employed as the principal methods of borehole analysis in subsurface characterization.

Wireline logging systems consist of three components (Figure 1):

1) downhole instrument (or sonde) introduced into a borehole that measures one or more physical properties of the formation

2) cable that connects the sonde to the surface, conducting power downhole and transmitting data uphole

3) logging truck that controls sonde location, provides power and houses a computer that controls sonde operation, as well as processes and displays data in real time. The resulting data are shown on a continuous strip chart commonly called a log.

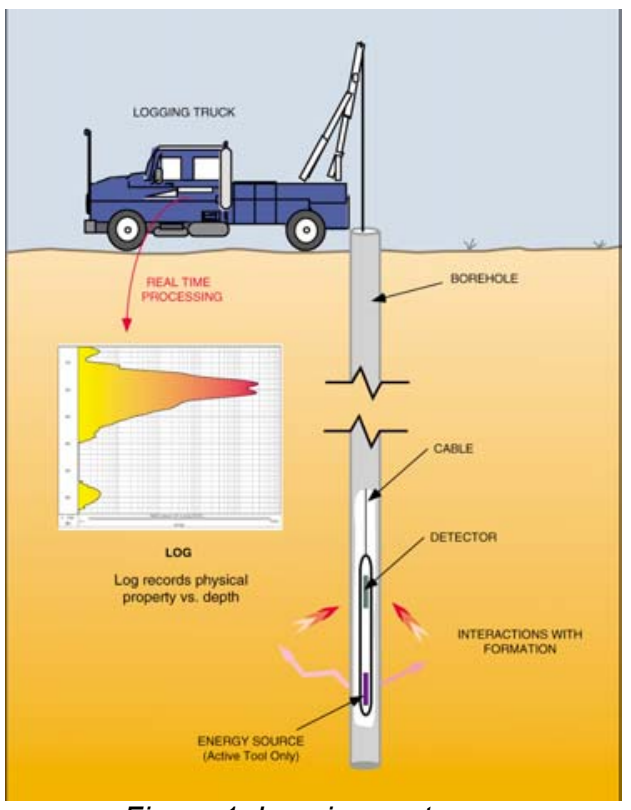

Figure 1. Logging system

Geophysical logging systems are designed to give an accurate and precise measurement of formation properties. Formation parameters commonly measured include porosity, moisture content, bulk geochemistry, hydraulic conductivity, orientation of bedding and fractures, identification and quantification of specific radionuclides and other elements and many others. 
Logging systems can also be used for downhole sampling and testing.

The integration of multiple logging technologies plus other data types (e.g., geologist's log, core analyses, surface geophysics, hydrologic test analyses) can lead to a fairly comprehensive picture of the shallow subsurface. The precision of the measurements in concert with the potential to measure the same volume repeatedly (i.e., reenter the same borehole) enhances the use of logging systems for monitoring.

This remainder of this paper presents several recently developed logging technologies that have been applied to aquifer characterization.

\section{Nuclear Magnetic Resonance Logging}

The Combinable Magnetic Resonance CMR tool uses the nuclear magnetic resonance (NMR) technique to log porous aquifers and predict their producibility (Allen et al., 1997). The unique advantage that NMR provides is a measure of pore size distribution independent of lithology. In the water industry, NMR logging is focused on delineating "producing" from "nonproducing" zones and further quantifying formation hydraulic conductivity and total versus effective porosity. In turn, this information can be used to determine optimal well yield.

The CMR tool measures the pore size distribution of the formation from which the porosity, bound and free water distribution, and hydraulic conductivity are estimated. This is achieved by utilizing a large permanent magnet that aligns the non-lattice bound hydrogen along a magnetic field (Figure 2). This process, called polarization, increases exponentially in time with a constant $T_{1}$. A magnetic pulse from a radio frequency antenna in the CMR tool rotates, or tips, the aligned protons into a plane perpendicular to the polarization. The protons, now aligned in a plane transverse to the polarization field, will start to precess around the direction of the field. The precessing protons sweep out oscillating magnetic fields like a radio antenna. The CMR tool employs a receiver connected to the same antennae used to induce the spinflipping pulse to measure these magnetic fields. The antennae and receivers are tuned to the resonance frequency of hydrogen nuclei and receive a tiny radio frequency signal from the precessing protons in the formation. Ideally, the spinning protons continue to precess around the direction of the external magnetic field, until they encounter an interaction that would change their spin orientation out of phase with others in the transverse -a transverse relaxation process. The time constant for the transverse relaxation process is called $T_{2}$. The decay of the precessing signal is the heart of the NMR measurement and is a function of 1) the intrinsic bulk relaxation rate within the borehole fluid, 2) the surface relaxation rate, and 3) diffusion (Kenyon et al 1995).

\footnotetext{
* Mark of Schlumberger
} 


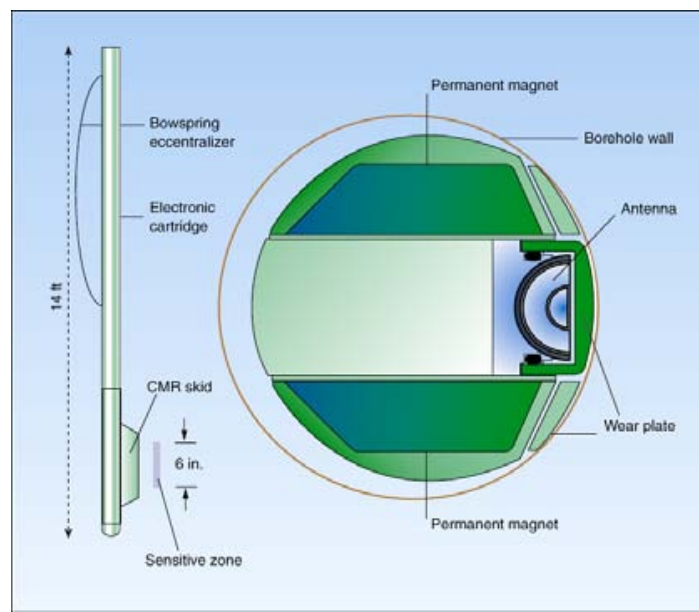

Figure 2: CMR tool schematic

In most formations, relaxation times depend on pore sizes. Small pores shorten relaxation times-the shortest times corresponding to clay-bound and capillary-bound water. Large pores allow long relaxation times (Figure 3 ). Therefore, the distribution of relaxation times is a measure of the distribution of pore sizes (Figure 4).

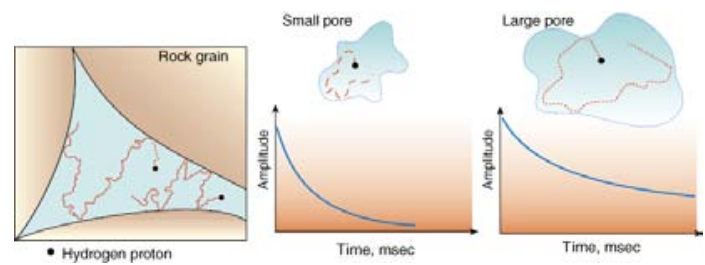

Figure 3: Relaxation time versus pore size

$\mathrm{T}_{2}$ relaxation times and their distributions may be interpreted to give other parameters such as hydraulic conductivity, producible porosity and irreducible water saturation. The following equation is commonly used to estimate intrinsic permeability or hydraulic conductivity:

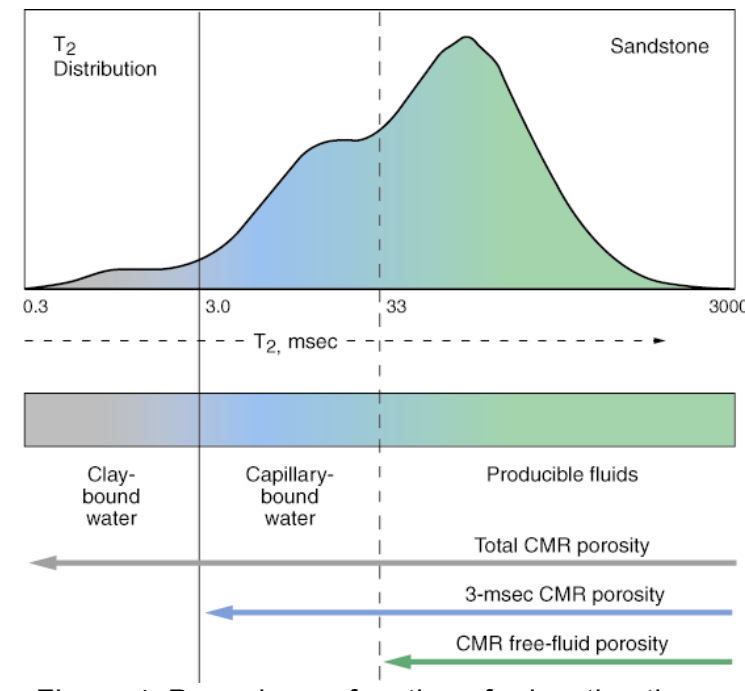

Figure 4: Pore size as function of relaxation time

$k_{N M R}=C\left(\phi_{N M R}\right)^{4}\left(T_{2, \log }\right)^{2}$

$k_{N M R} \quad$ estimated permeability

$\phi_{N M R}$ CMR porosity

$T_{2, \log }$ logarithmic mean of the $\mathrm{T}_{2}$ distribution

$C$ constant, typically 4 for sandstones and 0.1 for carbonates

As this equation indicates, an accurate estimation of hydraulic conductivity requires several core analyses to determine the correct value of $C$.

Figure 5 presents a portion of aquifer logged in New Mexico, US. Each logging track is based on CMR log data and include: effective, capillary, and clay-bound porosity (track1); pore size distribution (track 2); $\mathrm{T}_{2}$ distribution (tracks 3 and 4); hydraulic conductivity in logarithmic units of 


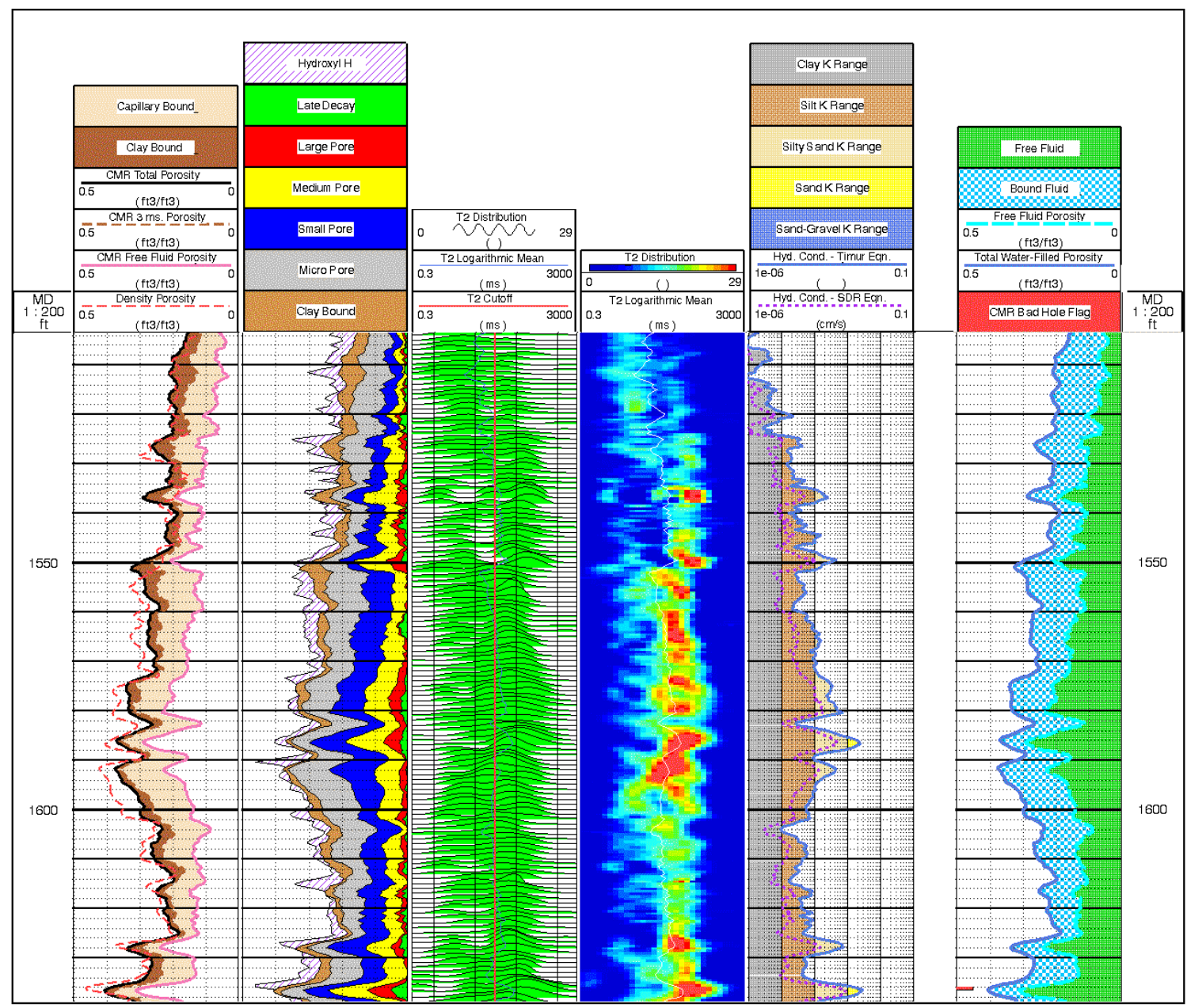

Figure 5: Nuclear magnetic resonance log of clastic aquifer

$\mathrm{cm} / \mathrm{sec}$ (track 5); and total plus effective porosity volumes (track 6). Each horizontal division is equivalent to 2 feet $(60 \mathrm{~cm})$ in depth.

All processing is typically performed at the wellsite. This logging tool operates in an open-hole that is either water- or air-filled. Vertical resolution is approximately $20 \mathrm{~cm}$. Valid measurements require a porosity greater than 3\%; thus, the measurements are typically insensitive to fractures. For characterization of a fractured aquifer the following tool is recommended.

\section{Electrical Imager Logging}

The Fullbore Formation MicoScanner Imager* FMI tool creates a picture of the borehole wall by mapping its electrical resistivity using an array of 192 small, pad-mounted button electrodes to provide an electrical image of the borehole with a resolution of $5 \mathrm{~mm}$ (Ekstrom et al. 1986).

The tool (Figure 6) contains arrays of microresistivity sensors set upon four orthogonal pads and attached flaps. During logging, the lower section of the tool emits current into the formation.

The current is recorded as a series of curves that represent relative changes 


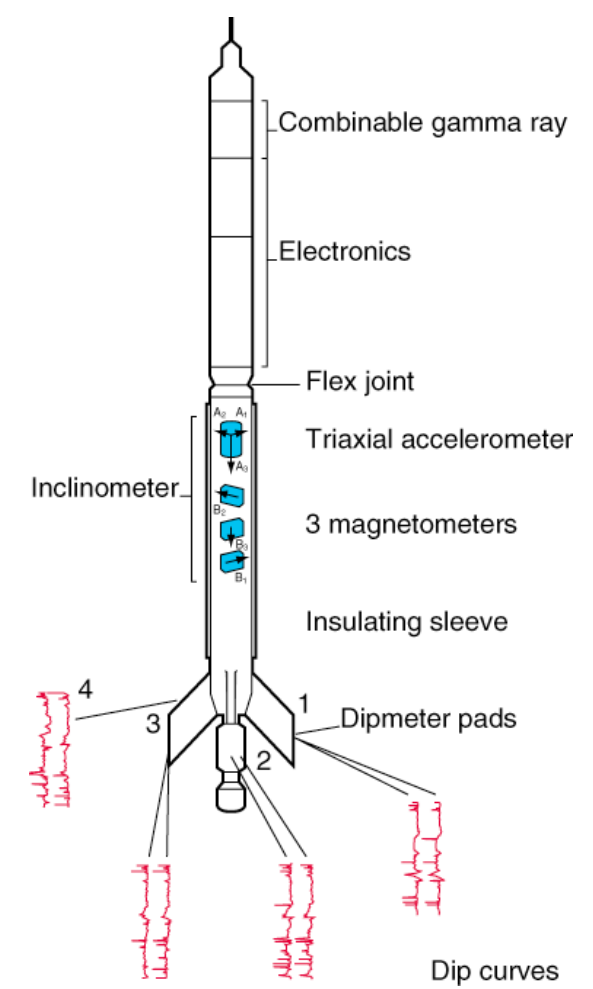

Figure 6: Schematic of electrical imager tool

in microresistivity caused by varying electrolytic conduction as a function of pore geometry, fracture geometry, or by cation exchange on the surfaces of clays and other conductive minerals. These effects produce variations on the images in response to porosity, fracture aperture, grain size, mineralogy, cementation and fluid type.

The current intensity measurements recorded in each button electrode, which reflect the microresistivity variations, are converted to variableintensity color images. The lightest tone representing the most resistive samples, and the darkest the most electrically conductive (Figure 7). The color is synthetic and does not indicate lithology or the true color of the formation.

A planar surface cutting the borehole describes an ellipse on the cylindrical borehole boundary surface. If the

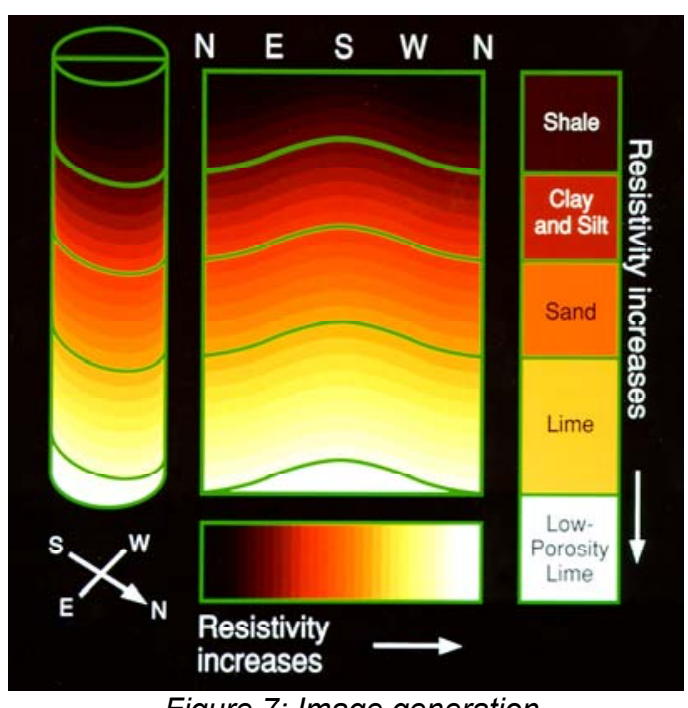

Figure 7: Image generation

cylinder representing the borehole side is cut open and unrolled to become a flat surface, the ellipse becomes a sine wave. The amplitude of this sinusoid is proportional to the apparent dip of the intersecting plane, and the orientation of the trough indicates its apparent azimuth.

A triaxial accelerometer permits determination of tool position, and three magnetometers allow determination of tool orientation. With these inputs, the orientation of all planar features that intersect the borehole wall (e.g., bedding and fractures) is calculated. Dip is represented on a log by a small circle with a tail. The position of the circle along the horizontal axis portrays dip magnitude, ranging from 0 to $90^{\circ}$ on the right. Tail direction is analogous to dip direction, with north at the top of the log.

Fractures form a fairly unambiguous feature on this type of log. Dark (electrically conductive) lines that typically cut across bedding, and sometimes parallel it, are usually considered open, water-filled fractures. Healed fractures typically appear light instead of dark. The image does not tell 
whether a fracture contributes to aquifer production; it tells only that the fracture

is present at the wellbore (Bourke et al. 1989). Determining whether the fracture will produce water, or act as a hydraulic conductivity path or barrier requires the calculation of fracture aperture.

Once fractures are mapped and their orientation is calculated, then fracture density and spacing can be computed. Fracture aperture can be estimated through additional data processing.

Forward modeling of the electrical field present around a fracture using a finiteelement code was used to determine the relationship between fracture aperture, formation resistivity, mud resistivity, and additional current flow caused by the presence of the fracture (Luthi and Souhaité 1990). The resulting equation is:

$A=\frac{W}{R_{m} \bullet c}\left(\frac{R_{x o}}{R_{m}}\right)^{1-b}$

$W$ fracture width $(\mathrm{mm})$

$R_{x o}$ formation resistivity

$R_{m}$ water resistivity

$A$ integrated excess current caused by presence of fracture

$c$ coefficient obtained numerically from forward modeling

$b$ exponent obtained numerically from forward modeling

Note that formation resistivity can not be determined with the imaging tool; it requires the integration of a conventional resistivity or induction log data.
A three-step process to detect, trace, and quantify fractures is used. The fractures are typically mapped as part of the interpretation process; the trace for each fracture is determined by mapping where electrical conductivity significantly exceeds local matrix conductivity followed by line sharpening; and apertures are computed for all fracture locations. This method allows the detection of fractures of $10 \mu \mathrm{m}$ aperture and may resolve fractures about $1 \mathrm{~cm}$ apart.

Figure 8 presents a portion of a log collected in a fractured basalt aquifer. This log depicts primarily the FMI results that include: images (tracks 3 and 5), calculated apertures in logarithmic scale (track 4), fracture orientation (track 6), fracture trace length and density (track 7). Each fracture trace with aperture is superimposed on the image in track 3.Track 2 depicts different porosity logs, and it includes the fracture porosity. Each horizontal division is equivalent to 2 feet $(60 \mathrm{~cm})$ in depth.

Fully processed images and dip data can also be provided at the wellsite in real time. Fracture analysis requires further processing. The tool is designed to work in a water-filled, open borehole. Unlike optical televiewers, this tool is unaffected by water opacity.

\section{References}

Allen, D., S. Crary, B. Freedman, M. Andreani, W. Klopf, R. Badry, C. Flaum, B. Kenyon, R. Kleinberg, P. Gossenberg, J. Horkowitz, D. Logan, J. Singer, and J. White. 1997. "How to Use Borehole Nuclear Magnetic Resonance." Oilfield Review, v. 9, n. 2, p. $34-57$. 
Bourke, L., P. Delfiner, J. Touiller, T. Fett, M. Grace, S. Luthi, O. Serra and E. Standen. 1989. "Using Formation MicroScanner Images." The Technical Review, v. 37, n. 1, p. $16-40$.

Ekstrom, M.P., C.A. Dahan, M.Y. Chen, P.M. Lloyd, and D.J. Rossi. 1986. "Formation Imaging with Microelectrical Scanning Arrays." Transaction of the SPWLA $27^{\text {th }} \quad$ Annual Logging Symposium, Houston, paper BB.
Kenyon, B., R. Kleinberg, C. Straley, G. Gubelin, and C. Morris: 1995. "Nuclear Magnetic Resonance ImagingTechnology for the $21^{\text {st }}$ Century." Oilfield

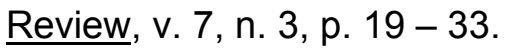

Luthi, S.M. and P. Souhaité. 1990. "Fracture Apertures from Electrical Borehole Scans." Geophysics, v. 55, n.7, p. $821-833$.

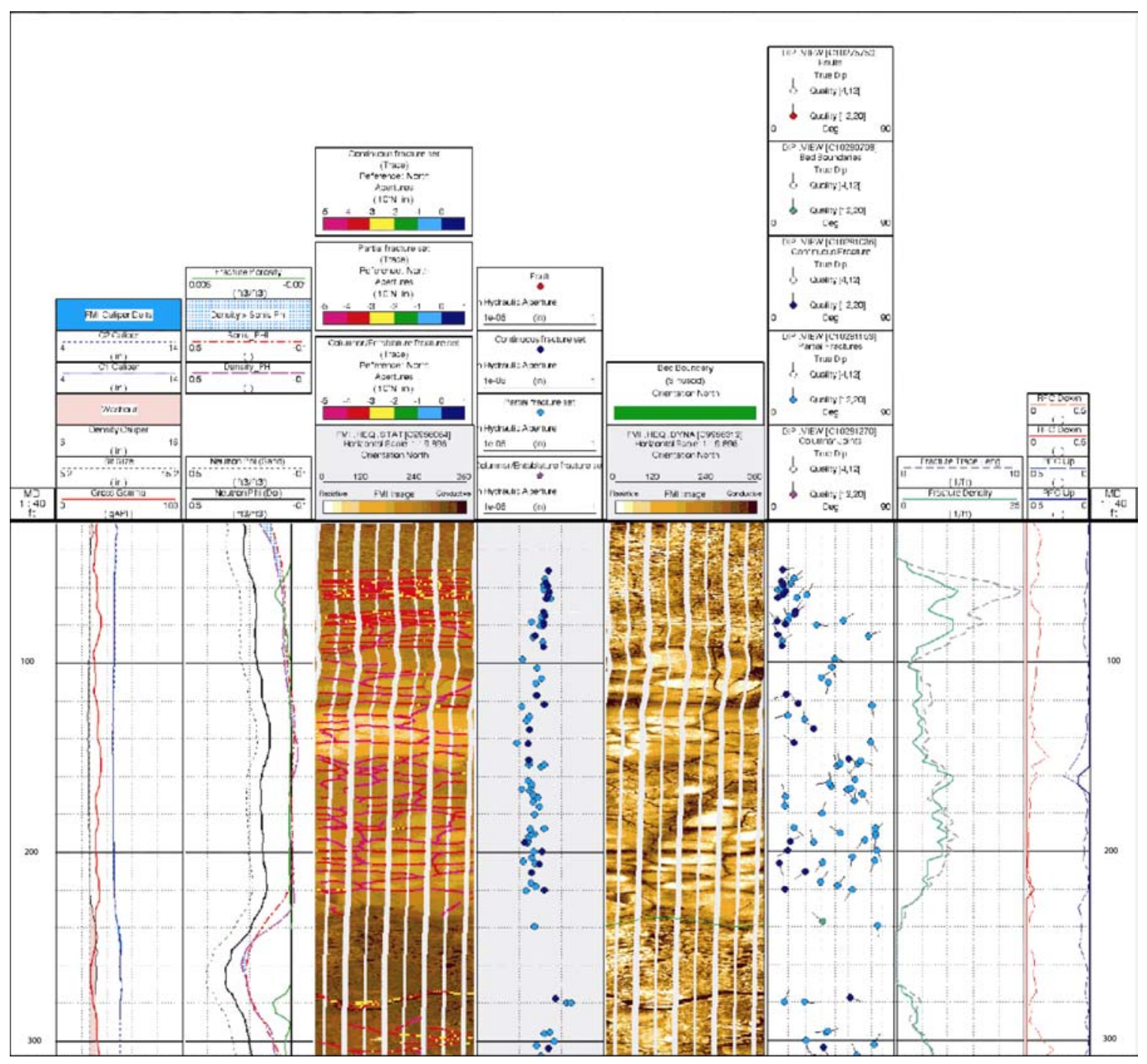

Figure 8: Electrical imager log of basalt 


\section{Appendix C}

\section{Examples of Folds and Faults in Columbia River Basalt Group Flows from the Columbia Basin}




\section{Appendix C}

\section{Examples of Folds and Faults in Columbia River Basalt Group Flows from the Columbia Basin}

This appendix provides examples of Yakima folds and the smaller-scale geologic features that are found in the fold belt.

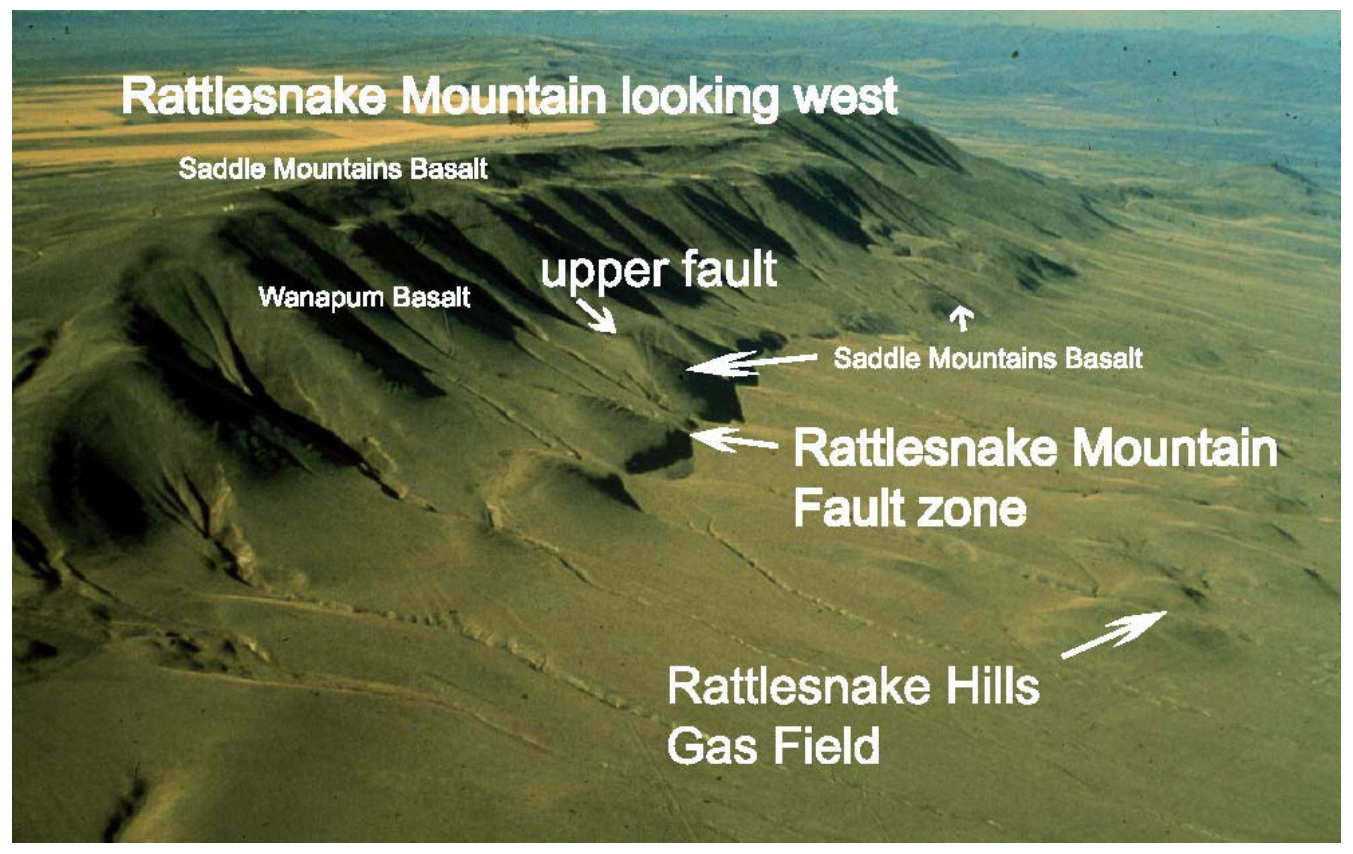

Figure C.1. Rattlesnake Mountain as Viewed from the East and Looking West. The main fault zone is visible at the base of the ridge. The scarp is actually hogbacks of the Elephant Mountain Member (10.5 Ma) tilted northeast. Rattlesnake Mountain is one of the highest Yakima fold with the crest of the ridge at 3600 feet elevation. 


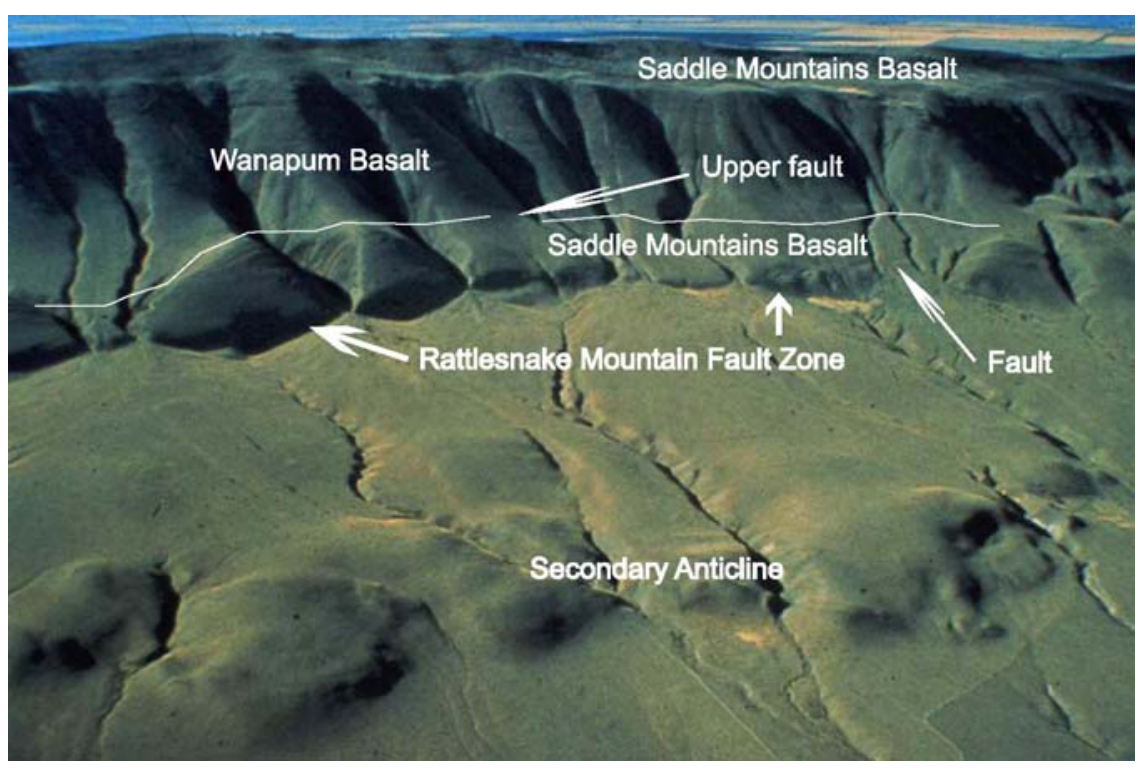

Figure C.2. Rattlesnake Mountain Looking Southwest. The secondary anticline is the Rattlesnake Hills gas field.

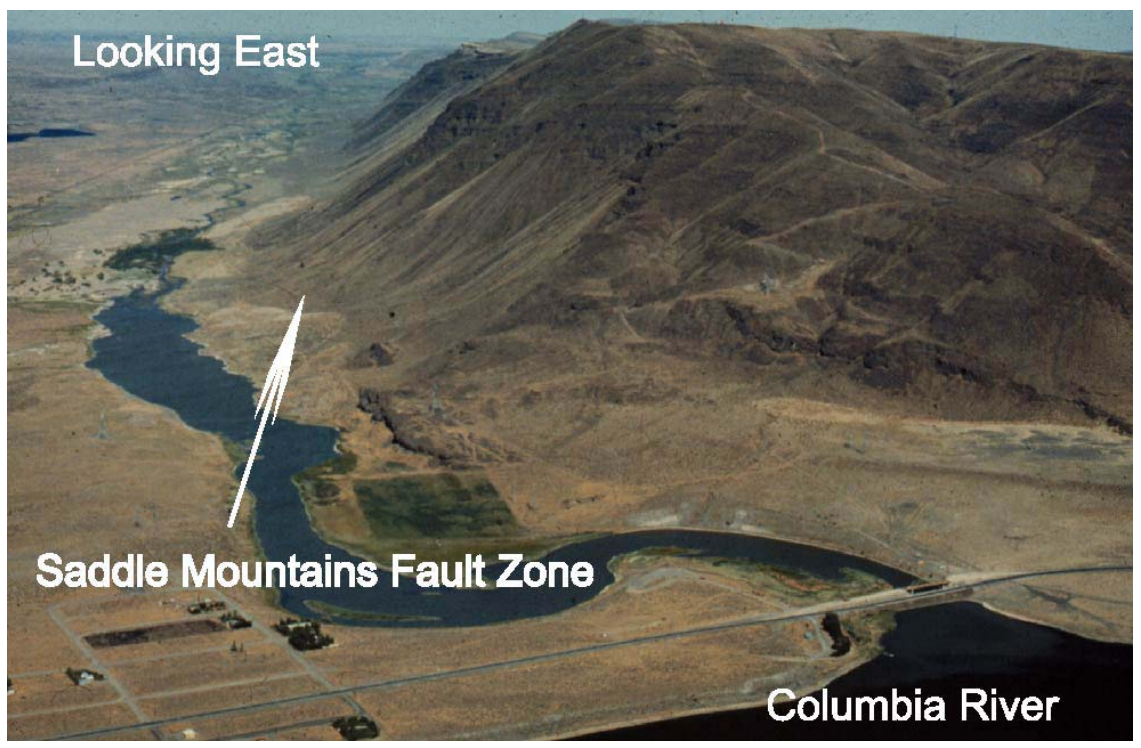

Figure C.3. Saddle Mountains Anticline Viewed from the West. The Priest Rapids Member (14.5 Ma) makes the surface rock in Crab Creek and the top flow at the highest pointing the foreground. 


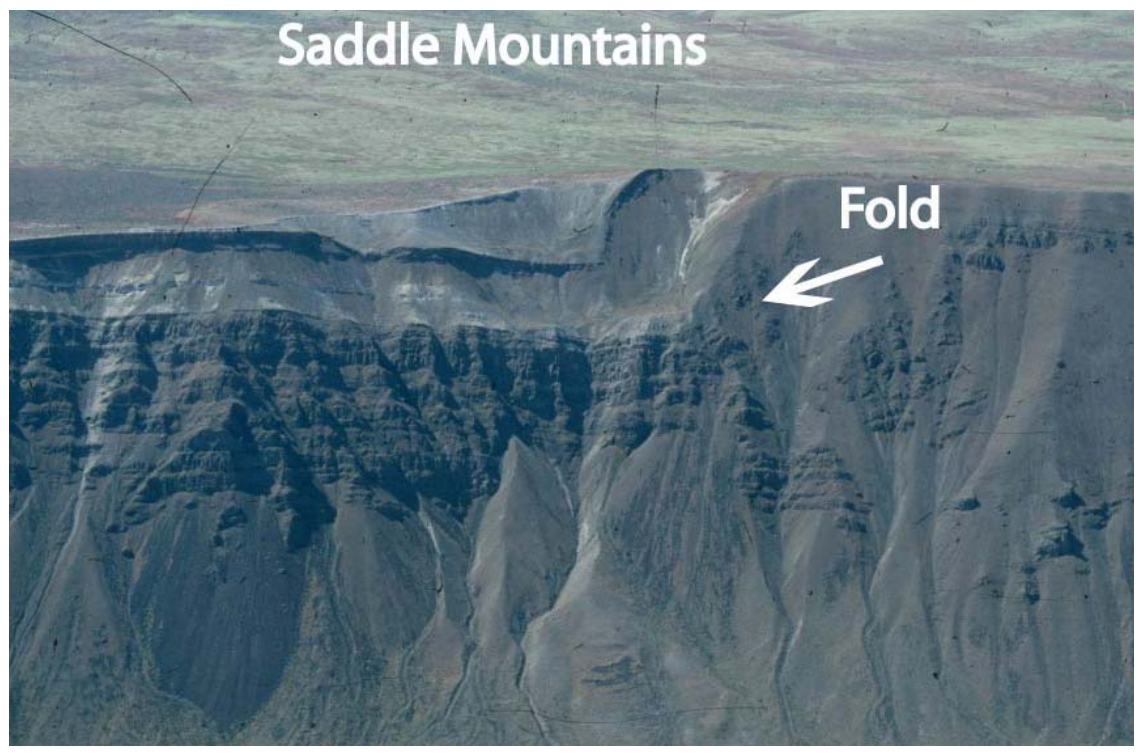

Figure C.4. Small Fold on the North Face of the Saddle Mountains. No fault could be found at this sharp bend. The uppermost resistant ledge in the fold is the Elephant Mountain Member (10.5 Ma) intercalated with Ellensburg Formation sediments forming a small basin.

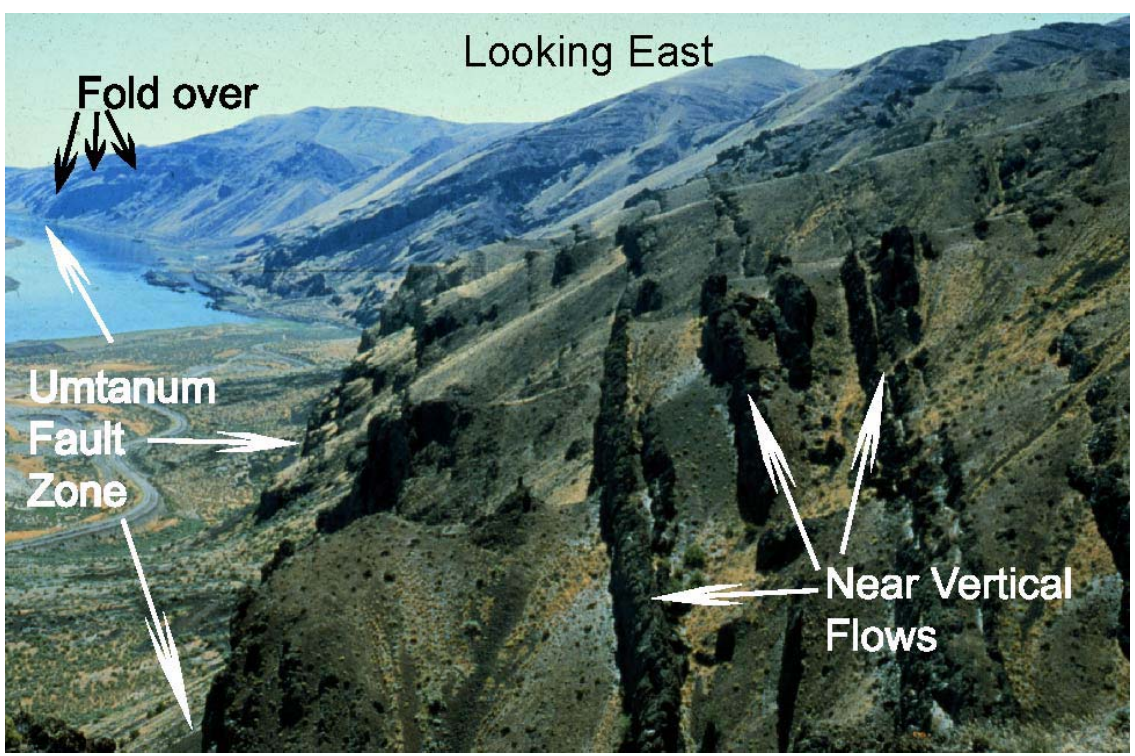

Figure C.5. Umtanum Ridge Anticline Viewed from Near Priest Rapids Dam 


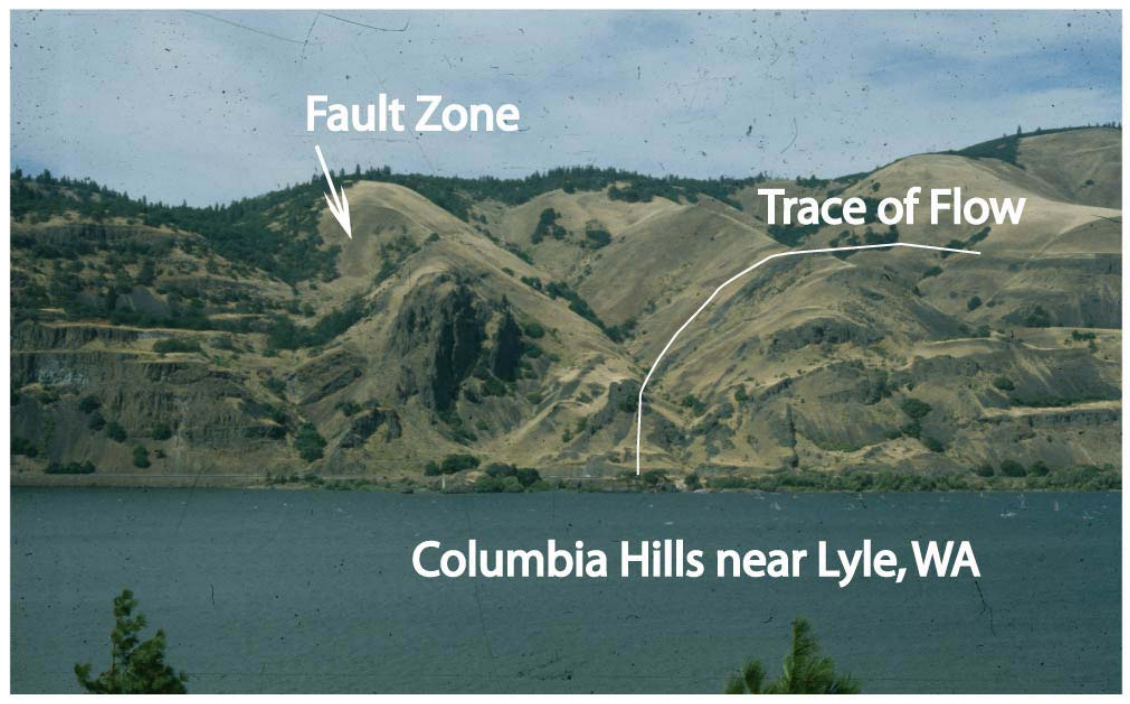

Figure C.6. Columbia Hills Anticline and Fault Where it Crosses the Columbia River on the East End of the Columbia Gorge

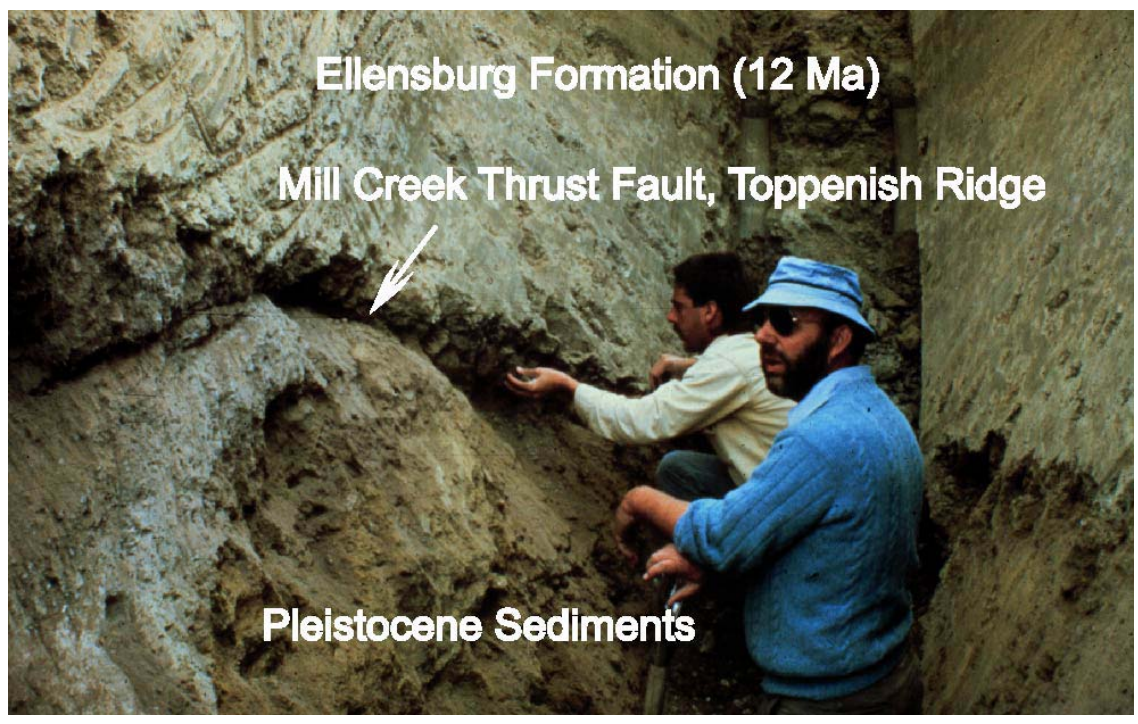

Figure C.7. Mill Creek Thrust Fault Exposed in Trench Cut into Toppenish Ridge. Movement of the upper plate is to the north (out of the page). 


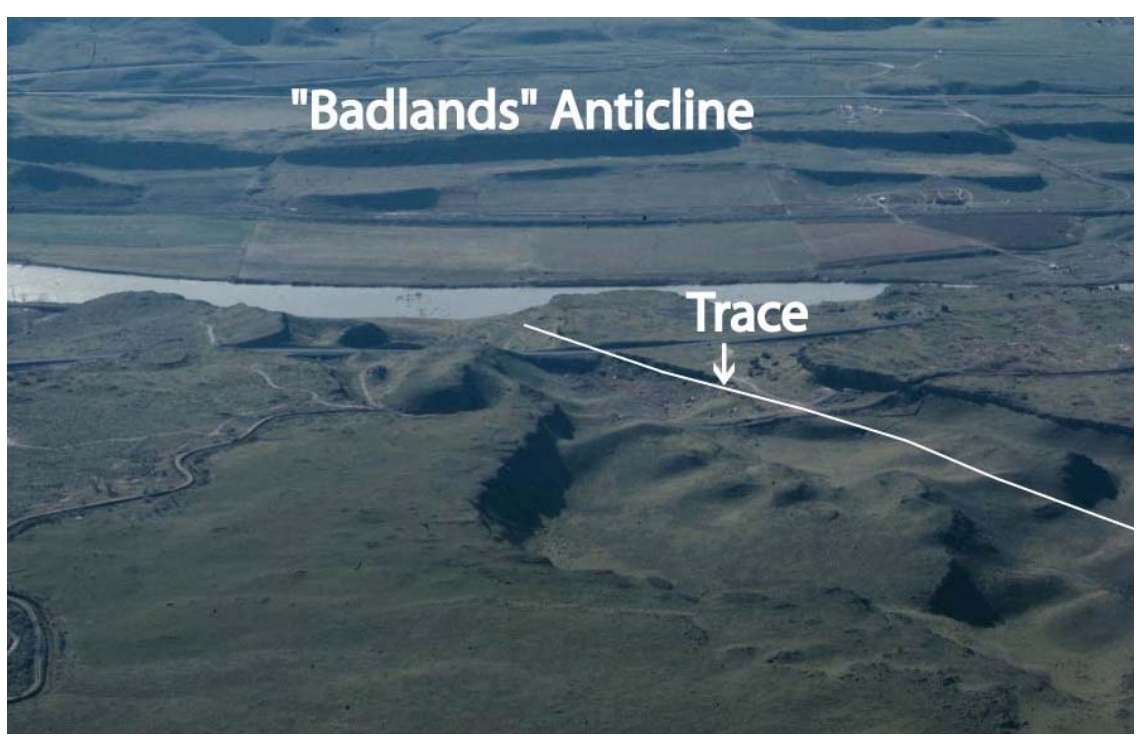

Figure C.8. Badlands Anticline. The badlands anticline is the northwest extension of the northwest segment of the Horse Heaven Hills anticline west of Benton City, Washington. View if from the north to the south along the Yakima River.

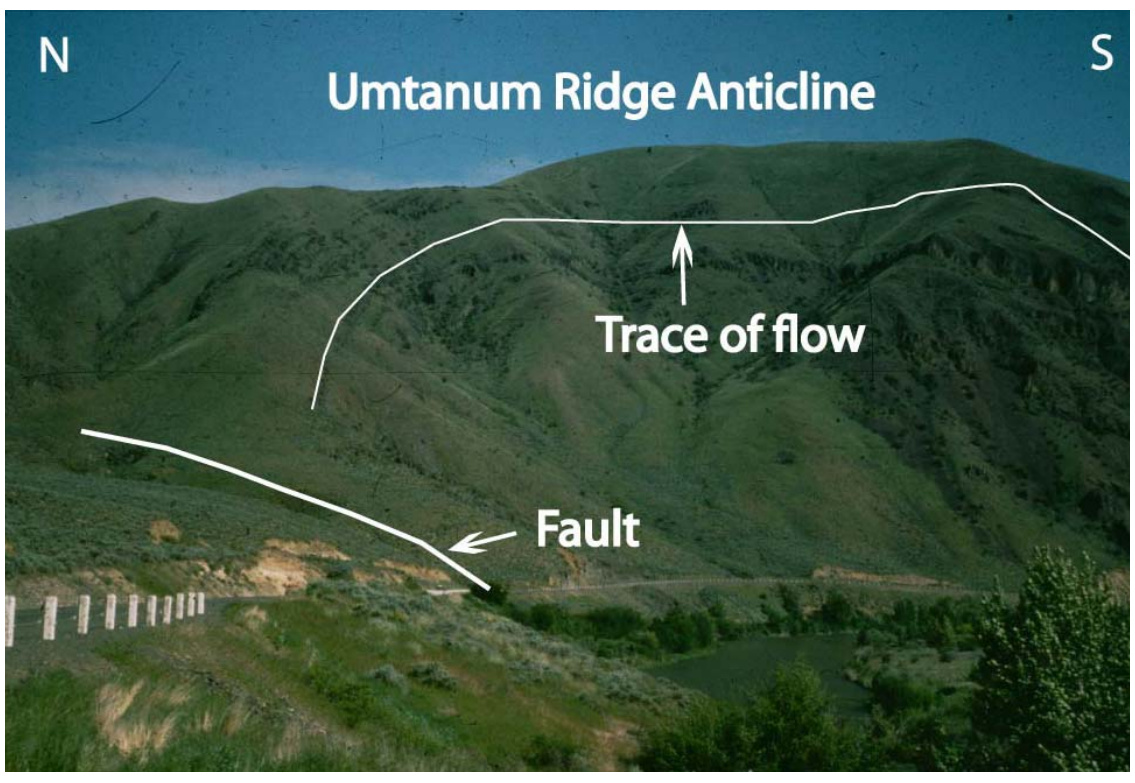

Figure C.9. Cross Section Through Umtanum Ridge Anticline in the Yakima River Canyon North of Yakima Washington 


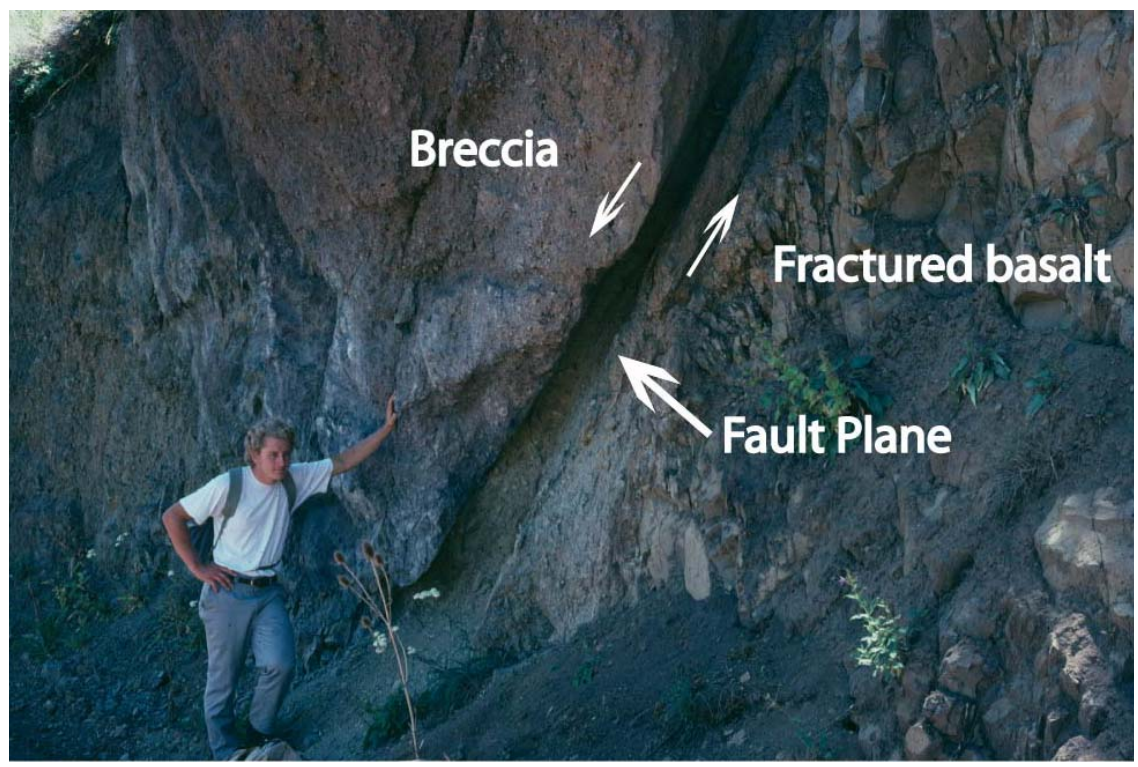

Figure C.10. Normal Fault in Grande Ronde Basalt from the Snake Canyon, Oregon-Washington-Idaho border. Note brecciated hanging wall.

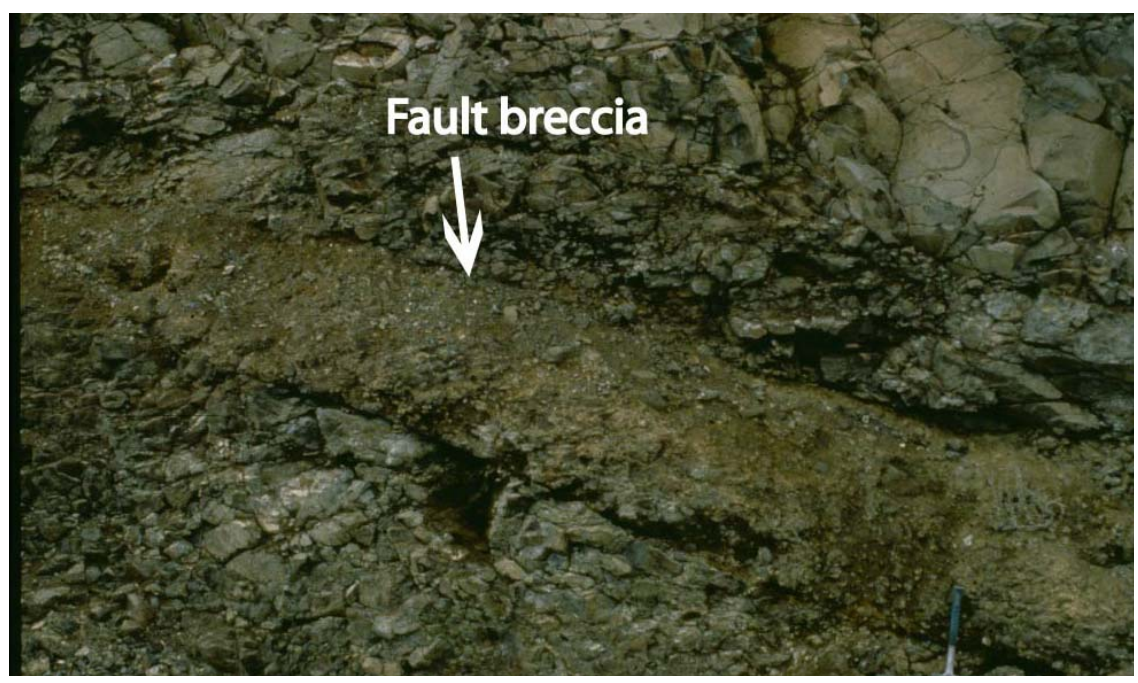

Figure C.11. Small Thrust Fault Zone in Basalt. Note pen in lower right for scale. Note brecciated nature of fault gouge. 


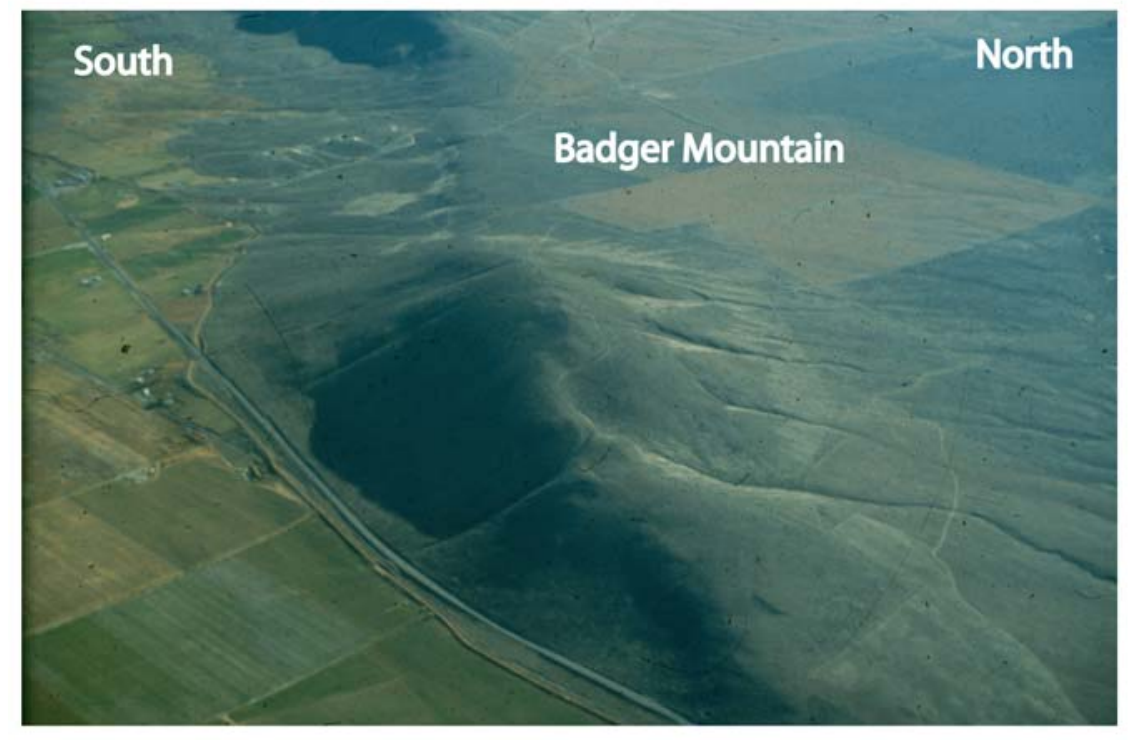

Figure C.12. Badger Mountain Looking Northwest. Badger Mountain is one of the small doubly plunging anticlines along the Rattlesnake-Wallula alignment in the Central Columbia Basin.
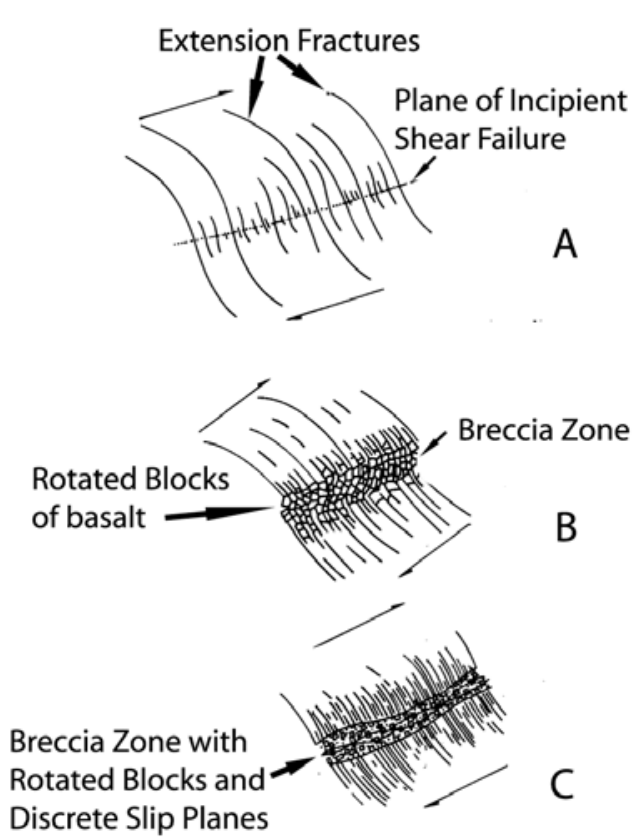

Figure C.13. Three Stages of the Development of a Breccia Zone (Price 1981). A. development of incipient shear zone. B. Shear zone begins to brecciate and blocks begin to rotate. $\mathrm{C}$. Breccia zone with rotated blocks and discrete slip planes. See Figure C-13 through C-18 for field examples from the development of these stages. 

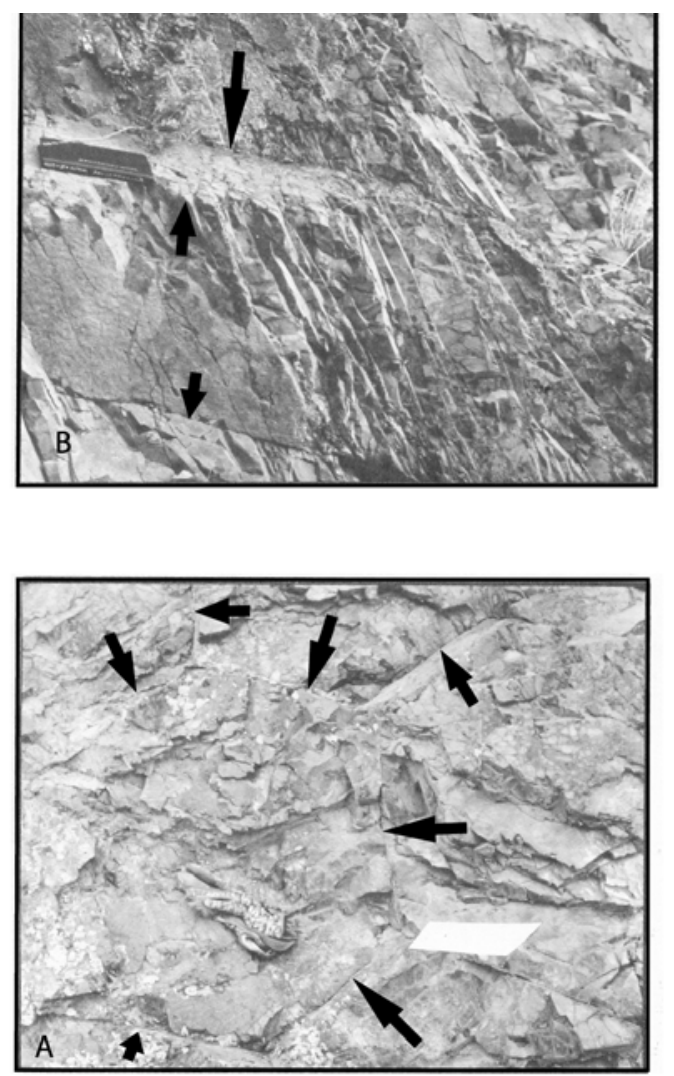

Figure C.14. Shattered Cooling Columns During Stage A of Figure C.13 (Price 1981). A. End view. Arrows show cooling fractures. B. Shattered brecciated columns lie on column face.

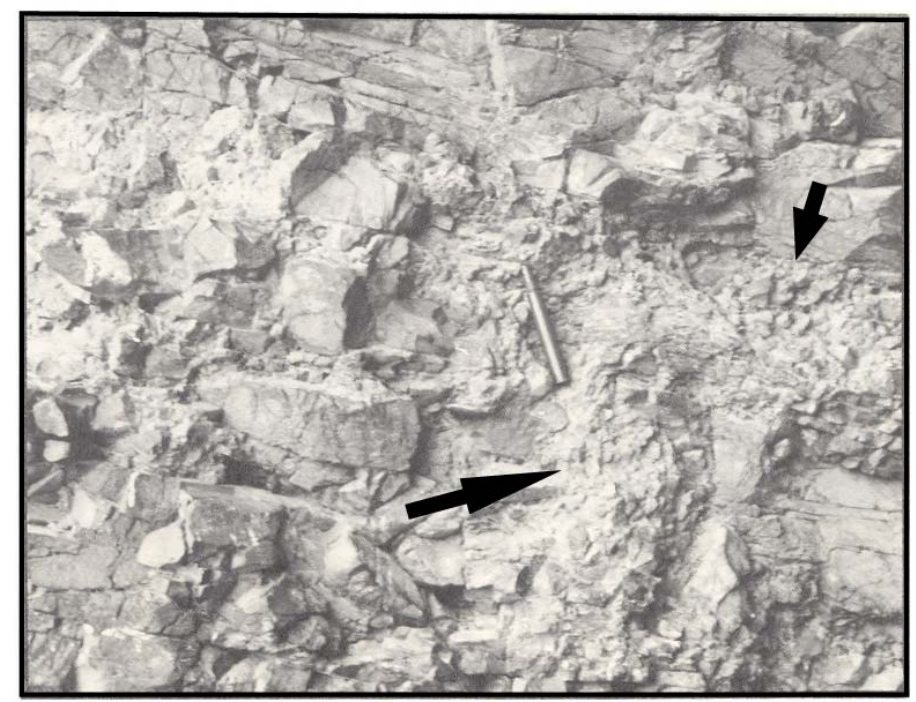

Figure C.15. Anastomosing Breccia Begins to Develop (Price 1981). Stage B Figure C.13. 


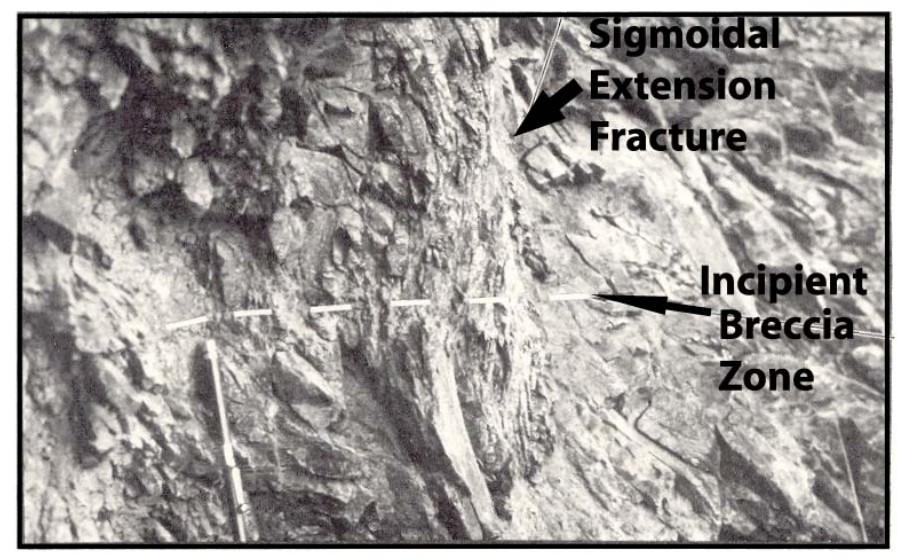

Figure C.16. Sigmodial Extension Fractures Develop as Rotation Begins (Stage B, Figure C.13) (Price 1981)

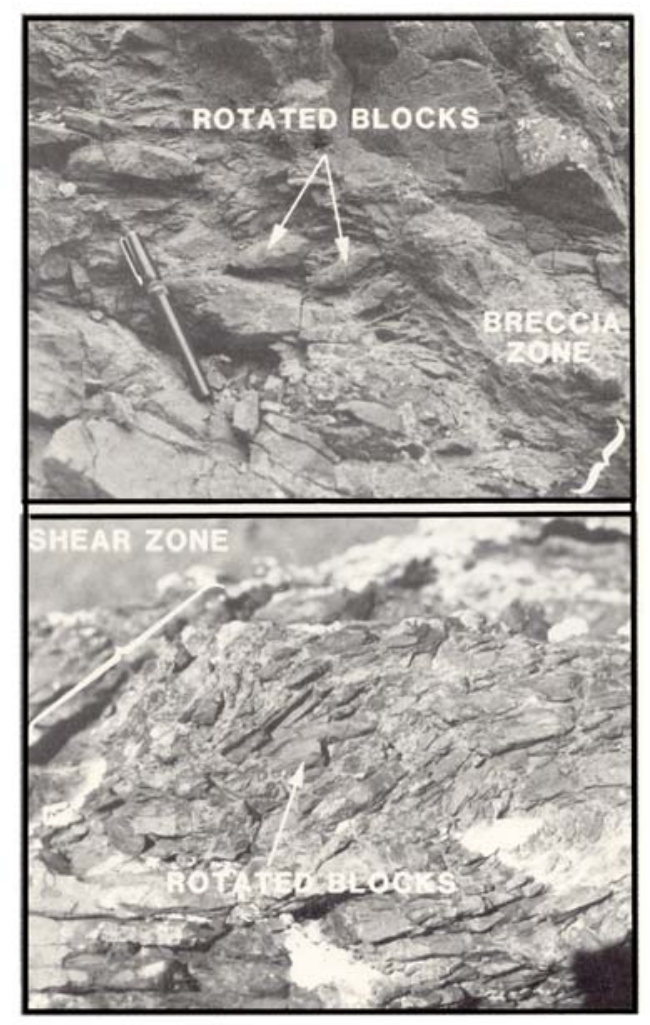

Figure C.17. Rotation of Blocks (Stage B, Figure C.13) (Price 1981) 


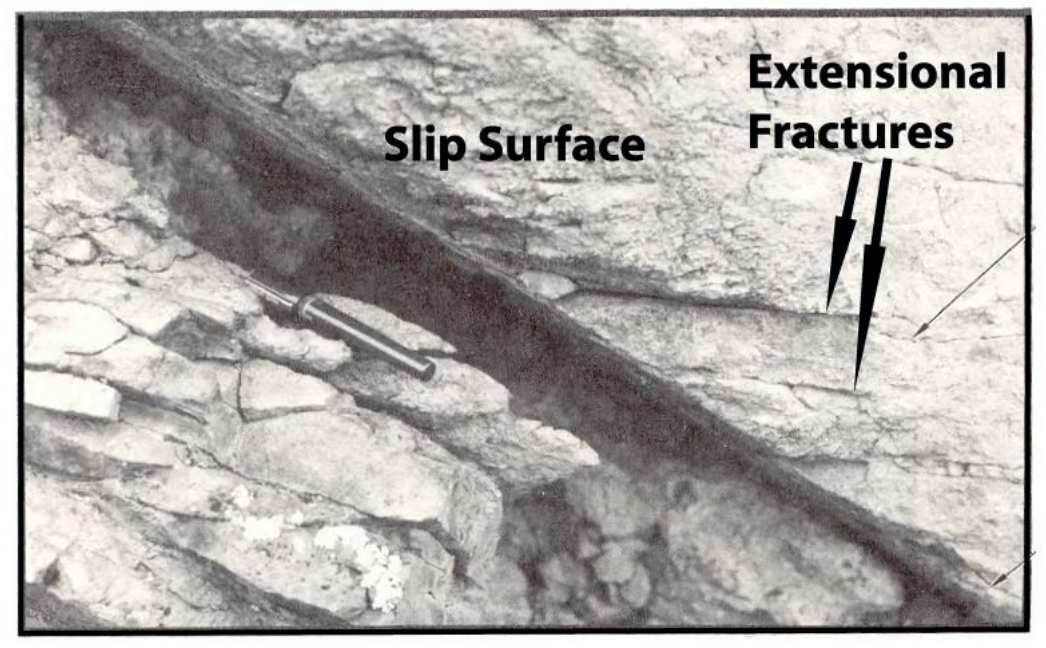

Figure C.18. Stage C, Figure C.13. Development of discrete slip surface (Price 1981). 

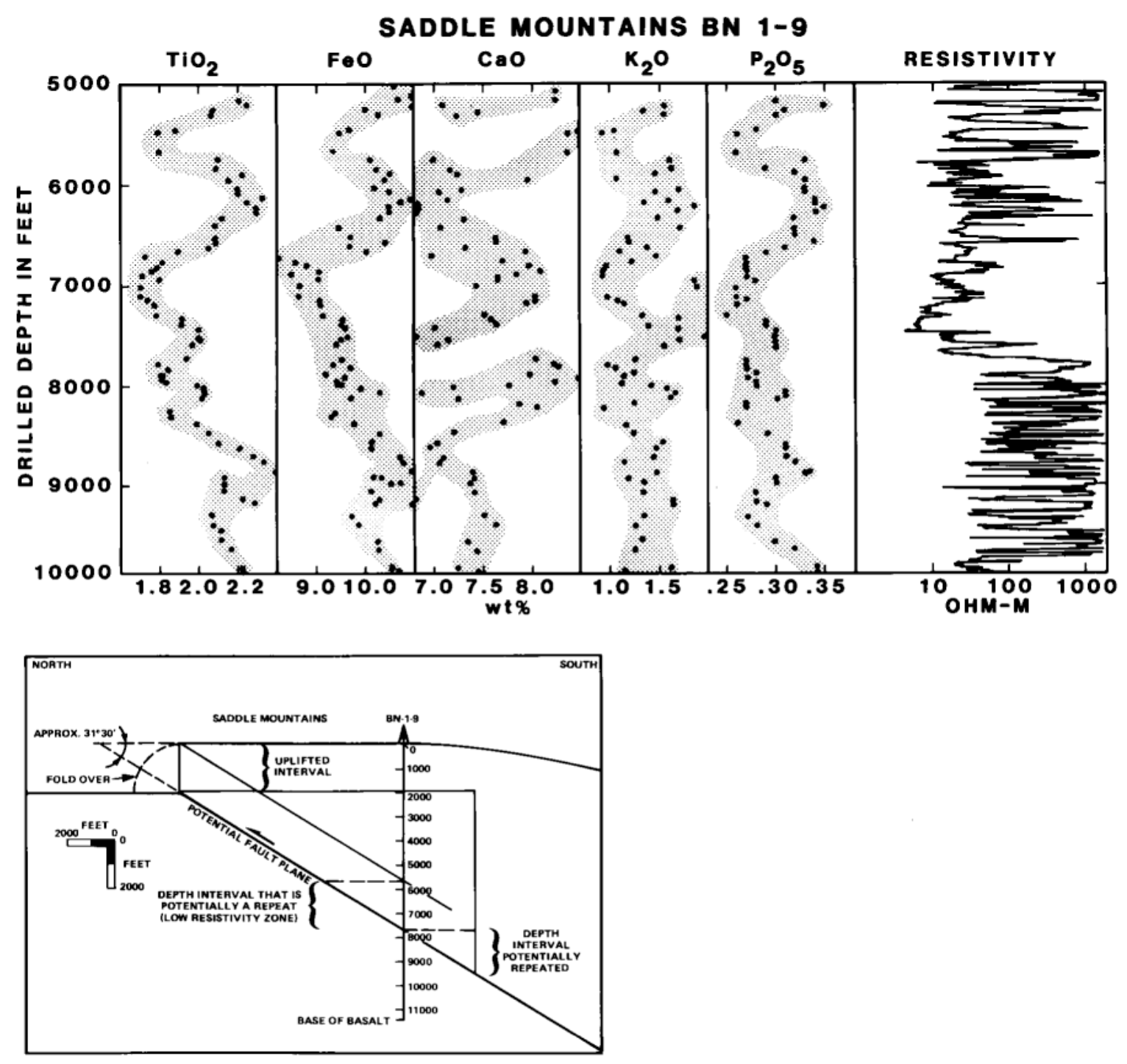

Figure C.19. Use of Chemistry for Determining if the Basalt Stratigraphy has Been Repeated Due to Faulting (from Reidel et al. 1989). The lower figure shows a no vertical exaggeration diagram of the Saddle Mountains with borehole 1-9 BN. The resistivity log suggests fracturing and potential faulting between 7,000 to 8,000 feet (low resistivity). The chemical diagrams show that there is no repeat in the chemistry of the flows indicating that there is no significant repeat in the stratigraphy due to faulting. 


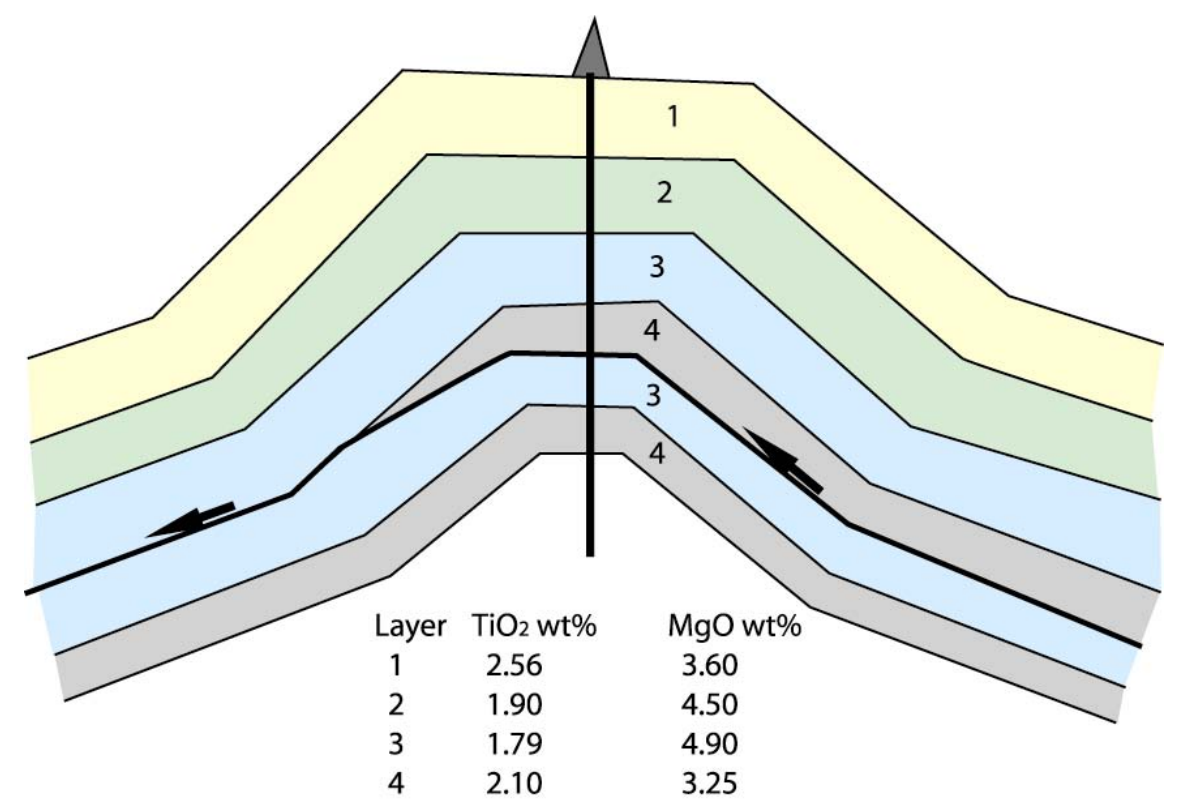

Figure C.20. Use of Chemistry for Determining Repeated Stratigraphy Due to Faulting. In this example, two flows ( 3 and 4 ) have been repeated by faulting and the chemistry shows the repeat. If chip samples were analyzed from the lava flows penetrated by the borehole, then chemistry of lava flows 3 and 4 would be repeated. To effectively use chemistry for identifying a repeated stratigraphy, the proper stratigraphic order would have to be known, including the lava flows below 4. A comparison of the "predicted" stratigraphy to the "actual" stratigraphy would then show the repeated lava flows. Establishing the "expected" stratigraphy for an area is discussed in Appendix G. 


\section{Appendix D}

\section{Examples of Surface Geophysical Surveys}




\section{Appendix D}

\section{Examples of Surface Geophysical Surveys}

This appendix provides selected regional and Hanford Site geophysical survey results. 


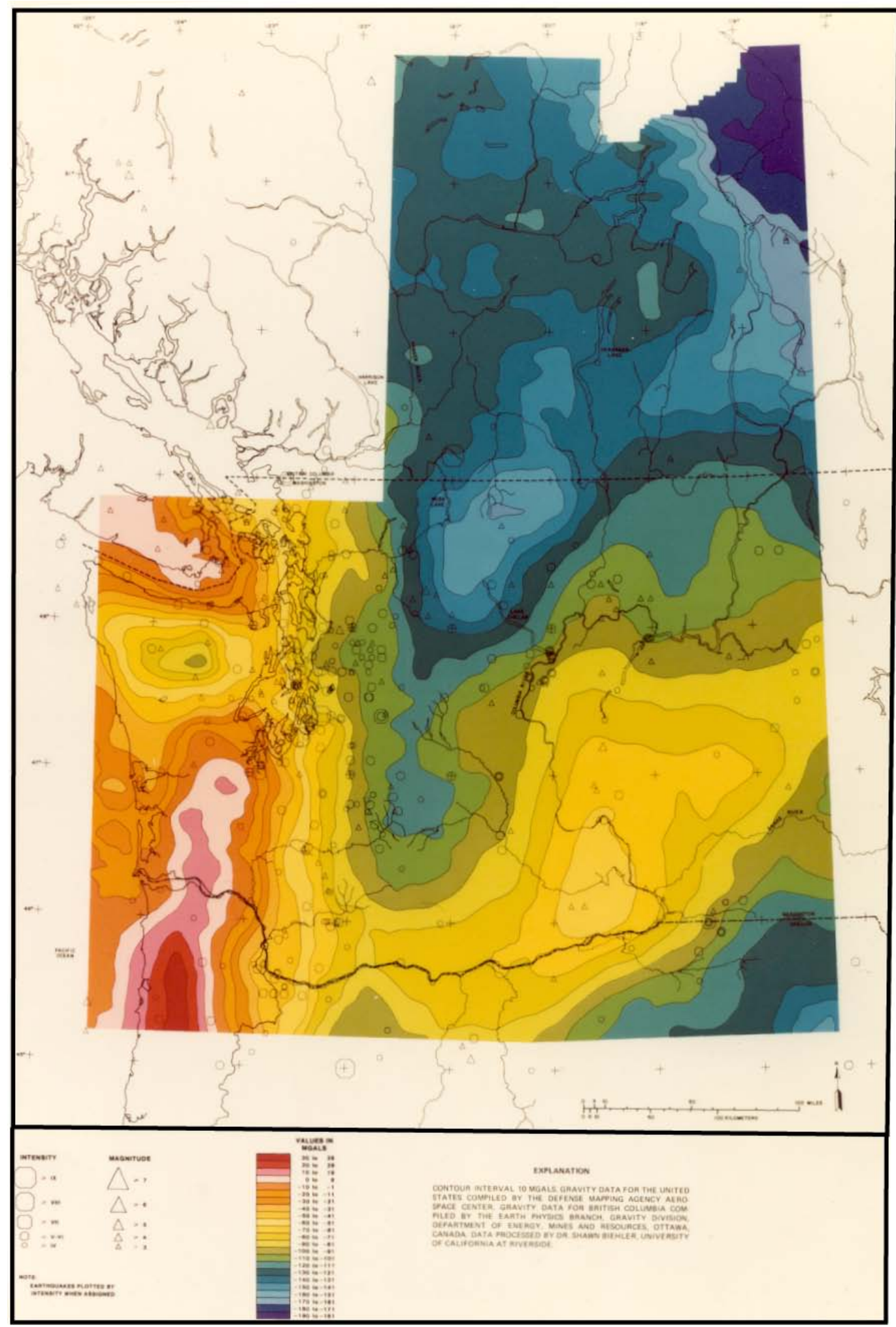

Figure D.1. Regional Gravity Map for the Columbia Basin (from WPPSS 1981) 


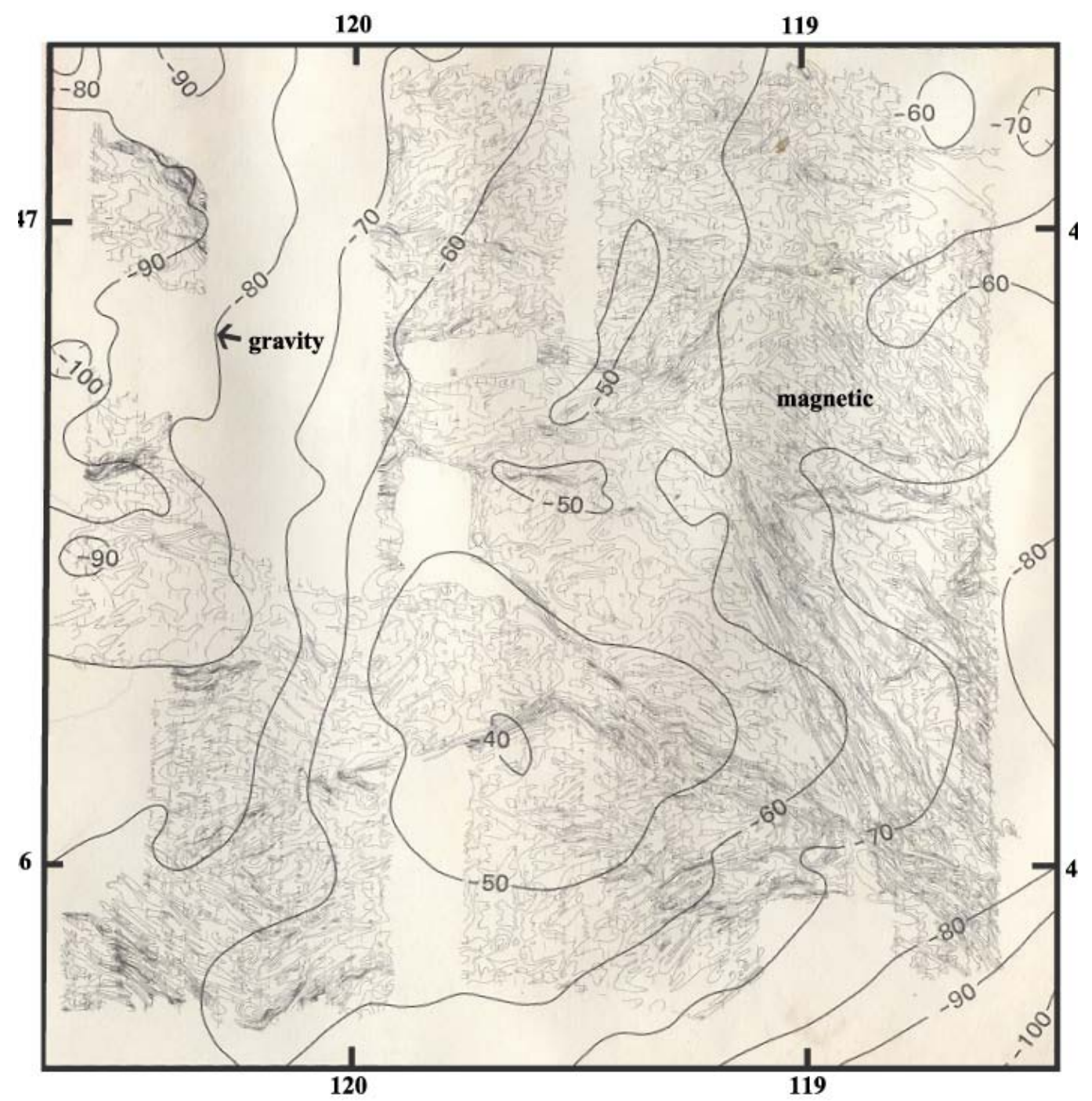

Figure D.2. Magnetic and Gravity Data from the Columbia Basin (Swanson et al. 1979a). The most prominent magnetic features on the map are the Yakima folds (e.g., Horse Heaven Hills centered at 40) and the northwest-trending Ice Harbor dike swarm on the east side of the map. 


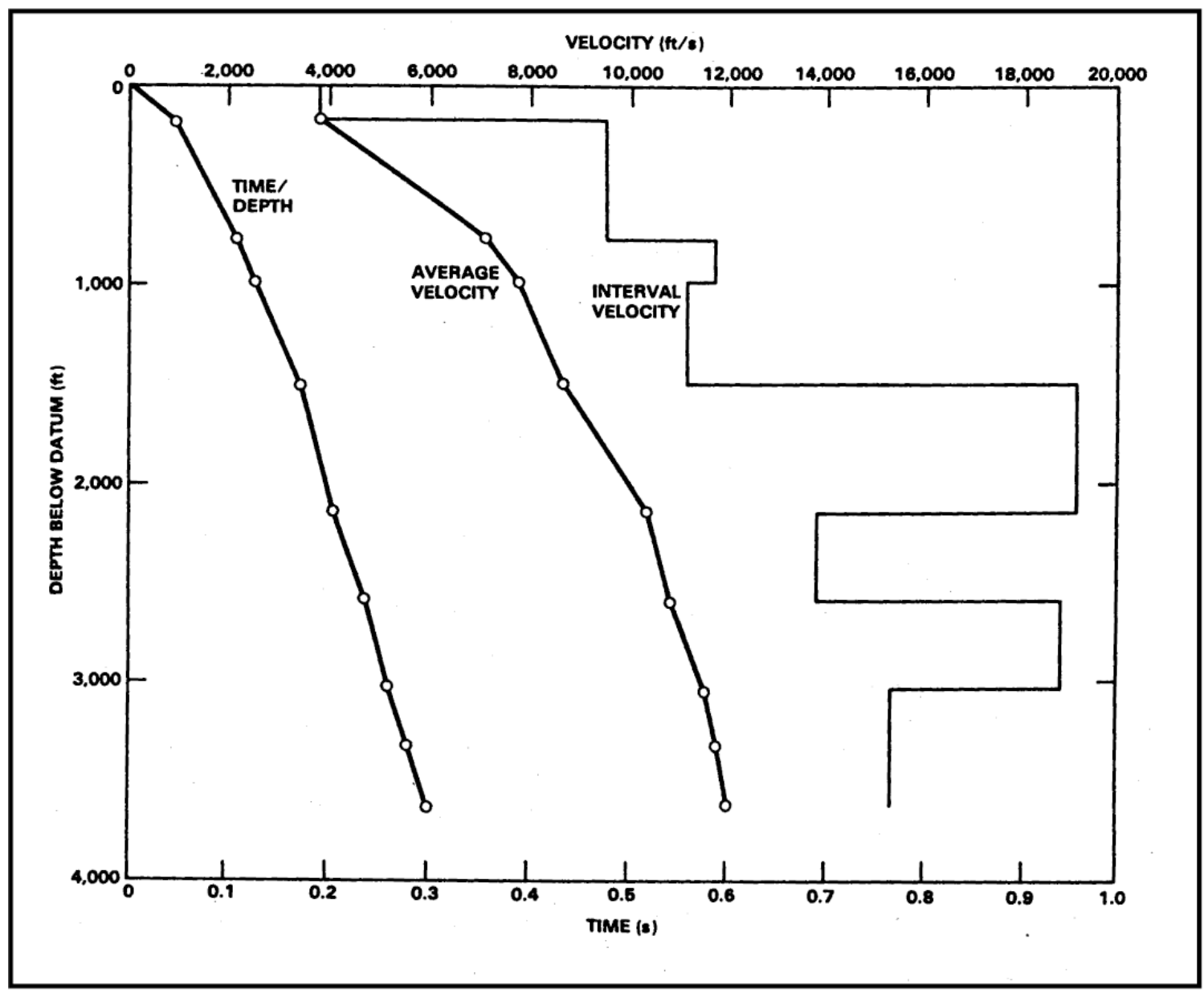

Figure D.3. Time versus Depth and Velocity Curves from Borehole DC-6 at the Hanford Site. See Figure D. 4 for location of borehole DC-6. From 0 feet to 350 feet is sediment overlying the basalt. The Saddle Mountains Basalt is from 350 feet to 993 feet. Wanapum Basalt is from 993 feet to 2,155 feet. The Grande Ronde Basalt is from 2,155 feet to total depth. The increasing velocity reflects fewer sedimentary interbeds between the younger, upper basalt lava flows. 


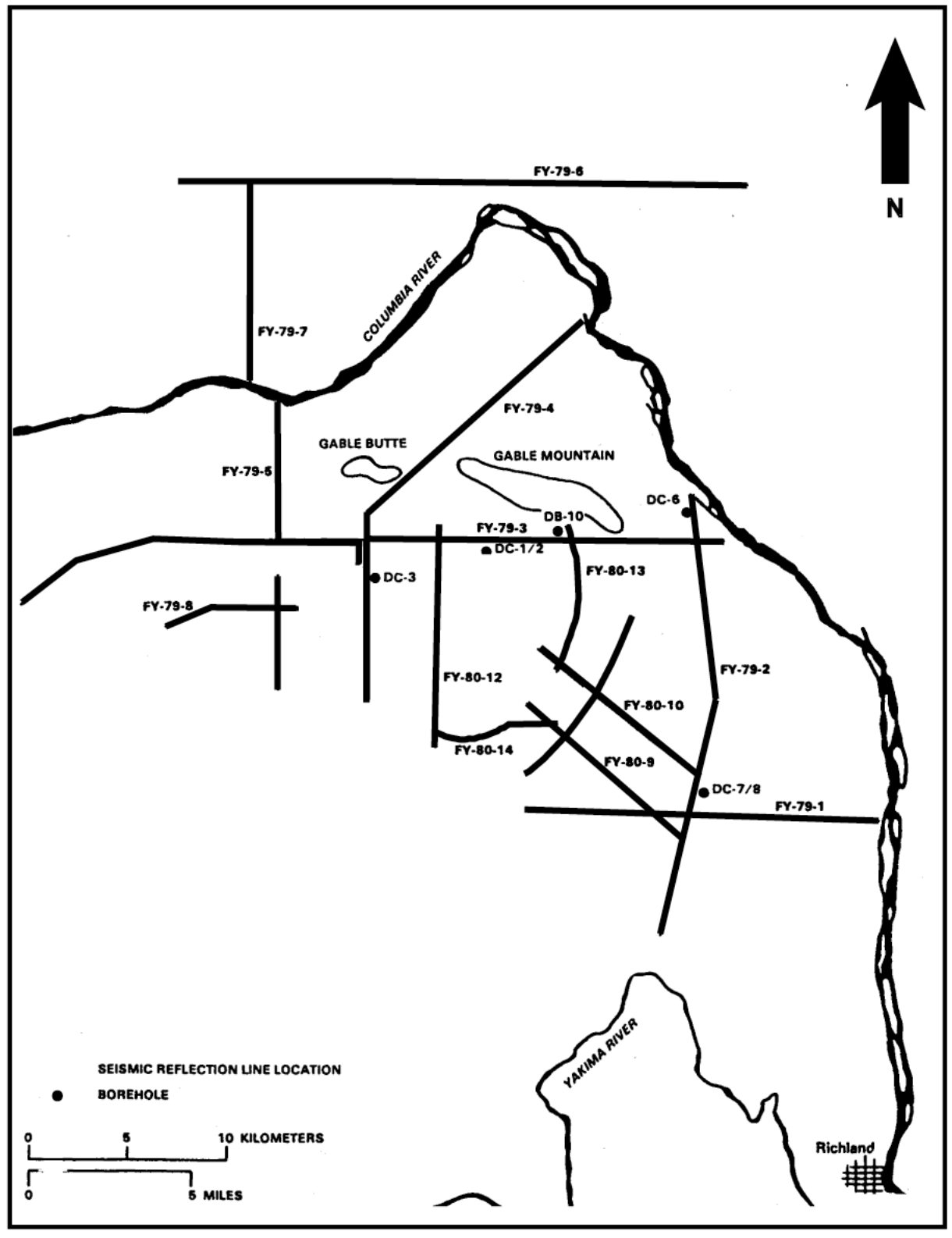

Figure D.4. Location of Seismic Reflection Lines Conducted on the Hanford Site 


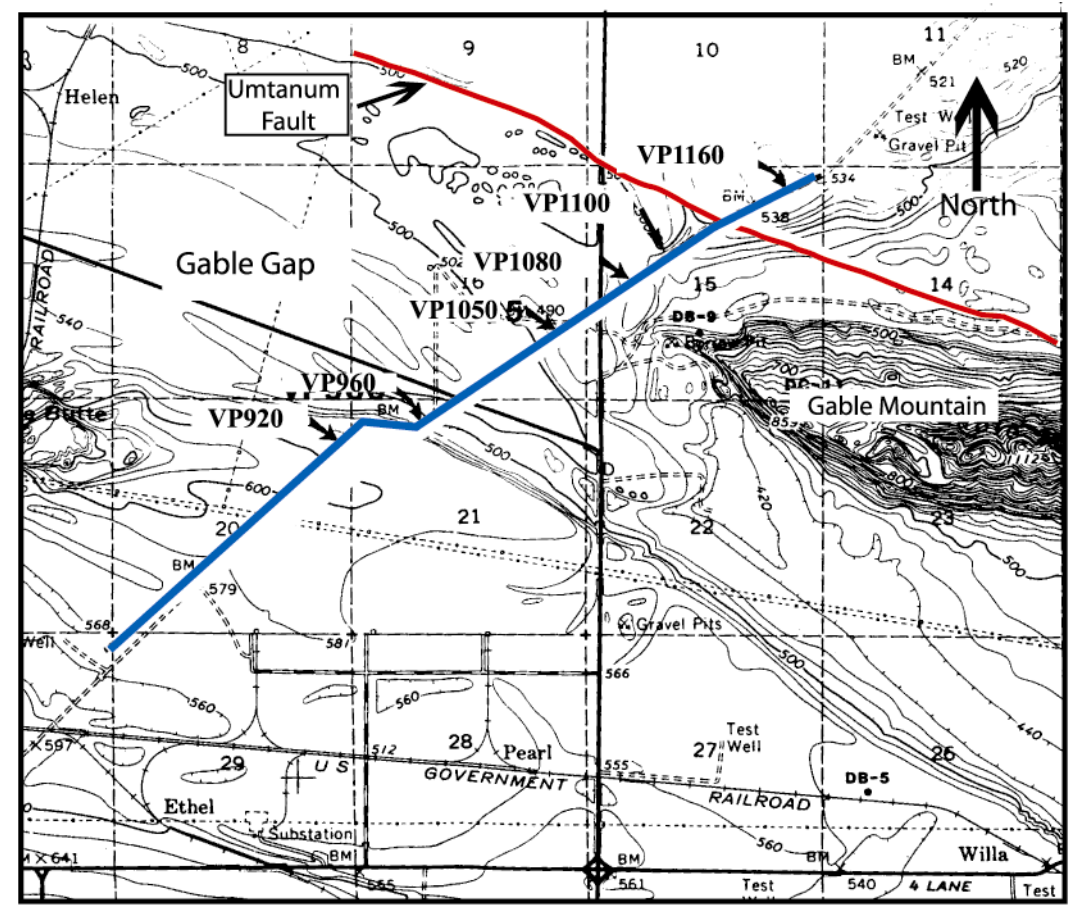

Figure D.5. Location for Seismic Reflection Line FY79-4 (Figure D.4) and Shown in Figure D.6. The seismic survey shown is located on the Hanford Site and crosses the Umtanum Ridge-Gable Mountain structure. 


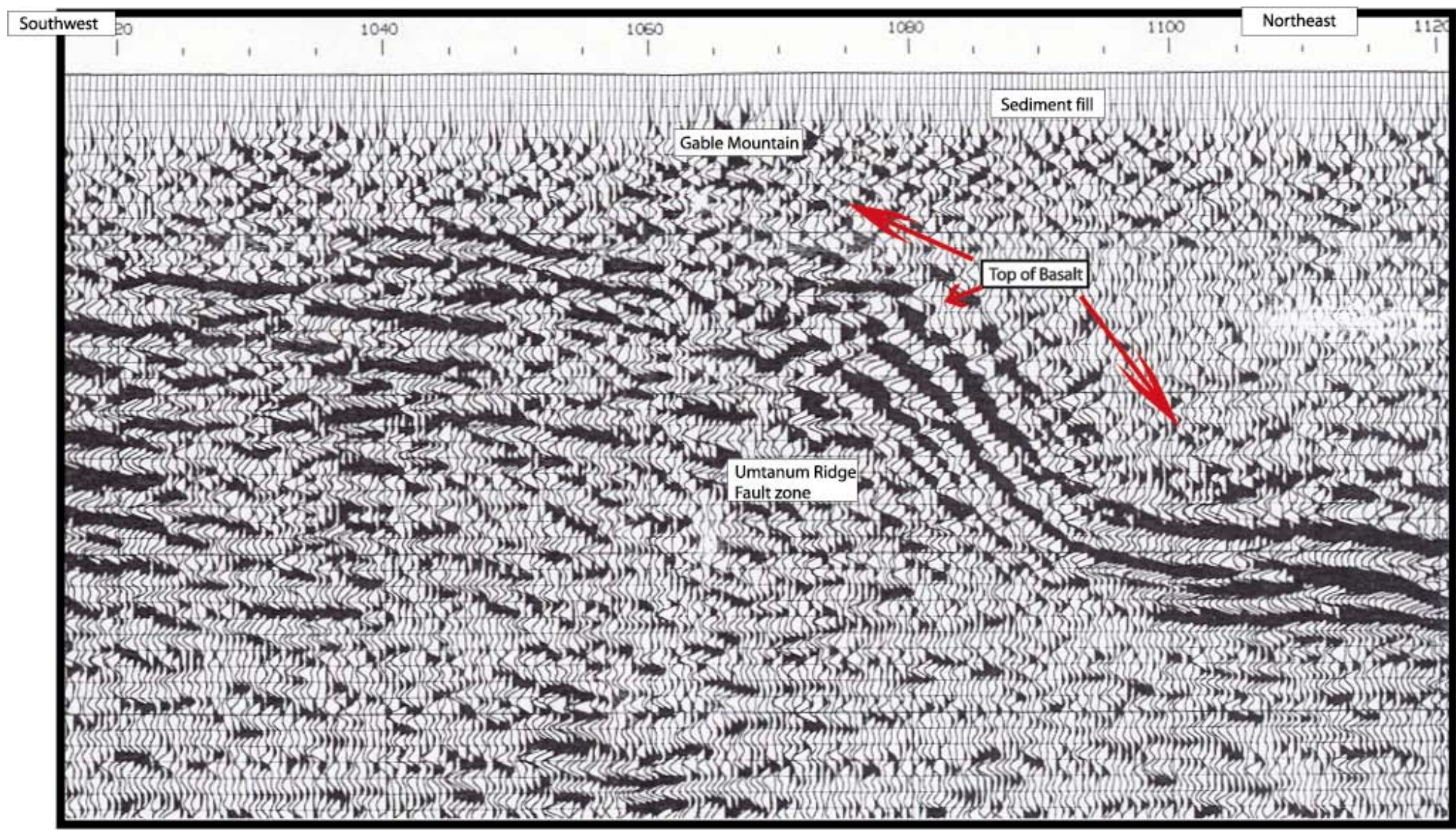

Figure D.6. Seismic Line Across the Gable Mountain-Umtanum Ridge Anticline (see Figure D.5 for location of seismic line) 


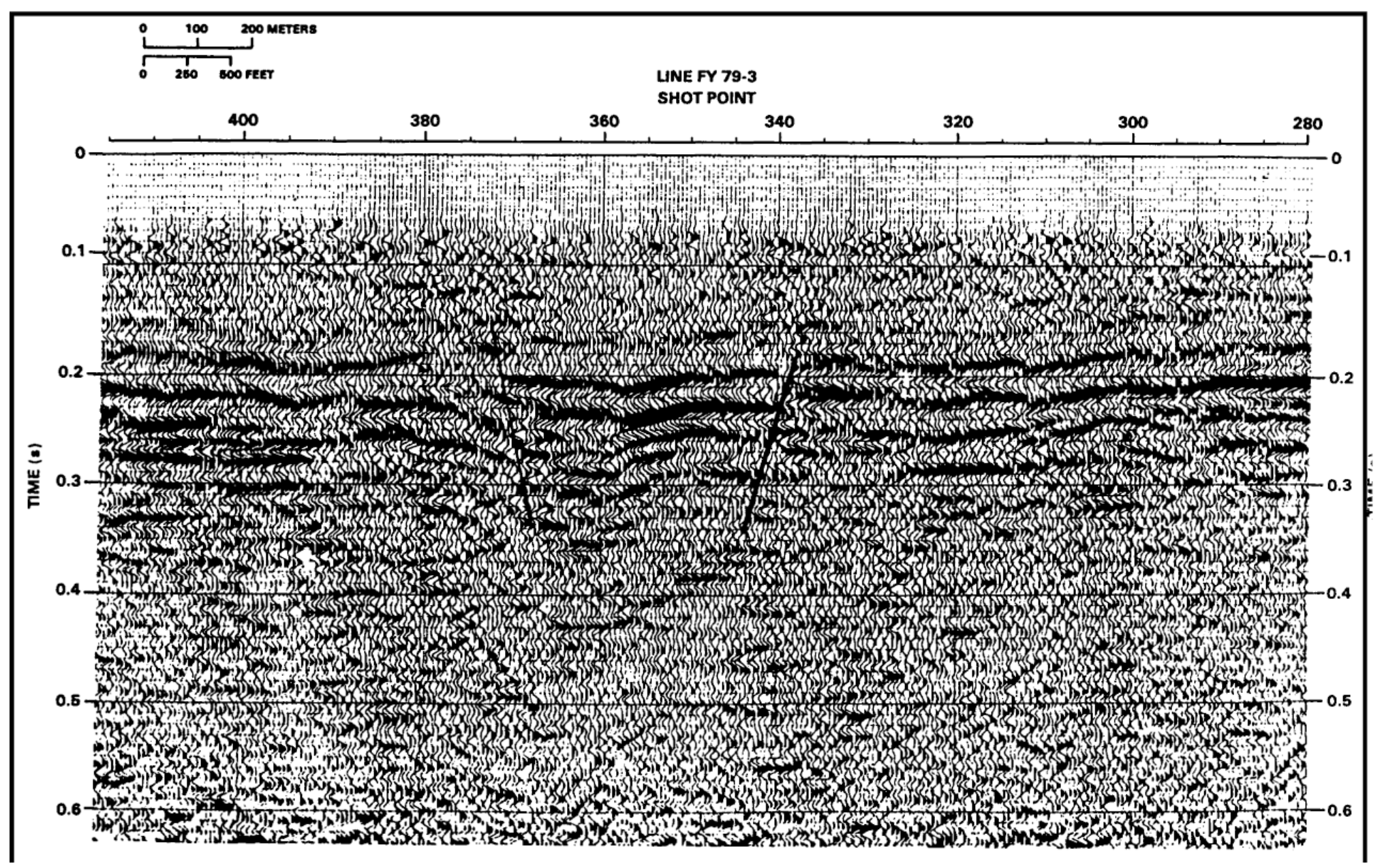

Figure D.7. West to East Seismic Reflection Line FY79-3 Crossing Normal Faults in Basalts (May Junction fault). West is to left and east is to right. (See Figure D.4 for location of seismic reflection line.) 


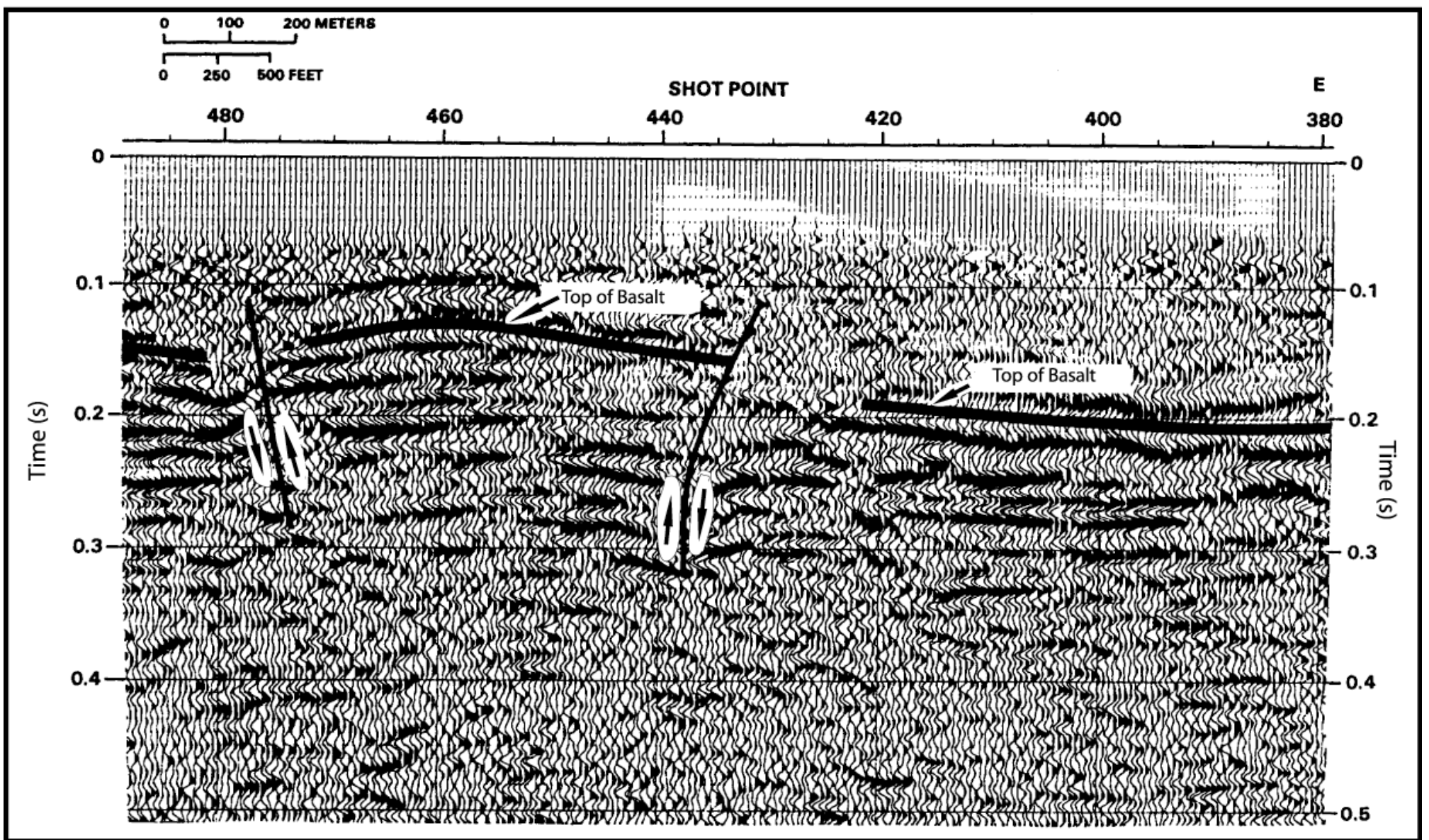

Figure D.8. Seismic Reflection Line Across Borehole DB-10 (Figure D.4) on Southern Portion of Gable Mountain Anticline. The eastern most fault is a reverse fault that was intersected by borehole DB-10. 


\section{Appendix E}

Hydrologic Characterization Tests 


\section{Appendix E}

\section{Hydrologic Characterization Tests}

The characterization tests discussed in this section are designed primarily for determination of hydraulic/storage properties of selected basalt interflow and caprock horizons. Tables E.1 and E.2 list the various hydrologic test methods discussed in this section, the hydrologic parameter(s) estimates derived from their analysis, and the relative areal extent of their characterization (test scale). In addition to hydraulic/storage properties, field test programs would also include hydraulic head and hydrochemistry characterization of selected basalt interflow zones. These three characterization elements (i.e., hydraulic

Table E.1. Summary of Hydrologic Tests for Basalt Interflow Characterization

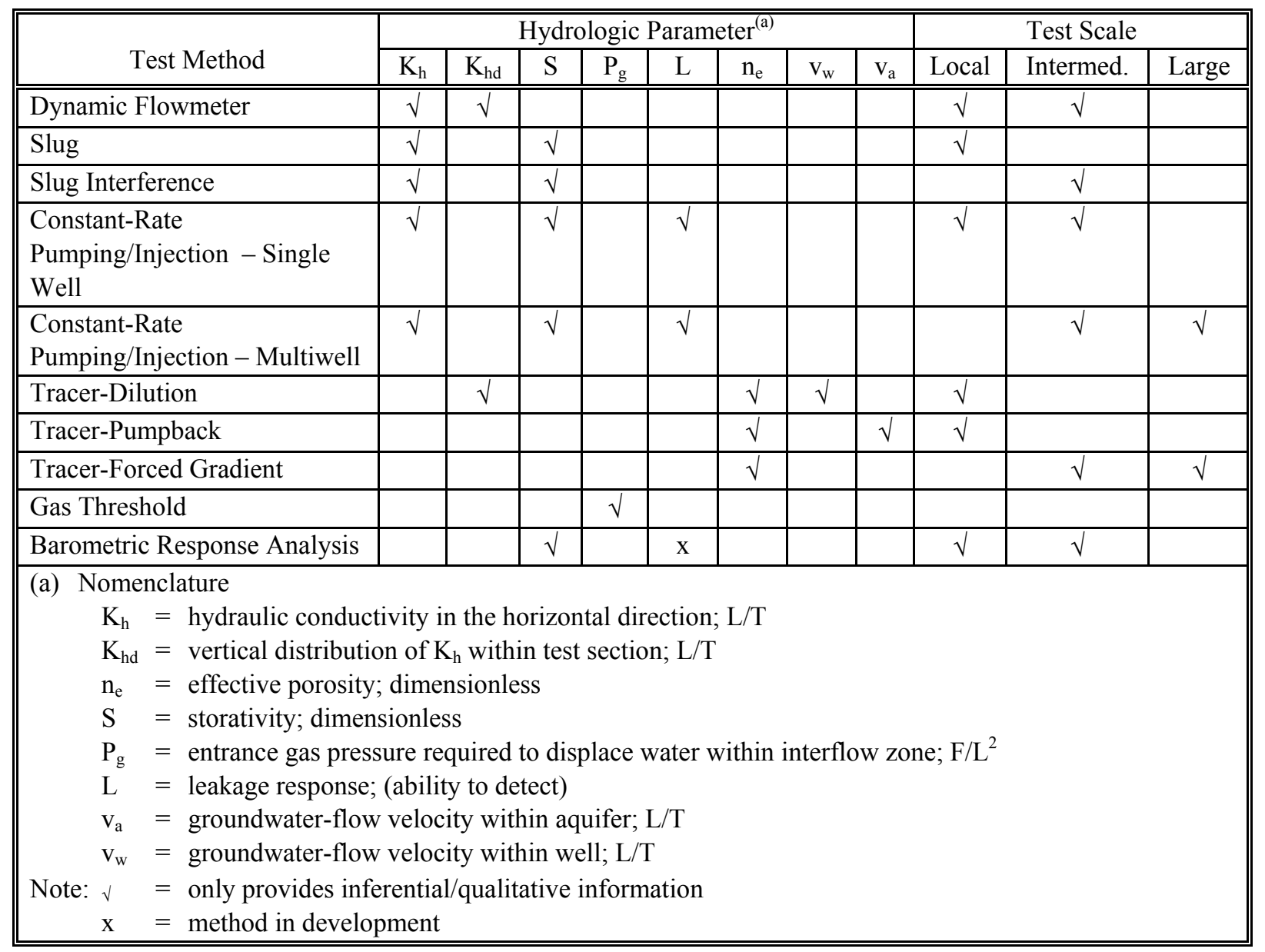


Table E.2. Summary of Hydrologic Tests for Basalt Interior/Caprock Characterization

\begin{tabular}{|c|c|c|c|c|c|c|c|c|c|}
\hline \multirow[b]{2}{*}{ Test Method } & \multicolumn{6}{|c|}{ Hydrologic Parameter $^{(\mathrm{a})}$} & \multicolumn{3}{|c|}{ Test Scale } \\
\hline & $\mathrm{K}_{\mathrm{h}}$ & $\mathrm{K}_{\mathrm{v}}$ & $\mathrm{K}_{\mathrm{D}}$ & $\mathrm{S}$ & $\mathrm{P}_{\mathrm{g}}$ & $\mathrm{L}$ & Local & Intermed. & Large \\
\hline Pulse & $\sqrt{1}$ & & & 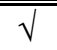 & & & $\bar{l} \sqrt{ }$ & & \\
\hline $\begin{array}{l}\text { Constant-Pressure Injection (Single } \\
\text { Well) }\end{array}$ & $\sqrt{ }$ & & & $\sqrt{ }$ & & $\sqrt{ }$ & $\sqrt{ }$ & & \\
\hline $\begin{array}{l}\text { Constant-Pressure Injection } \\
\text { (Multiwell) }\end{array}$ & $\sqrt{ }$ & $\sqrt{ }$ & $\sqrt{ }$ & $\sqrt{ }$ & & $\sqrt{ }$ & $\sqrt{ }$ & $\sqrt{ }$ & \\
\hline Ratio & $\sqrt{ }$ & $\sqrt{ }$ & $\sqrt{ }$ & $\sqrt{ }$ & & $\sqrt{ }$ & & $\sqrt{ }$ & $\sqrt{ }$ \\
\hline Gas Threshold & & & & & $\sqrt{ }$ & & $\sqrt{ }$ & & \\
\hline Laboratory Core Analyses & & $\sqrt{ }$ & & & $\sqrt{ }$ & & $\sqrt{\sqrt{ }}$ & & \\
\hline \multicolumn{10}{|c|}{$\begin{array}{l}\text { (a) Nomenclature } \\
\mathrm{K}_{\mathrm{h}}=\text { hydraulic conductivity in the horizontal direction; } \mathrm{L} / \mathrm{T} \\
\mathrm{K}_{\mathrm{v}}=\text { hydraulic conductivity in the vertical direction; } \mathrm{L} / \mathrm{T} \\
\mathrm{K}_{\mathrm{D}}=\text { vertical anisotropy }\left(\mathrm{K}_{\mathrm{v}} / \mathrm{K}_{\mathrm{h}} \text {; dimensionless }\right. \\
\mathrm{S}=\text { storativity; dimensionless } \\
\mathrm{P}_{\mathrm{g}}=\text { entrance gas pressure required to displace water from/through caprock; } \mathrm{F} / \mathrm{L}^{2} \\
\mathrm{~L}=\text { leakage response; (ability to detect) }\end{array}$} \\
\hline
\end{tabular}

head, hydraulic/storage properties, and hydrochemical content) can be readily included in the test strategy adopted for borehole characterization. Several test strategies for borehole characterization are discussed below. In addition, a report on hydraulic property data from the CRBG at the Hanford Site by Strait and Mercer is included at the end of this appendix.

This appendix used the English system rather than the metric system of units because, by convention, drilling and testing activities in boreholes are based on English system units. Also, drilling equipment and supplies are dominated by the English system. Thus, by using the English system in this appendix, the hydraulic testing methods will be compatible with aquifer drilling and characterization activities.

\section{E.1 Testing Strategies}

The following discussion describes two test strategies that may be adopted at a reconnaissance borehole location that will be drilled to provide an initial assessment of the suitability of CRBG interflow zones for natural gas storage. After the initial single borehole characterization is completed, a decision can be made as to whether the more extensive characterization (e.g., tracer tests, gas injection/recovery test), using multiple-well test techniques is warranted (which would require drilling and characterizing additional, nearby boreholes).

The following testing strategy is limited to the discussion of test sequencing at an initial reconnaissance borehole within a study area. The objective of the two strategies is the same, i.e., to determine whether candidate basalt interflow zones are present for the effective storage and retrieval of natural gas, 
and whether suitable caprocks are present to prevent significant leakage of the managed gas storage. In both test strategies, the collection of vertical/depth-dependent information pertaining to hydraulic properties, hydraulic head, and hydrochemical characteristics of the penetrated basalts are the primary investigative tools used to meet the test objectives. For discussion purposes, it is assumed that the well will be rotary drilled, of sufficient diameter to accommodate test equipment, and reflective of testing depths greater than $1,300 \mathrm{ft}$. It is also assumed that the testing to be discussed takes place solely within the Grande Ronde Basalt, and that overlying basalt and sedimentary units within the overlying Wanapum Basalt and Saddle Mountains Basalt (if present) have been effectively isolated using properly engineered cemented casing installations. Before isolation of the overlying Wanapum Basalt, it is also assumed that sufficient hydrologic characterization information (primarily hydraulic head and hydrochemistry) has been collected for selected lower Wanapum Basalt interflow zones for comparison with underlying Grande Ronde Basalt interflow test horizons. This information is valuable for assessing the Wanapum Basalt and Grande Ronde Basalt stratigraphic contact horizon (commonly delineated by the presence of the Vantage horizon, a sediment layer and/or an extensive saprolite layer) that has been noted previously as a regional confining layer separating groundwater flow systems within these two major CRBG formations.

Both test strategies include the collection of hydraulic head, hydraulic/storage properties, and hydrochemical characteristics of the penetrated basalt to meet the test objectives. How this is accomplished, however, is significantly different for the two test strategies. As might be expected, there are distinct advantages/disadvantages pertaining to characterization quality and costs that are associated with the strategy adopted, and variants or combinations of the two that could be used to meet specific test objective needs. This discussion, however, presents the two strategies-1) "drill first, test later," and 2) "test as you go" - as separate entities.

Principal characteristics of the first strategy include conducting hydrologic test characterization elements only after the borehole has been drilled to its final completion depth within the Grande Ronde Basalt, geophysically logged for individual basalt flow characterization, and described geologically based on drill cuttings or core analysis.

The primary focus of the first strategy (testing strategy 1) is assessment of the hydraulic characteristics of intersected Grande Ronde Basalt interflow zones. The test program consists of two basic test elements: 1) composite testing of multiple interflow zones intersected within the borehole using dynamic flowmeter/pumping tests, and 2) detailed hydrologic characterization of selected interflow zone(s) using standard straddle packer tests. A brief description of the two test elements is provided in Section E.2. Briefly stated, however, productive, individual basalt interflow zones are identified from the dynamic flowmeter test results. The inflow production results, together with interflow thickness/storage capacity information obtained from geophysical $\log$ analysis, are used in selecting candidate interflow zones for detailed hydrologic test characterization. The principal objective of detailed hydrologic testing is to provide quantitative estimates of the hydraulic properties, static hydraulic head, and hydrochemical characteristics of the various interflows tested. When examined together, the hydraulic head and hydrochemical depth profiles provide valuable information pertaining to the interrelationships and isolation potential of groundwater contained within the respective basalt interflows. 
The principal advantage of the first strategy (testing strategy 1) is the lower overall equipment costs (i.e., drilling rig time, downhole test system rental), when compared to other test strategies. A major disadvantage is that major pressure perturbations and groundwater incursions may be induced into the basalt formations surrounding the borehole during the extended, active borehole drilling phase. These drilling-induced effects may require lengthy extensions of test times to obtain representative static hydraulic heads and hydrochemical samples for the interflow zones selected for detailed testing.

The primary focus of the second strategy (testing strategy 2) is to provide detailed hydrologic characterization information at the time the interflow zone is penetrated. Drilling proceeds until the underlying dense basalt flow interior has been encountered. The newly drilled section of the borehole is then geophysically logged for basalt flow characterization. The interflow zone is tested exactly as in testing strategy 1, except that a single packer, test system is only required to achieve test zone isolation from the overlying open borehole section.

The principal advantages of testing strategy 2 are shorter test times and higher quality of the characterization data derived using this approach. Because the exposure time to drilling perturbations is minimized, test times required for acquiring representative static hydraulic heads and hydrochemical characteristics are greatly reduced. The major disadvantages of this strategy are the standby drilling rig and test equipment costs incurred when either activity is not taking place.

It should be noted that both strategies were used in DOE's basalt borehole characterization at the Hanford Site. As a generalization from the DOE experience, testing strategy 2 might be used where subsurface conditions within a region (i.e., from a geological or detailed hydrologic characterization perspective) are not well established. Conversely, testing strategy 1 might be used more efficaciously in more established areas, where nearby borehole data are available, and the need to develop a detailed vertical profile of hydraulic head and hydrochemistry between interflow zones is a lower priority.

Interflow zones selected for detailed testing are isolated within the open borehole using standard straddle packer test equipment systems. The hydrologic test system should also be equipped with a downhole shut-in tool (to expedite test zone recovery) and pressure sensors that allow monitoring of test interval response and borehole pressure response above and below the isolated interval. Monitoring borehole pressure responses above and below the interflow that is to be tested provides a means of assessing the integrity of packer seals during testing. Costly repeat tests can be minimized by careful selection of the packer depth settings within competent basalt flow interior sections above and below the test interflow zone. The final selection of competent packer depth settings can be greatly improved through use of borehole geophysical survey results (e.g., televiewer, resistivity, sonic) and core log analysis.

A detailed interflow testing sequence is summarized below. Individual hydrologic test methods are discussed in more detail in Section E.2. A normal test sequence for interflow zone characterization might include the following elements:

- Packer Inflation. The test tool is positioned and packers are inflated to isolate the test interval. 
- Pressure Stabilization. The downhole shut-in tool is closed and pressure is monitored to establish the static formation pressure. Time required for the pressure to approach static formation conditions depends on the severity of the borehole pressure drilling history effects and the hydraulic properties of the test interval.

- Slug Testing. This test is performed to provide initial estimates of test zone hydraulic properties (K and S), evaluate borehole damage/skin effects, and design the conduct of subsequent hydrologic test characterizations, e.g., constant-rate pumping test. This test is discussed in Section E.2.2.

- Constant-Rate Pumping Test. This test is conducted to provide detailed hydraulic property estimates, diagnostically evaluate operative aquifer conditions (e.g., leaky aquifer), and detect the presence of nearby hydrogeologic features (e.g., faults). Pumping tests also provide opportunities for the collection of representative water samples for detailed hydrochemical and isotopic analysis. This information is particularly useful for assessing the source and origin of groundwater and evaluating hydrologic intercommunication/ isolation between various interflow zones.

- Recovery From Constant-Rate Pumping Test. This test provides corroborative information (i.e., to drawdown pressure responses) during the constant-rate pumping test. The primary advantage for analysis of recovery data is its ease of application, and its insensitivity to flow rate variations that might have occurred during the constant-rate pumping test phase.

Following completion of detailed hydrologic testing of selected basalt interflow zones within the borehole, low-permeability caprock (flow interior) tests can be performed for zones immediately overlying the primary candidate interflow zone(s). The objective of these caprock tests is to provide initial, reconnaissance-level hydraulic properties for flow interior sections. Because of their inherently lower permeabilities, caprock tests generally take longer to complete (i.e., including pre-test pressure stabilization and testing) and are limited to smaller investigation areas around the borehole. These tests are discussed in Section E.3.

\section{E.2 Field Tests - Interflow Zones}

The following discussion pertains to hydraulic characterization tests that may be performed for characterizing basalt interflow zones, as part of implementing testing strategies (1) and/or (2). The hydrologic properties that can be determined and the relative measurement scale for the various tests are summarized in Table E.1.

\section{E.2.1 Dynamic Flowmeter Surveys}

Dynamic flowmeter/pumping tests provide a means of assessing, in a continuous fashion, the vertical distribution of hydraulic conductivity $\left(\mathrm{K}_{\mathrm{hd}}\right.$; see Table E.1) within an entire open borehole section. The $\mathrm{K}_{\mathrm{hd}}$ distribution is determined directly by measuring the distribution of inflow rate into the borehole test section during a constant-rate pumping test. A variety of flowmeters are available for measurement of inflow rate, including mechanical (spinner), heat-pulse, electromagnetic, and acoustic flow meters. Generally, mechanical flow meters are reserved for pumping tests conducted in higher permeability 
formations, while other flow-meter types are designed for lower inflow (or outflow) measurements. For most testing applications, commercially available mechanical flowmeters can be used successfully. Ideally, the flowmeter should be capable of resolving flow rates of at least $\pm 5 \%$ of the composite discharge pumped from the entire borehole section (e.g., for a 100 gpm pumping rate, a minimum $5 \mathrm{gpm}$ resolution is required).

The test is conducted by first installing the flowmeter (on wireline cable) at the bottom of the open borehole section to be characterized. A submersible pump with an adequate pumping capability (e.g., $\geq 100 \mathrm{gpm}$ ) for the given lift/depth conditions is then installed above the flowmeter in the upper cased well section. The pump depth setting within the borehole should be designed to allow sufficient drawdown capacity to perform a constant-rate pumping test in continuous fashion (e.g., $300 \mathrm{ft}$ below the static water level). During pumping, the flowmeter is repeatedly raised and lowered at a specified constantlogging speed. The logging speed selected is based on the pumping rate and flowmeter/borehole characteristics. It is assumed that the logging rate will be within the range of 20 to $50 \mathrm{ft} / \mathrm{min}$. A flowmeter/pumping test duration within the range of 2 to $8 \mathrm{~h}$ is expected to provide sufficient information for assessing the inflow characteristics of Grande Ronde interflow zones intersected by the borehole. Figure E.1 shows a schematic of test equipment and its deployment during performance of a dynamic flowmeter test. Conducting an ambient, "static" flowmeter profile of the open borehole section, before pump installation and performance of the "dynamic" flowmeter/pumping test also provides valuable information concerning "thieving" and producing zones under natural hydraulic gradient conditions.

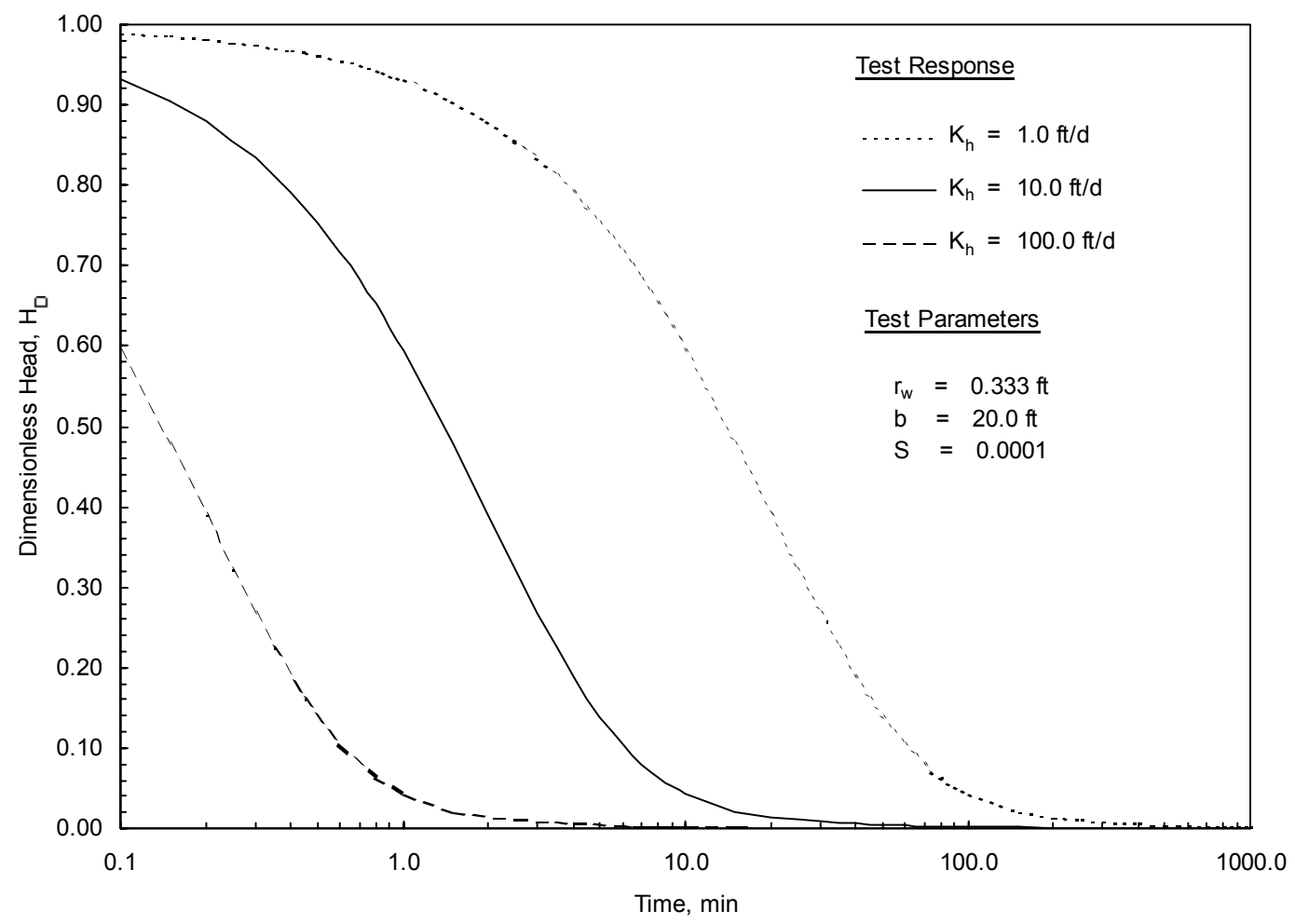

Figure E.1. Predicted Slug Test Response as a Function of Hydraulic Conductivity 
The distribution of inflow to the borehole is determined by simple mass balance calculation methods. It is important that the borehole diameter over the open borehole section be known for quantitative analysis of the flowmeter data. This can be quantified by running a caliper log before conducting the flowmeter/pumping test element. Examples and descriptions of flowmeter/pumping test investigations are provided in Molz et al. (1989) and Rehfeldt (1989).

Analysis of flowmeter inflow data, using the Cooper and Jacob (1946) method, provides a means of calculating the hydraulic conductivity $\left(\mathrm{K}_{\mathrm{h}}\right)$ for a particular interflow zone, once the inflow rate and composite borehole drawdown is known. The Cooper and Jacob (1946) method assumes that flow to the borehole is horizontal, and that horizontal head gradients are uniform away from the borehole. As indicated in Javandel and Witherspoon (1969) these conditions are established relatively early in composite borehole tests even for conditions where permeability contrasts between layers is large. Kabala (1994) provides a means for analyzing flow-meter tests for situations where the assumptions of Cooper and Jacob (1946) are not met.

Once pumping is terminated, sufficient time should be allotted (i.e., equivalent to the pumping time) to monitor recovery water levels back to pre-test, static conditions. The pressure responses measured during recovery can be analyzed to determine the composite transmissivity of all interflow zones intersected by the borehole. Examples of the methods and special procedures used for pumping test recovery analysis are presented in Earlougher (1977), Spane (1993), and Spane and Wurstner (1993).

\section{E.2.2 Slug/Slug Interference}

\section{E.2.2.1 Slug Tests}

Because of their ease of implementation and relatively short duration, slug tests are commonly used to provide initial estimates of hydraulic properties (e.g., range and spatial/vertical distribution of hydraulic conductivity, K). Because of the small displacement volumes employed, hydraulic properties determined using slug testing are representative of conditions relatively close to the borehole. For this reason, slugtest results are normally used in the design of subsequent hydrologic tests having greater areas of investigation (e.g., slug interference [Novakowski 1989; Spane 1996], and constant-rate pumping tests [Butler 1990; Spane 1993]).

To conduct this test, a known volume of water is instantaneously removed from (slug withdrawal) or added to (slug injection) the test interval. If a packer system is used, this can be performed by simply removing or adding water from the test tubing and opening the shut-in tool. The shut-in tool remains open during the recovery period. For open borehole test conditions, a large diameter rod of known volume can be instantaneously emplaced below or removed from the static water level within the well to initiate the test. Slug withdrawal tests can also be initiated using compressed air/gas to lower water level within the borehole. The use of compressed air to initiate slug withdrawal tests is discussed in Spane et al. (1996). The slug test response can be analyzed to estimate formation hydraulic properties $\left(\mathrm{K}_{\mathrm{h}}\right.$ and S; see Table E.1). Figure E.2 provides examples of slug test recovery profiles as a function of hydraulic conductivity $\left(\mathrm{K}_{\mathrm{h}}\right.$ ), for the listed well/aquifer conditions (well radius, $\mathrm{r}_{\mathrm{w}}=0.333 \mathrm{ft}$; interflow thickness, 


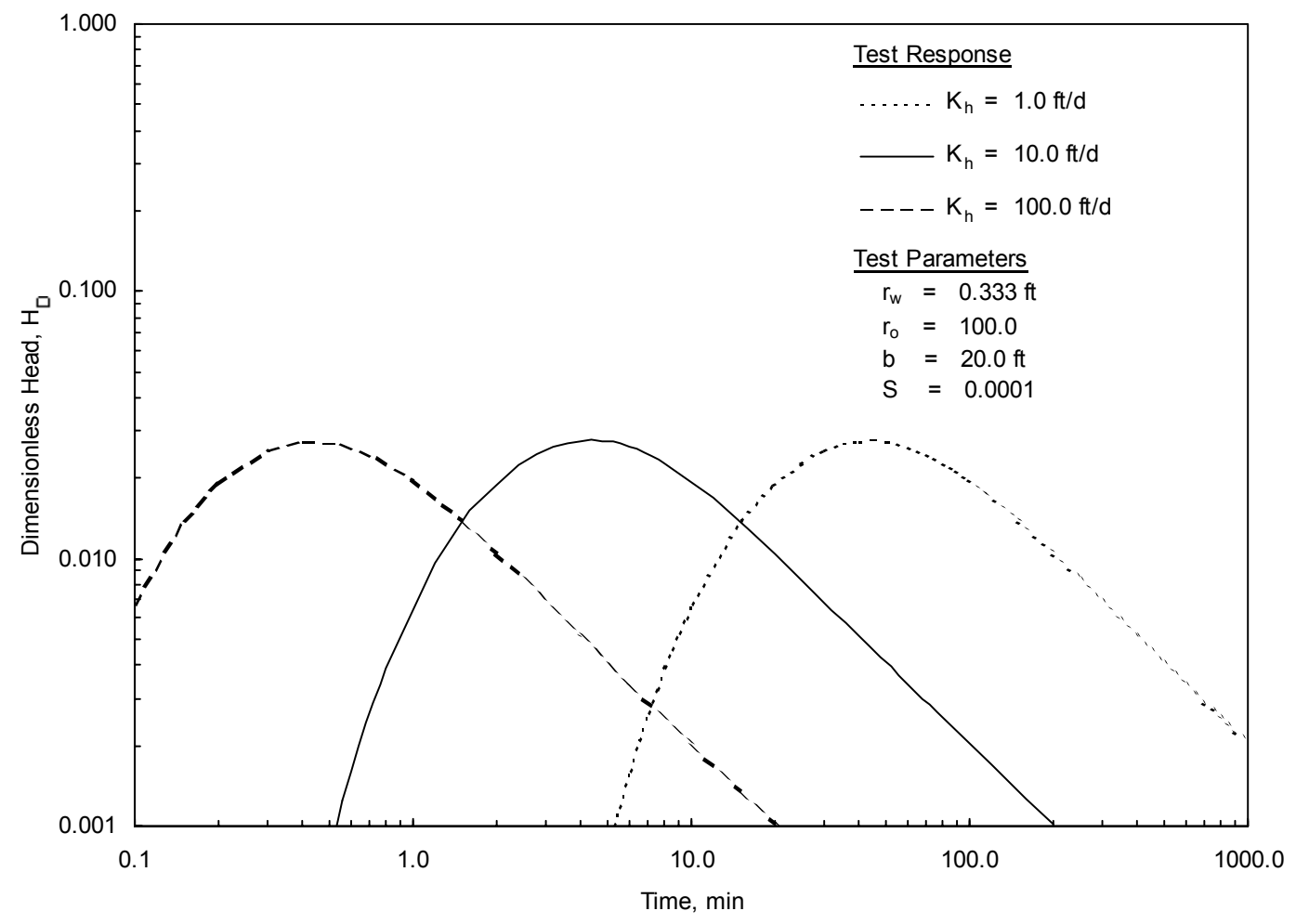

Figure E.2. Predicted Slug Interferene Test Response as a Function of Hydraulic Conductivity

$\mathrm{b}=20 \mathrm{ft}$; storativity, $\left.\mathrm{S}=10^{-4}\right)$. As shown in Figure E.2, the test response $\left(\mathrm{H}_{\mathrm{D}}=\right.$ observed response/initial stress applied; $\mathrm{H}_{\mathrm{o}} / \mathrm{H}$ ) is a direct function of the interflow permeability, with faster test recovery associated with higher zone permeability. A detailed description of the design, performance and analysis of slug tests is presented in Butler et al. (1994) and Butler (1998).

\section{E.2.2.2 Slug Interference Tests}

For slug interference testing, an observation well is required to monitor the surrounding pressure wave induced by the slug test administered at a stress well. A particular advantage of multi-well slug interference testing (i.e., in comparison to single-well slug tests) is a higher degree of resolution for hydraulic property estimates ( $\mathrm{K}_{\mathrm{h}}$ and $\mathrm{S}$; see Table E.1), which are reflective of a much larger area of investigation. These features, together with the relative ease and short test durations required, make this test method particularly attractive for reservoir characterization applications.

Figure E. 3 provides examples of slug interference test response at a distance of $100 \mathrm{ft}$ from the stress well (slug well) for the same test conditions used in Figure E.2. The test response $\left(\mathrm{H}_{\mathrm{D}}=\right.$ observed response/initial stress applied; $\mathrm{H}_{\mathrm{o}} / \mathrm{H}$ ) is a direct function of the interflow permeability; with faster test recovery associated with higher zone permeability. For the example shown in Figure E.3, an initial 100-ft "slug" stress applied at the stress well would produce a peak pressure perturbation of $\sim 3 \mathrm{ft}$ at the point of observation, with the inter-well permeability controlling the arrival time of the slug interference response. 


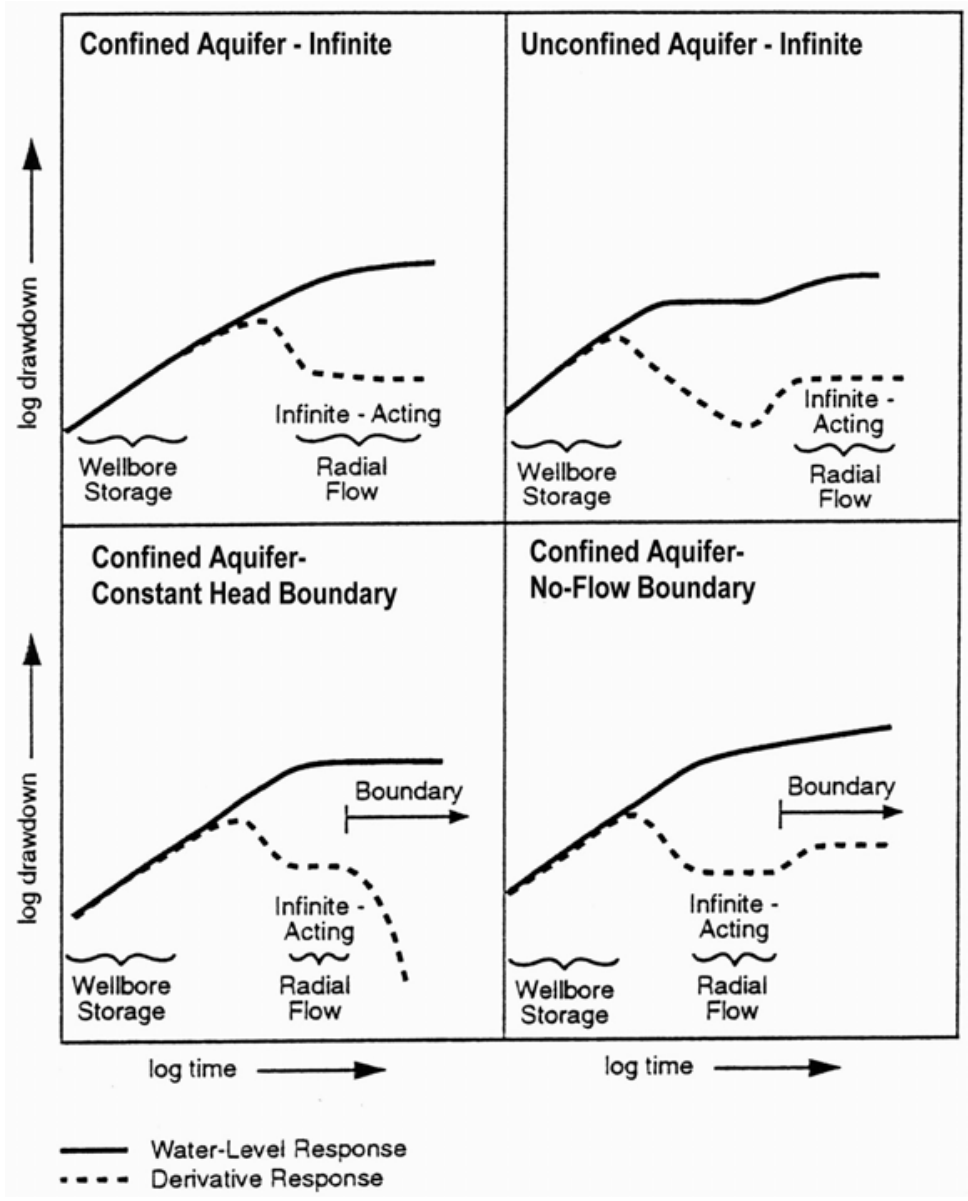

Figure E.3. Characteristic Log-Log Drawdown and Drawdown Derivative Plots for Various Hydrogeologic Formation and Boundary Conditions (adapted from Spane and Wurstner 1993)

Detailed descriptions of the design, performance and analysis of slug interference testing is provided in Novakowski (1989), Spane (1992), Spane (1996), and Spane et al. (1996).

\section{E.2.3 Constant-Rate Pumping}

During constant-rate pumping tests, groundwater is withdrawn from a well, which is dischargeregulated and maintained at a uniform rate. The water-level (pressure) response within the well is monitored during the active pumping phase and during the subsequent recovery phase following termination of pumping. The analysis of the drawdown and recovery water-level response within the pumping well (and for multi-well tests any nearby observation wells) provides a means for estimating hydraulic properties (see Table E.1) of the interflow zone(s) tested, as well as for discerning formational and non-formational flow conditions (e.g., wellbore storage, skin effects, presence of boundaries and leakage). It should be noted that constant-rate injection tests apply equally to the discussion in this section pertaining to pumping tests. In some situations where disposal of pumped groundwater may be 
an issue (and a large, dependable water source is available for injection), constant-rate injection tests may be preferable. Standard analytical methods used for the analysis of constant-rate tests include type-curve matching and straight-line methods.

Type-curve-matching methods are best applied to observation well data and not to pumping wells because of the additional head losses that occur at the pumped well. They can be used for pumped well analyses, however, if certain assumptions pertaining to well efficiency (i.e., well-skin effects $=0$ ) or the test interval (e.g., $\mathrm{S}$ is known) are made. This is the approach taken for single-well pumping test analysis within the petroleum industry. Type-curve-matching methods commonly used in the analysis of pumping test responses include those described in Theis (1935), Hantush (1964), and Neuman (1975).

For straight-line analysis methods, the rate of change of water levels within the well during drawdown and/or recovery is analyzed to estimate hydraulic properties. Because well effects are constant with time during constant-rate tests, straight-line methods can be used to analyze quantitatively the water-level response at both pumping and observation wells. The semilog, straight-line analysis techniques commonly used are based on either the Cooper and Jacob (1946) method (for drawdown analysis) or the Theis (1935) recovery method (for recovery analysis). These methods are theoretically restricted to the analysis of test responses from wells that fully penetrate nonleaky, homogeneous, isotropic, confined aquifers. Straight-line methods, however, may be applied under nonideal well and aquifer conditions if infiniteacting, radial flow conditions exist. Infinite-acting, radial flow conditions are indicated during testing when the change in pressure, at the point of observation, increases proportionately to the logarithm of time.

Log-log plots of water level versus time have traditionally been used for diagnostic purposes to examine pumping test drawdown data. More recently, the derivative of the water level or pressure has also been used as a diagnostic tool. Use of derivatives has been shown to improve significantly the diagnostic and quantitative analysis of various hydrologic test methods (Bourdet et al. 1989; Spane 1993; Spane and Wurstner 1993). The improvement in test analysis is attributed to the sensitivity of pressure derivatives to various test/formation conditions. Specific applications for which derivatives are particularly useful include the following:

- determining formation-response characteristics (nonleaky or leaky; confined or unconfined aquifer) and boundary conditions (impermeable or constant head)

- assisting in the selection of the appropriate type-curve solution through combined typecurve/derivative plot matching

- determining when infinite-acting, radial flow conditions are established and, therefore, when straightline analysis methods are applicable.

Figure E. 3 shows selected examples of log-log drawdown and derivative responses that are characteristic of some commonly encountered formation conditions. Spane (1993) provides a summary discussion on the use of standard and derivative-based analytical methods for constant-rate tests. 


\section{E.2.4 Tracer Tests}

A variety of single- and multi-well tracer tests are available that can be used for interflow zone characterization. Three tracer tests that may be particularly relevant for basalt interflow characterization include tracer-dilution, tracer drift/pumpback, and multi-well, forced-gradient tests. Table E.1 summarizes the various hydrologic parameters and areas of investigation for individual tracer test techniques.

For the tracer-dilution test, a solution with known tracer concentration is placed within the isolated test interval section. A particularly useful tracer for groundwater studies from a standpoint of nonreactivity, availability, and in-situ detection is bromide ion $\left(\mathrm{Br}^{-}\right)$. Initial bromide tracer concentrations normally used within the borehole are within the range of 100 to $200 \mathrm{mg} / \mathrm{L}\left(\mathrm{Br}^{-}\right)$. The decline of tracer concentration (i.e., "dilution") with time within the test interval can be monitored directly using a downhole bromide probe. (Note: If vertical distribution of permeability within the test interval is desired, then a vertical array of bromide specific-ion electrode probes can be installed at known depth intervals.) Based on the dilution characteristics observed, the in-well flow velocity $\left(\mathrm{v}_{\mathrm{w}}\right)$ and/or average hydraulic conductivity may be estimated for the specific interflow zone tested. This particular tracer method is invalid if in-well vertical flow conditions exist. This is why tracer-dilution tests are not usually applicable for testing large test intervals or open borehole sections. It should be well suited, however, for characterizations of typical interflow zone thickness of $\leq 30 \mathrm{ft}$. The presence of vertical flow within the well screen can also be identified by comparison of individual probe dilution response patterns, as described in Spane et al. (2001a, b). Descriptions of the performance and analysis of tracer-dilution test investigations are provided in Halevy et al. (1966), Hall et al. (1991), and Hall (1993).

For the tracer drift and pumpback test, a non-reactive (conservative) tracer of known concentration and volume is injected into the surrounding basalt interflow zone and allowed to "drift" away from the well for a specified residence period (e.g., 1 to 10 days). After the specified time is attained (usually determined by monitoring the dilution of the in-well concentration), a pumpback/constant-rate pumping test is initiated. The objective of the tracer pumpback is to "recapture" the tracer that has moved from the well to the surrounding aquifer. Tracer recovery is best determined by measuring the tracer concentration in water pumped from the well using an in-line, specific-ion/tracer probe within the pumped discharge water. Discrete groundwater samples are normally collected for laboratory analysis during the pumpback phase for corroboration of the in-line results. This tracer test can be combined with other characterization methods (e.g., tracer-dilution, constant-rate pumping) for field test efficiency. Characterization information obtained from the drift/pumpback test includes effective porosity $\left(\mathrm{n}_{\mathrm{e}}\right)$ and groundwater flow velocity $\left(v_{\mathrm{a}}\right)$. Like tracer-dilution testing, this tracer method is particularly sensitive to well effects and their impact on the surrounding flow field (Drost et al. 1968; Kearl et al. 1988). It is unknown if these sensitivities are relevant for basalt interflow zone characterization. Detailed descriptions of the performance and analysis of single-well, tracer injection/withdrawal tests are included in Güven et al. (1985), Leap and Kaplan (1988), and Hall et al. (1991).

For multi-well, forced-gradient tracer tests, a steady-state hydraulic gradient is established between a dual-well couplet. Once established, a conservative tracer (e.g., bromide) is administered at a neighboring monitor well, and the tracer breakthrough is monitored at the pumping (extraction) well location. 
The analysis of the tracer breakthrough pattern (i.e., time-concentration profile) provides intermediatescale information concerning aquifer dispersivity and effective porosity. The time required for establishment of steady-state conditions and tracer breakthrough is dependent on the existing aquifer hydraulic properties, injection/withdrawal rates, and well spacing (distance). Based on the expected test site conditions, tracer breakthrough may be anticipated within a range of 1 to 7 days. Multi-well forcedgradient tests can be conducted in several configurations: one where both wells are active and recirculation is used (i.e., an injection and extraction well couplet), and with only one active well (i.e., extraction well). Each configuration has advantages for various well/test site conditions. Detailed descriptions of the general performance and analysis of multi-well, forced-gradient tracer tests are provided in Gelhar (1982), Molz et al. (1986, 1988), and Huyakorn et al. (1986). An example of a multiwell, forced-gradient tracer test conducted for an interflow zone within the Grande Ronde Basalt is reported in Leonhart et al. $(1982,1985)$.

\section{E.2.5 Gas-Threshold Pressure Test}

The creation of a natural gas storage reservoir within basalt interflow zones will impose multiphase condition (i.e., gas and water) within the subsurface. For candidate interflow zones and overlying lowpermeability caprocks, capillary forces may hold groundwater within the pore interstities, even in the presence of a pressure gradient. The pressure required to overcome the capillary forces within an interflow zone to displace the "held" water with injected gas is referred to as the gas entry or gas threshold pressure (GTP). Because of the greater permeability and porosity afforded by interflow zones, GTP would be expected to be considerably lower than that for low-permeability/porosity flow interior caprock layers. Determination of the GTP within caprocks, however, is particularly important from a standpoint of leakage, since gas injection pressures within the candidate reservoir zone (interflow zone) are maintained at a pressure below the GTP within the caprock, and the effects of capillarity will impede the vertical leakage of stored reservoir gas. The importance of determining the GTP and capillary pressures within a reservoir horizon at the onset, as well during, the management of natural gas reservoirs within an aquifer system is discussed in Schafer et al. (1993).

For sedimentary formation caprocks, the GTP information is commonly determined by laboratory core tests, which (because of the small-scale dependence) require a large number of core test results for effective statistical analysis. Because permeabilities of basalt interflow and flow interior/caprock layers are inherently dependent on irregular fracture connectivity, the applicability of core analysis results for these units is highly questionable and best addressed using field tests. To conduct a field gas threshold pressure test (GTPT), gas must be emplaced within the entire testing string, and the test interval cannot be exposed to significant under- or over-pressurization before initiation of the test. To conduct a GTPT, the following pretest procedures are proposed:

- Use a straddle packer test system to isolate a candidate interflow zone or caprock interval within the borehole (see Figure E.4).

- Replace the water in the borehole test section (as completely as possible) by injecting gas into the isolated borehole test section using a separate gas injection line that extends from the surface through the upper packer and into the borehole test interval. 


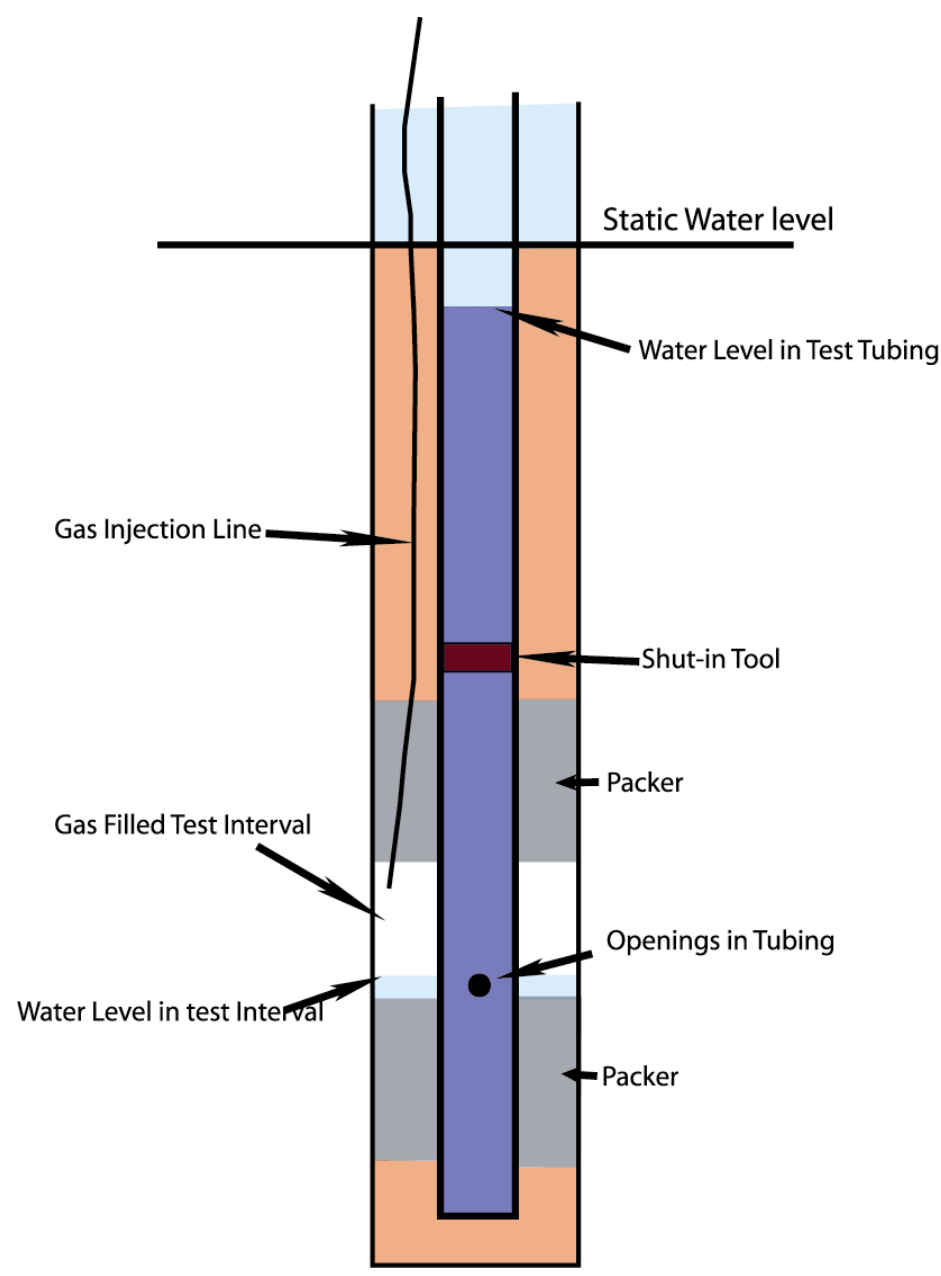

Figure E.4. Straddle Packer Test System

- To displace water from the borehole test section, gas is injected (while the shut-in tool is open) and with the water level in the test tubing string at a level slightly lower than prevailing static formation head conditions. To keep gas from being forced prematurely into the formation during water displacement, gas pressure should not exceed static formation pressure conditions.

- The displaced water from the borehole test section flows through the openings in the test tubing, which are located immediately above the bottom packer. The displaced water exits through the shutin tool and into the overlying test tubing string.

- When all the water has been displaced from the test section, (as determined from measurement of the injected gas volume), the shut-in tool is closed and gas pressure maintained at approximately static hydraulic head conditions until the start of the GTPT test.

After the water in the test interval has been replaced by gas, the GTPT is initiated by gradually increasing the gas pressure and observing the point where continuous injection of gas into the formation 
begins. It is preferable to introduce the gas into the test interval using a small diameter gas injection line, rather than the test tubing string to reduce the volume of gas required to fill the test system and the possibility of test system leakage that can occur at tubing string joint connections. An extended gas threshold pressure test (EGTPT) can also be conducted by allowing the gas injection to continue at constant pressure and observing changes in flow rate over time. Analysis of the changes of flow rate with time can be used to provide additional information pertaining to test formation hydraulic properties, using the analysis approaches described in this section.

\section{E.2.6 Barometric Response Analysis}

Barometric fluctuations represent an areal, blanket stress applied directly at land surface and to the open well water-level surface. The manner in which a well/aquifer system responds to changes in atmospheric pressure is variable and directly related to the degree of aquifer confinement and the hydraulic/ storage characteristics of the well/aquifer system. Rasmussen and Crawford (1997) and Spane (1999, 2002) describe three conceptual models of water-level measurements in wells to barometric pressure change. These models include an instantaneous well response within confined aquifers, a delayed well response within unconfined aquifers (because of the delayed transmission of barometric pressure through the vadose zone), and a delayed well response associated with well characteristics (i.e., wellbore storage and well-skin effects).

Plots for the three well-response models are shown in Figure E.5. The plots show the time-lag dependence of each barometric response model associated with a unit step change in atmospheric

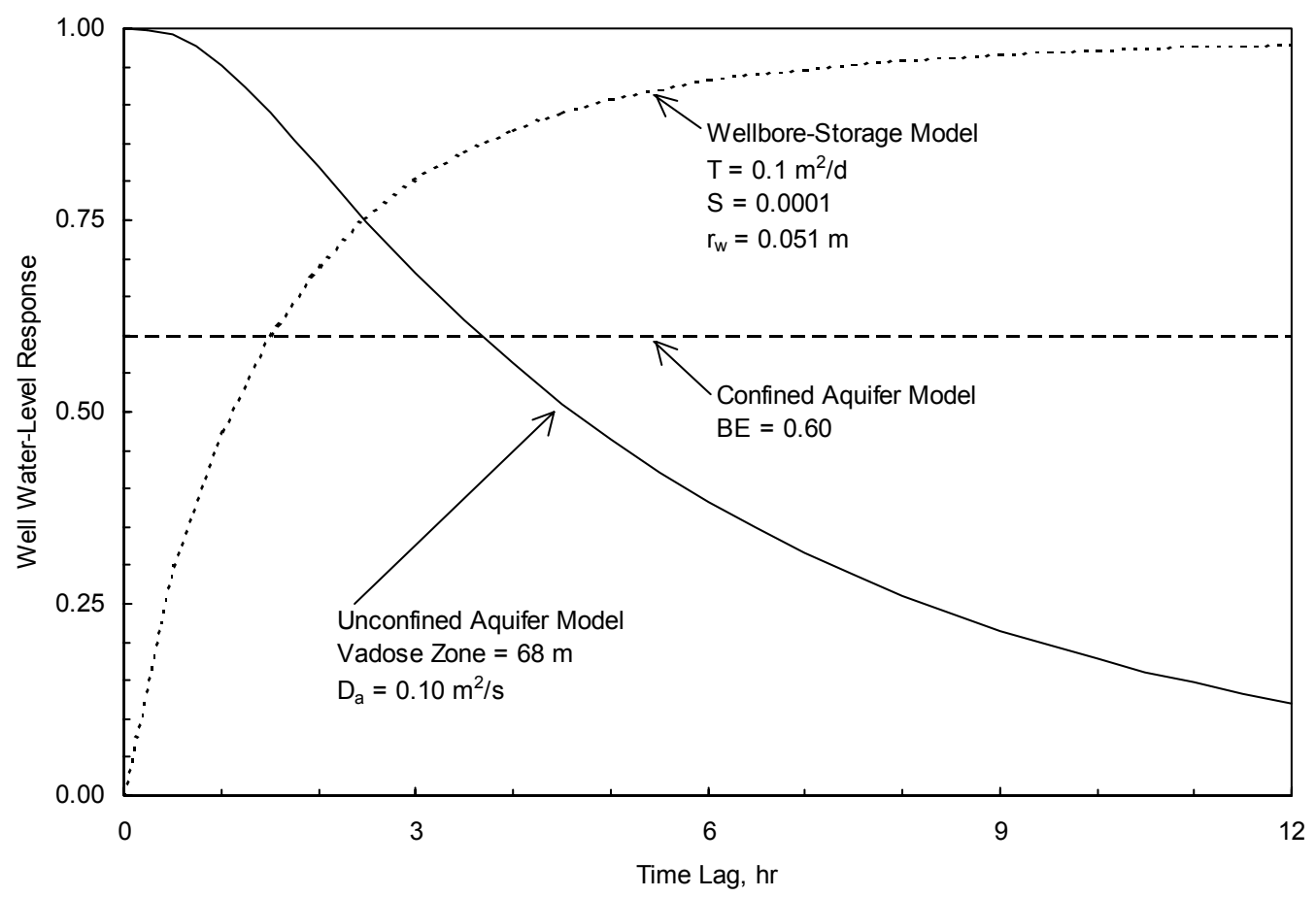

Figure E.5. Diagnostic Well/Barometric Response Models (adapted from Spane 1999) 
pressure. The plots were developed by performing multiple-regression analysis of well response to barometric pressure change over a time-lag period, as indicated in Rasmussen and Crawford (1997) and Spane (1999). As shown in the figure, each barometric response model has a distinguishing pattern that can be used diagnostically for response-model identification.

Of relevance in assessing the suitability of basalt interflow zones for natural gas storage is whether they exhibit leaky or nonleaky characteristics. As shown in Figure E.5, for completely nonleaky behavior, a confined aquifer exhibits no time-lag dependence, and a uniform well response (i.e., barometric efficiency, $B_{e}$ ) is indicated. Although not yet fully developed, leaky confined aquifer models are expected to exhibit a diagnostic pattern, which readily distinguishes them from nonleaky behavior. Additional research is required, however, to develop this diagnostic approach. The ability to distinguish leaky versus nonleaky behavior with simple barometric monitoring tests represents significant characterization cost savings over more expensive standard hydrologic tests. For barometric response characterization, the collection of hourly barometric and well pressure data is only required for minimum time periods of 1 to 2 weeks. (Note: Longer time periods up to 4 weeks may provide optimum diagnostic characterization.) Additionally, with the installation of a multi-level monitory borehole system, barometric response information from all candidate basalt interflow zones within a borehole can be collected during one data collection period.

An additional application of barometric response analysis is that the effective porosity, $\mathrm{n}_{\mathrm{e}}$, of interflow zones can be indirectly assessed using the interflow storativity (S), which is determined by multi-well, interference tests (e.g., constant-rate pumping) together with the observed $\left(\mathrm{B}_{\mathrm{e}}\right)$, in Jacob's classic barometric efficiency relationship (Jacob 1940):

$$
\mathrm{S}=\left(\phi \gamma_{\mathrm{w}} b\right) /\left(\mathrm{E}_{\mathrm{w}} \mathrm{B}_{\mathrm{e}}\right)
$$

where $\phi=$ effective porosity; dimensionless

$\gamma_{\mathrm{w}}=$ specific weight of the interflow groundwater; $\mathrm{F} / \mathrm{L}^{3}$

$\mathrm{b}=$ interflow zone effective thickness; $\mathrm{L}$

$\mathrm{E}_{\mathrm{w}}=$ bulk modulus of the interflow groundwater; $\mathrm{F} / \mathrm{L}^{2}$

$\mathrm{B}_{\mathrm{e}}=$ barometric efficiency; dimensionless

\section{E.3 Field Tests - Caprock Zones}

Hydraulic tests conducted in low-permeability formations can be significantly affected by borehole pressure history, temperature changes of fluid in the borehole, volume changes caused by deformation of test equipment, and the presence of gas in the formation and test system (Pickens et al. 1987). Care, therefore, should be taken to minimize these extraneous effects and to account for them in the test analysis. A normal test sequence for a low-permeability caprock interval would include the following steps:

1. Packer Inflation. The test tool is positioned, and packers are inflated to isolate the test interval.

2. Temperature Stabilization. The shut-in tool is open, and water level in the test tubing is approximately equal to the estimated static hydraulic head for the test formation. If the shut-in tool is closed 
immediately after setting the test equipment, temperature changes of the fluid within the lowpermeability interval may cause pressure changes. This period also allows effects from deformation of the test equipment to dissipate.

3. Pressure Stabilization. The shut-in tool is closed, and pressure is monitored to establish a pressure trend that can be extrapolated for the remaining test period. The pressure may stabilize and approach static formation conditions depending on the severity of the borehole pressure history effects and the hydraulic properties of the test interval.

4. Pulse Withdrawal Test. By removing water from the test tubing above the closed shut-in tool and then quickly opening and closing the shut-in tool, the interval is subjected to an under-pressure pulse. A small volume of water is removed from the interval in this process, and this volume will be determined from measurements of the water level in the test tubing before and after pulse test initiation. Recovery from the pressure pulse can be analyzed to estimate the hydraulic conductivity and storativity of the test interval (see Section E.3.2). However, because of the small volume of water removed from the test interval, these results pertain only to the formation very near to the borehole wall.

5. Constant-Head Injection Test. For this test, the shut-in tool is opened and water injected into the test interval under constant head (pressure). For cases where artesian flowing conditions exist or formation pressure conditions are too high, a constant-head withdrawal test can be performed by removing water at a sufficient rate to maintain a constant water level in the test tubing. The measured injection or withdrawal rate during the test can be analyzed for determining hydraulic properties for the test interval, as discussed in Section E.3.3.

6. Recovery From the Constant-Head Test. Following completion of the constant head test, the shutin tool is closed, and pressure within the test interval can be monitored. If a sufficient amount of data is collected following termination of the injection or withdrawal test, these data can be analyzed to corroborate the hydraulic properties determined from earlier tests.

Caprock leakage and/or vertical permeability are the important properties for assessing the viability of a natural gas storage reservoir within basalt interflow zones. Flow interior/caprock leakage/ vertical permeability can be determined by a number of direct and indirect test methods. Direct tests are conducted directly within the caprock or caprock samples for the determination of vertical permeability, and include laboratory core analysis, single- and multi-well pulse tests (pressurized slug tests), and constant-pressure injection tests. Indirect test methods are conducted within the candidate basalt interflow horizon, with vertical permeability or leakage in the overlying basalt caprock/flow interior determined by either the:

- departure from the theoretical nonleaky response for the test interflow zone

- presence of an observable hydrologic response within the overlying basalt interflow zone (i.e., above the caprock)

- ratio of the caprock to test interflow zone response. 
The following discussion pertains to hydraulic characterization tests that may be performed for characterizing basalt flow interior/caprock zones. The hydrologic properties that can be determined and the relative measurement scale for the various tests are summarized in Table E.2.

\section{E.3.1 Laboratory Core Analysis}

Because of their inherent small size, core samples provide characterization results reflective of very small-scale conditions, which are not readily transferable for determining large-scale caprock leakage conditions. In addition, groundwater flow within a basalt caprock/flow interior is controlled entirely by the occurrence of open/connected fracture zones. Core samples that do not contain fractures provide information pertaining only to basalt matrix permeability. Cores with fractures may not be representative of the flow interiors as a whole, due to the uncertainty of whether the fractures are natural or induced by the coring process, and whether the core fracture(s) actually represent connected in-situ fracture system conditions. For these reasons, small-scale core samples are not recommended for the primary determination of basalt caprock vertical permeability.

\section{E.3.2 Pulse}

Discussions pertaining to pulse and constant-pressure injection testing within basalt flow interiors are provided in Spane and Thorne (1985) and Thorne and Spane (1985). Both methods provide an average bulk permeability of the caprock interval tested and have limited areas of investigation. For the case of pulse testing, hydraulic caprock information derived from the test is representative of conditions in proximity of the borehole (e.g., several borehole diameters). Although results from pulse and constant-pressure injection tests are not directly applicable for assessing caprock leakage, valuable vertical permeability information can be derived when these tests are designed to test the entire caprock thickness, and the permeability results are compared with other flow interior tests conducted at surrounding borehole sites.

Pulse or pressurized slug tests have been widely used for hydraulic characterization of lowpermeability (i.e., $\leq 10^{-9} \mathrm{ft} / \mathrm{s}$ ) test formations. They differ from standard slug tests in that the dissipation of the instantaneous stress occurs under closed system conditions. As shown by Bredehoeft and Papadopulos (1980), the closed system conditions cause the stress to dissipate more rapidly than a standard slug test response, since the pressure change during a pulse test is controlled by fluid volume changes associated with the compressibility/elasticity of water and the surrounding test system. To illustrate this dramatic difference in test rate dissipation, Figure E.6 compares the response differences for a slug and pulse (closed-system slug) test conducted for the specified low-permeability test conditions specified in the figure. The more rapid decline exhibited for the pulse test response ( $\sim 1000 \mathrm{~min})$, as compared to the slug test $\left(>1.0 \times 10^{6} \mathrm{~min}\right)$, demonstrates why pulse testing is more viable for caprock characterization.

The analytical equations used for analysis of slug tests (e.g., Cooper et al. 1967) can also be used to analyze pulse tests (Bredehoeft and Papadopulos 1980). The equations, however, must be modified to account for the closed-system test conditions, by replacing the term for well casing radius, $r_{c}$, with: 


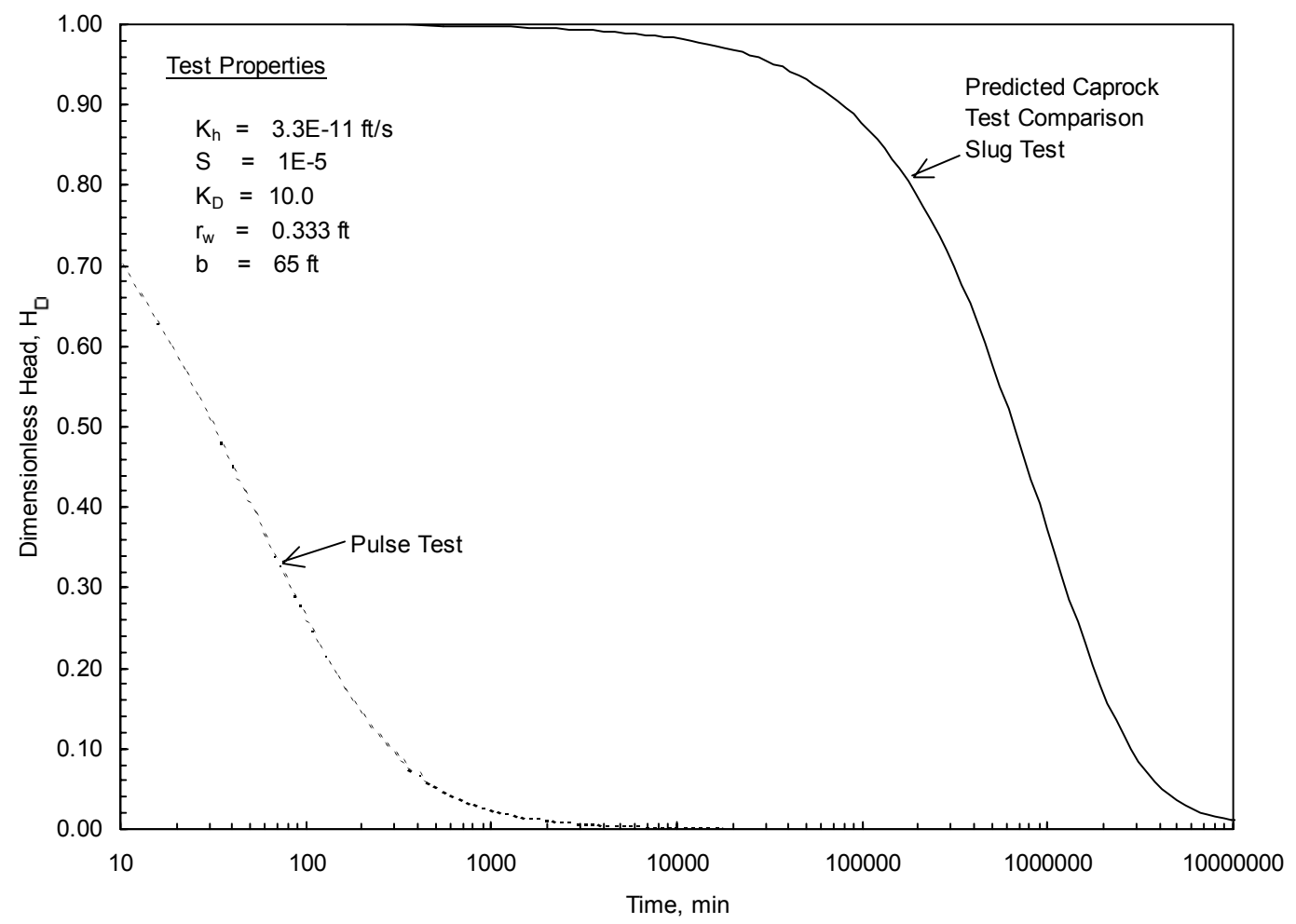

Figure E.6. Comparison for Pulse and Slug Test Responses

$$
\left.\mathrm{r}_{\mathrm{c}}=\left(\mathrm{V}_{\mathrm{w}} \mathrm{C}_{\mathrm{w}} \gamma_{\mathrm{w}}\right) / \pi\right)^{1 / 2}
$$

where $\mathrm{V}_{\mathrm{w}}=$ closed test system volume; $\left[\mathrm{L}^{3}\right]$

$\mathrm{C}_{\mathrm{w}}=$ compressibility of water; $[\mathrm{L} / \mathrm{F}]$

$\gamma_{\mathrm{w}}=$ specific weight of water; $\left[\mathrm{F} / \mathrm{L}^{3}\right]$.

Neuzil (1982) also identified the importance of evaluating the compressibility of the test system, $\mathrm{C}_{\mathrm{obs}}$, and replacing the $\mathrm{C}_{\mathrm{w}}$ with this parameter, when $\mathrm{C}_{\mathrm{obs}}>\mathrm{C}_{\mathrm{w}}$ for the relationship expressed in Equation (E.2).

Because the volumes of fluid are smaller (per unit pressure change) during pulse tests in comparison to slug tests, the radius of investigation is accordingly smaller. This fact makes pulse tests more susceptible to near well formation heterogeneities and skin effects. These characteristics and susceptibilities of pulse tests were described in detail in Moench and Hsieh (1986). Summaries of the application and interpretation of pulse tests for low-permeability characterization are provided in Thorne and Spane (1985) and Spane and Thorne (1985).

\section{E.3.3 Constant-Pressure Injection}

For constant-pressure (head) injection tests, a constant overpressure is applied that is greater than static test interval pressure. The injection rate declines during the test as a function of time, eventually reaching a steady-state flow rate. The early-time decline in injection rates can be analyzed using the 
transient straight-line solution presented by Jacob and Lohman (1952). Late-time, steady-state injection rates can be analyzed using the equation relationship presented in Zeigler (1976).

For detailed characterization of low permeability caprocks, it is recommended that multi-level constant-pressure injection tests be conducted. In a multi-level test, injection pressures are systematically increased with time, and the associated steady-state injection rates are recorded for each injection pressure. The advantage of conducting a multi-level injection test over a single-injection pressure test is the ability to assess dependence of permeability to injection pressure level. Permeability-pressure dependence may occur in fractured rock types (e.g., flow interiors) and clays. If no dependence is evident, a straight-line relationship between steady-state injection rate and injection pressure will be indicated. Examples of multi-level injection pressure tests and their analysis are provided in Spane and Thorne (1985).

Analysis of recovery pressures following termination of constant injection tests in low-permeability intervals usually is not performed. This is due to the excessive time required to reach radial flow conditions. For intermediate and/or higher permeability caprock intervals, however, recovery analyses can be used. Constant-rate recovery methods cannot be used unless steady-state injection rates are maintained for prolonged periods. In these instances, multi-rate analytical methods (to take into account the nonuniformity in injection rates) must be used. A description of the various multi-rate analytical approaches is presented in Earlougher (1977).

The radius of investigation for constant-pressure injection tests is greater than that for pulse tests, but still generally $<8 \mathrm{ft}$ for tests of $5 \mathrm{~h}$ or less, conducted within basalt flow interiors with hydraulic conductivities of $\leq 10^{-11} \mathrm{ft} / \mathrm{s}$. Figure E.7 shows the difference depths of investigation surrounding the borehole for the listed caprock and test conditions.

\section{E.3.4 Indirect Interflow Leakage Response Tests}

Caprock leakage can be inferred indirectly from hydraulic tests conducted within candidate basalt interflow zones. Basically, these methods rely on departures from theoretical nonleaky interflow responses, as the basis for assessing caprock leakage. There are several significant drawbacks associated with indirect methods. Commonly, they are insensitive to all but significant leakage, and, if detected, they do not discriminate whether leakage is occurring in overlying or underlying confining caprock horizons.

To demonstrate the insensitivity of leakage on interflow response, Figure E. 8 shows the predicted drawdown and drawdown derivative response for a constant-rate pumping test conducted within a basalt interflow zone for selected leaky caprock conditions. For comparison, the ideal interflow response for nonleaky (impermeable) caprock conditions is also included. The predicted responses were calculated based on a pumping rate of $150 \mathrm{gpm}$, and the following candidate interflow properties: hydraulic conductivity $(\mathrm{K})=3.3 \times 10^{-5} \mathrm{ft} / \mathrm{s}\left(\sim 1\right.$ darcy); interflow storativity $(\mathrm{S})$ and caprock storativity $\left(\mathrm{S}^{\prime}\right)=$ $1 \times 10^{4}$; interflow thickness $(\mathrm{b})$ and caprock thickness $\left(\mathrm{b}^{\prime}\right)=100 \mathrm{ft}$; and observation borehole distance $\left(\mathrm{r}_{\mathrm{o}}\right)$ $=300 \mathrm{ft}$. As shown, the drawdown derivative plot can be used to determine definitively the presence of leakage within the interflow test response; however, for the test conditions considered, a threshold 


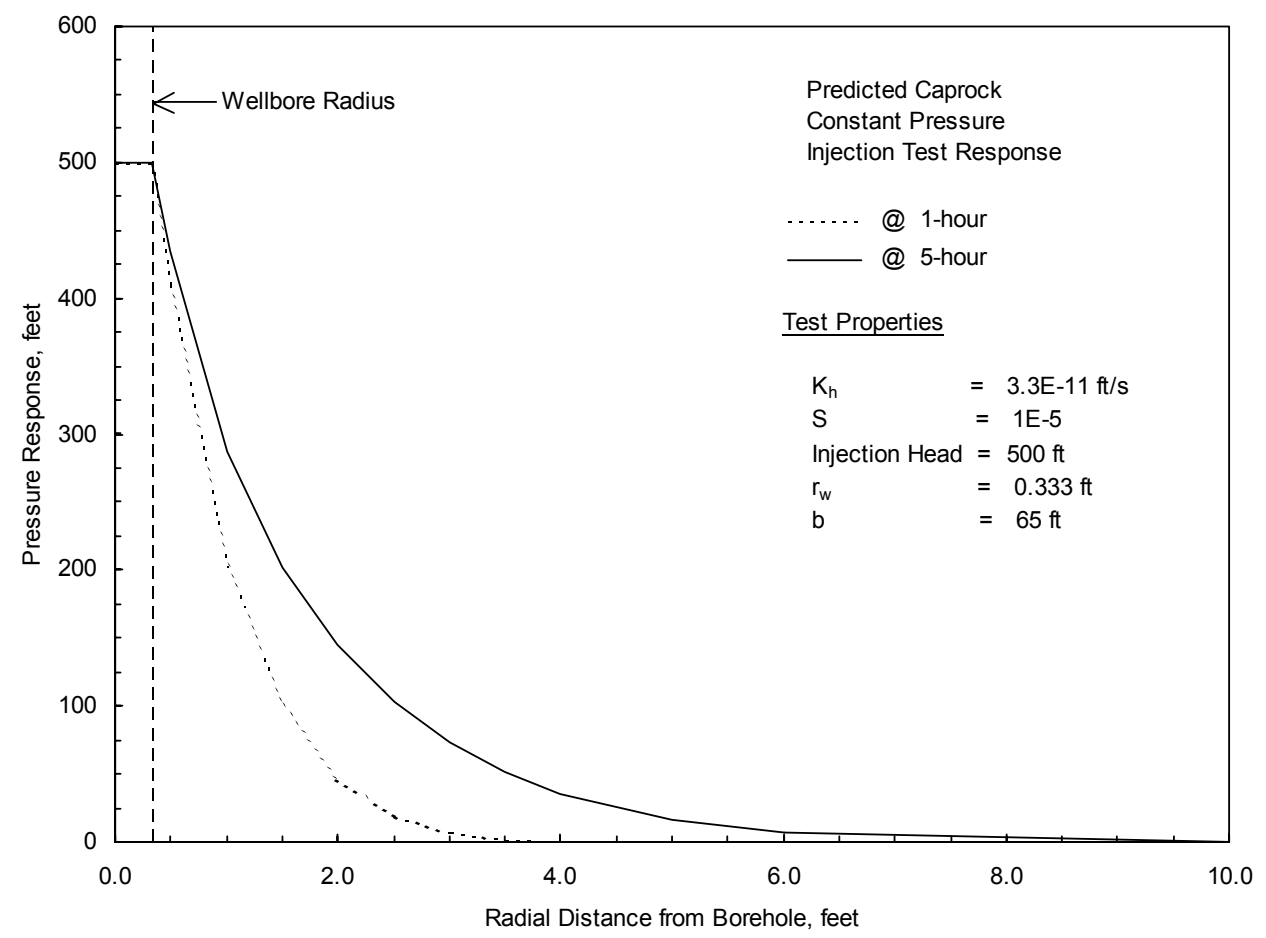

Figure E.7. Radius of Investigation for Constant Pressure Injection Test

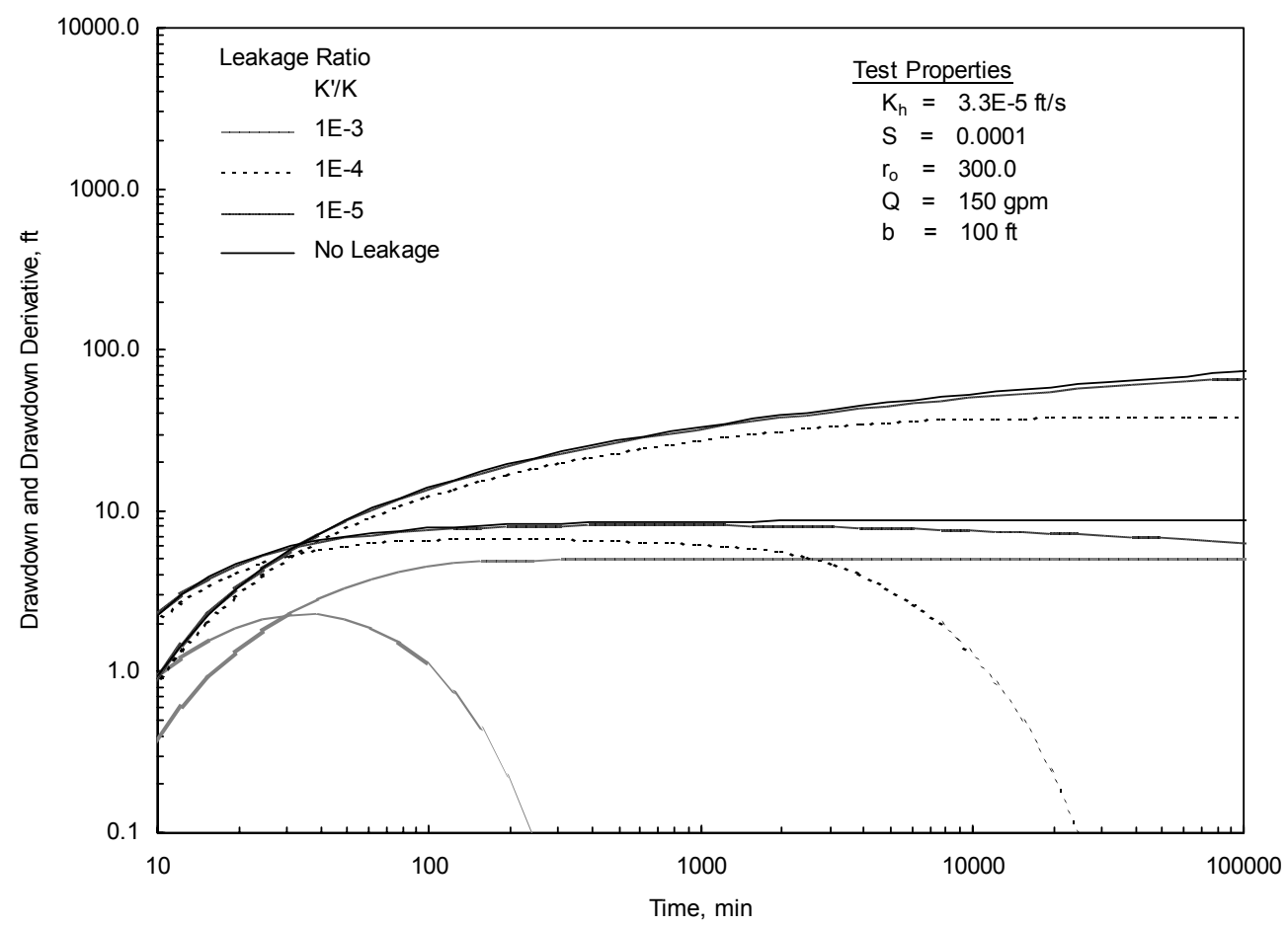

Figure E.8. Predicted Interflow Zone Drawdown and Drawdown Derivative Leakage Responses, During a Constant-Rate Pumping Test 
caprock vertical permeability of $\geq 1.1 \times 10^{-9} \mathrm{~m} / \mathrm{s}$ can only be resolved for tests conducted for durations of $\sim 3$ month or more. This relatively low sensitivity to leakage effects, and the test's inability to discern whether leakage is from the overlying caprock or underlying basalt flow interior, limits its use for quantitative caprock leakage assessment.

The above discussion pertains only to the observed response within the stressed (i.e., pumped) interflow zone. Information concerning caprock leakage can also be obtained by monitoring the response within the interflow zone immediately above the basalt caprock during testing. Figure E.9 shows predicted pressure responses near the top and bottom of a basalt caprock (flow interior) during testing for the same test conditions considered in Figure E.8 (for $\mathrm{K}^{\prime} / \mathrm{K}=1 \times 10^{-5}$ ). As indicated, a considerable length of time is required to propagate the test response across the caprock layer to the overlying interflow zone ( 1 month). That overlying interflow zone permeability tends to dampen the propagated pressure response through the intervening caprock limits the practical use of this test for detecting test responses only for those associated with large caprock leakage.

\section{E.3.5 Ratio Test Method}

A multi-well test that was developed specifically for field assessment of caprock leakage characteristics (associated with natural gas storage applications) requires a constant-rate pumping test within the

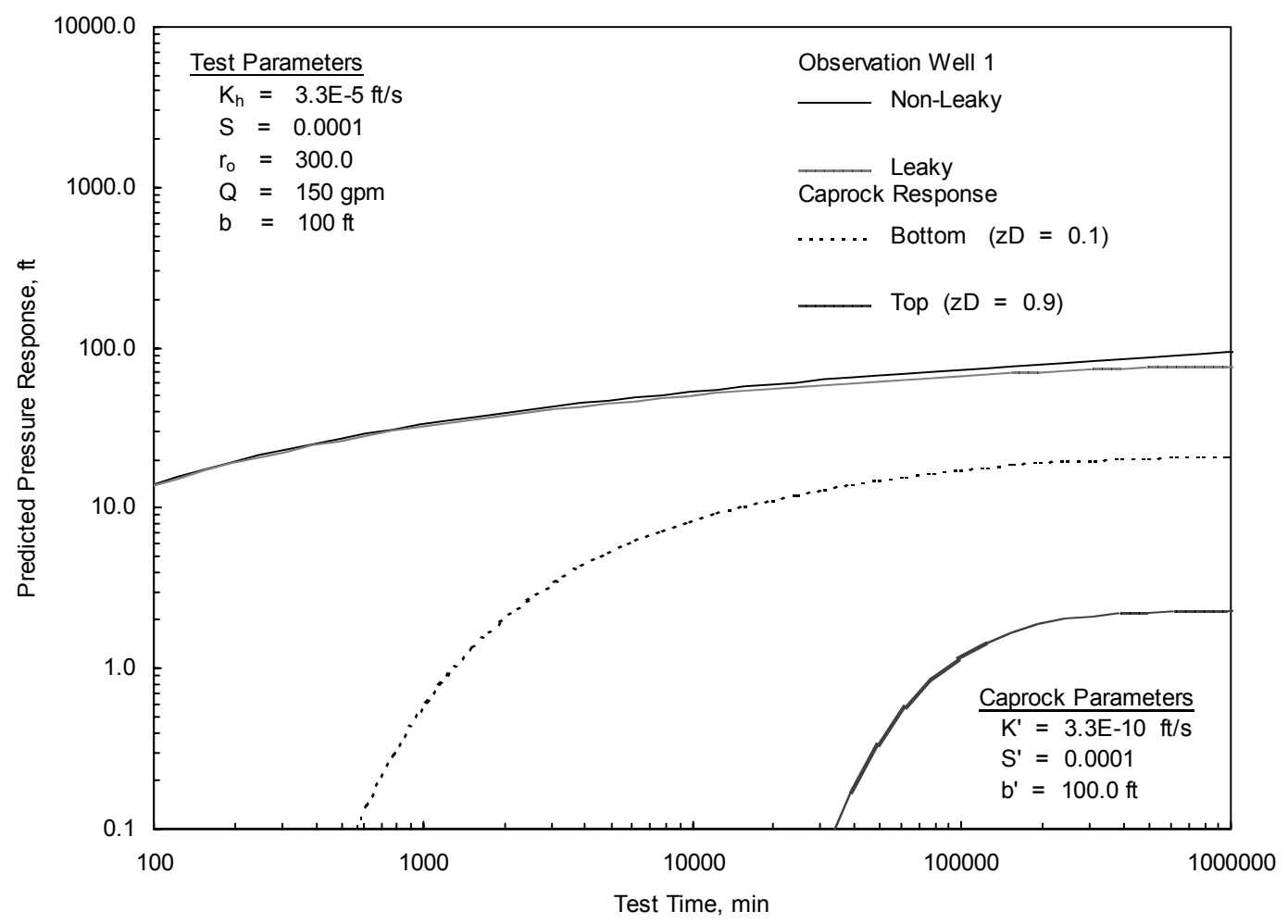

Figure E.9. Predicted Caprock Pressure Responses, During a Constant-Rate Pumping Test of the Underlying Interflow Zone 
candidate storage horizon and monitoring of the associated pressure interference response in the adjacent low-permeability interval (e.g., Neuman and Witherspoon 1972). The "Ratio" of the drawdown response within the low-permeability caprock and the drawdown observed within the pumped interflow zone can be used to estimate the vertical hydraulic diffusivity $\left(\mathrm{K}_{\mathrm{v}}{ }^{\prime} / \mathrm{S}_{\mathrm{s}}{ }^{\prime}\right)$ of the caprock horizon. When combined with independent estimates for $\mathrm{S}_{\mathrm{s}}$ ' (e.g., by direct field tests or laboratory core consolidation tests), the $\mathrm{K}_{\mathrm{v}}$ for the caprock can be estimated.

These are two significant advantages of this method: it can be used to determine leakage and the $\mathrm{K}_{\mathrm{v}}$ for caprocks at the point of measurement, and leakage responses can be observed more rapidly than discerned either within the pumped interflow zone or for waiting to propagating the stress response to adjacent interflow zones. For example, Figure E.9 indicates that a discernible response within the caprock (i.e., $10 \mathrm{ft}$ into the caprock) would be observed in less than 1,000 min, for the specified test site conditions, which is significantly less than either the time needed for detecting a interflow leakage response (i.e., comparison of the non-leaky and leaky response curves) or the time required to propagate the pressure signal to the overlying interflow zone (i.e., the top caprock response). It should be noted, however, that only a few "Ratio" tests for confining layer/caprock characterization have been performed and published in the literature. "Ratio" test results for an interflow zone and its associated overlying flow interior caprock within the Grande Ronde Basalt are reported in Spane et al. (1983).

In summary, based on the available information, it is recommended that the quantification of intermediate- to large-scale caprock leakage characteristics be accomplished by the analysis of inter-well test responses between two or more well sites, at inter-well distances of $\leq 300 \mathrm{ft}$. For these distances, and the threshold caprock permeabilities expected, tests would likely have to be of long duration (i.e., $\sim 1$ to 3 weeks or more), and would be best quantified by monitoring both caprock and interflow zone responses. Because of the test observation requirements, the best opportunity for monitoring these responses is to use a dedicated multi-level monitoring system (e.g., Westbay Instruments, Mosdax system) within the observation and stress well locations.

\section{E.4 Hydrology Test Equipment Considerations}

Because of the depths $(>460 \mathrm{~m})$ and types of hydrologic tests recommended, downhole borehole test equipment systems commonly used in nuclear repository and petroleum industry are recommended for CRBG interflow zone characterization. As noted in Section E.1, these systems include an inflatable straddle-packer system for isolating selected interflow zones from the surrounding open borehole and a multiple-pressure sensor system for monitoring pressures within, below, and above the isolated interflow zone. Monitoring pressures above and below the inflow zone tested is required for assessing isolation during the period of testing. The pressures should be recorded at land surface on a "real-time" basis (e.g., wireline or telemetered system) for efficient control of tests and characterization costs. A shut-in tool immediately above the packer system also provides for test system isolation at test formation depths and facilitates performance of the hydrologic tests used during characterization activities.

\section{E.4.1 Low-Permeability Test Systems}

Although commercially available test systems are adequate for most interflow zone characterization investigations, hydraulic testing of low-permeability caprock intervals requires more sophisticated 
equipment. As noted by previous investigators (e.g., Pickens et al. 1987), low-permeability formations can be significantly affected by borehole pressure history, temperature changes of fluid in the borehole, volume changes caused by deformation of test equipment, and the presence of gas in the formation and test system. Care, therefore, should be taken to minimize these extraneous effects during testing and to account for them in the test analysis. Extraneous effects that can adversely affect the performance and results of low permeability tests pertain mainly to test system deformation effects. Efforts, therefore, should be exercised to use test systems with minimal packer compliancy (i.e., elasticity) and shut-in tool displacement stresses (i.e., zero displacement shut-in tool). Because of the equipment constraints imposed by low-permeability testing, it is unlikely that one test system can be used universally for both interflow and caprock characterization applications.

\section{E.4.2 Multi-Level Monitoring Systems}

Commercially available straddle-packer test systems used for deep borehole testing can be configured to monitor the pressure response within a maximum of two isolated zones. The testing of individual basalt interflow zones within an open borehole section (testing strategy 2; Section E.1) requires the repeated moving of the straddle-packer system(s). Each resetting of the test packer system requires the equilibration/stabilization of test interval pressures prior to initiating hydrologic testing, which for lowpermeability caprock testing can be quite lengthy. Significantly more information can be derived from use of a multi-level monitoring test system that would enable the simultaneous monitoring of hydrologic test responses within a number of permeable basalt interflows and overlying caprock layers with one test system packer installation. Specifically, the use of a multi-level monitoring system would allow:

- detailed hydrologic data coverage for more test zones than would be achievable using standard straddle-packer systems

- full borehole, inter-well characterization using one test system installation

- multiple-hydrologic characterization capabilities (e.g., multi-depth, caprock monitoring for leakage assessment, pressurized/formation depth hydrochemical sampling) not capable with standard-packer systems

- full cross-formational response assessment from the affects induced during drilling a neighboring borehole (i.e., before formal hydrologic testing).

Multi-level test systems have been used successfully for deep monitoring/characterization applications within various nuclear repository programs (e.g., Westbay Instruments, Inc.). They have also been used successfully to isolate and monitor selected CRBG interflow zones as part of the DOE programs. Other domestic program applications include Yucca Mountain (Nevada); Oak Ridge (Tennessee); and Los Alamos (New Mexico). International programs using multi-level monitoring systems to support site characterization applications include Nagra (Switzerland); Nirex (United Kingdom); Andra (France); ENRESA (Spain); JNC/JNFL (Japan); and KAERI (Korea). The number of intervals monitored using multi-level systems within nuclear repository programs generally range between 3 and 31 zones per installation. Figure E.10 shows a generalized example of a multi-level monitoring system deployment within a layered basalt flow sequence. In this example, basalt interflow zones (indicated by higher porosity zones in the figure) are isolated within the borehole by inflatable packers within adjacent basalt 


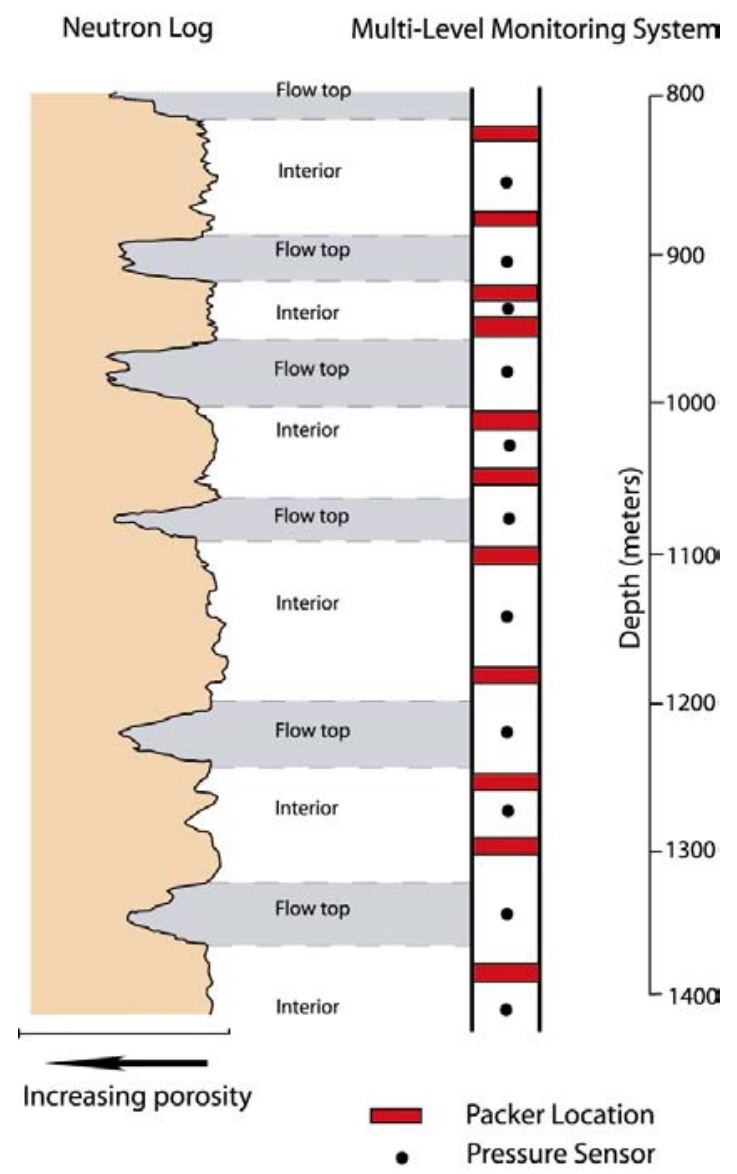

Figure E.10. Schematic of Generalized Multi-Level System for Pressure Testing in a Layered Basalt Flow Sequence

flow interior sections (indicated by low porosity sections in the figure). Pressure responses for controlled hydrologic tests are monitored for the various basalt interflow and interior zones using downhole pressure sensors that are situated between the isolating packers.

It can be assumed that the initial purchase/lease costs for multi-level monitoring systems are higher in comparison to standard straddle-packer systems. Offsetting these higher initial costs, however, are the cost savings associated with using a single borehole installation (versus repeated depth settings using conventional straddle packers) and the significant technical advantage of monitoring multiple test horizons during characterization activities. It should be noted, however, that while multi-level monitoring systems have demonstrated advanced deep borehole characterization/monitoring capabilities (to depths of 4,000 ft), they have not been used in similar applications in the natural gas storage industry. This may be attributed to the gas industry's unfamiliarity with monitoring equipment developments within groundwater hydrology and nuclear repository studies. Nevertheless, multi-level monitoring systems offer distinct advantages not only in initial suitability assessment investigations, but also in any subsequent monitoring of the performance of a natural gas storage reservoir during use. This would be relevant not only for the ongoing evaluation for storage of natural gas within deep basalt formations, but also for all natural gas storage projects. 


\title{
SD-BWI-DP-O51
}

REV 2

Hydraulic Property Data from Selected Test Zones on the Hanford Site

\author{
S.R. Strait \\ R.B. Mercer \\ Hydrologic Testing Group \\ Basalt Waste Isolation Project
}

May 1987

Prepared for the United States

Department of Energy Under

Contract DE-AC06-77RL01030

Rockwell International

Rockwell Hanford Operations

North American Space Operations

Richland, Washington 99352

E. 25 


\section{SD-BWI-DP-051}

REV 2

\section{CONTENTS}

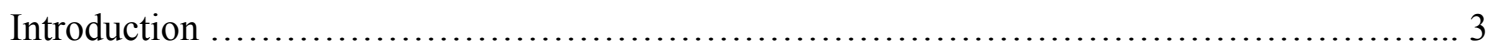

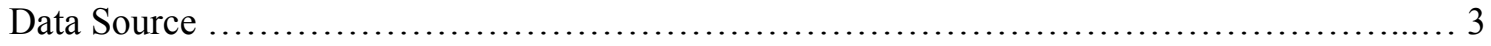

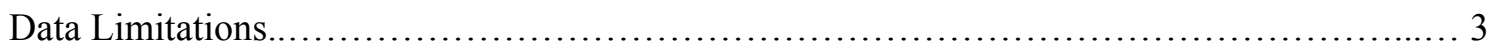

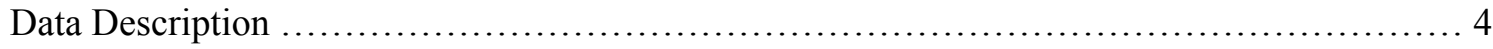

Table:

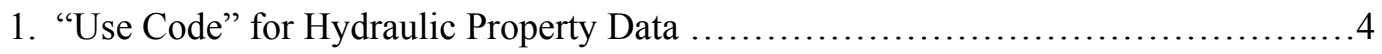

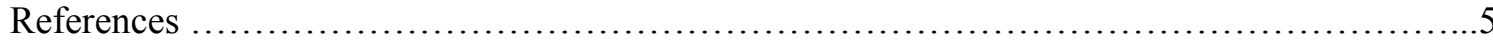

Appendix

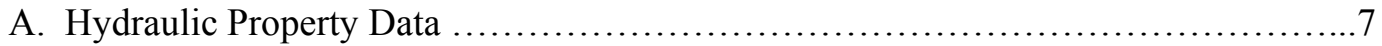

Note: This is a re-typed version of the original report. While the re-typed version has been reviewed for accuracy, errors may exist. 


\title{
SD-BWI-DP-O51 \\ REV 2
}

\section{INTRODUCTION}

Over the past eight years, hydrologists from the Basalt Waste Isolation Project (BWIP) have done extensive hydrologic testing in the Columbia River Basalts underlying the Hanford Site. The test intervals included within this report include all tested flow tops, interbedded sediments, flow interiors, and intraflow structures within the Saddle Mountains, Wanapum, and Grande Ronde Basalts. The majority of the tests consisted of single borehole tests conducted in boreholes that were progressively drilled and tested (Strait and others, 1982, RHO-BW-SA-189). Other tests were in existing boreholes in which test zones were isolated using straddle packers. Hydrologic tests conducted prior to 1982 used surface based depth-to-water measurements and tests conducted after 1982 utilized downhole pressure sensing probes for monitoring hydrologic test response.

\section{DATA SOURCE}

Sources of information contained within this document include BWIP documents (see references) and BWIP raw data files. All raw hydrologic data used to calculate the hydraulic properties are stored in the Hydrologic Testing Group field file and BWIP's Basalt Records Management Center (BRMC). Raw data is available upon request from the BRMC).

\author{
Basalt Records Management Center (no longer in existence) \\ Basalt Waste Isolation Project \\ Rockwell Hanford Operations \\ P.O. Box 800 \\ Richland, Washington 99352 \\ Telephone: (509) 376-1102
}

\section{DATA LIMITATIONS}

The hydrologic test data that have been verified by internal and/or external technical review and issued in a Rockwell Hanford Operations document (see references) has no limitations on its use. In this case the transmissivity values, in units of meters squared per second, have been determined to be accurate to two significant figures.

The values reported are considered to be the best estimate of transmissivity. The best estimate is obtained by examining the test results and associated analysis of the various hydrologic tests conducted (constant discharge, slug, pulse, constant drawdown, and constant head injection tests). Generally, results from long duration and/or high stress tests are given more weight in determining hydraulic properties, which are considered more representative of the test horizon. 


\section{SD-BWI-DP-051 \\ REV 2}

The effective test interval thickness is determined by examination of the geophysical logs and core, if available. The observed hydraulic head parameters, which were obtained from depth-to-water measurements, are recorded as elevation above mean sea level (MSL) to the nearest meter, with an assigned uncertainty $(\underline{+})$ value. The uncertainty value results from non-equilibrium conditions at the time of measurement and instrument inaccuracies. The hydraulic head vales have not bee corrected for fluiddensity effect, borehole deviation, and barometric or earth tide effects. Hydrologic test data that have not undergone verification by issuance of a document have not been validated by peer or technical review. In these cases, the transmissivities are presented in an order of magnitude range with hydraulic head values assigned a larger uncertainty value. Hydrologic test data over the past six years were collected in accordance to Basalt Operation procedure, C-2.8. Some of the existing data may have to undergo a qualifying process to meet the requirements of the 10 CRF 60, Subpart G Quality Assurance Program. This method has yet to be determined.

All raw data files and analyses of raw data were examined by BWIP hydrologists. Based on the examination, the use of the data was established. The "use code" developed was based upon results of the data review and is presented in Table 1. Data (e.g., transmissivity) contained within this report are preliminary and subject to change with further analysis. Changes to the data will be documented in subsequent revisions to this data package.

\section{DATA DESCRIPTION}

This data package contains the borehole, stratigraphic horizons, use code, isolated interval, effective test interval, transmissivity, observed hydraulic head, and the uncertainty in the hydraulic head.

Table 1. "Use Code" for Hydraulic Property Data

Use Code

Data Use

0 The data has been verified by internal and/or external peer or technical review and has unlimited use.

1 Hydrologic data and analyses appear to be of good quality, but the data has not been verified by any peer or technical review. The data use should be limited to conceptual modeling.

2 The data and analyses are of questionable quality and should not be used except in the most qualitative manner. 


\section{SD-BWI-DP-O51 \\ REV 2}

\section{REFERENCES}

Brown, WR, S R Bruce, and SR Strait. 1984. Hydrologic Test Results for the Upper Cohassett Flow Interior at Borehole DC-16A, Hanford Site, Washington. SD-BWI-TI-166, Rev. 0, Rockwell Hanford Operations, Richland, Washington.

Jackson, RL, JR Raymond, and SL Prater. 1983. Results of Hydrologic Testing of the Cold Creek Interbed and Umatilla Basalt Flow Top at Borehole DC-15. SD-BWI-TI-150, Rev. 0, Rockwell Hanford Operations, Richland, Washington.

Jackson, RL, LD Diediker, RK Ledgerwood, and MD Veatch. 1984. Piezometer Completion Report for Borehole Cluster Sites DC-19, DC-20, and DC-22. SD-BWI-TI-226, Rev. 1. Rockwell Hanford Operations, Richland, Washington.

Jackson, RL, LC Swanson, LD Diediker, RL Jones, and RK Ledgerwood. 1986. Design, Drilling, and Construction of Well RRL-2B, and Piezometer Nest RRL-2C. SD-BWI-TI-329, Rev. 0, Rockwell Hanford Operations, Richland, Washington.

Spane, FA, Jr., MP Howland, and SR Strait. 1980. Hydrogeologic Properties and Groundwater Chemistry of the Rattlesnake Ridge Interbed at Well 699-25-80 (DB-14), Hanford Site. RHO-LD67, Rockwell Hanford Operations, Richland, Washington.

Spane, FA, Jr. 1981. Hydrogeologic Properties and Hydrochemistry for the Levey Interbed at Well 699S11-E12A. RHO-BWI-LD-27, Rockwell Hanford Operations, Richland, Washington.

Spane, FA, Jr. and PD Thorne.1985. The Effect of Drilling Fluid Invasion on the Hydraulic Characterization of the Roza Flow Interior at Borehole DB-2. SD-BWI-TI-176, Rev. 1, Rockwell Hanford Operations, Richland, Washington.

Strait, SR and WR Brown.1983. Hydrologic Test Results for the Rattlesnake Ridge Interbed and Pamona Basalt Flow Top at Borehole DB-15. SD-BWI-TI-130, Rockwell Hanford Operations, Richland, Washington.

Strait, SR and WR Brown.1983. Hydrologic Test Results for the Selah Interbed at Borehole DB-15. SDBWI-TI-131, Rev. 0, Rockwell Hanford Operations, Richland, Washington.

Strait, SR and WR Brown.1983. Hydrologic Test Results of the Cold Creek Interbed and Asotin Basalt Flow Top at Borehole DB-15. SD-BWI-TI-142, Rev. 0, Rockwell Hanford Operations, Richland, Washington.

Strait, SR and BA Moore. 1982. Geohydrology of the Rattlesnake Ridge Interbed in the Gable Mountain Pond Area. RHO-ST-38, Rockwell Hanford Operations, Richland, Washington.

Strait, SR and FA Spane, Jr. 1982. Preliminary Results of Hydrologic Testing the Composite Middle Sentinel Bluffs Basalt Flow Bottom at Borehole RRL-2 (3,247-3,344 ft.). SD-BWI-TI- 095, Rev. 0, Rockwell Hanford Operations, Richland, Washington. 


\section{SD-BWI-DP-O51 \\ REV 2}

Strait, SR and FA Spane, Jr. 1982. Preliminary Results of Hydrologic Testing the Umtanum Basalt Flow Top at Borehole RRL-2 (3,568-3,781 ft.). SD-BWI-TI-105, Rev. 0, Rockwell Hanford Operations, Richland, Washington.

Strait, SR and FA Spane, Jr. 1982. Preliminary Results of Hydrologic Testing the Middle Sentinel Bluffs Basalt Colonnade/Entablature at Borehole RRL-2 (3,175-3,244 ft.). SD-BWI-TI-109, Rev. 0, Rockwell Hanford Operations, Richland, Washington.

Strait, SR and FA Spane, Jr. 1982. Preliminary Results of Hydrologic Testing the Umtanum Basalt Entablature at Borehole RRL-2 (3,762-3,805 ft.). SD-BWI-TI-107, Rev. 0, Rockwell Hanford Operations, Richland, Washington.

Strait, SR and FA Spane, Jr. 1983. Preliminary Results of Hydrologic Testing the Middle Sentinel Bluffs Flow Top at Borehole RRL-2 (2,981-3,020 ft.). SD-BWI-TI-102, Rev. 0, Rockwell Hanford Operations, Richland, Washington.

Strait, SR and FA Spane, Jr. 1983. Preliminary Results of Hydrologic Testing the Middle Sentinel Bluffs Vesicular Zone at Borehole RRL-2 (3,057-3,172 ft.). SD-BWI-TI-090, Rev. 0, Rockwell Hanford Operations, Richland, Washington.

Strait, SR and FA Spane, Jr. 1983. Preliminary Results of Hydrologic Testing the Umtanum Basalt Fracture Zone at Borehole RRL-2 (3,781-3,827 ft.). SD-BWI-TI-089, Rev.0, Rockwell Hanford Operations, Richland, Washington.

Strait, SR. 1984. Hydrologic Field Testing Procedures, Basalt Operating Procedures, C-208. Rockwell Hanford Operations, Richland, Washington.

Strait, SR, FA Spane, Jr., RL Jackson, and WW Pidcoe. 1982. Hydrologic Testing Methodology and Results from Deep Basalt Boreholes. RHO-BW-SA-189, Rockwell Hanford Operations, Richland, Washington and GSA-Rocky Mountain Section, May 1982.

Thorne, PD and FA Spane, Jr. 1984. Hydrologic Test Results for the Rocky Coulee Flow Interior at Borehole DC-4. SD-BWI-TI-175, Rev. 0, Rockwell Hanford Operations, Richland, Washington. 


\section{SD-BWI-DP-051}

REV 2

APPENDIX A

Hydraulic Property Data 


\section{SD-BWI-DP-O51}

\section{REV 2}

\begin{tabular}{|c|c|c|c|c|c|c|}
\hline Borehole & $\begin{array}{l}\text { Strat. } \\
\text { Horizon }\end{array}$ & $\begin{array}{l}\text { Use } \\
\text { Code }\end{array}$ & $\begin{array}{l}\text { Isolated } \\
\text { Interval } \\
\text { (m) }\end{array}$ & $\begin{array}{c}\text { Effective } \\
\text { Test Interval } \\
\text { (m) }\end{array}$ & $\begin{array}{l}\text { Trans- } \\
\text { missivity } \\
(\mathrm{m} 2 / \mathrm{sec})\end{array}$ & $\begin{array}{c}\text { Observed } \\
\text { Hydraulic Head } \\
\text { (m) MSL }\end{array}$ \\
\hline DC-3 & Umtanum $\mathrm{C} / \mathrm{E}$ & 1 & $1092-1108$ & $1092-1108$ & $\begin{array}{c}1.0 \mathrm{E}-12 \text { to } \\
1.0 \mathrm{E}-11\end{array}$ & NA \\
\hline \multirow[t]{2}{*}{ DC-4 } & Rocky Coulee C/E & 0 & $882-897$ & $882-897$ & $1.3 \mathrm{E}-12$ & $\begin{array}{c}\text { NA } \\
\text { SD-BWI-TI-175 }\end{array}$ \\
\hline & Cohassett FT & 1 & $899-915$ & $904-909$ & $\begin{array}{c}1.0 \mathrm{E}-07 \text { to } \\
1.0 \mathrm{E}-06\end{array}$ & $128 \pm ?$ \\
\hline \multirow[t]{2}{*}{ DC-5 } & Cohassett FT & 1 & $899-915$ & $904-909$ & $\begin{array}{c}1.0 \mathrm{E}-07 \text { to } \\
1.0 \mathrm{E}-06\end{array}$ & NA \\
\hline & Cohassett $\mathrm{C} / \mathrm{E}$ & 1 & $964-976$ & $964-976$ & $\begin{array}{c}1.0 \mathrm{E}-12 \text { to } \\
1.0 \mathrm{E}-11\end{array}$ & NA \\
\hline \multirow[t]{9}{*}{ DC-6 } & $\begin{array}{l}\text { Grande Ronde } \\
\text { Composite }\end{array}$ & 1 & $689-1321$ & NA & $\begin{array}{c}1.0 \mathrm{E}-05 \text { to } \\
1.0 \mathrm{E}-04\end{array}$ & NA \\
\hline & Grande Ronde FT & 1 & $730-822$ & $\begin{array}{l}733-746 \\
748-756 \\
761-765 \\
776-783\end{array}$ & $\begin{array}{l}1.0 \mathrm{E}-05 \text { to } \\
1.0 \mathrm{E}-04\end{array}$ & $130 \pm ?$ \\
\hline & Grande Ronde FT & 1 & $822-882$ & $\begin{array}{l}821-851 \\
853-872\end{array}$ & $\begin{array}{c}1.0 \mathrm{E}-05 \text { to } \\
1.0 \mathrm{E}-04\end{array}$ & $130 \pm ?$ \\
\hline & Umtanum FT & 1 & $912-938$ & $925-934$ & $\begin{array}{c}1.0 \mathrm{E}-07 \text { to } \\
1.0 \mathrm{E}-06\end{array}$ & $136 \pm 1.5$ \\
\hline & Umtanum $\mathrm{C} / \mathrm{E}$ & 1 & $938-989$ & $938-989$ & $\begin{array}{c}1.0 \mathrm{E}-12 \text { to } \\
1.0 \mathrm{E}-10\end{array}$ & NA \\
\hline & Umtanum FB & 1 & $988-1076$ & $\begin{array}{c}933-1004 \\
1015-1025 \\
1030-1033\end{array}$ & $\begin{array}{l}1.0 \mathrm{E}-06 \text { to } \\
1.0 \mathrm{E}-05\end{array}$ & $136+?$ \\
\hline & Grande Ronde FT & 1 & $1076-1166$ & $\begin{array}{c}1077-1082 \\
1088-1092 \\
1097-1098 \\
1100-1102 \\
1103-1113 \\
1116-1120 \\
1123-1159\end{array}$ & $\begin{array}{c}1.0 \mathrm{E}-05 \text { to } \\
1.0 \mathrm{E}-04\end{array}$ & $137 \pm ?$ \\
\hline & Grande Ronde C/E & 1 & $1166-1271$ & $1166-1271$ & $\begin{array}{c}1.0 \mathrm{E}-12 \text { to } \\
1.0 \mathrm{E}-11\end{array}$ & NA \\
\hline & Grande Ronde FT & 1 & $1271-1321$ & $1275-1286$ & $\begin{array}{l}1.0 \mathrm{E}-06 \text { to } \\
1.0 \mathrm{E}-05\end{array}$ & $140 \pm 1.5$ \\
\hline DC-7 & $\begin{array}{c}\text { Grande Ronde } \\
\text { Composite }\end{array}$ & 1 & $1254-1526$ & NA & $\begin{array}{c}1.0 \mathrm{E}-06 \text { to } \\
1.0 \mathrm{E}-05\end{array}$ & $>122$ \\
\hline
\end{tabular}




\section{SD-BWI-DP-O51}

\section{REV 2}

\begin{tabular}{|c|c|c|c|c|c|c|}
\hline Borehole & $\begin{array}{l}\text { Strat. } \\
\text { Horizon }\end{array}$ & $\begin{array}{l}\text { Use } \\
\text { Code }\end{array}$ & $\begin{array}{l}\text { Isolated } \\
\text { Interval } \\
\text { (m) }\end{array}$ & $\begin{array}{c}\text { Effective } \\
\text { Test Interval } \\
\text { (m) }\end{array}$ & $\begin{array}{l}\text { Trans- } \\
\text { missivity } \\
(\mathrm{m} 2 / \mathrm{sec})\end{array}$ & $\begin{array}{l}\text { Observed } \\
\text { Hydraulic Head } \\
\text { (m) MSL }\end{array}$ \\
\hline & $\begin{array}{l}\text { Grande Ronde } \\
\text { Composite }\end{array}$ & 1 & $1256-1298$ & $\begin{array}{l}1261-1263 \\
1279-1283 \\
1287-1293\end{array}$ & $\begin{array}{l}1.0 \mathrm{E}-09 \text { to } \\
1.0 \mathrm{E}-08\end{array}$ & NA \\
\hline & $\begin{array}{c}\text { Grande Ronde } 20 \\
\text { FT }\end{array}$ & 1 & $1299-1351$ & $\begin{array}{l}1311-1317 \\
1319-1344\end{array}$ & $\begin{array}{l}1.0 \mathrm{E}-09 \text { to } \\
1.0 \mathrm{E}-08\end{array}$ & NA \\
\hline & $\begin{array}{l}\text { Grande Ronde } \\
\text { Composite }\end{array}$ & 1 & $1355-1407$ & $\begin{array}{l}1367-1370 \\
1374-1384 \\
1386-1389 \\
1392-1396\end{array}$ & $\begin{array}{l}1.0 \mathrm{E}-07 \text { to } \\
1.0 \mathrm{E}-06\end{array}$ & $>124$ \\
\hline & $\begin{array}{c}\text { Grande Ronde } 29 \\
\text { FT }\end{array}$ & 1 & $1428-1471$ & $\begin{array}{l}1430-1433 \\
1435-1466\end{array}$ & $\begin{array}{l}1.0 \mathrm{E}-06 \text { to } \\
1.0 \mathrm{E}-05\end{array}$ & $123+.9$ \\
\hline & $\begin{array}{l}\text { Grande Ronde } \\
\text { Composite }\end{array}$ & 1 & $1472-1526$ & $\begin{array}{l}1482-1482 \\
1487-1493 \\
1495-1508\end{array}$ & $\begin{array}{c}<1.0 \mathrm{E}-07 \\
\text { to }\end{array}$ & $>119$ \\
\hline DC-7/8 & $\begin{array}{c}\text { McCoy Canyon } \\
\text { FT }\end{array}$ & 1 & $1039-1060$ & $1053-1059$ & $\begin{array}{l}1.0 \mathrm{E}-07 \text { to } \\
1.0 \mathrm{E}-06\end{array}$ & $124 \pm 1.2$ \\
\hline \multirow[t]{11}{*}{ DC-12 } & Rosalia FT & 1 & $371-382$ & $373-382$ & $\begin{array}{l}1.0 \mathrm{E}-04 \text { to } \\
1.0 \mathrm{E}-03\end{array}$ & $124 \pm ?$ \\
\hline & $\begin{array}{c}\text { Quincy IB/Roza } \\
\text { FT }\end{array}$ & 1 & $405-416$ & $\begin{array}{l}405-406 \\
408-413 \\
413-416\end{array}$ & $\begin{array}{l}1.0 \mathrm{E}-04 \text { to } \\
1.0 \mathrm{E}-03\end{array}$ & $123 \pm ?$ \\
\hline & Sentinel Gap FT & 1 & $460-468$ & $436-467$ & $\begin{array}{l}1.0 \mathrm{E}-05 \text { to } \\
1.0 \mathrm{E}-04\end{array}$ & $124 \pm ?$ \\
\hline & Sand Hollow 2 FT & 1 & $514-521$ & $515-519$ & $\begin{array}{l}1.0 \mathrm{E}-05 \text { to } \\
1.0 \mathrm{E}-04\end{array}$ & $124+?$ \\
\hline & Ginkgo 2 FT & 1 & $582-605$ & $\begin{array}{l}584-585 \\
586-605\end{array}$ & $\begin{array}{l}1.0 \mathrm{E}-07 \text { to } \\
1.0 \mathrm{E}-06\end{array}$ & $124 \pm ?$ \\
\hline & Ginkgo $1 \mathrm{FT}$ & 1 & $625-634$ & $\begin{array}{l}627-630 \\
632-634\end{array}$ & $\begin{array}{l}1.0 \mathrm{E}-04 \text { to } \\
1.0 \mathrm{E}-03\end{array}$ & $124+?$ \\
\hline & $\begin{array}{c}\text { Palouse Falls } \\
\text { IB/Grande Ronde } \\
1 \mathrm{FT}\end{array}$ & 1 & $676-689$ & $677-684$ & $\begin{array}{l}1.0 \mathrm{E}-07 \text { to } \\
1.0 \mathrm{E}-06\end{array}$ & $123 \pm ?$ \\
\hline & $\begin{array}{c}\text { Grande Ronde } 2 \\
\text { FT }\end{array}$ & 1 & $691-701$ & $\begin{array}{l}694-696 \\
698-701\end{array}$ & $\begin{array}{l}1.0 \mathrm{E}-06 \text { to } \\
1.0 \mathrm{E}-05\end{array}$ & $124 \pm .6$ \\
\hline & Rocky Coulee FT & 1 & $734-746$ & $736-743$ & $\begin{array}{l}1.0 \mathrm{E}-05 \text { to } \\
1.0 \mathrm{E}-04\end{array}$ & $124 \pm .6$ \\
\hline & $\begin{array}{l}\text { Cohassett } \\
\text { Composite }\end{array}$ & 1 & $782-811$ & $\begin{array}{l}784-787 \\
789-792 \\
794-807\end{array}$ & $\begin{array}{l}1.0 \mathrm{E}-07 \text { to } \\
1.0 \mathrm{E}-06\end{array}$ & NA \\
\hline & $\begin{array}{c}\text { Grande Ronde } 7 \\
\text { FT }\end{array}$ & 1 & $859-867$ & $862-865$ & $\begin{array}{l}1.0 \mathrm{E}-03 \text { to } \\
1.0 \mathrm{E}-02\end{array}$ & $124 \pm .6$ \\
\hline
\end{tabular}




\section{SD-BWI-DP-O51}

\section{REV 2}

\begin{tabular}{|c|c|c|c|c|c|c|}
\hline Borehole & $\begin{array}{l}\text { Strat. } \\
\text { Horizon }\end{array}$ & $\begin{array}{l}\text { Use } \\
\text { Code }\end{array}$ & $\begin{array}{l}\text { Isolated } \\
\text { Interval } \\
\text { (m) }\end{array}$ & $\begin{array}{c}\text { Effective } \\
\text { Test Interval } \\
\text { (m) }\end{array}$ & $\begin{array}{l}\text { Trans- } \\
\text { missivity } \\
(\mathrm{m} 2 / \mathrm{sec})\end{array}$ & $\begin{array}{c}\text { Observed } \\
\text { Hydraulic Head } \\
\text { (m) MSL }\end{array}$ \\
\hline & $\begin{array}{c}\text { Grande Ronde } 8 \\
\text { FT }\end{array}$ & 1 & $865-873$ & $867-871$ & $\begin{array}{c}1.0 \mathrm{E}-04 \text { to } \\
1.0 \mathrm{E}-03\end{array}$ & $124 \pm .6$ \\
\hline & $\begin{array}{l}\text { Grande Ronde } \\
\text { Composite }\end{array}$ & 1 & $908-961$ & $\begin{array}{l}913-927 \\
942-947 \\
949-955\end{array}$ & $\begin{array}{l}1.0 \mathrm{E}-07 \text { to } \\
1.0 \mathrm{E}-06\end{array}$ & NA \\
\hline & $\begin{array}{c}\text { McCoy Canyon } \\
\text { FT }\end{array}$ & 1 & $935-961$ & $\begin{array}{l}942-947 \\
949-955\end{array}$ & $\begin{array}{l}1.0 \mathrm{E}-08 \text { to } \\
1.0 \mathrm{E}-07\end{array}$ & NA \\
\hline & Umtanum FT & 1 & $975-1000$ & $\begin{array}{l}979-988 \\
990-995\end{array}$ & $\begin{array}{l}1.0 \mathrm{E}-10 \text { to } \\
1.0 \mathrm{E}-08\end{array}$ & NA \\
\hline & $\begin{array}{l}\text { Grande Ronde } \\
\text { Composite }\end{array}$ & 1 & $1018-1241$ & NA & $\begin{array}{l}1.0 \mathrm{E}-04 \text { to } \\
1.0 \mathrm{E}-03\end{array}$ & $124+?$ \\
\hline & $\begin{array}{l}\text { Grande Ronde } \\
\text { Composite }\end{array}$ & 1 & $1226-1241$ & $1227-1237$ & $\begin{array}{l}1.0 \mathrm{E}-04 \text { to } \\
1.0 \mathrm{E}-03\end{array}$ & $124 \pm ?$ \\
\hline & $\begin{array}{l}\text { Grande Ronde } \\
\text { Composite }\end{array}$ & 1 & $1245-1358$ & NA & $\begin{array}{l}1.0 \mathrm{E}-04 \text { to } \\
1.0 \mathrm{E}-03\end{array}$ & $124 \pm ?$ \\
\hline & $\begin{array}{l}\text { Grande Ronde } \\
\text { Composite }\end{array}$ & 1 & $1324-1358$ & NA & $\begin{array}{l}1.0 \mathrm{E}-04 \text { to } \\
1.0 \mathrm{E}-03\end{array}$ & $124 \pm ?$ \\
\hline \multirow[t]{12}{*}{ DC-14 } & $\begin{array}{c}\text { Elephant } \\
\text { Mountain FT }\end{array}$ & 1 & $112-145$ & $120-126$ & $\begin{array}{l}1.0 \mathrm{E}-06 \text { to } \\
1.0 \mathrm{E}-05\end{array}$ & $115 \pm ?$ \\
\hline & $\begin{array}{c}\text { Rattlesnake Ridge } \\
\text { IB }\end{array}$ & 1 & $145-164$ & $150-162$ & $\begin{array}{l}1.0 \mathrm{E}-05 \text { to } \\
1.0 \mathrm{E}-04\end{array}$ & $122 \pm ?$ \\
\hline & Selah IB & 1 & $206-234$ & $214-231$ & $\begin{array}{l}1.0 \mathrm{E}-04 \text { to } \\
1.0 \mathrm{E}-03\end{array}$ & $124 \pm ?$ \\
\hline & Asotin FT & 1 & $268-276$ & $270-276$ & $\begin{array}{l}1.0 \mathrm{E}-03 \text { to } \\
1.0 \mathrm{E}-02\end{array}$ & $150 \pm ?$ \\
\hline & Asotin FT & 1 & $277-281$ & $279-281$ & $\begin{array}{l}1.0 \mathrm{E}-03 \text { to } \\
1.0 \mathrm{E}-02\end{array}$ & $150 \pm ?$ \\
\hline & Asotin FT & 1 & $282-295$ & $288-294$ & $\begin{array}{l}1.0 \mathrm{E}-04 \text { to } \\
1.0 \mathrm{E}-03\end{array}$ & NA \\
\hline & Mabton IB & 1 & $295-330$ & NA & $\begin{array}{l}1.0 \mathrm{E}-05 \text { to } \\
1.0 \mathrm{E}-04\end{array}$ & $149 \pm ?$ \\
\hline & Priest Rapids FT & 1 & $360-363$ & $362-362$ & $\begin{array}{l}1.0 \mathrm{E}-04 \text { to } \\
1.0 \mathrm{E}-03\end{array}$ & $151 \pm ?$ \\
\hline & Priest Rapids FT & 1 & $365-371$ & $366-370$ & $\begin{array}{c}1.0 \mathrm{E}-03 \text { to } \\
1.0 \mathrm{E}-02\end{array}$ & $150 \pm ?$ \\
\hline & Priest Rapids FT & 1 & $371-387$ & $372-374$ & $\begin{array}{l}1.0 \mathrm{E}-03 \text { to } \\
1.0 \mathrm{E}-02\end{array}$ & $151 \pm ?$ \\
\hline & Roza FT & 1 & $392-409$ & $395-408$ & $\begin{array}{l}1.0 \mathrm{E}-03 \text { to } \\
1.0 \mathrm{E}-02\end{array}$ & $150 \pm ?$ \\
\hline & $\begin{array}{l}\text { Frenchman } \\
\text { Springs FT }\end{array}$ & 1 & $451-462$ & $455-459$ & $\begin{array}{l}1.0 \mathrm{E}-05 \text { to } \\
1.0 \mathrm{E}-04\end{array}$ & $148 \pm ?$ \\
\hline
\end{tabular}




\section{SD-BWI-DP-O51}

\section{REV 2}

\begin{tabular}{|c|c|c|c|c|c|c|}
\hline Borehole & $\begin{array}{l}\text { Strat. } \\
\text { Horizon }\end{array}$ & $\begin{array}{l}\text { Use } \\
\text { Code }\end{array}$ & $\begin{array}{l}\text { Isolated } \\
\text { Interval } \\
\text { (m) }\end{array}$ & $\begin{array}{c}\text { Effective } \\
\text { Test Interval } \\
\text { (m) }\end{array}$ & $\begin{array}{l}\text { Trans- } \\
\text { missivity } \\
(\mathrm{m} 2 / \mathrm{sec})\end{array}$ & $\begin{array}{c}\text { Observed } \\
\text { Hydraulic Head } \\
\text { (m) MSL }\end{array}$ \\
\hline & Frenchman & 1 & $480-497$ & $488-496$ & $1.0 \mathrm{E}-04$ to & $149 \pm ?$ \\
\hline & Springs FT & & & & $1.0 \mathrm{E}-03$ & \\
\hline & Frenchman & 1 & $500-521$ & $512-517$ & $1.0 \mathrm{E}-04$ to & $149 \pm ?$ \\
\hline & Springs FT & & & & $1.0 \mathrm{E}-03$ & \\
\hline & Frenchman & 1 & $524-555$ & $529-532$ & $1.0 \mathrm{E}-04$ to & $149 \pm ?$ \\
\hline & Springs FT & & & $536-539$ & $1.0 \mathrm{E}-03$ & \\
\hline & Frenchman & 1 & $555-572$ & $560-565$ & $1.0 \mathrm{E}-04$ to & $148+?$ \\
\hline & Springs FT & & & & $1.0 \mathrm{E}-03$ & \\
\hline & Frenchman & 1 & $572-604$ & $575-581$ & $1.0 \mathrm{E}-03$ to & $134 \pm ?$ \\
\hline & Springs FT & & & $587-597$ & $1.0 \mathrm{E}-02$ & \\
\hline & Vantage & 1 & $646-681$ & $653-661$ & $1.0 \mathrm{E}-04$ to & $143 \pm ?$ \\
\hline & IB/Grande Ronde & & & $668-671$ & $1.0 \mathrm{E}-03$ & \\
\hline & FT & & & $672-675$ & & \\
\hline & Grande Ronde FT & 1 & $718-733$ & $722-729$ & $\begin{array}{l}1.0 \mathrm{E}-07 \text { to } \\
1.0 \mathrm{E}-06\end{array}$ & $133 \pm 1.5$ \\
\hline & Grande Ronde FT & 1 & $735-766$ & $747-755$ & $\begin{array}{l}1.0 \mathrm{E}-06 \text { to } \\
1.0 \mathrm{E}-05\end{array}$ & $135 \pm .6$ \\
\hline & Grande Ronde FT & 1 & $810-876$ & $819-824$ & $1.0 \mathrm{E}-07$ to & $133 \pm ?$ \\
\hline & & & & $833-840$ & $1.0 \mathrm{E}-06$ & \\
\hline & & & & $861-871$ & & \\
\hline & Grande Ronde FT & 1 & $841-876$ & $861-871$ & $\begin{array}{c}1.0 \mathrm{E}-09 \text { to } \\
1.0 \mathrm{E}-08\end{array}$ & $133 \pm 1.5$ \\
\hline & Grande Ronde FT & 1 & $878-907$ & $882-900$ & $\begin{array}{l}1.0 \mathrm{E}-07 \text { to } \\
1.0 \mathrm{E}-06\end{array}$ & $133 \pm 1.5$ \\
\hline & Umtanum FT & 1 & $933-958$ & $936-956$ & $\begin{array}{l}1.0 \mathrm{E}-05 \text { to } \\
1.0 \mathrm{E}-04\end{array}$ & $134+.3$ \\
\hline & Grande Ronde FT & 1 & $969-983$ & $975-980$ & $\begin{array}{l}1.0 \mathrm{E}-06 \text { to } \\
1.0 \mathrm{E}-05\end{array}$ & $134+.3$ \\
\hline & Grande Ronde FT & 1 & 994-1017 & $999-1015$ & $\begin{array}{l}1.0 \mathrm{E}-05 \text { to } \\
1.0 \mathrm{E}-04\end{array}$ & $134+?$ \\
\hline \multirow[t]{6}{*}{ DC-15 } & Levey IB & 1 & $84-105$ & $87-95$ & $\begin{array}{l}1.0 \mathrm{E}-04 \text { to } \\
1.0 \mathrm{E}-03\end{array}$ & $112+.3$ \\
\hline & $\begin{array}{c}\text { Rattlesnake Ridge } \\
\text { IB }\end{array}$ & 1 & $127-151$ & $133-150$ & $\begin{array}{l}1.0 \mathrm{E}-04 \text { to } \\
1.0 \mathrm{E}-03\end{array}$ & $117 \pm .3$ \\
\hline & Selah IB & 1 & $183-192$ & $183-188$ & $\begin{array}{l}1.0 \mathrm{E}-05 \text { to } \\
1.0 \mathrm{E}-04\end{array}$ & $109 \pm .6$ \\
\hline & Esquatzel FT & 1 & $192-201$ & $193-198$ & $\begin{array}{l}1.0 \mathrm{E}-05 \text { to } \\
1.0 \mathrm{E}-04\end{array}$ & $109 \pm .6$ \\
\hline & Cold Creek IB & 0 & $217-240$ & $220-239$ & $3.1 \mathrm{E}-05$ & $109 \pm .9$ \\
\hline & Mabton IB & 1 & $306-327$ & $310-324$ & $\begin{array}{l}1.0 \mathrm{E}-05 \text { to } \\
1.0 \mathrm{E}-04\end{array}$ & $\begin{array}{c}\text { SD-BWI-TI-150 } \\
117 \pm .6\end{array}$ \\
\hline
\end{tabular}




\section{SD-BWI-DP-O51}

\section{REV 2}

\begin{tabular}{|c|c|c|c|c|c|c|}
\hline Borehole & $\begin{array}{l}\text { Strat. } \\
\text { Horizon }\end{array}$ & $\begin{array}{l}\text { Use } \\
\text { Code }\end{array}$ & $\begin{array}{l}\text { Isolated } \\
\text { Interval } \\
\text { (m) }\end{array}$ & $\begin{array}{c}\text { Effective } \\
\text { Test Interval } \\
\text { (m) }\end{array}$ & $\begin{array}{l}\text { Trans- } \\
\text { missivity } \\
(\mathrm{m} 2 / \mathrm{sec})\end{array}$ & $\begin{array}{l}\text { Observed } \\
\text { Hydraulic Head } \\
\text { (m) MSL }\end{array}$ \\
\hline & Priest Rapids & 1 & $350-362$ & $351-358$ & $\begin{array}{l}1.0 \mathrm{E}-07 \text { to } \\
1.0 \mathrm{E}-06\end{array}$ & $118 \pm ?$ \\
\hline & $\begin{array}{c}\text { Priest Rapids/Roza } \\
\text { FT }\end{array}$ & 1 & $372-394$ & $378-392$ & $\begin{array}{l}1.0 \mathrm{E}-03 \text { to } \\
1.0 \mathrm{E}-02\end{array}$ & $118+.3$ \\
\hline & Roza FT & 1 & $414-424$ & $416-419$ & $\begin{array}{l}1.0 \mathrm{E}-04 \text { to } \\
1.0 \mathrm{E}-03\end{array}$ & $118+.3$ \\
\hline & Sentinel Gap FT & 1 & $425-449$ & $429-431$ & $\begin{array}{l}1.0 \mathrm{E}-06 \text { to } \\
1.0 \mathrm{E}-05\end{array}$ & $118+.6$ \\
\hline & Wallula Gap FT & 1 & $451-459$ & $453-458$ & $\begin{array}{l}1.0 \mathrm{E}-03 \text { to } \\
1.0 \mathrm{E}-02\end{array}$ & $118 \pm .3$ \\
\hline & Sand Hollow 3 FT & 1 & $459-473$ & $463-468$ & $\begin{array}{l}1.0 \mathrm{E}-04 \text { to } \\
1.0 \mathrm{E}-03\end{array}$ & $118+.3$ \\
\hline & Sand Hollow 2 FT & 1 & $469-486$ & $475-481$ & $\begin{array}{l}1.0 \mathrm{E}-03 \text { to } \\
1.0 \mathrm{E}-02\end{array}$ & $118+.3$ \\
\hline & Ginkgo 2 FT & 1 & $529-559$ & $\begin{array}{l}530-531 \\
543-561\end{array}$ & $\begin{array}{l}1.0 \mathrm{E}-06 \text { to } \\
1.0 \mathrm{E}-05\end{array}$ & $118 \pm .6$ \\
\hline & Ginkgo 1 FT & 1 & $559-575$ & $561-573$ & $\begin{array}{l}1.0 \mathrm{E}-03 \text { to } \\
1.0 \mathrm{E}-02\end{array}$ & $118+.3$ \\
\hline & $\begin{array}{c}\text { Vantage } \\
\text { IB/Grande Ronde } \\
1 \mathrm{FT}\end{array}$ & 1 & $640-670$ & $645-661$ & $\begin{array}{l}1.0 \mathrm{E}-06 \text { to } \\
1.0 \mathrm{E}-05\end{array}$ & $119 \pm .6$ \\
\hline & Rocky Coulee FT & 1 & $679-714$ & $\begin{array}{l}685-686 \\
690-699\end{array}$ & $\begin{array}{l}1.0 \mathrm{E}-03 \text { to } \\
1.0 \mathrm{E}-02\end{array}$ & $118 \pm .6$ \\
\hline & $\begin{array}{c}\text { Grande Ronde } 5 \\
\text { FT }\end{array}$ & 1 & $723-758$ & $744-747$ & $\begin{array}{l}1.0 \mathrm{E}-06 \text { to } \\
1.0 \mathrm{E}-05\end{array}$ & $119 \pm .6$ \\
\hline & Cohassett FT & 1 & $760-777$ & $768-775$ & $\begin{array}{l}1.0 \mathrm{E}-04 \text { to } \\
1.0 \mathrm{E}-03\end{array}$ & $119+.6$ \\
\hline & $\begin{array}{c}\text { Grande Ronde } 7 \\
\text { FT }\end{array}$ & 2 & $808-823$ & $810-812$ & $<1.0 \mathrm{E}-04$ & $119 \pm ?$ \\
\hline & $\begin{array}{c}\text { Grande Ronde } 9 \\
\text { FT }\end{array}$ & 1 & $821-842$ & $\begin{array}{l}832-834 \\
840-842\end{array}$ & $\begin{array}{l}1.0 \mathrm{E}-06 \text { to } \\
1.0 \mathrm{E}-05\end{array}$ & $119 \pm .6$ \\
\hline & $\begin{array}{c}\text { Grande Ronde } 11 \\
\text { FT }\end{array}$ & 1 & $857-874$ & $862-873$ & $\begin{array}{l}1.0 \mathrm{E}-06 \text { to } \\
1.0 \mathrm{E}-05\end{array}$ & $119+.6$ \\
\hline & Umtanum FT & 1 & $903-949$ & $910-946$ & $>1.0 \mathrm{E}-04$ & $122+.3$ \\
\hline & $\begin{array}{c}\text { Grande Ronde } 14 \\
\text { FT }\end{array}$ & 1 & $989-1005$ & $991-1003$ & $\begin{array}{l}1.0 \mathrm{E}-06 \text { to } \\
1.0 \mathrm{E}-05\end{array}$ & $112 \pm ?$ \\
\hline & $\begin{array}{l}\text { Very High Mg } \\
\text { Flow FT }\end{array}$ & 1 & $1006-1040$ & $1016-1031$ & $\begin{array}{l}1.0 \mathrm{E}-06 \text { to } \\
1.0 \mathrm{E}-05\end{array}$ & $117 \pm ?$ \\
\hline & $\begin{array}{c}\text { Grade Ronde } 17 \\
\text { FT }\end{array}$ & 1 & $1101-1108$ & $1102-1106$ & $<1.0 \mathrm{E}-08$ & NA \\
\hline & $\begin{array}{c}\text { Grande Ronde } 19 \\
\text { FT }\end{array}$ & 1 & $1140-1172$ & $1141-1168$ & $\begin{array}{l}1.0 \mathrm{E}-08 \text { to } \\
1.0 \mathrm{E}-07\end{array}$ & NA \\
\hline
\end{tabular}




\section{SD-BWI-DP-O51}

\section{REV 2}

\begin{tabular}{|c|c|c|c|c|c|c|}
\hline Borehole & $\begin{array}{l}\text { Strat. } \\
\text { Horizon }\end{array}$ & $\begin{array}{l}\text { Use } \\
\text { Code }\end{array}$ & $\begin{array}{l}\text { Isolated } \\
\text { Interval } \\
\text { (m) }\end{array}$ & $\begin{array}{c}\text { Effective } \\
\text { Test Interval } \\
\text { (m) }\end{array}$ & $\begin{array}{l}\text { Trans- } \\
\text { missivity } \\
(\mathrm{m} 2 / \mathrm{sec})\end{array}$ & $\begin{array}{c}\text { Observed } \\
\text { Hydraulic Head } \\
\text { (m) MSL }\end{array}$ \\
\hline & $\begin{array}{l}\text { Grande Ronde } 20 \text {, } \\
21 \& 22 \text { FTS }\end{array}$ & 1 & $1261-1293$ & $\begin{array}{l}1267-1277 \\
1281-1286\end{array}$ & $\begin{array}{l}1.0 \mathrm{E}-06 \text { to } \\
1.0 \mathrm{E}-05\end{array}$ & $123 \pm .6$ \\
\hline \multirow[t]{19}{*}{ DC-16A } & $\begin{array}{c}\text { Rattlesnake Ridge } \\
\text { IB }\end{array}$ & 1 & $204-255$ & $208-246$ & $\begin{array}{l}1.0 \mathrm{E}-03 \text { to } \\
1.0 \mathrm{E}-02\end{array}$ & $137 \pm ?$ \\
\hline & Selah IB & 1 & $283-311$ & $287-306$ & $\begin{array}{c}1.0 \mathrm{E}-05 \text { to } \\
1.0 \mathrm{E}-04\end{array}$ & $134 \pm ?$ \\
\hline & Cold Creek IB & 1 & $329-369$ & $337-359$ & $\begin{array}{l}1.0 \mathrm{E}-06 \text { to } \\
1.0 \mathrm{E}-05\end{array}$ & $127 \pm ?$ \\
\hline & Mabton IB & 1 & $425-478$ & $433-462$ & $\begin{array}{l}1.0 \mathrm{E}-04 \text { to } \\
1.0 \mathrm{E}-03\end{array}$ & $128+?$ \\
\hline & Priest Rapids FT & 1 & $515-527$ & $520-521$ & $\begin{array}{l}1.0 \mathrm{E}-06 \text { to } \\
1.0 \mathrm{E}-05\end{array}$ & $116 \pm ?$ \\
\hline & Roza FT & 1 & $536-557$ & $540-544$ & $\begin{array}{c}1.0 \mathrm{E}-02 \text { to } \\
1.0 \mathrm{E}-01\end{array}$ & $123 \pm ?$ \\
\hline & $\begin{array}{l}\text { Frenchman } \\
\text { Springs FT }\end{array}$ & 1 & $577-610$ & $593-596$ & $\begin{array}{l}1.0 \mathrm{E}-03 \text { to } \\
1.0 \mathrm{E}-02\end{array}$ & $123 \pm ?$ \\
\hline & $\begin{array}{l}\text { Frenchman } \\
\text { Springs FT }\end{array}$ & 1 & $642-657$ & $648-651$ & $\begin{array}{c}1.0 \mathrm{E}-05 \text { to } \\
1.0 \mathrm{E}-04\end{array}$ & $123 \pm ?$ \\
\hline & $\begin{array}{l}\text { Frenchman } \\
\text { Springs FT }\end{array}$ & 1 & $682-689$ & $682-684$ & $\begin{array}{c}1.0 \mathrm{E}-03 \text { to } \\
1.0 \mathrm{E}-02\end{array}$ & $122 \pm ?$ \\
\hline & $\begin{array}{l}\text { Frenchman } \\
\text { Springs FT }\end{array}$ & 1 & $691-723$ & $\begin{array}{l}694-698 \\
704-708 \\
709-714 \\
715-723\end{array}$ & $\begin{array}{l}1.0 \mathrm{E}-05 \text { to } \\
1.0 \mathrm{E}-04\end{array}$ & $123 \pm ?$ \\
\hline & $\begin{array}{l}\text { Frenchman } \\
\text { Springs FT }\end{array}$ & 1 & $755-780$ & $762-780$ & $\begin{array}{l}1.0 \mathrm{E}-03 \text { to } \\
1.0 \mathrm{E}-02\end{array}$ & $123+?$ \\
\hline & $\begin{array}{l}\text { Frenchman } \\
\text { Springs F }\end{array}$ & 1 & $788-802$ & $792-802$ & $\begin{array}{c}1.0 \mathrm{E}-04 \text { to } \\
1.0 \mathrm{E}-03\end{array}$ & $123 \pm ?$ \\
\hline & Vantage IB & 1 & $814-832$ & $\begin{array}{l}825-828 \\
828-828 \\
829-829\end{array}$ & $\begin{array}{c}1.0 \mathrm{E}-04 \text { to } \\
1.0 \mathrm{E}-03\end{array}$ & $123 \pm ?$ \\
\hline & Grande Ronde FT & 1 & $814-860$ & $825-829$ & $>1.0 \mathrm{E}-04$ & $122 \pm .6$ \\
\hline & Grande Ronde FT & 1 & $864-898$ & $869-885$ & $\begin{array}{c}1.0 \mathrm{E}-07 \text { to } \\
1.0 \mathrm{E}-04\end{array}$ & $122 \pm .6$ \\
\hline & Cohassett FT & 1 & $905-941$ & $\begin{array}{l}909-919 \\
922-929\end{array}$ & $\begin{array}{c}1.0 \mathrm{E}-08 \text { to } \\
1.0 \mathrm{E}-04\end{array}$ & $122 \pm .9$ \\
\hline & $\begin{array}{l}\text { Cohassett C/E } \\
\text { (vesicular zone) }\end{array}$ & 0 & $941-992$ & $941-992$ & $2.6 \mathrm{E}-07$ & $\begin{array}{c}\text { NA } \\
\text { SD-BWI-TI-166 }\end{array}$ \\
\hline & Cohassett $\mathrm{C} / \mathrm{E}$ & 1 & $961-992$ & $961-992$ & $\begin{array}{c}1.0 \mathrm{E}-12 \text { to } \\
1.0 \mathrm{E}-11\end{array}$ & NA \\
\hline & Birkett FT & 1 & $992-1024$ & $1000-1019$ & $\begin{array}{c}1.0 \mathrm{E}-09 \text { to } \\
1.0 \mathrm{E}-08\end{array}$ & $122 \pm .9$ \\
\hline
\end{tabular}




\section{SD-BWI-DP-O51}

\section{REV 2}

\begin{tabular}{|c|c|c|c|c|c|c|}
\hline Borehole & $\begin{array}{l}\text { Strat. } \\
\text { Horizon }\end{array}$ & $\begin{array}{l}\text { Use } \\
\text { Code }\end{array}$ & $\begin{array}{l}\text { Isolated } \\
\text { Interval } \\
\text { (m) }\end{array}$ & $\begin{array}{c}\text { Effective } \\
\text { Test Interval } \\
\text { (m) }\end{array}$ & $\begin{array}{l}\text { Trans- } \\
\text { missivity } \\
(\mathrm{m} 2 / \mathrm{sec})\end{array}$ & $\begin{array}{c}\text { Observed } \\
\text { Hydraulic Head } \\
\text { (m) MSL }\end{array}$ \\
\hline & Grande Ronde FT & 1 & $1031-1065$ & NA & $\begin{array}{c}1.0 \mathrm{E}-10 \text { to } \\
1.0 \mathrm{E}-09\end{array}$ & NA \\
\hline & $\begin{array}{c}\text { McCoy Canyon } \\
\text { FT }\end{array}$ & 1 & $1070-1082$ & NA & NA & $123 \pm ?$ \\
\hline & Umtanum FT & 1 & $1104-1136$ & $1105-1131$ & $\begin{array}{l}1.0 \mathrm{E}-06 \text { to } \\
1.0 \mathrm{E}-05\end{array}$ & $123 \pm .9$ \\
\hline & Umtanum $\mathrm{C} / \mathrm{E}$ & 1 & $1137-1178$ & $1137-1178$ & $\begin{array}{l}1.0 \mathrm{E}-09 \text { to } \\
1.0 \mathrm{E}-08\end{array}$ & NA \\
\hline & Grande Ronde FT & 1 & $1193-1231$ & $1202-1209$ & $\begin{array}{l}1.0 \mathrm{E}-06 \text { to } \\
1.0 \mathrm{E}-06\end{array}$ & $123 \pm .9$ \\
\hline \multirow[t]{6}{*}{ DC-19C } & Priest Rapids FT & 1 & $503-595$ & $507-516$ & $\begin{array}{l}1.0 \mathrm{E}-04 \text { to } \\
1.0 \mathrm{E}-03\end{array}$ & $\begin{array}{c}\text { NA } \\
\text { SD-BWI-TI-226 }\end{array}$ \\
\hline & Sentinel Gap FT & 1 & $557-595$ & $575-591$ & $\begin{array}{l}1.0 \mathrm{E}-05 \text { to } \\
1.0 \mathrm{E}-04\end{array}$ & $\begin{array}{c}\text { NA } \\
\text { SD-BWI-TI-226 }\end{array}$ \\
\hline & Ginkgo FT & 1 & $738-752$ & $\begin{array}{l}738-739 \\
744-750\end{array}$ & $>1.1 \mathrm{E}-04$ & $\begin{array}{c}\text { NA } \\
\text { SD-BWI-TI-226 }\end{array}$ \\
\hline & Rocky Coulee FT & 1 & $852-866$ & $853-864$ & $\begin{array}{l}1.0 \mathrm{E}-07 \text { to } \\
1.1 \mathrm{E}-06\end{array}$ & $\begin{array}{c}\text { NA } \\
\text { SD-BWI-TI-226 }\end{array}$ \\
\hline & Cohassett C/E & 1 & $951-980$ & $959-973$ & $\begin{array}{l}1.0 \mathrm{E}-11 \text { to } \\
1.1 \mathrm{E}-10\end{array}$ & $\begin{array}{c}\text { NA } \\
\text { SD-BWI-TI-226 }\end{array}$ \\
\hline & Umtanum FT & 1 & $1093-1118$ & $1095-1116$ & $\begin{array}{l}1.0 \mathrm{E}-05 \text { to } \\
1.1 \mathrm{E}-04\end{array}$ & $\begin{array}{c}\text { NA } \\
\text { SD-BWI-TI-226 }\end{array}$ \\
\hline \multirow[t]{4}{*}{ DC-20C } & Sentinel Gap FT & 1 & $563-615$ & $567-574$ & $\begin{array}{l}1.0 \mathrm{E}-03 \text { to } \\
1.1 \mathrm{E}-02\end{array}$ & $\begin{array}{c}\text { NA } \\
\text { SD-BWI-TI-226 }\end{array}$ \\
\hline & Ginkgo FT & 1 & $725-777$ & $733-743$ & $\begin{array}{l}1.0 \mathrm{E}-05 \text { to } \\
1.1 \mathrm{E}-04\end{array}$ & $\begin{array}{c}\text { NA } \\
\text { SD-BWI-TI-226 }\end{array}$ \\
\hline & Cohassett FT & 1 & $892-944$ & $894-897$ & $\begin{array}{l}1.0 \mathrm{E}-07 \text { to } \\
1.1 \mathrm{E}-06\end{array}$ & $\begin{array}{c}\text { NA } \\
\text { SD-BWI-TI-226 }\end{array}$ \\
\hline & Umtanum FT & 1 & $1080-1131$ & $1083-1117$ & $\begin{array}{l}1.0 \mathrm{E}-07 \text { to } \\
1.1 \mathrm{E}-06\end{array}$ & $\begin{array}{c}\text { NA } \\
\text { SD-BWI-TI-226 }\end{array}$ \\
\hline \multirow[t]{2}{*}{ DC-22C } & Rocky Coulee FT & 1 & $877-922$ & $878-886$ & $\begin{array}{l}1.0 \mathrm{E}-09 \text { to } \\
1.1 \mathrm{E}-05\end{array}$ & $\begin{array}{c}\text { NA } \\
\text { SD-BWI-TI-226 }\end{array}$ \\
\hline & Umtanum FT & 1 & $1126-1172$ & $1127-1164$ & $\begin{array}{l}1.1 \mathrm{E}-05 \text { to } \\
1.1 \mathrm{E}-03\end{array}$ & $\begin{array}{c}\text { NA } \\
\text { SD-BWI-TI-226 }\end{array}$ \\
\hline \multirow[t]{2}{*}{ DC-23GR } & Rosalia FT & 1 & $410-434$ & NA & $\begin{array}{l}1.0 \mathrm{E}-03 \text { to } \\
1.0 \mathrm{E}-02\end{array}$ & NA \\
\hline & Sentinel Gap FT & 1 & $481-498$ & NA & $\begin{array}{c}1.0 \mathrm{E}-02 \text { to } \\
1.0 \mathrm{E}-01\end{array}$ & NA \\
\hline
\end{tabular}




\section{SD-BWI-DP-O51}

\section{REV 2}

\begin{tabular}{|c|c|c|c|c|c|c|}
\hline Borehole & $\begin{array}{l}\text { Strat. } \\
\text { Horizon }\end{array}$ & $\begin{array}{l}\text { Use } \\
\text { Code }\end{array}$ & $\begin{array}{l}\text { Isolated } \\
\text { Interval } \\
\text { (m) }\end{array}$ & $\begin{array}{c}\text { Effective } \\
\text { Test Interval } \\
\text { (m) }\end{array}$ & $\begin{array}{l}\text { Trans- } \\
\text { missivity } \\
(\mathrm{m} 2 / \mathrm{sec})\end{array}$ & $\begin{array}{c}\text { Observed } \\
\text { Hydraulic Head } \\
\text { (m) MSL }\end{array}$ \\
\hline & Ginkgo FT & 1 & $657-675$ & NA & $\begin{array}{c}1.0 \mathrm{E}-06 \text { to } \\
1.0 \mathrm{E}-04\end{array}$ & NA \\
\hline & Rocky Coulee FT & 1 & $742-757$ & NA & $\begin{array}{c}1.0 \mathrm{E}-08 \text { to } \\
1.0 \mathrm{E}-07\end{array}$ & NA \\
\hline & Cohassett FT & 1 & $797-821$ & NA & $\begin{array}{c}1.0 \mathrm{E}-09 \text { to } \\
1.0 \mathrm{E}-08\end{array}$ & NA \\
\hline & Birkett FT & 1 & $891-907$ & NA & $\begin{array}{c}1.0 \mathrm{E}-08 \text { to } \\
1.0 \mathrm{E}-06\end{array}$ & NA \\
\hline & Umtanum FT & 1 & $1006-1027$ & NA & $\begin{array}{l}1.0 \mathrm{E}-08 \text { to } \\
1.0 \mathrm{E}-05\end{array}$ & NA \\
\hline \multirow[t]{2}{*}{ DB-1 } & Mabton IB & 1 & $297-302$ & NA & $\begin{array}{c}1.0 \mathrm{E}-03 \text { to } \\
1.0 \mathrm{E}-02\end{array}$ & $117 \pm ?$ \\
\hline & Priest Rapids FT & 1 & $329-347$ & NA & $\begin{array}{l}1.0 \mathrm{E}-04 \text { to } \\
1.0 \mathrm{E}-03\end{array}$ & NA \\
\hline \multirow[t]{4}{*}{ DB-2 } & Mabton IB & 1 & $274-282$ & $274-282$ & $\begin{array}{c}1.0 \mathrm{E}-03 \text { to } \\
1.0 \mathrm{E}-02\end{array}$ & $117 \pm ?$ \\
\hline & Roza FT & 1 & $355-363$ & $356-360$ & $\begin{array}{c}1.0 \mathrm{E}-05 \text { to } \\
1.0 \mathrm{E}-04\end{array}$ & NA \\
\hline & Roza C/E & 0 & $363-388$ & $363-388$ & $3.5 \mathrm{E}-10$ & $\begin{array}{c}\text { NA } \\
\text { SD-BWI-TI-176 }\end{array}$ \\
\hline & $\begin{array}{c}\text { Priest Rapids } \\
\text { Composite }\end{array}$ & 1 & $313-363$ & $\begin{array}{l}313-323 \\
335-338\end{array}$ & $\begin{array}{l}1.0 \mathrm{E}-04 \text { to } \\
1.0 \mathrm{E}-03\end{array}$ & NA \\
\hline DB-4 & Mabton IB & 1 & $415-428$ & $415-428$ & $\begin{array}{l}1.0 \mathrm{E}-03 \text { to } \\
1.0 \mathrm{E}-02\end{array}$ & $128+?$ \\
\hline DB-5 & Mabton IB & 1 & $248-277$ & $254-277$ & $\begin{array}{l}1.0 \mathrm{E}-04 \text { to } \\
1.0 \mathrm{E}-03\end{array}$ & $124 \pm ?$ \\
\hline DB-7 & Mabton IB & 1 & $182-247$ & $237-247$ & $\begin{array}{l}1.0 \mathrm{E}-03 \text { to } \\
1.0 \mathrm{E}-02\end{array}$ & $122 \pm ?$ \\
\hline DB-9 & Mabton IB & 1 & $141-180$ & $149-180$ & $\begin{array}{l}1.0 \mathrm{E}-04 \text { to } \\
1.0 \mathrm{E}-03\end{array}$ & $123 \pm ?$ \\
\hline DB-10 & Mabton IB & 1 & $242-272$ & $257-272$ & $\begin{array}{l}1.0 \mathrm{E}-07 \text { to } \\
1.0 \mathrm{E}-06\end{array}$ & $125 \pm ?$ \\
\hline \multirow[t]{2}{*}{ DB-11 } & Mabton IB & 1 & $216-316$ & 264-307 & $\begin{array}{c}1.0 \mathrm{E}-07 \text { to } \\
1.0 \mathrm{E}-06\end{array}$ & $206 \pm ?$ \\
\hline & Priest Rapids FT & 1 & $311-319$ & $319-319$ & NA & $288 \pm ?$ \\
\hline
\end{tabular}




\section{SD-BWI-DP-O51}

\section{REV 2}

\begin{tabular}{|c|c|c|c|c|c|c|}
\hline Borehole & $\begin{array}{l}\text { Strat. } \\
\text { Horizon }\end{array}$ & $\begin{array}{l}\text { Use } \\
\text { Code }\end{array}$ & $\begin{array}{l}\text { Isolated } \\
\text { Interval } \\
\text { (m) }\end{array}$ & $\begin{array}{c}\text { Effective } \\
\text { Test Interval } \\
\text { (m) }\end{array}$ & $\begin{array}{l}\text { Trans- } \\
\text { missivity } \\
(\mathrm{m} 2 / \mathrm{sec})\end{array}$ & $\begin{array}{c}\text { Observed } \\
\text { Hydraulic Head } \\
\text { (m) MSL }\end{array}$ \\
\hline \multirow{4}{*}{ DB-12 } & Priest Rapids FT & 1 & $316-369$ & $365-369$ & NA & $292 \pm ?$ \\
\hline & Mabton IB & 1 & $115-156$ & $115-156$ & $\begin{array}{l}1.0 \mathrm{E}-03 \text { to } \\
1.0 \mathrm{E}-02\end{array}$ & $122 \pm ?$ \\
\hline & Priest Rapids FT & 1 & $160-199$ & $179-180$ & $\begin{array}{c}1.0 \mathrm{E}-02 \text { to } \\
1.0 \mathrm{E}-01\end{array}$ & NA \\
\hline & Priest Rapids FT & 1 & $201-215$ & $207-210$ & $\begin{array}{l}1.0 \mathrm{E}-02 \text { to } \\
1.0 \mathrm{E}-01\end{array}$ & NA \\
\hline \multirow[t]{5}{*}{ DB-13 } & $\begin{array}{c}\text { Elephant } \\
\text { Mountain FT }\end{array}$ & 0 & $115-116$ & NA & $\begin{array}{l}1.0 \mathrm{E}-03 \text { to } \\
1.0 \mathrm{E}-02\end{array}$ & NA \\
\hline & $\begin{array}{c}\text { Rattlesnake Ridge } \\
\text { IB }\end{array}$ & 1 & $141-163$ & NA & $\begin{array}{l}1.0 \mathrm{E}-04 \text { to } \\
1.0 \mathrm{E}-03\end{array}$ & NA \\
\hline & Selah IB & 1 & $219-225$ & NA & $\begin{array}{l}1.0 \mathrm{E}-04 \text { to } \\
1.0 \mathrm{E}-03\end{array}$ & NA \\
\hline & Cold Creek IB & 1 & $264-287$ & NA & $\begin{array}{l}1.0 \mathrm{E}-04 \text { to } \\
1.0 \mathrm{E}-03\end{array}$ & NA \\
\hline & Mabton IB & 1 & $364-394$ & $364-394$ & $\begin{array}{l}1.0 \mathrm{E}-03 \text { to } \\
1.0 \mathrm{E}-02\end{array}$ & $129 \pm ?$ \\
\hline \multirow[t]{4}{*}{ DB-14 } & $\begin{array}{l}\text { Rattlesnake Ridge } \\
\text { IB }\end{array}$ & 0 & $64-88$ & $64-88$ & $1.0 \mathrm{E}-05$ & $\begin{array}{c}\text { 136.5+? } \\
\text { RHO-LD-67 }\end{array}$ \\
\hline & Selah IB & 1 & $137-150$ & $138-150$ & $\begin{array}{l}1.0 \mathrm{E}-05 \text { to } \\
1.0 \mathrm{E}-04\end{array}$ & NA \\
\hline & Cold Creek IB & 1 & $188-202$ & $188-202$ & $\begin{array}{l}1.0 \mathrm{E}-03 \text { to } \\
1.0 \mathrm{E}-02\end{array}$ & NA \\
\hline & Mabton IB & 1 & $280-315$ & $280-310$ & $\begin{array}{l}1.0 \mathrm{E}-04 \text { to } \\
1.0 \mathrm{E}-03\end{array}$ & $128+?$ \\
\hline \multirow[t]{7}{*}{ DB-15 } & $\begin{array}{l}\text { Rattlesnake Ridge } \\
\text { IB }\end{array}$ & 0 & $46-68$ & $51-68$ & $5.1 \mathrm{E}-04$ to & $\begin{array}{c}125+? \\
\text { SD-BWI-TI-130 }\end{array}$ \\
\hline & Selah IB & 0 & $113-129$ & $122-129$ & 8.2E-06 & $\begin{array}{c}124 \pm ? \\
\text { SD-BWI-TI-131 }\end{array}$ \\
\hline & Cold Creek IB & 0 & $155-188$ & $158-187$ & $1.8 \mathrm{E}-03$ & $\begin{array}{c}124+? \\
\text { SD-BWI-TI-142 }\end{array}$ \\
\hline & $\begin{array}{c}\text { Asotin/Umatilla } \\
\text { FT }\end{array}$ & 1 & $208-208$ & $203-208$ & $\begin{array}{l}1.0 \mathrm{E}-04 \text { to } \\
1.0 \mathrm{E}-03\end{array}$ & $124 \pm ?$ \\
\hline & Umatilla FT & 1 & $207-230$ & $210-230$ & $\begin{array}{l}1.0 \mathrm{E}-03 \text { to } \\
1.0 \mathrm{E}-02\end{array}$ & $124 \pm ?$ \\
\hline & Mabton IB & 1 & $230-257$ & $230-257$ & $\begin{array}{l}1.0 \mathrm{E}-03 \text { to } \\
1.0 \mathrm{E}-02\end{array}$ & $124 \pm ?$ \\
\hline & Priest Rapids FT & 1 & $262-295$ & $280-291$ & $\begin{array}{l}1.0 \mathrm{E}-03 \text { to } \\
1.0 \mathrm{E}-02\end{array}$ & $125 \pm ?$ \\
\hline
\end{tabular}




\section{SD-BWI-DP-O51}

\section{REV 2}

\begin{tabular}{|c|c|c|c|c|c|c|}
\hline Borehole & $\begin{array}{l}\text { Strat. } \\
\text { Horizon }\end{array}$ & $\begin{array}{l}\text { Use } \\
\text { Code }\end{array}$ & $\begin{array}{l}\text { Isolated } \\
\text { Interval } \\
\text { (m) }\end{array}$ & $\begin{array}{c}\text { Effective } \\
\text { Test Interval } \\
\text { (m) }\end{array}$ & $\begin{array}{l}\text { Trans- } \\
\text { missivity } \\
(\mathrm{m} 2 / \mathrm{sec})\end{array}$ & $\begin{array}{c}\text { Observed } \\
\text { Hydraulic Head } \\
\text { (m) MSL }\end{array}$ \\
\hline & Roza FT & 1 & $319-337$ & $323-337$ & $\begin{array}{c}1.0 \mathrm{E}-03 \text { to } \\
1.0 \mathrm{E}-02\end{array}$ & $125 \pm ?$ \\
\hline & Roza C/E & 1 & $338-350$ & $338-350$ & $\begin{array}{l}1.0 \mathrm{E}-11 \text { to } \\
1.0 \mathrm{E}-10\end{array}$ & NA \\
\hline & Squaw Creek IB & 1 & $377-393$ & $383-393$ & NA & $125 \pm ?$ \\
\hline & $\begin{array}{l}\text { Frenchman } \\
\text { Springs FT }\end{array}$ & 1 & $396-409$ & $399-409$ & $\begin{array}{c}1.0 \mathrm{E}-04 \text { to } \\
1.0 \mathrm{E}-03\end{array}$ & $124 \pm ?$ \\
\hline & $\begin{array}{l}\text { Frenchman } \\
\text { Springs FT }\end{array}$ & 1 & $412-418$ & $414-418$ & $\begin{array}{c}1.0 \mathrm{E}-04 \text { to } \\
1.0 \mathrm{E}-03\end{array}$ & $125 \pm ?$ \\
\hline & $\begin{array}{l}\text { Frenchman } \\
\text { Springs FT }\end{array}$ & 1 & $425-440$ & $431-440$ & $\begin{array}{c}1.0 \mathrm{E}-04 \text { to } \\
1.0 \mathrm{E}-03\end{array}$ & $126+?$ \\
\hline & $\begin{array}{l}\text { Frenchman } \\
\text { Springs FT }\end{array}$ & 1 & $442-466$ & $445-466$ & $\begin{array}{c}1.0 \mathrm{E}-05 \text { to } \\
1.0 \mathrm{E}-04\end{array}$ & $125 \pm ?$ \\
\hline & $\begin{array}{l}\text { Frenchman } \\
\text { Springs FT }\end{array}$ & 1 & $479-513$ & $481-484$ & $\begin{array}{c}1.0 \mathrm{E}-04 \text { to } \\
1.0 \mathrm{E}-03\end{array}$ & $125 \pm ?$ \\
\hline & $\begin{array}{l}\text { Frenchman } \\
\text { Springs FT }\end{array}$ & 1 & $524-549$ & $532-535$ & $\begin{array}{c}1.0 \mathrm{E}-08 \text { to } \\
1.0 \mathrm{E}-07\end{array}$ & $124 \pm ?$ \\
\hline & $\begin{array}{l}\text { Frenchman } \\
\text { Springs FT }\end{array}$ & 1 & $549-589$ & $568-574$ & $\begin{array}{c}1.0 \mathrm{E}-09 \text { to } \\
1.0 \mathrm{E}-08\end{array}$ & $123 \pm ?$ \\
\hline & Vantage IB & 1 & $589-601$ & $597-601$ & $\begin{array}{l}1.0 \mathrm{E}-12 \text { to } \\
1.0 \mathrm{E}-10\end{array}$ & NA \\
\hline \multirow[t]{9}{*}{ RRL-2A } & Mabton IB & 1 & $416-471$ & $426-442$ & $\begin{array}{c}1.0 \mathrm{E}-08 \text { to } \\
1.0 \mathrm{E}-07\end{array}$ & $127 \pm ?$ \\
\hline & Priest Rapids FT & 1 & $480-522$ & $515-522$ & $\begin{array}{l}1.0 \mathrm{E}-04 \text { to } \\
1.0 \mathrm{E}-03\end{array}$ & $122 \pm ?$ \\
\hline & Roza FT & 1 & $529-540$ & $533-536$ & $\begin{array}{c}1.0 \mathrm{E}-03 \text { to } \\
1.0 \mathrm{E}-02\end{array}$ & $123 \pm ?$ \\
\hline & $\begin{array}{c}\text { Upper Frenchman } \\
\text { Springs FTS }\end{array}$ & 1 & $581-677$ & $\begin{array}{l}586-593 \\
641-644 \\
676-677\end{array}$ & $\begin{array}{l}1.0 \mathrm{E}-03 \text { to } \\
1.0 \mathrm{E}-02\end{array}$ & $123+?$ \\
\hline & $\begin{array}{c}\text { Lower Frenchman } \\
\text { Springs FTS }\end{array}$ & 1 & $684-806$ & $\begin{array}{l}692-699 \\
725-735 \\
759-763 \\
796-800\end{array}$ & $\begin{array}{l}1.0 \mathrm{E}-03 \text { to } \\
1.0 \mathrm{E}-02\end{array}$ & $122+?$ \\
\hline & Vantage IB & 1 & $812-827$ & $814-820$ & $\begin{array}{c}1.0 \mathrm{E}-06 \text { to } \\
1.0 \mathrm{E}-05\end{array}$ & $122.6 \pm ?$ \\
\hline & Grande Ronde FT & 1 & $829-888$ & $\begin{array}{l}829-841 \\
860-866\end{array}$ & $\begin{array}{c}1.0 \mathrm{E}-06 \text { to } \\
1.0 \mathrm{E}-05\end{array}$ & $121 \pm ?$ \\
\hline & Rocky Coulee C/E & 1 & 894-909 & 894-909 & $\begin{array}{l}1.0 \mathrm{E}-11 \text { to } \\
1.0 \mathrm{E}-10\end{array}$ & NA \\
\hline & Cohassett FT & 0 & $909-920$ & $912-918$ & $4.5 \mathrm{E}-08$ & $\begin{array}{c}121.8 \pm 0.1 \\
\text { SD-BWI-TI-102 }\end{array}$ \\
\hline
\end{tabular}




\section{SD-BWI-DP-O51}

\section{REV 2}

\begin{tabular}{|c|c|c|c|c|c|c|}
\hline Borehole & $\begin{array}{l}\text { Strat. } \\
\text { Horizon }\end{array}$ & $\begin{array}{l}\text { Use } \\
\text { Code }\end{array}$ & $\begin{array}{l}\text { Isolated } \\
\text { Interval } \\
\text { (m) }\end{array}$ & $\begin{array}{c}\text { Effective } \\
\text { Test Interval } \\
\text { (m) }\end{array}$ & $\begin{array}{l}\text { Trans- } \\
\text { missivity } \\
(\mathrm{m} 2 / \mathrm{sec})\end{array}$ & $\begin{array}{c}\text { Observed } \\
\text { Hydraulic Head } \\
\text { (m) MSL }\end{array}$ \\
\hline & $\begin{array}{c}\text { Cohassett C/E } \\
\text { (vesticular zone) }\end{array}$ & 0 & $932-967$ & $940-945$ & $2.8 \mathrm{E}-10$ & $\begin{array}{c}\text { NA } \\
\text { SD-BWI-TI-090 }\end{array}$ \\
\hline & Cohassett C/E & 0 & $968-989$ & $968-989$ & 4.7E-12 & $\begin{array}{c}\text { NA } \\
\text { SD-BWI-TI-109 }\end{array}$ \\
\hline & Birkett FT & 0 & $990-1019$ & $992-1016$ & $8.2 \mathrm{E}-04$ & $\begin{array}{c}123.5 \pm 0.5 \\
\text { SD-BWI-TI-095 }\end{array}$ \\
\hline & Grande Ronde FT & 1 & $1027-1055$ & $\begin{array}{l}1031-1035 \\
1040-1047\end{array}$ & $\begin{array}{c}1.0 \mathrm{E}-10 \text { to } \\
1.0 \mathrm{E}-09\end{array}$ & NA \\
\hline & $\begin{array}{c}\text { McCoy Canyon } \\
\text { FT }\end{array}$ & 1 & $1056-1074$ & $1059-1065$ & $\begin{array}{l}1.0 \mathrm{E}-10 \text { to } \\
1.0 \mathrm{E}-09\end{array}$ & NA \\
\hline & McCoy Canyon E & 1 & $1088-1095$ & $1088-1095$ & $\begin{array}{c}1.0 \mathrm{E}-11 \text { to } \\
1.0 \mathrm{E}-10\end{array}$ & NA \\
\hline & $\begin{array}{c}\text { Umtanum } \\
\text { Composite FTS }\end{array}$ & 0 & $1088-1152$ & $1096-1144$ & $5.1 \mathrm{E}-04$ & $\begin{array}{c}123.7 \pm 0.1 \\
\text { SD-BWI-TI-105 }\end{array}$ \\
\hline & Umtanum FT & 1 & $1135-1152$ & $1140-1143$ & $\begin{array}{l}1.0 \mathrm{E}-06 \text { to } \\
1.0 \mathrm{E}-05\end{array}$ & $124 \pm ?$ \\
\hline & Umtanum E & 0 & $1147-1160$ & $1147-1160$ & $1.7 \mathrm{E}-11$ & $\begin{array}{c}\text { NA } \\
\text { SD-BWI-TI-107 }\end{array}$ \\
\hline & $\begin{array}{l}\text { Umtanum E } \\
\text { (fracture zone) }\end{array}$ & 0 & $1152-1166$ & $1164-1166$ & $9.4 \mathrm{E}-04$ & $\begin{array}{c}\text { NA } \\
\text { SD-BWI-TI-089 }\end{array}$ \\
\hline & Umtanum FB & 1 & $1170-1185$ & $1170-1178$ & $\begin{array}{l}1.0 \mathrm{E}-04 \text { to } \\
1.0 \mathrm{E}-03\end{array}$ & $124 \pm 0.5$ \\
\hline RRL-2B/A & Rocky Coulee FT & 0 & $846-871$ & $860-866$ & $7.0 \mathrm{E}-06$ & $\begin{array}{c}\text { NA } \\
\text { SD-BWI-TI-329 }\end{array}$ \\
\hline RRL-2B/C & Rocky Coulee FT & 0 & $846-871$ & $858-864$ & $1.6 \mathrm{E}-06$ & $\begin{array}{c}\text { NA } \\
\text { SD-BWI-TI-329 }\end{array}$ \\
\hline \multirow[t]{5}{*}{ RRL-2C } & Rocky Coulee C/E & 1 & $882-889$ & $882-889$ & $\begin{array}{c}1.0 \mathrm{E}-10 \text { to } \\
1.1 \mathrm{E}-09\end{array}$ & $\begin{array}{c}\text { NA } \\
\text { SD-BWI-TI-329 }\end{array}$ \\
\hline & Cohassett FT & 1 & $903-912$ & $909-914$ & $\begin{array}{l}1.0 \mathrm{E}-10 \text { to } \\
1.1 \mathrm{E}-09\end{array}$ & $\begin{array}{c}\text { NA } \\
\text { SD-BWI-TI-329 }\end{array}$ \\
\hline & Cohassett C & 1 & $959-966$ & $959-966$ & $\begin{array}{l}1.0 \mathrm{E}-10 \text { to } \\
1.1 \mathrm{E}-09\end{array}$ & $\begin{array}{c}\text { NA } \\
\text { SD-BWI-TI-329 }\end{array}$ \\
\hline & Birkett FT & 1 & 846-1038 & $985-997$ & $\begin{array}{l}1.0 \mathrm{E}-04 \text { to } \\
1.1 \mathrm{E}-03\end{array}$ & $\begin{array}{c}\text { NA } \\
\text { SD-BWI-TI-329 }\end{array}$ \\
\hline & Birkett C/E & 1 & $1010-1017$ & $1010-1017$ & $\begin{array}{c}1.0 \mathrm{E}-10 \text { to } \\
1.1 \mathrm{E}-09\end{array}$ & $\begin{array}{c}\text { NA } \\
\text { SD-BWI-TI-329 }\end{array}$ \\
\hline RRL-6 & $\begin{array}{l}\text { Frenchman } \\
\text { Springs FB }\end{array}$ & 1 & $641-653$ & $\begin{array}{l}647-651 \\
654-655\end{array}$ & $\begin{array}{c}1.0 \mathrm{E}-11 \text { to } \\
1.0 \mathrm{E}-10\end{array}$ & NA \\
\hline
\end{tabular}




\section{SD-BWI-DP-O51}

\section{REV 2}

\begin{tabular}{|c|c|c|c|c|c|c|}
\hline Borehole & $\begin{array}{l}\text { Strat. } \\
\text { Horizon }\end{array}$ & $\begin{array}{l}\text { Use } \\
\text { Code }\end{array}$ & $\begin{array}{l}\text { Isolated } \\
\text { Interval } \\
\text { (m) }\end{array}$ & $\begin{array}{c}\text { Effective } \\
\text { Test Interval } \\
\text { (m) }\end{array}$ & $\begin{array}{l}\text { Trans- } \\
\text { missivity } \\
(\mathrm{m} 2 / \mathrm{sec})\end{array}$ & $\begin{array}{c}\text { Observed } \\
\text { Hydraulic Head } \\
\text { (m) MSL }\end{array}$ \\
\hline & Cohassett FT & 1 & $940-951$ & $943-948$ & $\begin{array}{l}1.0 \mathrm{E}-11 \text { to } \\
1.0 \mathrm{E}-10\end{array}$ & NA \\
\hline & Cohassett C/E & 1 & $954-1016$ & $954-1016$ & $\begin{array}{c}1.0 \mathrm{E}-14 \text { to } \\
1.0 \mathrm{E}-11\end{array}$ & NA \\
\hline & Birkett FT & 1 & $1015-1041$ & $1019-1039$ & $\begin{array}{c}1.0 \mathrm{E}-08 \text { to } \\
1.0 \mathrm{E}-07\end{array}$ & NA \\
\hline & $\begin{array}{c}\text { McCoy Canyon } \\
\text { C/E }\end{array}$ & 1 & $1104-1126$ & $1104-1126$ & $\begin{array}{c}1.0 \mathrm{E}-13 \text { to } \\
1.0 \mathrm{E}-10\end{array}$ & NA \\
\hline & Umtanum FT & 1 & $1130-1165$ & $1132-1161$ & $\begin{array}{c}1.0 \mathrm{E}-07 \text { to } \\
1.0 \mathrm{E}-06\end{array}$ & NA \\
\hline & Umtanum $\mathrm{C} / \mathrm{E}$ & 1 & $1166-1200$ & $1166-1200$ & $\begin{array}{c}1.0 \mathrm{E}-12 \text { to } \\
1.0 \mathrm{E}-11\end{array}$ & NA \\
\hline & $\begin{array}{c}\text { Grande Ronde } 11 \\
\text { FT }\end{array}$ & 1 & $1201-1231$ & $\begin{array}{l}1203-1206 \\
1219-1221\end{array}$ & $\begin{array}{l}1.0 \mathrm{E}-09 \text { to } \\
1.0 \mathrm{E}-08\end{array}$ & NA \\
\hline \multirow[t]{6}{*}{ RRL-14 } & Cohassett FT & 1 & $938-959$ & $\begin{array}{l}939-946 \\
948-950\end{array}$ & $\begin{array}{l}1.0 \mathrm{E}-06 \text { to } \\
1.0 \mathrm{E}-05\end{array}$ & $124 \pm 1.5$ \\
\hline & Cohassett C/E & 1 & $957-1010$ & $957-1010$ & $\begin{array}{c}1.0 \mathrm{E}-12 \text { to } \\
1.0 \mathrm{E}-11\end{array}$ & NA \\
\hline & Birkett FT & 1 & $1004-1037$ & $1012-1036$ & $\begin{array}{l}1.0 \mathrm{E}-07 \text { to } \\
1.0 \mathrm{E}-04\end{array}$ & $125 \pm 1.5$ \\
\hline & Umtanum FT & 1 & $1132-1163$ & $1135-1156$ & $\begin{array}{l}1.0 \mathrm{E}-06 \text { to } \\
1.0 \mathrm{E}-05\end{array}$ & $123 \pm 1.5$ \\
\hline & Umtanum C/E & 1 & $1164-1190$ & $1164-1190$ & $\begin{array}{l}1.0 \mathrm{E}-13 \text { to } \\
1.0 \mathrm{E}-12\end{array}$ & NA \\
\hline & $\begin{array}{l}\text { Very High Mg } \\
\text { Flow FT }\end{array}$ & 1 & $1181-1205$ & $1194-1139$ & $\begin{array}{l}1.0 \mathrm{E}-08 \text { to } \\
1.0 \mathrm{E}-07\end{array}$ & NA \\
\hline \multirow[t]{11}{*}{ McGee } & Rosalia FT & 1 & $247-251$ & NA & $\begin{array}{l}1.0 \mathrm{E}-02 \text { to } \\
1.0 \mathrm{E}-01\end{array}$ & NA \\
\hline & Upper Roza FT & 1 & $282-285$ & NA & $\begin{array}{c}1.0 \mathrm{E}-02 \text { to } \\
1.0 \mathrm{E}-01\end{array}$ & NA \\
\hline & Lower Roza FT & 1 & $313-334$ & $326-333$ & $>1.0 \mathrm{E}-03$ & $279 \pm ?$ \\
\hline & Sentinel Gap FT & 1 & $335-356$ & $339-350$ & $>1.0 \mathrm{E}-03$ & $277 \pm ?$ \\
\hline & Sand Hollow 2 FT & 1 & $402-420$ & $406-418$ & $>1.0 \mathrm{E}-03$ & $278+?$ \\
\hline & Sand Hollow 1 FT & 1 & $428-439$ & $429-433$ & $>1.0 \mathrm{E}-03$ & $278 \pm ?$ \\
\hline & Silver Falls FT & 1 & $440-452$ & $443-450$ & $>1.0 \mathrm{E}-03$ & $278 \pm ?$ \\
\hline & Ginkgo 2 FT & 1 & $482-512$ & $487-495$ & $>1.0 \mathrm{E}-03$ & $278 \pm ?$ \\
\hline & Ginkgo 1 FT & 1 & $510-533$ & $517-524$ & $>1.0 \mathrm{E}-03$ & $279 \pm ?$ \\
\hline & $\begin{array}{l}\text { Frenchman } \\
\text { Springs FTS }\end{array}$ & 1 & $538-562$ & $555-560$ & $\begin{array}{l}1.0 \mathrm{E}-06 \text { to } \\
1.0 \mathrm{E}-05\end{array}$ & $280 \pm ?$ \\
\hline & Vantage IB & 1 & $563-575$ & $567-570$ & $\begin{array}{l}1.0 \mathrm{E}-08 \text { to } \\
1.0 \mathrm{E}-07\end{array}$ & $202 \pm 1.5$ \\
\hline
\end{tabular}




\section{SD-BWI-DP-O51}

\section{REV 2}

\begin{tabular}{|c|c|c|c|c|c|c|}
\hline Borehole & $\begin{array}{c}\text { Strat. } \\
\text { Horizon }\end{array}$ & $\begin{array}{l}\text { Use } \\
\text { Code }\end{array}$ & $\begin{array}{l}\text { Isolated } \\
\text { Interval } \\
\text { (m) }\end{array}$ & $\begin{array}{c}\text { Effective } \\
\text { Test Interval } \\
\text { (m) }\end{array}$ & $\begin{array}{l}\text { Trans- } \\
\text { missivity } \\
(\mathrm{m} 2 / \mathrm{sec})\end{array}$ & $\begin{array}{c}\text { Observed } \\
\text { Hydraulic Head } \\
\text { (m) MSL }\end{array}$ \\
\hline & Vantage IB & 1 & $566-592$ & $\begin{array}{l}567-570 \\
581-585\end{array}$ & $\begin{array}{c}1.0 \mathrm{E}-07 \text { to } \\
1.0 \mathrm{E}-06\end{array}$ & $187 \pm 1.5$ \\
\hline & $\begin{array}{c}\text { Grande Ronde } 2 \\
\text { FT }\end{array}$ & & $593-607$ & $593-597$ & $\begin{array}{c}1.0 \mathrm{E}-04 \text { to } \\
1.0 \mathrm{E}-03\end{array}$ & $183 \pm ?$ \\
\hline & Rocky Coulee FT & 1 & $607-638$ & $607-615$ & $\begin{array}{c}1.0 \mathrm{E}-04 \text { to } \\
1.0 \mathrm{E}-03\end{array}$ & $183 \pm ?$ \\
\hline & $\begin{array}{c}\text { Grande Ronde } 4 \\
\text { FT }\end{array}$ & 1 & $649-670$ & $658-662$ & $\begin{array}{c}1.0 \mathrm{E}-07 \text { to } \\
1.0 \mathrm{E}-06\end{array}$ & $183+?$ \\
\hline & Cohassett FT & 1 & $667-712$ & $\begin{array}{l}670-676 \\
679-681\end{array}$ & $\begin{array}{c}1.0 \mathrm{E}-04 \text { to } \\
1.0 \mathrm{E}-03\end{array}$ & $183 \pm ?$ \\
\hline & $\begin{array}{c}\text { Grande Ronde } 6 \\
\text { FT }\end{array}$ & 1 & $729-769$ & $739-747$ & $\begin{array}{c}1.0 \mathrm{E}-06 \text { to } \\
1.0 \mathrm{E}-05\end{array}$ & $180 \pm 1.5$ \\
\hline & $\begin{array}{c}\text { McCoy Canyon } \\
\text { FT }\end{array}$ & 1 & $799-841$ & $\begin{array}{l}799-802 \\
805-813 \\
815-819\end{array}$ & $\begin{array}{l}1.0 \mathrm{E}-06 \text { to } \\
1.0 \mathrm{E}-05\end{array}$ & $183+?$ \\
\hline & $\begin{array}{l}\text { Very High Mg } \\
\text { Flow FT }\end{array}$ & 1 & $900-952$ & $\begin{array}{l}922-927 \\
929-936 \\
941-943\end{array}$ & $\begin{array}{l}1.0 \mathrm{E}-07 \text { to } \\
1.0 \mathrm{E}-06\end{array}$ & $183 \pm 1.5$ \\
\hline OBRIAN & Priest Rapids FT & 1 & $183-213$ & $209-212$ & $\begin{array}{c}1.0 \mathrm{E}-01 \text { to } \\
1.0 \mathrm{E}+00\end{array}$ & NAA \\
\hline FORD & Priest Rapids FT & 1 & $218-237$ & $226-229$ & $\begin{array}{l}1.0 \mathrm{E}-02 \text { to } \\
1.0 \mathrm{E}-01\end{array}$ & NA \\
\hline ENYEART & Priest Rapids FT & 1 & $293-333$ & $326-332$ & $\begin{array}{l}1.0 \mathrm{E}-02 \text { to } \\
1.0 \mathrm{E}-01\end{array}$ & NA \\
\hline $699-52-48$ & $\begin{array}{c}\text { Rattlesnake Ridge } \\
\text { IB }\end{array}$ & 0 & $44-59$ & $44-59$ & $1.0 \mathrm{E}-05$ & $\begin{array}{c}\text { NA } \\
\text { RHO-ST-38 }\end{array}$ \\
\hline $699-53-50$ & $\begin{array}{l}\text { Rattlesnake Ridge } \\
\text { IB }\end{array}$ & 0 & $45-59$ & $45-59$ & $1.0 \mathrm{E}-04$ & $\begin{array}{c}\text { NA } \\
\text { RHO-ST-38 }\end{array}$ \\
\hline $699-51-46$ & $\begin{array}{c}\text { Rattlesnake Ridge } \\
\text { IB }\end{array}$ & 0 & $37-50$ & $37-50$ & $1.0 \mathrm{E}-05$ & $\begin{array}{c}\text { NA } \\
\text { RHO-ST-38 }\end{array}$ \\
\hline $699-52-46$ & $\begin{array}{c}\text { Rattlesnake Ridge } \\
\text { IB }\end{array}$ & 0 & $50-69$ & $50-69$ & $1.0 \mathrm{E}-04$ & $\begin{array}{c}\text { NA } \\
\text { RHO-ST-38 }\end{array}$ \\
\hline $699-50-45$ & $\begin{array}{c}\text { Rattlesnake Ridge } \\
\text { IB }\end{array}$ & 0 & $41-54$ & $41-54$ & $1.0 \mathrm{E}-04$ & $\begin{array}{c}\text { NA } \\
\text { RHO-ST-38 }\end{array}$ \\
\hline
\end{tabular}




\section{SD-BWI-DP-O51}

\section{REV 2}

\begin{tabular}{|c|c|c|c|c|c|c|}
\hline Borehole & $\begin{array}{c}\text { Strat. } \\
\text { Horizon }\end{array}$ & $\begin{array}{l}\text { Use } \\
\text { Code }\end{array}$ & $\begin{array}{l}\text { Isolated } \\
\text { Interval } \\
\text { (m) }\end{array}$ & $\begin{array}{c}\text { Effective } \\
\text { Test Interval } \\
\text { (m) }\end{array}$ & $\begin{array}{l}\text { Trans- } \\
\text { missivity } \\
(\mathrm{m} 2 / \mathrm{sec})\end{array}$ & $\begin{array}{c}\text { Observed } \\
\text { Hydraulic Head } \\
\text { (m) MSL }\end{array}$ \\
\hline $699-50-48$ & $\begin{array}{l}\text { Rattlesnake Ridge } \\
\text { IB }\end{array}$ & 0 & $65-76$ & $65-76$ & $1.0 \mathrm{E}-04$ & $\begin{array}{c}\text { NA } \\
\text { RHO-ST-38 }\end{array}$ \\
\hline $699-47-50$ & $\begin{array}{l}\text { Rattlesnake Ridge } \\
\text { IB }\end{array}$ & 0 & $79-90$ & $79-90$ & $1.0 \mathrm{E}-04$ & $\begin{array}{c}\text { NA } \\
\text { RHO-ST-38 }\end{array}$ \\
\hline $\begin{array}{l}\text { 699-S11- } \\
\text { E12A }\end{array}$ & Levey IB & 0 & $69-86$ & $73-81$ & $1.0 \mathrm{E}-05$ & $\begin{array}{c}\text { NA } \\
\text { RHO-BWI-LD-27 }\end{array}$ \\
\hline $69-114-60$ & $\begin{array}{l}\text { Lower Saddle } \\
\text { Mountains } \\
\text { Composite }\end{array}$ & 1 & $234-263$ & $234-263$ & NA & $149 \pm ?$ \\
\hline BH-16 & Selah IB & 1 & $250-282$ & $265-280$ & $\begin{array}{l}1.0 \mathrm{E}-05 \text { to } \\
1.0 \mathrm{E}-04\end{array}$ & NA \\
\hline \multirow[t]{2}{*}{ BH-17 } & Asotin FT & 1 & $312-334$ & $314-318$ & $\begin{array}{l}1.0 \mathrm{E}-07 \text { to } \\
1.0 \mathrm{E}-06\end{array}$ & NA \\
\hline & Mabton IB & 1 & $390-403$ & $387-406$ & NA & $125 \pm ?$ \\
\hline
\end{tabular}

Note: FT - Flow Top

FB - Flow Bottom

C/E - Colonnade / Entablature

E - Entablature

IB - Interbed

Composite - Test Interval spans more than one hydro-stratigraphic zone. 


\section{Appendix F}

Isotopic and Hydrochemical Data 


\section{Appendix F}

\section{Isotopic and Hydrochemical Data}

This appendix includes isotopic and hydrochemical data that was acquired for DOE-sponsored site characterization studies for the former Basalt Waste Isolation Project (BWIP). The data listing is a subset of the full BWIP hydrochemistry database (Early et al. 1986). A limited amount of noble gas isotope data are provided in Section 4.0 of the main text of this report.

Analytical results are primarily for sampling conducted at discrete depths using a drill and test method. This involved drilling into the dense basalt interior below a zone to be tested and placing a packer in the dense interior of basalt overlying the target zone. After completing all hydrologic testing and sampling at a test zone it was sealed by injection of cement grout to prevent cross flow during drilling to the next lower aquifer. Quality control, analytical, and data collection methods for the groundwater sampling program are described in Early et al. (1986).

Data from a total of 25 Pasco Basin deep characterization wells (Figure F.1) are included, representing a wide range of structural, stratigraphic, and hydrogeologic conditions likely to be encountered in other locations across the Columbia Basin. Most of the original BWIP project wells were decommissioned and are no longer available for sampling or testing. Some key wells do remain that can be used for additional hydrologic and hydrochemical sampling purposes.

Water quality data from regional water supply wells are available from the USGS (e.g., Steinkampf and Hearn 1996). Use of the data set in this appendix together with regional water quality data, should allow inferences about hydrochemical conditions elsewhere in the region for site selection or characterization planning.

Explanatory notes for Table F.1 are as follows:

1. Results for replicates appear as more than one entry for an individual interval.

2. Stratigraphic interval designations are as follows: $\mathrm{W}=$ Wanapum Basalt; $\mathrm{SMB}=$ Saddle Mountains Basalt; GRB $=$ Grande Ronde basalt; Tpr $=$ Priest Rapids Member; $\mathrm{Tr}=$ Roza Member; Tfs $=$ Frenchman Springs Member; V = Vantage Horizon (interbed); RRI = Interbed between Elephant Mountain and Pomona members; SI = Interbed between Pomona and Esquatzel Members; CCI = Interbed between Esquatzel and Astotin Members; Mabton = Interbed between Priest Rapids and Umatilla Members; N2 $=2^{\text {nd }}$ Normal Magnetostratigraphic Unit of Grande Ronde Basalt; R2 $=2^{\text {nd }}$ Reversed Magnetostratigraphic Unit of Grande Ronde Basalt; UMT = Umtanum flow of Grande 


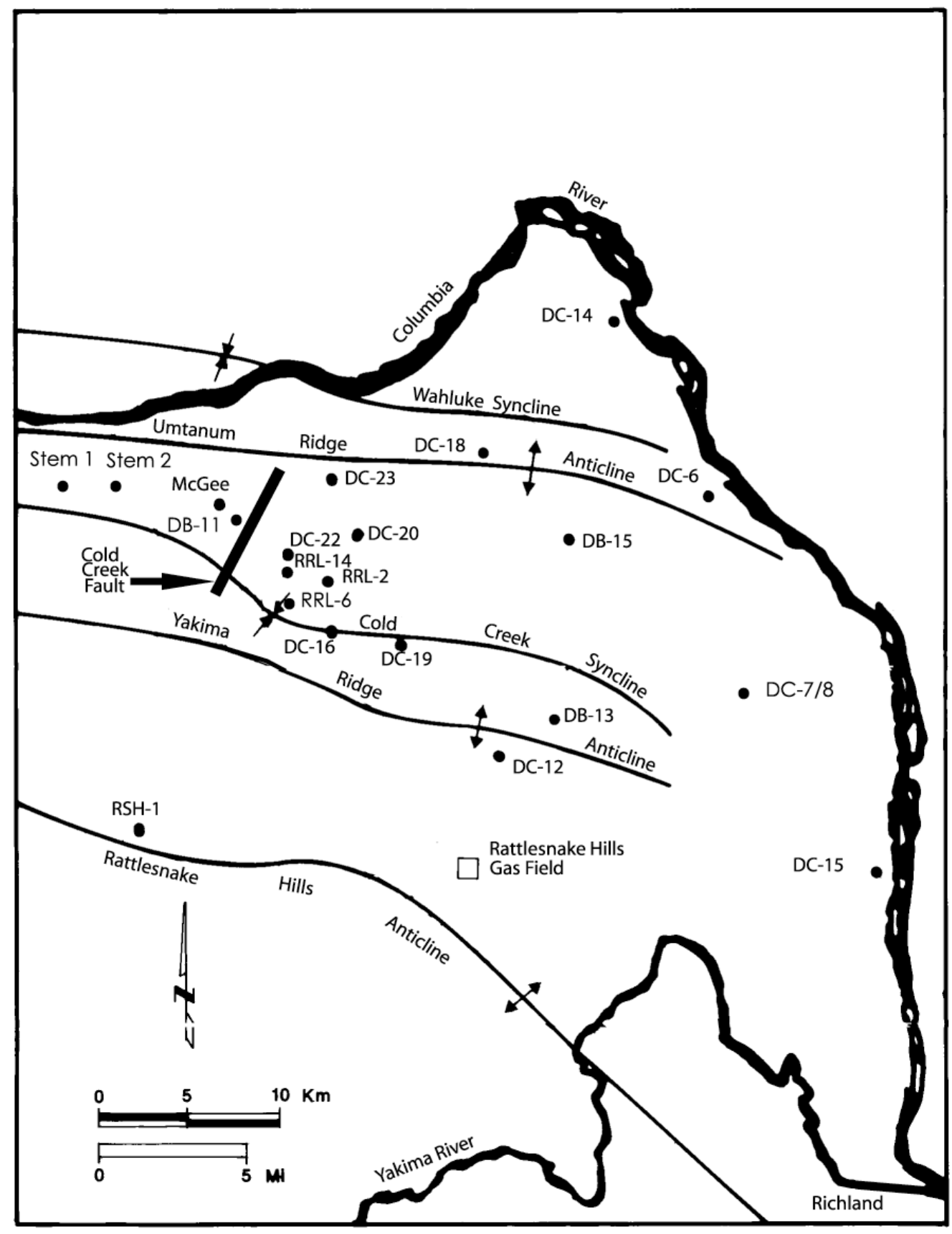

Figure F.1. Wells Drilled into Columbia River Basalt in the Pasco Basin

Ronde Basalt; $\mathrm{RC}=$ Rocky Coulee flow of Grande Ronde Basalt; $\mathrm{COH}=$ Cohassett flow of Grande Ronde Basalt; FZ = Fracture Zone. Depths for stratigraphic intervals are shown in the next-to-last column of Table F.1.

3. Most of the methane measurements were available only as relative mole percent from the mass spectrometry laboratory. Results for samples analyzed by gas chromatography using the purge and 
trap method yielded both methane and nitrogen concentrations as well as relative mole percent data. Other indirect measures of methane abundances were made based on gas flow rate measurements from a gas separator barrel. The latter measurements also included relative compositional data for the gas phase. Methane abundance or concentration $(\mathrm{mg} / \mathrm{L})$ in those cases where only relative or mole percent data were available (Table F.1, columns 5 and 6) was calculated (column 4) from the following relationship based on gas solubility and Henry's Law:

$$
\mathrm{CH}_{4}(\mathrm{mg} / \mathrm{L})=\mathrm{RxSxCxK}=\mathrm{Rx} 10.2
$$

$\mathrm{R}=$ Methane/nitrogen mole ratio

$\mathrm{S}=$ Solubility of nitrogen in water $\left(0.745 \mathrm{mM}\right.$ at $\left.15^{\circ} \mathrm{C}\right)$

$\mathrm{C}=16 \mathrm{mg} / \mathrm{mM}$; moles $/ \mathrm{L}$ to $\mathrm{mg} / \mathrm{L}$ conversion

$\mathrm{K}=$ Ratio of Henry's Law constants $(0.855)$ for nitrogen/methane to correct for differential fractionation between liquid and gas phase during sampling of gas phase samples or vacuum extraction of liquid samples.

4. Measured methane concentrations using purge and trap gas chromatography or gas flow rate measurements from gas separator barrel are shown in column 7 of Table F.1. Comparison of direct measurements (column 7) with derived or calculated values (column 4) indicates reasonable agreement between the two methods.

Definitions for column headings and abbreviations used in Table F.1 are as follows:

ORP - oxidation-reduction potential in $\mathrm{mV}$

ALK - - alkalinity expressed as $\mathrm{mg} / \mathrm{L}$ of calcium carbonate

$13 \mathrm{C}(\mathrm{CH} 4)$ - carbon-13 in methane expressed as the difference or "delta" or "del" relative to carbon12 in units of parts per thousand, o/oo, relative to a standard

$\mathrm{D}(\mathrm{CH} 4) \quad-\quad$ deuterium (H-2) in methane, del o/oo (relative to hydrogen-1)

13(TIC) - carbon-13, isotopic composition of total inorganic carbon, del o/oo (relative to carbon-12)

$\mathrm{D}(\mathrm{H} 2 \mathrm{O}) \quad$ - deuterium $(\mathrm{H}-2)$ in water, del o/oo (relative to hydrogen-1)

34S(SO4) - $\quad$ sulfur-34, isotopic composition of sulfate, del o/oo (relative to sulfur-32)

180 - oxygen-18 in water, del o/oo (relative to oxygen-16) 
Table F.1. Selected Hydrochemical Data for Basalt Aquifers in the Pasco Basin (excerpted from Early et al. 1986)

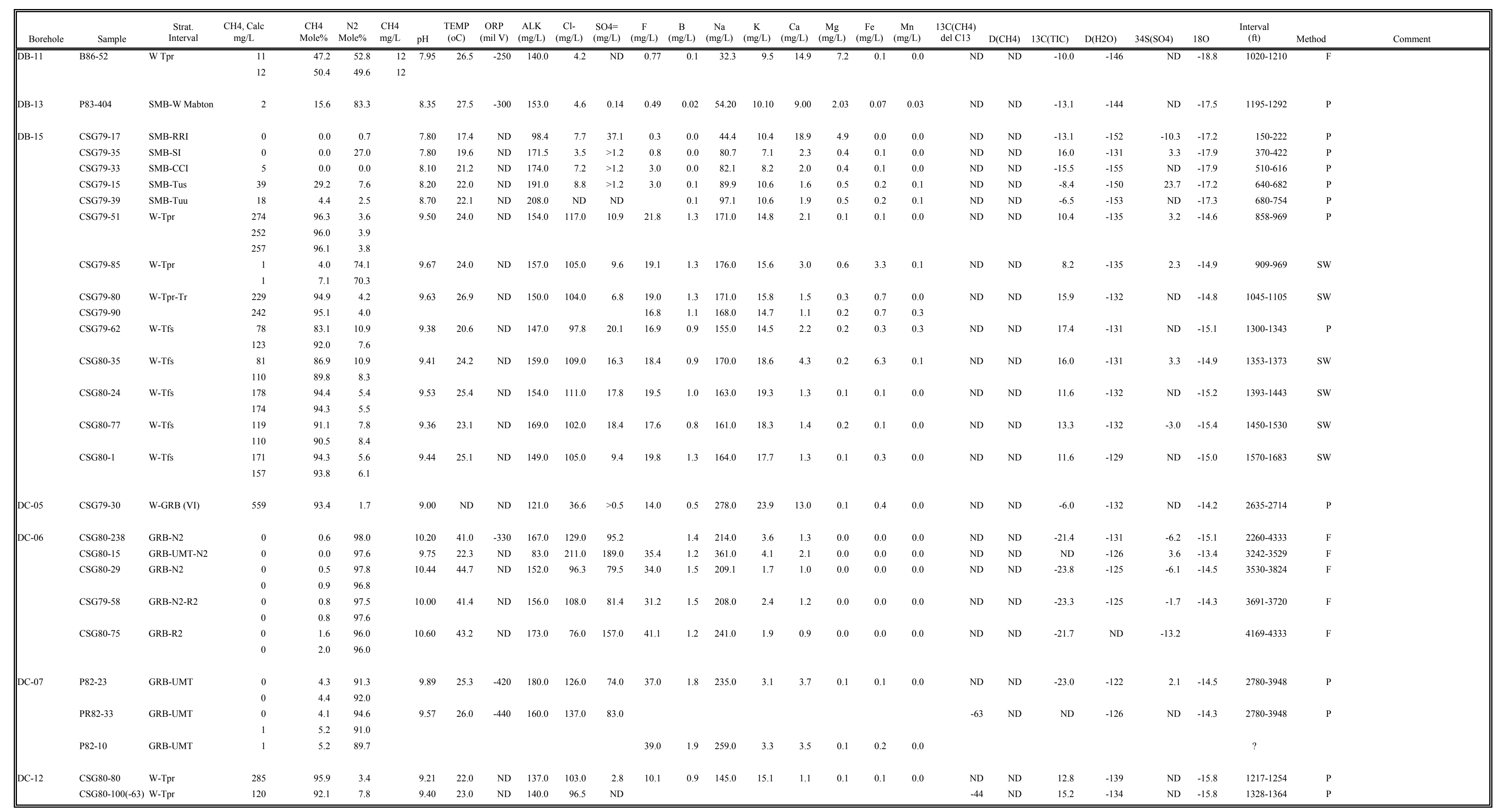


Table F.1. (contd)

\begin{tabular}{|c|c|c|c|c|c|c|c|c|c|c|c|c|c|c|c|c|c|c|c|c|c|c|c|c|c|c|c|c|c|}
\hline Borehole & Sample & $\begin{array}{c}\text { Strat. } \\
\text { Interval }\end{array}$ & $\begin{array}{c}\mathrm{CH}^{\mathrm{CH}, \mathrm{Calc}} \\
\text { mg/L }\end{array}$ & $\begin{array}{l}\text { CH4 } \\
\text { Mole \% }\end{array}$ & $\begin{array}{c}\mathrm{N} 2 \\
\text { Mole\% }\end{array}$ & $\begin{array}{c}\mathrm{CH} 4 \\
\mathrm{mg} / \mathrm{L}\end{array}$ & $\mathrm{pH}$ & $\begin{array}{l}\text { TEMP } \\
\text { (oC) }\end{array}$ & $\begin{array}{c}\text { ORP } \\
\text { (mil V) }\end{array}$ & $\begin{array}{c}\mathrm{ALK} \\
(\mathrm{mg} L \mathrm{~L})\end{array}$ & $\begin{array}{c}\mathrm{Cl}- \\
(\mathrm{mg} / \mathrm{L})\end{array}$ & $\begin{array}{c}\mathrm{SO} 4= \\
(\mathrm{mg} / \mathrm{L})\end{array}$ & $\underset{(\mathrm{mg} L)}{\mathrm{F}}$ & $\underset{(\mathrm{mg} / \mathrm{L})}{\mathrm{B}}$ & $\begin{array}{c}\mathrm{Na} \\
(\mathrm{mg} / \mathrm{L})\end{array}$ & $\underset{(\mathrm{mg} L)}{\mathrm{K}}$ & $\begin{array}{c}\mathrm{Ca} \\
(\mathrm{mg} L)\end{array}$ & $\begin{array}{c}\mathrm{Mg} \\
(\mathrm{mg} / \mathrm{L})\end{array}$ & $\begin{array}{c}\mathrm{Fe} \\
(\mathrm{mg} / \mathrm{L})\end{array}$ & $\begin{array}{c}\mathrm{Mn} \\
(\mathrm{mg} L \mathrm{~L})\end{array}$ & 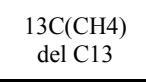 & $\mathrm{D}(\mathrm{CH} 4)$ & $13 \mathrm{C}(\mathrm{TIC})$ & $\mathrm{D}(\mathrm{H} 2 \mathrm{O})$ & $34 \mathrm{~S}(\mathrm{SO} 4)$ & 180 & $\begin{array}{c}\text { Interval } \\
\text { (ti) }\end{array}$ & Method & Comment \\
\hline & & & $\overline{c 165}$ & 94.1 & \begin{tabular}{c|c|}
5.8 \\
\end{tabular} & & & & & & & & & & & & & & & & & & & & & & & & \\
\hline & CSG80-97 & W-Tr-Tfs & 181 & 92.7 & 5.2 & & 9.46 & 22.6 & ND & 143.0 & 105.0 & 1.4 & 8.2 & 0.8 & $\begin{array}{ll}323.0 \\
\end{array}$ & 13.7 & 1.6 & 0.1 & 0.0 & 0.0 & -43.7 & ND & 14.8 & -136 & ND & -15.9 & $1508-1534$ & $\mathrm{P}$ & \\
\hline & CSG80-32 & W-Tfs & 119 & 91.9 & 7.9 & & 9.52 & 23.8 & ND & 173.0 & 109.0 & 5.9 & & 1.3 & 244.0 & 26.5 & 3.9 & 0.2 & 0.2 & 0.0 & ND & ND & 8.0 & -133 & ND & -15.6 & $1688-1710$ & $\mathrm{P}$ & \\
\hline & CSG80-124 & W-Tfs & 112 & 91.5 & 8.3 & & 9.38 & 24.1 & ND & 140.0 & 102.0 & ND & 9.8 & 0.8 & $\begin{array}{l}3 \\
3\end{array}$ & 16.3 & 1.1 & 0.1 & 0.1 & 0.0 & -44.2 & ND & 15.2 & -140 & ND & -16.8 & 2050-2079 & AL/G & \\
\hline & CSG80-234 & GRB-N2 & 0 & 0.1 & 99.2 & & 10.18 & 26.1 & -300 & 211.0 & 104.0 & 15.4 & 12.6 & 0.8 & $\begin{array}{ll}357.0 \\
3\end{array}$ & 15.7 & 5.0 & 0.1 & 0.0 & 0.2 & $\mathrm{ND}$ & $\mathrm{ND}$ & 2.5 & -136 & 10.3 & -16.1 & 2838-2864 & $\mathrm{AL} / \mathrm{IG}$ & \\
\hline \multirow{18}{*}{ DC-14 } & CSG80-144 & W-Tpr & 0 & 0.0 & 98.6 & & 8.84 & 24.1 & ND & 134.0 & 6.3 & 21.8 & 1.0 & 0.0 & 65.6 & 20.4 & 2.7 & 0.3 & 0.1 & 0.0 & $\mathrm{ND}$ & $\mathrm{ND}$ & -12.2 & -152 & 7.9 & -19.6 & 1180-1192 & $\mathrm{F}$ & \\
\hline & CSG80-112 & W-Tpr & 0 & 0.0 & 98.7 & & 8.75 & 28.3 & -120 & 134.0 & 6.6 & 16.6 & 0.8 & 0.0 & 62.7 & 21.3 & 3.2 & 0.2 & 0.0 & 0.0 & $\mathrm{ND}$ & $\mathrm{ND}$ & -12.2 & -151 & ND & -19.5 & $1285-1346$ & $\mathrm{~F}$ & \\
\hline & CSG80-155 & W-Tfs & 0 & 0.0 & 99.0 & & 9.41 & 30.7 & -215 & 146.0 & 6.9 & 20.5 & 2.2 & 0.1 & 76.1 & 11.9 & 1.2 & 0.1 & 0.0 & 0.0 & ND & ND & -12.4 & -149 & 2.8 & -19.4 & $1575-1632$ & F & \\
\hline & CSG80-104 & W-Tfs & 0 & 0.0 & 98.8 & & 9.57 & 24.7 & -120 & 149.0 & 5.1 & $\mathrm{ND}$ & 1.8 & 0.0 & 79.4 & 12.2 & 1.6 & 0.1 & 0.0 & 0.0 & $\mathrm{ND}$ & $\mathrm{ND}$ & -12.3 & -151 & 9.8 & -19.4 & $1614-1708$ & $\mathrm{~F}$ & \\
\hline & CSG80-170 & W-Tfs & 0 & 0.0 & 98.7 & & 9.38 & 34.5 & -225 & 160.0 & 5.1 & 18.6 & 2.2 & 0.1 & $\quad 78.2$ & 14.1 & 0.9 & 0.0 & 0.0 & 0.0 & ND & ND & -12.7 & -152 & 13.6 & -19.4 & 1820-1875 & F & \\
\hline & CSG80-117 & W-Tfs & 0 & 0.0 & 98.8 & & 9.65 & 36.2 & -300 & 188.0 & 7.0 & 24.8 & 3.6 & 0.0 & 114.0 & 11.7 & 0.7 & 0.0 & 0.1 & 0.0 & ND & ND & -12.9 & -148 & 7.8 & -18.6 & $1888-1983$ & $\mathrm{~F}$ & \\
\hline & PDG81-30 & GRB-UMT & 1 & 0.0 & 0.2 & & 9.59 & 19.8 & -280 & 109.0 & 231.0 & 145.0 & 40.6 & 1.0 & 316.0 & 8.1 & 4.1 & 0.0 & 0.0 & 0.3 & ND & ND & -17.3 & -115 & 2.7 & -13.1 & $3060-3144$ & F & \\
\hline & P82-8 & GRB & 0 & 0.0 & 98.0 & & 9.64 & 28.5 & -418 & 109.0 & 247.0 & 134.0 & & 1.4 & 316.0 & 5.6 & 1.3 & 0.1 & 0.0 & 0.0 & $\mathrm{ND}$ & $\mathrm{ND}$ & -21.8 & -115 & 10.1 & -14.0 & $3260-3335$ & $\mathrm{~F}$ & \\
\hline & P82-315 & & 0 & 0.1 & 98.0 & & ND & $\mathrm{ND}$ & ND & ND & ND & ND & & & & & & & & & ND & $\mathrm{ND}$ & ND & ND & $\mathrm{ND}$ & ND & $3620-3335$ & & \\
\hline & P83-156 & GRB-N2 & 0 & 0.1 & 98.5 & & 9.53 & 31.2 & -290 & 110.0 & 253.0 & 141.0 & 48.4 & 1.4 & 337.0 & 5.8 & 1.3 & 0.1 & 0.0 & 0.0 & ND & ND & -23.6 & -113 & $\mathrm{ND}$ & -14.3 & $3260-3335$ & $\mathrm{~F}$ & \\
\hline & P83-152 & GRB-N2 & 0 & 0.0 & 98.3 & & 9.15 & 29.4 & -310 & 110.0 & 254.0 & 141.0 & 48.7 & 1.4 & 336.0 & 5.7 & 1.6 & 0.1 & 0.0 & 0.0 & ND & ND & -22.9 & -111 & ND & -14.2 & $3260-3335$ & F & \\
\hline & P83-157 & GRB-N2 & 0 & 0.2 & 98.3 & & 9.20 & 30.0 & -320 & 123.0 & 254.0 & 140.0 & 50.7 & 1.5 & 338.0 & 5.9 & 1.3 & 0.1 & 0.0 & 0.0 & $\mathrm{ND}$ & ND & -22.2 & -113 & $\mathrm{ND}$ & -14.2 & $3260-3335$ & $\mathrm{~F}$ & \\
\hline & P83-178 & GRB-N2 & 0 & 0.1 & 98.4 & & 9.60 & 29.7 & ND & 109.0 & 254.0 & 140.0 & 48.3 & 1.4 & 328.0 & 5.7 & 1.3 & 0.1 & 0.0 & 0.0 & ND & $\mathrm{ND}$ & -23.4 & -112 & ND & -13.9 & $3260-3335$ & F & \\
\hline & P83-183 & GRB-N2 & 0 & 0.1 & 98.4 & & 9.30 & 30.2 & -320 & 118.0 & 254.0 & 141.0 & 49.8 & 1.1 & 330.0 & 5.9 & 1.3 & 0.1 & 0.0 & 0.0 & ND & ND & -23.4 & -113 & ND & -14.9 & $3260-3335$ & F & \\
\hline & P83-154 & GRB-N2 & 0 & 0.1 & 98.4 & & 9.33 & 30.2 & ND & 120.0 & 254.0 & 141.0 & 50.1 & 1.7 & 336.0 & 5.7 & 1.3 & 0.1 & 0.0 & 0.0 & ND & $\mathrm{ND}$ & $\mathrm{ND}$ & -114 & $\mathrm{ND}$ & -14.0 & $3260-3335$ & $\mathrm{~F}$ & \\
\hline & P83-150 & GRB-N2 & 0 & 0.1 & 84.3 & & 9.20 & 30.5 & -300 & 108.0 & 253.0 & 140.0 & 49.0 & 1.7 & 335.0 & 5.8 & 1.4 & 0.1 & 0.0 & 0.0 & ND & ND & -21.8 & -115 & ND & -14.0 & $3260-3335$ & $\mathrm{~F}$ & \\
\hline & P83-266 & GRB-N2 & 0 & 0.0 & 98.4 & & 9.30 & 30.5 & -300 & 117.0 & 252.0 & 140.0 & 50.1 & 1.4 & 326.0 & 5.7 & 1.3 & 0.1 & 0.0 & 0.0 & ND & ND & ND & -114 & ND & -14.0 & $3260-3335$ & $\mathrm{~F}$ & \\
\hline & P83-261 & GRB-N2 & 0 & 0.0 & 80.6 & & & & & & & & 48.9 & 1.1 & 333.0 & 5.9 & 1.4 & 0.1 & 0.0 & 0.0 & & & & & & & & & \\
\hline \multirow[t]{9}{*}{ CC-15 } & CSG80-57 & SMB-CCI & 76 & 82.5 & 11.1 & & 8.06 & 20.6 & $\mathrm{ND}$ & 248.0 & 15.5 & $\mathrm{ND}$ & 1.1 & 0.0 & 112.3 & 12.1 & 3.1 & 0.5 & 0.3 & 0.0 & -63.6 & ND & 4.1 & -141 & ND & -17.1 & $713-787$ & $\mathrm{P}$ & \\
\hline & CSG80-87 & SMB-MABTON & 309 & 96.7 & 3.2 & & 8.27 & 19.7 & $\mathrm{ND}$ & 233.0 & 17.9 & ND & 2.0 & 0.1 & 109.0 & 13.6 & 2.6 & 1.0 & 0.5 & 0.0 & -46.5 & $\mathrm{ND}$ & 14.5 & -138 & ND & -16.8 & $1003-1072$ & $\mathrm{P}$ & \\
\hline & CSG80-137 & W-Tpr & 75 & 87.9 & 11.9 & & 9.42 & 24.7 & $\mathrm{ND}$ & 130.0 & 46.8 & 2.0 & 11.5 & 0.3 & 89.1 & 11.1 & 1.1 & 0.0 & 0.0 & 0.0 & -67.1 & ND & 0.3 & -136 & $\mathrm{ND}$ & -17.2 & 1219-1293 & $\mathrm{P}$ & \\
\hline & CSG80-176 & W-Tr & 41 & 80.0 & 19.7 & & 9.31 & 26.6 & -240 & 139.0 & 35.2 & ND & 9.5 & 0.2 & 97.5 & 14.2 & 1.0 & 0.0 & 0.0 & 0.0 & -76.5 & $5 \quad-264.7$ & -10.0 & -139 & $\mathrm{ND}$ & -17.1 & $1357-1390$ & $\mathrm{AL} / \mathrm{IG}$ & \\
\hline & CSG80-135 & W-Tfs & 37 & 78.2 & 21.5 & & 9.43 & 27.2 & -300 & 149.0 & 40.1 & 2.7 & 9.1 & 0.2 & 98.1 & 14.5 & 1.5 & 0.0 & 0.0 & 0.0 & -69.9 & -255.3 & -9.4 & -137 & -1.7 & -17.5 & 1481-1506 & AL/G & \\
\hline & CSG80-120 & W-Tfs & 20 & 65.7 & 33.8 & & 9.36 & 23.6 & -140 & 162.0 & 44.5 & 1.3 & 10.9 & 0.2 & 102.0 & 15.9 & 1.3 & 0.1 & 0.1 & 0.0 & -88.4 & $4-264.1$ & -5.2 & -137 & $\mathrm{ND}$ & -17.4 & $1540-1593$ & $\mathrm{AL} / \mathrm{IG}$ & \\
\hline & CSG80-131 & W-Tfs & 0 & 0.1 & 98.5 & & 9.54 & 27.7 & -380 & 152.0 & 66.0 & 7.5 & 11.8 & 0.3 & 117.0 & 13.6 & 1.0 & 0.0 & 0.1 & 0.0 & $\mathrm{ND}$ & ND & -17.0 & -137 & 33.8 & -16.5 & $1735-1833$ & $\mathrm{AL} / \mathrm{IG}$ & \\
\hline & CSG80-193 & W-Tfs & 0 & 0.4 & 97.8 & & 9.63 & 29.0 & -420 & 173.0 & 70.7 & 4.8 & 8.6 & 0.2 & 113.0 & 13.3 & 1.4 & 0.0 & 0.0 & 0.0 & $\mathrm{ND}$ & $\mathrm{ND}$ & -22.1 & -139 & $\mathrm{ND}$ & -17.4 & 1834-1887 & $\mathrm{AL} / \mathrm{IG}$ & \\
\hline & P82-94 & GRB-R2 & 0 & 1.3 & 97.5 & & 9.81 & 18.6 & -330 & 146.0 & 137.0 & 107.2 & 46.3 & 2.3 & 271.0 & 2.9 & 1.8 & 0.1 & 0.2 & 0.0 & ND & ND & -30.7 & -124 & -16.0 & -18.1 & 4138-4243 & AL/G & \\
\hline \multirow[t]{11}{*}{ DC-16A } & P82-17 & SMB-SI & 0 & 0.0 & 98.5 & & 8.04 & 24.1 & -245 & 148.0 & 3.6 & 4.4 & 0.5 & 0.0 & 46.6 & 6.4 & 14.9 & 3.5 & & & $\mathrm{ND}$ & ND & -14.3 & -146 & 33.1 & -18.0 & 928-1021 & P & \\
\hline & & & 0 & 0.0 & 98.4 & & & & & & & & & & & & & & & & & & & & & & & & \\
\hline & P82-93 & SMB-MABTON & 1 & 9.9 & 88.5 & & 8.86 & 25.4 & -310 & 184.0 & 5.1 & 4.6 & 0.6 & 0.1 & 68.7 & 11.6 & 6.0 & 1.5 & & & ND & ND & -11.8 & -145 & 8.6 & -18.3 & $1395-1568$ & $P$ & \\
\hline & P82-19(82-72) & W-Tpr-Tr & 126 & 92.4 & 7.4 & & 9.14 & 28.7 & -450 & 150.0 & 146.0 & 2.0 & & 0.5 & 165.0 & 17.0 & 2.0 & 0.1 & & & -44.9 & ND & 9.4 & -138 & 7.9 & -16.4 & 1760-1828 & $\mathrm{P}$ & \\
\hline & & & 126 & 92.4 & 7.4 & & & & & & & & & & & & & & & & & & & & & & & & \\
\hline & & & 102 & 87.9 & 8.8 & & & & & & & & & & & & & & & & & & & & & & & & \\
\hline & & & 144 & 91.9 & 6.5 & & & & & & & & & & & & & & & & & & & & & & & & \\
\hline & & & 144 & 91.9 & 6.5 & & & & & & & & & & & & & & & & & & & & & & & & \\
\hline & P82-188 & W-Tr-Tfs & 6 & 30.3 & 54.5 & & 9.43 & 21.5 & -405 & 151.0 & 172.0 & 1.2 & 10.0 & 0.6 & 180.0 & 18.3 & 1.7 & 0.1 & 1 & & ND & ND & 10.7 & -136 & ND & -16.0 & 1892-2000 & WINDMI & \\
\hline & & & 175 & 94.4 & 5.5 & & & & & & & & & & & & & & & & & & & & & & & & \\
\hline & P82-124 & W-Tfse & 0 & $\begin{array}{l}0.7 \\
690\end{array}$ & $\begin{array}{l}77.1 \\
302\end{array}$ & & 939 & 238 & -335 & 1440 & 1110 & 19 & 130 & 06 & 1420 & 203 & 17 & 01 & & & -640 & ND & -27 & -137 & 89 & -164 & $2105-2156$ & WM & \\
\hline
\end{tabular}


Table F.1. (contd)

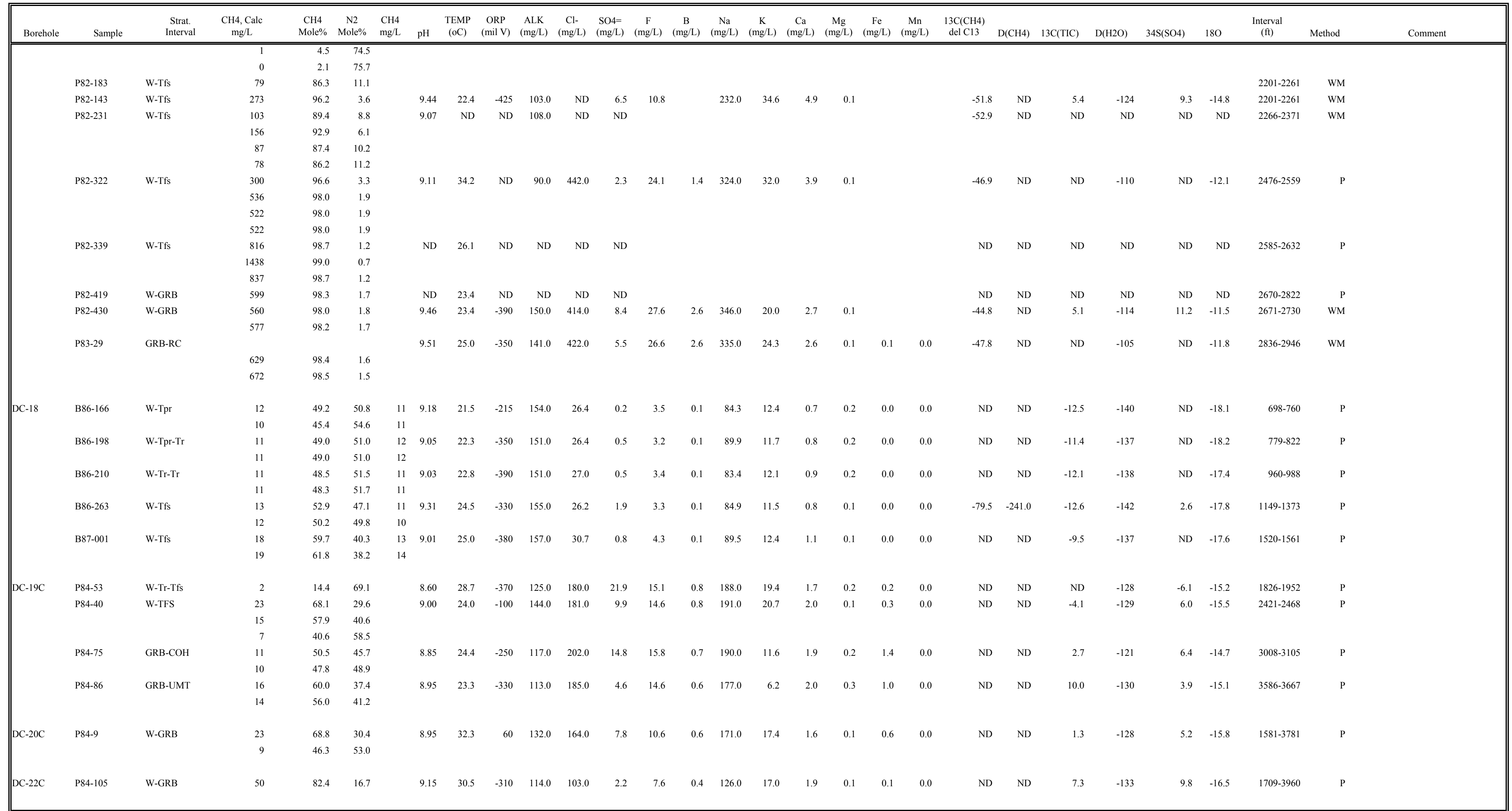


Table F.1. (contd)

\begin{tabular}{|c|c|c|c|c|c|c|c|c|c|c|c|c|c|c|c|c|c|c|c|c|c|c|c|c|c|c|c|c|c|}
\hline Borehole & Sample & $\begin{array}{c}\text { Strat. } \\
\text { Interval }\end{array}$ & $\begin{array}{c}\mathrm{CH} 4 \text {, Calc } \\
\text { mglL }\end{array}$ & $\begin{array}{r}\text { CH4 } \\
\text { Mole\% } \\
\end{array}$ & $\begin{array}{c}\mathrm{N} 2 \\
\text { Mole\% }\end{array}$ & $\begin{array}{c}\mathrm{CH} 4 \\
\mathrm{mg} \mathrm{L}\end{array}$ & $\mathrm{pH}$ & $\begin{array}{l}\text { TEMP } \\
\text { (oC) }\end{array}$ & $\begin{array}{c}\mathrm{ORP} \\
(\text { mil } \mathrm{V})\end{array}$ & $\begin{array}{c}\text { ALK } \\
(\mathrm{mg} / \mathrm{L})\end{array}$ & $\begin{array}{c}\mathrm{Cl}- \\
(\mathrm{mglL})\end{array}$ & $\begin{array}{c}\mathrm{SO4}= \\
(\mathrm{mglL})\end{array}$ & $\underset{(\mathrm{m} g / \mathrm{L})}{\mathrm{F}}$ & $\underset{(\mathrm{mg} / \mathrm{L})}{\mathrm{B}}$ & $\begin{array}{c}\mathrm{Na} \\
(\mathrm{mg} / \mathrm{L})\end{array}$ & $\underset{(\mathrm{mg} L)}{\mathrm{K}}$ & $\begin{array}{c}\mathrm{Ca} \\
(\mathrm{mg} / \mathrm{L})\end{array}$ & $\begin{array}{c}\mathrm{Mg} \\
(\mathrm{mg} / \mathrm{L})\end{array}$ & $\begin{array}{c}\mathrm{Fe} \\
(\mathrm{mglL})\end{array}$ & $\begin{array}{c}\mathrm{Mn} \\
(\mathrm{mg} L)\end{array}$ & 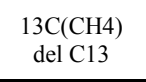 & $\mathrm{D}(\mathrm{CH} 4)$ & $13 \mathrm{C}(\mathrm{TIC})$ & $\mathrm{D}(\mathrm{H} 2 \mathrm{O})$ & $34 \mathrm{~S}(\mathrm{SO} 4)$ & 180 & $\begin{array}{c}\text { Interval } \\
\text { (ft) }\end{array}$ & Method & Comment \\
\hline \multirow[t]{4}{*}{$\overline{\overline{\mathrm{DC}}-23 \mathrm{GR}}$} & B86-133 & 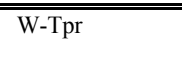 & $\begin{array}{l}80 \\
83\end{array}$ & $\begin{array}{l}85.2 \\
85.7\end{array}$ & $\begin{array}{l}10.8 \\
10 .\end{array}$ & $\begin{array}{l}120^{*} \\
110^{+}\end{array}$ & 9.33 & $\begin{array}{l}29.0 \\
\end{array}$ & -255 & 124.0 & 133.5 & 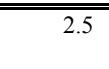 & 7.0 & $\overline{0.2}$ & 134.8 & 20.2 & 4.1 & $\overline{0.2}$ & 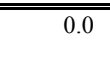 & \begin{tabular}{c|}
0.0 \\
\end{tabular} & $\begin{array}{ll}-35.2 \\
\end{array}$ & $2-134.0$ & 99.0 & "-137 & 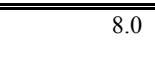 & $\begin{array}{ll}-16.9 \\
\end{array}$ & $1345-1425$ & $\overline{\bar{P}}$ & \\
\hline & B86-141 & W-Tr-Tfs & 89 & 83.6 & 9.6 & $150^{*}$ & 9.25 & 29.7 & -355 & 110.0 & 117.0 & 4.5 & 6.3 & 0.2 & 120.2 & 19.3 & 3.8 & 0.2 & 0.0 & 0.0 & -55.9 & -220.0 & 8.3 & -134 & 10.0 & -17.6 & $1575-1635$ & $\mathrm{P}$ & \\
\hline & B86-181 & W-Tfs & $<1$ & 1.2 & 98.8 & 0 & 9.92 & 26.5 & -410 & 167.0 & 64.6 & 1.4 & 16.9 & 0.4 & 127.8 & 12.2 & 2.5 & 0.2 & 0.0 & 0.0 & ND & ND & -23.5 & 129 & $\mathrm{ND}$ & -16.3 & $2155-2216$ & $\mathrm{P}$ & \\
\hline & B86-274 & GRB-UMT & & & & & 9.49 & 23.0 & -275 & 135.0 & 305.0 & 5.6 & 25.6 & 0.8 & 281.7 & 12.7 & 2.5 & 0.2 & 0.1 & 0.0 & ND & $\mathrm{ND}$ & -25.8 & -115 & 9.7 & -13.9 & $3275-3384$ & $\mathrm{P}$ & \\
\hline DNR-BR-01 & B86-310 & w & 21 & 63.9 & 36.1 & 15 & 8.05 & 24.8 & -155 & 131.0 & 4.5 & ND & 0.7 & 0.1 & 25.3 & 5.8 & 15.4 & 9.6 & 0.0 & 0.0 & ND & $\mathrm{ND}$ & -9.9 & -133 & ND & -16.8 & 603-1145 & $\mathrm{P}$ & \\
\hline ENYEART & P84-166 & w & 6 & 31.5 & 55.4 & & 8.05 & 22.0 & -210 & 147.0 & 4.7 & 1.8 & 1.0 & 0.0 & 26.3 & 6.4 & 18.1 & 11.2 & 0.1 & 0.1 & ND & ND & -12.3 & -137 & ND & -16.9 & $935-1092$ & $\mathrm{~F}$ & \\
\hline MARLEY-4 & B86-295 & $\mathrm{w}$ & 11 & 48.1 & 51.9 & 8 & 8.14 & 23.0 & 45 & 128.0 & 4.0 & ND & 0.6 & 0.1 & 23.8 & 5.1 & 15.5 & 9.7 & 0.0 & 0.0 & $\mathrm{ND}$ & ND & -12.1 & -137 & ND & -16.4 & 724-1377 & $\mathrm{P}$ & \\
\hline \multirow[t]{18}{*}{ MCGEE } & P82-7 & W-Tpr & 10 & 44.0 & 46.0 & & 7.66 & 26.1 & -300 & 145.0 & 4.6 & $\mathrm{ND}$ & 0.7 & 0.0 & 27.7 & 7.3 & 15.6 & 8.3 & 0.1 & 0.1 & ND & ND & -11.2 & -146 & ND & -17.9 & 691-978 & $\mathrm{F}$ & \\
\hline & P82-64 & W-Tpr & 5 & 33.4 & 64.8 & & 7.68 & 26.3 & -365 & 139.0 & 4.8 & ND & 0.7 & 0.0 & 29.7 & 8.0 & 16.6 & 8.7 & 0.1 & 0.1 & ND & ND & -11.1 & -140 & ND & -18.0 & 692-925 & $\mathrm{F}$ & \\
\hline & P82-263 & W-Tr & 5 & 34.4 & 64.2 & & 7.70 & 26.7 & -250 & 139.0 & 4.1 & ND & 0.6 & 0.0 & 27.0 & 7.0 & 16.4 & 8.6 & 0.2 & 0.0 & ND & ND & -11.1 & -144 & ND & -17.9 & 1028-1096 & $\mathrm{F}$ & \\
\hline & & & 5 & 34.5 & 64.3 & & & & & & & & & & & & & & & & & & & & & & & & \\
\hline & P82-397 & W-Tfs & 5 & 33.6 & 65.2 & & 8.11 & 28.2 & -200 & 142.0 & 4.8 & ND & 0.6 & 0.0 & 28.6 & 7.5 & 16.5 & 9.0 & 0.1 & 0.1 & -49.9 & ND & -11.4 & -144 & ND & -17.9 & 1099-1167 & $\mathrm{F}$ & \\
\hline & & & 5 & 33.7 & 65.1 & & & & & & & & & & & & & & & & & & & & & & & & \\
\hline & P82-424 & W-Tfs & $\begin{array}{l}3 \\
4\end{array}$ & $\begin{array}{l}21.2 \\
27.7\end{array}$ & $\begin{array}{l}77.1 \\
71.0\end{array}$ & & 7.45 & 30.5 & -170 & 146.0 & 5.1 & ND & 0.7 & 0.0 & 28.1 & 7.7 & 17.3 & 9.5 & 0.2 & 0.0 & ND & ND & -11.6 & -146 & ND & -18.0 & $1320-1378$ & $\mathrm{~F}$ & \\
\hline & & & 5 & 31.8 & 66.9 & & & & & & & & & & & & & & & & & & & & & & & & \\
\hline & & & 5 & 32.0 & 66.7 & & & & & & & & & & & & & & & & & & & & & & & & \\
\hline & P82-436 & W-Tfs & 4 & 28.7 & 70.0 & & 7.80 & 31.7 & -100 & 148.0 & 4.2 & 0.2 & 0.7 & 0.0 & 28.2 & 7.8 & 17.2 & 9.2 & 0.1 & 0.0 & $\mathrm{ND}$ & ND & -11.5 & -148 & $\mathrm{ND}$ & -18.0 & 1404-1440 & $\mathrm{F}$ & \\
\hline & P83-32 & W-Tfs & 4 & 26.6 & 71.0 & & 7.56 & 20.4 & -150 & 148.0 & 4.6 & 0.1 & 0.6 & 0.0 & 27.4 & 7.8 & 17.7 & 8.5 & 0.5 & 0.1 & ND & ND & -11.2 & -145 & ND & -18.4 & 1443-1483 & $\mathrm{F}$ & \\
\hline & P83-83 & W-Tfs & 4 & 28.4 & 70.3 & & 8.16 & 31.8 & -230 & 151.0 & 5.0 & 0.1 & 0.6 & 0.0 & 28.7 & 7.8 & 18.0 & 9.3 & 0.1 & 0.0 & ND & ND & -11.5 & -146 & ND & -18.3 & 1581-1680 & $\mathrm{F}$ & \\
\hline & P83-188 & W-Tfs & 4 & 26.5 & 72.5 & & 8.00 & 31.8 & -210 & 150.0 & 4.8 & ND & 0.6 & 0.0 & 31.8 & 9.2 & 17.8 & 5.8 & 0.1 & 0.0 & ND & ND & -11.0 & -145 & ND & -18.8 & $1674-1750$ & $\mathrm{~F}$ & \\
\hline & P83-331 & GRB-RC & 13 & 54.2 & 44.1 & & 9.05 & 27.8 & -350 & 185.0 & 7.5 & 1.6 & 3.4 & 0.1 & 87.1 & 8.1 & 1.1 & 0.1 & 0.1 & 0.0 & ND & ND & -4.1 & -143 & ND & -17.4 & 1991-2092 & wM & \\
\hline & P83-476 & GRB-COH & 12 & 50.3 & 44.0 & & 9.40 & 26.6 & -300 & 181.0 & 7.6 & 0.4 & 3.5 & 0.0 & 90.9 & 8.4 & 0.9 & 0.1 & 0.1 & 0.0 & $\mathrm{ND}$ & ND & -4.5 & -142 & ND & -17.6 & $2188-2337$ & wM & \\
\hline & P83-513 & GRB-COH & 3 & 19.1 & 75.1 & & 9.50 & 27.9 & -340 & 176.0 & 48.4 & 1.1 & 11.0 & 0.1 & 120.0 & 9.7 & 1.2 & 0.1 & 0.1 & 0.0 & ND & ND & ND & -144 & ND & -17.5 & 2393-2524 & wM & \\
\hline & P84-24 & GRB-UMT & 5 & 31.0 & 67.9 & & 9.45 & 25.8 & -410 & 208.0 & 48.4 & 6.2 & 9.3 & 0.1 & 130.0 & 10.2 & 1.0 & 0.1 & 0.2 & 0.0 & ND & ND & -10.7 & -145 & ND & -17.4 & $2854-3123$ & wM & \\
\hline & CSG80-64 & GRB-COH & & & & & & & & & & & 0.7 & 0.0 & 29.7 & 8.9 & 16.6 & 9.3 & 0.1 & 0.1 & -51.6 & & -11.2 & -142 & ND & -17.3 & 692-925 & $\mathrm{F}$ & \\
\hline \multirow[t]{14}{*}{ RRL-02 } & P82-65 & w-Tpr-Tr & 52 & 83.3 & 16.2 & & 9.32 & 21.8 & -385 & 155.0 & 122.0 & 2.0 & 8.6 & 0.4 & 141.0 & 15.5 & 1.9 & 0.1 & 0.4 & 0.0 & ND & ND & 8.5 & -136 & ND & -16.0 & $1735-1773$ & AL/IG & \\
\hline & P82-401 & GRB-COH & 421 & 97.6 & 2.4 & & 9.71 & 23.4 & -290 & 165.0 & 403.0 & 4.2 & 20.0 & 3.5 & 337.0 & 13.8 & 2.2 & 0.1 & 0.1 & 0.0 & ND & ND & 15.3 & -116 & 7.8 & -11.6 & $3247-3344$ & wM & \\
\hline & & & 3 & 19.8 & 62.7 & & & & & & & & & & & & & & & & & & & & & & & & \\
\hline & & & 689 & 98.2 & 1.5 & & & & & & & & & & & & & & & & & & & & & & & & \\
\hline & P84-7 & GBR-COH & 797 & 98.7 & 1.3 & & 9.60 & 19.5 & -365 & 149.0 & 416.0 & 1.0 & 14.0 & 2.9 & 353.0 & 13.5 & 2.4 & 0.1 & 0.1 & 0.0 & ND & ND & 19.7 & -112 & 11.2 & -10.8 & $3247-3344$ & wM & \\
\hline & P82-364 & GRB-UMT & 589 & 97.9 & 1.7 & & 9.41 & 29.4 & -220 & 136.0 & 451.0 & 1.7 & 18.2 & 3.4 & 355.0 & 9.4 & 1.6 & 0.1 & 0.1 & 0.0 & -37.8 & ND & 16.9 & -110 & 2.1 & -11.2 & $3568-3781$ & wM & \\
\hline & & & 316 & 96.7 & 3.1 & & & & & & & & & & & & & & & & & & & & & & & & \\
\hline & & & 505 & 97.8 & 2.0 & & & & & & & & & & & & & & & & & & & & & & & & \\
\hline & & & 532 & 97.9 & 1.9 & & & & & & & & & & & & & & & & & & & & & & & & \\
\hline & & & 447 & 97.2 & 2.2 & & & & & & & & & & & & & & & & & & & & & & & & \\
\hline & P82-309 & GRB-UMT(FZ) & 275 & 96.2 & 3.6 & & 9.34 & 25.9 & ND & 132.0 & 384.0 & 3.5 & 17.2 & 3.1 & 336.0 & 8.5 & 2.8 & 0.2 & 0.1 & 0.0 & -38.4 & ND & ND & ND & ND & ND & $3781-3827$ & wM & \\
\hline & P82-456 & GRB-HMG & 931 & 98.9 & 1.1 & & 9.78 & 22.3 & -300 & 135.0 & 455.0 & 2.4 & 20.1 & 3.5 & 364.0 & 5.9 & 1.8 & 0.1 & 0.1 & 0.0 & -38.3 & ND & 16.4 & -114 & 5.8 & -11.1 & $3837-3889$ & wм & \\
\hline & & & 610 & 98.3 & 1.6 & & & & & & & & & & & & & & & & & & & & & & & & \\
\hline & & & 408 & 97.5 & 2.4 & & & & & & & & & & & & & & & & & & & & & & & & \\
\hline
\end{tabular}


Table F.1. (contd)

\begin{tabular}{|c|c|c|c|c|c|c|c|c|c|c|c|c|c|c|c|c|c|c|c|c|c|c|c|c|c|c|c|c|c|}
\hline \begin{tabular}{|r} 
Borehole \\
\end{tabular} & Sample & $\begin{array}{c}\text { Strat. } \\
\text { Interval } \\
\end{array}$ & $\begin{array}{c}\mathrm{CH} 4 \text {, Calc } \\
\mathrm{mg} / \mathrm{L}\end{array}$ & $\begin{array}{c}\text { CH4 } \\
\text { Mole\% } \\
\end{array}$ & $\begin{array}{c}\mathrm{N} 2 \\
\text { Mole\% } \\
\end{array}$ & $\begin{array}{c}\mathrm{CH} 4 \\
\mathrm{mg} / \mathrm{L}\end{array}$ & $\mathrm{pH}$ & $\begin{array}{c}\text { TEMP } \\
(\mathrm{OC}) \\
\end{array}$ & $\begin{array}{c}\text { ORP } \\
(\mathrm{mil} \text { V) }\end{array}$ & $\begin{array}{c}\mathrm{ALK} \\
(\mathrm{mg} / \mathrm{L})\end{array}$ & 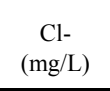 & $\begin{array}{c}\mathrm{SO} 4= \\
(\mathrm{mg} / \mathrm{L})\end{array}$ & $\underset{(\mathrm{mg} / \mathrm{L})}{\mathrm{F}}$ & $\begin{array}{c}\mathrm{B} \\
(\mathrm{mg} / \mathrm{L})\end{array}$ & $\begin{array}{c}\mathrm{Na} \\
(\mathrm{mg} / \mathrm{L})\end{array}$ & $\underset{\substack{\mathrm{K} \\
(\mathrm{mg} L)}}{\mathrm{s}}$ & $\underset{(\mathrm{mg} / \mathrm{L})}{\mathrm{Ca}}$ & $\begin{array}{c}\mathrm{Mg} \\
(\mathrm{mg} / \mathrm{L})\end{array}$ & $\underset{\substack{\mathrm{Fe} \\
(\mathrm{mg} / \mathrm{L})}}{\mathrm{f}}$ & $\underset{\substack{\mathrm{Mn} \\
(\mathrm{mg} \mathrm{L})}}{\mathrm{Mn}}$ & $\begin{array}{l}13 \mathrm{C}(\mathrm{CH} 4) \\
\mathrm{del} \mathrm{Cl} 3\end{array}$ & $\mathrm{D}(\mathrm{CH} 4)$ & $13 \mathrm{C}(\mathrm{TIC})$ & $\mathrm{D}(\mathrm{H} 2 \mathrm{O})$ & $345\left(\mathrm{SO}_{4}\right)$ & 180 & $\begin{array}{c}\text { Interval } \\
\text { (ft) }\end{array}$ & Method & Comment \\
\hline \multirow[t]{2}{*}{\begin{tabular}{|l|l|} 
RRL-02C \\
\end{tabular}} & "1886-313 & $\begin{array}{l}\text { GRB-N22 } \\
\end{array}$ & (1662 & $\begin{array}{l}98.3 \\
\end{array}$ & 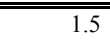 & $2580^{*}$ & & & & & & & & & & & & & & & & & & & & & & & \\
\hline & & & 637 & 98.3 & 1.6 & & & & & & & & & & & & & & & & & & & & & & & & \\
\hline RRL-06B & P83-25 & GRB-UMT & 478 & 97.8 & 2.1 & & $\mathrm{ND}$ & $\mathrm{ND}$ & $\mathrm{ND}$ & $\mathrm{ND}$ & ND & $\mathrm{ND}$ & & & & & & & & & ND & ND & $\mathrm{ND}$ & $\mathrm{ND}$ & $\mathrm{ND}$ & ND & $3708-3823$ & $\mathrm{P}$ & \\
\hline \multirow{6}{*}{ RRL-14 } & P82-403 & $\mathrm{GRB}-\mathrm{COH}$ & 606 & 983 & 1.7 & & 9.48 & 220 & $=50$ & 1950 & 3750 & & 243 & 23 & 3369 & 247 & 21 & 01 & 0 & 00 & -441 & $\mathrm{ND}$ & $\mathrm{ND}$ & $\mathrm{ND}$ & $\mathrm{ND}$ & $\mathrm{ND}$ & $3017-3147$ & WM & \\
\hline & & & 622 & 98.4 & 1.6 & & & & & & & & & & & & & & & & -439 & N & & & & & & & \\
\hline & P84-11 & GRB-COH & 493 & 97.9 & 2.0 & & $\mathrm{ND}$ & $\mathrm{ND}$ & ND & $\mathrm{ND}$ & ND & ND & & & & & & & & & ND & ND & ND & ND & ND & ND & $3077-3140$ & & \\
\hline & P83-151 & GRB-COH & 457 & 97.5 & 2.2 & & ND & $\mathrm{ND}$ & ND & ND & ND & ND & & & & & & & & & ND & ND & ND & ND & ND & ND & $3294-3814$ & & \\
\hline & P83-49 & GRB-UMT & 525 & 98.0 & 1.9 & & ND & ND & ND & $\mathrm{ND}$ & ND & $\mathrm{ND}$ & & & & & & & & & -47.9 & $\mathrm{ND}$ & ND & $\mathrm{ND}$ & ND & ND & $3715-3814$ & wM & \\
\hline & & & 519 & 97.5 & 1.9 & & & & & & & & & & & & & & & & & & & & & & & & \\
\hline \multirow[t]{2}{*}{ STEM-1 } & B86-31 & W-Tpr-Tfs & 2 & 15.0 & 85.0 & 2 & 7.80 & 19.5 & -150 & 157.0 & 4.9 & 0.2 & 0.6 & 0.1 & 25.2 & 5.7 & 20.3 & 12.6 & 0.0 & 0.0 & $\mathrm{ND}$ & ND & ND & ND & ND & ND & $469-970$ & $\mathrm{P}$ & \\
\hline & B85-252 & W-Tpr-Tfs & 1 & 9.8 & 90.2 & 1 & & & & & & & & & & & & & & & & & -14.0 & -130 & -4.4 & -17.1 & $469-970$ & $\mathrm{P}$ & \\
\hline \multirow[t]{2}{*}{ STEM-2 } & B86-354 & W-Tpr-Tfs & 5 & 27.5 & 72.5 & 3 & 8.05 & 19.5 & -25 & 152.0 & 4.8 & ND & & & & & & & & & $\mathrm{ND}$ & $\mathrm{ND}$ & -13.4 & -148 & ND & -17.2 & $565-1002$ & $\mathrm{P}$ & \\
\hline & B86-19 & & 3 & 26.6 & 73.4 & 3 & & & & & & & 0.6 & 0.1 & 25.1 & 5.9 & 19.7 & 12.1 & 0.1 & 0.0 & & & -13.4 & -134 & ND & -17.3 & $565-1002$ & $P$ & \\
\hline
\end{tabular}




\section{Appendix G}

Identification of Columbia River Basalt Group Flows 


\section{Appendix G}

\section{Identification of Columbia River Basalt Group Flows}

This appendix is designed as a tool to identify the stratigraphic interval encountered during drilling.

\subsection{Identification of Columbia River Basalt}

Lava flows of the Columbia River Basalt Group (Figure G.1) are identified using a combination of lithology, paleomagnetic properties, and chemical composition. Experience is the best way of making correct identifications but the chemical composition provides the least ambiguous way of properly identifying a lava flow. Table G. 1 shows the chemical composition of the larger lava flows of the Columbia River basalt Group. Although this selection does not include every flow known, it provides compositions of the ones that will be of most importance for characterization because of their great lateral extent.

The compositions in Table G.1 are listed from the youngest at the top to the oldest at the bottom. The names are those shown in Figure G.1. Variation diagrams shown in Figures G.2 through G.9 are useful plots for distinguishing many of the lava flows. Geologic maps and distribution maps of the lava flows provide a first "cut" at determining what lava flows should or should not be present at a site. Figure G.10 is a geologic map showing the distribution of the main formations. Figure G.11 is a geologic map showing the distributions of the main lava flows. Figure G.12 shows the distribution of the main lava flows in Figure G.1.

\subsection{Procedure.}

- Upon determining the location of the characterization borehole, first determine the uppermost lava flow exposed at the surface. This should be done by first consulting the geologic map for the area. Figures G.10, G.11, and G.12 provide maps showing which lava flows can be expected to be present at a site. However, these are small scale and it is recommended that the 1:100,000 scale geologic maps be used (Appendix H). The Columbia Basin has been mapped in very good detail so the surface flow identification should be reliable.

- Once the surface flow has been identified, consult the maps showing the distribution for the various lava flows of the Columbia River Basalt Group in Figure G.12. The distribution maps will allow you to determine the stratigraphic units that are present in your area.

- Upon determining the stratigraphic units present in your area, you can assemble a representative chemical composition stratigraphy for your area from Table G.1.

- Once you have received the chemistry from samples that you have submitted for analysis, match the analyses to your "theoretical" stratigraphy. The most important oxides to consider are: 
$\circ \quad \mathrm{TiO}_{2}$

○ $\mathrm{MgO}$

$\circ \mathrm{P}_{2} \mathrm{O}_{5}$

O $\mathrm{Zr}$

- Most Saddle Mountains Basalt will be easy to discriminate because of the diverse chemistry of the flows (e.g., Figure G.2).

- $\mathrm{TiO}_{2}$ and $\mathrm{P}_{2} \mathrm{O}_{5}$ will allow an initial discrimination (e.g., Figure G.3). Flows of the Wanapum Basalt typically will have higher $\mathrm{TiO}_{2}$ than the Grande Ronde Basalt. Often when $\mathrm{TiO}_{2}$ is used in conjunction with other trace elements such as Ba (Figure G.4) or Cr (Figure G.5), a finer discrimination can be recognized. $\mathrm{P}_{2} \mathrm{O}_{5}$ with trace elements is also useful (Figure G.6).

- Grande Ronde Basalt flows will be the most difficult to separate. $\mathrm{TiO}_{2}$ and $\mathrm{Cr}$ (Figure G.5) allow some discrimination. The upper most flows will be the high $\mathrm{MgO}$ Member of Sentinel Bluffs flows (Figure G.1). The Sentinel Bluffs flows are wide spread and will be easily recognized. A distinctive flow called the Member of Umtanum flow (Figure G.1) and a compositionally similar one called the Member of Winter Water flow(s) underlie the Sentinel Bluffs flows. Deeper Grande Ronde Basalt flows will be more difficult to distinguish and direct compositional comparisons should be made to Table G.1. Figures G.7, G.8, and G.9 provide other examples of useful discriminations. 


\begin{tabular}{|c|c|c|c|c|c|c|c|}
\hline \multicolumn{2}{|c|}{ Series } & \multicolumn{2}{|c|}{ Group } & Formation & \multirow[b]{2}{*}{ Lower Monumental Member } & \multirow{2}{*}{\begin{tabular}{|c}
$\begin{array}{c}\text { Isotopic } \\
\text { Age (m.y) }\end{array}$ \\
6 \\
\end{tabular}} & \multirow{2}{*}{$\begin{array}{c}\text { Magnetic } \\
\text { Polarity } \\
\mathrm{N} \\
\end{array}$} \\
\hline \multirow{51}{*}{ 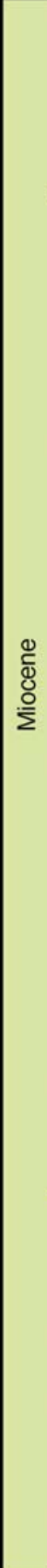 } & \multirow{6}{*}{$\begin{array}{l}\text { 홍 } \\
\text { 음 }\end{array}$} & \multirow{51}{*}{ 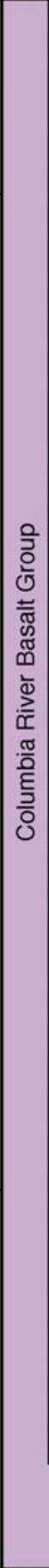 } & \multirow{51}{*}{ 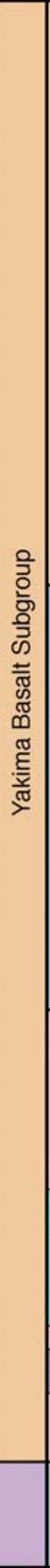 } & \multirow{17}{*}{$\begin{array}{c}\text { Saddle } \\
\text { Mountains } \\
\text { Basalt }\end{array}$} & & & \\
\hline & & & & & $\begin{array}{l}\text { Ice-Harbor Member } \\
\text { Basalt of Goose Island }\end{array}$ & 8.5 & $\mathrm{~N}$ \\
\hline & & & & & Basalt of Martindale & & $\mathrm{R}$ \\
\hline & & & & & Basalt of Basin City & & $\mathrm{N}$ \\
\hline & & & & & Buford Member & & $\mathrm{R}$ \\
\hline & & & & & Elephant Mountain Member & 10.5 & $\mathrm{~N}, \mathrm{~T}$ \\
\hline & \multirow{31}{*}{$\begin{array}{l}\frac{\Phi}{\bar{D}} \\
\frac{0}{\Sigma}\end{array}$} & & & & Pomona Member & 12 & $\mathrm{R}$ \\
\hline & & & & & Esquatzel Member & $\mathrm{N}$ & \\
\hline & & & & & $\begin{array}{r}\text { Weissenfels Ridge Member } \\
\text { Basalt of Slippery Creek }\end{array}$ & & $\mathrm{N}$ \\
\hline & & & & & Basalt of Tenmile Creek & & $\mathrm{N}$ \\
\hline & & & & & Basalt of Lewiston Orchards & & $\mathrm{N}$ \\
\hline & & & & & Basalt of Cloverland & & $\mathrm{N}$ \\
\hline & & & & & $\begin{array}{l}\text { Asotin Member } \\
\text { Basalt of Huntzinger }\end{array}$ & 13 & $\mathrm{~N}$ \\
\hline & & & & & $\begin{array}{c}\text { Wilbur Creek Member } \\
\text { Basalt of Lapwal }\end{array}$ & & $\mathrm{N}$ \\
\hline & & & & & Basalt of Wahluke & & $\mathrm{N}$ \\
\hline & & & & & $\begin{array}{l}\text { Umatilla Member } \\
\text { Basalt of Sillusi }\end{array}$ & & $\mathrm{N}$ \\
\hline & & & & & Basalt of Umatilla & & $\mathrm{N}$ \\
\hline & & & & \multirow{13}{*}{$\begin{array}{l}\text { Wanapum } \\
\text { Basalt }\end{array}$} & $\begin{array}{l}\text { Priest Rapids Member } \\
\text { Basalt of Lolo }\end{array}$ & 14.5 & $R$ \\
\hline & & & & & Basalt of Rosalia & & $\mathrm{R}$ \\
\hline & & & & & Roza Member & & T, R \\
\hline & & & & & Shumaker Creek Member & & $\mathrm{N}$ \\
\hline & & & & & $\begin{array}{c}\text { Frenchman Springs Member } \\
\text { Basalt of Lyons Ferry }\end{array}$ & & $\mathrm{N}$ \\
\hline & & & & & Basalt of Sentinel Gap & & $\mathrm{N}$ \\
\hline & & & & & Basalt of Sand Hollow & 15.3 & $\mathrm{~N}$ \\
\hline & & & & & Basalt of Silver Falls & & $\mathrm{N}, \mathrm{E}$ \\
\hline & & & & & Basalt of Ginkgo & 15.6 & $E$ \\
\hline & & & & & Basalt of Palouse Falls & & $E$ \\
\hline & & & & & $\begin{array}{l}\text { Eckler Mountain Member } \\
\text { Basalt of Dodge }\end{array}$ & & $\mathrm{N}$ \\
\hline & & & & & Basalt of Robinette Mountain & & $\mathrm{N}$ \\
\hline & & & & & Vantage Horizon & & \\
\hline & & & & & Member of Sentinel Bluffs & 15.6 & \multirow{7}{*}{$\mathrm{N}_{2}$} \\
\hline & & & & & Member of Slack Canyon & & \\
\hline & & & & & Member of Fields Spring & & \\
\hline & & & & & Member of Winter Water & & \\
\hline & & & & & Member of Umtanum & & \\
\hline & & & & & Member of Ortley & & \\
\hline & & & & & Member of Armstrong Canyon & & \\
\hline & \multirow{14}{*}{$\sum_{3}^{\grave{1}}$} & & & \multirow{6}{*}{ 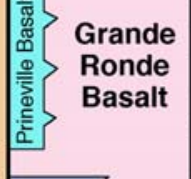 } & Member of Meyer Ridge & & \multirow{4}{*}{$\mathrm{R}_{2}$} \\
\hline & & & & & Member of Grouse Creek & & \\
\hline & & & & & Member of Wapshilla Ridge & & \\
\hline & & & & & Member of Mt. Horrible & & \\
\hline & & & & & $>$ Member of China Creek & & $\mathrm{N}_{1}$ \\
\hline & & & & & Member of Downy Gulch & & \\
\hline & & & & $\begin{array}{l}\text { Picture } \\
\text { Gorge }\end{array}$ & Member of Center Creek & & \\
\hline & & & & - Basalt & Member of Rogersburg & & $\mathrm{R}_{1}$ \\
\hline & & & & & Teepee Butte Member & & \\
\hline & & & & & Member of Buckhorn Springs & 16.5 & \\
\hline & & & & & & & $R_{1}$ \\
\hline & & & & Imnaha & & & $\mathrm{T}$ \\
\hline & & & & Basalt & & & No \\
\hline & & & & & & 17.5 & $\mathrm{R}_{0}$ \\
\hline
\end{tabular}

Figure G.1. Stratigraphic Nomenclature for the Columbia River Basalt Group that is Used in this Report 


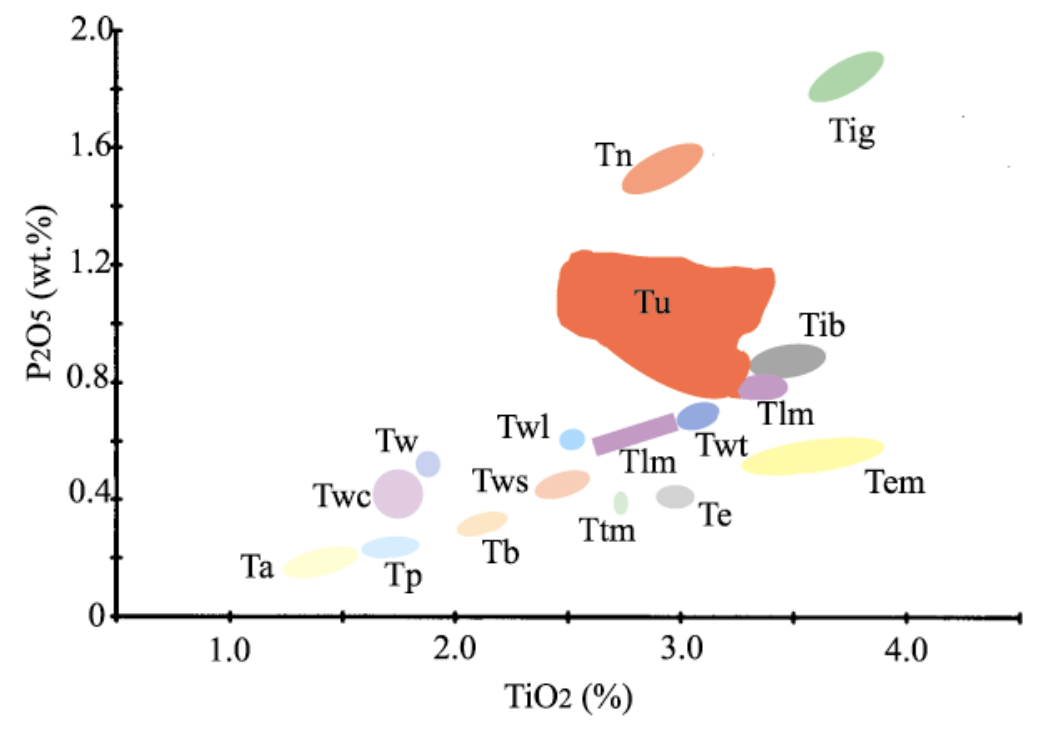

Figure G.2. $\mathrm{TiO}_{2}$ Versus $\mathrm{P}_{2} \mathrm{O}_{5}$ for all Saddle Mountains Basalt Flows

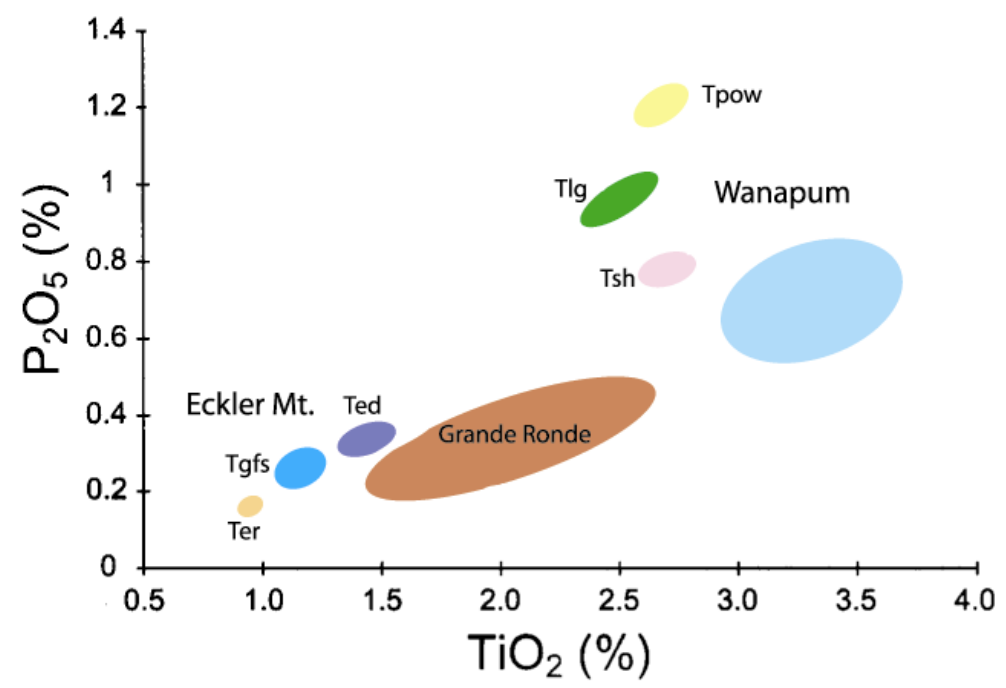

Figure G.3. $\mathrm{TiO}_{2}$ Versus $\mathrm{P}_{2} \mathrm{O}_{5}$ for Grande Ronde Basalt, Wanapum Basalt and Eckler Mountain Member 


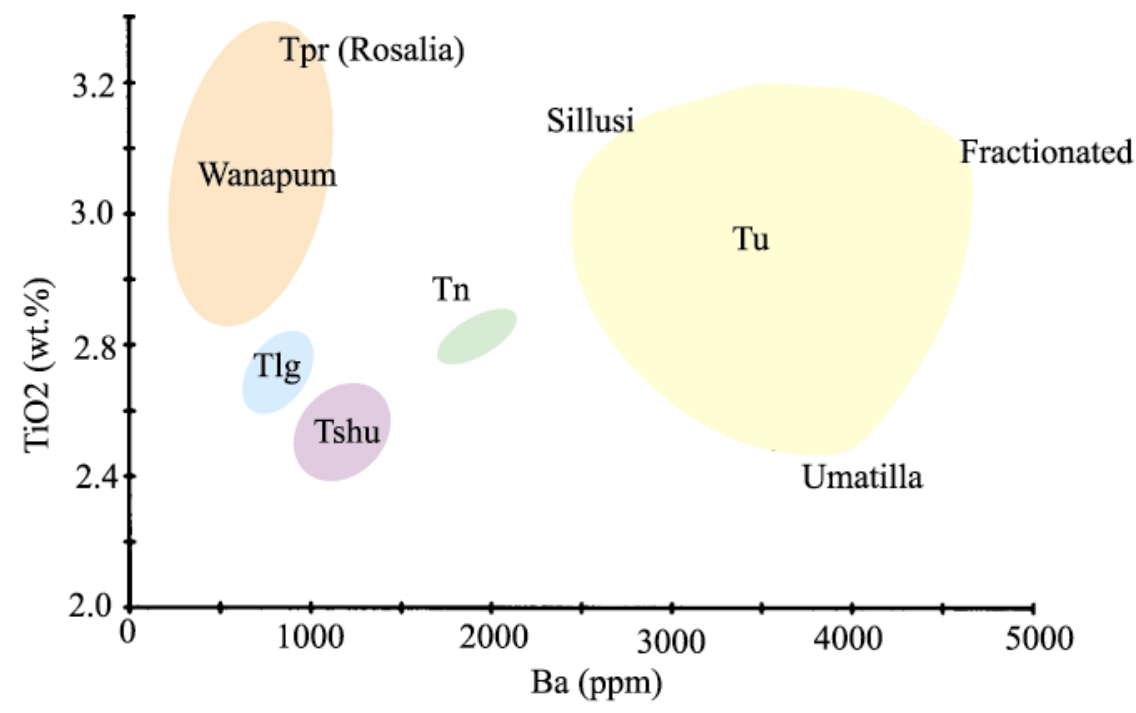

Figure G.4. $\mathrm{TiO}_{2}$ Versus $\mathrm{Ba}$ for the Wanapum Basalt and Selected Flows of the Saddle Mountains Basalt and Eckler Mountain Member

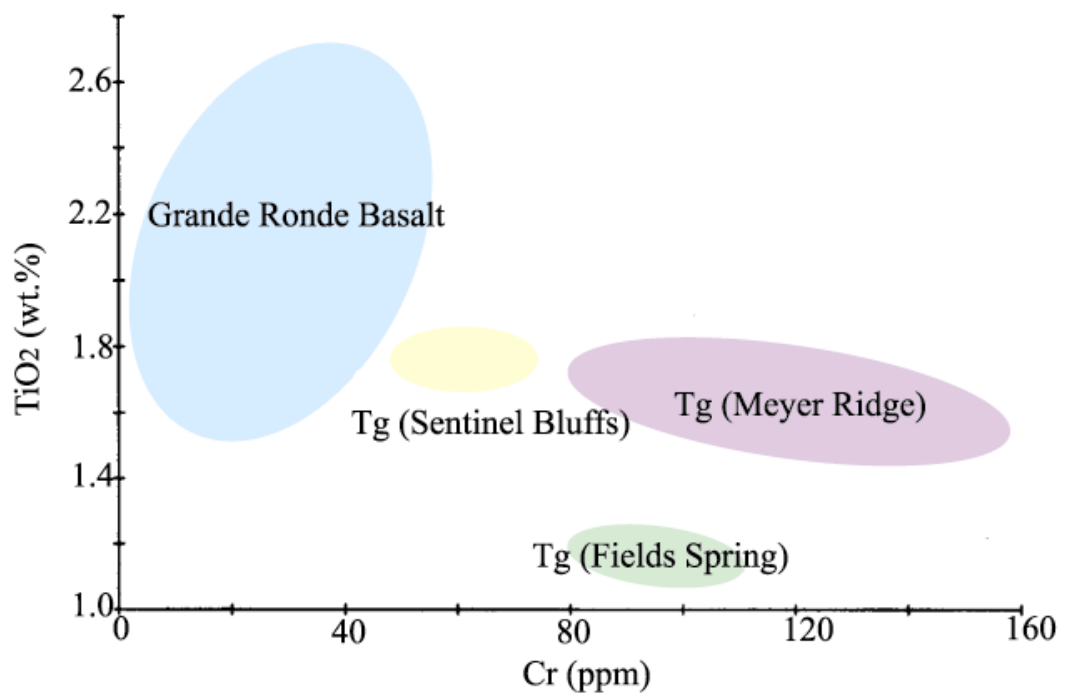

Figure G.5. $\mathrm{TiO}_{2}$ Versus $\mathrm{Cr}$ for Selected Flows of the Grande Ronde Basalt 


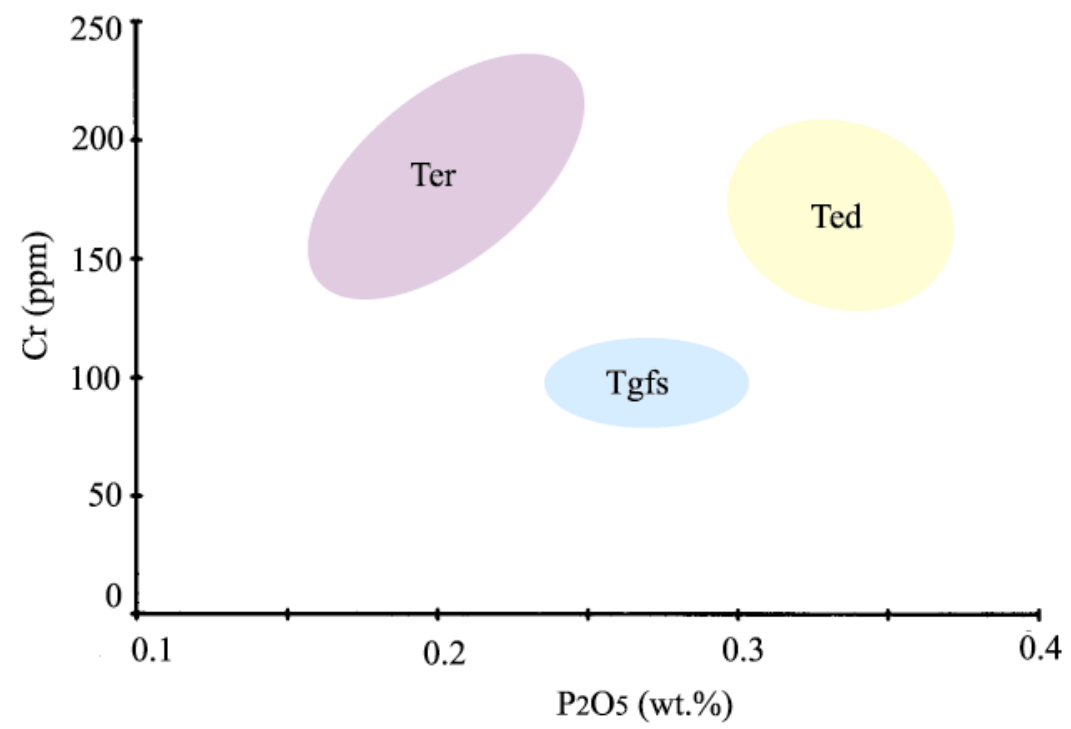

Figure G.6. $\mathrm{P}_{2} \mathrm{O}_{5}$ Versus $\mathrm{Cr}$ for the Fields Spring Member of the Grande Ronde Basalt and the Selected Flows of the Eckler Mountain Member

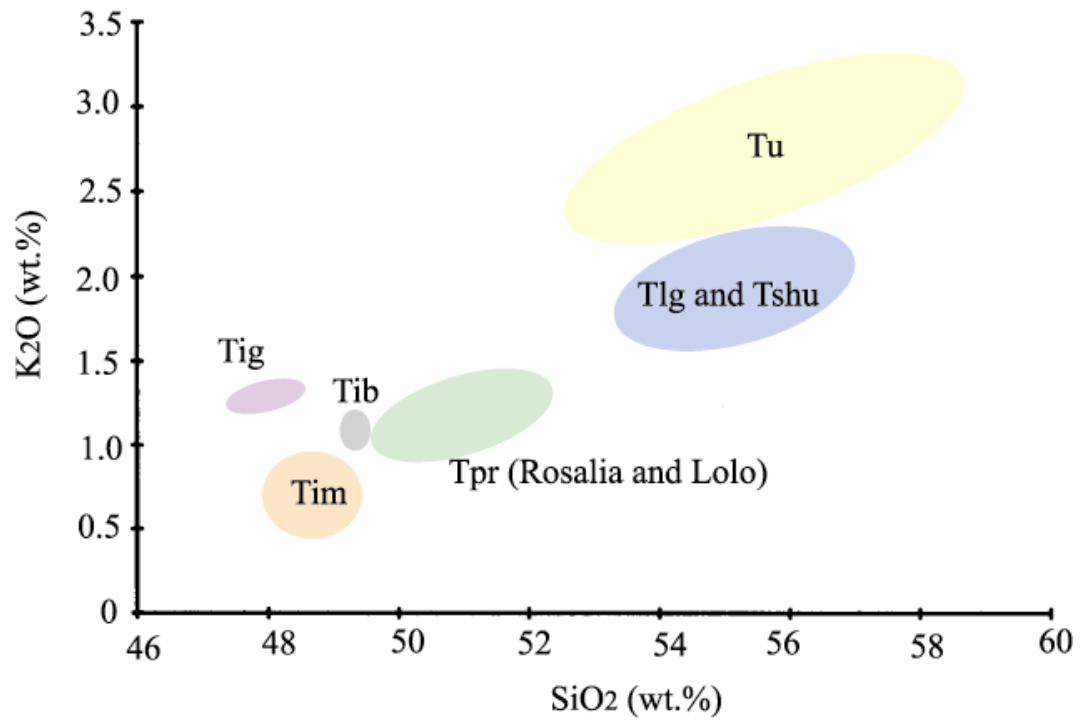

Figure G.7. $\mathrm{K}_{2} \mathrm{O}$ Versus $\mathrm{SiO}_{2}$ for Ice Harbor Member, Umatilla Member and Priest Rapids Member Flows 


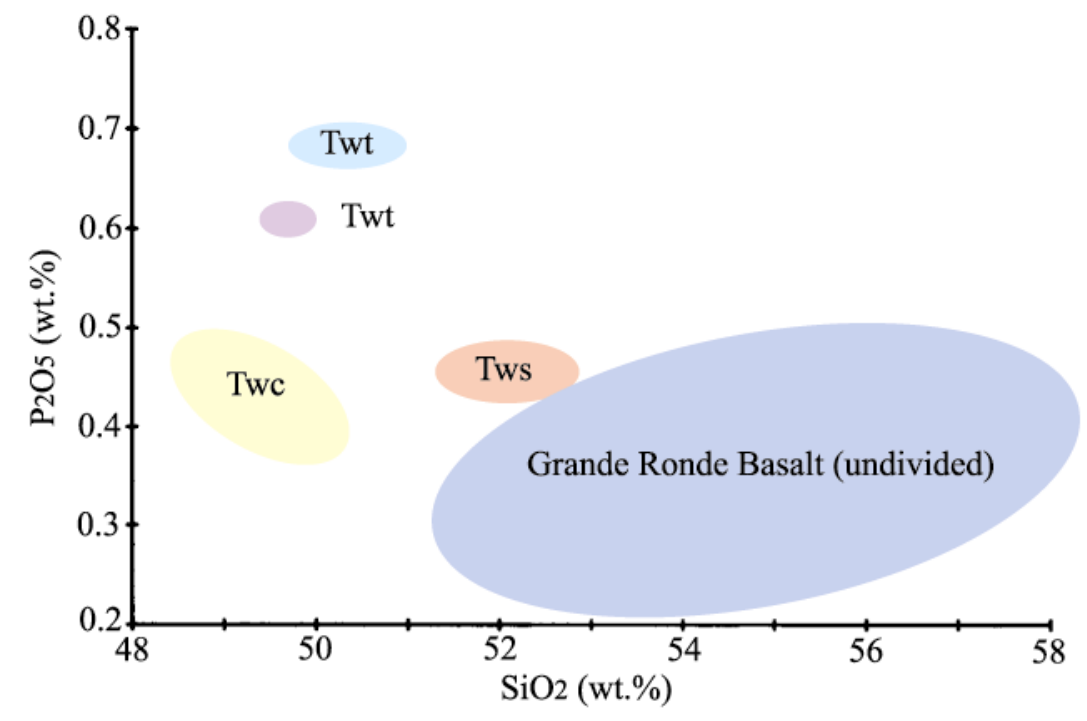

Figure G.8. $\mathrm{SiO}_{2}$ Versus $\mathrm{P}_{2} \mathrm{O}_{5}$ for Grande Ronde Basalt and Selected Saddle Mountains Basalt Flows

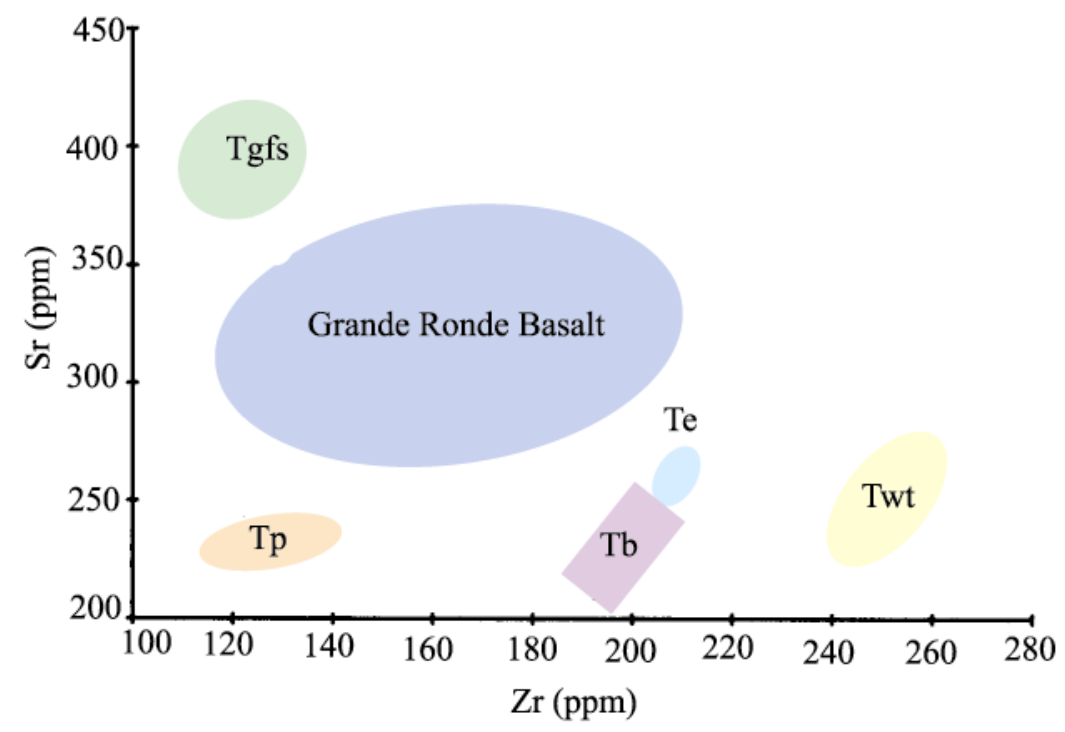

Figure G.9. Sr Versus Zr for Grande Ronde Basalt and Selected Flows of the Saddle Mountains Basalt 


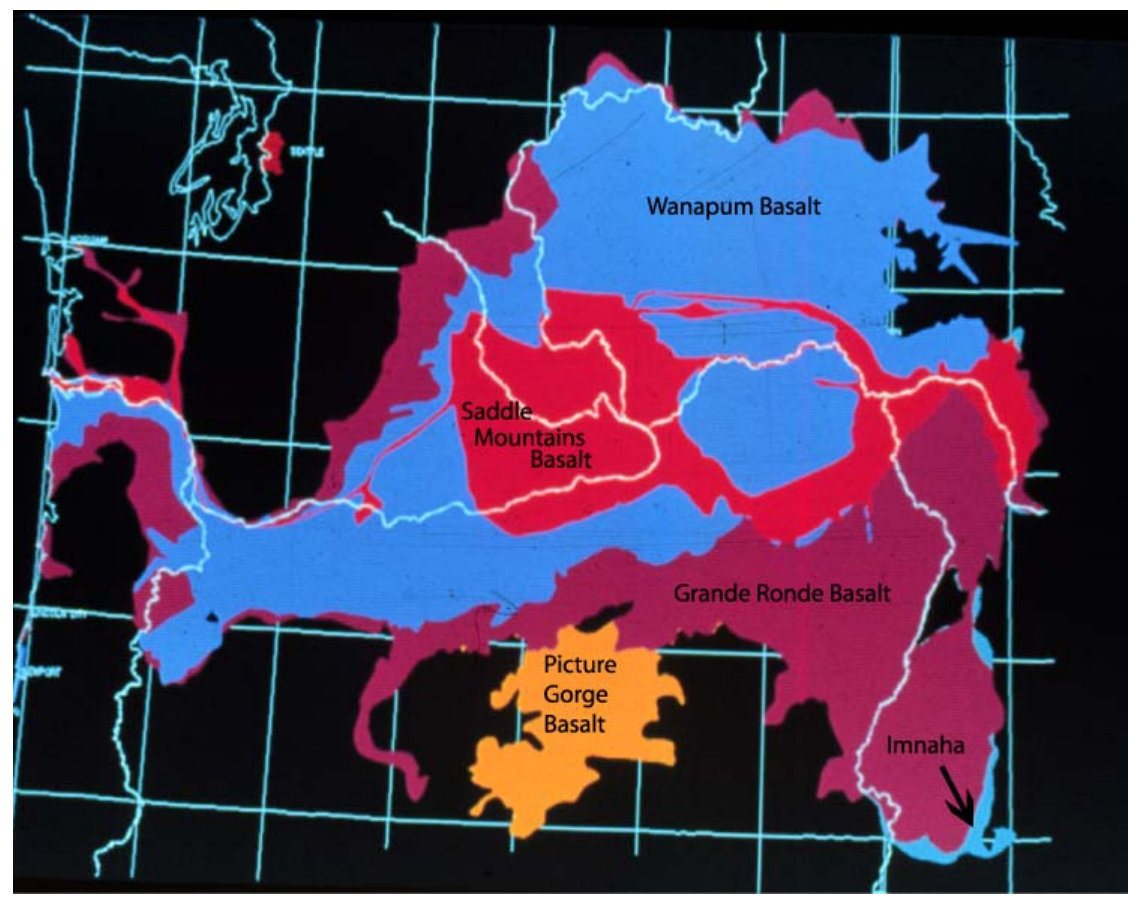

Figure G.10. Distribution of Columbia River Basalt Group Formations (see Figure G.1)

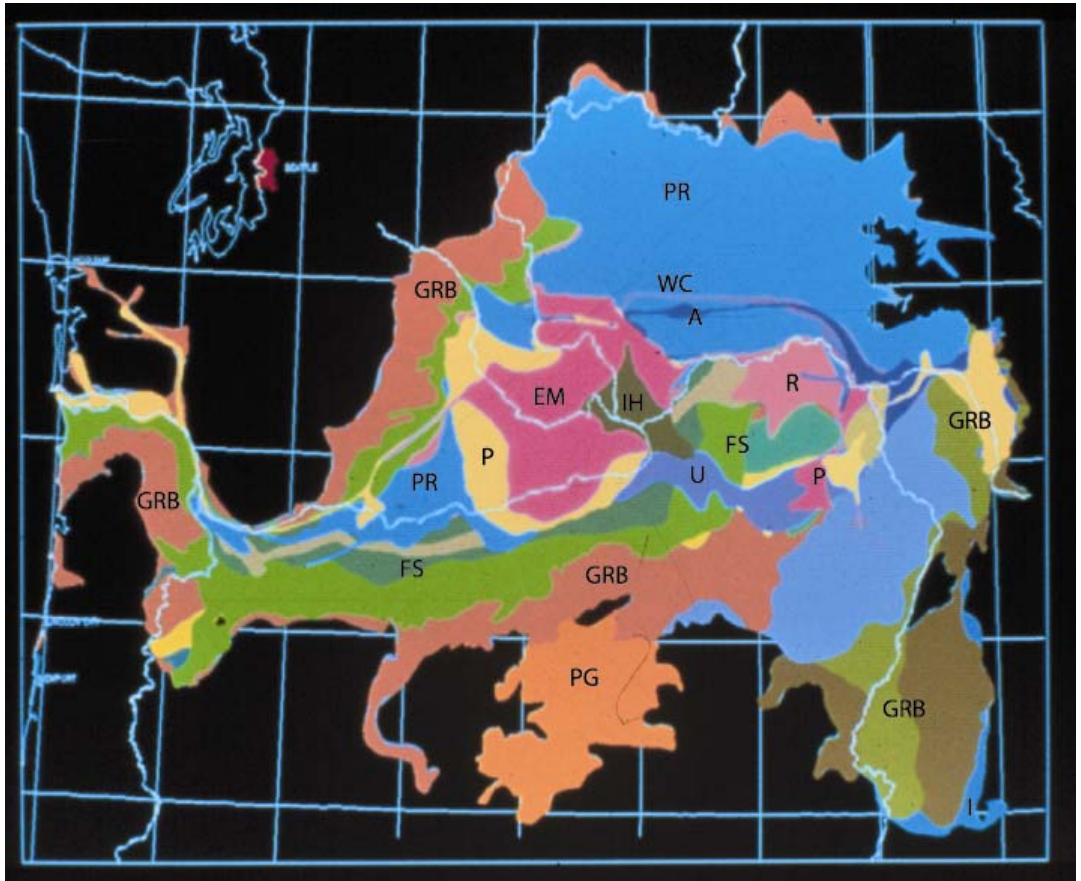

Figure G.11. Geologic Map of the Columbia River Basalt Group Showing Uppermost Lava Flows Distributed Across the Areal Extent of the Lava Flows 

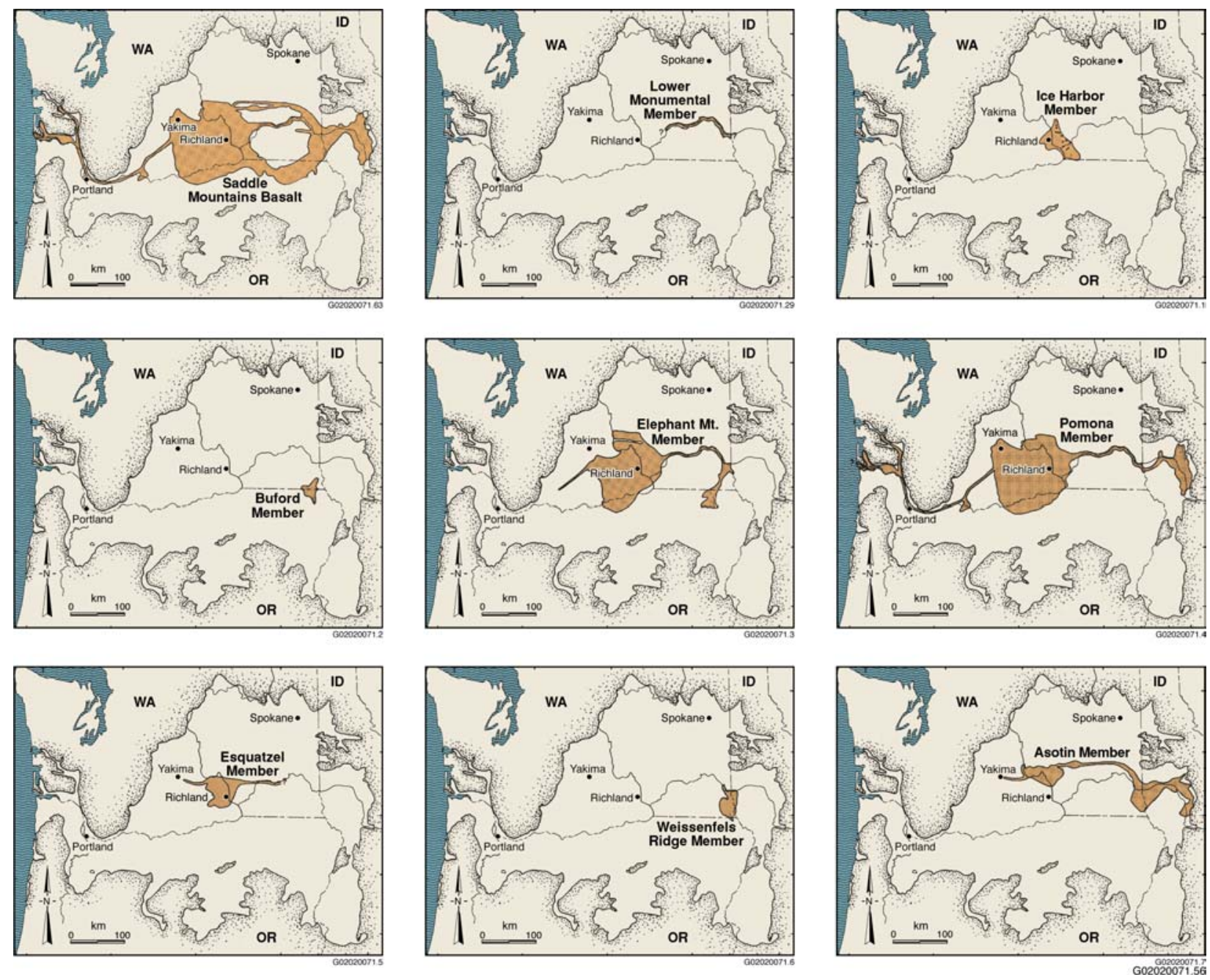

Figure G.12. Distribution Maps of Columbia River Basalt Group Flows (see Figure G.1 for nomenclature) 

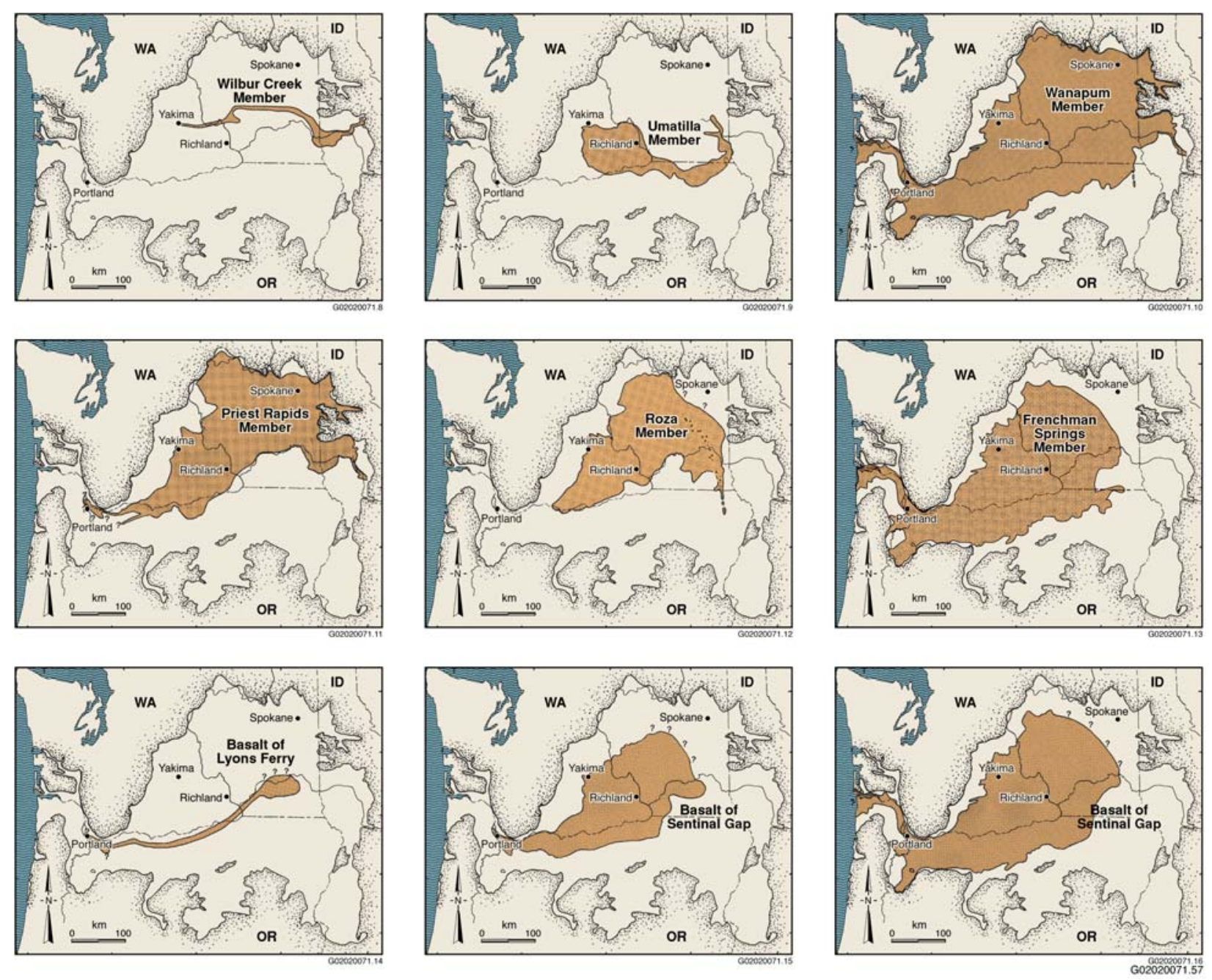

Figure G.12. (contd) Distribution Maps of Columbia River Basalt Group Flows (see Figure G.1 for nomenclature) 

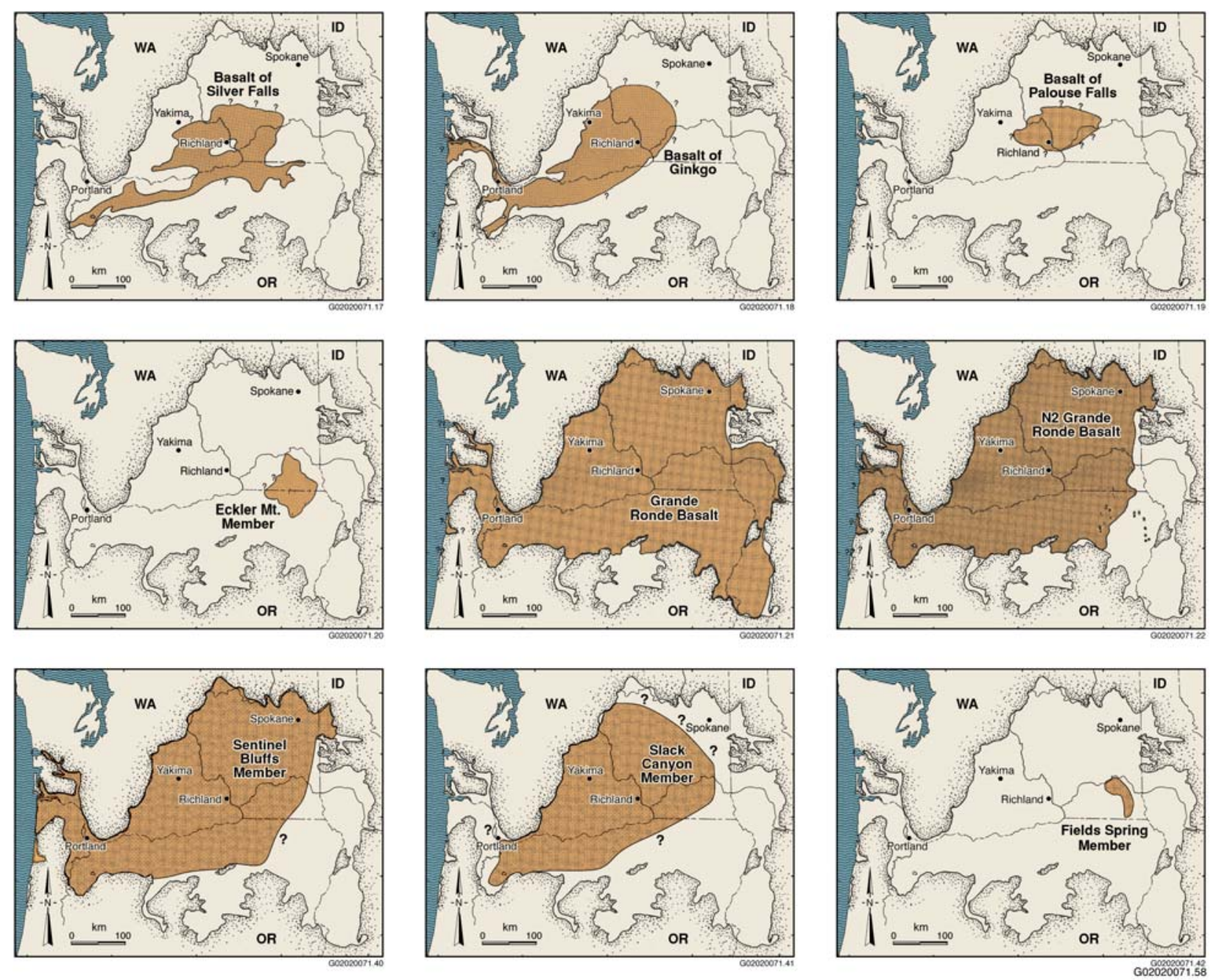

Figure G.12. (contd) Distribution Maps of Columbia River Basalt Group Flows (see Figure G.1 for nomenclature) 

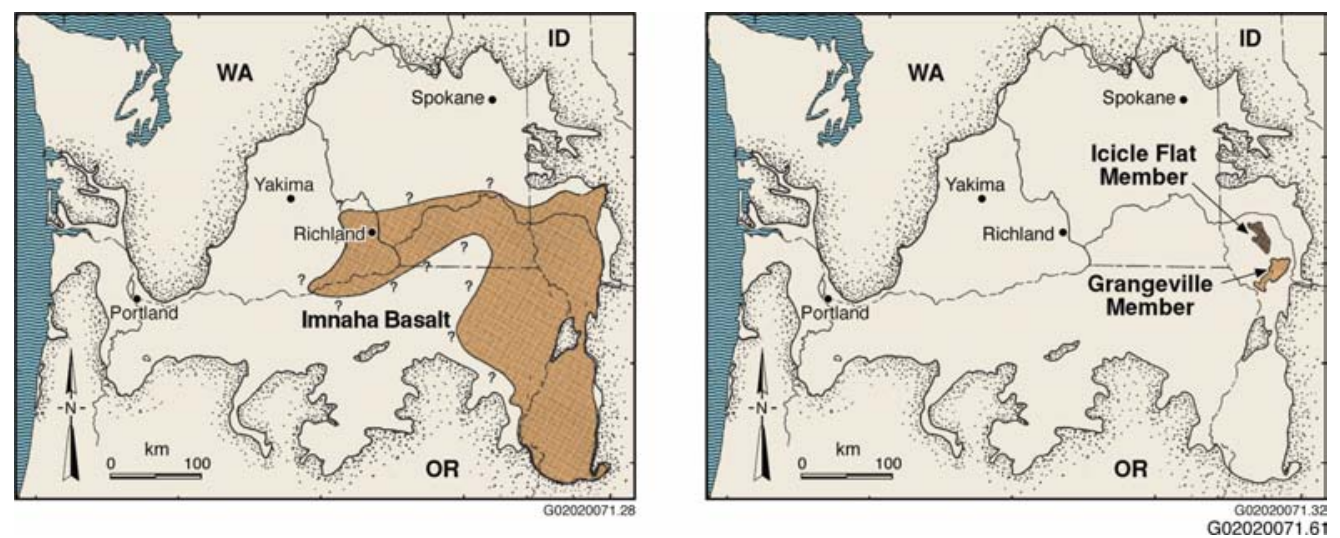

Figure G.12. (contd) Distribution Maps of Columbia River Basalt Group Flows (see Figure G.1 for nomenclature) 
Table G.1. Chemical Composition of Columbia River Basalt Group Flows (see Figure G.1 for Nomenclature)

\begin{tabular}{|c|c|c|c|c|c|c|c|c|c|c|c|c|c|c|c|c|c|c|c|c|c|c|c|c|c|}
\hline \multirow[b]{2}{*}{ Formation } & \multirow[b]{2}{*}{ Unit Ident. } & \multicolumn{11}{|c|}{ Major Oxides (weight per cent) } & \multicolumn{13}{|c|}{$\begin{array}{l}\text { Trace Elements (ppm) } \\
\end{array}$} \\
\hline & & $\mathrm{SiO}_{2}$ & $\mathrm{TiO}_{2}$ & $\mathrm{Al}_{2} \mathrm{O}_{3}$ & $\mathrm{FeO}^{*}$ & $\mathrm{MnO}$ & $\mathrm{CaO}$ & $\mathrm{MgO}$ & $\mathrm{K}_{2} \mathrm{O}$ & $\mathrm{Na}_{2} \mathrm{O}$ & $\mathrm{P}_{2} \mathrm{O}_{5}$ & TOTAL & $\mathrm{Ni}$ & $\mathrm{Cr}$ & $\mathrm{Sc}$ & $\mathrm{V}$ & $\mathrm{Rb}$ & $\mathrm{Ba}$ & $\mathrm{Sr}$ & $\mathrm{Zr}$ & $\mathrm{Y}$ & $\mathrm{Nb}$ & $\mathrm{Cu}$ & $\mathrm{Zn}$ & $\mathrm{Ga}$ \\
\hline$\overline{\text { SMB }}$ & Lower Monumental & 51.26 & 2.682 & 13.94 & 12.84 & 0.215 & 9.10 & 5.43 & 1.05 & 2.89 & 0.601 & 100.01 & 29 & $\overline{776}$ & 37 & 347 & 225 & $\overline{527}$ & 315 & 190 & $\overline{42}$ & 26.5 & $\overline{17}$ & $\overline{1124}$ & 27 \\
\hline SMB & Lower Monumental & 51.09 & 2.742 & 13.79 & 13.24 & 0.214 & 9.11 & 5.27 & 1.10 & 2.83 & 0.614 & 100.00 & 25 & 72 & 39 & 352 & 32 & 528 & 323 & 190 & 43 & 24.6 & 16 & 119 & 22 \\
\hline SMB & Lower Monumental & 51.48 & 2.943 & 14.03 & 13.17 & 0.213 & 8.80 & 4.40 & 1.50 & 2.79 & 0.669 & 100.01 & 17 & 25 & 28 & 320 & 33 & 525 & 355 & 178 & 38 & 31.2 & 7 & 130 & 23 \\
\hline SMB & Ice Harbor, basalt of Goose Island & 47.85 & 3.809 & 11.83 & 16.99 & 0.280 & 9.06 & 4.32 & 1.28 & 2.71 & 1.859 & 99.99 & 8 & 29 & 43 & 207 & 23 & 816 & 248 & 460 & 107 & 55.3 & 4 & 222 & 25 \\
\hline SMB & Ice Harbor, basalt of Goose Island & 47.98 & 3.703 & 11.54 & 17.69 & 0.288 & 8.76 & 4.18 & 1.34 & 2.70 & 1.824 & 99.99 & 13 & 32 & 41 & 210 & 25 & 870 & 237 & 483 & 110 & 56.2 & 8 & 224 & 24 \\
\hline SMB & Ice Harbor, basalt of Martindale & 48.40 & 3.376 & 13.35 & 14.28 & 0.211 & 10.42 & 6.07 & 0.51 & 2.62 & 0.767 & 99.99 & 33 & 181 & 44 & 360 & 1 & 496 & 253 & 246 & 55 & 28.4 & 37 & 147 & 25 \\
\hline SMB & Ice Harbor, basalt of Martindale & 48.50 & 3.390 & 13.07 & 14.71 & 0.215 & 10.18 & 5.81 & 0.69 & 2.64 & 0.812 & 99.99 & 26 & 171 & 40 & 356 & 10 & 512 & 250 & 254 & 57 & 29.8 & 34 & 150 & 20 \\
\hline SMB & Ice Harbor, basalt of Martindale & 48.67 & 3.380 & 13.08 & 14.54 & 0.221 & 10.06 & 5.84 & 0.78 & 2.58 & 0.831 & 99.99 & 32 & 163 & 42 & 350 & 14 & 543 & 249 & 265 & 58 & 30.4 & 35 & 158 & 24 \\
\hline SMB & Ice Harbor, basalt of Martindale & 48.57 & 3.301 & 13.10 & 14.76 & 0.228 & 9.99 & 5.82 & 0.84 & 2.57 & 0.808 & 99.99 & 30 & 174 & 43 & 347 & 14 & 496 & 245 & 257 & 58 & 29.9 & 30 & 152 & 22 \\
\hline SMB & Ice Harbor, basalt of Martindale & 48.59 & 3.349 & 13.21 & 14.24 & 0.222 & 10.30 & 6.03 & 0.66 & 2.62 & 0.776 & 99.99 & 25 & 176 & 40 & 358 & 10 & 493 & 248 & 248 & 56 & 28.4 & 32 & 149 & 23 \\
\hline SMB & Ice Harbor, basalt of Martindale & 48.60 & 3.350 & 13.19 & 14.36 & 0.219 & 10.07 & 6.09 & 0.78 & 2.58 & 0.768 & 99.99 & 28 & 180 & 44 & 349 & 13 & 494 & 247 & 249 & 55 & 29.4 & 26 & 149 & 18 \\
\hline SMB & Ice Harbor, basalt of Basin City & 49.29 & 3.560 & 12.82 & 14.78 & 0.222 & 9.49 & 5.21 & 1.01 & 2.74 & 0.880 & 99.99 & 20 & 109 & 45 & 364 & 20 & 635 & 251 & 289 & 62 & 32.4 & 23 & 156 & 23 \\
\hline SMB & Ice Harbor, basalt of Basin City & 49.36 & 3.612 & 13.00 & 14.46 & 0.211 & 9.63 & 5.12 & 1.00 & 2.72 & 0.891 & 99.99 & 13 & 108 & 40 & 369 & 17 & 714 & 259 & 289 & 63 & 33.1 & 26 & 160 & 22 \\
\hline SMB & Buford & 54.42 & 2.070 & 14.05 & 11.58 & 0.188 & 8.46 & 4.73 & 1.37 & 2.82 & 0.305 & 99.99 & 20 & 51 & 31 & 298 & 45 & 472 & 226 & 198 & 40 & 22.0 & 47 & 113 & 24 \\
\hline SMB & Buford & 54.65 & 2.098 & 14.29 & 10.96 & 0.185 & 8.57 & 4.72 & 1.54 & 2.66 & 0.328 & 100.00 & 20 & 58 & 31 & 295 & 46 & 675 & 228 & 200 & 43 & 23.0 & 56 & 119 & 24 \\
\hline SMB & Buford & 54.69 & 2.068 & 14.02 & 11.58 & 0.166 & 8.16 & 4.83 & 1.47 & 2.71 & 0.312 & 100.01 & 18 & 45 & 30 & 295 & 44 & 386 & 210 & 193 & 41 & 24.7 & 29 & 104 & 22 \\
\hline SMB & Elephant Mtn. & 52.14 & 3.484 & 12.86 & 14.70 & 0.215 & 8.56 & 4.10 & 1.12 & 2.26 & 0.552 & 99.99 & 11 & 21 & 34 & 393 & 31 & 471 & 235 & 234 & 53 & 29.4 & 7 & 147 & 22 \\
\hline SMB & Elephant Mtn. & 51.51 & 3.381 & 13.18 & 14.79 & 0.219 & 8.53 & 4.13 & 1.28 & 2.43 & 0.530 & 99.98 & 10 & 34 & 33 & 398 & 32 & 452 & 234 & 238 & 46 & 28.0 & 41 & 161 & 23 \\
\hline SMB & Elephant Mtn. & 51.43 & 3.505 & 13.23 & 14.36 & 0.206 & 8.70 & 4.02 & 1.40 & 2.60 & 0.555 & 100.01 & 14 & 41 & 33 & 399 & 32 & 573 & 243 & 246 & 50 & 29.0 & 48 & 159 & 24 \\
\hline SMB & Elephant Mtn. & 51.62 & 3.480 & 12.98 & 14.59 & 0.212 & 8.52 & 4.33 & 1.19 & 2.54 & 0.538 & 100.00 & 14 & 41 & 33 & 386 & 34 & 448 & 231 & 240 & 48 & 29.0 & 31 & 155 & 19 \\
\hline SMB & Elephant Mtn. & 52.55 & 3.622 & 13.48 & 12.89 & 0.202 & 8.94 & 3.93 & 1.27 & 2.54 & 0.566 & 99.99 & 17 & 31 & 41 & 425 & 33 & 488 & 247 & 240 & 53 & 28.5 & 19 & 150 & 22 \\
\hline SMB & Elephant Mtn. & 51.59 & 3.538 & 13.20 & \begin{tabular}{|l|l|}
14.69 \\
\end{tabular} & 0.208 & 8.65 & 3.93 & 1.11 & 2.53 & 0.550 & 100.00 & 12 & 34 & 35 & 418 & 31 & 426 & 239 & 236 & 50 & 28.7 & 13 & 148 & 20 \\
\hline SMB & Elephant Mtn. & 51.54 & 3.500 & 13.59 & 13.14 & 0.187 & 10.38 & 3.33 & 1.06 & 2.73 & 0.543 & 100.00 & 2 & 26 & 41 & 401 & 27 & 2107 & 317 & 240 & 48 & 27.5 & 8 & 148 & 24 \\
\hline SMB & Elephant Mtn. & 51.78 & 3.690 & 12.92 & 14.43 & 0.203 & 8.74 & 3.72 & 1.30 & 2.64 & 0.570 & 99.99 & 8 & 22 & 38 & 427 & 30 & 478 & 241 & 255 & 53 & 28.0 & 6 & 155 & 27 \\
\hline SMB & Elephant Mtn. & 51.37 & 3.580 & 12.78 & 14.77 & 0.213 & 8.53 & 4.22 & 1.33 & 2.65 & 0.563 & 100.01 & 4 & 25 & 37 & 414 & 33 & 460 & 230 & 253 & 51 & 29.2 & 12 & 154 & 26 \\
\hline SMB & Pomona & 54.90 & 1.606 & 14.51 & 10.41 & 0.168 & 9.93 & 6.41 & 0.81 & 2.53 & 0.240 & 101.51 & 36 & 93 & 25 & 266 & 21 & 277 & 234 & 138 & 31 & 13.3 & 47 & 95 & 20 \\
\hline SMB & Pomona & 53.20 & 1.635 & 14.51 & 10.61 & 0.175 & 10.43 & 6.90 & 0.73 & 2.48 & 0.229 & 100.90 & 40 & 99 & 27 & 278 & 16 & 245 & 228 & 135 & 29 & 14.4 & 49 & 97 & 19 \\
\hline SMB & Pomona & 54.39 & 1.694 & 14.19 & 10.90 & 0.192 & 8.68 & 4.70 & 1.15 & 3.01 & 0.287 & 99.19 & 15 & 50 & 36 & 301 & 33 & 500 & 308 & 157 & 34 & 13.6 & 28 & 112 & 19 \\
\hline SMB & Pomona & 53.02 & 1.693 & 15.28 & 9.30 & 0.176 & 11.86 & 5.34 & 0.73 & 2.36 & 0.234 & 99.99 & 41 & 112 & 38 & 295 & 19 & 620 & 240 & 136 & 30 & 15.5 & 55 & 94 & 20 \\
\hline SMB & Weis. R., Slip.Cr. & 52.46 & 2.491 & 14.27 & 11.47 & 0.190 & 9.67 & 5.26 & 0.90 & 2.83 & 0.455 & 100.00 & 23 & 47 & 34 & 334 & 24 & 731 & 266 & 173 & 38 & 22.0 & 67 & 124 & 20 \\
\hline SMB & Weis. R., Slip.Cr. & 51.79 & 2.409 & 14.01 & 12.40 & 0.209 & 9.46 & 5.59 & 1.02 & 2.66 & 0.453 & 100.00 & 20 & 50 & 32 & 317 & 24 & 470 & 257 & 169 & 35 & 21.0 & 52 & 116 & 23 \\
\hline SMB & Weis. R., Slip.Cr. & 51.79 & 2.444 & 14.22 & 12.07 & 0.219 & 9.78 & 5.30 & 1.01 & 2.71 & 0.448 & 99.99 & 24 & 48 & 34 & 313 & 25 & 425 & 257 & 168 & 35 & 21.0 & 57 & 125 & 18 \\
\hline SMB & Weis. R., Ten. Cr. & 49.99 & 3.094 & 13.46 & 14.58 & 0.239 & 9.14 & 5.04 & 1.08 & 2.70 & 0.687 & 100.01 & 25 & 53 & 39 & 396 & 22 & 586 & 233 & 244 & 51 & 31.0 & 38 & 144 & 21 \\
\hline SMB & Weis. R., Ten. Cr. & 50.85 & 3.146 & 13.80 & 14.10 & 0.186 & 8.71 & 4.45 & 1.08 & 2.98 & 0.689 & 99.99 & 23 & 56 & 38 & 396 & 24 & 567 & 238 & 247 & 50 & 33.0 & 75 & 154 & 25 \\
\hline SMB & Weis. R., Ten. Cr. & 50.40 & 3.009 & 13.38 & 13.86 & 0.216 & 9.52 & 5.21 & 0.97 & 2.77 & 0.670 & 100.01 & 27 & 65 & 37 & 356 & 16 & 705 & 268 & 261 & 50 & 31.0 & 73 & 156 & 24 \\
\hline SMB & Weis. R., Lew. Or. & 49.53 & 2.537 & 14.38 & 10.94 & 0.229 & 12.25 & 6.61 & 0.48 & 2.42 & 0.615 & 99.99 & 73 & 252 & 41 & 318 & 9 & 399 & 241 & 177 & 43 & 22.5 & 57 & 117 & 18 \\
\hline SMB & Weis. R., Clov. & 49.55 & 1.812 & 15.42 & 10.71 & 0.169 & 11.21 & 7.75 & 0.39 & 2.54 & 0.443 & 99.99 & 70 & 280 & 31 & 240 & 10 & 649 & 269 & 117 & 27 & 15.3 & 55 & 93 & 21 \\
\hline SMB & Weis. R., Clov. & 50.15 & 1.750 & 15.76 & 10.40 & 0.154 & 11.52 & 6.98 & 0.35 & 2.52 & 0.410 & 99.99 & 68 & 293 & 42 & 253 & 6 & 335 & 272 & 110 & 25 & 12.8 & 41 & 98 & 19 \\
\hline SMB & Asotin & 50.84 & 1.409 & 15.95 & 9.79 & 0.148 & 11.17 & 7.65 & 0.45 & 2.41 & 0.182 & 100.00 & 108 & 271 & 34 & 253 & 8 & 288 & 251 & 111 & 24 & 10.7 & 82 & 81 & 18 \\
\hline SMB & Asotin & 50.57 & 1.403 & 16.19 & 9.80 & 0.159 & 11.26 & 7.67 & 0.38 & 2.38 & 0.180 & 99.99 & 112 & 286 & 32 & 250 & 7 & 231 & 249 & 107 & 23 & \begin{tabular}{|l|l|}
10.7 \\
\end{tabular} & 73 & 84 & 16 \\
\hline SMB & Asotin & 50.18 & 1.514 & 16.00 & 9.91 & 0.165 & 11.11 & 8.03 & 0.47 & 2.42 & 0.199 & 100.00 & 118 & 258 & 34 & 264 & 8 & 232 & 247 & 116 & 25 & 11.0 & 79 & 83 & 21 \\
\hline SMB & Asotin & 50.25 & 1.406 & 16.26 & 9.49 & 0.154 & 11.14 & 8.24 & 0.51 & 2.38 & 0.173 & 100.00 & 126 & 279 & 34 & 243 & 7 & 220 & 246 & 109 & 24 & 10.0 & 104 & 90 & 17 \\
\hline SMB & Asotin & 50.20 & 1.362 & 16.31 & 9.45 & 0.156 & 11.14 & 8.41 & 0.51 & 2.29 & 0.169 & 100.00 & 133 & 280 & 35 & 233 & 10 & 203 & 246 & 104 & 21 & 9.0 & 87 & 74 & 17 \\
\hline SMB & Asotin & 50.41 & 1.390 & 16.20 & 9.56 & 0.160 & 11.10 & 8.14 & 0.50 & 2.36 & 0.177 & 100.00 & 129 & 281 & 36 & 248 & 8 & 235 & 249 & 110 & 25 & 9.0 & 106 & 94 & 15 \\
\hline SMB & Asotin & 50.29 & 1.399 & 16.30 & 9.52 & 0.158 & 11.07 & 8.34 & 0.48 & 2.27 & 0.174 & 100.00 & 135 & 278 & 38 & 242 & 8 & 224 & 246 & 109 & 22 & 10.0 & 100 & 96 & 16 \\
\hline SMB & Asotin & 50.88 & 1.455 & 16.14 & \begin{tabular}{|l|}
8.91 \\
\end{tabular} & 0.159 & 11.27 & \begin{tabular}{|l|l|}
8.20 \\
\end{tabular} & 0.52 & $\begin{array}{l}2.30 \\
\end{array}$ & 0.175 & 100.01 & \begin{tabular}{|l|l|}
121 \\
\end{tabular} & 289 & 31 & 256 & 10 & 172 & 241 & \begin{tabular}{|l|l|}
107 \\
\end{tabular} & 25 & $\begin{array}{l}9.7 \\
\end{array}$ & 93 & 82 & 17 \\
\hline SMB & Asotin & 51.30 & 1.434 & 16.22 & 8.82 & 0.154 & 11.13 & 7.89 & 0.57 & 2.29 & 0.195 & 100.00 & \begin{tabular}{|l|l|}
139 \\
\end{tabular} & 272 & 32 & 238 & 12 & 236 & 262 & 114 & 25 & 11.5 & 93 & 87 & 19 \\
\hline
\end{tabular}


Table G.1. (contd)

\begin{tabular}{|c|c|c|c|c|c|c|c|c|c|c|c|c|c|c|c|c|c|c|c|c|c|c|c|c|c|}
\hline \multirow[b]{2}{*}{ Formation } & \multirow[b]{2}{*}{ Unit Ident. } & \multicolumn{11}{|c|}{ Major Oxides (weight per cent) } & \multicolumn{13}{|c|}{ Trace Elements (ppm) } \\
\hline & & $\mathrm{SiO}_{2}$ & $\mathrm{TiO}_{2}$ & $\mathrm{Al}_{2} \mathrm{O}_{3}$ & $\mathrm{FeO}^{*}$ & $\mathrm{MnO}$ & $\mathrm{CaO}$ & $\mathrm{MgO}$ & $\mathrm{K}_{2} \mathrm{O}$ & $\mathrm{Na}_{2} \mathrm{O}$ & $\mathrm{P}_{2} \mathrm{O}_{5}$ & TOTAL & $\mathrm{Ni}$ & $\mathrm{Cr}$ & Sc & $\mathrm{v}$ & $\mathrm{Rb}$ & $\mathrm{Ba}$ & $\mathrm{Sr}$ & $\mathrm{Zr}$ & $\mathrm{Y}$ & $\mathrm{Nb}$ & $\mathrm{Cu}$ & $\mathrm{Zn}$ & $\mathrm{Ga}$ \\
\hline$\overline{\mathrm{SMB}}$ & Wilbur Creek & 55.20 & 1.863 & 14.67 & 10.46 & 0.157 & 8.29 & 4.28 & 1.74 & 2.79 & 0.538 & 100.00 & 32 & $\overline{442}$ & $\overline{133}$ & 2267 & 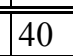 & 833 & 277 & 2224 & 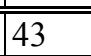 & 19.7 & 119 & 1117 & 20 \\
\hline SMB & Wilbur Creek & 54.37 & 1.895 & 14.29 & 11.48 & 0.191 & 8.41 & 4.32 & 1.88 & 2.65 & 0.517 & 100.00 & 29 & 32 & 31 & 270 & 39 & 869 & 277 & 222 & 43 & 19.9 & 20 & 116 & 21 \\
\hline SMB & Wilbur Creek & 54.60 & 1.875 & 14.63 & 11.06 & 0.170 & 8.41 & 4.34 & 1.71 & 2.71 & 0.502 & 100.00 & 29 & 36 & 33 & 278 & 40 & 878 & 283 & 228 & 44 & 20.4 & 22 & 119 & 22 \\
\hline SMB & Esquatzel & 54.40 & 3.026 & 13.26 & 13.34 & 0.188 & 7.62 & 3.84 & 1.65 & 3.00 & 0.408 & 100.73 & 3 & 13 & 19 & 347 & 47 & 576 & 258 & 208 & 40 & 24.8 & 9 & 128 & 24 \\
\hline SMB & Esquatzel & 53.81 & 3.083 & 13.09 & 13.61 & 0.192 & 7.54 & 3.81 & 1.71 & 3.02 & 0.408 & 100.27 & 0 & 14 & 21 & 365 & 44 & 591 & 257 & 212 & 43 & 24.8 & 14 & 303 & 23 \\
\hline SMB & Umatilla, basalt of Sillusi. & 56.16 & 2.870 & 14.55 & 9.97 & 0.216 & 6.62 & 1.89 & 2.93 & 3.76 & 1.030 & 100.00 & 1 & 11 & 30 & 155 & 48 & 3785 & 297 & 482 & 58 & 25.5 & 11 & 139 & 23 \\
\hline SMB & Umatilla, basalt of Sillusi. & 54.50 & 2.810 & 13.80 & 12.32 & 0.320 & 6.48 & 2.59 & 2.82 & 3.41 & 0.960 & 100.01 & $\frac{1}{2}$ & 12 & 27 & 168 & 45 & 3513 & 288 & 442 & 52 & 24.9 & 2 & 135 & 25 \\
\hline SMB & Umatilla, basalt of Sillusi. & 55.52 & 2.640 & 13.98 & 11.96 & 0.196 & 5.75 & 2.26 & 2.77 & 3.89 & 1.040 & 100.01 & 0 & 13 & 27 & 133 & 51 & 3808 & 282 & 447 & 87 & 25.3 & 8 & 147 & 23 \\
\hline SMB & Umatilla, basalt of Sillusi. & 55.23 & 2.604 & 13.74 & 12.13 & 0.185 & 5.93 & 2.64 & 2.76 & 3.78 & 1.010 & 100.01 & 0 & 19 & 26 & 135 & 47 & 3513 & 268 & 439 & 51 & 23.7 & 2 & 137 & 21 \\
\hline SMB & Umatilla, basalt of Sillusi. & 57.07 & 2.939 & 15.08 & 8.87 & 0.158 & 6.65 & 1.82 & 3.03 & 3.30 & 1.084 & 100.00 & 9 & 15 & 31 & 197 & 48 & 3770 & 311 & 460 & 55 & 27.5 & 4 & 137 & 22 \\
\hline SMB & Umatilla, basalt of Sillusi. & 55.27 & 2.689 & 14.01 & 11.96 & 0.229 & 6.45 & 2.35 & 2.80 & 3.26 & 0.990 & 100.01 & 2 & 13 & 28 & 171 & 48 & 3432 & 288 & 444 & 51 & 27.2 & 6 & 128 & 22 \\
\hline SMB & Umatilla, basalt of Sillusi. & 54.34 & 3.094 & 13.83 & 11.86 & 0.238 & 7.44 & 2.56 & 2.55 & 3.24 & 0.843 & 100.00 & 0 & 10 & 31 & 244 & 44 & 2810 & 286 & 392 & 48 & 24.6 & 5 & 126 & 21 \\
\hline SMB & Umatilla, basalt of Sillusi. & 57.59 & 2.678 & 14.65 & 10.16 & 0.107 & 5.67 & 1.51 & 2.96 & 3.60 & 1.073 & 100.00 & 6 & 16 & 31 & 143 & 48 & 3756 & 294 & 475 & 50 & 27.5 & 5 & 127 & 23 \\
\hline SMB & Umatilla, basalt of Sillusi. & 56.19 & 2.975 & 14.33 & 10.68 & 0.167 & 6.49 & 2.17 & 2.61 & 3.50 & 0.912 & 100.02 & 14 & 23 & 30 & 217 & 46 & 3195 & 306 & 423 & 51 & 26.0 & 6 & 129 & 21 \\
\hline SMB & Umatilla, basalt of Sillusi. & 57.02 & 2.730 & 14.34 & 10.61 & 0.156 & 5.70 & 1.51 & 2.98 & 3.86 & 1.100 & 100.01 & 0 & 0 & 31 & 146 & 50 & 3758 & 290 & 491 & 55 & 25.9 & 0 & 148 & 22 \\
\hline SMB & Umatilla, basalt of Sillusi. & 54.72 & 2.670 & 13.63 & 12.12 & 0.195 & 6.51 & 2.73 & 2.89 & 3.56 & 0.970 & 100.00 & 0 & 8 & 30 & 147 & 50 & 3401 & 282 & 449 & 51 & 24.2 & 7 & 132 & 21 \\
\hline SMB & Umatilla, basalt of Sillusi. & 55.45 & 2.700 & 13.77 & 11.98 & 0.172 & 6.27 & 2.33 & 2.65 & 3.69 & 0.980 & 99.99 & 0 & 10 & 31 & 153 & 39 & 3475 & 283 & 452 & 51 & 24.0 & 2 & 134 & 22 \\
\hline SMB & Umatilla, basalt of Sillusi. & 55.35 & 2.589 & 13.82 & 11.91 & 0.162 & 6.27 & 2.29 & 2.81 & 3.78 & 1.030 & 100.01 & 0 & 14 & 31 & 139 & 36 & 3641 & 289 & 464 & 52 & 25.7 & 0 & 133 & 22 \\
\hline SMB & Umatilla, basalt of Umatill & 54.12 & 3.040 & 13.56 & 12.71 & 0.185 & 6.52 & 2.99 & 2.44 & 3.60 & 0.830 & 100.00 & 0 & 12 & 35 & 224 & 44 & 2833 & 273 & 406 & 48 & 23.8 & D & 130 & 22 \\
\hline SMB & Umatilla, basalt of Umatilla & 54.29 & 3.070 & 13.65 & 12.31 & 0.182 & 6.59 & 2.97 & 2.45 & 3.64 & 0.830 & 99.98 & 0 & 12 & 31 & 233 & 45 & 2839 & 273 & 405 & 48 & 22.8 & 8 & 134 & 22 \\
\hline SMB & Umatilla, basalt of Umatilla & 53.55 & 3.160 & 13.53 & 13.12 & 0.300 & 6.84 & 2.87 & 2.60 & 3.24 & 0.790 & 100.00 & 0 & 14 & 33 & 2 & 46 & 2731 & 286 & 395 & 48 & 23.8 & 3 & 130 & 22 \\
\hline SMB & Umatilla, basalt of Umatilla & 53.81 & 3.130 & 13.51 & 12.78 & 0.201 & 6.75 & 3.18 & 2.59 & 3.28 & 0.780 & 100.01 & 5 & 19 & 29 & 252 & 48 & 2743 & 280 & 408 & 49 & 23.8 & 4 & 131 & 22 \\
\hline SMB & Umatilla, basalt of Umatilla & 53.94 & 3.120 & 13.75 & 12.54 & 0.188 & 6.68 & 2.98 & 2.43 & 3.56 & 0.810 & 100.00 & 0 & 13 & 30 & 245 & 43 & 2849 & 279 & 412 & 49 & 24.1 & 5 & 139 & 21 \\
\hline SMB & Umatilla, basalt of Umatilla & 53.83 & 3.190 & 13.82 & 12.45 & 0.208 & 6.89 & 2.90 & 2.48 & 3.43 & 0.800 & 100.00 & 0 & 15 & 33 & 250 & 43 & 2855 & 286 & 417 & 49 & 23.3 & 5 & 138 & 25 \\
\hline SMB & Umatilla, basalt of Umatilla & 53.14 & 3.180 & 13.84 & 13.10 & 0.250 & 6.69 & 3.08 & 2.36 & 3.54 & 0.810 & 99.99 & 0 & 16 & 27 & 255 & 38 & 2883 & 280 & 411 & 48 & 23.3 & 4 & 137 & 23 \\
\hline SMB & Umatilla, basalt of Umatilla & 54.60 & 2.990 & 13.65 & 12.38 & 0.175 & 6.51 & 2.75 & 2.45 & 3.66 & 0.830 & 100.00 & 0 & 13 & 29 & 214 & 42 & 2965 & 272 & 431 & 48 & 23.9 & 5 & 132 & 22 \\
\hline SMB & Umatilla, basalt of Umatilla & 53.74 & 3.080 & 13.41 & 13.05 & 0.204 & 6.68 & 3.11 & 2.46 & 3.48 & 0.780 & 99.99 & 0 & 16 & 33 & 236 & 44 & 2767 & 275 & 402 & 46 & 23.7 & 7 & 127 & 23 \\
\hline SMB & Umatilla, basalt of Umatilla & 53.31 & 3.190 & 13.52 & 12.98 & 0.199 & 6.89 & 3.32 & 2.45 & 3.38 & 0.770 & 100.01 & 0 & 12 & 30 & 265 & 42 & 2670 & 279 & 389 & 47 & 23.7 & 6 & 130 & 23 \\
\hline SMB & Umatilla, basalt of Umatilla & 53.98 & 3.130 & 13.70 & 12.24 & 0.192 & 6.66 & 3.29 & 2.38 & 3.62 & 0.810 & 100.00 & 0 & 14 & 31 & 229 & 42 & 2773 & 266 & 394 & 47 & 23.6 & 6 & 127 & 21 \\
\hline SMB & Umatilla, basalt & 54.03 & 3.430 & 15.04 & 10.83 & 0.155 & 6.96 & 2.59 & 2.27 & 3.79 & 0.900 & 100.00 & 1 & 13 & 32 & 256 & 24 & 3337 & 306 & 449 & 55 & 25.6 & 7 & 152 & 25 \\
\hline SMB & Umatilla, basalt of Umatilla & 53.78 & 3.120 & 13.47 & 12.76 & 0.206 & 6.74 & 3.22 & 2.51 & 3.41 & 0.790 & 100.01 & 1 & 18 & 29 & 232 & 42 & 2762 & 273 & 391 & 48 & 24.4 & 2 & 129 & 23 \\
\hline SMB & Umatilla, basalt of Umatilla & 54.17 & 3.100 & 13.69 & 12.39 & 0.207 & 6.84 & 2.89 & 2.39 & 3.49 & 0.830 & 100 & 6 & 20 & 35 & 244 & 39 & 2967 & 286 & 396 & 48 & 23.4 & 4 & 131 & 22 \\
\hline SMB & Umatilla, basalt of Umatilla & 54.02 & 2.910 & 13.77 & 13.04 & 0.170 & 6.62 & 2.61 & 2.39 & 3.57 & 0.900 & 100.00 & 0 & 14 & 28 & 189 & 46 & 3164 & 287 & 430 & 50 & 25.1 & 4 & 132 & 22 \\
\hline SMB & Umatilla, basalt of Umatilla & 51.14 & 3.27 & 14.09 & 12.75 & 0.221 & 9.87 & 4.19 & 1.05 & 2.61 & 0.80 & 100.00 & 34 & 105 & 41 & 376 & 29 & \begin{tabular}{|l|l|l|}
1392 \\
\end{tabular} & $\frac{201}{324}$ & 181 & 46 & 18.5 & 43 & $\frac{1142}{142}$ & $\frac{22}{23}$ \\
\hline SMB & Umatilla, basalt of $\mathrm{U}$ & 53.82 & 3.010 & 13.57 & 12.78 & 0.215 & 6.61 & 3.08 & 2.72 & 3.35 & 0.830 & 99.99 & 0 & 12 & 32 & 218 & 44 & 2925 & 277 & 417 & 48 & 23.0 & 14 & 139 & 25 \\
\hline SMB & Umatilla, basalt of Umatilla & 53.95 & 3.010 & 13.63 & 12.80 & 0.203 & 6.69 & 3.06 & 2.40 & 3.43 & 0.830 & 100.00 & 0 & 19 & 30 & 223 & 42 & 2912 & 279 & 409 & 50 & 23.9 & 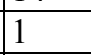 & 130 & 24 \\
\hline WB & Priest Rapids, basalt of Lolo & 50.58 & 2.632 & 13.41 & 13.97 & 0.230 & 9.44 & 5.74 & 0.97 & 2.68 & 0.725 & 100.38 & 33 & 99 & 41 & 320 & 25 & 510 & 290 & 181 & 48 & 16.3 & 23 & 197 & 35 \\
\hline $\mathrm{WB}$ & Priest Rapids, basalt of Lolo & 49.88 & 3.011 & 13.57 & 13.97 & 0.229 & 9.81 & 5.42 & 1.11 & 2.79 & 0.729 & 100.52 & 36 & 102 & 39 & 348 & 29 & 506 & 272 & 180 & 47 & 16.9 & 24 & 279 & 138 \\
\hline WB & Priest Rapids, basalt of Lolo & 50.64 & 3.249 & 13.42 & 14.32 & 0.241 & 9.36 & 5.12 & 1.01 & 2.72 & 0.763 & 100.84 & 29 & 93 & 39 & 363 & 27 & 505 & 283 & 184 & 47 & 17.7 & 24 & 139 & 80 \\
\hline WB & Priest Rapids, basalt of Lolo & 50.43 & 3.068 & 13.57 & 13.64 & 0.230 & 9.07 & 5.53 & 1.23 & 2.46 & 0.760 & 99.99 & 45 & 115 & 40 & 357 & 25 & 536 & 288 & 172 & 45 & 18.9 & 32 & 133 & 23 \\
\hline WB & Priest Rapids, basalt of Lolo & 49.93 & 3.049 & 13.28 & 14.30 & 0.253 & 8.94 & 5.77 & 1.11 & 2.61 & 0.748 & 99.99 & 53 & 102 & 40 & 341 & 25 & 479 & 281 & 169 & 44 & 18.1 & 35 & 130 & 19 \\
\hline WB & Priest Rapids, basalt of Lolo & 49.94 & 3.073 & 13.38 & 14.60 & 0.243 & 9.03 & 5.33 & 1.09 & 2.55 & 0.771 & 100.01 & 50 & 113 & 42 & 343 & 23 & 485 & 286 & 173 & 46 & 17.6 & 36 & 133 & 20 \\
\hline WB & Priest Rapids, basalt of Lolo & 50.78 & 3.087 & 13.35 & 14.20 & 0.214 & 9.04 & 4.90 & 1.05 & 2.62 & 0.766 & 100.0 & 37 & 95 & 39 & 365 & 22 & 469 & 285 & 172 & 44 & 18.2 & 34 & 130 & 23 \\
\hline WB & Priest Rapids, basalt of Lolo & 51.29 & 3.299 & 14.25 & 12.44 & 0.221 & 9.79 & 4.15 & 1.09 & 2.67 & 0.808 & 100.01 & 50 & 119 & 41 & 389 & 27 & 451 & 300 & 184 & 49 & 19.4 & 39 & 138 & 21 \\
\hline WB & Priest Rapids, basalt of Lolo & 50.77 & 3.174 & 13.70 & 13.48 & 0.213 & 9.45 & 4.80 & 1.06 & 2.58 & 0.773 & 100.00 & 41 & 104 & 38 & 372 & 23 & 470 & 294 & 176 & 45 & 19.4 & 37 & 133 & 24 \\
\hline WB & Priest Rapids, basalt of Lolo & 50.43 & 3.125 & 13.53 & 13.66 & 0.231 & 9.11 & 5.46 & 1.10 & 2.59 & 0.758 & 99.99 & 40 & 105 & 39 & 358 & 22 & 476 & 290 & 173 & 44 & 17.0 & 32 & 135 & 23 \\
\hline
\end{tabular}


Table G.1. (contd)

\begin{tabular}{|c|c|c|c|c|c|c|c|c|c|c|c|c|c|c|c|c|c|c|c|c|c|c|c|c|c|}
\hline \multirow[b]{2}{*}{ Formation } & \multirow[b]{2}{*}{ Unit Ident. } & \multicolumn{11}{|c|}{ Major Oxides (weight per cent) } & \multicolumn{13}{|c|}{$\begin{array}{l}\text { Trace Elements (ppm) } \\
\end{array}$} \\
\hline & & $\mathrm{SiO}_{2}$ & $\mathrm{TiO}_{2}$ & $\mathrm{Al}_{2} \mathrm{O}_{3}$ & $\mathrm{FeO}^{*}$ & $\mathrm{MnO}$ & $\mathrm{CaO}$ & $\mathrm{MgO}$ & $\mathrm{K}_{2} \mathrm{O}$ & $\mathrm{Na}_{2} \mathrm{O}$ & $\mathrm{P}_{2} \mathrm{O}_{5}$ & TOTAL & $\mathrm{Ni}$ & $\mathrm{Cr}$ & Sc & $\mathrm{V}$ & $\mathrm{Rb}$ & $\mathrm{Ba}$ & $\mathrm{Sr}$ & $\mathrm{Zr}$ & $\mathrm{Y}$ & $\mathrm{Nb}$ & $\mathrm{Cu}$ & $\mathrm{Zn}$ & $\mathrm{Ga}$ \\
\hline$\overline{\mathrm{WB}}$ & Priest Rapids, basalt of Lolo & 50.18 & 3.201 & 13.29 & 14.19 & 0.234 & 9.35 & 5.12 & 1.14 & 2.53 & 0.776 & 100.01 & 34 & 97 & 143 & 361 & 25 & 426 & 288 & 176 & 47 & 18.6 & 449 & 143 & 22 \\
\hline WB & Priest Rapids, basalt of Lolo & 51.16 & 3.212 & 13.91 & 12.79 & 0.209 & 9.64 & 4.48 & 1.13 & 2.69 & 0.783 & 100.00 & 48 & 110 & 36 & 388 & 28 & 593 & 299 & 178 & 47 & 19.0 & 37 & 137 & 23 \\
\hline WB & Priest Rapids, basalt of Lolo & 50.79 & 3.206 & 13.81 & 13.31 & 0.212 & 9.44 & 4.78 & 1.12 & 2.54 & 0.784 & 99.99 & 39 & 102 & 37 & 359 & 23 & 650 & 298 & 179 & 47 & 19.8 & 38 & 137 & 24 \\
\hline WB & Priest Rapids, basalt of Lolo & 50.94 & 3.211 & 13.79 & 12.81 & 0.209 & 9.59 & 4.90 & 1.12 & 2.63 & 0.796 & 100.00 & 31 & 95 & 41 & 378 & 25 & 588 & 302 & 180 & 49 & 18.3 & 38 & 132 & 22 \\
\hline WB & Priest Rapids, basalt of Lolo & 50.55 & 3.161 & 13.37 & 13.70 & 0.233 & 9.20 & 5.20 & 1.09 & 2.72 & 0.772 & 100.00 & 50 & 110 & 39 & 372 & 24 & 473 & 288 & 175 & 44 & 18.0 & 36 & 135 & 23 \\
\hline WB & Priest Rapids, basalt of Rosalia & 50.40 & 3.533 & 12.97 & 14.82 & 0.239 & 8.91 & 4.36 & 1.11 & 2.87 & 0.820 & 100.03 & 7 & 25 & 44 & 427 & 21 & 606 & 301 & 223 & 55 & 19.3 & 25 & 163 & 21 \\
\hline WB & Priest Rapids, basalt of Rosalia & 49.99 & 3.595 & 12.74 & 14.85 & 0.242 & 9.32 & 4.61 & 1.13 & 2.87 & 0.763 & 100.11 & 6 & 25 & 42 & 406 & 25 & 567 & 291 & 207 & 51 & 19.4 & 25 & 171 & 8 \\
\hline WB & Priest Rapids, basalt of Rosalia & 49.82 & 3.300 & 14.15 & 12.67 & 0.210 & 10.31 & 4.83 & 1.10 & 2.83 & 0.770 & 99.99 & 27 & 97 & 44 & 364 & 23 & 483 & 310 & 179 & 43 & 17.1 & 27 & 129 & 24 \\
\hline WB & Priest Rapids, basalt of Rosalia & 50.25 & 3.88 & 13.34 & 15.12 & 0.30 & 9.52 & 3.98 & 0.46 & 2.26 & 0.89 & 100.00 & 0 & 24 & 36 & 426 & 13 & 317 & 245 & 264 & 61 & 27.5 & 17 & 147 & 23 \\
\hline WB & Priest Rapids, basalt of Rosalia & 49.90 & 3.310 & 13.40 & 14.33 & 0.250 & 9.26 & 4.97 & 0.98 & 2.78 & 0.810 & 99.99 & 30 & 87 & 43 & 367 & 24 & 625 & 314 & 187 & 46 & 17.1 & 31 & 134 & 24 \\
\hline WB & Priest Rapids, basalt of Rosalia & 50.32 & 3.290 & 13.70 & 13.80 & 0.220 & 9.43 & 4.67 & 1.07 & 2.71 & 0.780 & 99.99 & 29 & 90 & 44 & 361 & 26 & 587 & 302 & 184 & 46 & 17.1 & 31 & 143 & 20 \\
\hline WB & Priest Rapids, basalt of Rosalia & 50.13 & 3.260 & 13.71 & 13.59 & 0.220 & 9.36 & 4.96 & 1.09 & 2.89 & 0.790 & 100.00 & 30 & 94 & 44 & 352 & 23 & 501 & 298 & 183 & 44 & 16.7 & 30 & 140 & 24 \\
\hline WB & Priest Rapids, basalt of Rosalia & 50.70 & 3.26 & 13.76 & 12.89 & 0.213 & 9.40 & 5.01 & 1.18 & 2.81 & 0.79 & 100.00 & 37 & 100 & 41 & 359 & 24 & 470 & 291 & 182 & 43 & 19.4 & 33 & 145 & 22 \\
\hline WB & Roza & 51.10 & 3.270 & 13.43 & 13.94 & 0.224 & 8.65 & 4.40 & 1.32 & 2.95 & 0.710 & 99.99 & 10 & 36 & 38 & 406 & 33 & 545 & 307 & 191 & 42 & 16.6 & 13 & 143 & 24 \\
\hline WB & Roza & 51.19 & 3.240 & 13.31 & 14.20 & 0.222 & 8.52 & 4.39 & 1.43 & 2.79 & 0.700 & 99.99 & 7 & 35 & 43 & 416 & 34 & 576 & 308 & 191 & 44 & 16.1 & 16 & 139 & 23 \\
\hline WB & Roza & 51.07 & 3.260 & 13.35 & 14.13 & 0.228 & 8.56 & 4.43 & 1.34 & 2.94 & 0.700 & 100.01 & 6 & 33 & 47 & 412 & 32 & \begin{tabular}{|l|l|}
553 \\
\end{tabular} & 305 & 191 & 43 & 16.5 & 19 & 138 & 22 \\
\hline WB & Roza & 51.01 & 3.280 & 13.42 & \begin{tabular}{|l|l}
13.97 \\
\end{tabular} & 0.240 & 8.84 & 4.20 & 1.49 & 2.83 & 0.720 & 100.00 & 8 & 31 & 42 & 424 & 34 & 544 & 309 & 191 & 42 & 16.3 & 19 & 143 & 25 \\
\hline WB & Roza & 52.02 & 3.264 & 13.82 & 12.56 & 0.494 & 8.93 & 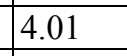 & 1.29 & 2.88 & 0.732 & 100.00 & 36 & 56 & 40 & 433 & 31 & 6888 & 332 & 192 & 47 & 17.6 & 26 & 139 & 26 \\
\hline WB & Roza & 51.23 & 3.310 & 13.53 & 13.58 & 0.222 & 8.77 & \begin{tabular}{|l|l|}
4.30 \\
\end{tabular} & 1.35 & \begin{tabular}{|l|}
2.99 \\
\end{tabular} & $\mid 0.730$ & 100.01 & 10 & 33 & 41 & 431 & 30 & \begin{tabular}{|l|l|}
613 \\
\end{tabular} & 317 & 198 & 47 & 17.3 & 25 & 146 & 24 \\
\hline WB & Roza & 52.69 & 3.296 & 13.90 & 12.46 & 0.211 & 8.87 & \begin{tabular}{|l}
3.67 \\
\end{tabular} & 1.43 & 2.73 & 0.732 & 99.99 & 16 & 43 & 43 & 428 & 33 & 546 & 319 & 191 & 45 & \begin{tabular}{|l|l}
19.3 \\
\end{tabular} & 30 & 143 & 23 \\
\hline WB & Roza & 51.29 & 3.196 & 13.42 & 14.73 & 0.199 & 8.64 & 4.13 & $\begin{array}{l}1.09 \\
\end{array}$ & 2.62 & \begin{tabular}{|l|l|} 
\\
\end{tabular} & 100.00 & \begin{tabular}{|l|}
17 \\
\end{tabular} & 47 & 40 & 392 & 27 & 560 & 315 & 185 & 45 & \begin{tabular}{|l|l}
17.3 \\
\end{tabular} & 23 & 132 & 21 \\
\hline WB & Roza & 50.24 & 3.099 & 13.62 & 13.80 & 0.231 & 9.19 & \begin{tabular}{|l|l}
5.53 \\
\end{tabular} & 0.98 & 2.59 & 0.721 & 100.00 & 56 & 123 & 42 & 356 & 20 & 484 & 288 & 161 & 42 & $\mid \begin{array}{l}17.0 \\
\end{array}$ & 27 & 129 & 19 \\
\hline WB & Roza & 52.01 & 3.160 & 13.59 & 13.60 & 0.209 & \begin{tabular}{|l}
8.59 \\
\end{tabular} & \begin{tabular}{|l|l|}
4.02 \\
\end{tabular} & 1.27 & \begin{tabular}{|l}
2.84 \\
\end{tabular} & 0.701 & 99.99 & 28 & 58 & 39 & 424 & 29 & 561 & 313 & 186 & 45 & \begin{tabular}{|l|l|}
17.7 \\
\end{tabular} & 26 & 136 & 23 \\
\hline WB & Roza & 52.09 & 3.243 & 13.78 & 13.42 & 0.211 & 8.83 & 3.85 & 1.26 & 2.60 & 0.713 & 100.00 & 12 & 44 & 39 & 433 & 34 & 515 & 329 & 187 & 48 & \begin{tabular}{|l|l}
19.7 \\
\end{tabular} & 29 & 136 & 22 \\
\hline WB & Roza & 52.14 & 3.239 & 13.98 & 12.83 & 0.193 & 8.94 & 3.94 & $\begin{array}{ll}1.28 \\
\end{array}$ & 2.75 & 0.708 & 100.00 & 13 & 40 & 42 & 432 & 30 & 659 & 324 & 188 & 46 & 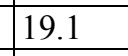 & 24 & 135 & 20 \\
\hline WB & Roza & 51.49 & 3.142 & 13.48 & 13.94 & 0.226 & 8.56 & \begin{tabular}{|l|l} 
\\
\end{tabular} & 1.47 & \begin{tabular}{|l|} 
\\
\end{tabular} .61 & 0.704 & 99.99 & 16 & 44 & 40 & 410 & 30 & 509 & 308 & 183 & 45 & 20.2 & 24 & 132 & 22 \\
\hline WB & Roza & 51.73 & 3.026 & 13.85 & 13.24 & 0.221 & 8.98 & 4.21 & 1.27 & 2.85 & 0.632 & 100.01 & 25 & 72 & 40 & 400 & 29 & 504 & 311 & 177 & 43 & \begin{tabular}{|l|l}
17.7 \\
\end{tabular} & 43 & 143 & 16 \\
\hline WB & Roza & 51.31 & 3.147 & 13.14 & 14.49 & 0.233 & 8.63 & 4.21 & 1.48 & 2.67 & 0.700 & 100.01 & 19 & 49 & 38 & 418 & 32 & 587 & 310 & 185 & 45 & 18.2 & 34 & 136 & 22 \\
\hline WB & Roza & 51.53 & 3.148 & 13.34 & 14.00 & 0.223 & \begin{tabular}{|l|l|}
8.71 \\
\end{tabular} & \begin{tabular}{|l|l} 
\\
\end{tabular} & 1.45 & \begin{tabular}{|l|}
2.60 \\
\end{tabular} & \begin{tabular}{|l|l|}
0.727 \\
\end{tabular} & 100.00 & \begin{tabular}{|l|l}
19 \\
\end{tabular} & 46 & 38 & 421 & 33 & \begin{tabular}{|l|}
543 \\
\end{tabular} & $\begin{array}{l}307 \\
\end{array}$ & 183 & 44 & \begin{tabular}{|l|l|}
17.8 \\
\end{tabular} & 23 & \begin{tabular}{|l|l|}
137 \\
\end{tabular} & 26 \\
\hline WB & Fr.Spr., basalt of Lyns.F. & 52.24 & 3.13 & 13.22 & 14.22 & 0.201 & 8.07 & 4.05 & 1.34 & 2.92 & 0.61 & 100.00 & 0 & 26 & 47 & 462 & 41 & 545 & 310 & 192 & 41 & 15.3 & 44 & 160 & 20 \\
\hline WB & Fr.Spr., basalt of Lyns.F. & 51.90 & 3.062 & 12.99 & 14.38 & 0.220 & 8.20 & 4.24 & 1.49 & 2.92 & 0.611 & 100.01 & 3 & 25 & 39 & 446 & 33 & 579 & 315 & 193 & 41 & 16.7 & 20 & 147 & 23 \\
\hline WB & Fr.Spr., basalt of Lyns.F. & 51.85 & 3.17 & 13.24 & 14.15 & 0.215 & 8.73 & 4.14 & 1.07 & 2.89 & 0.547 & 100.00 & 3 & 32 & 45 & 457 & 20 & 549 & 324 & 182 & 39 & 15.7 & 23 & 142 & 26 \\
\hline WB & Fr.Spr., basalt of Lyns.F. & 51.77 & 3.086 & 13.02 & 14.45 & 0.243 & 8.19 & 4.25 & 1.44 & 2.95 & 0.607 & 100.01 & 0 & 25 & 40 & 437 & 35 & 533 & 308 & 192 & 41 & 15.2 & 9 & 141 & 21 \\
\hline WB & Fr.Spr., basalt of Lyns.F. & 51.83 & 3.114 & 13.36 & 13.99 & 0.210 & 8.44 & 4.13 & 1.46 & 2.88 & 0.594 & 100.01 & 3 & 28 & 43 & 460 & 31 & 576 & 319 & 188 & 42 & 15.5 & 8 & 142 & 22 \\
\hline WB & Fr.Spr., basalt of Lyns.F. & 51.55 & 3.17 & 13.20 & 14.94 & 0.194 & 8.39 & 4.00 & 1.16 & 2.79 & 0.61 & 100.00 & 1 & 26 & 43 & 445 & 31 & 530 & 321 & 196 & 42 & 17.3 & 22 & 141 & 21 \\
\hline WB & Fr.Spr., basalt of Sentinel Gap & 51.59 & 13.19 & 3.110 & 14.50 & 0.217 & 8.61 & 4.18 & 1.40 & 2.92 & 0.614 & 100.33 & 1 & 27 & 41 & 429 & 38 & 554 & 312 & 193 & 47 & 16.8 & 22 & 145 & 14 \\
\hline WB & Fr.Spr., basalt of Sentinel Gap & 51.93 & 13.13 & 3.085 & 14.42 & 0.218 & 8.31 & 4.36 & 1.33 & 3.21 & 0.612 & 100.61 & 0 & 28 & 40 & 444 & 34 & 579 & 304 & 189 & 45 & 17.6 & 25 & 141 & 11 \\
\hline WB & Fr.Spr., basalt of Sentinel Gap & 51.65 & 13.03 & 3.068 & 14.80 & 0.231 & 8.17 & 4.42 & 1.30 & 3.12 & 0.614 & 100.40 & 3 & 31 & 38 & 431 & 31 & 582 & 305 & 192 & 45 & 17.0 & 22 & 147 & 14 \\
\hline WB & Fr.Spr., basalt of Sentinel Gap & 52.47 & 3.200 & 13.62 & 12.63 & 0.211 & 8.48 & 4.15 & 1.31 & 3.26 & 0.660 & 99.99 & 4 & 25 & 44 & 446 & 33 & 667 & 336 & 197 & 49 & 16.8 & 8 & 148 & 26 \\
\hline WB & Fr.Spr., basalt of Sentinel Gap & 52.12 & 3.170 & 13.34 & 13.94 & 0.207 & 8.31 & 4.04 & 1.38 & 2.85 & 0.650 & 100.01 & 0 & 21 & 48 & 444 & 39 & 602 & 323 & 194 & 48 & 17.1 & 12 & 146 & 26 \\
\hline WB & Fr.Spr., basalt of Sentinel Gap & 52.35 & 3.260 & 13.75 & 12.68 & 0.200 & 8.59 & 4.03 & 1.33 & 3.11 & 0.690 & 99.99 & 5 & 23 & 44 & 449 & 31 & 624 & 328 & 199 & 45 & 17.8 & 15 & 145 & 27 \\
\hline WB & Fr.Spr., basalt of Sentinel Gap & 52.03 & 3.170 & 13.45 & 13.47 & 0.209 & 8.43 & 4.15 & 1.36 & 3.08 & 0.650 & 100.00 & 8 & 24 & 43 & 452 & 31 & 592 & 324 & 194 & 46 & 17.5 & 8 & 145 & 27 \\
\hline WB & Fr.Spr., basalt of Sentinel Gap & 52.13 & 3.230 & 13.38 & 13.40 & 0.280 & 8.48 & 3.97 & 1.52 & 2.95 & 0.660 & 100.00 & 5 & 24 & 36 & 448 & 35 & 655 & 323 & 196 & 48 & 17.5 & 11 & 148 & 25 \\
\hline WB & Fr.Spr., basalt of Sentinel Gap & 51.52 & 3.070 & 13.03 & 14.51 & 0.220 & 8.14 & 4.36 & 1.47 & 3.03 & 0.630 & 99.98 & 2 & 26 & 41 & 445 & 34 & 579 & 310 & 189 & 40 & 16.6 & 4 & 142 & 23 \\
\hline $\mathrm{WB}$ & Fr.Spr., basalt of Sentinel Gap & 52.49 & 3.217 & 13.55 & 12.86 & 0.205 & 8.58 & 3.94 & 1.53 & 2.97 & 0.655 & 100.00 & 3 & 26 & 41 & 431 & 37 & 555 & 325 & 195 & 45 & 16.4 & 10 & 152 & 22 \\
\hline WB & Fr.Spr., basalt of Sentinel Gap & 51.90 & 3.172 & 13.42 & 13.58 & 0.219 & 8.41 & 4.11 & 1.54 & 3.00 & 0.652 & 100.00 & 5 & 24 & 44 & 433 & 36 & 603 & 322 & 192 & 43 & 16.2 & 11 & 150 & 27 \\
\hline
\end{tabular}


Table G.1. (contd)

\begin{tabular}{|c|c|c|c|c|c|c|c|c|c|c|c|c|c|c|c|c|c|c|c|c|c|c|c|c|c|}
\hline \multirow{2}{*}{ Formation } & \multirow[b]{2}{*}{ Unit Ident. } & \multicolumn{11}{|c|}{ Major Oxides (weight per cent) } & \multicolumn{13}{|c|}{$\begin{array}{l}\text { Trace Elements (ppm) } \\
\end{array}$} \\
\hline & & $\mathrm{SiO}_{2}$ & $\mathrm{TiO}_{2}$ & $\mathrm{Al}_{2} \mathrm{O}_{3}$ & $\mathrm{FeO}^{*}$ & $\mathrm{MnO}$ & $\mathrm{CaO}$ & $\mathrm{MgO}$ & $\mathrm{K}_{2} \mathrm{O}$ & $\mathrm{Na}_{2} \mathrm{O}$ & $\mathrm{P}_{2} \mathrm{O}_{5}$ & TOTAL & $\mathrm{Ni}$ & $\mathrm{Cr}$ & $\mathrm{Sc}$ & $\mathrm{V}$ & $\mathrm{Rb}$ & $\mathrm{Ba}$ & $\mathrm{Sr}$ & $\mathrm{Zr}$ & $\mathrm{Y}$ & $\mathrm{Nb}$ & $\mathrm{Cu}$ & $\mathrm{Zn}$ & $\mathrm{Ga}$ \\
\hline$\overline{\mathrm{WB}}$ & Fr.Spr., basalt of Sentinel Gap & 51.80 & 3.124 & 13.13 & 14.41 & 0.211 & 8.18 & 4.11 & 1.31 & 3.08 & 0.642 & 100.00 & 0 & 24 & 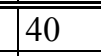 & 422 & 229 & 579 & 308 & 191 & $\overline{142}$ & 16.2 & 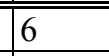 & 140 & 22 \\
\hline WB & Fr.Spr., basalt of Sentinel Gap & 52.01 & 3.164 & 13.37 & 13.71 & 0.244 & 8.41 & 4.02 & 1.37 & 3.05 & 0.637 & 99.99 & 6 & 29 & 43 & 442 & 34 & 649 & 318 & 203 & 46 & 17.1 & 15 & 153 & 22 \\
\hline WB & Fr.Spr., basalt of Sentinel Gap & 52.16 & 3.124 & 13.21 & 14.03 & 0.211 & 8.22 & 4.03 & 1.33 & 3.06 & 0.637 & 100.01 & 1 & 27 & 38 & 447 & 30 & 570 & 309 & 191 & 41 & 17.7 & 8 & 144 & 22 \\
\hline WB & Fr.Spr., basalt of Sentinel Gap & 51.61 & 3.114 & 13.25 & 14.14 & 0.227 & 8.26 & 4.26 & 1.58 & 2.92 & 0.640 & 100.00 & 2 & 24 & 44 & 434 & 37 & 563 & 312 & 190 & 42 & 15.7 & 11 & 141 & 23 \\
\hline WB & Fr.Spr., basalt of Sand Hollow & 52.65 & 3.053 & 14.29 & 12.39 & 0.184 & 9.07 & 3.83 & 1.16 & 2.74 & 0.627 & 99.99 & 32 & 76 & 40 & 425 & 27 & 541 & 314 & 181 & 43 & 17.7 & 35 & 141 & 21 \\
\hline WB & Fr.Spr., basalt of Sand Hollow & 52.62 & 3.165 & 14.76 & 11.64 & 0.177 & 9.33 & 3.73 & 1.11 & 2.83 & 0.632 & 99.99 & 19 & 74 & 41 & 452 & 30 & 521 & 339 & 185 & 45 & 18.7 & 25 & 131 & 24 \\
\hline WB & Fr.Spr., basalt of Sand Hollow & 50.98 & 3.026 & 13.99 & 14.25 & 0.217 & 8.83 & 4.58 & 1.01 & 2.52 & 0.601 & 100.00 & 23 & 72 & 37 & 423 & 22 & 566 & 317 & 174 & 43 & 17.0 & 34 & 125 & 23 \\
\hline WB & Fr.Spr., basalt of Sand Hollow & 51.55 & 2.944 & 13.90 & 13.68 & 0.215 & 8.73 & 4.51 & 1.32 & 2.55 & 0.598 & 100.00 & 16 & 62 & 39 & 406 & 30 & 519 & 311 & 172 & 42 & 17.9 & 23 & 127 & 21 \\
\hline WB & Fr.Spr., basalt of Sand Hollow & 51.45 & 2.929 & 13.76 & 13.92 & 0.218 & 8.74 & 4.40 & 1.25 & 2.72 & 0.617 & 100.00 & 38 & 84 & 43 & 410 & 29 & 510 & 309 & 179 & 43 & 16.7 & 29 & 129 & 22 \\
\hline & Fr.Spr., basalt of Sand Hollow & 52.01 & 2.955 & 13.40 & 13.84 & 0.219 & 8.41 & 4.56 & 1.28 & 3.07 & 0.564 & 100.31 & 12 & 57 & 39 & 418 & 33 & 575 & 314 & 181 & 41 & 15.6 & 23 & 138 & 18 \\
\hline & Fr.Spr., basalt of Sand Hollow & 51.74 & 2.934 & 13.30 & 14.30 & 0.220 & 8.31 & 4.49 & 1.39 & 2.99 & 0.558 & 100.23 & 4 & 49 & 44 & 414 & 37 & 541 & 312 & 183 & 44 & 16.7 & 25 & 137 & 12 \\
\hline & Fr.Spr., basalt of Silver Falls & 51.10 & 3.180 & 13.48 & 14.68 & 0.221 & 8.53 & 4.07 & 1.08 & 2.97 & 0.622 & 99.93 & 1 & 25 & 42 & 423 & 31 & 498 & 329 & 186 & 43 & 15.9 & 24 & 144 & 11 \\
\hline & Fr.Spr., basalt of Silver Falls & 51.95 & 3.096 & 13.59 & 14.65 & 0.224 & 8.45 & 4.24 & 1.31 & 3.04 & 0.610 & 101.16 & 1 & 23 & 41 & 417 & 36 & 530 & 324 & 180 & 43 & 16.7 & 24 & 144 & 11 \\
\hline & Fr.Spr., basalt of Silver Falls & 51.51 & 3.170 & 13.55 & 14.59 & 0.219 & 8.37 & 3.94 & 1.16 & 3.15 & 0.636 & 100.30 & 0 & 27 & 37 & 437 & 31 & 556 & 325 & 183 & 44 & 16.4 & 21 & 151 & 11 \\
\hline & Fr.Spr., basalt of Silver Falls & 51.25 & 3.106 & 13.42 & 14.66 & 0.226 & 8.47 & 4.08 & 1.13 & 3.05 & 0.616 & 100.01 & 1 & 25 & 42 & 416 & 31 & 543 & 325 & 179 & 41 & 16.2 & 24 & 156 & 11 \\
\hline & Fr.Spr., basalt of Silver Falls & 51.46 & 3.115 & 13.22 & 14.62 & 0.223 & 8.36 & 4.23 & 1.32 & 3.06 & 0.632 & 100.24 & 2 & 22 & 38 & 416 & 37 & 562 & 324 & 182 & 43 & 15.6 & 24 & 147 & 13 \\
\hline & Fr.Spr., basalt of Silver Falls & 51.50 & 3.110 & 13.30 & 14.81 & 0.222 & 8.34 & 4.27 & 1.37 & 3.00 & 0.618 & 100.54 & 1 & 24 & 41 & 406 & 36 & 542 & 322 & 180 & 42 & 16.2 & 22 & 138 & 8 \\
\hline & Fr.Spr., Ginkgo & 52.18 & 3.134 & 13.39 & 14.43 & 0.230 & 8.36 & 3.97 & 1.32 & 3.12 & 0.712 & 100.85 & 0 & 22 & 41 & 386 & 37 & 586 & 333 & 183 & 45 & 16.9 & 25 & 143 & 5 \\
\hline & Fr.Spr., Ginkgo & 51.68 & 3.252 & 13.34 & 14.51 & 0.212 & 8.44 & 3.80 & 1.42 & 3.09 & 0.640 & 100.38 & 2 & 25 & 42 & 419 & 46 & 552 & 326 & 183 & 45 & \begin{tabular}{|l|}
16.7 \\
\end{tabular} & 23 & 137 & 13 \\
\hline & Fr.Spr., Ginkgo & 51.40 & 3.086 & 13.10 & 14.79 & 0.228 & 8.26 & 4.20 & 1.33 & 3.10 & 0.665 & 100.16 & 0 & 21 & 39 & 382 & 34 & 564 & 328 & 180 & 43 & 15.4 & 27 & 138 & 10 \\
\hline & Fr.Spr., Ginkgo & 51.62 & 3.133 & 13.27 & 14.62 & 0.231 & 8.33 & 3.96 & 1.27 & 3.02 & 0.699 & 100.15 & 1 & 24 & 41 & 383 & 36 & 546 & 324 & 183 & 44 & 16.1 & 25 & 144 & 9 \\
\hline & Fr.Spr., Ginkgo & 51.71 & 3.108 & 13.23 & 14.90 & 0.230 & 8.19 & 4.19 & 1.26 & 3.14 & 0.679 & 100.64 & 0 & 25 & 39 & 390 & 35 & 564 & 323 & 183 & 45 & 16.1 & 23 & 141 & 12 \\
\hline & Fr.Spr., Ginkgo & 51.40 & 3.102 & 13.19 & 14.90 & 0.228 & 8.22 & 4.23 & 1.19 & 3.18 & 0.675 & 100.32 & 1 & 25 & 41 & 386 & 30 & 570 & 320 & 179 & 42 & 17.4 & 23 & 146 & 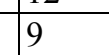 \\
\hline & Fr.Spr., basalt of Palouse Falls & 51.29 & 3.125 & 13.17 & 14.36 & 0.236 & 8.56 & 4.25 & 0.93 & 3.10 & 0.537 & 99.56 & 12 & 43 & 45 & 386 & 22 & 494 & 301 & 163 & 43 & 14.9 & 23 & 142 & 20 \\
\hline & Fr.Spr., basalt of Palouse Falls & 51.74 & 3.275 & 13.45 & 14.19 & 0.221 & 8.26 & 4.19 & 1.14 & 3.28 & 0.558 & 100.30 & 13 & 36 & 44 & 415 & 28 & 549 & 304 & 167 & 44 & 15.3 & 21 & 145 & 21 \\
\hline & Fr.Spr., basalt of Palouse Falls & 52.16 & 3.195 & 13.51 & 14.21 & 0.244 & 8.11 & 4.01 & 1.14 & 3.27 & 0.552 & 100.40 & 11 & 38 & 42 & 391 & 29 & 535 & 303 & 173 & 46 & 15.0 & 22 & 141 & 17 \\
\hline WB & Eckler Mtn., Schumaker Creek & 55.04 & 2.517 & 13.45 & 13.23 & 0.248 & 6.42 & 2.62 & 1.89 & 3.64 & 0.948 & 100.00 & 0 & 5 & 39 & 163 & 49 & 1040 & 331 & 244 & 66 & 22.7 & 12 & 168 & 23 \\
\hline WB & Eckler Mtn., Schumaker Creek & 55.32 & 2.496 & 13.38 & 12.37 & 0.229 & 6.80 & 2.89 & 1.90 & 3.67 & 0.950 & 100.01 & 0 & 6 & 39 & 160 & 44 & 1021 & 327 & 245 & 66 & 21.7 & 5 & 159 & 24 \\
\hline WB & Eckler Mtn., Schumaker Creek & 55.04 & 2.466 & 13.29 & 13.23 & 0.226 & 6.54 & 2.74 & 1.91 & 3.62 & 0.949 & 100.01 & 0 & 6 & 38 & 154 & 50 & 1015 & 328 & 248 & 65 & 23.1 & 9 & 157 & 24 \\
\hline WB & Eckler Mtn., Schumaker Creek & 54.73 & 2.647 & 14.30 & 11.59 & 0.251 & 7.13 & 2.93 & 1.71 & 3.70 & 1.010 & 100.00 & 1 & 3 & 39 & 173 & 28 & 1156 & 356 & 257 & 70 & 22.4 & 11 & 171 & 24 \\
\hline WB & Eckler Mtn., Schumaker Creek & 54.53 & 2.494 & 13.46 & 13.16 & 0.269 & 6.88 & 2.85 & 1.82 & 3.57 & 0.976 & 100.01 & 0 & 5 & 37 & 159 & 38 & 1070 & 339 & 249 & 65 & 23.1 & 12 & 166 & 22 \\
\hline WB & Eckler Mtn., Dodge & 51.82 & 1.399 & 15.04 & 10.78 & 0.191 & 10.46 & 6.29 & 0.57 & 3.11 & 0.335 & 100.00 & 41 & 160 & 45 & 337 & 8 & 323 & 393 & 122 & 30 & 7.7 & 99 & 105 & 20 \\
\hline WB & Eckler Mtn., Dodge & 52.31 & 1.457 & 15.69 & 11.14 & 0.129 & 10.17 & 5.33 & 0.51 & 2.92 & 0.334 & 99.99 & 36 & 171 & 46 & 316 & 9 & 342 & 387 & 125 & 31 & 8.9 & 77 & 154 & 20 \\
\hline WB & Eckler Mtn., Dodge & 51.62 & 1.448 & 15.03 & 10.93 & 0.185 & 10.49 & 6.26 & 0.52 & 3.17 & 0.344 & 100.00 & 38 & 150 & 49 & 344 & 8 & 309 & 395 & 126 & 32 & 10.2 & 91 & 109 & 20 \\
\hline WB & Eckler Mtn., Dodge & 51.77 & 1.456 & 15.12 & 10.72 & 0.185 & 10.52 & 6.21 & 0.58 & 3.09 & 0.358 & 100.01 & 40 & 155 & 47 & 340 & 12 & 330 & 399 & 125 & 29 & 9.2 & 102 & 102 & 21 \\
\hline WB & Eckler Mtn., Dodge & 51.78 & 1.507 & 15.37 & 10.26 & 0.190 & 10.53 & 6.23 & 0.56 & 3.20 & 0.361 & 99.99 & 42 & 158 & 46 & 334 & 10 & 335 & 395 & 128 & 32 & 8.9 & 105 & 105 & 21 \\
\hline WB & Eckler Mtn., Dodge & 52.49 & 1.535 & 16.00 & 9.22 & 0.151 & 11.47 & 5.18 & 0.51 & 3.11 & 0.344 & 100.01 & 38 & 177 & 49 & 364 & 7 & 279 & 416 & 129 & 30 & 7.9 & 106 & 107 & 19 \\
\hline WB & Eckler Mtn., Dodge & 51.78 & 1.466 & 14.83 & 11.38 & 0.175 & 10.02 & 6.12 & 0.73 & 3.15 & 0.347 & 100.00 & 36 & 148 & 42 & 329 & 14 & 366 & 364 & 125 & 29 & 7.3 & 77 & 103 & 19 \\
\hline WB & Eckler Mtn., Dodge & 51.21 & 1.401 & 15.35 & 11.23 & 0.213 & 10.32 & 6.27 & 0.50 & 3.18 & 0.326 & 100.00 & 40 & 168 & 47 & 342 & 6 & 354 & 392 & 122 & 31 & 9.0 & 87 & 101 & 19 \\
\hline WB & Eckler Mtn., Dodge & 52.56 & 1.427 & 15.11 & 10.41 & 0.159 & 10.15 & 5.98 & 0.69 & 3.19 & 0.330 & 100.01 & 41 & 168 & 45 & 322 & 14 & 327 & 381 & 124 & 34 & 10.8 & 93 & 103 & 19 \\
\hline WB & Eckler Mtn., Dodge & 53.11 & 1.340 & 15.55 & 9.83 & 0.145 & 10.25 & 5.45 & 0.71 & 3.29 & 0.313 & 99.99 & 36 & 169 & 45 & 307 & 14 & 309 & 388 & 120 & 31 & 10.4 & 72 & 93 & 19 \\
\hline WB & Eckler Mtn. Robinette Mtn. & 49.44 & 0.958 & 17.12 & 10.27 & 0.182 & 11.13 & 7.95 & 0.24 & 2.53 & 0.174 & 99.99 & 82 & 145 & 37 & 263 & 4 & 129 & 333 & 72 & 21 & 6.4 & 87 & 85 & 18 \\
\hline GRB & Basalt of Sentinel Bluffs & 55.69 & 14.60 & 1.789 & 11.39 & 0.193 & 4.78 & 8.51 & 3.01 & 1.08 & 0.303 & & 284 & 38 & 9 & 48 & 161 & 105 & 33 & 19 & 12.3 & 26 & 528 & 36 & 302 \\
\hline GRB & Basalt of Sentinel Bluffs & 55.16 & 14.41 & 1.819 & 11.33 & 0.191 & 4.82 & 8.50 & 3.30 & 1.08 & 0.300 & 100.91 & 311 & 40 & 8 & 49 & 162 & 115 & 35 & 23 & 12.9 & 20 & 522 & 35 & 300 \\
\hline GRB & Basalt of Sentinel Bluffs & 55.69 & 14.60 & 1.789 & 11.39 & 0.193 & 4.78 & 8.51 & 3.01 & 1.08 & 0.303 & 101.34 & 284 & 38 & 9 & 48 & 161 & 105 & 33 & 19 & 12.3 & 26 & 528 & 36 & 302 \\
\hline GRB & Basalt of Sentinel Bluffs & 55.89 & 14.61 & 1.673 & 11.05 & 0.187 & 4.91 & 8.40 & 3.14 & 1.22 & 0.285 & 101.36 & 289 & 35 & 10 & 50 & 160 & 105 & 32 & 21 & 11.4 & 31 & 521 & 32 & 303 \\
\hline GRB & Basalt of Sentinel Bluffs & 55.31 & 14.47 & 1.703 & 10.99 & 0.185 & 4.88 & 8.39 & 3.36 & 1.22 & 0.282 & 100.79 & 295 & 40 & 4 & 53 & 162 & 111 & 34 & 22 & 12.5 & 23 & 534 & 32 & 303 \\
\hline
\end{tabular}


Table G.1. (contd)

\begin{tabular}{|c|c|c|c|c|c|c|c|c|c|c|c|c|c|c|c|c|c|c|c|c|c|c|c|c|c|}
\hline \multirow[b]{2}{*}{ Formation } & \multirow[b]{2}{*}{ Unit Ident. } & \multicolumn{11}{|c|}{ Major Oxides (weight per cent) } & \multicolumn{13}{|c|}{ Trace Elements (ppm) } \\
\hline & & $\mathrm{SiO}_{2}$ & $\mathrm{TiO}_{2}$ & $\mathrm{Al}_{2} \mathrm{O}_{3}$ & $\mathrm{FeO}^{*}$ & $\mathrm{MnO}$ & $\mathrm{CaO}$ & $\mathrm{MgO}$ & $\mathrm{K}_{2} \mathrm{O}$ & $\mathrm{Na}_{2} \mathrm{O}$ & $\frac{\mathrm{P}_{2} \mathrm{O}_{5}}{2}$ & TOTAL & $\mathrm{Ni}$ & $\mathrm{Cr}$ & $\mathrm{Sc}$ & $\mathrm{V}$ & $\mathrm{Rb}$ & $\mathrm{Ba}$ & $\mathrm{Sr}$ & $\mathrm{Zr}$ & $\mathrm{Y}$ & $\mathrm{Nb}$ & $\mathrm{Cu}$ & $\mathrm{Zn}$ & $\mathrm{Ga}$ \\
\hline GRB & Basalt of Sentinel Bluffs & 55.89 & 14.61 & 1.673 & 11.05 & 0.187 & 4.91 & 8.40 & 3.14 & 1.22 & 0.285 & & 289 & 35 & 10 & 50 & 160 & 105 & 32 & 21 & 11.4 & $\overline{132}$ & 521 & 32 & 303 \\
\hline GRB & Basalt of Sentinel Bluffs & 54.49 & 14.42 & 1.665 & 11.36 & 0.197 & 5.07 & 9.03 & 2.98 & 0.99 & 0.272 & 100.47 & 312 & 37 & 10 & 52 & 149 & 102 & 30 & 19 & 10.6 & 28 & 412 & 30 & 309 \\
\hline GRB & Basalt of Sentinel Bluffs & 54.49 & 14.42 & 1.665 & 11.36 & 0.197 & 5.07 & 9.03 & 2.98 & 0.99 & 0.272 & & 312 & 37 & 10 & 52 & 149 & 102 & 30 & 19 & 10.6 & 28 & 412 & 30 & 309 \\
\hline GRB & Basalt of Sentinel Bluffs & 54.32 & 14.57 & 1.698 & 11.30 & 0.194 & 5.28 & 9.04 & 3.15 & 0.99 & 0.270 & 100.81 & 311 & 38 & , & 51 & 150 & 107 & 33 & 20 & 12.1 & 22 & 426 & 28 & 309 \\
\hline GRB & Basalt of Sentinel Bluffs & 55.27 & 15.06 & 1.659 & 11.26 & 0.199 & 5.06 & 8.84 & 3.03 & 0.96 & 0.278 & 101.62 & 304 & 37 & 10 & 54 & 150 & 103 & 31 & 19 & 11.4 & 38 & 503 & 17 & 312 \\
\hline GRB & Basalt of Sentinel Bluffs & 55.27 & 15.06 & 1.659 & 11.26 & 0.199 & 5.06 & 8.84 & 3.03 & 0.96 & 0.278 & & 304 & 37 & 10 & 54 & 150 & 103 & 31 & 19 & 11.4 & 38 & 503 & 17 & 312 \\
\hline GRB & Basalt of Sentinel Bluffs & 54.50 & 14.86 & 1.691 & 11.22 & 0.195 & 5.12 & 8.81 & 3.34 & 0.96 & 0.271 & 100.97 & 319 & 37 & 8 & 53 & 151 & 109 & 34 & 24 & 11.3 & 24 & 481 & 16 & 313 \\
\hline GRB & Basalt of Sentinel Bluffs & 55.28 & 14.73 & 1.725 & 11.62 & 0.199 & 4.89 & 8.71 & 2.96 & 1.14 & 0.302 & 101.56 & 293 & 33 & 8 & 45 & 156 & 111 & 29 & 23 & 10.7 & 32 & 511 & 35 & 315 \\
\hline GRB & Basalt of Sentinel Bluffs & 54.70 & 14.54 & 1.758 & 11.57 & 0.194 & 4.92 & 8.69 & 3.25 & 1.14 & 0.302 & 101.06 & 317 & 34 & 3 & 46 & 157 & 114 & 34 & 22 & 12.2 & 18 & 522 & 32 & 313 \\
\hline GRB & Basalt of Sentinel Bluffs & 54.93 & 14.41 & 1.758 & 11.36 & 0.192 & 4.99 & 8.59 & 3.26 & 1.21 & 0.310 & 101.01 & 310 & 36 & 2 & 43 & 157 & 113 & 35 & 24 & 14.3 & 19 & 509 & 31 & 308 \\
\hline GRB & Basalt of Sentinel Bluffs & 55.23 & 14.34 & 1.721 & 11.37 & 0.198 & 4.77 & 8.57 & 3.05 & 1.21 & 0.318 & 100.78 & 300 & 35 & 11 & 49 & 156 & 112 & 31 & 22 & 14.0 & 27 & 488 & 33 & 308 \\
\hline GRB & Basalt of Sentinel Bluffs & 55.51 & 14.60 & 1.722 & 11.49 & 0.197 & 4.85 & 8.61 & 2.93 & 1.22 & 0.311 & 101.44 & 303 & 35 & 11 & 47 & 154 & 110 & 32 & 19 & 11.7 & 37 & 507 & 33 & 310 \\
\hline GRB & Basalt of Sentinel Bluffs & 55.02 & 14.29 & 1.753 & 11.39 & 0.194 & 4.89 & 8.56 & 3.12 & 1.23 & 0.318 & 100.77 & 309 & 30 & 10 & 48 & 156 & 111 & 33 & 21 & 11.7 & 18 & 503 & 33 & 308 \\
\hline GRB & Basalt of Sentinel Bluffs & 55.14 & 14.18 & 1.819 & 11.50 & 0.195 & 4.57 & 8.42 & 3.20 & 1.22 & 0.353 & 100.60 & 289 & 37 & 2 & 41 & 163 & 117 & 36 & 22 & 12.7 & 19 & 562 & 32 & 310 \\
\hline GRB & Basalt of Sentinel Bluffs & 55.32 & 14.41 & 1.786 & 11.59 & 0.197 & 4.52 & 8.44 & 3.07 & 1.22 & 0.348 & 100.90 & 285 & 35 & 8 & 42 & 161 & 110 & 33 & 21 & 13.8 & 31 & 550 & 34 & 310 \\
\hline GRB & Basalt of Sentinel Bluffs & 54.42 & 14.34 & 1.833 & 11.73 & 0.196 & 5.08 & 8.92 & 3.10 & 1.01 & 0.289 & 100.92 & 341 & 39 & 5 & 48 & 154 & 109 & 34 & 22 & 12.2 & 22 & 438 & 29 & 310 \\
\hline GRB & Basalt of Sentinel Bluffs & 55.02 & 14.64 & 1.800 & 11.79 & 0.200 & 5.01 & 8.94 & 2.94 & 1.01 & 0.285 & 101.64 & 308 & 35 & 12 & 49 & 152 & 107 & 31 & 24 & 10.8 & 29 & 434 & 29 & 310 \\
\hline GRB & Basalt of Sentinel Bluffs & 54.49 & 14.17 & 1.745 & 11.81 & 0.204 & 4.90 & 8.83 & 3.08 & 1.04 & 0.283 & 100.55 & 323 & 37 & 9 & 50 & 153 & 107 & 31 & 24 & 11.8 & 29 & 458 & 33 & 310 \\
\hline GRB & Basalt of Sentinel Bluffs & 54.87 & 14.21 & 1.798 & 11.73 & 0.200 & 4.97 & 8.80 & 3.09 & 1.04 & 0.287 & 101.00 & 333 & 39 & 9 & 44 & 152 & 110 & 32 & 23 & 11.4 & 28 & 426 & 33 & 309 \\
\hline GRB & Basalt of Sentinel Bluffs & 54.27 & 14.28 & 1.776 & 11.64 & 0.192 & 5.10 & 8.99 & 3.09 & 0.97 & 0.278 & 100.59 & 338 & 39 & 8 & 51 & 149 & 108 & 32 & 20 & 12.5 & 26 & 407 & 29 & 310 \\
\hline GRB & Basalt of Sentinel Bluffs & 54.28 & 14.29 & 1.739 & 11.75 & 0.197 & 5.07 & 9.00 & 3.06 & 0.97 & 0.273 & 100.63 & 317 & 36 & 10 & 54 & 149 & 108 & 30 & 21 & 12.0 & 39 & 419 & 30 & 310 \\
\hline GRB & Basalt of Sentinel Bluffs & 54.75 & 13.99 & 1.877 & 11.92 & 0.202 & 4.83 & 8.56 & 3.13 & 1.18 & 0.362 & 100.80 & 288 & 38 & 8 & 46 & 160 & 119 & 36 & 20 & 12.7 & 21 & 470 & 34 & 306 \\
\hline GRB & Basalt of Sentinel Bluffs & 54.47 & 14.02 & 1.833 & 11.96 & 0.207 & 4.77 & 8.59 & 3.07 & 1.18 & 0.361 & 100.46 & 289 & 35 & 9 & 43 & 160 & 109 & 33 & 23 & 12.4 & 28 & 471 & 36 & 307 \\
\hline GRB & Basalt of Sentinel Bluffs & 54.08 & 14.09 & 1.764 & 11.55 & 0.202 & 5.13 & 8.88 & 3.03 & 1.13 & 0.276 & 100.13 & 312 & 38 & 14 & 59 & 150 & 104 & 33 & 22 & 9.9 & 36 & 425 & 29 & 304 \\
\hline GRB & Basalt of Sentinel Bluffs & 54.69 & 14.07 & 1.789 & 11.53 & 0.196 & 5.16 & 8.86 & 2.97 & 1.13 & 0.284 & 100.68 & 331 & 39 & 8 & 52 & 150 & 110 & 33 & 20 & 12.0 & 28 & 429 & 28 & 301 \\
\hline GRB & Basalt of Sentinel Bluffs & 55.34 & 14.33 & 1.847 & 11.58 & 0.193 & 4.74 & 8.70 & 3.16 & 1.19 & 0.294 & 101.37 & 338 & 45 & 6 & 40 & 154 & 109 & 33 & 21 & 12.0 & 29 & 481 & 30 & 311 \\
\hline GRB & Basalt of Sentinel Bluffs & 54.41 & 14.20 & 1.798 & 11.68 & 0.198 & 4.62 & 8.71 & 3.13 & 1.19 & 0.292 & 100.23 & 331 & 37 & 10 & 45 & 154 & 110 & 32 & 25 & 12.9 & 32 & 456 & 30 & 315 \\
\hline GRB & Basalt of Sentinel Bluffs & 55.03 & 14.26 & 1.820 & 11.64 & 0.195 & 4.85 & 8.75 & 3.20 & 1.14 & 0.288 & 101.17 & 318 & 35 & 8 & 44 & 153 & 109 & 33 & 21 & 11.6 & 29 & 445 & 29 & 307 \\
\hline GRB & Basalt of Sentinel Bluffs & 54.45 & 14.26 & 1.792 & 11.74 & 0.197 & 4.77 & 8.76 & 3.15 & 1.13 & 0.285 & 100.53 & 323 & 37 & 10 & 53 & 152 & 105 & 31 & 20 & 12.5 & 34 & 438 & 30 & 308 \\
\hline GRB & Basalt of Sentinel Bluffs & 54.62 & 14.38 & 1.776 & 11.43 & 0.206 & 5.11 & 8.86 & 3.11 & 1.09 & 0.297 & 100.88 & 306 & 34 & 15 & 51 & 149 & 107 & 31 & 19 & 11.0 & 35 & 476 & 26 & 304 \\
\hline GRB & Basalt of Sentinel Bluffs & 54.99 & 14.26 & 1.814 & 11.37 & 0.201 & 5.24 & 8.82 & 3.16 & 1.09 & 0.304 & 101.25 & 307 & 39 & 7 & 51 & 152 & 113 & 34 & 19 & 12.3 & 24 & 463 & 25 & 304 \\
\hline GRB & Basalt of Sentinel Bluffs & 54.98 & 14.27 & 1.906 & 12.09 & 0.209 & 4.99 & 8.89 & 3.18 & 0.90 & 0.313 & 101.73 & 329 & 40 & 3 & 41 & 156 & 117 & 35 & 23 & 13.1 & 23 & 459 & 24 & 309 \\
\hline GRB & Basalt of Sentinel Bluffs & 54.73 & 14.20 & 1.867 & 12.27 & 0.213 & 4.85 & 8.91 & 3.13 & 0.89 & 0.309 & 101.37 & 311 & 36 & 8 & 41 & 155 & 110 & 32 & 19 & 12.6 & 28 & 451 & 26 & 313 \\
\hline GRB & Basalt of Sentinel Bluffs & 54.54 & 14.04 & 1.889 & 12.08 & 0.205 & 5.03 & 8.72 & 3.13 & 0.97 & 0.298 & 100.90 & 327 & 40 & 7 & 39 & 154 & 115 & 34 & 19 & 11.1 & 24 & 459 & 27 & 307 \\
\hline GRB & Basalt of Sentinel Bluffs & 54.30 & 14.06 & 1.852 & 12.18 & 0.209 & 4.93 & 8.74 & 3.13 & 0.96 & 0.296 & 100.66 & 316 & 35 & 7 & 43 & 153 & 111 & 33 & 22 & 11.6 & 33 & 431 & 28 & 306 \\
\hline GRB & Basalt of Sentinel Bluffs & 54.41 & 13.94 & 1.921 & 12.15 & 0.206 & 4.83 & 8.58 & 3.17 & 1.01 & 0.317 & 100.53 & 321 & 40 & 4 & 43 & 159 & 115 & 36 & 23 & 13.0 & 20 & 483 & 26 & 308 \\
\hline GRB & Basalt of Sentinel Bluffs & 54.35 & 14.04 & 1.883 & 12.24 & 0.212 & 4.73 & 8.59 & 3.12 & 1.01 & 0.313 & 100.49 & 306 & 35 & 11 & 40 & 156 & 116 & 32 & 24 & 12.8 & 32 & 458 & 29 & 309 \\
\hline GRB & Basalt of Sentinel Bluffs & 54.28 & 14.11 & 1.902 & 12.25 & 0.205 & 4.97 & 8.76 & 3.13 & 0.91 & 0.276 & 100.79 & 340 & 39 & 1 & 28 & 151 & 117 & 33 & 23 & 11.8 & 26 & 431 & 31 & 316 \\
\hline GRB & Basalt of Sentinel Bluffs & 54.02 & 14.13 & 1.852 & 12.36 & 0.207 & 4.87 & 8.76 & 3.13 & 0.90 & 0.274 & 100.50 & 333 & 38 & 6 & 34 & 151 & 110 & 31 & 23 & 12.1 & 29 & 405 & 31 & 318 \\
\hline GRB & Basalt of Sentinel Bluffs & 53.94 & 13.89 & 1.845 & 12.15 & \begin{tabular}{|l|l|}
0.207 \\
\end{tabular} & 4.80 & 8.64 & 3.06 & 1.03 & 0.277 & 99.84 & 322 & 36 & 6 & 29 & 149 & 109 & 31 & 21 & 12.0 & 26 & 416 & 31 & 315 \\
\hline GRB & Basalt of Sentinel Bluffs & 54.16 & 13.91 & 1.881 & 12.03 & 0.201 & 4.93 & 8.64 & 3.07 & 1.03 & 0.281 & 100.13 & 342 & 40 & 4 & 27 & 150 & 115 & 33 & 21 & 12.1 & 20 & 435 & 30 & 314 \\
\hline GRB & Basalt of Sentinel Bluffs & 54.05 & 13.84 & 1.844 & 12.37 & 0.208 & 4.77 & 8.63 & 3.07 & 1.02 & 0.278 & 100.08 & 329 & 35 & 5 & 32 & 152 & 112 & 31 & 20 & 11.8 & 35 & 435 & 30 & 316 \\
\hline GRB & Basalt of Sentinel Bluffs & 54.40 & 13.99 & 1.888 & 12.27 & 0.202 & 4.90 & 8.62 & 3.10 & 1.03 & 0.284 & 100.68 & 326 & 40 & 6 & 29 & 152 & 113 & 32 & 21 & 11.7 & 18 & 430 & 29 & 312 \\
\hline GRB & Basalt of Sentinel Bluffs & 54.93 & 13.90 & 1.962 & 12.21 & 0.206 & 4.55 & 8.41 & 3.28 & 1.01 & 0.306 & 100.76 & 342 & 41 & 5 & 31 & 156 & 117 & 34 & 23 & 13.3 & 15 & 459 & 33 & 314 \\
\hline GRB & Basalt of Sentinel Bluffs & 54.65 & 13.91 & 1.918 & 12.29 & 0.211 & 4.49 & 8.44 & 3.21 & 1.01 & 0.302 & 100.43 & 339 & 37 & 4 & 31 & 154 & 111 & 32 & 22 & 12.8 & 25 & 458 & 33 & 316 \\
\hline GRB & Basalt of Sentinel Bluffs & 54.38 & 13.85 & 1.920 & 12.36 & 0.208 & 4.49 & 8.38 & 3.22 & 1.10 & 0.302 & 100.21 & 339 & 37 & 5 & 31 & 156 & 110 & 31 & 21 & 12.6 & 20 & 474 & 27 & 313 \\
\hline GRB & Basalt of Sentinel Bluffs & 54.92 & 13.87 & 1.963 & 12.32 & 0.204 & 4.61 & 8.35 & 3.25 & 1.10 & 0.303 & 100.89 & 336 & 40 & 1 & 25 & 157 & 118 & 33 & 22 & 12.8 & 14 & 468 & 26 & 315 \\
\hline
\end{tabular}


Table G.1. (contd)

\begin{tabular}{|c|c|c|c|c|c|c|c|c|c|c|c|c|c|c|c|c|c|c|c|c|c|c|c|c|c|}
\hline \multirow[b]{2}{*}{ Formation } & \multirow[b]{2}{*}{ Unit Ident. } & \multicolumn{11}{|c|}{ Major Oxides (weight per cent) } & \multicolumn{13}{|c|}{ Trace Elements (ppm) } \\
\hline & & $\mathrm{SiO}_{2}$ & $\mathrm{TiO}_{2}$ & $\mathrm{Al}_{2} \mathrm{O}_{3}$ & $\mathrm{FeO}^{*}$ & $\mathrm{MnO}$ & $\mathrm{CaO}$ & $\mathrm{MgO}$ & $\mathrm{K}_{2} \mathrm{O}$ & $\mathrm{Na}_{2} \mathrm{O}$ & $\mathrm{P}_{2} \mathrm{O}_{5}$ & TOTAL & $\mathrm{Ni}$ & $\mathrm{Cr}$ & $\mathrm{Sc}$ & $\mathrm{V}$ & $\mathrm{Rb}$ & $\mathrm{Ba}$ & $\mathrm{Sr}$ & $\mathrm{Zr}$ & $\mathrm{Y}$ & $\mathrm{Nb}$ & $\mathrm{Cu}$ & $\mathrm{Zn}$ & $\mathrm{Ga}$ \\
\hline 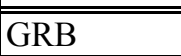 & $\begin{array}{l}\text { Basalt of Sentinel Bluffs } \\
\end{array}$ & 54.45 & 13.74 & $\begin{array}{ll}1.960 \\
\end{array}$ & 12.12 & 0.206 & $\overline{c 4.63}$ & 8.33 & 3.15 & 1.14 & 0.307 & 100.03 & 341 & 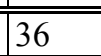 & 1 & 225 & 156 & 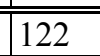 & $\overline{34}$ & 24 & 112.1 & 18 & 4458 & 31 & $\overline{2312}$ \\
\hline GRB & Basalt of Sentinel Bluffs & 54.18 & 13.75 & 1.922 & 12.20 & 0.210 & 4.51 & 8.35 & 3.10 & 1.14 & 0.302 & 99.66 & 337 & 37 & 4 & 25 & 155 & 114 & 32 & 21 & 11.6 & 29 & 453 & 33 & 311 \\
\hline GRB & Basalt of Umtanum & 55.52 & 13.52 & 2.147 & 12.72 & 0.214 & 3.40 & 7.15 & 3.37 & 1.63 & 0.378 & 100.05 & 324 & 31 & 0 & 19 & 178 & 124 & 36 & 23 & 14.1 & 12 & 596 & 48 & 309 \\
\hline GRB & Basalt of Umtanum & 55.79 & 13.45 & 2.191 & 12.64 & 0.210 & 3.43 & 7.17 & 3.38 & 1.62 & 0.384 & 100.27 & 325 & 33 & 0 & 12 & 180 & 132 & 40 & 24 & 14.6 & 0 & 608 & 45 & 308 \\
\hline GRB & Basalt of Umtanum & 56.02 & 13.43 & 2.162 & 12.55 & 0.205 & 3.40 & 7.10 & 3.43 & 1.56 & 0.385 & 100.24 & 324 & 35 & 0 & 17 & 179 & 131 & 38 & 21 & 13.3 & 3 & 615 & 45 & 310 \\
\hline GRB & Basalt of Umtanum & 55.74 & 13.33 & 2.131 & 12.65 & 0.210 & 3.35 & 7.09 & 3.36 & 1.57 & 0.382 & 99.81 & 321 & 32 & 4 & 16 & 178 & 124 & 37 & 22 & 15.0 & 5 & 588 & 45 & 312 \\
\hline GRB & Basalt of Umtanum & 55.53 & 13.35 & 2.286 & 12.94 & 0.210 & 3.39 & 7.15 & 3.47 & 1.45 & 0.390 & 100.17 & 315 & 31 & 2 & 18 & 183 & 133 & 39 & 23 & 14.9 & 0 & 614 & 49 & 308 \\
\hline GRB & Basalt of Umtanum & 55.46 & 13.43 & 2.224 & 13.02 & 0.216 & 3.35 & 7.17 & 3.48 & 1.45 & 0.386 & 100.19 & 297 & 33 & 3 & 18 & 180 & 125 & 37 & 19 & 13.7 & 9 & 583 & 48 & 312 \\
\hline GRB & Basalt of Fields Spring & 53.43 & 1.169 & 15.22 & 9.76 & 0.176 & 10.28 & 6.25 & 0.54 & 2.92 & 0.262 & 100.01 & 17 & 101 & 45 & 283 & 11 & 404 & 395 & 123 & 26 & 8.0 & 57 & 92 & 21 \\
\hline GRB & Basalt of Fields Spring & 54.14 & 1.154 & 15.02 & 9.15 & 0.226 & 10.19 & 6.19 & 0.76 & 2.91 & 0.266 & 100.01 & 15 & 94 & 51 & 264 & 16 & 422 & 388 & 122 & 25 & 7.3 & 48 & 95 & 17 \\
\hline GRB & Basalt of Fields Spring & 53.10 & 1.098 & 15.27 & 9.46 & 0.172 & 10.61 & 6.57 & 0.52 & 2.94 & 0.250 & 99.99 & 21 & 100 & 45 & 255 & 10 & 355 & 391 & 114 & 24 & 7.5 & 68 & 88 & 18 \\
\hline GRB & Basalt of Fields Spring & 53.86 & 1.175 & 14.83 & 9.62 & 0.183 & 10.16 & 6.15 & 0.80 & 2.95 & 0.273 & 100.00 & 18 & 95 & 47 & 264 & 16 & 466 & 388 & 124 & 26 & 7.9 & 52 & 91 & 20 \\
\hline GRB & Basalt of Fields Spring & 53.86 & 1.128 & 14.93 & 9.41 & 0.172 & 10.26 & 6.27 & 0.75 & 2.95 & 0.275 & 100.01 & 20 & 95 & 45 & 267 & 15 & 456 & 389 & 117 & 25 & 7.5 & 47 & 89 & 17 \\
\hline GRB & Basalt of Fields Spring & 53.65 & 1.135 & 15.15 & 9.36 & 0.170 & 10.35 & 6.31 & 0.69 & 2.92 & 0.260 & 100.00 & 18 & 96 & 48 & 263 & 14 & 410 & 387 & 116 & 25 & 7.2 & 116 & 93 & 18 \\
\hline GRB & Basalt of Fields Spring & 53.63 & 1.104 & 15.10 & 9.36 & 0.172 & 10.39 & 6.41 & 0.67 & 2.91 & 0.240 & 99.99 & 18 & 99 & 48 & 257 & 13 & 362 & 388 & 112 & 24 & 6.6 & 52 & 90 & 21 \\
\hline GRB & Basalt of Fields Spring & 53.97 & 1.163 & 14.82 & 9.60 & 0.182 & 10.01 & 6.14 & 0.76 & 3.09 & 0.270 & 100.01 & 15 & 90 & 46 & 265 & 14 & 422 & 383 & 119 & 25 & 7.6 & 64 & 95 & 18 \\
\hline GRB & Basalt of Fields Spring & 53.77 & 1.191 & 14.96 & 9.67 & 0.178 & 10.03 & 6.13 & 0.79 & 3.02 & 0.270 & 100.01 & 19 & 88 & 43 & 264 & 16 & 433 & 387 & 120 & 25 & 7.9 & 49 & 88 & 16 \\
\hline \begin{tabular}{|l|} 
GRB \\
\end{tabular} & Basalt of Fields Spring & 54.08 & 1.118 & 15.01 & 9.07 & 0.172 & 10.20 & 6.29 & 0.82 & 2.99 & 0.257 & 100.01 & $\mid 17$ & 91 & 44 & 266 & 17 & 417 & 388 & 118 & 24 & 8.5 & 51 & 86 & 16 \\
\hline GRB & Basalt of Fields Spring & 53.83 & 1.114 & 15.10 & 9.17 & 0.172 & 10.26 & 6.35 & 0.73 & 3.02 & 0.254 & 100.00 & 18 & 96 & 41 & 273 & 15 & 368 & 385 & 116 & 25 & 7.8 & 36 & 92 & 21 \\
\hline GRB & Basalt of Fields Spring & 54.16 & 1.152 & 14.91 & 9.55 & 0.181 & 10.06 & 6.12 & 0.77 & 2.84 & 0.271 & 100.01 & 22 & 93 & 39 & 267 & 18 & 550 & 388 & 122 & 29 & 9.0 & 65 & 91 & 17 \\
\hline GRB & Basalt of Fields Spring & 54.00 & 1.189 & 15.07 & 9.43 & 0.196 & 10.06 & \begin{tabular}{|l|l|l|l|l}
6.07 \\
\end{tabular} & 0.78 & 2.93 & 0.277 & 100.00 & 22 & 99 & 38 & 247 & 16 & 489 & 384 & 125 & 26 & 9.0 & 61 & 95 & 20 \\
\hline GRB & Basalt of Fields Spring & 53.81 & 1.216 & 15.02 & 9.56 & 0.240 & 10.10 & 6.02 & 0.70 & 3.04 & 0.283 & 99.99 & 15 & 87 & 46 & 276 & 16 & 403 & 391 & 127 & 28 & 7.7 & 46 & 96 & 21 \\
\hline GRB & Basalt of Fields Spring & 54.22 & 1.174 & 14.96 & 9.37 & 0.174 & 10.23 & 5.84 & 0.84 & 2.91 & 0.273 & 99.99 & 13 & 95 & 42 & 260 & 17 & 410 & 387 & 123 & 26 & 7.9 & 62 & 92 & 22 \\
\hline GRB & Basalt of Fields Spring & 53.50 & 1.164 & 15.09 & 9.96 & 0.174 & 10.18 & 6.13 & 0.60 & 2.95 & 0.267 & 100.02 & 18 & 89 & 51 & 261 & 15 & 339 & 388 & 120 & 24 & 7.4 & 33 & 81 & 17 \\
\hline GRB & Basalt of Fields Spring & 53.50 & 1.152 & 15.10 & 9.57 & 0.174 & 10.35 & 6.21 & 0.72 & 2.97 & 0.267 & 100.01 & \begin{tabular}{|l|}
17 \\
\end{tabular} & 92 & 47 & 257 & 15 & 656 & 411 & 120 & 27 & 6.6 & 39 & 88 & 18 \\
\hline GRB & Basalt of Fields Spring & 54.09 & 1.232 & 14.99 & 9.91 & 0.180 & 9.81 & 5.70 & 0.79 & 2.99 & 0.330 & 100.00 & 17 & 88 & 43 & 275 & 17 & 433 & 380 & 134 & 27 & 9.4 & 19 & 90 & 19 \\
\hline GRB & Basalt of Fields Spring & 53.80 & 1.185 & 15.17 & 9.70 & 0.170 & 10.28 & 5.89 & 0.65 & 2.88 & 0.267 & 99.99 & 15 & 94 & 44 & 265 & 14 & 372 & 398 & 124 & 27 & 9.4 & 37 & 91 & 21 \\
\hline GRB & Basalt of Fields Spring & 54.10 & 1.184 & 14.94 & 9.28 & 0.181 & 10.02 & 5.96 & 1.09 & 2.97 & 0.276 & 100.00 & 14 & 83 & 47 & 253 & 22 & 456 & 386 & 125 & 26 & 7.9 & 53 & 92 & 18 \\
\hline GRB & Basalt of Fields Spring & 53.21 & 1.238 & 15.67 & 10.27 & 0.185 & 10.32 & 5.41 & 0.46 & 2.95 & 0.288 & 100.00 & 11 & 93 & 47 & 264 & 9 & 347 & 412 & 130 & 29 & 9.0 & 51 & 92 & 20 \\
\hline GRB & Basalt of Fields Spring & 54.20 & 1.187 & 14.80 & 9.21 & 0.185 & 9.93 & 6.15 & 1.17 & 2.89 & 0.277 & 100.00 & 16 & 86 & 45 & 268 & 21 & 388 & 372 & 123 & 27 & 8.6 & 51 & 91 & 17 \\
\hline GRB & Basalt of Fields Spring & 54.37 & 1.148 & 15.02 & 9.48 & 0.176 & 10.00 & 5.99 & 0.76 & 2.78 & 0.269 & 99.99 & 21 & 96 & 46 & 255 & 18 & 390 & 380 & 120 & 27 & \begin{tabular}{|l|l|}
9.7 \\
\end{tabular} & \begin{tabular}{|l|l|}
67 \\
\end{tabular} & 88 & 16 \\
\hline GRB & Basalt of Fields Spring & 54.33 & 1.170 & 15.02 & 9.57 & 0.173 & 9.87 & 5.95 & 0.73 & 2.93 & 0.266 & 100.01 & 26 & 97 & 43 & 271 & 14 & 397 & 378 & 121 & 28 & 9.0 & 61 & 89 & 16 \\
\hline GRB & Basalt of Fields Spring & 54.07 & 1.165 & 15.12 & 9.63 & 0.180 & 9.96 & 5.92 & 0.72 & 2.96 & 0.273 & 100.00 & 20 & 98 & 47 & 272 & 13 & 383 & 383 & 120 & 26 & 9.6 & 60 & 89 & 19 \\
\hline GRB & Basalt of Fields Spring & 54.59 & 1.125 & 15.14 & 8.76 & 0.183 & 10.12 & 6.21 & 0.92 & 2.68 & 0.292 & 100.02 & 22 & 102 & 40 & 259 & 16 & 398 & 377 & 116 & 25 & 9.9 & 62 & 87 & 15 \\
\hline \begin{tabular}{|l|} 
GRB \\
\end{tabular} & Basalt of Fields Spring & 54.05 & 1.094 & 15.36 & 9.14 & 0.174 & 10.24 & \begin{tabular}{|l|l|l|l|}
6.17 \\
\end{tabular} & 0.66 & 2.86 & 0.252 & 100.00 & 24 & 106 & 46 & 269 & 11 & 477 & 392 & 111 & 25 & 7.2 & 51 & 88 & 15 \\
\hline GRB & Basalt of Fields Spring & 53.36 & 1.207 & 15.54 & 9.91 & 0.188 & 10.15 & 6.05 & 0.51 & 2.81 & 0.273 & 100.00 & 18 & 100 & 47 & 261 & 7 & 410 & 383 & 123 & 27 & 8.0 & 45 & 90 & 18 \\
\hline GRB & Basalt of Fields Spring & 54.58 & 1.111 & 15.03 & 9.24 & 0.178 & 10.02 & 6.08 & 0.81 & 2.70 & 0.268 & 100.02 & 38 & 109 & 41 & 250 & 17 & 384 & 385 & 116 & 26 & 8.6 & 50 & 81 & 21 \\
\hline GRB & Basalt of Fields Spring & 54.60 & 1.176 & 15.18 & 9.19 & 0.155 & 9.91 & 5.89 & 0.78 & 2.86 & 0.263 & 100.00 & 25 & 104 & 43 & 261 & 15 & 379 & 377 & 118 & 24 & 7.2 & 65 & 91 & 18 \\
\hline GRB & Basalt of Fields Spring & 54.24 & 1.123 & 15.28 & 8.88 & 0.169 & 10.50 & 6.06 & 0.74 & 2.74 & 0.266 & 100.00 & 29 & 110 & 46 & 258 & 17 & 374 & 387 & 116 & 26 & 9.4 & 75 & 84 & 18 \\
\hline GRB & Basalt of Meyer Ridge & 53.94 & 1.645 & 14.58 & 10.51 & 0.198 & 9.65 & 5.35 & 0.96 & 2.91 & 0.252 & 100.00 & 29 & 113 & 40 & 314 & 20 & 446 & 315 & 134 & 32 & 9.7 & 48 & 104 & 21 \\
\hline GRB & Basalt of Meyer Ridge & 53.66 & 1.644 & 14.45 & 11.26 & 0.182 & 9.21 & 5.16 & 1.10 & 3.08 & 0.261 & 100.01 & 28 & 110 & 41 & 316 & 28 & 476 & 304 & 135 & 30 & 11.1 & 62 & 102 & 21 \\
\hline GRB & Basalt of Meyer Ridge & 53.43 & 1.637 & 14.50 & 10.90 & 0.183 & 9.48 & 5.50 & 0.98 & 3.13 & 0.260 & 100.00 & 25 & 112 & 41 & 319 & 19 & 408 & 308 & 134 & 30 & 9.6 & 51 & 100 & 20 \\
\hline GRB & Basalt of Meyer Ridge & 53.33 & 1.757 & 14.56 & 11.53 & 0.183 & 9.17 & 5.14 & 1.04 & 3.01 & 0.274 & 99.99 & 23 & 95 & 44 & 310 & 26 & 532 & 311 & 146 & 31 & 9.5 & 47 & 108 & 22 \\
\hline GRB & Basalt of Meyer Ridge & 52.93 & 1.659 & 14.69 & 10.99 & 0.201 & 9.74 & 5.56 & 0.91 & 3.06 & 0.263 & 100.00 & 24 & 113 & 46 & 312 & 18 & 549 & 322 & 137 & 30 & 10.9 & 29 & 98 & 23 \\
\hline GRB & Basalt of Meyer Ridge & 53.41 & 1.635 & 14.37 & 11.23 & 0.176 & 9.26 & 5.58 & 1.05 & 3.03 & 0.256 & 100.00 & 27 & 108 & 41 & 306 & 26 & 433 & 303 & 135 & 29 & 10.0 & 54 & 102 & 22 \\
\hline GRB & Basalt of Meyer Ridge & 53.74 & 1.694 & 14.41 & 10.85 & 0.191 & 9.35 & 5.28 & 1.07 & 3.14 & 0.270 & 100.00 & 20 & 92 & 43 & 321 & 23 & 469 & 313 & 138 & 31 & 9.1 & 48 & 104 & 21 \\
\hline GRB & Basalt of Meyer Ridge & 53.67 & 1.657 & 14.50 & 10.93 & 0.183 & 9.50 & 5.32 & 1.00 & 2.99 & 0.261 & 100.01 & 27 & 108 & 42 & 316 & 23 & 391 & 312 & 137 & 30 & 10.4 & 70 & 104 & 20 \\
\hline
\end{tabular}


Table G.1. (contd)

\begin{tabular}{|c|c|c|c|c|c|c|c|c|c|c|c|c|c|c|c|c|c|c|c|c|c|c|c|c|c|}
\hline \multirow[b]{2}{*}{ Formation } & \multirow[b]{2}{*}{ Unit Ident. } & \multicolumn{11}{|c|}{ Major Oxides (weight per cent) } & \multicolumn{13}{|c|}{ Trace Elements (ppm) } \\
\hline & & $\mathrm{SiO}_{2}$ & $\mathrm{TiO}_{2}$ & $\mathrm{Al}_{2} \mathrm{O}_{3}$ & $\mathrm{FeO}^{*}$ & $\mathrm{MnO}$ & $\mathrm{CaO}$ & $\mathrm{MgO}$ & $\mathrm{K}_{2} \mathrm{O}$ & $\mathrm{Na}_{2} \mathrm{O}$ & $\mathrm{P}_{2} \mathrm{O}_{5}$ & TOTAL & $\mathrm{Ni}$ & $\mathrm{Cr}$ & $\mathrm{Sc}$ & $\mathrm{V}$ & $\mathrm{Rb}$ & $\mathrm{Ba}$ & $\mathrm{Sr}$ & $\mathrm{Zr}$ & $\mathrm{Y}$ & $\mathrm{Nb}$ & $\mathrm{Cu}$ & $\mathrm{Zn}$ & $\mathrm{Ga}$ \\
\hline 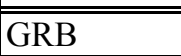 & Basalt of Meyer Ridge & 53.34 & 1.650 & 114.45 & 11.25 & 0.186 & 9.42 & 5.42 & 1.01 & 3.02 & 0.261 & 100.01 & 20 & 106 & $\overline{141}$ & 310 & 23 & 4427 & 308 & 1137 & 29 & 11.5 & $\overline{771}$ & 1102 & 21 \\
\hline GRB & Basalt of Meyer Ridge & 53.36 & 1.591 & 14.56 & 10.86 & 0.193 & 9.60 & 5.60 & 0.95 & 3.04 & 0.248 & 100.00 & 23 & 114 & 42 & 319 & 23 & 404 & 313 & 132 & 29 & 11.3 & 59 & 99 & 20 \\
\hline GRB & Basalt of Meyer Ridge & 52.57 & 1.673 & 14.42 & 11.34 & 0.197 & 10.04 & 5.60 & 0.85 & 3.03 & 0.281 & 100.00 & 15 & 119 & 45 & 348 & 15 & 410 & 371 & 127 & 28 & 9.0 & 42 & 111 & 19 \\
\hline GRB & Basalt of Meyer Ridge & 52.20 & 1.683 & 14.48 & 11.65 & 0.196 & 9.83 & 5.74 & 0.67 & 3.27 & 0.266 & 99.99 & 13 & 122 & 41 & 352 & 11 & 402 & 369 & 117 & 30 & 10.2 & 45 & 107 & 19 \\
\hline GRB & Basalt of Meyer Ridge & 53.44 & 1.656 & 14.76 & 10.67 & 0.191 & 9.58 & 5.53 & 0.89 & 3.02 & 0.259 & 100.00 & 23 & 110 & 41 & 328 & 22 & 614 & 329 & 136 & 29 & 11.2 & 45 & 103 & 20 \\
\hline GRB & Basalt of Meyer Ridge & 53.59 & 1.547 & 14.74 & 10.63 & 0.169 & 9.70 & 5.68 & 0.83 & 2.88 & 0.244 & 100.01 & 45 & 144 & 37 & 307 & 18 & 373 & 318 & 129 & 29 & 11.0 & 76 & 97 & 16 \\
\hline GRB & Basalt of Meyer Ridge & 53.43 & 1.530 & 14.94 & 10.68 & 0.205 & 9.64 & 5.80 & 0.97 & 2.57 & 0.241 & 100.01 & 39 & 150 & 35 & 294 & 25 & 531 & 319 & 128 & 32 & 11.0 & 90 & 104 & 20 \\
\hline GRB & Basalt of Meyer Ridge & 53.80 & 1.616 & 14.54 & 11.26 & 0.199 & 9.10 & 5.21 & 1.06 & 2.95 & 0.265 & 100.00 & 31 & 125 & 34 & 309 & 31 & 461 & 305 & 138 & 32 & 12.0 & 72 & 107 & 16 \\
\hline GRB & Basalt of Meyer Ridge & 54.18 & 1.628 & 14.76 & 10.36 & 0.225 & 9.55 & 5.08 & 1.09 & 2.87 & 0.262 & 100.01 & 35 & 105 & 38 & 324 & 27 & 438 & 320 & 137 & 31 & 13.0 & 70 & 103 & 21 \\
\hline GRB & Basalt of Meyer Ridge & 54.31 & 1.700 & 14.40 & 11.01 & 0.196 & 9.00 & 4.90 & 1.27 & 2.93 & 0.273 & 99.99 & 26 & 95 & 35 & 320 & 35 & 467 & 306 & 143 & 30 & 12.0 & 56 & 113 & 15 \\
\hline GRB & Basalt of Meyer Ridge & 53.56 & 1.546 & 14.79 & 10.87 & 0.180 & 9.58 & 5.61 & 0.92 & 2.70 & 0.245 & 100.00 & 46 & 141 & 41 & 290 & 24 & 434 & 316 & 130 & 29 & 13.0 & 90 & 111 & 18 \\
\hline GRB & Basalt of Meyer Ridge & 53.08 & 1.672 & 15.06 & 11.33 & 0.173 & 9.46 & 5.37 & 0.78 & 2.81 & 0.263 & 100.00 & 37 & 126 & 39 & 322 & 15 & 470 & 314 & 139 & 28 & 12.0 & 75 & 113 & 16 \\
\hline GRB & Basalt of Meyer Ridge & 53.08 & 1.672 & 15.06 & 11.33 & 0.173 & 9.46 & 5.37 & 0.78 & 2.81 & 0.263 & 100.00 & 37 & 126 & 39 & 322 & 15 & 470 & 314 & 139 & 28 & 12.0 & 75 & 113 & 16 \\
\hline GRB & Basalt of Meyer Ridge & 54.07 & 1.585 & 15.01 & 10.35 & 0.155 & 9.56 & \begin{tabular}{|l|l|}
5.30 \\
\end{tabular} & 0.91 & 2.81 & 0.249 & 100.00 & 38 & 142 & 41 & 326 & 18 & 350 & 311 & 128 & 31 & 10.5 & 79 & 97 & 17 \\
\hline GRB & Basalt of Meyer Ridge & 53.69 & 1.622 & 14.98 & 10.06 & 0.157 & 10.10 & 5.42 & 0.88 & 2.84 & 0.248 & 100.00 & 32 & 135 & 47 & 313 & 25 & 346 & 325 & 132 & 31 & 11.1 & 47 & 101 & 22 \\
\hline GRB & Basalt of Meyer Ridge & 54.77 & 1.765 & 14.89 & 9.43 & 0.184 & 9.27 & 5.00 & 1.21 & 3.20 & 0.283 & 100.00 & 30 & 86 & 44 & 329 & 31 & 489 & 324 & 149 & 34 & 9.7 & 47 & 111 & 22 \\
\hline GRB & Basalt of Meyer Ridge & 53.32 & 1.677 & 14.56 & 11.51 & 0.165 & 9.45 & 5.23 & 0.83 & 2.99 & 0.260 & 99.99 & 20 & 94 & 45 & 317 & 20 & 408 & 316 & 140 & 33 & $\mid 11.1$ & 57 & 101 & 20 \\
\hline \begin{tabular}{|l|} 
GRB \\
\end{tabular} & Basalt of Meyer Ridge & 54.23 & 1.730 & 14.50 & 10.88 & 0.183 & 9.12 & 4.91 & 1.07 & 3.10 & 0.277 & 100.00 & 20 & 95 & 45 & 323 & 24 & 479 & 308 & 143 & 33 & 11.3 & 43 & 107 & 20 \\
\hline GRB & Basalt of Meyer Ridge & 54.02 & 1.746 & 14.59 & 10.63 & 0.179 & 9.33 & 5.06 & 1.04 & 3.13 & 0.279 & 100.00 & 19 & 82 & 43 & 332 & 24 & 437 & 312 & 143 & 33 & 13.5 & 50 & 163 & 24 \\
\hline GRB & Basalt of Meyer Ridge & 53.53 & 1.650 & 14.54 & 10.98 & 0.185 & 9.53 & 5.39 & 1.02 & 2.92 & 0.264 & 100.01 & 27 & 105 & 43 & 307 & 26 & 469 & 313 & 138 & 31 & 11.8 & 64 & 102 & 20 \\
\hline GRB & Basalt of Meyer Ridge & 54.21 & 1.738 & 14.46 & 10.74 & 0.181 & 9.09 & 5.05 & 1.14 & 3.11 & 0.278 & 100.00 & 20 & 98 & 40 & 314 & 24 & 480 & 309 & 146 & 33 & 12.1 & 49 & 107 & 20 \\
\hline GRB & Basalt of Meyer Ridge & 53.89 & 1.730 & 14.49 & 10.83 & 0.169 & 9.45 & 5.04 & 1.03 & 3.09 & 0.275 & 99.99 & 20 & 85 & 47 & 328 & 21 & 433 & 311 & 142 & 33 & 11.3 & 54 & 105 & 22 \\
\hline GRB & Basalt of Meyer Ridge & 51.73 & 1.703 & 14.57 & 12.55 & 0.25 & 9.76 & 5.46 & 0.66 & 2.97 & 0.358 & 100.00 & 15 & 123 & 42 & 347 & 9 & 553 & 367 & 130 & 33 & 10.9 & 52 & 107 & 23 \\
\hline GRB & Basalt of Meyer Ridge & 54.42 & 1.750 & 14.69 & 10.07 & 0.169 & 9.51 & 4.91 & 1.24 & 2.96 & 0.280 & 100.00 & 21 & 93 & 39 & 318 & 28 & 409 & 314 & 144 & 33 & 12.8 & 71 & 108 & 23 \\
\hline \begin{tabular}{|l|} 
GRB \\
\end{tabular} & Basalt of Meyer Ridge & 53.84 & 1.655 & 14.77 & 10.26 & 0.174 & 9.77 & 5.29 & 0.94 & 3.04 & 0.258 & 100.00 & 24 & 118 & 45 & 318 & 20 & 411 & 325 & 136 & 31 & 10.5 & 64 & 106 & 21 \\
\hline GRB & Basalt of Meyer Ridge & 52.35 & 1.768 & 14.88 & 12.56 & 0.173 & 9.24 & 5.06 & 0.72 & 2.98 & 0.276 & 100.01 & 18 & 97 & 37 & 326 & 18 & 422 & 324 & 149 & 32 & 10.2 & 36 & 112 & 17 \\
\hline GRB & Basalt of Meyer Ridge & 54.38 & 1.713 & 14.44 & 10.92 & 0.171 & 9.00 & 5.02 & 1.17 & 2.93 & 0.267 & 100.01 & 22 & 97 & 38 & 328 & 27 & 499 & 313 & 141 & 30 & 10.9 & 46 & 99 & 18 \\
\hline GRB & Basalt of Meyer Ridge & 54.00 & 1.706 & 14.38 & 11.00 & 0.189 & 9.12 & 5.29 & 1.10 & 2.95 & 0.267 & 100.00 & 21 & 90 & 41 & 320 & 29 & 507 & 314 & 140 & 31 & 11.1 & 53 & 107 & 19 \\
\hline GRB & Basalt of Meyer Ridge & 53.90 & 1.596 & 14.68 & 10.67 & 0.174 & 9.62 & 5.40 & 0.92 & 2.79 & 0.256 & 100.01 & 34 & 119 & 40 & 320 & 19 & 404 & 312 & 133 & 31 & 11.7 & 70 & 101 & 17 \\
\hline GRB & Basalt of Meyer Ridge & 54.61 & 1.684 & 14.62 & 10.67 & 0.188 & 8.96 & 4.99 & 1.14 & 2.86 & 0.267 & 99.99 & 22 & 99 & 37 & 323 & 25 & 494 & 307 & 140 & 32 & 12.7 & 56 & 100 & 16 \\
\hline GRB & Basalt of Meyer Ridge & 54.40 & 1.659 & 14.71 & 10.49 & 0.186 & 9.19 & 5.14 & 1.15 & 2.80 & 0.267 & 99.99 & 28 & 97 & 41 & 330 & 28 & 429 & 307 & 136 & 32 & 12.4 & \begin{tabular}{|l|l|}
63 \\
\end{tabular} & 102 & 21 \\
\hline GRB & Basalt of Meyer Ridge & 53.63 & 1.597 & 14.89 & 11.06 & 0.182 & 9.49 & 5.40 & 0.90 & 2.59 & 0.245 & 99.98 & 30 & 124 & 542 & 319 & 26 & 460 & 318 & 130 & 31 & 11.4 & 62 & 96 & 18 \\
\hline GRB & Basalt of Meyer Ridge & 54.17 & 1.749 & 14.59 & 10.75 & 0.179 & 9.04 & 4.93 & 1.25 & 3.06 & 0.276 & 99.99 & 23 & 94 & 40 & 337 & 30 & 524 & 312 & 146 & 33 & 10.1 & 47 & 105 & 20 \\
\hline GRB & Basalt of Meyer Ridge & 53.65 & 1.721 & 14.47 & 10.99 & 0.173 & 9.41 & 5.16 & 1.00 & 3.16 & 0.274 & 100.01 & 19 & 89 & 45 & 316 & 19 & 454 & 316 & 143 & 32 & 11.3 & 57 & 106 & 21 \\
\hline \begin{tabular}{|l|} 
GRB \\
\end{tabular} & Basalt of Meyer Ridge & 54.12 & 1.739 & 14.44 & 10.93 & 0.196 & 8.99 & \begin{tabular}{|l|}
5.04 \\
\end{tabular} & 1.16 & 3.11 & 0.275 & 100.00 & 21 & 89 & 50 & 330 & 27 & 499 & 308 & 146 & 31 & 11.2 & 46 & 105 & 18 \\
\hline GRB & Basalt of Meyer Ridge & 53.30 & 1.631 & 14.64 & 10.87 & 0.169 & 9.80 & 5.43 & 0.85 & 3.06 & 0.253 & 100.00 & 26 & 120 & 48 & 309 & 16 & 389 & 323 & 134 & 31 & 11.9 & 47 & 101 & 22 \\
\hline GRB & Basalt of Meyer Ridge & 53.95 & 1.671 & 14.85 & 9.96 & 0.187 & 9.75 & 5.34 & 0.93 & 3.10 & 0.265 & 100.00 & 29 & 114 & 46 & 321 & 18 & 476 & 323 & 138 & 30 & 10.5 & 68 & 104 & 19 \\
\hline GRB & Basalt of Meyer Ridge & 53.05 & 1.571 & 14.58 & 10.78 & 0.163 & 9.71 & \begin{tabular}{|l|}
6.03 \\
\end{tabular} & 0.82 & 3.06 & 0.247 & 100.01 & 35 & 143 & 44 & 293 & 12 & 368 & 313 & 129 & 30 & 10.2 & 68 & 100 & 21 \\
\hline GRB & Basalt of Meyer Ridge & 53.28 & 1.630 & 14.52 & 10.89 & 0.186 & 9.52 & 5.60 & 0.91 & 3.20 & 0.256 & 99.99 & 26 & 113 & 47 & 314 & 15 & 382 & 315 & 134 & 30 & 10.6 & 54 & 100 & 20 \\
\hline GRB & Basalt of Meyer Ridge & 53.79 & 1.730 & 14.36 & 11.37 & 0.176 & 9.00 & 5.04 & 1.19 & 3.06 & 0.271 & 99.99 & 21 & 94 & 40 & 314 & 28 & 453 & 305 & 144 & 32 & 11.0 & 44 & 105 & 18 \\
\hline GRB & Basalt of Meyer Ridge & 53.67 & 1.719 & 14.37 & 11.72 & 0.182 & 8.88 & 5.04 & 1.15 & 3.00 & 0.269 & 100.00 & 20 & 97 & 43 & 326 & 30 & 435 & 305 & 141 & 31 & 10.9 & 53 & 105 & 19 \\
\hline GRB & Basalt of Meyer Ridge & 53.73 & 1.705 & 14.81 & 11.01 & 0.166 & 9.28 & 5.07 & 0.97 & 2.98 & 0.270 & 99.99 & 23 & 109 & 44 & 329 & 22 & 457 & 321 & 141 & 33 & 10.6 & 40 & 99 & 22 \\
\hline GRB & Basalt of Meyer Ridge & 53.93 & 1.694 & 14.42 & 11.50 & 0.176 & 8.94 & 4.96 & 1.18 & 2.93 & 0.275 & 100.01 & 18 & 89 & 45 & 315 & 30 & 493 & 313 & 144 & 33 & 13.3 & 46 & 110 & 20 \\
\hline GRB & Basalt of Meyer Ridge & 53.99 & 1.703 & 14.32 & 11.14 & 0.192 & 8.93 & 5.14 & 1.24 & 3.07 & 0.274 & 100.00 & 20 & 88 & 39 & 322 & 28 & 445 & 303 & 145 & 31 & 11.0 & 49 & 106 & 20 \\
\hline GRB & Basalt of Meyer Ridge & 53.55 & 1.712 & 14.31 & 11.82 & 0.185 & 8.92 & 5.11 & 1.08 & 3.05 & 0.267 & 100.00 & 18 & 91 & 47 & 322 & 25 & 539 & 311 & 143 & 32 & 10.7 & 39 & 99 & 19 \\
\hline GRB & Basalt of Meyer Ridge & 53.61 & 1.614 & 14.40 & 10.90 & 0.188 & 9.48 & 5.56 & 0.91 & 3.09 & 0.255 & 100.01 & 27 & 116 & 38 & 311 & 15 & 404 & 307 & 135 & 31 & 10.3 & 58 & 99 & 17 \\
\hline GRB & Basalt of Meyer Ridge & 53.44 & 1.596 & 14.45 & 10.88 & 0.172 & 9.68 & 5.66 & 0.83 & 3.03 & 0.249 & 99.99 & 30 & 125 & 39 & 309 & 13 & 369 & 309 & 131 & 29 & 11.0 & 56 & 101 & 21 \\
\hline
\end{tabular}


Table G.1. (contd)

\begin{tabular}{|c|c|c|c|c|c|c|c|c|c|c|c|c|c|c|c|c|c|c|c|c|c|c|c|c|c|}
\hline \multirow[b]{2}{*}{ Formation } & \multirow[b]{2}{*}{ Unit Ident. } & \multicolumn{11}{|c|}{ Major Oxides (weight per cent) } & \multicolumn{13}{|c|}{ Trace Elements (ppm) } \\
\hline & & $\mathrm{SiO}_{2}$ & $\mathrm{TiO}_{2}$ & $\mathrm{Al}_{2} \mathrm{O}_{3}$ & $\mathrm{FeO}^{*}$ & $\mathrm{MnO}$ & $\mathrm{CaO}$ & $\mathrm{MgO}$ & $\mathrm{K}_{2} \mathrm{O}$ & $\mathrm{Na}_{2} \mathrm{O}$ & $\mathrm{P}_{2} \mathrm{O}_{5}$ & TOTAL & $\mathrm{Ni}$ & $\mathrm{Cr}$ & $\mathrm{Sc}$ & $\mathrm{V}$ & $\mathrm{Rb}$ & $\mathrm{Ba}$ & $\mathrm{Sr}$ & $\mathrm{Zr}$ & $\mathrm{Y}$ & $\mathrm{Nb}$ & $\mathrm{Cu}$ & $\mathrm{Zn}$ & $\mathrm{Ga}$ \\
\hline 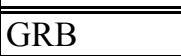 & Basalt of Meyer Ridge & 54.19 & 1.673 & $\begin{array}{lll}14.40 \\
140\end{array}$ & 11.06 & 0.202 & 8.88 & 5.12 & 21.18 & 3.04 & 0.267 & 100.01 & 221 & 96 & 43 & 306 & 29 & 731 & 323 & 1141 & 31 & 111.3 & $\overline{145}$ & 1108 & $\overline{19}$ \\
\hline GRB & Basalt of Meyer Ridge & 54.22 & 1.713 & 14.33 & 10.95 & 0.186 & 8.87 & 5.19 & 1.11 & 3.17 & 0.271 & 100.01 & 20 & 95 & 39 & 316 & 26 & 480 & 303 & 144 & 31 & 12.4 & 51 & 107 & 21 \\
\hline GRB & Basalt of Meyer Ridge & 53.63 & 1.636 & 14.26 & 11.35 & 0.199 & 9.33 & 5.38 & 0.94 & 3.01 & 0.258 & 99.99 & 22 & 102 & 40 & 311 & 18 & 483 & 310 & 135 & 31 & 10.6 & 50 & 102 & 22 \\
\hline GRB & Basalt of Meyer Ridge & 54.39 & 1.711 & 14.35 & 10.76 & 0.186 & 8.92 & 5.16 & 1.09 & 3.16 & 0.274 & 100.00 & 20 & 100 & 39 & 326 & 24 & 505 & 308 & 144 & 29 & 11.5 & 52 & 107 & 21 \\
\hline GRB & Basalt of Meyer Ridge & 52.47 & 1.718 & 14.18 & 11.71 & 0.202 & 9.64 & 5.67 & 1.19 & 2.92 & 0.290 & 99.99 & 11 & 110 & 47 & 342 & 20 & 384 & 351 & 130 & 31 & 10.6 & 40 & 108 & 21 \\
\hline GRB & Basalt of Meyer Ridge & 53.28 & 1.702 & 14.43 & 11.31 & 0.196 & 9.86 & 5.00 & 0.97 & 2.95 & 0.288 & 99.99 & 8 & 107 & 50 & 363 & 27 & 400 & 361 & 129 & 29 & 10.9 & 40 & 111 & 20 \\
\hline GRB & Basalt of Meyer Ridge & 54.40 & 1.691 & 14.64 & 10.24 & 0.172 & 9.16 & 5.20 & 1.20 & 3.03 & 0.267 & 100.00 & 20 & 96 & 44 & 327 & 28 & 475 & 311 & 141 & 30 & 10.2 & 50 & 104 & 19 \\
\hline GRB & Basalt of Meyer Ridge & 54.49 & 1.735 & 14.37 & 10.48 & 0.187 & 9.01 & 5.19 & 1.19 & 3.08 & 0.266 & 100.00 & 22 & 93 & 37 & 330 & 25 & 460 & 308 & 142 & 30 & 10.0 & 49 & 110 & 20 \\
\hline GRB & Basalt of Meyer Ridge & 54.25 & 1.724 & 14.56 & 10.29 & 0.185 & 9.33 & 5.22 & 1.11 & 3.07 & 0.270 & 100.01 & 24 & 102 & 37 & 321 & 22 & 474 & 310 & 141 & 30 & 10.4 & 55 & 104 & 17 \\
\hline GRB & Basalt of Meyer Ridge & 51.72 & 1.771 & 15.53 & 12.64 & 0.181 & 9.76 & 4.72 & 0.44 & 2.98 & 0.254 & 100.00 & 22 & 119 & 45 & 306 & 8 & 408 & 329 & 146 & 30 & 11.7 & 51 & 106 & 23 \\
\hline GRB & Basalt of Meyer Ridge & 53.52 & 1.672 & 14.76 & 10.56 & 0.172 & 9.67 & 5.40 & 0.96 & 3.03 & 0.254 & 100.00 & 25 & 112 & 41 & 317 & 22 & 423 & 320 & 136 & 35 & 10.9 & 83 & 123 & 21 \\
\hline GRB & Basalt of Meyer Ridge & 54.45 & 1.693 & 14.84 & 10.44 & 0.184 & 9.02 & 5.08 & 1.04 & 3.00 & 0.266 & 100.01 & 28 & 105 & 37 & 316 & 18 & 436 & 300 & 138 & 32 & 12.0 & 50 & 103 & 23 \\
\hline GRB & Basalt of Meyer Ridge & 54.83 & 1.684 & 14.66 & 10.18 & 0.191 & 9.01 & 5.12 & 1.17 & 2.89 & 0.267 & 100.00 & 34 & 106 & 38 & 331 & 27 & 431 & 296 & 137 & 32 & 13.0 & 52 & 102 & 19 \\
\hline GRB & Basalt of Meyer Ridge & 54.14 & 1.624 & 14.62 & 10.60 & 0.191 & 9.33 & 5.34 & 1.14 & 2.74 & 0.263 & 99.99 & 32 & 109 & 43 & 312 & 26 & 403 & 304 & 134 & 30 & 12.7 & $\mid 61$ & 98 & 21 \\
\hline GRB & Basalt of Meyer Ridge & 55.43 & 1.718 & 14.89 & 9.30 & 0.179 & 9.13 & 5.02 & 1.11 & 2.94 & 0.278 & 100.00 & 29 & 117 & 43 & 310 & 24 & 570 & 312 & 143 & 33 & 12.1 & 51 & 102 & 21 \\
\hline GRB & Basalt of Meyer Ridge & 54.48 & 1.741 & 14.58 & 10.42 & 0.198 & 9.22 & 5.27 & 0.86 & 2.96 & 0.267 & 100.00 & 26 & 89 & 41 & 321 & 22 & 620 & 311 & 144 & 33 & 12.9 & 37 & 107 & 20 \\
\hline GRB & Basalt of Meyer Ridge & 53.57 & 1.640 & 14.55 & 11.14 & 0.185 & 9.34 & 5.33 & 1.02 & 2.97 & 0.261 & 100.01 & 25 & 89 & 36 & 307 & 25 & 417 & 311 & 137 & 31 & 11.0 & 83 & 111 & 22 \\
\hline \begin{tabular}{|l|} 
GRB \\
\end{tabular} & Basalt of Meyer Ridge & 53.45 & 1.608 & 14.94 & 11.19 & 0.192 & 9.70 & \begin{tabular}{|l|}
5.02 \\
\end{tabular} & 0.84 & 2.80 & 0.252 & 99.99 & 31 & 131 & 37 & 307 & 25 & 422 & 331 & 136 & 32 & 11.0 & 79 & 110 & 15 \\
\hline GRB & Basalt of Meyer Ridge & 53.52 & 1.577 & 14.68 & 11.12 & 0.238 & 9.50 & 5.46 & 0.89 & 2.75 & 0.250 & 99.99 & 32 & 123 & 36 & 298 & 24 & 508 & 311 & 131 & 29 & 11.0 & 80 & 105 & 16 \\
\hline GRB & Basalt of Meyer Ridge & 53.57 & 1.508 & 14.96 & 10.41 & 0.179 & 9.51 & 5.89 & 0.94 & 2.80 & 0.241 & 100.01 & 40 & 141 & 39 & 292 & 24 & 379 & 305 & 126 & 28 & 11.0 & 68 & 99 & 20 \\
\hline GRB & Basalt of Meyer Ridge & 53.43 & 1.614 & 14.94 & 11.42 & 0.166 & 9.50 & 5.20 & 0.90 & 2.59 & 0.251 & 100.01 & 35 & 126 & 38 & 304 & 26 & 369 & 322 & 135 & 30 & 11.0 & 80 & 109 & 21 \\
\hline GRB & Basalt of Meyer Ridge & 54.09 & 1.588 & 14.89 & 10.13 & 0.168 & 9.54 & 5.44 & 0.99 & 2.92 & 0.252 & 100.01 & 36 & 152 & 36 & 304 & 21 & 470 & 310 & 132 & 30 & 11.0 & 59 & 99 & 19 \\
\hline GRB & Basalt of Meyer Ridge & 53.54 & 1.538 & 14.81 & 10.71 & 0.196 & 9.70 & 5.59 & 0.85 & 2.83 & 0.244 & 100.01 & 35 & 134 & 38 & 315 & 16 & 468 & 313 & 131 & 30 & 11.0 & 77 & 104 & 24 \\
\hline GRB & Basalt of Meyer Ridge & 54.45 & 1.688 & 14.37 & 10.89 & 0.194 & 8.98 & \begin{tabular}{|l|}
5.09 \\
\end{tabular} & 1.29 & 2.78 & 0.274 & 100.01 & 25 & 98 & 38 & 311 & 34 & 400 & 301 & 138 & 33 & 13.2 & 49 & 104 & 19 \\
\hline \begin{tabular}{|l|} 
GRB \\
\end{tabular} & Basalt of Meyer Ridge & 54.19 & 1.703 & 14.35 & 10.73 & 0.192 & 9.38 & 5.10 & 1.24 & 2.84 & 0.274 & 100.00 & 31 & 91 & 41 & 314 & 29 & 393 & 308 & 139 & 34 & 12.0 & 66 & 107 & 25 \\
\hline GRB & Basalt of Meyer Ridge & 54.11 & 1.633 & 14.47 & 10.62 & 0.199 & 9.33 & 5.44 & 1.11 & 2.82 & 0.267 & 100.00 & 30 & 101 & 38 & 305 & 27 & 379 & 304 & 132 & 29 & 10.6 & 62 & 100 & 20 \\
\hline GRB & Basalt of Meyer Ridge & 53.99 & 1.588 & 14.39 & 10.72 & 0.189 & 9.48 & 5.50 & 1.03 & 2.85 & 0.260 & 100.00 & 34 & 116 & 38 & 294 & 25 & 371 & 305 & 131 & 31 & 9.3 & 68 & 98 & 23 \\
\hline GRB & Basalt of Meyer Ridge & 53.91 & 1.553 & 14.58 & 10.26 & 0.189 & 9.70 & 5.75 & 0.94 & 2.87 & 0.246 & 100.00 & 38 & 131 & 39 & 307 & 22 & 344 & 308 & 124 & 29 & 8.5 & 67 & 97 & 22 \\
\hline GRB & Basalt of Meyer Ridge & 54.79 & 1.730 & 14.84 & 11.79 & 0.200 & 8.10 & 3.97 & 1.20 & 3.09 & 0.280 & 99.99 & 31 & & & 259 & 21 & 546 & 318 & 147 & 34 & 12.7 & 60 & 103 & 18 \\
\hline GRB & Basalt of Meyer Ridge & 54.85 & 1.730 & 14.83 & 11.70 & 0.200 & 8.12 & 4.02 & 1.20 & 3.06 & 0.280 & 99.99 & 43 & & & 289 & 23 & 518 & 318 & 148 & 36 & 13.4 & 59 & 103 & 22 \\
\hline GRB & Basalt of Meyer Ridge & 54.27 & 1.550 & 14.65 & 10.12 & 0.180 & 9.62 & 5.47 & 0.97 & 2.93 & 0.240 & 100.00 & 75 & 134 & 37 & 303 & 24 & 395 & 305 & 129 & 28 & 11.1 & $\mid 68$ & 94 & 19 \\
\hline GRB & Basalt of Wapshilla Ridge & 53.79 & 1.528 & 14.73 & 10.74 & 0.178 & 9.86 & 5.39 & 0.83 & 2.70 & 0.246 & 99.99 & 36 & 150 & 39 & 291 & 27 & 432 & 310 & 124 & 30 & 9.1 & 54 & 92 & 19 \\
\hline GRB & Basalt of Wapshilla Ridge & 57.30 & 2.460 & 14.68 & 11.73 & 0.107 & 5.61 & 2.14 & 1.79 & 3.74 & 0.441 & 100.00 & 10 & 20 & 41 & 353 & 58 & 729 & 331 & 194 & 40 & 17.5 & 33 & 143 & 24 \\
\hline GRB & Basalt of Wapshilla Ridge & 54.00 & 2.629 & 14.05 & 13.97 & 0.145 & 6.67 & 2.43 & 1.95 & 3.65 & 0.499 & 100.00 & 5 & 19 & 37 & 423 & 45 & 700 & 336 & 194 & 38 & 14.6 & 3 & 114 & 23 \\
\hline GRB & Basalt of Wapshilla Ridge & 54.19 & 2.64 & 14.04 & 13.74 & 0.147 & 6.70 & 2.46 & 1.96 & 3.63 & 0.499 & 100.00 & $\mid 6$ & 21 & 37 & 417 & 45 & 708 & 334 & 193 & 39 & 12.3 & 4 & 109 & 22 \\
\hline GRB & Basalt of Wapshilla Ridge & 54.33 & 2.241 & 13.66 & 13.09 & 0.188 & 7.36 & 3.52 & 1.64 & 3.47 & 0.501 & 100.00 & 5 & 18 & 44 & 374 & 35 & 642 & 317 & 181 & 37 & 15.1 & 26 & 129 & 24 \\
\hline GRB & Basalt of Wapshilla Ridge & 54.45 & 2.215 & 13.78 & 12.39 & 0.197 & 7.73 & 3.82 & 1.76 & 3.23 & 0.420 & 100.00 & 8 & 21 & 39 & 367 & 40 & 602 & 321 & 180 & 38 & 12.3 & 49 & 134 & 22 \\
\hline GRB & Basalt of Wapshilla Ridge & 54.61 & 2.239 & 13.91 & 12.20 & 0.214 & 7.68 & 3.77 & 1.79 & 3.17 & 0.422 & 100.00 & 4 & 21 & $\mid 46$ & 368 & 48 & 737 & 324 & 180 & 41 & 13.4 & 43 & 131 & 20 \\
\hline GRB & Basalt of Wapshilla Ridge & 55.09 & 2.214 & 13.68 & 12.35 & 0.187 & 7.62 & 3.53 & 1.70 & 3.24 & 0.387 & 100.00 & 1 & 16 & 38 & 393 & 44 & 638 & 317 & 179 & 40 & 14.9 & 20 & 128 & 23 \\
\hline GRB & Basalt of Wapshilla Ridge & 54.72 & 2.320 & 13.68 & 12.55 & 0.199 & 7.36 & 3.62 & 1.99 & 3.16 & 0.402 & 100.00 & 6 & 18 & 34 & 432 & 42 & 678 & 321 & 174 & 36 & 12.1 & 6 & 129 & 19 \\
\hline GRB & Basalt of Wapshilla Ridge & 54.76 & 2.409 & 13.64 & 12.84 & 0.204 & 7.11 & 3.49 & 1.85 & 3.19 & 0.499 & 100.00 & 2 & 21 & 35 & 366 & 43 & 633 & 317 & 189 & 41 & 14.6 & 13 & 134 & 20 \\
\hline GRB & Basalt of Wapshilla Ridge & 55.57 & 2.427 & 13.91 & 12.29 & 0.25 & 7.01 & 3.21 & 1.74 & 3.14 & 0.463 & 100.00 & 0 & 12 & 35 & 323 & 45 & 753 & 329 & 200 & 38 & 15.1 & 4 & 131 & 24 \\
\hline GRB & Basalt of Wapshilla Ridge & 57.30 & 2.368 & 14.11 & 9.93 & 0.193 & 6.97 & 3.24 & 2.34 & 3.11 & 0.441 & 100.00 & 2 & 13 & 34 & 314 & 56 & 965 & 345 & 207 & 41 & 14.1 & 3 & 135 & 24 \\
\hline GRB & Basalt of Wapshilla Ridge & 55.19 & 2.230 & 13.82 & 12.59 & 0.214 & 7.23 & 3.48 & 1.54 & 3.29 & 0.417 & 100.00 & 5 & 20 & 38 & 376 & 41 & 635 & 309 & 176 & 35 & 12.9 & 49 & 136 & 20 \\
\hline GRB & Basalt of Wapshilla Ridge & 54.78 & 2.126 & 13.81 & 13.35 & 0.219 & 7.29 & 3.27 & 1.51 & 3.23 & 0.402 & 100.00 & 15 & 35 & 39 & 364 & 38 & 607 & 320 & 173 & 39 & 12.9 & 49 & 118 & 22 \\
\hline GRB & Basalt of Wapshilla Ridge & 55.14 & 2.241 & 13.75 & 12.40 & 0.203 & 7.39 & 3.62 & 1.57 & 3.24 & 0.438 & 100.00 & 25 & 35 & 36 & 369 & 32 & 652 & 331 & 175 & 37 & 15.6 & 27 & 122 & 18 \\
\hline GRB & Basalt of Wapshilla Ridge & 55.36 & 2.260 & 13.74 & 12.55 & 0.199 & 7.28 & 3.53 & 1.58 & 3.05 & 0.448 & 100.00 & 18 & 30 & 36 & 371 & 46 & 646 & 321 & 176 & 41 & 16.6 & 29 & 121 & 23 \\
\hline
\end{tabular}


Table G.1. (contd)

\begin{tabular}{|c|c|c|c|c|c|c|c|c|c|c|c|c|c|c|c|c|c|c|c|c|c|c|c|c|c|}
\hline \multirow[b]{2}{*}{ Formation } & \multirow[b]{2}{*}{ Unit Ident. } & \multicolumn{11}{|c|}{ Major Oxides (weight per cent) } & \multicolumn{13}{|c|}{ Trace Elements (ppm) } \\
\hline & & $\mathrm{SiO}_{2}$ & $\mathrm{TiO}_{2}$ & $\mathrm{Al}_{2} \mathrm{O}_{3}$ & $\mathrm{FeO}^{*}$ & $\mathrm{MnO}$ & $\mathrm{CaO}$ & $\mathrm{MgO}$ & $\mathrm{K}_{2} \mathrm{O}$ & $\mathrm{Na}_{2} \mathrm{O}$ & $\frac{\mathrm{P}_{2} \mathrm{O}_{5}}{2}$ & TOTAL & $\mathrm{Ni}$ & $\mathrm{Cr}$ & $\mathrm{Sc}$ & $\mathrm{V}$ & $\mathrm{Rb}$ & $\mathrm{Ba}$ & $\mathrm{Sr}$ & $\mathrm{Zr}$ & $\mathrm{Y}$ & $\mathrm{Nb}$ & $\mathrm{Cu}$ & $\mathrm{Zn}$ & $\mathrm{Ga}$ \\
\hline$\overline{\overline{\text { GRB }}}$ & R2 MSU undiff. & 54.56 & 1.891 & 14.14 & 12.20 & 0.198 & 8.36 & 4.17 & 1.32 & 2.75 & 0.416 & 100.00 & 5 & 41 & 39 & 243 & 31 & 496 & 317 & 163 & 38 & 15.2 & 24 & 116 & 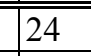 \\
\hline GRB & R2 MSU undiff. & 55.20 & 2.362 & 13.52 & 13.01 & 0.214 & 7.13 & 3.39 & 1.78 & 3.01 & 0.400 & 100.00 & 3 & 16 & 37 & 363 & 46 & 651 & 321 & 172 & 39 & 15.2 & 6 & 128 & 21 \\
\hline GRB & R2 MSU undiff. & 54.39 & 2.294 & 13.62 & 12.80 & 0.186 & 7.27 & 3.66 & 1.63 & 3.71 & 0.450 & 100.00 & 9 & 14 & 42 & 379 & 42 & 648 & 312 & 181 & 40 & 15.7 & 27 & 126 & 23 \\
\hline GRB & R2 MSU undiff. & 54.21 & 2.202 & 13.70 & 13.18 & 0.179 & 7.55 & 3.77 & 1.57 & 3.22 & 0.420 & 100.00 & 3 & 20 & 46 & 362 & 44 & 598 & 324 & 180 & 41 & 14.3 & 39 & 126 & 21 \\
\hline GRB & R2 MSU undiff. & 54.40 & 2.511 & 13.68 & 12.57 & 0.208 & 7.26 & 3.61 & 1.81 & 3.50 & 0.445 & 100.00 & 7 & 15 & 44 & 416 & 43 & 681 & 316 & 193 & 41 & 14.8 & 19 & 135 & 23 \\
\hline GRB & R2 MSU undiff. & 54.15 & 2.563 & 13.74 & 12.82 & 0.171 & 6.94 & 4.01 & 1.68 & 3.48 & 0.436 & 100.00 & 9 & 20 & 37 & 431 & 43 & 632 & 314 & 187 & 39 & 14.1 & 19 & 131 & 20 \\
\hline GRB & R2 MSU undiff. & 54.05 & 2.564 & 13.73 & 12.83 & 0.171 & 6.96 & 3.96 & 1.69 & 3.60 & 0.439 & 100.00 & 7 & 18 & 43 & 439 & 45 & 636 & 315 & 187 & 38 & 14.0 & 18 & 130 & 25 \\
\hline GRB & R2 MSU undiff. & 56.31 & 2.197 & 13.85 & 12.02 & 0.164 & 6.36 & 3.08 & 1.89 & 3.72 & 0.406 & 100.00 & 0 & 17 & 37 & 339 & 60 & 689 & 343 & 184 & 36 & 13.1 & 5 & 124 & 22 \\
\hline GRB & R2 MSU undiff. & 54.31 & 2.515 & 13.61 & 13.06 & 0.232 & 7.22 & 3.56 & 1.65 & 3.41 & 0.441 & 100.00 & 2 & 18 & 40 & 409 & 39 & 659 & 320 & 190 & 41 & 13.3 & 14 & 129 & 22 \\
\hline GRB & R2 MSU undiff. & 54.43 & 2.194 & 13.80 & 12.29 & 0.204 & 7.68 & 3.88 & 1.57 & 3.53 & 0.419 & 100.00 & 4 & 18 & 45 & 378 & 38 & 593 & 320 & 179 & 39 & 14.9 & 41 & 126 & 21 \\
\hline GRB & R2 MSU undiff. & 54.53 & 2.311 & 13.66 & 12.84 & 0.194 & 7.50 & 3.53 & 1.61 & 3.39 & 0.442 & 100.00 & 7 & 16 & 40 & 379 & 36 & 635 & 324 & 182 & 40 & 16.0 & 22 & 123 & 23 \\
\hline GRB & R2 MSU undiff. & 54.43 & 2.511 & 13.79 & 11.59 & 0.201 & 8.13 & 4.09 & 1.56 & 3.22 & 0.485 & 100.00 & 2 & 27 & 41 & 305 & 31 & 576 & 321 & 178 & 38 & 14.3 & 20 & 136 & 21 \\
\hline GRB & R2 MSU undiff. & 55.47 & 2.341 & 13.81 & 11.87 & 0.192 & 7.29 & 3.50 & 1.72 & 3.34 & 0.466 & 100.00 & 9 & 18 & 36 & 360 & 46 & 1023 & 328 & 183 & 37 & 16.1 & 25 & 131 & 20 \\
\hline GRB & R2 MSU undiff. & 54.50 & 2.205 & 13.66 & 12.51 & 0.206 & 7.60 & 3.94 & 1.59 & 3.37 & 0.415 & 100.00 & 3 & 22 & 44 & 370 & 41 & 592 & 308 & 175 & 36 & 14.0 & 36 & 127 & 22 \\
\hline GRB & R2 MSU undiff. & 55.13 & 2.047 & 13.87 & 11.81 & 0.195 & 7.61 & 3.89 & 1.67 & 3.44 & 0.345 & 100.00 & 5 & 17 & 41 & 352 & 41 & 612 & 309 & 169 & 33 & 13.6 & 23 & 118 & 21 \\
\hline GRB & R2 MSU undiff. & 55.01 & 2.250 & 13.60 & 12.37 & 0.201 & 7.38 & 3.55 & 1.81 & 3.42 & 0.407 & 100.00 & 2 & 16 & 40 & 379 & 42 & 624 & 309 & 178 & 38 & 12.3 & 17 & 126 & 21 \\
\hline GRB & R2 MSU undiff. & 53.47 & 2.560 & 13.64 & 13.07 & 0.189 & 8.38 & 4.08 & 1.13 & 3.00 & 0.474 & 100.00 & 0 & 23 & 39 & 307 & 28 & 517 & 331 & 178 & 39 & 13.1 & 8 & 126 & 24 \\
\hline GRB & R2 MSU undiff. & 55.46 & 2.117 & 13.80 & 11.56 & 0.193 & 7.70 & 4.05 & 1.43 & 3.35 & 0.345 & 100.00 & 0 & 17 & 36 & 363 & 31 & 572 & 320 & 165 & 35 & 11.3 & 8 & 122 & 25 \\
\hline GRB & R2 MSU undiff. & 54.83 & 2.173 & 13.79 & 11.80 & 0.199 & 7.93 & 4.12 & 1.60 & 3.20 & 0.362 & 100.00 & 2 & 18 & 36 & 388 & 34 & 513 & 323 & 161 & 34 & 10.5 & 9 & 125 & 21 \\
\hline GRB & R2 MSU undiff. & 56.06 & 2.221 & 13.95 & 11.82 & 0.188 & 6.93 & 3.34 & 1.93 & 3.15 & 0.401 & 100.00 & 0 & 15 & 34 & 336 & 52 & 691 & 348 & 180 & 37 & 12.7 & 1 & 125 & 24 \\
\hline GRB & R2 MSU undiff. & 55.61 & 2.367 & 13.57 & 12.61 & 0.221 & 6.63 & 2.92 & 1.94 & 3.64 & 0.476 & 100.00 & 0 & 11 & 33 & 354 & 58 & 682 & 309 & 198 & 39 & 14.2 & 7 & 137 & 23 \\
\hline GRB & R2 MSU undiff. & 55.78 & 2.361 & 13.64 & 12.25 & 0.220 & 6.63 & 2.96 & 1.94 & 3.75 & 0.475 & 100.00 & 0 & 10 & 34 & 353 & 56 & 700 & 310 & 196 & 40 & 14.0 & 9 & 136 & 22 \\
\hline GRB & R2 MSU undiff. & 57.15 & 2.426 & 14.48 & 9.63 & 0.26 & 6.87 & 3.16 & 2.39 & 3.19 & 0.448 & 100.00 & 0 & 12 & 28 & 331 & 58 & 780 & 340 & 209 & 41 & 16.0 & 4 & 137 & 25 \\
\hline GRB & R2 MSU undiff. & 54.80 & 2.559 & 13.80 & 11.90 & 0.218 & 7.37 & 3.66 & 1.72 & 3.51 & 0.464 & 100.00 & 10 & 17 & 34 & 396 & 39 & 697 & 323 & 188 & 42 & 15.3 & 17 & 127 & 19 \\
\hline GRB & R2 MSU undiff. & 54.90 & 2.564 & 13.85 & 11.68 & 0.219 & 7.41 & 3.68 & 1.72 & 3.52 & 0.468 & 100.00 & 7 & 18 & 30 & 406 & 38 & 711 & 324 & 189 & 43 & 14.5 & 14 & 134 & 24 \\
\hline GRB & R2 MSU undiff. & 54.39 & 1.935 & 13.92 & 12.18 & 0.202 & 8.41 & 4.28 & 1.31 & 2.97 & 0.413 & 100.00 & 4 & 38 & 34 & 271 & 30 & 485 & 317 & 168 & 38 & 12.3 & 15 & 121 & 23 \\
\hline GRB & R2 MSU undiff. & 57.27 & 2.002 & 14.00 & 10.52 & 0.174 & 6.97 & 3.30 & 2.15 & 3.28 & 0.332 & 100.00 & 0 & 13 & 35 & 323 & 56 & 768 & 317 & 186 & 37 & 12.9 & 6 & 121 & 21 \\
\hline GRB & R2 MSU undiff. & 55.40 & 2.307 & 13.85 & 11.82 & 0.200 & 7.29 & 3.56 & 1.89 & 3.26 & 0.414 & 99.99 & 5 & 18 & 40 & 370 & 44 & 899 & 328 & 184 & 40 & 12.9 & 23 & 132 & 23 \\
\hline GRB & R2 MSU undiff. & 52.70 & 2.512 & 14.77 & 14.29 & 0.191 & 7.31 & 3.16 & 1.25 & 3.34 & 0.471 & 99.99 & 7 & 17 & 42 & 369 & 32 & 685 & 350 & 197 & 38 & 16.4 & 34 & 131 & 26 \\
\hline GRB & R2 MSU undiff. & 54.66 & 2.511 & 13.76 & 12.33 & 0.197 & 7.25 & 3.52 & 1.78 & 3.54 & 0.452 & 100.00 & 5 & 15 & 37 & 394 & 40 & 706 & 324 & 195 & 42 & 13.8 & 22 & 132 & 21 \\
\hline GRB & R2 MSU undiff. & 54.51 & 2.517 & 13.71 & 12.61 & 0.183 & 7.03 & 3.62 & 1.74 & 3.62 & 0.456 & 100.00 & 6 & 18 & 38 & 396 & 45 & 676 & 315 & 190 & 41 & 13.6 & 12 & 133 & 22 \\
\hline GRB & R2 MSU undiff. & 56.34 & 2.323 & 13.90 & 11.54 & 0.177 & 6.78 & 3.09 & 2.15 & 3.29 & 0.435 & 100.03 & 0 & 14 & 34 & 325 & 62 & 814 & 332 & 205 & 44 & 15.3 & 2 & 133 & 26 \\
\hline GRB & R2 MSU undiff. & 55.51 & 2.323 & 13.87 & 12.22 & 0.190 & 6.98 & 3.32 & 2.03 & 3.13 & 0.424 & 100.00 & 0 & 13 & 38 & 337 & 49 & 765 & 332 & 203 & 42 & 15.0 & 3 & 132 & 25 \\
\hline GRB & R2 MSU undiff. & 54.79 & 2.356 & 13.67 & 12.98 & 0.206 & 7.01 & 3.38 & 1.83 & 3.31 & 0.457 & 99.99 & 0 & 12 & 38 & 376 & 47 & 681 & 327 & 197 & 42 & 15.1 & 4 & 133 & 23 \\
\hline GRB & R2 MSU undiff. & 54.84 & 2.341 & 13.59 & 13.41 & 0.196 & 6.85 & 3.20 & 1.90 & 3.22 & 0.459 & 100.01 & 0 & 13 & 34 & 355 & 53 & 724 & 324 & 199 & 42 & 15.1 & 7 & 134 & 21 \\
\hline GRB & R2 MSU undiff. & 54.86 & 2.338 & 13.91 & 12.03 & 0.202 & 7.51 & 3.50 & 2.01 & 3.23 & 0.413 & 100.00 & 5 & 20 & 44 & 424 & 43 & 652 & 331 & 177 & 40 & 13.7 & 6 & 130 & 23 \\
\hline GRB & R2 MSU undiff. & 54.84 & 2.250 & 13.67 & 12.94 & 0.192 & 7.15 & 3.66 & 1.58 & 3.31 & 0.403 & 100.00 & 4 & 17 & 38 & 374 & 37 & 648 & 310 & 181 & 42 & 16.1 & 24 & 130 & 22 \\
\hline GRB & R2 MSU undiff. & 55.24 & 2.595 & 14.06 & 11.68 & 0.174 & 7.53 & 3.38 & 1.70 & 3.21 & 0.440 & 100.01 & 6 & 17 & 34 & 409 & 41 & 677 & 329 & 192 & 43 & 15.1 & 25 & 138 & 25 \\
\hline GRB & R2 MSU undiff. & 54.65 & 2.203 & 13.65 & 12.91 & 0.199 & 7.67 & 3.64 & 1.59 & 3.06 & 0.413 & 99.99 & 2 & 21 & 35 & 372 & 45 & 591 & 315 & 178 & 43 & 15.7 & 43 & 131 & 23 \\
\hline GRB & R2 MSU undiff. & 54.62 & 2.291 & 13.96 & 12.57 & 0.190 & 7.49 & 3.59 & 1.39 & 3.45 & 0.462 & 100.01 & 13 & 41 & 39 & 379 & 33 & 582 & 340 & 160 & 38 & 12.9 & 20 & 122 & 20 \\
\hline GRB & R2 MSU undiff. & 55.10 & 2.110 & 13.97 & 12.12 & 0.200 & 7.32 & 4.01 & 1.54 & 3.21 & 0.410 & 99.99 & 10 & 16 & 35 & 380 & 40 & 591 & 301 & 170 & 39 & 15.7 & 45 & 120 & 23 \\
\hline GRB & R2 MSU undiff. & 55.55 & 2.388 & 13.71 & 12.52 & 0.210 & 7.13 & 3.30 & 1.61 & 3.18 & 0.402 & 100.00 & 1 & 16 & 41 & 365 & 36 & 629 & 325 & 175 & 41 & 15.9 & 10 & 127 & 24 \\
\hline GRB & R2 MSU undiff. & 54.59 & 2.280 & 13.81 & 12.38 & 0.218 & 7.82 & 3.88 & 1.40 & 3.18 & 0.453 & 100.01 & 13 & 40 & 41 & 383 & 35 & 606 & 341 & 161 & 39 & 12.6 & 16 & 122 & 25 \\
\hline GRB & R2 MSU undiff. & 56.61 & 2.270 & 14.01 & 10.96 & 0.220 & 7.08 & 3.40 & 1.92 & 3.14 & 0.400 & 100.01 & 45 & 12 & 32 & 334 & 58 & 846 & 364 & 180 & 37 & 14.6 & 14 & 121 & 21 \\
\hline GRB & R2 MSU undiff. & 56.06 & 2.140 & 13.94 & 12.15 & 0.190 & 6.83 & 3.28 & 1.91 & 3.11 & 0.400 & 100.01 & 25 & - & & 332 & 47 & 686 & 346 & 179 & 34 & 15.2 & 21 & 116 & 19 \\
\hline GRB & R2 MSU undiff. & 55.84 & 2.280 & 13.65 & 12.75 & 0.190 & 6.56 & 3.03 & 1.79 & 3.44 & 0.470 & 100.00 & 210 & 3 & 32 & 337 & 51 & 701 & 313 & 197 & 44 & 17.1 & 20 & 135 & 21 \\
\hline GRB & R2 MSU undiff. & 55.98 & 2.290 & 13.63 & 12.56 & 0.190 & 6.59 & 2.99 & 1.81 & 3.49 & 0.470 & 100.00 & 17 & & & 342 & 51 & 707 & 313 & 198 & 45 & 17.5 & 20 & 137 & 25 \\
\hline
\end{tabular}


Table G.1. (contd)

\begin{tabular}{|c|c|c|c|c|c|c|c|c|c|c|c|c|c|c|c|c|c|c|c|c|c|c|c|c|c|}
\hline \multirow{2}{*}{ Formation } & \multirow[b]{2}{*}{ Unit Ident. } & \multicolumn{11}{|c|}{ Major Oxides (weight per cent) } & \multicolumn{13}{|c|}{ Trace Elements (ppm) } \\
\hline & & $\mathrm{SiO}_{2}$ & $\mathrm{TiO}_{2}$ & $\mathrm{Al}_{2} \mathrm{O}_{3}$ & $\mathrm{FeO}^{*}$ & $\mathrm{MnO}$ & $\mathrm{CaO}$ & $\mathrm{MgO}$ & $\mathrm{K}_{2} \mathrm{O}$ & $\mathrm{Na}_{2} \mathrm{O}$ & $\mathrm{P}_{2} \mathrm{O}_{5}$ & TOTAL & $\mathrm{Ni}$ & $\mathrm{Cr}$ & $\mathrm{Sc}$ & $\mathrm{V}$ & $\mathrm{Rb}$ & $\mathrm{Ba}$ & $\mathrm{Sr}$ & $\mathrm{Zr}$ & $\mathrm{Y}$ & $\mathrm{Nb}$ & $\mathrm{Cu}$ & $\mathrm{Zn}$ & $\mathrm{Ga}$ \\
\hline$\overline{\text { GRB }}$ & R2 MSU undiff. & 55.61 & 2.290 & 13.64 & 12.78 & 0.200 & 6.82 & 3.17 & 2.18 & 2.85 & 0.460 & 100.00 & 20 & 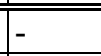 & & 335 & 52 & 715 & 317 & 1196 & 442 & 15.1 & $\overline{120}$ & 1128 & 23 \\
\hline GRB & R2 MSU undiff. & 55.86 & 2.280 & 13.85 & 11.92 & 0.190 & 6.87 & 3.28 & 2.06 & 3.27 & 0.420 & 100.00 & 12 & - & - & 307 & 50 & 737 & 317 & 196 & 39 & 17.0 & 10 & 119 & 25 \\
\hline GRB & R2 MSU undiff. & 53.55 & 2.580 & 14.23 & 13.76 & 0.220 & 7.20 & 3.46 & 1.78 & 2.76 & 0.460 & 100.00 & 31 & - & - & 377 & 43 & 656 & 335 & 194 & 40 & 17.1 & 29 & 125 & 23 \\
\hline GRB & R2 MSU undiff. & 54.37 & 2.120 & 13.66 & 13.07 & 0.200 & 7.55 & 3.86 & 1.71 & 3.04 & 0.430 & 100.01 & 32 & 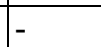 & & 359 & 43 & 588 & 311 & 175 & 36 & 14.8 & 51 & 118 & 19 \\
\hline GRB & R2 MSU undiff. & 54.65 & 2.130 & 13.68 & 12.72 & 0.200 & 7.62 & 3.78 & 1.76 & 3.04 & 0.410 & 99.99 & 26 & - & - & 354 & 45 & 582 & 314 & 173 & 37 & 14.2 & 44 & 118 & 24 \\
\hline GRB & R2 MSU undiff. & 57.09 & 2.380 & 14.04 & 10.13 & 0.200 & 7.19 & 3.38 & 2.04 & \begin{tabular}{|l|}
3.09 \\
\end{tabular} & 0.460 & 100.00 & \begin{tabular}{|l|}
40 \\
\end{tabular} & 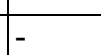 & & 323 & 52 & 986 & 359 & 187 & 40 & 16.0 & 36 & 128 & 20 \\
\hline GRB & R2 MSU undiff. & 57.08 & 2.400 & 14.02 & 10.09 & 0.200 & 7.24 & 3.33 & 2.08 & 3.11 & 0.460 & 100.01 & 69 & 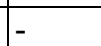 & & 339 & 53 & 999 & 359 & 190 & 41 & 17.0 & 29 & 128 & 21 \\
\hline GRB & N1 MSU undiff. & 54.60 & 1.869 & 14.11 & 12.15 & 0.186 & 8.01 & 4.20 & 1.53 & 3.04 & 0.307 & 100.00 & 2 & 18 & 40 & 332 & 29 & 507 & 328 & 160 & 35 & 10.9 & 29 & 112 & 22 \\
\hline GRB & N1 MSU undiff. & 54.44 & 1.708 & 14.53 & 11.13 & 0.166 & \begin{tabular}{|l|}
8.71 \\
\end{tabular} & 4.98 & 1.07 & \begin{tabular}{|l|}
3.01 \\
\end{tabular} & 0.256 & 100.00 & $\mid 5$ & 22 & 35 & 313 & 24 & 470 & 340 & 148 & 31 & 9.7 & 35 & 103 & 21 \\
\hline GRB & N1 MSU undiff. & 54.97 & 1.712 & 14.49 & 10.70 & 0.173 & 8.62 & 4.81 & 1.30 & 2.97 & 0.259 & 100.00 & 5 & 24 & 35 & 318 & 35 & 425 & 327 & 144 & 30 & 10.4 & 24 & 104 & 18 \\
\hline GRB & N1 MSU undiff. & 55.04 & 1.973 & 14.19 & 11.75 & 0.207 & 7.96 & 4.12 & 1.10 & 3.31 & 0.348 & 100.00 & 5 & 20 & 36 & 390 & 20 & 535 & 325 & 160 & 34 & 10.4 & 16 & 123 & 20 \\
\hline GRB & N1 MSU undiff. & 55.34 & 1.693 & 14.43 & 11.04 & 0.143 & 7.97 & 4.75 & 1.23 & 3.16 & 0.247 & 100.00 & 8 & 28 & 39 & 311 & 37 & 440 & 318 & 142 & 31 & 10.0 & 36 & 103 & 19 \\
\hline GRB & N1 MSU undiff. & 55.10 & 1.713 & 14.50 & 10.99 & 0.179 & 8.42 & 4.72 & 1.15 & 2.96 & 0.272 & 100.00 & 10 & 28 & 39 & 316 & 28 & 448 & 324 & 144 & 34 & 12.7 & 39 & 109 & 20 \\
\hline GRB & N1 MSU undiff. & 54.90 & 1.672 & 14.52 & 10.90 & \begin{tabular}{|l|l|}
0.184 \\
\end{tabular} & 8.56 & 4.83 & 1.13 & 3.06 & 0.253 & 100.01 & 11 & 33 & 39 & 316 & 27 & 442 & 323 & 140 & 30 & 10.4 & 34 & 103 & 21 \\
\hline GRB & N1 MSU undiff. & 55.10 & 1.694 & 14.77 & 10.42 & 0.173 & 8.73 & 4.86 & 1.11 & 2.86 & 0.271 & 99.99 & 14 & 43 & 34 & 316 & 26 & 428 & 330 & 142 & 34 & 11.5 & 27 & 104 & 20 \\
\hline GRB & N1 MSU undiff. & 57.51 & 2.180 & 13.66 & 11.25 & 0.180 & 6.55 & 2.91 & 2.05 & 3.38 & 0.320 & 99.99 & $\mid 50$ & 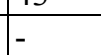 & & 348 & 53 & 693 & 315 & 196 & 39 & 15.2 & 26 & 127 & 22 \\
\hline GRB & N1 MSU undiff. & 55.76 & 2.050 & 13.98 & 11.79 & 0.170 & 7.60 & 3.85 & 1.65 & 2.84 & 0.290 & 99.98 & 30 & - & - & 309 & 42 & 551 & 318 & 173 & 36 & 14.4 & 48 & 112 & 19 \\
\hline GRB & N1 MSU undiff. & 56.14 & 2.060 & 14.10 & 11.28 & 0.170 & 7.60 & 3.86 & 1.65 & 2.84 & 0.290 & 99.99 & 34 & - & - & 345 & 45 & 606 & 320 & 178 & 35 & 14.3 & 43 & 111 & 21 \\
\hline GRB & N1 MSU undiff. & 55.44 & 2.000 & 13.75 & 12.04 & 0.210 & 7.75 & 3.91 & 1.57 & 3.02 & 0.310 & 100.00 & $\mid 27$ & 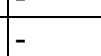 & & 323 & 40 & 572 & 317 & 172 & 34 & 14.6 & 39 & 111 & 20 \\
\hline GRB & N1 MSU undiff. & 55.01 & 2.110 & 13.65 & 12.43 & 0.210 & 7.51 & 3.75 & 1.75 & 3.15 & 0.430 & 100.00 & 45 & 11 & 37 & 387 & 36 & 613 & 319 & 181 & 40 & 13.9 & 60 & 128 & 21 \\
\hline GRB & N1 MSU undiff. & 55.32 & 2.120 & 14.02 & 11.89 & 0.200 & 7.56 & 3.61 & 1.75 & 3.12 & 0.420 & 100.01 & 33 & & & 394 & 37 & 668 & 325 & 183 & 40 & 13.4 & 52 & 124 & 20 \\
\hline GRB & N1 MSU undiff. & 55.87 & 2.000 & 13.74 & 12.45 & 0.190 & 7.21 & 3.67 & 1.64 & 2.91 & 0.310 & 99.99 & 25 & 5 & 31 & 349 & 44 & 560 & 311 & 183 & 38 & 16.0 & 30 & 113 & 21 \\
\hline GRB & N1 MSU undiff. & 55.99 & 1.710 & 14.12 & 11.23 & \begin{tabular}{|l|l|}
0.190 \\
\end{tabular} & 7.79 & \begin{tabular}{|l|l|}
4.18 \\
\end{tabular} & 1.39 & 3.17 & 0.230 & 100.00 & 26 & 7 & 34 & 312 & 35 & 487 & 315 & 150 & 31 & 12.8 & 16 & \begin{tabular}{|l|}
102 \\
\end{tabular} & 23 \\
\hline GRB & N1 MSU undiff. & 56.14 & 1.740 & 14.27 & 11.07 & 0.190 & 7.79 & 4.05 & 1.62 & 2.90 & 0.230 & 100.00 & 15 & - & & 320 & 47 & 517 & 318 & 153 & 32 & 12.6 & 22 & 105 & 20 \\
\hline GRB & N1 MSU undiff. & 54.96 & 1.690 & 14.60 & 10.64 & 0.190 & 8.61 & 4.81 & 1.37 & 2.85 & 0.280 & 100.00 & 31 & - & - & 292 & 31 & 519 & 323 & 147 & 31 & 12.0 & 19 & 104 & 18 \\
\hline GRB & N1 MSU undiff. & 55.08 & 1.670 & 14.55 & 10.96 & 0.190 & \begin{tabular}{|l|l|}
8.63 \\
\end{tabular} & 4.74 & 1.18 & 2.75 & 0.270 & 100.02 & 30 & 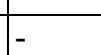 & - & 285 & 30 & 450 & 317 & 145 & 31 & 12.0 & 24 & 106 & 20 \\
\hline GRB & N1 MSU undiff. & 54.62 & 2.130 & 13.64 & 13.00 & 0.210 & 7.48 & 3.82 & 1.68 & 3.04 & 0.390 & 100.01 & \begin{tabular}{|l|}
16 \\
\end{tabular} & - & - & 365 & 41 & 548 & 310 & 161 & 34 & 11.8 & 16 & 114 & 21 \\
\hline GRB & N1 MSU undiff. & 54.62 & 2.240 & 13.56 & 12.67 & 0.210 & 7.64 & 3.75 & 1.78 & 3.11 & 0.420 & 100.00 & 26 & - & & 422 & 38 & 554 & 314 & 168 & 38 & 15.4 & 42 & 122 & 19 \\
\hline GRB & N1 MSU undiff. & 54.69 & \begin{tabular}{|l|l|}
2.24170 \\
\end{tabular} & 13.83 & 13.03 & $\mid 0.170$ & 7.07 & \begin{tabular}{|l|l|}
.73 \\
\end{tabular} & 1.10 & \begin{tabular}{|l|}
2.11 \\
\end{tabular} & 0.390 & \begin{tabular}{|l|l|}
100.01 \\
\end{tabular} & \begin{tabular}{|l|}
23 \\
23
\end{tabular} & 19 & 34 & 381 & 38 & \begin{tabular}{|l|l|}
532 \\
\end{tabular} & 322 & 160 & 35 & $\mid 13.1$ & $\frac{42}{21}$ & $\frac{122}{119}$ & 22 \\
\hline GRB & N1 MSU undiff. & 55.15 & 2.010 & 14.05 & 11.73 & 0.200 & 7.83 & 4.05 & 1.51 & 3.08 & 0.390 & 100.00 & 27 & - & ותן & 368 & 37 & 521 & 319 & 160 & 34 & 12.2 & 32 & 117 & 18 \\
\hline GRB & N1 MSU undiff. & 54.41 & 2.010 & 13.72 & 13.06 & 0.210 & 7.74 & 4.02 & 1.28 & 3.18 & 0.390 & 100.02 & 45 & - & & 356 & 29 & 538 & 319 & 158 & 36 & 11.9 & 31 & 113 & 21 \\
\hline GRB & N1 MSU undiff. & 53.99 & $\begin{array}{l}2.010 \\
2.040\end{array}$ & 14.01 & 13.06 & 0.210 & 7.83 & $\mid \begin{array}{l}7.02 \\
.09\end{array}$ & 1.43 & \begin{tabular}{|l|l|}
.16 \\
\end{tabular} & 0.390 & 99.98 & 38 & - & - & 358 & 39 & 534 & 320 & 158 & 37 & 12.0 & 29 & 113 & 18 \\
\hline GRB & N1 MSU undiff. & 53.90 & \begin{tabular}{|l|l|}
2.090 \\
\end{tabular} & 14.20 & 13.27 & 0.210 & 7.86 & 3.85 & 1.28 & 2.94 & 0.390 & 99.99 & 24 & + & & 290 & 32 & 492 & 324 & 163 & 36 & 12.8 & 37 & 119 & 20 \\
\hline GRB & N1 MSU undiff. & 54.72 & 1.860 & 13.87 & 12.36 & 0.210 & 7.75 & 4.25 & 1.31 & 3.34 & 0.330 & 100.00 & 47 & 15 & 35 & 364 & 33 & 500 & 316 & 157 & 34 & 13.9 & 43 & 112 & 21 \\
\hline GRB & N1 MSU undiff. & 55.52 & 1.840 & 13.99 & 11.88 & 0.180 & 7.62 & 4.02 & 1.37 & 3.25 & 0.330 & 100.00 & 39 & - & - & 360 & 41 & 521 & 311 & 155 & 33 & 12.3 & 37 & 106 & 20 \\
\hline GRB & N1 MSU undiff. & 55.70 & $\begin{array}{l}1.070 \\
.910\end{array}$ & 14.03 & 11.65 & 0.210 & 7.60 & 3.86 & 1.47 & \begin{tabular}{|l|}
3.23 \\
\end{tabular} & 0.350 & 100.01 & \begin{tabular}{|l|l|}
11 \\
\end{tabular} & 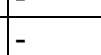 & & 356 & 31 & 537 & 319 & 170 & 36 & 13.5 & 42 & 115 & 21 \\
\hline GRB & N1 MSU undiff. & 55.23 & 1.700 & 14.52 & 10.60 & 0.180 & 8.50 & \begin{tabular}{|l|l|}
4.62 \\
\end{tabular} & 1.47 & 2.91 & 0.260 & 99.99 & 132 & $1-$ & - & 325 & 31 & 446 & 327 & 146 & 31 & 11.2 & 33 & 106 & 24 \\
\hline GRB & N1 MSU undiff. & 54.40 & 2.260 & 13.78 & 12.75 & 0.220 & 7.65 & 3.94 & 1.41 & 3.14 & 0.450 & 100.00 & 30 & 21 & 35 & 385 & 29 & 557 & 329 & 161 & 36 & 12.6 & 28 & 124 & 22 \\
\hline GRB & N1 MSU undiff. & 54.44 & \begin{tabular}{|l|l|}
2.1800 \\
\end{tabular} & 13.99 & 12.94 & $\mid 0.200$ & 7.75 & 3.85 & $\begin{array}{l}1.41 \\
1.40\end{array}$ & \begin{tabular}{|l|}
.14 \\
\end{tabular} & 0.370 & \begin{tabular}{|l|l|}
100.02 \\
\end{tabular} & $\mid 70$ & \begin{tabular}{|l|}
21 \\
15
\end{tabular} & 35 & 356 & 34 & 482 & 330 & 164 & 34 & 13.5 & $\frac{20}{21}$ & $\mid 121$ & 20 \\
\hline GRB & R1 MSU undiff. & 54.81 & $\mid 2.180$ & 13.88 & 12.16 & 0.240 & 7.35 & 3.96 & 1.48 & 3.49 & 0.440 & 99.99 & 21 & $\mid 19$ & 37 & 331 & 31 & 606 & 347 & 186 & 39 & 14.9 & 66 & 119 & 23 \\
\hline GRB & R1 MSU undiff. & 53.63 & 2.180 & 14.00 & 12.54 & 0.220 & 8.37 & 4.25 & 1.01 & 3.38 & 0.420 & 100.00 & 30 & 18 & 37 & 418 & 15 & 500 & 319 & 183 & 43 & 15.3 & 115 & 118 & 23 \\
\hline GRB & R1 MSU undiff. & 53.74 & $\frac{2.100}{2.350}$ & \begin{tabular}{|l|l|l|l}
13.97 \\
\end{tabular} & $\frac{12.04}{11.85}$ & $\frac{0.200}{0.200}$ & \begin{tabular}{|l|l|}
8.57 \\
\end{tabular} & \begin{tabular}{|l|}
4.25 \\
4.65
\end{tabular} & $\frac{1.01}{1.29}$ & \begin{tabular}{|l|l|}
.50 \\
2.95
\end{tabular} & $\mid \begin{array}{l}0.40 \\
0.360\end{array}$ & $\frac{100.00}{100.00}$ & $\mid 32$ & $\frac{10}{61}$ & 34 & \begin{tabular}{|l|l|}
410 \\
318
\end{tabular} & $\frac{15}{28}$ & $\frac{000}{451}$ & 340 & $\frac{105}{176}$ & $\mid \begin{array}{l}45 \\
33\end{array}$ & \begin{tabular}{|l|}
1.5 \\
17.1
\end{tabular} & $\frac{111}{40}$ & \begin{tabular}{|l|l|}
107 \\
107
\end{tabular} & $\frac{25}{23}$ \\
\hline GRB & R1 MSU undiff. & 53.97 & 2.350 & 14.10 & 11.73 & 0.190 & \begin{tabular}{|l|l|}
8.61 \\
\end{tabular} & 4.56 & 1.27 & 2.83 & 0.400 & 100.01 & 37 & & & 328 & 40 & 491 & 351 & 180 & 35 & $\mid 16.2$ & 42 & 118 & 19 \\
\hline GRB & R1 MSU undiff. & 52.56 & 2.290 & 14.03 & 12.33 & 0.210 & 9.12 & \begin{tabular}{|l|}
5.18 \\
\end{tabular} & 1.06 & 2.89 & 0.340 & 100.01 & \begin{tabular}{|l|}
79 \\
\end{tabular} & - & & 325 & 27 & 381 & 341 & 175 & 33 & 14.8 & 90 & 113 & 23 \\
\hline GRB & R1 MSU undiff. & 52.42 & 2.400 & 14.44 & 12.18 & 0.210 & 8.97 & 5.05 & 1.11 & 2.89 & 0.350 & 100.02 & 86 & - & & 338 & 13 & 395 & 342 & 177 & 35 & 15.3 & 95 & 113 & 24 \\
\hline GRB & R1 MSU undiff. & 52.37 & \begin{tabular}{|l|l|}
2.2900 \\
2.290
\end{tabular} & 14.15 & \begin{tabular}{|l|l|}
2.10 \\
12.17
\end{tabular} & $\mid 0.220$ & \begin{tabular}{|l|l|}
9.27 \\
\end{tabular} & \begin{tabular}{|l|}
5.24 \\
\end{tabular} & \begin{tabular}{|l|l|}
1.11 \\
\end{tabular} & \begin{tabular}{|l|}
2.06 \\
\end{tabular} & 0.330 & 99.99 & \begin{tabular}{|l|}
51 \\
\end{tabular} & & & 330 & 22 & 379 & 343 & 174 & 35 & \begin{tabular}{|l|}
16.0 \\
16.0
\end{tabular} & 93 & $\mid 109$ & 21 \\
\hline GRB & R1 MSU undiff. & 53.49 & 1.860 & 14.49 & 11.41 & 0.210 & 9.22 & 5.10 & \begin{tabular}{|l|}
0.97 \\
\end{tabular} & 2.95 & 0.300 & 100.00 & 39 & 82 & 35 & 339 & 24 & 344 & 344 & 153 & 31 & 12.8 & 107 & 104 & 19 \\
\hline
\end{tabular}


Table G.1. (contd)

\begin{tabular}{|c|c|c|c|c|c|c|c|c|c|c|c|c|c|c|c|c|c|c|c|c|c|c|c|c|c|}
\hline \multirow[b]{2}{*}{ Formation } & \multirow[b]{2}{*}{ Unit Ident. } & \multicolumn{11}{|c|}{ Major Oxides (weight per cent) } & \multicolumn{13}{|c|}{ Trace Elements (ppm) } \\
\hline & & $\mathrm{SiO}_{2}$ & $\mathrm{TiO}_{2}$ & $\mathrm{Al}_{2} \mathrm{O}_{3}$ & $\mathrm{FeO}^{*}$ & $\mathrm{MnO}$ & $\mathrm{CaO}$ & $\mathrm{MgO}$ & $\mathrm{K}_{2} \mathrm{O}$ & $\mathrm{Na}_{2} \mathrm{O}$ & $\mathrm{P}_{2} \mathrm{O}_{5}$ & TOTAL & $\mathrm{Ni}$ & $\mathrm{Cr}$ & Sc & $\mathrm{V}$ & $\mathrm{Rb}$ & $\mathrm{Ba}$ & $\mathrm{Sr}$ & $\mathrm{Zr}$ & $\mathrm{Y}$ & $\mathrm{Nb}$ & $\mathrm{Cu}$ & $\mathrm{Zn}$ & $\mathrm{Ga}$ \\
\hline GRB & R1 MSU undiff. & 54.38 & 2.230 & 13.71 & 12.48 & 0.250 & 7.83 & 4.05 & 1.40 & 3.28 & 0.380 & 999.99 & 28 & 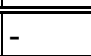 & - & 378 & 33 & $\overline{500}$ & 313 & 183 & 39 & 16.0 & $\overline{189}$ & 1120 & $\overline{222}$ \\
\hline GRB & R1 MSU undiff. & 54.02 & 2.230 & 13.72 & 12.86 & 0.230 & 7.78 & 4.19 & 1.30 & 3.28 & 0.380 & 99.99 & 38 & & - & 372 & 21 & 520 & 316 & 181 & 39 & 16.4 & 86 & 121 & 19 \\
\hline GRB & R1 MSU undiff. & 54.31 & 2.280 & 13.90 & 12.15 & 0.190 & 7.90 & 4.21 & 1.42 & 3.26 & 0.380 & 100.00 & 51 & 34 & 33 & 337 & 26 & 522 & 330 & 184 & 35 & 15.3 & 72 & 116 & 22 \\
\hline GRB & R1 MSU undiff. & 54.44 & 2.290 & 13.92 & 12.02 & 0.190 & 8.01 & 4.24 & 1.37 & 3.14 & 0.380 & 100.00 & 41 & & - & 298 & 23 & 527 & 343 & 186 & 36 & 15.6 & 71 & 109 & 21 \\
\hline GRB & R1 MSU undiff. & 54.52 & 2.270 & 14.12 & 11.77 & 0.230 & 8.09 & 3.97 & 1.56 & 3.09 & 0.380 & 100.00 & 32 & - & - & 321 & 52 & 694 & 355 & 183 & 36 & 17.3 & 79 & 110 & 24 \\
\hline GRB & R1 MSU undiff. & 54.14 & 2.120 & 14.27 & 11.34 & 0.180 & 8.36 & 4.74 & 1.33 & 3.20 & 0.310 & 99.99 & 53 & - & - & 317 & 25 & 467 & 334 & 177 & 34 & 15.3 & 88 & 112 & 21 \\
\hline GRB & R1 MSU undiff. & 54.33 & $\mid 2.130$ & 14.32 & 11.34 & 0.210 & 8.43 & 4.58 & 1.45 & 2.90 & 0.310 & 100.00 & 56 & 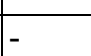 & 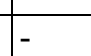 & 309 & 40 & 503 & 339 & 182 & 35 & 16.2 & \begin{tabular}{|l|}
68 \\
\end{tabular} & 112 & 23 \\
\hline GRB & R1 MSU undiff. & 54.20 & 2.110 & 14.36 & 11.64 & 0.190 & 8.37 & 4.46 & 1.32 & 3.03 & 0.310 & 99.99 & 84 & 39 & 34 & 343 & 34 & 503 & 351 & 177 & 34 & \begin{tabular}{|l|}
13.7 \\
\end{tabular} & \begin{tabular}{|l|}
67 \\
\end{tabular} & 112 & 20 \\
\hline GRB & R1 MSU undiff. & 55.07 & 2.070 & 14.41 & 11.70 & 0.190 & 7.54 & 4.08 & 1.30 & 3.28 & 0.360 & 100.00 & 16 & & - & 342 & 21 & 617 & 360 & 183 & 34 & 15.3 & 37 & 119 & 23 \\
\hline Imnaha & & 49.64 & 1.852 & 16.55 & 11.61 & 0.174 & 9.35 & 6.98 & 1.03 & 2.57 & 0.242 & 100.00 & 133 & 120 & 30 & 256 & 24 & 216 & 527 & 134 & 26 & 10.0 & 94 & 92 & 18 \\
\hline Imnaha & & 49.99 & 2.066 & 16.17 & 11.64 & 0.171 & 9.53 & 6.45 & 0.71 & 3.00 & 0.264 & 100.00 & 117 & 128 & 33 & 268 & 14 & 244 & 391 & 149 & 30 & 13.0 & 129 & 102 & 20 \\
\hline Imnaha & & 50.07 & 2.221 & 16.00 & 12.48 & 0.203 & 7.97 & 5.63 & 0.45 & 4.70 & 0.267 & 100.00 & 95 & 137 & 30 & 302 & 8 & 163 & 378 & 151 & 29 & \begin{tabular}{|l|l}
12.3 \\
\end{tabular} & 168 & $\mid 107$ & 17 \\
\hline Imnaha & & 49.31 & 2.405 & 16.59 & 12.57 & 0.175 & 8.75 & 6.38 & 0.72 & 2.79 & \begin{tabular}{|l|}
0.309 \\
\end{tabular} & 100.00 & 121 & 135 & 30 & 268 & 12 & 261 & 354 & 164 & 31 & 13.6 & 175 & 109 & 24 \\
\hline Imnaha & & 51.28 & 2.703 & 14.15 & \begin{tabular}{|l|l}
13.37 \\
\end{tabular} & 0.206 & 9.14 & \begin{tabular}{|l|l|}
4.60 \\
\end{tabular} & 0.98 & 3.19 & $\begin{array}{l}0.378 \\
\end{array}$ & 100.00 & 41 & 111 & 35 & 375 & 20 & 371 & 321 & 198 & 42 & \begin{tabular}{|l|l}
16.0 \\
\end{tabular} & 135 & 128 & 21 \\
\hline Imnaha & & 51.30 & 2.226 & 16.38 & 11.06 & 0.163 & 9.11 & 5.48 & 0.94 & 3.04 & 0.287 & 100.00 & 43 & 81 & 31 & 259 & 25 & 321 & 368 & 165 & 31 & \begin{tabular}{|l|l}
14.6 \\
\end{tabular} & 106 & 104 & 24 \\
\hline Imnaha & & 52.86 & 2.777 & 13.33 & \begin{tabular}{|l|l}
13.87 \\
\end{tabular} & 0.235 & 8.05 & \begin{tabular}{|l|l}
4.00 \\
\end{tabular} & 1.15 & 3.25 & 0.480 & 100.00 & 13 & 25 & 33 & 392 & 30 & 447 & 315 & 228 & 47 & 20.1 & 82 & 135 & 22 \\
\hline Imnaha & & 49.24 & 1.921 & 16.53 & 11.48 & \begin{tabular}{|l}
0.177 \\
\end{tabular} & 9.36 & $\mid 6.80$ & 2.35 & 1.90 & 0.246 & 100.00 & 110 & 120 & 29 & 276 & 65 & 189 & 324 & 135 & 30 & 11.9 & 98 & 93 & 20 \\
\hline $\begin{array}{l}\text { Reidel, S. P. } \\
\text { Sinclair, K., } \\
\text { Hutter, I. L. } \\
\text { Hagood, M. } \\
\text { Tolan, T. L., } \\
\text { Hooper, P. . } \\
\text { Bentley, R., } \\
\text { Division of } \\
\text { Derkey, R. F } \\
\text { Reidel, S. P. } \\
\text { SMB = Sadc } \\
\text { WB = Wana } \\
\text { GRB = Gran }\end{array}$ & $\begin{array}{l}\text { C. 1986. Structure and E } \\
\text { with M. H. Beeson. } 198 \\
\text { c, and B. A. Gillespie. } 19 \\
\text { unpublished data, Central } \\
\text { jeology and Earth Resour } \\
\text {., M. M. Hamilton, and D. D. } \\
\text { and M. M. Valenta. } 200 \\
\text { le Mountains Basalt. } \\
\text { pum Basalt. } \\
\text { de Ronde Basalt. }\end{array}$ & $\begin{array}{l}\text { ic Map } \\
\text { Unive } \\
\text { le Rep } \\
\text { g. } 199 \\
\text { ary Che }\end{array}$ & $\begin{array}{l}\text { of the Por } \\
\text { sity, and } \\
\text { rt } 93-4 \text {. } \\
\text { Prelimi } \\
\text { nistry, Pe }\end{array}$ & $\begin{array}{l}\text { neroy Ar } \\
\text { J. E. Sch }\end{array}$ & $\begin{array}{l}\text { a, Southe } \\
\text { ster (com }\end{array}$ & $\begin{array}{l}\text { ia River } \\
\text { antern Wa } \\
\text { piler). } 19\end{array}$ & $\begin{array}{l}\text { Basalt Gr } \\
\text { shington } \\
\text { 93. Geol }\end{array}$ & Washin & ngton D & vision $\mathrm{o}$ & f Geolo & $\begin{array}{l}\text { of Oregon a } \\
\text { and Earth } R \\
00 \text { Quadrang }\end{array}$ & nd Wat & $\mathrm{s}_{1} \mathrm{O}_{1}$ & -File $R$ & $\begin{array}{l}\text { epor } \\
\text { and }\end{array}$ & 6-5. & no & Portiti & the & nive & ngton. & م & Vas & \\
\hline
\end{tabular}




\section{Appendix H}

Catalog of Surface Mapping 


\section{Appendix H}

\section{Catalog of Surface Mapping}

This appendix contains a general index of maps from Washington, Oregon, and Idaho, that includes areas covered by the CRBG. Because the Washington portion of the Columbia Basin is the primary target for natural gas storage, two reports issued by the Washington Division of Geology and Earth Resources also are included with this appendix. These reports are:

- Index to Geologic and Geophysical Mapping of Washington, Part I - Published and Open-Filed Reports 1899-2001 by Connie J. Manson, February 2002.

- Index to Geologic and Geophysical mapping of Washington, Part II - Theses 1901 - 2001 by Connie J. Manson, February 2002. 


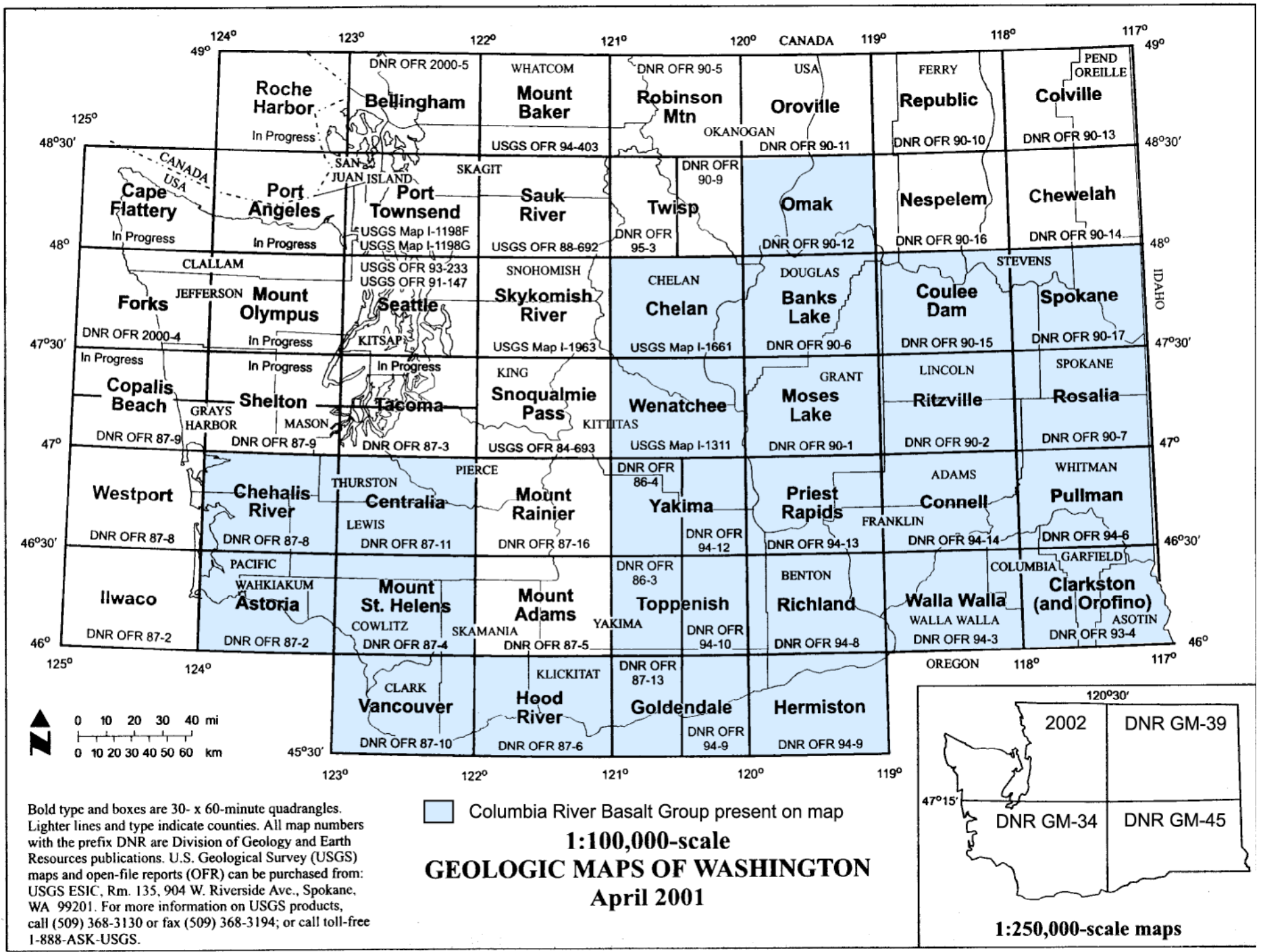

Figure H.1. Geologic Maps in Washington Containing Columbia River Basalt Group Rocks 


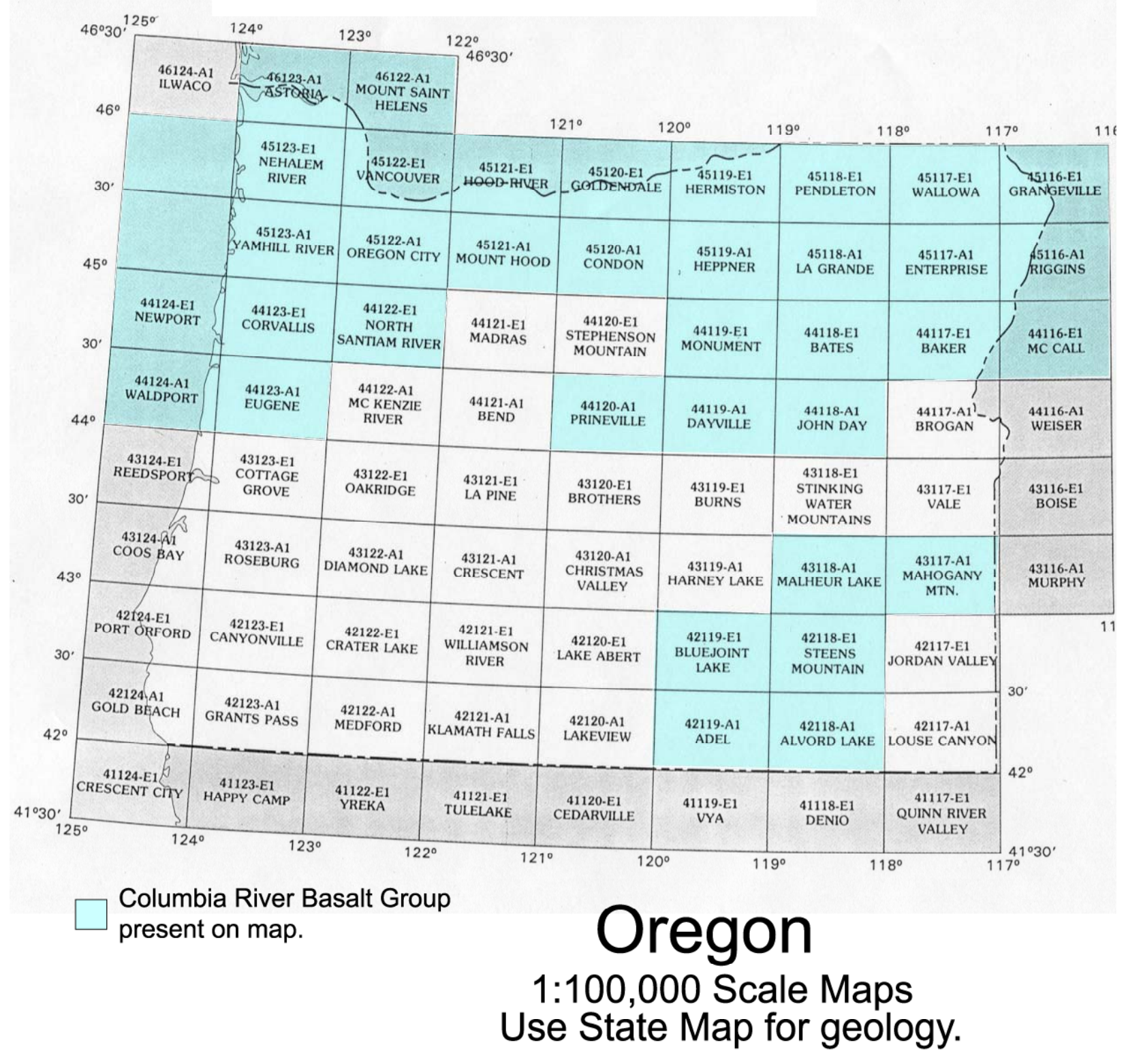

Figure H.2. Map Areas in Oregon Containing Columbia River Basalt Group Rocks. Presently the state geologic map provides the best coverage. 


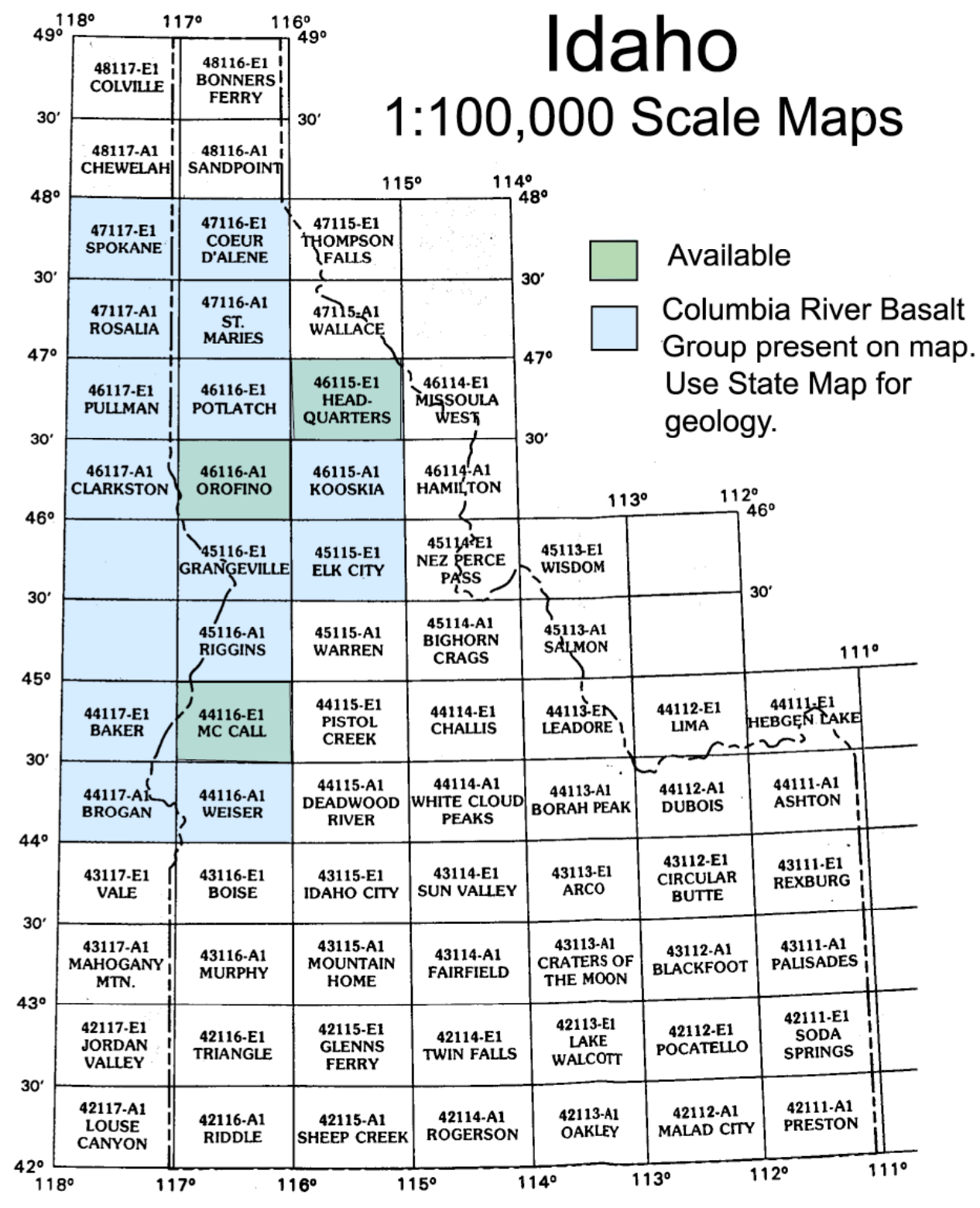

Figure H.3. Map Areas in Oregon Containing Columbia River Basalt Group Rock Presently the state geologic map provides the best coverage. 